UNIVERSIDADE FEDERAL DO PARANÁ

PROGRAMA DE PÓS-GRADUAÇÃO EM ENGENHARIA DE CONSTRUÇÃO CIVIL

DIEGO JESUS DE SOUZA

CAPACIDADE DE ADIÇÕES MINERAIS EM MITIGAR O ATAQUE POR SULFATOS DE SÓDIO E MAGNÉSIO EM ARGAMASSAS DE CIMENTO PORTLAND

CURITIBA,

2016. 
DIEGO JESUS DE SOUZA

\section{CAPACIDADE DE ADIÇÕES MINERAIS EM MITIGAR O ATAQUE POR SULFATOS DE SÓDIO E MAGNÉSIO EM ARGAMASSAS DE CIMENTO \\ PORTLAND}

Dissertação apresentada como requisito parcial à obtenção do grau de Mestre em Engenharia de Construção Civil, no Curso de Pós-Graduação em Engenharia de Construção Civil, área de concentração em Materiais e Estruturas, Setor de Tecnologia, Universidade Federal do Paraná.

Orientador:

Prof. Dr. Marcelo Henrique Farias de Medeiros

Coorientador:

Prof. Dr. Juarez Hoppe Filho

\section{CURITIBA,}


Capacidade de adições minerais em mitigar o ataque por sulfatos de sódio e magnésio em argamassas de cimento portland / Diego Jesus de Souza. - Curitiba, 2016..

228f. : il. [algumas color.] ; $30 \mathrm{~cm}$.

Dissertação (mestrado) - Universidade Federal do Paraná, Setor de Tecnologia, Programa de Pós-graduação em Engenharia de Construção Civil, 2016.

Orientador: Marcelo Henrique Farias de Medeiros -- Coorientador: Juarez Hoppe Filho.

1. Cimento Portland . 2. Durabilidade (Engenharia). 3. Engenharia de Construção Civil. I. Universidade Federal do Paraná. II. , Medeiros, Marcelo Henrique Farias de. III. Hoppe Filho, Juarez. IV. Título. 
TERMO DE APROVAÇÃO

DIEGO JESUS DE SOUZA

CAPACIDADE DE ADIÇÕES MINERAIS EM MITIGAR O ATAQUE POR SULFATOS DE SÓDIO E MAGNÉSIO EM ARGAMASSAS DE CIMENTO PORTLAND

Dissertação aprovada como requisito parcial para obtenção do grau de Mestre em Engenharia de Construção Civil, no Programa de Pós-Graduação em Engenharia de Construção Civil da Universidade Federal do Paraná, pela banca examinadora formada pelos professores:

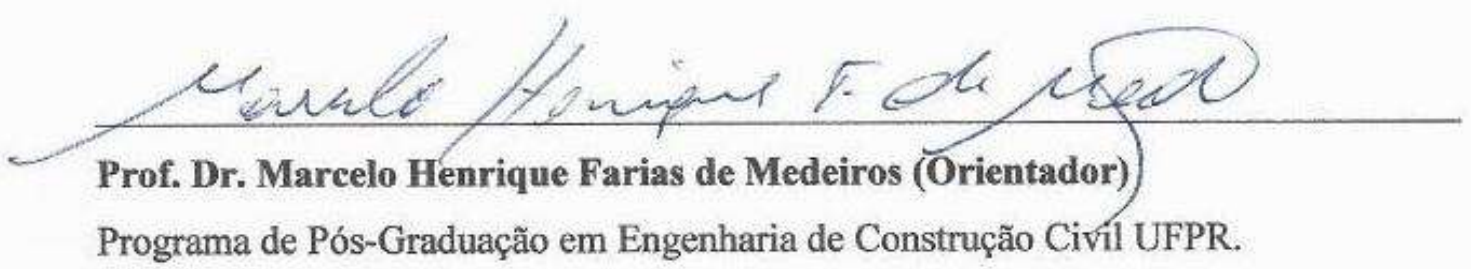

Prof. Dr. Juarez Hoppe Filho (Coorientador)

Departamento de Construção Civil da Universidade Federal do Oeste da Bahia (UFOB)

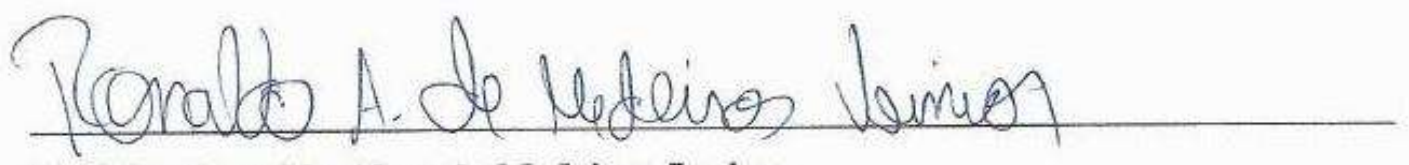

Prof. Dr. Ronaldo Alves de Medeiros Junior

Programa de Pós-Graduação em Engenharia de Construção Civil UFPR.

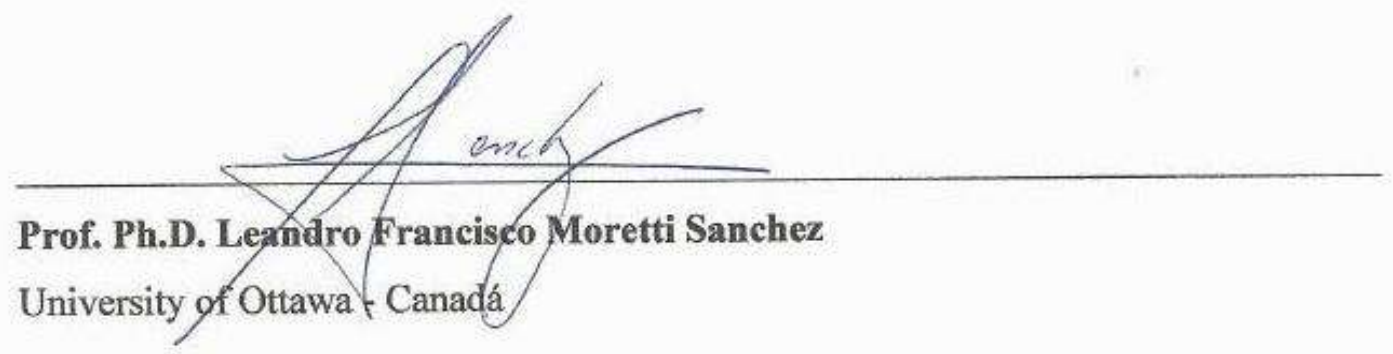

Curitiba, 30 da junho de 2016. 


\section{AGRADECIMENTOS}

O caminho para atingirmos nossos objetivos consiste na superação diária de desafios que, sem o apoio, conhecimento, compreensão e a boa vontade de algumas pessoas, jamais teríamos êxito.

Agradeço ao Professor Dr. Marcelo Henrique Farias de Medeiros e ao Professor Dr. Juarez Hoppe Filho pela orientação, incentivo, paciência, conhecimento, tempo e dedicação na elaboração deste trabalho, que, além de excelentes orientadores, mostraram-se grandes amigos.

À minha esposa Daiana, por todo o carinho, companheirismo, incentivo e confiança.

À minha família, por todo o apoio e paciência em todas as fases do meu desenvolvimento.

A todos os Professores do curso de Pós-Graduação em Engenharia de Construção Civil da Universidade Federal do Paraná por transmitirem seus conhecimentos a nós alunos.

Um agradecimento especial aos amigos técnicos de laboratório, Douglas Mancini e Ricardo Volert, pois sem vocês, dificilmente todos os ensaios necessários para conclusão deste trabalho teriam ocorrido.

À equipe EMEA, assim como ao Professor Ph.D. Mauro Lacerda Santos Filho, pela oportunidade concebida de fazer parte de um trabalho motivador e inovador que é o Desenvolvimento de Metodologia Objetiva das Condições Funcionais e Estruturais de Obras de Arte Especiais. E claro, porque não, à equipe de nobres colegas aventureiros, a Equipe 3.

Aos amigos e a todos aqueles que de alguma forma contribuíram para o meu desenvolvimento dentro e fora da Universidade.

A CAPES e ao governo brasileiro pela concessão de bolsa, este último, também pela implantação das cotas sociais e raciais. 


\section{SOUZA, D. J. Capacidade de adições minerais em mitigar o ataque por sulfatos de sódio}

e magnésio em argamassas de cimento Portland. Dissertação (Mestrado em Engenharia de

Construção Civil) - Universidade Federal do Paraná, Curitiba. 2016

\section{RESUMO}

As estruturas de concreto, desde sua fase de projeto e durante sua vida útil, estão sujeitas a uma série de fatores que poderão comprometer sua durabilidade e até mesmo sua estabilidade. $\mathrm{O}$ ataque por sulfatos é um termo usado para descrever uma série de reações químicas entre íons sulfato e compostos hidratados da pasta de cimento endurecida. Estas reações deletérias são capazes de formar compostos expansíveis passíveis de gerar tensões, fragilizando e fissurando a matriz cimentícia, facilitando assim, a entrada de novos agentes agressivos. As adições minerais, por sua vez, têm apresentado inúmeros benefícios às propriedades do concreto, tanto no estado fresco quanto no estado endurecido. O presente trabalho tem por objetivo analisar o comportamento e a influência da substituição parcial do cimento Portland (10\%, em massa) por adições minerais inertes e pozolânicas na produção de barras de argamassa expostas à solução de sulfato de sódio e de magnésio, por um período de exposição de 140 dias. Fundamentado na análise e avaliação das características químicas do ataque por sulfatos, da variação dimensional e de propriedades físicas e mecânicas a partir a utilização de ensaios auxiliares, além dos preconizados por norma. Desta forma, foi proposta a comparação qualitativa das fases hidratadas formadas por meio da difratometria de raios-X, de propriedades físicas a partir da variação resultante dimensional linear e volumétrica, variações de resistência à tração na flexão e compressão, de massa, da propagação de ondas ultrassônicas longitudinais e de módulo de elasticidade dinâmico para argamassas de diferentes composições e expostas a diferentes tipos de sulfato. Para tanto, utilizou-se de 11 diferentes amostras, sendo uma delas composta por cimento Portland CPV - ARI, exclusivamente, e as demais com substituição parcial por: filer quartzoso e calcário; resíduo de cerâmica vermelha com três diferentes tempos de moagem; sílica de casca de arroz; metacaulim; sílica ativa; e cinza volante. Nada obstante, utilizou-se, também como referência, argamassa composta por cimento do tipo CP V - ARI RS. Os resultados mostram que as composições químicas das pastas (cimento + adição mineral) influenciam diretamente no grau do ataque por sulfatos, todavia, de forma antagônica para as soluções agressivas utilizadas. Ou seja, para o $\mathrm{Na}_{2} \mathrm{SO}_{4}$, o aumento do teor de $\mathrm{CH}$ tornou as argamassas mais suscetíveis à degradação, enquanto que para o $\mathrm{MgSO}_{4}$, a intensidade do ataque diminuiu. Desta forma, a utilização do cimento RS e das adições minerais tidas como super pozolanas garantiram um desempenho melhor frente o sulfato de sódio, porém, diante do sulfato de magnésio, foram prejudiciais, principalmente, quanto ao desempenho mecânico. Por fim, os resultados obtidos com os ensaios adicionais à NBR 13.583:2014 (variação resultante volumétrica, de resistência à tração na flexão e compressão, de massa, da propagação de ondas ultrassônicas longitudinais e de módulo de elasticidade dinâmico) mostram uma realidade contrária e, ao mesmo tempo, muito mais abrangente, do que o apresentado na expansão linear (conforme a norma relacionada), levando a crer que a análise do ataque por sulfatos pode ser insuficiente quando avaliado apenas unidimensionalmente.

Palavras-Chave: Ataque por sulfatos, Adição mineral, Pozolana, Cimento Portland. 
SOUZA, D. J. Capacity of minerals additions to mitigate the sodium and magnesium

sulfate attack in Portland cement mortars. Master's thesis, Federal University of Parana, 2016

\begin{abstract}
Concrete structures are subject to a number of factors that may compromise its durability and even stability. The attack by sulfates is a term used to describe a series of chemical reactions between sulfate ions and components of hydrated cement paste. These deleterious reactions are capable of forming expansible compounds that can generate tensions, weakening and cracking of the cementitious matrix, thus facilitating the entry of new aggressive agents. Mineral additions have brought numerous benefits to the concrete properties, both in fresh and hardened state. This study aims to analyze the behavior and influence of the partial replacement of Portland cement (10\% by weight) of inert mineral admixtures and pozzolanic in the production of mortar bars exposed to sodium sulfate solution and magnesium sulfate solution for a period of 140 days exposure. Based on the analysis and evaluation of the chemical characteristics of the sulfate attack, dimensional variation and physical and mechanical properties from the use of auxiliary tests beyond those recommended by the standard method. Therefore, it was proposed to compare the chemical analysis by diffraction of $\mathrm{x}$-Rays, physical properties from the linear dimensional change resulting from and volumetric tensile strength variation in bending and compression, mass of the propagation of ultrasonic waves longitudinal and dynamic modulus of mortars of different compositions and exposed to different types solutions. Therefore, are used 11 different samples composed of Portland cement CPV - ARI exclusively and partially replaced by: quartz and calcareous filler; Red clay waste with three different grinding times; rice husk ask; metakaolin; silica fume; and fly ash. Nonetheless, it is also used as a reference mortar comprising cement type CPV - ARI with sulfate resistance. The results showed that chemical compositions of pastes (cement + mineral addition) directly influence the degree of sulfate attack, however, in contrary to the two aggressive solutions used. For $\mathrm{Na}_{2} \mathrm{SO}_{4}$ with the increasing of $\mathrm{CH}$ content became more susceptible to degradation mortar, while for $\mathrm{MgSO}_{4}$ the decreased intensity of the attack. Thus, the use of sulfate resistance cement and mineral additions taken as super pozzolans ensured an excellent performance against the sodium sulfate, but for the magnesium sulfate are harmful, especially, as to mechanical performance. Finally, the results obtained empirically with additional tests that the NBR 13.583: 2014 (volume change resulting from tensile strength in bending and compression, the mass propagation of longitudinal ultrasonic waves and $\mathrm{E}_{\mathrm{CD}}$ ) show an opposite reality, the same time, much more comprehensive than that presented in linear expansion (as the related standard), leading us to believe that the analysis of the attack by sulfates may be insufficient when evaluated only unidimensional test methods.
\end{abstract}

Keywords: Attack of sulfates, mineral addition, pozzolana, Portland cement. 


\section{LISTA DE FIGURAS}

Figura 1: Mecanismo de ataque por sulfato de sódio. Adaptado de Santhanam, Cohen e Olek (2003).

Figura 2: Mecanismo de ataque por sulfato de magnésio. Adaptado de Santhanam, Cohen e Olek (2003)

Figura 3: Reações entre solução de sulfato de sódio e produtos da hidratação do cimento Portland. Adaptado de Skalny, Marchand e Odler (2002).

Figura 4: Modelo de variação dimensional de barras de argamassa expostas ao ataque por sulfato de sódio. Adaptado de Santhanan, Cohen e Olek (2002).

Figura 5: Esquema de variação da resistência superficial. Baseado nos resultados de Ouyang et al. (2014).....

Figura 6: Reações entre solução de sulfato de magnésio e produtos da hidratação do cimento Portland. Adaptado de Skalny, Marchand e Odler (2002).

Figura 7: Modelo de variação dimensional de barras de argamassa expostas ao ataque por sulfato de magnésio e sulfato de sódio. Adaptado de Santhanan, Cohen e Olek (2002).

Figura 8: Influência da relação $\mathrm{C}_{3} \mathrm{~A} / \mathrm{C}_{4} \mathrm{AF}$ na expansão por ataque por sulfatos. Adaptado de Tikalsky et al. (2002)

Figura 9: Diagrama dos principais fatores que influenciam no processo de transporte de fluidos no concreto.

Figura 10: Modelo de tendência de expansão de argamassas de cimento Portland, imersas em soluções de sulfato de sódio e sulfato de magnésio em diferentes concentrações. Adaptado de Santhanan, Cohen e Olek (2002).

Figura 11: Representação da variação da quantidade de moléculas com energia para reação em função da temperatura. Adaptado de Atkins e Jones (2011).

Figura 12: Tendência da expansão de barras de argamassa de cimento Portland expostas a diferentes temperaturas. Adaptado de Santhanam et al. (2002.b)

Figura 13: Difratograma de amostras de concreto deterioradas pelo ataque por sulfato de sódio após 510 dias de exposição. Fonte: Adaptado de Lee et al. (2005). 60

Figura 14: Preparo da amostra para ensaio de Fluorescência de Raios-X.......................72

Figura 15: Espectrômetro de fluorescência de raios-X (Shimadzu). ............................ 72

Figura 16: Difratogramas dos fíleres calcário e quartzoso.................................... 76

Figura 17: Difratogramas das adições minerais resíduo de cerâmica vermelha, metacaulim e cinza volante 
Figura 18: Mudança na coloração da amostra de SCA antes e após ensaio de Perda ao Fogo 79 Figura 19: Difratogramas das adições minerais sílica ativa e sílica de casca de arroz.

Figura 20: Correlação entre o tempo de moagem do RCV no moinho de bolas e os resultados de B.E.T.

Figura 21: Distribuição granulométrica da Areia normal brasileira.

Figura 22: Esquema geral para representação das atividades realizadas em argamassa.

Figura 23: Corpos de prova imersos em solução de sulfato de sódio.

Figura 24: Detalhe da superfície de uma barra com acúmulo de gel durante a exposição à solução de sulfato de magnésio.

Figura 25: Leitura inicial sendo realizada com auxílio de um pórtico metálico dotado de relógio comparador

Figura 26: Esquema dos pontos nos quais se efetuaram as leituras

Figura 27: Detalhe do posicionamento e ruptura de tração na flexão do corpo de prova na prensa.

Figura 28: Detalhe de posicionamento e ruptura de compressão do corpo de prova.

Figura 29: Equipamento Ultrasonic Pulse Velocity - Pundit Lab

Figura 30: Esquema do posicionamento dos transdutores para emissão e recepção da onda ultrassônica. .96

Figura 31: Etapa de acondicionamento das pastas para ensaios de DRX.

Figura 32: Expansão resultante das séries expostas ao sulfato de sódio (segundo NBR 13.583:2014) e ao sulfato de magnésio por um período de 42 dias

Figura 33: Expansão resultante das séries expostas ao sulfato de sódio e ao sulfato de magnésio por um período de 140 dias.

Figura 34: Correlação entre o teor de portlandita e a expansão resultante devido ao ataque por sulfato de sódio, para período de exposição de 20 semanas.

Figura 35: Barra de argamassa da série FQ com excessiva formação gelatinosa na superfície devido à interação com o sulfato de magnésio.

Figura 36: Comparação entre expansão resultante de duas séries de mesma composição e com diferentes formas de exposição, com e sem limpeza superficial quando expostas ao sulfato de magnésio.

Figura 37: Comparação entre barras de argamassa da série SA expostas nas três diferentes soluções, por um período de 20 semanas.

Figura 38: Análise comparativa do $\mathrm{pH}$ das soluções de $\mathrm{Ca}(\mathrm{OH})_{2}, \mathrm{Na}_{2} \mathrm{SO}_{4}$ e $\mathrm{MgSO}_{4}$ ao longo de 20 semanas. 
Figura 39: Desagregação da pasta de cimento Portland devido ao ataque por sulfato de magnésio.

Figura 40: Expansão resultante das séries expostas por um período de 20 semanas nas soluções de sulfato de sódio e sulfato de magnésio.

Figura 41: Comparação da expansão ocasionada pelo ataque por sulfato de sódio e da solução de hidróxido de cálcio para a série RCV 1,0 h. (a) fissuração mapeada apresentada e (b) empenamento

Figura 42: Expansão resultante das séries CP V - ARI e RCV expostas ao sulfato de sódio por um período de 210 dias (30 semanas).

Figura 43: Fissuração apresentada pela série MT frente ao ataque por sulfato de sódio por um período de exposição de 20 semanas.................................................... 121

Figura 44: Comparação entre os desgastes superficiais das séries MT, SCA e SA. 121

Figura 45: Difratograma de amostra do gel acumulado na superfície dos corpos de prova da série de referência CP V - ARI expostos à solução de sulfato de magnésio, para 42 dias de exposição.

Figura 46: Micrografia eletrônica da deposição de camadas formadas a partir da reação de amostras de cimento Portland com solução de sulfato de magnésio ( $\mathrm{S} 1$ e $\mathrm{S} 2-\mathrm{MgSO}_{4}$. $\mathrm{H}_{2} \mathrm{O}$; B - Brucita; e, G - Gipsita). Fonte: Bonen (1992).

Figura 47: Representação dos picos de brucita, calcita, etringita, gipsita, C-S-H, M-S-H e portlandita para série $\mathrm{FQ}$ em exposição de 140 dias às soluções de $\mathrm{C}-\mathrm{Ca}(\mathrm{OH})_{2} ; \mathrm{S}-$ $\mathrm{Na}_{2} \mathrm{SO}_{4} ; \mathrm{e}, \mathrm{M}-\mathrm{MgSO}_{4}$.

Figura 48: Difratograma das séries de referência (CP V - ARI e CP V - ARI RS) para exposição por 140 dias nas três soluções de cura final, nas posições de $2 \theta$ variando de $8^{\circ}$ a $13^{\circ}$.

Figura 49: Difratograma das séries de referência (CP V - ARI e CP V - ARI RS) para exposição por 140 dias nas três soluções de cura final, nas posições de $2 \theta$ variando de $30^{\circ}$ a $35^{\circ}$

Figura 50: Difratograma das séries de adições inertes (Fíler calcário e Fíler Quartzoso) para exposição por 140 dias nas três soluções de cura final, nas posições de $2 \theta$ variando de $8^{\circ}$ a $13^{\circ}$ e em comparação à série de referência CP V - ARI.

Figura 51: Difratograma das séries de adições inertes (Fíler calcário e Fíler Quartzoso) para exposição por 140 dias nas três soluções de cura final, nas posições de $2 \theta$ variando de $30^{\circ}$ a $35^{\circ}$ e em comparação à série de referência CP V - ARI. 
Figura 52: Difratograma das séries de adições de baixa reatividade (resíduo de cerâmica vermelha e cinza volante) para exposição por 140 dias nas três soluções de cura final, nas posições de $2 \theta$ variando de $8^{\circ}$ a $13^{\circ}$ e em comparação à série de referência CP V - ARI. .. 130 Figura 53: Difratograma das séries de adições de baixa reatividade (resíduo de cerâmica vermelha e cinza volante) para exposição por 140 dias nas três soluções de cura final, nas posições de $2 \theta$ variando de $30^{\circ}$ a $35^{\circ}$ e em comparação à série de referência $\mathrm{CP} V$ - ARI. 131 Figura 54: Difratograma das séries de adições de alta reatividade (metacaulim, sílica ativa e sílica de casca de arroz) para exposição por 140 dias nas três soluções de cura final, nas posições de $2 \theta$ variando de $8^{\circ}$ a $13^{\circ}$ e em comparação à série de referência CP V - ARI. .. 132 Figura 55: Difratograma das séries de adições de alta reatividade (metacaulim, sílica ativa e sílica de casca de arroz) para exposição por 140 dias nas três soluções de cura final, nas posições de $2 \theta$ variando de $30^{\circ}$ a $35^{\circ}$ e em comparação à série de referência $\mathrm{CP}$ V - ARI .133 Figura 56: Correlação entre a contagem dos picos de 100\% de intensidade de etringita $\left(9,14\right.$ 20) devido a exposição à solução de $\mathrm{Na}_{2} \mathrm{SO}_{4}$ e monossulfoaluminato de cálcio hidratado $(9,932 \theta)$ devido exposição à solução de $\mathrm{Ca}(\mathrm{OH})_{2}$ com o teor de aluminato do sistema composto por $90 \%$ de cimento Portland e $10 \%$ de adições minerais sílicoaluminosas (resíduo de cerâmica vermelha, cinza volante e metacaulim) 134

Figura 57: Variação volumétrica resultante das séries expostas à solução de sulfato de sódio e sulfato de magnésio por um período de 6 semanas (42 dias).

Figura 58: Análise comparativa entre médias de variação volumétrica (teste de Tukey, para nível de significância de 5\%) de mesmas séries para soluções agressivas distintas (S sulfato de sódio e $\mathrm{M}$ - sulfato de magnésio) para 6 semanas de exposição

Figura 59: Variação resultante de massa das séries expostas à solução de sulfato de sódio e sulfato de magnésio por um período de 6 semanas (42 dias).

Figura 60: Variação resultante da velocidade ultrassônica das séries expostas à solução de sulfato de sódio e sulfato de magnésio por um período de 6 semanas (42 dias).

Figura 61: Análise comparativa entre médias de variação de massa e velocidade ultrassônica (teste de Tukey para nível de significância de 5\%) de mesmas séries para soluções agressivas distintas ( $\mathrm{S}$ - sulfato de sódio e $\mathrm{M}$ - sulfato de magnésio) para 6 semanas de exposição. 139

Figura 62: Variação volumétrica resultante das séries expostas por um período de 20 semanas nas soluções de sulfato de sódio e sulfato de magnésio 
Figura 63: Influência da geometria dos corpos de prova na expansão resultante devido ao ataque por sulfatos

Figura 64: Correlação entre a expansão dimensional linear e a expansão volumétrica das amostras expostas ao sulfato de sódio por um período de 20 semanas

Figura 65: Variação Resultante de Massa das séries expostas por um período de 20 semanas nas soluções de sulfato de sódio e sulfato de magnésio....

Figura 66: Variação Ultrassônica Resultante das séries expostas por um período de 20 semanas nas soluções de sulfato de sódio e sulfato de magnésio.

Figura 67: Correlação entre valores obtidos em 20 semanas de exposição para Variação Resultante de Massa, Variação de Volume e Variação da Velocidade Ultrassônica com o Teor de Hidróxido de Cálcio Teórico em exposição ao sulfato de sódio.

Figura 68: Correlação entre valores obtidos em 20 semanas de exposição para Variação Resultante de Massa, Variação de Volume e Variação da Velocidade Ultrassônica com o Teor de Hidróxido de Cálcio Teórico em exposição ao sulfato de magnésio.

Figura 69: Variações Resultantes de Volume, Massa e Velocidade Ultrassônica das séries expostas ao sulfato de sódio e ao sulfato de magnésio por um período de 140 dias.

Figura 70: Fissuração causada pelo ataque por sulfato de sódio em barras de argamassa da série CP V - ARI exposta por um período de 20 semanas.

Figura 71: Comparação entre a degradação das amostras de diferentes dimensões (superior esquerda $40 \times 40 \times 160 \mathrm{~mm}$, inferior esquerda $25 \times 25 \times 285 \mathrm{~mm}$ e direita seção da amostra $40 \times 40 \times 160 \mathrm{~mm}$ ) da série MT exposta ao sulfato de sódio.

Figura 72: Correlação entre o teor de $\mathrm{Al}_{2} \mathrm{O}_{3}$ das adições minerais pozolânicas e suas respectivas variações resultantes volumétricas para exposição ao sulfato de sódio por um período de 140 dias.

Figura 73: Comparação visual entre a influência das três soluções nas quais a série MT fora exposta $\left(\mathrm{Ca}[\mathrm{OH}]_{2}\right.$, referência; $\mathrm{Na}_{2} \mathrm{SO}_{4}$, sulfato de sódio; e $\mathrm{MgSO}_{4}$, sulfato de magnésio)

Figura 74: Comparação visual entre a influência das três soluções nas quais a série SA fora exposta ( $\mathrm{Ca}[\mathrm{OH}]_{2}$, referência; $\mathrm{Na}_{2} \mathrm{SO}_{4}$, sulfato de sódio; e $\mathrm{MgSO}_{4}$, sulfato de magnésio) ... 154 Figura 75: Correlação entre os resultados obtidos para amostras de dimensões $40 \times 40 \times 160 \mathrm{~mm}$ e $25 \times 25 \times 285 \mathrm{~mm}$ frente à exposição ao ataque por sulfato de sódio

Figura 76: Módulo de Elasticidade Dinâmico para as séries estudadas e expostas por 6 semanas (42 dias) para cada uma das soluções de imersão: Esquerda, referência $\left(\mathrm{Ca}[\mathrm{OH}]_{2}\right)$; centro, sulfato de sódio $\left(\mathrm{Na}_{2} \mathrm{SO}_{4}\right)$; e, direita, sulfato de magnésio $\left(\mathrm{MgSO}_{4}\right) \ldots 156$ 
Figura 77: Variação Resultante no Módulo de Elasticidade Dinâmico das amostras expostas ao sulfato de sódio e ao sulfato de magnésio por um período de 20 semanas.

Figura 78: Relação entre as variações resultantes de volume, massa e de velocidade ultrassônica com a variação resultante do módulo de elasticidade dinâmico, para 20 semanas de exposição ao sulfato de sódio e sulfato de magnésio.

Figura 79: Módulo de Elasticidade Dinâmico para as séries estudadas e expostas por 20 semanas (140 dias) para cada uma das soluções de imersão: Esquerda, referência $\left(\mathrm{Ca}[\mathrm{OH}]_{2}\right)$; centro, sulfato de sódio $\left(\mathrm{Na}_{2} \mathrm{SO}_{4}\right)$; e, direita, sulfato de magnésio $\left(\mathrm{MgSO}_{4}\right) \ldots 160$ Figura 80: Resistencia à Tração na Flexão para exposição de 6 e 20 semanas às três soluções finais $\left(\mathrm{Ca}[\mathrm{OH}]_{2}, \mathrm{Na}_{2} \mathrm{SO}_{4}\right.$ e $\left.\mathrm{MgSO}_{4}\right)$.

Figura 81: Análise comparativa entre médias (teste de Tukey para nível de significância de $5 \%$ ) de mesmas séries para soluções agressivas distintas ( $\mathrm{S}$ - sulfato de sódio e $\mathrm{M}$ - sulfato de magnésio) para 6 e 20 semanas de exposição.

Figura 82: Resistência à Tração na Flexão para as séries de amostras ao longo de 20 semanas de exposição às três soluções finais $\left(\mathrm{Ca}[\mathrm{OH}]_{2}, \mathrm{Na}_{2} \mathrm{SO}_{4}\right.$ e $\left.\mathrm{MgSO}_{4}\right)$.

Figura 83: Resistência à Compressão para as séries estudadas e expostas por 6 semanas (42 dias) para cada uma das soluções de imersão: Esquerda, referência $\left(\mathrm{Ca}[\mathrm{OH}]_{2}\right)$; centro, sulfato de sódio $\left(\mathrm{Na}_{2} \mathrm{SO}_{4}\right)$; e, direita, sulfato de magnésio $\left(\mathrm{MgSO}_{4}\right)$.

Figura 84: Análise comparativa entre médias de resistência à compressão (teste de Tukey para nível de significância de 5\%) de mesmas séries para soluções agressivas distintas (C hidróxido de cálcio, $\mathrm{S}$ - sulfato de sódio e $\mathrm{M}$ - sulfato de magnésio) para 6 semanas de exposição.

Figura 85: Variação Resultante de Resistência à Compressão das amostras expostas ao sulfato de sódio e ao sulfato de magnésio por um período de 20 semanas.

Figura 86: Correlação entre valores obtidos em 20 semanas de exposição para Variação da Resistência à Compressão com o Teor de Hidróxido de Cálcio Teórico em exposição ao sulfato de sódio e ao sulfato de magnésio.

Figura 87: Correlação entre valores obtidos em 20 semanas de exposição para Variação Resultante no Módulo de Elasticidade Dinâmico com o Teor de Hidróxido de Cálcio Teórico em exposição ao sulfato de sódio e ao sulfato de magnésio.

Figura 88: Resistência à Compressão para as séries de amostras ao longo de 20 semanas de exposição às três soluções finais $\left(\mathrm{Ca}[\mathrm{OH}]_{2}, \mathrm{Na}_{2} \mathrm{SO}_{4}\right.$ e $\left.\mathrm{MgSO}_{4}\right)$. 
Figura 89: Resistência à Compressão para as séries estudadas e expostas por 20 semanas (140 dias) para cada uma das soluções de imersão: Esquerda, referência $\left(\mathrm{Ca}[\mathrm{OH}]_{2}\right)$; centro, sulfato de sódio $\left(\mathrm{Na}_{2} \mathrm{SO}_{4}\right)$; e, direita, sulfato de magnésio $\left(\mathrm{MgSO}_{4}\right)$.

Figura 90: Análise comparativa entre médias de resistência à compressão (teste de Tukey para nível de significância de 5\%) entre as séries ARI e RS para soluções agressivas distintas (C - hidróxido de cálcio, $\mathrm{S}$ - sulfato de sódio e $\mathrm{M}$ - sulfato de magnésio) para 20 semanas de exposição

Figura 91: Análise comparativa entre médias de resistência à compressão (teste de Tukey) entre as séries ARI e FQ para soluções agressivas distintas (C - hidróxido de cálcio, $\mathrm{S}$ sulfato de sódio e $\mathrm{M}$ - sulfato de magnésio) para 20 semanas de exposição.

Figura 92: Análise comparativa entre médias de resistência à compressão (teste de Tukey para nível de significância de 5\%) entre as séries ARI e CV para soluções agressivas distintas (C - hidróxido de cálcio, $\mathrm{S}$ - sulfato de sódio e $\mathrm{M}$ - sulfato de magnésio) para 20 semanas de exposição

Figura 93: Análise comparativa entre médias de resistência à compressão (teste de Tukey para nível de significância de 5\%) entre as séries ARI x MT, ARI x SA e ARI x SCA para soluções agressivas distintas $(\mathrm{C}$ - hidróxido de cálcio, $\mathrm{S}$ - sulfato de sódio e $\mathrm{M}$ - sulfato de magnésio) para 20 semanas de exposição.

Figura 94: Distribuição granulométrica dos aglomerantes utilizados.

Figura 95: Difratograma das amostras da série CP V - ARI para 14 dias de idade e 0 dias de exposição nas posições de $2 \theta$ variando de $8^{\circ}$ a $39^{\circ}$

Figura 96: Difratograma das amostras da série CP V - ARI para 140 dias de exposição nas posições de $2 \theta$ variando de $8^{\circ}$ a $23^{\circ}$ (Soluções de exposição: $\mathrm{C}-\mathrm{Ca}(\mathrm{OH})_{2} ; \mathrm{S}-\mathrm{Na}_{2} \mathrm{SO}_{4}$; e, $\left.\mathrm{M}-\mathrm{MgSO}_{4}\right)$.

Figura 97: Difratograma das amostras da série CP V - ARI para 140 dias de exposição nas posições de $2 \theta$ variando de $23^{\circ}$ a $39^{\circ}$ (Soluções de exposição: $\mathrm{C}-\mathrm{Ca}(\mathrm{OH})_{2} ; \mathrm{S}-\mathrm{Na}_{2} \mathrm{SO}_{4}$; e, $\left.\mathrm{M}-\mathrm{MgSO}_{4}\right)$.

Figura 98: Difratograma das amostras da série CP V - ARI RS para 14 dias de idade e 0 dias de exposição nas posições de $2 \theta$ variando de $8^{\circ}$ a $39^{\circ}$ Figura 99: Difratograma das amostras da série CP V - ARI RS para 140 dias de exposição nas posições de $2 \theta$ variando de $8^{\circ}$ a $23^{\circ}$ (Soluções de exposição: $\mathrm{C}-\mathrm{Ca}(\mathrm{OH})_{2} ; \mathrm{S}-$ $\left.\mathrm{Na}_{2} \mathrm{SO}_{4} ; \mathrm{e}, \mathrm{M}-\mathrm{MgSO}_{4}\right)$. 
Figura 100: Difratograma das amostras da série CP V - ARI RS para 140 dias de exposição nas posições de $2 \theta$ variando de $23^{\circ}$ a $39^{\circ}$ (Soluções de exposição: $\mathrm{C}-\mathrm{Ca}(\mathrm{OH})_{2}$; $\left.\mathrm{S}-\mathrm{Na}_{2} \mathrm{SO}_{4} ; \mathrm{e}, \mathrm{M}-\mathrm{MgSO}_{4}\right)$

Figura 101: Difratograma das amostras da série FC para 14 dias de idade e 0 dias de exposição nas posições de $2 \theta$ variando de $8^{\circ}$ a $39^{\circ}$

Figura 102: Difratograma das amostras da série FC para 140 dias de exposição nas posições de $2 \theta$ variando de $8^{\circ}$ a $23^{\circ}$ (Soluções de exposição: $\mathrm{C}-\mathrm{Ca}(\mathrm{OH})_{2} ; \mathrm{S}-\mathrm{Na}_{2} \mathrm{SO}_{4}$; e, $\left.\mathrm{M}-\mathrm{MgSO}_{4}\right)$.

Figura 103: Difratograma das amostras da série FC para 140 dias de exposição nas posições de $2 \theta$ variando de $23^{\circ}$ a $39^{\circ}$ (Soluções de exposição: $\mathrm{C}-\mathrm{Ca}(\mathrm{OH})_{2} ; \mathrm{S}-\mathrm{Na}_{2} \mathrm{SO}_{4}$; e, $\left.\mathrm{M}-\mathrm{MgSO}_{4}\right)$.

Figura 104: Difratograma das amostras da série FQ para 14 dias de idade e 0 dias de exposição nas posições de $2 \theta$ variando de $8^{\circ}$ a $39^{\circ}$

Figura 105: Difratograma das amostras da série FQ para 140 dias de exposição nas posições de $2 \theta$ variando de $8^{\circ}$ a $23^{\circ}$ (Soluções de exposição: $\mathrm{C}-\mathrm{Ca}(\mathrm{OH})_{2} ; \mathrm{S}-\mathrm{Na}_{2} \mathrm{SO}_{4} ;$ e, $\left.\mathrm{M}-\mathrm{MgSO}_{4}\right)$.

Figura 106: Difratograma das amostras da série FQ para 140 dias de exposição nas posições de $2 \theta$ variando de $23^{\circ}$ a $39^{\circ}$ (Soluções de exposição: $\mathrm{C}-\mathrm{Ca}(\mathrm{OH})_{2} ; \mathrm{S}-\mathrm{Na}_{2} \mathrm{SO}_{4}$; $\left.\mathrm{e}, \mathrm{M}-\mathrm{MgSO}_{4}\right)$.

Figura 107: Difratograma das amostras da série CV para 14 dias de idade e 0 dias de exposição nas posições de $2 \theta$ variando de $8^{\circ}$ a $39^{\circ}$

Figura 108: Difratograma das amostras da série CV para 140 dias de exposição nas posições de $2 \theta$ variando de $8^{\circ}$ a $23^{\circ}$ (Soluções de exposição: $\mathrm{C}-\mathrm{Ca}(\mathrm{OH})_{2} ; \mathrm{S}-\mathrm{Na}_{2} \mathrm{SO}_{4}$; e, $\left.\mathrm{M}-\mathrm{MgSO}_{4}\right)$

Figura 109: Difratograma das amostras da série CV para 140 dias de exposição nas posições de $2 \theta$ variando de $23^{\circ}$ a $39^{\circ}$ (Soluções de exposição: $\mathrm{C}-\mathrm{Ca}(\mathrm{OH})_{2} ; \mathrm{S}-\mathrm{Na}_{2} \mathrm{SO}_{4}$; $\left.\mathrm{e}, \mathrm{M}-\mathrm{MgSO}_{4}\right)$.

Figura 110: Difratograma das amostras da série RCV para 140 dias de exposição nas posições de $2 \theta$ variando de $8^{\circ}$ a $23^{\circ}$ (Soluções de exposição: $\mathrm{C}-\mathrm{Ca}(\mathrm{OH})_{2} ; \mathrm{S}-\mathrm{Na}_{2} \mathrm{SO}_{4}$; e, $\left.\mathrm{M}-\mathrm{MgSO}_{4}\right)$.

Figura 111: Difratograma das amostras da série RCV para 140 dias de exposição nas posições de $2 \theta$ variando de $23^{\circ}$ a $39^{\circ}$ (Soluções de exposição: $\mathrm{C}-\mathrm{Ca}(\mathrm{OH})_{2} ; \mathrm{S}-\mathrm{Na}_{2} \mathrm{SO}_{4}$; $\left.\mathrm{e}, \mathrm{M}-\mathrm{MgSO}_{4}\right)$. 
Figura 112: Difratograma das amostras da série MT para 14 dias de idade e 0 dias de exposição nas posições de $2 \theta$ variando de $8^{\circ}$ a $39^{\circ}$

Figura 113: Difratograma das amostras da série MT para 140 dias de exposição nas posições de $2 \theta$ variando de $8^{\circ}$ a $23^{\circ}$ (Soluções de exposição: $\mathrm{C}-\mathrm{Ca}(\mathrm{OH})_{2} ; \mathrm{S}-\mathrm{Na}_{2} \mathrm{SO}_{4}$; e, $\left.\mathrm{M}-\mathrm{MgSO}_{4}\right)$.

Figura 114: Difratograma das amostras da série MT para 140 dias de exposição nas posições de $2 \theta$ variando de $23^{\circ}$ a $39^{\circ}$ (Soluções de exposição: $\mathrm{C}-\mathrm{Ca}(\mathrm{OH})_{2} ; \mathrm{S}-\mathrm{Na}_{2} \mathrm{SO}_{4}$; $\left.\mathrm{e}, \mathrm{M}-\mathrm{MgSO}_{4}\right)$. 226

Figura 115: Difratograma das amostras da série SA para 14 dias de idade e 0 dias de exposição nas posições de $2 \theta$ variando de $8^{\circ}$ a $39^{\circ}$

Figura 116: Difratograma das amostras da série SA para 140 dias de exposição nas posições de $2 \theta$ variando de $8^{\circ}$ a $23^{\circ}$ (Soluções de exposição: $\mathrm{C}-\mathrm{Ca}(\mathrm{OH})_{2} ; \mathrm{S}-\mathrm{Na}_{2} \mathrm{SO}_{4}$; e, $\left.\mathrm{M}-\mathrm{MgSO}_{4}\right)$.

Figura 117: Difratograma das amostras da série SA para 140 dias de exposição nas posições de $2 \theta$ variando de $23^{\circ}$ a $39^{\circ}$ (Soluções de exposição: $\mathrm{C}-\mathrm{Ca}(\mathrm{OH})_{2} ; \mathrm{S}-\mathrm{Na}_{2} \mathrm{SO}_{4}$; e, $\left.\mathrm{M}-\mathrm{MgSO}_{4}\right)$.

Figura 118: Difratograma das amostras da série SCA para 14 dias de idade e 0 dias de exposição nas posições de $2 \theta$ variando de $8^{\circ}$ a $39^{\circ}$

Figura 119: Difratograma das amostras da série SCA para 140 dias de exposição nas posições de $2 \theta$ variando de $8^{\circ}$ a $23^{\circ}$ (Soluções de exposição: $\mathrm{C}-\mathrm{Ca}(\mathrm{OH})_{2} ; \mathrm{S}-\mathrm{Na}_{2} \mathrm{SO}_{4}$; e, $\left.\mathrm{M}-\mathrm{MgSO}_{4}\right)$.

Figura 120: Difratograma das amostras da série SCA para 140 dias de exposição nas posições de $2 \theta$ variando de $23^{\circ}$ a $39^{\circ}$ (Soluções de exposição: $\mathrm{C}-\mathrm{Ca}(\mathrm{OH})_{2} ; \mathrm{S}-\mathrm{Na}_{2} \mathrm{SO}_{4}$; e, $\left.\mathrm{M}-\mathrm{MgSO}_{4}\right)$. 


\section{LISTA DE TABELAS}

Tabela 1: Comparação de solubilidade entre sulfato anidro, cálcio, sódio e magnésio..........44

Tabela 2: Requisitos para concreto exposto a soluções contendo sulfatos. ......................50

Tabela 3: Críticas à norma ASTM C 1012 segundo algumas publicações........................ 59

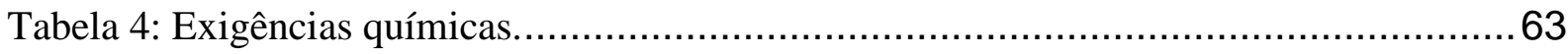

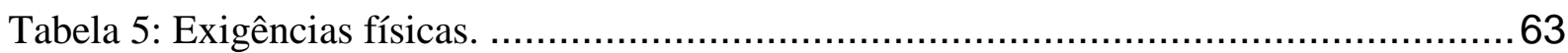

Tabela 6: Composição química dos cimentos CP V - ARI e CP V - ARI RS ....................74

Tabela 7: Características físicas do cimento CP V - ARI ....................................... 74

Tabela 8: Composição química das adições minerais inertes.................................... 75

Tabela 9: Características físicas das Adições Minerais Inertes ................................. 77

Tabela 10: Composição química das Adições Minerais Pozolânicas .............................. 77

Tabela 11: Características físicas do Resíduo de Cerâmica Vermelha ............................... 80

Tabela 12: Composição das argamassas para moldagem dos corpos de prova de $25 \mathrm{~mm} \mathrm{x}$

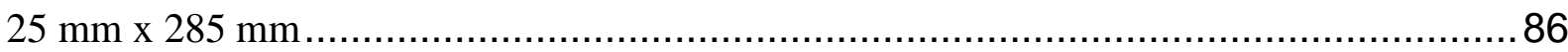

Tabela 13: Composição das argamassas para moldagem dos corpos de prova de $40 \mathrm{~mm} x$

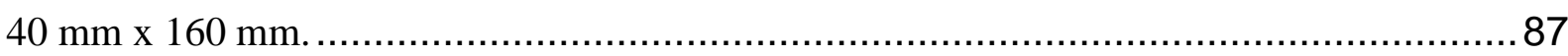

Tabela 14: Composição das soluções de cura final ............................................. 88

Tabela 15: Composição das Pastas de cimento Portland .......................................... 98

Tabela 16: Atividade Pozolânica pelo método Chapelle modificado.............................101

Tabela 17: Consumo de portlandita para cada adição estudada ................................... 103

Tabela 18: Teores dos compostos de Bogue para os cimentos CP V - ARI e CP V - ARI

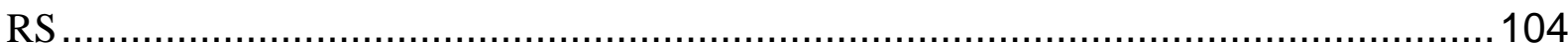

Tabela 19a: Teores de minerais formados a partir da hidratação (teórica) dos cimentos .....105

Tabela 20: Teor remanescente de portlandita após reação de hidratação do cimento Portland e consumo por atividade pozolânica....................................................... 106

Tabela 21: Tempo para Início da Fissuração das amostras expostas às soluções de $\mathrm{Na}_{2} \mathrm{SO}_{4}$ e $\mathrm{MgSO}_{4}$ 165

Tabela 22: Tempo para Início da Fissuração das amostras expostas às soluções de $\mathrm{Na}_{2} \mathrm{SO}_{4}$

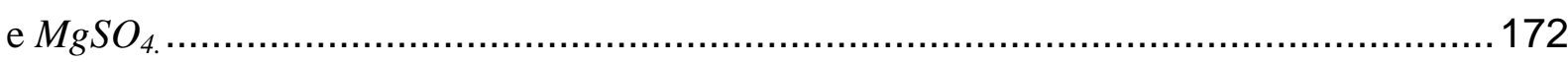

Tabela 23: Analise química do cimento CP V - ARI ......................................... 202

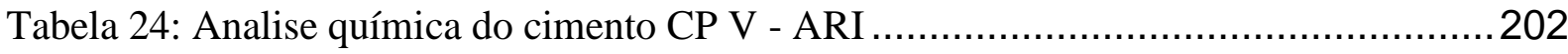


Tabela 25: Teste de Tukey para resultados de Variação Dimensional Linear das amostras expostas em solução de sulfato de Sódio por um período de 6 semanas, conforme NBR 13.583:2014

Tabela 26: Teste de Tukey para resultados de Variação Dimensional Linear das amostras expostas em solução de sulfato de Magnésio por um período de 6 semanas, adaptação da NBR 13.583:2014

Tabela 27: Teste de Tukey para resultados de Variação Dimensional Linear das amostras expostas em solução de sulfato de Sódio por um período de 20 semanas

Tabela 28: Teste de Tukey para resultados de Variação Dimensional Linear das amostras expostas em solução de sulfato de Magnésio por um período de 20 semanas

Tabela 29: Teste de Tukey para resultados de Variação Volumétrica das amostras expostas em solução de sulfato de Sódio por um período de 6 semanas 208

Tabela 30: Teste de Tukey para resultados de Variação Volumétrica das amostras expostas em solução de sulfato de Magnésio por um período de 6 semanas

Tabela 31: Teste de Tukey para resultados de Variação Volumétrica das amostras expostas em solução de sulfato de Sódio por um período de 20 semanas

Tabela 32: Teste de Tukey para resultados de Variação Volumétrica das amostras expostas em solução de sulfato de Magnésio por um período de 20 semanas

Tabela 33: Teste de Tukey para resultados de Variação Resultante de Massa das amostras expostas em solução de sulfato de Sódio por um período de 6 semanas

Tabela 34: Teste de Tukey para resultados de Variação Resultante de Massa das amostras expostas em solução de sulfato de Magnésio por um período de 6 semanas

Tabela 35: Teste de Tukey para resultados de Variação Resultante de Massa das amostras expostas em solução de sulfato de Sódio por um período de 20 semanas

Tabela 36: Teste de Tukey para resultados de Variação Resultante de Massa das amostras expostas em solução de sulfato de Magnésio por um período de 20 semanas

Tabela 37: Teste de Tukey para resultados de Variação Resultante de Velocidade Ultrassônica das amostras expostas em solução de sulfato de Sódio por um período de 6 semanas

Tabela 38: Teste de Tukey para resultados de Variação Resultante de Velocidade Ultrassônica das amostras expostas em solução de sulfato de Magnésio por um período de 6 semanas 
Tabela 39: Teste de Tukey para resultados de Variação Resultante de Velocidade Ultrassônica das amostras expostas em solução de sulfato de Sódio por um período de 20 semanas

Tabela 40: Teste de Tukey para resultados de Variação Resultante de Velocidade Ultrassônica das amostras expostas em solução de sulfato de Magnésio por um período de 20 semanas

Tabela 41: Teste de Tukey para resultados de Variação Resultante no Módulo de Elasticidade Dinâmico das amostras expostas em solução de sulfato de Sódio por um período de 6 semanas

Tabela 42: Teste de Tukey para resultados de Variação Resultante no Módulo de Elasticidade Dinâmico das amostras expostas em solução de sulfato de Magnésio por um período de 6 semanas

Tabela 43: Teste de Tukey para resultados de Variação Resultante no Módulo de Elasticidade Dinâmico das amostras expostas em solução de sulfato de Sódio por um período de 20 semanas.

Tabela 44: Teste de Tukey para resultados de Variação Resultante no Módulo de Elasticidade Dinâmico das amostras expostas em solução de sulfato de Magnésio por um período de 20 semanas.

Tabela 45: Teste de Tukey para resultados de Módulo de Elasticidade Dinâmico das amostras expostas às soluções de: $\mathrm{C}$ - Hidróxido de cálcio; $\mathrm{S}$ - Sulfato de Sódio; e $\mathrm{M}$ Sulfato de Magnésio por um período de 6 semanas

Tabela 46: Teste de Tukey para resultados de Módulo de Elasticidade Dinâmico das amostras expostas às soluções de: $\mathrm{C}$ - Hidróxido de cálcio; $\mathrm{S}$ - Sulfato de Sódio; e M Sulfato de Magnésio por um período de 20 semanas

Tabela 47: Teste de Tukey para resultados de Resistência à Tração na Flexão das amostras expostas às soluções de: $\mathrm{C}$ - Hidróxido de cálcio; $\mathrm{S}$ - Sulfato de Sódio; e M - Sulfato de Magnésio por um período de 6 semanas

Tabela 48: Teste de Tukey para resultados de Resistência à Tração na Flexão das amostras expostas às soluções de: $\mathrm{C}$ - Hidróxido de cálcio; $\mathrm{S}$ - Sulfato de Sódio; e M - Sulfato de Magnésio por um período de 20 semanas

Tabela 49: Teste de Tukey para resultados de Resistência à Compressão das amostras expostas às soluções de: $\mathrm{C}$ - Hidróxido de cálcio; $\mathrm{S}$ - Sulfato de Sódio; e M - Sulfato de Magnésio por um período de 6 semanas 
Tabela 50: Teste de Tukey para resultados de Resistência à Compressão das amostras expostas às soluções de: C - Hidróxido de cálcio; S - Sulfato de Sódio; e M - Sulfato de Magnésio por um período de 20 semanas ................................................ 219

Tabela 51: Detalhamento dos minerais observados nos difratogramas apresentados 219 


\section{LISTA DE SÍMBOLOS}

$\mathrm{a} / \mathrm{c}$

AFm

$\mathrm{AFt}$

ASTM

$\mathrm{cm}$

${ }^{\circ} \mathrm{C}$

$\mathrm{CaCO}_{3}$

$\mathrm{C}-\mathrm{A}-\mathrm{H}$

$\mathrm{C}-\mathrm{A}-\overline{\mathrm{S}}-\mathrm{H}$

$\mathrm{C}-\mathrm{S}-\mathrm{H}$

$\mathrm{CH}$

$\mathrm{C}_{2} \mathrm{~S}$

$\mathrm{C}_{3} \mathrm{~S}$

$\mathrm{C}_{3} \mathrm{~A}$

$\mathrm{C}_{4} \mathrm{AF}$

$\mathrm{CaO}$

CPV - ARI

CPs

$\mathrm{CaSO}_{4} \cdot 2 \mathrm{H}_{2} \mathrm{O}$

CV

DEF

FC

FQ

$\mathrm{f}_{\mathrm{ck}}$

$\mathrm{Fe}_{2} \mathrm{O}_{3}$

$2 \mathrm{FeSO}_{4}$

$\mathrm{K}_{2} \mathrm{SO}_{4}$

$\mathrm{kg}$

$\mathrm{Mg}^{2+}$

$\mathrm{MgO}$

$\mathrm{Mg}(\mathrm{OH})_{2}$
- Relação água/cimento

- Monossulfoaluminato de cálcio hidratado

- Trissulfoaluminato de cálcio hidratado (etringita)

- American Society for Testing and Materials

- Centímetro (10 $0^{-2}$ metro $)$

- Graus Celsius

- Carbonato de cálcio

- Aluminato de cálcio hidratado

- Etringita

- Silicato de cálcio hidratado $\left(3 \mathrm{CaO} .2 \mathrm{SiO}_{2} \cdot 2 \mathrm{H}_{2} \mathrm{O}\right)$

- Hidróxido de cálcio (portlandita), $\left[\mathrm{Ca}(\mathrm{OH})_{2}\right]$

- Silicato dicálcico $\left(2 \mathrm{CaO} . \mathrm{SiO}_{2}\right)$

- Silicato tricálcico $\left(3 \mathrm{CaO} . \mathrm{SiO}_{2}\right)$

- Aluminato tricálcico $\left(3 \mathrm{CaO} . \mathrm{Al}_{2} \mathrm{O}_{3}\right)$

- Ferroaluminato tetracálcico $\left(4 \mathrm{CaO} \cdot \mathrm{Al}_{2} \mathrm{O}_{3} \cdot \mathrm{Fe}_{2} \mathrm{O}_{3}\right)$

- Cal virgem

- Cimento Portland de alta resistência inicial

- Corpos de prova

- Gipsita

- Cinza volante

- Delayed ettringite formation (formação de etringita tardia)

- Fíler calcário

- Fíler quartzoso

-Resistência característica do concreto à compressão

- Óxido de ferro

- Sulfato de ferro

- Sulfato de potássio

- Quilograma

- Cátion magnésio

- Magnésia - Óxido de magnésio

- Hidróxido de magnésio (brucita) 


\begin{tabular}{|c|c|}
\hline $\mathrm{MgSO}_{4}$ & - Sulfato de magnésio \\
\hline MT & - Metacaulim \\
\hline $\mathrm{ml}$ & - Mililitros \\
\hline $\mathrm{mm}$ & - Milímetro ( $10^{-3}$ metro $)$ \\
\hline$\mu \mathrm{m}$ & - Micrometro $\left(10^{-6}\right.$ metro $)$ \\
\hline $\mathrm{nm}$ & - Nanometro (10 ${ }^{-9}$ metro $)$ \\
\hline $\mathrm{Na}^{+}$ & - Cátion sódio \\
\hline $\mathrm{Na}_{2} \mathrm{O}$ & - Óxido de sódio \\
\hline$\left(\mathrm{NH}_{4}\right)_{2} \mathrm{SO}_{4}$ & - Sulfato de amônio \\
\hline $\mathrm{Na}_{2} \mathrm{SO}_{4}$ & - Sulfato de sódio \\
\hline $\mathrm{pH}$ & - Potencial de hidrogênio \\
\hline $\mathrm{RCV}$ & - Resíduo de cerâmica vermelha \\
\hline SA & - Sílica ativa \\
\hline SCA & - Sílica de casca de arroz \\
\hline $\mathrm{SO}_{3}$ & - Anidro sulfúrico \\
\hline $\mathrm{SO}_{4}{ }^{2-}$ & - Íon sulfato \\
\hline $\mathrm{TiO}_{2}$ & - Óxido de titânio \\
\hline
\end{tabular}




\section{SUMÁRIO}

1 INTRODUÇÃO

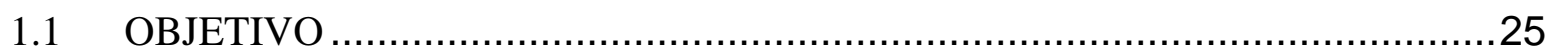

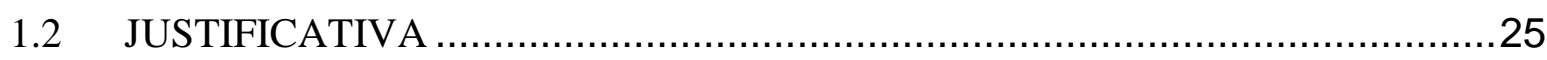

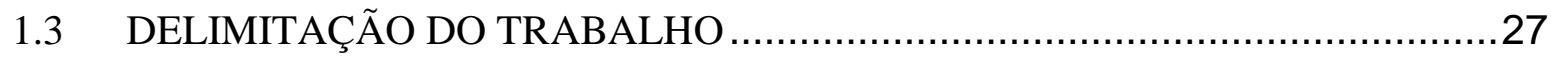

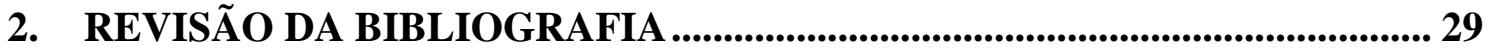

2.1 PRINCIPAIS PRODUTOS DA HIDRATAÇÃO DO CIMENTO PORTLAND ....29

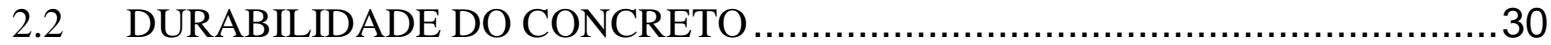

2.3 ATAQUE POR SULFATOS EM ESTRUTURAS DE CONCRETO ...................31

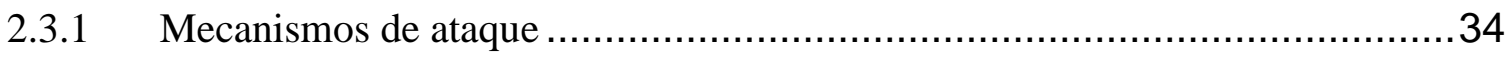

2.3.2 Reação química no ataque por sulfato de sódio (Na2SO4).......................41

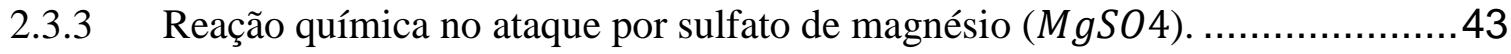

2.3.4 Variáveis que influenciam no ataque externo por sulfatos .......................46

2.3.5 Avaliação do ataque por sulfatos ................................................ 53

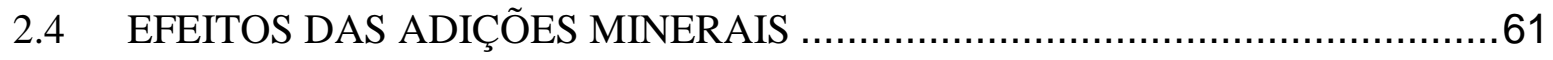

2.4.1 Influência das adições minerais no ataque por sulfatos ...........................63

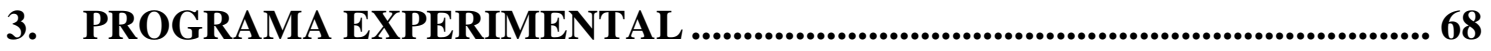

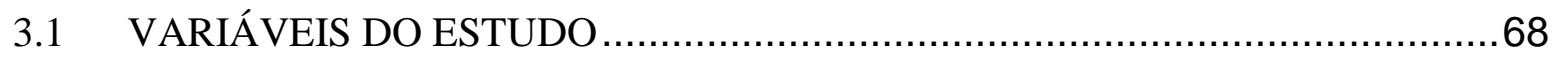

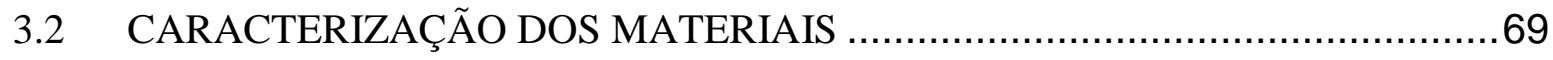

3.2.1 Ensaios em cimento e adições minerais.............................................69

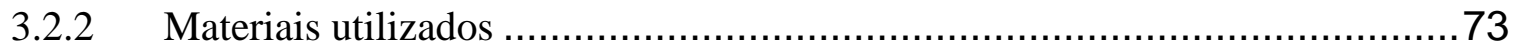

3.3 ANÁLISE QUÍMICA TEÓRICA DAS COMPOSIÇÕES ESTUDADAS ............82

3.4 AVALIAÇÃO DO ATAQUE POR SULFATOS EM ARGAMASSAS ...............85

3.4.1 Preparo de amostras para ensaios em argamassa .................................. 85

3.4.2 Preparo das soluções de exposição ......................................................... 88

3.4.3 Exposição das amostras de argamassa ............................................... 89

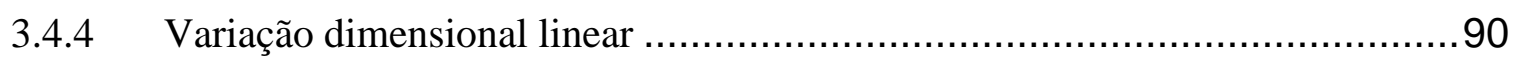

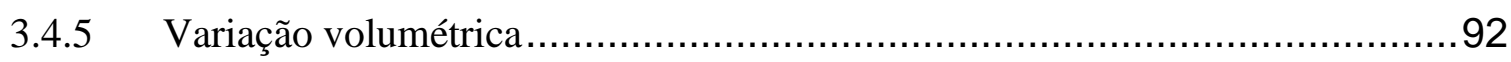

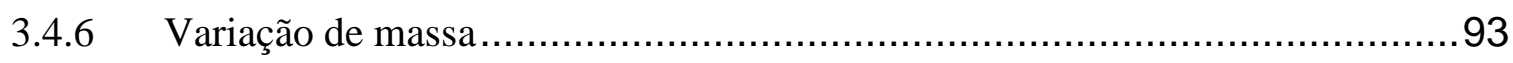

3.4.7 Resistência à compressão e à tração na flexão ....................................93

3.4.8 Variação da velocidade ultrassônica .................................................... 95 
3.4.9 Módulo de elasticidade

3.5 AVALIAÇÃO DO ATAQUE POR SULFATOS EM PASTAS DE CIMENTO ....98

3.5.1 Preparo de amostras para ensaios em pasta....................................... 99

3.5.2 Exposição às soluções de sulfato de sódio e sulfato de magnésio .................100

4 RESULTADOS E DISCUSSÕES 101

4.1 ATIVIDADE POZOLÂNICA DAS ADIÇÕES MINERAIS .........................101

4.2 ANÁLISE QUÍMICA TEÓRICA DOS CIMENTOS ................................... 103

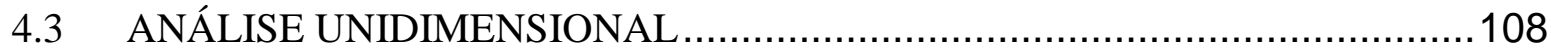

4.4 ANÁLISE QUÍMICO-MINERALÓGICA DAS COMPOSIÇÕES ESTUDADAS .... 122

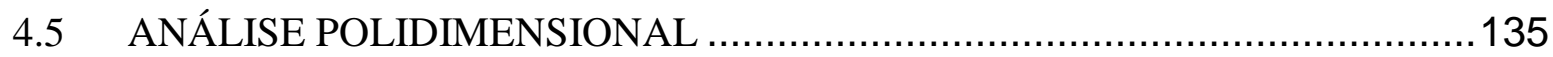

4.6 ANÁLISE DO COMPORTAMENTO MECÂNICO ….................................155

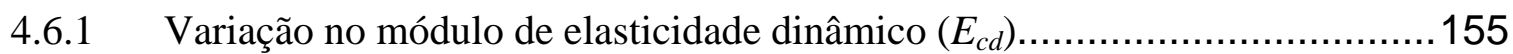

4.6.2 Variação na resistência à tração na flexão ........................................... 162

4.6.3 Variação de resistência à compressão ...........................................166

5. CONSIDERAÇÕES FINAIS ......................................................................... 179

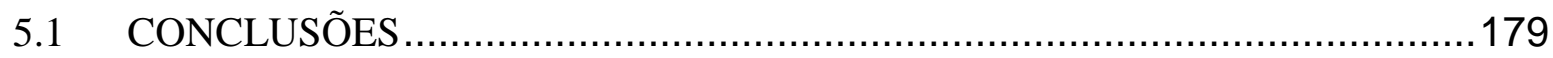

5.1.1 Quanto aos métodos utilizados para análise do ataque por sulfatos .............179

5.1.2 Quanto aos aglomerantes e adições .................................................181

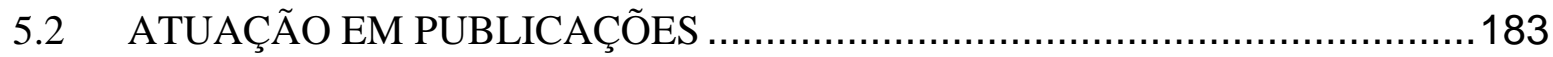

5.3 SUGESTÕES PARA TRABALHOS FUTUROS .................................. 185

REFERÊNCIAS BIBLIOGRÁFICAS ............................................................ 186

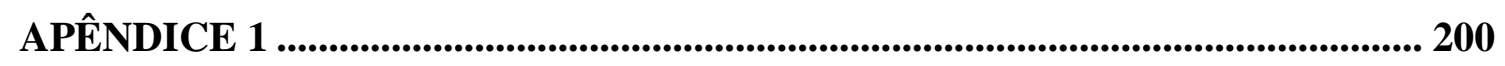




\section{INTRODUÇÃO}

As estruturas de concreto, desde sua fase de projeto e durante sua vida útil, estão sujeitas a uma série de fatores que poderão comprometer sua durabilidade e até mesmo sua estabilidade. As estruturas em geral, a partir do momento de sua execução, entram em contato com o ambiente no qual está inserida e ficam expostas aos agentes de deterioração, que podem alterar as propriedades dos materiais utilizados em menor ou maior escala, dependendo do desempenho pré-estabelecido para a estrutura (BAUER, 1994; MEHTA E MONTEIRO, 2014).

A deterioração do concreto pode ser causada por aspectos físicos, químicos ou uma combinação destes. O ataque por sulfatos é um termo usado para descrever uma série de reações químicas entre íons sulfato e compostos hidratados da pasta de cimento endurecida. Em comparação com outras reações químicas agressivas, os sulfatos são os mais danosos ao concreto quando presentes na forma de gases ou líquidos (BICZÓK, 1972; SKALNY, MARCHAND E ODLER, 2002; AL-AKHRAS, 2006; NEVILLE E BROOKS, 2013).

É comum encontrar concentrações de sulfatos agressivas ao concreto em ambientes naturais e industriais, como por exemplo: águas subterrâneas, que podem conter sulfatos de cálcio, magnésio, potássio e sódio; solos, águas marinhas e águas da agricultura; efluentes de fornos que usam combustíveis com alto grau de enxofre; efluentes de indústrias químicas; decomposição de materiais orgânicos em pântanos, lagos pouco profundos e poços de mineração; e canos de esgoto com a formação de gás sulfídrico $\left(H_{2} S\right)$, que é transformado em ácido sulfúrico pela ação de bactérias (COLLEPARDI, 2003; MONTEIRO E KURTIS, 2003; NEVILLE, 2004; MEHTA E MONTEIRO, 2014).

As adições minerais, por sua vez, têm apresentado benefícios a algumas propriedades do concreto, tanto no estado fresco quanto no estado endurecido. Soma-se ainda ao fato da substituição parcial do cimento por adições minerais, a melhoria da resistência à fissuração térmica, o aumento da impermeabilidade por refinamento dos poros, e como resultado da redução de alcalinidade, uma durabilidade maior a ataques químicos, tais como, águas sulfatadas e expansão álcali-agregado (NEVILLE, 1997; LAWRENCE et al., 2003; MEHTA E MONTEIRO, 2014; RAHHAL et al., 2012; ZENG et al., 2012).

$\mathrm{O}$ avanço nas pesquisas relacionadas à durabilidade do concreto disponibiliza, ao meio técnico-científico, informações capazes de tornar as estruturas de concreto mais duráveis. Inúmeras obras, com ênfase às expostas em ambientes altamente agressivos, apresentam 
degradação precoce, remetendo a falhas de especificação prévia que garantam adequada funcionalidade e durabilidade.

A adoção de práticas relacionadas ao aprimoramento da durabilidade do concreto, além de prolongar a vida útil, reduz as intervenções para a recuperação da estrutura e, consequentemente, o aporte financeiro para restabelecer o adequado desempenho.

\subsection{OBJETIVO}

Analisar o comportamento e a influência da substituição parcial do cimento Portland por adições minerais inertes e pozolânicas em mitigar a degradação do ataque por sulfato de sódio e sulfato de magnésio em argamassas e pastas de cimento Portland, por um período de exposição de 140 dias. Além disso, avaliar as características químicas do ataque por sulfatos, da variação dimensional e de propriedades físicas e mecânicas a partir a utilização de ensaios auxiliares além dos preconizados por norma.

\subsection{JUSTIFICATIVA}

O concreto, como qualquer outro material, está sujeito à ação do meio ambiente e pode, com isso, ter perda de durabilidade e até mesmo degradação prematura. O combate eficiente ante a deterioração do concreto só poderá se concretizar quando houver a valorização dos conhecimentos científicos. Os conhecimentos técnico-científicos devem ser aplicados à realidade da obra a fim de que sejam obtidas estruturas cada vez mais duráveis, usando os recursos disponíveis de forma consciente e eficiente. Neste sentido, o uso de adições minerais tem demonstrado uma boa eficácia quanto à melhoria de algumas propriedades do concreto, aumentando sua resistência e durabilidade quando utilizadas criteriosamente, haja vista que pode haver situações cuja presença de adições minerais reduz o desempenho do material.

Sabe-se que a deterioração do concreto ocorre basicamente por processos físicoquímicos, sendo que na prática, a deterioração raramente é devida a uma causa única. Geralmente estes processos estão fortemente entrelaçados e reforçando-se mutuamente ao ponto de que até mesmo a separação de causa e efeito se torna difícil (MEHTA E MONTEIRO, 2014).

$\mathrm{O}$ ataque por sulfatos se dá por uma série de reações químicas entre íons sulfato $\left(\mathrm{SO}_{4}^{2-}\right)$ e componentes hidratados da pasta de cimento em presença de umidade, podendo 
formar compostos expansivos, como por exemplo, gipsita, etringita e taumasita, capazes de gerar tensões de tração, fissurando e diminuindo a capacidade portante da matriz cimentícia, facilitando assim, a entrada de novos agentes agressivos. Ressalta-se, que uma vez iniciado o ataque por sulfatos às estruturas à base de cimento Portland, sua recuperação completa tornase difícil. Nada obstante, diagnosticar e prognosticar prematuramente este efeito danoso é importante para um tratamento adequado e que, ao mesmo tempo, decorra em menores danos estruturais. Por outro lado, a prevenção representa a prática mais eficiente no embate ao ataque por sulfatos, logo, adequar a estrutura ao ambiente ao qual estará inserida, ainda em fase de projeto, torna-se de grande importância, principalmente, em termos econômicos.

Diante deste contexto, neste estudo optou-se por analisar a capacidade de adições minerais em reduzir o efeito do ataque por sulfato no concreto. Tendo em vista que, por exemplo, materiais pozolânicos ao serem adicionados na mistura do concreto reagem com o hidróxido de cálcio formando compostos hidratados secundários, similares aos formados na hidratação do cimento Portland, essenciais para a resistência da matriz, além de poderem reduzir o calor de hidratação, o que diminui consideravelmente a fissuração térmica do concreto.

Considerando que todos os anos são gerados milhares de toneladas de resíduos industriais (como a cinza de casca de arroz), resíduos de construção civil (como resíduos de cerâmicas), entre outros, este trabalho estuda a possibilidade de emprego destes materiais como adição para concreto, uma vez que, a utilização dos mesmos pode trazer um benefício técnico, econômico, energético e ecológico.

- Justificativas técnicas: a utilização de adições minerais na composição do concreto pode trazer inúmeros benefícios às propriedades do concreto, como por exemplo: melhoria das propriedades reológicas, diminuindo a tendência de segregação e melhorando sua coesão; diminuição da permeabilidade devido ao refinamento dos poros capilares; redução do calor de hidratação; aumento da resistência aos ataques químicos; e redução da reação álcali-agregado. Todavia, algumas adições minerais podem, ao mesmo tempo em que melhoram alguma propriedade do concreto, piorar em outras, como por exemplo, dificultar a trabalhabilidade devido a elevada finura e consumo excessivo de água, favorecer o ataque de agentes agressivos devido a sua composição química. E, dependendo do teor adicionado, consumir toda a reserva alcalina do concreto, o que pode favorecer a corrosão de armaduras. Logo, torna-se de grande importância a identificação de teores adequados, para cada tipo de adição, para 
que se possa suprir as necessidades projetadas sem que haja decorrências prejudiciais em outras vertentes.

- Justificativas econômicas e energéticas: a redução do consumo do clínquer (podendo chegar a até $70 \%$ ) tem efeito significativo em termos econômicos, principalmente quando se trata de obras com grande consumo de concreto. Soma-se ainda que, a produção de cimento no Brasil, no ano de 2012 foi de aproximadamente 69 milhões de toneladas, segundo a Câmara Brasileira da Indústria da Construção (CBIC, 2014). Intimamente relacionado ao fator econômico está o consumo de energia, pois para a produção do clínquer, como exemplo, é necessário atingir uma temperatura de aproximadamente $1450{ }^{\circ} \mathrm{C}$ e em média consome-se $825 \mathrm{kcal} / \mathrm{kg}$ de acordo com um levantamento feito pelo Sindicato Nacional da Indústria do Cimento (SNIC) em 2008. Com este pano de fundo, se através de pesquisas, provar-se a viabilidade técnica da substituição parcial do clínquer por uma adição mineral que seja mais fácil de moer ou necessite ser processada a temperaturas abaixo da temperatura de queima do clínquer, isso vai se traduzir em menor gasto energético e redução de custo.

- Justificativas ecológicas: a utilização de adições minerais na fabricação do cimento possibilita: 1 - uso de menor quantidade de recursos naturais, como por exemplo, o calcário para a produção do clínquer; 2 - menor consumo de energia térmica para a calcinação e produção do mesmo; 3 - destinação de resíduos industriais evitando a acumulação em aterros que podem contaminar o ambiente. Desse modo, torna-se de grande importância o estudo de materiais que possam servir de adições minerais para produção de concreto. O resultado pode ajudar a atender a grande demanda de consumo de cimento no país e, ao mesmo tempo, reduzir o impacto ambiental do mesmo.

\subsection{DELIMITAÇÃO DO TRABALHO}

Esta pesquisa está delimitada à análise da influência de adições minerais, em substituição parcial do cimento Portland (teor de 10\%, em massa) na composição de barras prismáticas de argamassa e pastas que serão expostas ao ataque por sulfato de sódio e magnésio, por um período de 140 dias. O ataque por sulfatos será induzido por imersão dos corpos de prova em solução agressiva, ou seja, os íons sulfato serão de fonte externa às amostras. Cabe ressaltar, que estes ensaios serão realizados de forma acelerada, ou seja, há uma contribuição de energia externa para a aceleração das reações químicas, esta energia é 
proveniente da temperatura de exposição das barras, neste caso, imersas em solução à $40^{\circ} \mathrm{C}$, e, com elevada concentração íons sulfato $\left(6,763 \%\right.$ de $\mathrm{SO}_{4}^{2-} /$ litro $)$, baseado nas preconizações da ABNT NBR 13.583:2014. 


\section{REVISÃO DA BIBLIOGRAFIA}

Inicialmente ao se estudar a deterioração do concreto frente à ação dos sulfatos, é de grande importância ter o conhecimento dos principais produtos de hidratação do cimento Portland, esses que são agentes elementares neste processo.

\subsection{PRINCIPAIS PRODUTOS DA HIDRATAÇÃO DO CIMENTO PORTLAND}

Pesquisadores como Monteiro (1993); Neville (1997) e Mehta e Monteiro (2014), frisam que o concreto possui uma complexa microestrutura, e que, ter ciência deste fator, é de grande importância para obter um material mais durável, a fim de que durante sua vida útil, seja acometido por um grau de deterioração mais brando.

O concreto é constituído, em sua grande maioria, de agregados envoltos em uma pasta de cimento, contendo, ou não, adições e aditivos. Segundo Mehta e Monteiro (2014), a pasta de cimento na qual os agregados estão mergulhados, é composta por um material finamente pulverizado que, ao reagir quimicamente com a água, produz compostos hidratados com propriedades ligantes.

Conforme Bauer (1994), o cimento Portland é constituído fundamentalmente pela cal $(\mathrm{CaO})$, sílica $\left(\mathrm{SiO}_{2}\right)$, alumina $\left(\mathrm{Al}_{2} \mathrm{O}_{3}\right)$ e óxido de ferro $\left(\mathrm{Fe}_{2} \mathrm{O}_{3}\right)$ que constituem, geralmente, de $95 \%$ a $96 \%$ do total de óxidos. Outros constituintes estão presentes em menores quantidades, como por exemplo, magnésia $(\mathrm{MgO})$, anidro sulfúrico $\left(\mathrm{SO}_{3}\right)$, óxido de sódio $\left(\mathrm{Na}_{2} \mathrm{O}\right)$, óxido de potássio $\left(\mathrm{K}_{2} \mathrm{O}\right)$, óxido de titânio $\left(\mathrm{TiO}_{2}\right)$ e outras variadas substâncias.

O cimento Portland é um composto formado a partir da moagem do clínquer com adição de sulfato de cálcio dihidratado (gipsita), calcário, pozolanas ou escórias. Os principais constituintes do clínquer são: Silicato tricálcico $\left(C_{3} S\right)$, Silicato dicálcico $\left(C_{2} S\right)$, Aluminato tricálcico $\left(C_{3} A\right)$ e o Ferroaluminatotetracálcico $\left(C_{4} A F\right)$.

Quando a pasta de cimento é hidratada, sem o acréscimo de adições minerais, de acordo com Mehta e Monteiro (2014), as quatro principais fases sólidas existentes na pasta de cimento são:

$\rightarrow$ Silicato de cálcio hidratado: é conhecido como C-S-H e representa 50 a $60 \%$ do volume de sólidos da pasta de cimento, quando completamente hidratada. É a fase mais importante, determinando as propriedades de resistência da pasta. Resulta da hidratação do $\left(C_{2} S\right)$ e do $\left(C_{3} S\right)$; 
$\rightarrow$ Hidróxido de Cálcio $(\mathrm{CH})$ : é também chamado de portlandita e responsabiliza-se por 20 a $25 \%$ do volume total de sólidos na pasta de cimento hidratada. Com a hidratação, formam-se grandes cristais de hidróxido de cálcio, o que limita a sua área superficial e o deixa menos resistente do que o $C-S-H$. Os cristais de hidróxido de cálcio são os responsáveis por manter alcalino o $p H$ da solução aquosa contida nos poros do concreto;

$\rightarrow$ Sulfoaluminatos de cálcio hidratados: ocupam de 15 a $20 \%$ do volume total da pasta de cimento hidratada. Durante a hidratação do cimento, dependendo da concentração de aluminato e íons sulfato na solução, o produto cristalino formado é o trissulfoaluminato de cálcio hidratado (AFt), também conhecido como etringita, ou o monossulfoaluminato de cálcio hidratado (AFm). A etringita geralmente é o primeiro hidrato a se cristalizar devido à alta relação sulfato/aluminato na fase aquosa, ao longo da primeira hora de hidratação. Mais tarde, após o sulfato ter sido consumido, quando a concentração de aluminato volta a se elevar, a etringita se torna instável e é convertida para a fase de monossulfato, que é o produto final da hidratação de cimentos Portland com mais de $5 \%$ de $\left(C_{3} A\right)$. A presença de monossulfato torna o concreto vulnerável ao ataque por sulfato, haja vista que o excesso de íons $\mathrm{SO}_{4}^{2-}$ advindas, por exemplo, de fonte externa, pode reconverter o monossulfoaluminato de cálcio hidratado em etringita secundária, sendo esta última, mais volumosa;

$\rightarrow$ Grão de clínquer não hidratados: são partículas da ordem de 1 a $50 \mu \mathrm{m}$ que não entraram em contato com água de hidratação.

\subsection{DURABILIDADE DO CONCRETO}

A insuficiência da durabilidade se manifesta por uma deterioração que pode ser originada por fatores externos ou por causas internas ao próprio concreto. As diferentes formas de ação podem ser físicas, químicas ou mecânicas e raramente a deterioração do concreto se deve a uma única causa isolada (NEVILLE, 1997).

Segundo Mehta e Monteiro (2014), há uma estreita relação entre resistência e durabilidade, sendo definida como vida útil de um material sob algumas condições ambientais. Contudo, Hoppe Filho et al. (2013) e Medeiros Junior et al. (2014) evidenciaram em seus experimentos que a resistência à compressão não garante a durabilidade em condições de serviço, embora seja um fator de influência relevante. Ou seja, é simplificar demais considerar que basta regular a resistência à compressão do concreto para que sua 
durabilidade seja adequada, como é feito no controle das maiorias das obras atuais. Pode-se dizer que a durabilidade do concreto de cimento Portland é definida como sua capacidade de resistir à ação das intempéries, ataques químicos, abrasão ou qualquer outro processo de deterioração, isto é, o concreto durável conservará a sua forma original, qualidade e capacidade de utilização quando exposto ao meio ambiente.

De acordo com Souza e Ripper (1998), a associação dos conceitos vida útil e durabilidade é inevitável. Os autores entendem como durabilidade, o parâmetro que relaciona a aplicação das características de deterioração do concreto e dos sistemas estruturais, a uma determinada construção, individualizando pela resposta que dará aos efeitos da agressividade ambiental, definindo então, a vida útil da mesma.

\subsection{ATAQUE POR SULFATOS EM ESTRUTURAS DE CONCRETO}

Os íons sulfato $\left(\mathrm{SO}_{4}^{2-}\right)$ presentes em meios podem vir a difundirem-se por entre os poros da estrutura do concreto e reagirem quimicamente com os materiais de base cimentícia, e, com o tempo, podem causar deterioração do concreto, reduzindo consideravelmente a sua durabilidade.

A interação dos íons $\left(\mathrm{SO}_{4}^{2-}\right)$ com os compostos hidratados do cimento Portland podem causar expansão, fissuração, lascamento e perda de massa em muitas das estruturas de concreto expostas a tais agentes agressivos, como por exemplo, pontes, píeres, fundações, tubulações de concreto, etc. Os íons sulfato podem ter origem nos solos, águas subterrâneas e águas marinhas que, na maioria das vezes podem ser encontrados em combinação com íons metálicos como o sódio, magnésio, cálcio e potássio, e também em estruturas moleculares que possuem caraterísticas de metais, como por exemplo, o amônio (MEHTA, 1983; WEE et al., 2000; AL-AKHRAS, 2006).

De acordo com Brown (2002), o ataque por sulfatos pode ocorrer de diferentes formas, sendo estas, classificadas em cinco categorias:

- Forma clássica de ataque por sulfatos, associado à formação de gipsita e formação de etringita secundária: é a forma mais comum de ataque por sulfatos, é resultante da difusão de íons sulfato, oriundo de uma fonte externa, que interagem com os produtos hidratados do cimento que compõem a massa cimentante, como por exemplo: hidróxido de cálcio, formando gipsita; e, aluminatos, formando etringita. Estes dois produtos são mais volumosos (cerca de 1,2 a 2,2 vezes) que os produtos iniciais da reação de hidratação do cimento e, como consequência, há a geração de 
tensões internas na pasta, o que poderá ocasionar expansão, fissurações e decorrente deterioração (HOOTON, 1993; AL-AKHRAS, 2006);

- Efeito físico, associado à cristalização dos sais de sulfato: Tal efeito é comumente associado à recristalização de soluções contendo sais de sulfatos como, por exemplo, $\mathrm{Na}_{2} \mathrm{SO}_{4}$, ou seja, conversão dos íons solubilizados em Mirabilita $\left(\mathrm{Na}_{2} \mathrm{SO}_{4} \cdot 10 \mathrm{H}_{2} \mathrm{O}\right)$, e, por fim, após nova recristalização, em Thenardita $\left(\mathrm{Na}_{2} \mathrm{SO}_{4}\right)$ (conforme pode ser visto na Eq. 1 e Eq. 2). Concentrações de íons $\left(\mathrm{SO}_{4}^{2-}\right)$, em meio aquoso, penetram no interior da estrutura cimentícia por capilaridade, permeabilidade ou difusão. Todavia, estas concentrações podem ficar muito elevadas devido à evaporação, relativamente lenta, da água, formando assim, os cristais. Consequentemente, estes sais cristalinos passam a ocupar um maior volume do que quando estavam dissolvidos em meio aquoso, portanto, este ganho de volume pode gerar expansão e degradação do concreto (TIPLER E MOSCA, 2006; BRUNETAUD et al. 2012);

$$
\begin{array}{ccc}
\multicolumn{2}{c}{\text { Evanoracão }} \\
2 \mathrm{Na}^{+}+\mathrm{SO}_{4}^{2-} & \rightarrow & \mathrm{Na}_{2} \mathrm{SO}_{4} \cdot 10 \mathrm{H}_{2} \mathrm{O} \\
\text { Solucão } & \multicolumn{2}{c}{\text { Cristalizacão }} \\
& \text { Recristalizacão } \\
\mathrm{Na}_{2} \mathrm{SO}_{4} \cdot 10 \mathrm{H}_{2} \mathrm{O} & \rightarrow & \mathrm{Na}_{2} \mathrm{SO}_{4} \\
\text { Mirabilita } & & \text { Thenardita }
\end{array}
$$$$
\text { Eq. } 1
$$

Eq. 2

- Ataque interno, associado à presença de contaminantes nos compósitos: nesta forma de ataque por sulfatos, o íon $\left(\mathrm{SO}_{4}^{2-}\right)$ é de origem interna ao próprio material de base cimentícia, através de agregados contaminados ou cimentos com teores elevados de tri-óxido de enxofre $\left(\mathrm{SO}_{3}\right)$. Tais quais, servem como fonte de liberação de íons sulfato passíveis de reação com os produtos da hidratação do cimento Portland;

- Ataque interno, associado à formação de etringita tardia (DEF - Delayed Ettringite Formation): segundo Collepardi (2003), este processo de formação da etringita tardia inicia-se depois que o endurecimento do concreto é substancialmente completado, e geralmente é associado à decomposição térmica (temperaturas próximas ou maiores que $70^{\circ} \mathrm{C}$ ) de etringita primária, ocorrendo, principalmente, em estruturas de concreto massa, cujo calor de hidratação pode 
ultrapassar os $70{ }^{\circ} \mathrm{C}$. Esta decomposição da etringita primária libera íons sulfatos, que ficam absorvidos nas estruturas de silicato de cálcio hidratados (C-S-H), e, posteriormente, os íons são dissolvidos por um meio aquoso, reagem novamente, e então formam a etringita tardia. Geralmente, o espaço físico onde ocorrem estas interações e formação deste produto expansivo é na zona de transição, ou zona de interface pasta-agregado, que constantemente é apontada como a região mais frágil da estrutura interna do concreto, pois a adesão entre a pasta e o agregado, de modo geral, é dada pelo contato físico de ambos e pela força de atração de Van Der Waals, tida como, relativamente fraca (TIPLER E MOSCA, 2006; MEHTA E MONTEIRO, 2014);

- Formação de taumasita: ocorre devido ao ataque simultâneo dos íons de sulfato $\left(\mathrm{SO}_{4}^{2-}\right)$ e de carbonatos $\left(\mathrm{CO}_{3}^{2-}\right)$ que, associados à baixa temperatura, resulta na formação de taumasita $\left(\mathrm{CaSiO}_{3} \cdot \mathrm{CaCO}_{3} \cdot \mathrm{CaSO}_{4} \cdot 15 \mathrm{H}_{2} \mathrm{O}\right)$. Comumente a formação deste produto é acompanhada pela mais severa perda de resistência e adesão, pois transforma o concreto endurecido em uma massa pastosa, tendo em vista que uma parte significativa da estrutura C-S-H pode ser destruída pela reação. Este processo pode ocorrer com todos os tipos de sais de sulfato e é favorecido pela umidade atmosférica e baixas temperaturas $\left(<10^{\circ} \mathrm{C}\right)$ (COLLEPARDI, 2003; CRAMMOND, 2003).

De acordo com Biczók (1972), como resultado do ataque de sais de sulfato, em um momento inicial, o concreto tem sua resistência aumentada. Seus poros são preenchidos por cristais formados com reações de sulfatos, aumentando sua compacidade portante. Entretanto, estes cristais continuam a aumentar de volume, exercendo tensões internas que acabam deteriorando o concreto. Os sais de sulfato comumente encontrados na natureza são listados a seguir, em ordem alfabética:

- Sulfato de alumínio: possui fórmula molecular $\mathrm{Al}_{2}\left(\mathrm{SO}_{4}\right)_{3}$, é frequentemente utilizado como agente coagulante em sistemas de tratamento de água e esgoto, assim como na manufatura de papéis e na indústria têxtil;

- Sulfato de amônio: possui fórmula molecular $\left(\mathrm{NH}_{4}\right)_{2} \mathrm{SO}_{4}$, é um composto inorgânico comumente usado na agricultura como fertilizante, desta forma, solos e águas subterrâneas próximas às zonas de agricultura podem conter concentrações elevadas de sulfato de amônio; 
- Sulfato de cálcio: possui fórmula molecular $\mathrm{CaSO}_{4}$, este composto serve como matéria prima na fabricação de giz escolar e gesso. Na natureza pode se apresentar como um composto mineral na forma de cristal de anidrita e gipsita;

- Sulfato de cobre: possui fórmula molecular $\mathrm{CuSO}_{4}$, em sua forma penta-hidratado, tem função fungicida e, quando misturado com cal, é utilizado para controle de fungos na agricultura. É também utilizado como algicida no tratamento de águas;

- Sulfato de ferro: possui fórmula molecular $\mathrm{FeSO}_{4}$, comumente utilizado como corante, todavia, a exposição ao ar de minerais como a marcassita e a pirita, ambos $\mathrm{FeS}_{2}$, podem, por oxidação, formar sulfato de ferro, podendo estar presentes em águas subterrâneas, solos e agregados (BAUER, 1994);

- Sulfato de magnésio: fórmula molecular $\mathrm{MgSO}_{4}$ é comumente encontrada em solos e águas subterrâneas devido ao seu uso na agricultura e jardinagem, pois é empregado como corretor da deficiência de magnésio dos solos. Pode ser encontrado também em efluentes industriais e águas marinhas;

- Sulfato de potássio: formulação molecular $\mathrm{K}_{2} \mathrm{SO}_{4}$, é um composto químico muito utilizado como adubo químico e fertilizante, com isso, é comumente encontrado em solos e águas subterrâneas;

- Sulfato de sódio: possui fórmula molecular $\mathrm{Na}_{2} \mathrm{SO}_{4}$, é um composto muito utilizado em diversas aplicações industriais como processamento de celulose, assim como, na produção de vidros, detergentes e corantes para tecido. Pode ser oriundo do mineral mirabilita $\left(\mathrm{Na}_{2} \mathrm{SO}_{4} \cdot 10 \mathrm{H}_{2} \mathrm{O}\right)$, e é um dos sais de sulfatos mais comuns encontrados em solos, lagos, rios e águas subterrâneas.

Deste modo, o escopo deste trabalho é o estudo da interação dos sulfatos de sódio e de magnésio, haja vista que são os mais encontrados na natureza. Por fim, a avaliação será pela forma clássica de ataque por sulfatos, ou seja, de íons sulfato oriundos de uma fonte externa, que penetram na pasta de cimento hidratada por meio da sua microestrutura porosa.

\subsubsection{Mecanismos de ataque}

$\mathrm{O}$ ataque por sulfatos, assim como a maioria das interações do meio com as estruturas de concreto, são processos de deterioração que envolve aspectos tanto químicos quanto físicos, pois ambos os efeitos estão intrinsecamente conectados, tendo em vista que os 
processos expansivos, especificamente a sua ocorrência e cinética, são, em certa medida, relacionados com as condições nas quais podem ocorrer. A exemplo disso, a permeabilidade do concreto, um aspecto físico, é essencial quanto à penetração de íons sulfato, estes que, consequentemente, podem vir a reagir quimicamente com produtos da hidratação do cimento, gerando produtos expansíveis, podendo fissurar o concreto, o que aumentará a permeabilidade do mesmo, permitindo o ingresso de mais soluções agressivas.

De modo geral, pode-se caracterizar o processo de ataque por sulfatos em três etapas: difusão dos íons agressivos para o interior do concreto; interações químicas entre os íons e os produtos de hidratação do cimento; e, por fim, deterioração da matriz cimentante (NEVILLE, 1997; SANTHANAM et al., 2003; MEHTA E MONTEIRO, 2014).

Contudo, cabe evidenciar os fenômenos que têm maior influência na avaliação do ataque por sulfato, que são: a concentração da solução agressiva; presença de um ou mais agentes agressivos, como por exemplo, interação entre íons sulfato e íons carbonato; temperatura; ciclos de molhagem e secagem; e efeitos de tensões mecânicas. Todavia, em ensaios laboratoriais, cabe acrescentar ainda: $p H$; dimensões e forma dos corpos de prova; e por fim, o critério de avaliação (SCHNEIDER e CHEN, 1998; SANTHANAM, 2001). Os produtos decorrentes do ataque por fonte externa de sulfatos à matriz cimentícia são:

- $\quad$ Formação de Gipsita $\left(\mathrm{CaSO}_{4} \cdot 2 \mathrm{H}_{2} \mathrm{O}\right)$ :

O sulfato de cálcio dihidratado, ou gipsita, pode ser formado pelo ataque externo por sulfatos devido à interação dos íons $\mathrm{SO}_{4}^{2-}$ em meio aquoso com a portlandita (Eq. 3), e, segundo Neville (1997) possui propriedades expansivas, podendo chegar, na fase sólida, a 1,2 vezes do volume do produto inicial, ou seja, da portlandita.

$$
\mathrm{SO}_{4}^{2-}+\mathrm{Ca}(\mathrm{OH})_{2}+2 \mathrm{H}_{2} \mathrm{O} \rightarrow \mathrm{CaSO}_{4} \cdot 2 \mathrm{H}_{2} \mathrm{O}+2 \mathrm{OH}^{-}
$$

Maior volume

Eq. 3

A formação de gipsita, como resultado de reações por troca de cátions, é capaz de causar expansão, dependendo do tipo de cátion presente na solução de sulfato $\left(M g^{2+}\right.$, $\mathrm{Na}^{+}$e $\left.\mathrm{K}^{+}\right)$. Neste processo de degradação, tanto o hidróxido de cálcio $\left[\mathrm{Ca}(\mathrm{OH})_{2}\right]$ como o $C-S-H$ da pasta de cimento Portland podem ser convertidos em gipsita (TIAN e COHEN, 2000; MEHTA e MONTEIRO, 2014). 
Cabe salientar que na reação do $C-S-H$ com íons sulfeto (Eq. 4), por exemplo, há a decomposição do silicato de cálcio hidratado em gipsita e sílica gel, logo, além da formação do produto expansivo há também perda de resistência mecânica do compósito (SKALNY et al. 2002).

$$
\begin{aligned}
& \text { Gipsita Sílica Gel } \\
& 3 \mathrm{SO}_{3}+6 \mathrm{H}_{2} \mathrm{O}+3 \mathrm{CaO} \cdot 2 \mathrm{SiO}_{2} \cdot 3 \mathrm{H}_{2} \mathrm{O} \rightarrow 3 \mathrm{CaSO}_{4} \cdot 6 \mathrm{H}_{2} \mathrm{O}+2 \mathrm{SiO}_{2} \cdot 3 \mathrm{H}_{2} \mathrm{O} \\
& \text { C-S-H }
\end{aligned}
$$

- Formação de Etringita $\left(3 \mathrm{CaO} \cdot \mathrm{Al}_{2} \mathrm{O}_{3} \cdot 3 \mathrm{CaSO}_{4} \cdot 32 \mathrm{H}_{2} \mathrm{O}\right)$ :

As expansões do concreto relacionadas aos sulfatos, geralmente são associadas à etringita, esta que, pode ser formada em concentrações relativamente baixas de sulfatos, sendo desta forma, o produto de expansão do concreto mais comum. Em virtude da baixa resistência à tração do concreto, deformações provenientes da expansão podem levar à fissuração e, consequentemente, redução da resistência e do desempenho da peça (SKALNY et al. 2002).

Durante o processo de hidratação do cimento Portland, a gipsita, adicionada ao cimento para o controle de pega, combina-se com os aluminatos, formando etringita primária. Contudo, após o consumo completo do sulfato, gradualmente a etringita é convertida em monossulfoaluminato de cálcio hidratado, que é o produto final da hidratação do concreto (Eq. 5). Entretanto, se o monossulfoaluminato de cálcio hidratado entrar em contato com íons de sulfato, provindos, por exemplo, de uma fonte externa, a reação pode ser revertida, ou seja, o monossulfoaluminato pode ser reconvertido em etringita (Eq. 6) (TAYLOR, 1997).

Escassez de sulfato:

monossulfoaluminato de cálcio

2. $\left(3 \mathrm{CaO} \cdot \mathrm{Al}_{2} \mathrm{O}_{3}\right)+6 \mathrm{CaO} \cdot \mathrm{Al}_{2} \mathrm{O}_{3} \cdot 3 \mathrm{SO}_{3} \cdot 32 \mathrm{H}_{2} \mathrm{O}+4 \mathrm{H}_{2} \mathrm{O} \rightarrow 3 \cdot\left(4 \mathrm{CaO} \cdot \mathrm{Al}_{2} \mathrm{O}_{3} \cdot \mathrm{SO}_{3} \cdot 12 \mathrm{H}_{2} \mathrm{O}\right)$ $\mathrm{C}_{3} \mathrm{~A}$

Excesso de sulfatos:

$$
\begin{aligned}
& \text { monossulfoaluminato de cálcio } \\
& \begin{array}{l}
2 \mathrm{CaSO}_{4} \cdot 4 \mathrm{H}_{2} \mathrm{O}+4 \mathrm{CaO} \cdot \mathrm{Al}_{2} \mathrm{O}_{3} \cdot \mathrm{SO}_{3} \cdot 12 \mathrm{H}_{2} \mathrm{O}+16 \mathrm{H}_{2} \mathrm{O} \rightarrow 3 \mathrm{CaO} \cdot \mathrm{Al}_{2} \mathrm{O}_{3} \cdot 3 \mathrm{CaSO}_{4} \cdot 32 \mathrm{H}_{2} \mathrm{O} \\
\text { Gipsita }
\end{array} \\
& \text { Trissulfoaluminato de cálcio (Etringita) }
\end{aligned}
$$


Portanto, quando produtos hidratados do cimento (portlandita e monossulfoaluminato de cálcio hidratado) entram em contato com meio ambiente contendo sulfato, muda-se a condição de equilíbrio. Primeiro há a formação de gipsita devido à reação da portlandita com o sulfato, e então, o monossulfoaluminato de cálcio hidratado tende a retornar ao seu estado inicial, formando etringita.

Todavia, estas são as abordagens relacionadas ao íon $\mathrm{SO}_{4}^{2-}$, contudo o cátion associado ao ânion comentado, também pode interagir com os produtos da hidratação do cimento Portland, seja em reação direta ou como catalizador.

Assim, um aspecto importante no estudo é em relação ao cátion associado, pois o comportamento físico e químico da matéria depende da maneira pela qual os átomos interagem, e esta, por sua vez, dependem da sua estrutura (RUSSELL, 1994). O mecanismo de ataque para o ânion $\left(\mathrm{SO}_{4}^{2-}\right)$ é diferente para cada um dos cátions ( $\mathrm{Ca}, \mathrm{Na}, \mathrm{K}, \mathrm{Mg}$, etc.) uma vez que cada cátion possui uma interação distinta em relação à matriz cimentícia, e também, a proporção entre ânion e cátion de cada um dos sais também é variável, tendo em vista que a massa molecular é dependente da massa de cada um dos átomos.

Desta forma, são vários os estudos que apontam que soluções de $\mathrm{MgSO}_{4}$ são mais agressivas que soluções de $\mathrm{Na}_{2} \mathrm{SO}_{4}$ para a mesma concentração, como por exemplo, Neville (1997), Santhanam et al. (2002), Skalny et al. (2002), Neville (2004), Behfarnia e Farshadfar (2013) e Mehta e Monteiro (2014). Isto porque na solução de sulfato de sódio a reação com os produtos hidratados do cimento ocorre com os ânions $\mathrm{SO}_{4}^{2-}$, e, sua principal reação é com o hidróxido de cálcio $\mathrm{Ca}(\mathrm{OH})_{2}$, formando gipsita, e quando há também a interação da gipsita com aluminatos, há a formação de etringita (SANTHANAM, et al., 2002), enquanto que o cátion $\mathrm{Na}^{+}$interage com o $\mathrm{OH}^{-}$liberado na formação da gipsita, o que ocasiona em um aumento do $\mathrm{pH}$ da solução, que pode servir como catalizador da reação deletéria (NEVILLE, 2004). Enquanto que para a solução de sulfato de magnésio, além da reação com os ânions $\mathrm{SO}_{4}^{2-}$, há também reação com os cátions $\mathrm{Mg}^{2+}$. Desta forma, o $\mathrm{MgSO}_{4}$ tem sua reação com o $\mathrm{Ca}(\mathrm{OH})_{2}$ formando brucita $\left(\mathrm{Mg}(\mathrm{OH})_{2}\right)$, gipsita; etringita (na interação com fases aluminatos), e, também com as estrutura $C-S-H$, onde há a descalcificação do silicato de cálcio hidratado e formação de silicato de magnésio hidratado $(M-S-H)$, que possui baixa capacidade de ligação e nenhuma propriedade cimentante (COHEN e BENTUR, 1998; CHATVEERA e LERTWATTANAURUK, 2009). 
- Mecanismo de ataque para o sulfato de sódio:

Santhanam et al. (2003) propuseram um passo a passo dos mecanismos de ataque para o sulfato de sódio em ensaio laboratorial com barras de argamassa:

Passo 1 - As amostras de argamassa são imersas em solução agressiva de sulfato de sódio de $p H$ entre $6-8$;

Passo 2 - A solução ao redor dos corpos de prova tende a ter um aumento no $p H$ para uma faixa de 11 - 12, podendo até chegar a 13, devido ao início da interação da solução agressiva com a portlandita, o que libera íons $\mathrm{OH}^{-}$formando $\mathrm{NaOH}$, o que aumenta o $p H$. Somado a este fato, ainda há a penetração dos ânions de sulfato para o interior da amostra. Desta forma, inicia-se a formação de gipsita e etringita nos vazios da região mais superficial dos corpos de prova, entretanto, sem causar tensões internas;

Passo 3 - Os produtos formados pela reação preenchem os vazios das camadas superficiais da pasta e começam a gerar tensões internas de tração que são suportadas pelas camadas alteradas da pasta de cimento;

Passo 4 - As tensões de tração exercidas pelos produtos expansivos ultrapassam a capacidade resistente da pasta de cimento, desta forma, inicia-se o processo de fissuração;

Passo 5 - A difusão dos íons agressivos tende a aumentar devido ao surgimento das fissuras. Desta forma há o preenchimento dos poros, por produtos expansivos, nas regiões do entorno por onde há o desenvolvimento da fissuração;

Passo 6 - Iniciam-se as interações da solução agressiva com regiões mais profundas da pasta, formando mais produtos expansivos e dando sequência ao mecanismo de ataque.

A Figura 1 representa o processo de degradação de uma barra de argamassa imersa em solução de sulfato de sódio. 

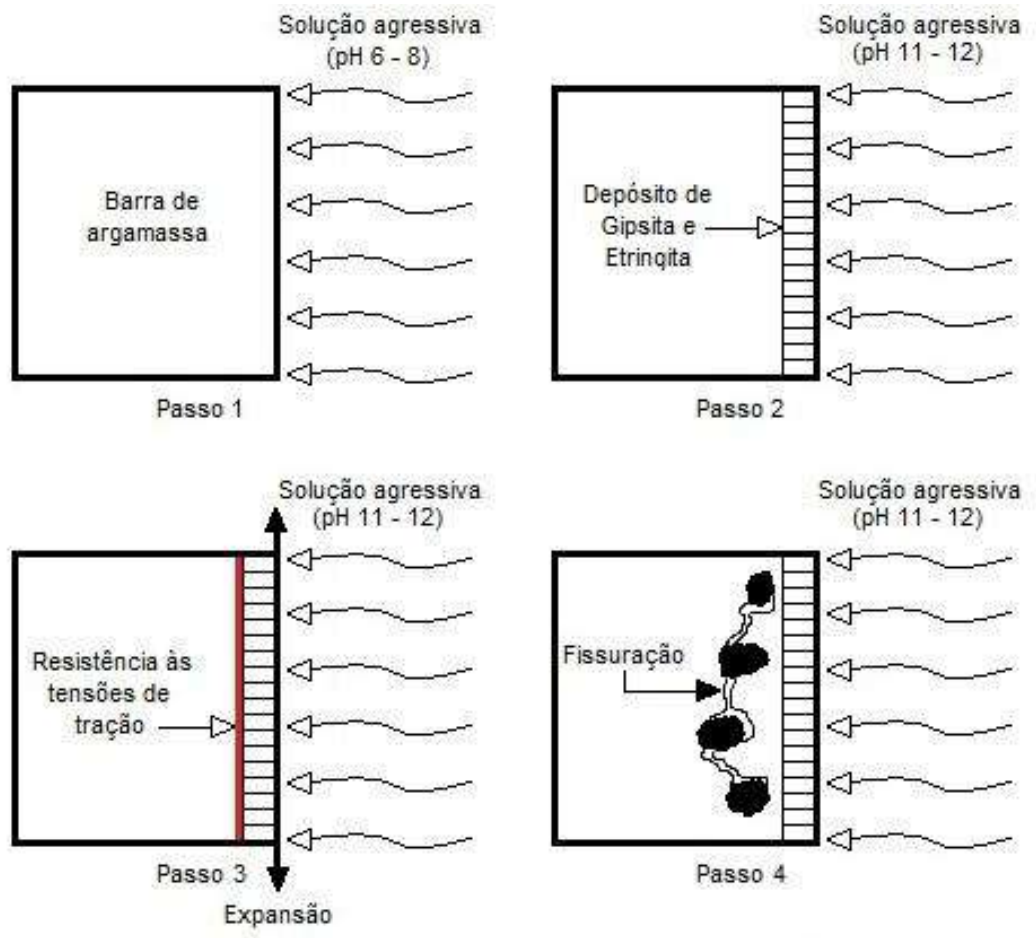

Passo 4
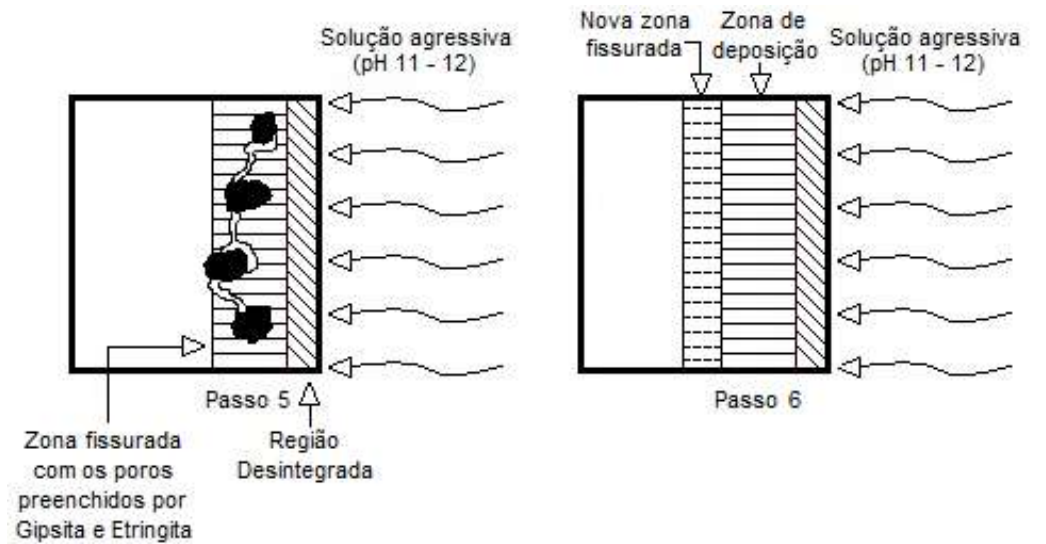

Passo 6

Figura 1: Mecanismo de ataque por sulfato de sódio. Adaptado de Santhanam, Cohen e Olek (2003).

- Mecanismo de ataque para o sulfato de magnésio:

Assim como para o ataque por sulfato de sódio, Santhanam et al. (2003) também propuseram um passo a passo dos mecanismos de ataque do sulfato de magnésio em ensaio laboratorial com barras de argamassa:

Passo 1 - As amostras de argamassa são imersas em solução agressiva de sulfato de magnésio de $p H$ entre $7-8$;

Passo 2 - Logo após a imersão a solução ao redor dos corpos de prova tendem a ter um leve aumento no $p H$ para uma faixa de 9 - 10 devido à interação da solução presente nos poros superficiais das amostras que possuem $p H$ elevado. Juntamente com este fenômeno há a formação de brucita $\left[\mathrm{Mg}(\mathrm{OH})_{2}\right]$, e gipsita na superfície das 
barras, devido à reação entre a solução agressiva e o $\mathrm{Ca}(\mathrm{OH})_{2}$ da pasta de cimento hidratada.

Passo 3 - Os produtos formados pela reação, gipsita, brucita e etringita (esta última que após redução do $p H$ pode decompor-se em gipsita), preenchem os vazios das camadas superficiais da pasta e começam a gerar tensões internas de tração que ultrapassam a capacidade resistente da pasta de cimento, desta forma, inicia-se o processo de fissuração;

Passo 4 - Com a formação de brucita, o $p H$ da solução aquosa presente nos poros da argamassa começa a baixar, pois tal material possui solubilidade muito inferior a da portlandita, logo libera menos $\mathrm{OH}^{-}$em meio aquoso. Desta forma há a desestabilização das estruturas $C-S-H$ que começam a liberar hidróxido de cálcio para elevação do $p H$. Todavia, este processo, além da descalcificação do silicato de cálcio hidratado, permite a formação de silicato de magnésio hidratado $(M-S-H)$ que não possui nenhuma capacidade cimentante.

A Figura 2 representa o processo de degradação de uma barra de argamassa imersa em solução de sulfato de magnésio. Todavia, cabe ressaltar que as reações químicas que ocorrem com a interação de solução de sulfato de sódio e de magnésio serão explicadas detalhadamente nos capítulos 2.3 .2 e 2.3.3, a seguir.
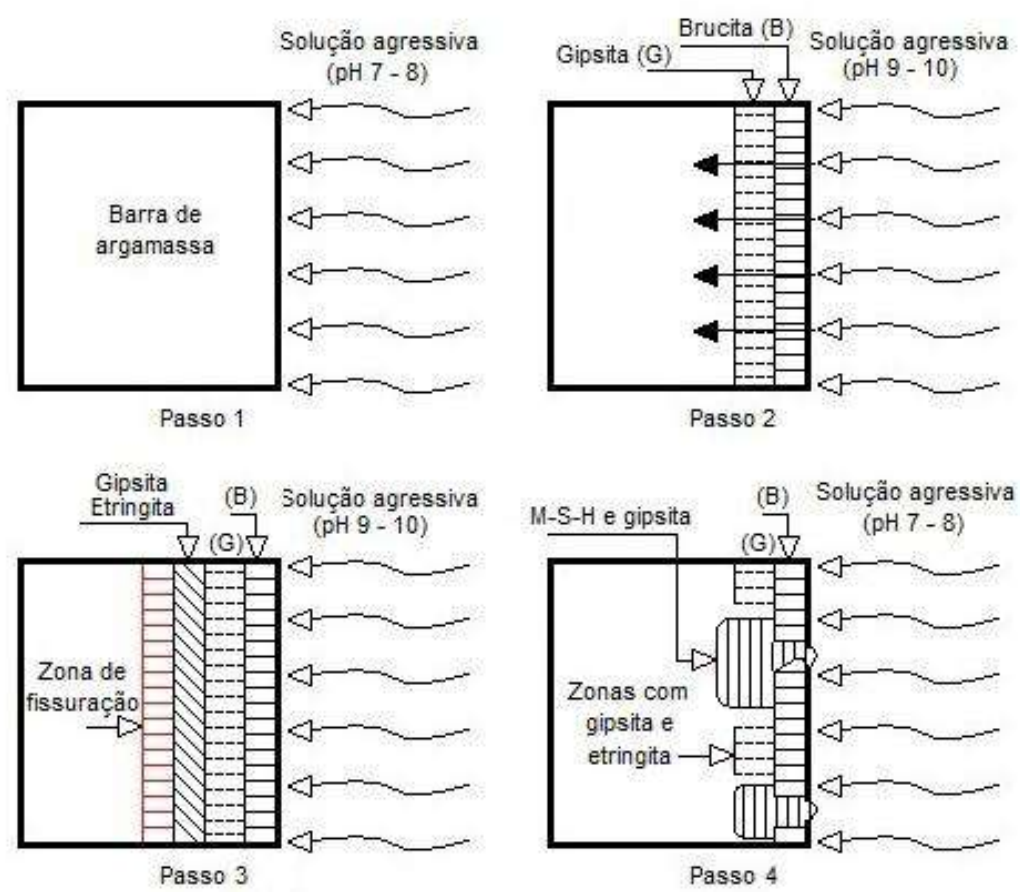

Figura 2: Mecanismo de ataque por sulfato de magnésio. Adaptado de Santhanam, Cohen e Olek (2003) 
2.3.2 Reação química no ataque por sulfato de sódio $\left(\mathrm{Na}_{2} \mathrm{SO}_{4}\right)$.

O sulfato de sódio anidro apresenta uma massa molar de 142,04 $\mathrm{g} / \mathrm{mol}$ composta em $32,37 \%$ de $\mathrm{Na}^{+}$(2 x 22,99 u.m.a.) e 67,63\% de $\mathrm{SO}_{4}^{2-}$ (32,06 u.m.a. +4 x 16,00 u.m.a.) solubilidade de $4,76 \mathrm{~g} / 100 \mathrm{~mL}$ de água a uma temperatura de $0{ }^{\circ} \mathrm{C}$, cerca de vinte vezes maior que a do sulfato de cálcio, desta forma, o $\mathrm{Na}_{2} \mathrm{SO}_{4}$ é mais agressivo. As interações do sulfato de sódio podem ocorrer com dois produtos da hidratação do cimento: com o hidróxido de cálcio $\left[\mathrm{Ca}(\mathrm{OH})_{2}\right]$ (Eq. 7) e com as fases do sulfoaluminato de cálcio hidratado (Eq. 8).

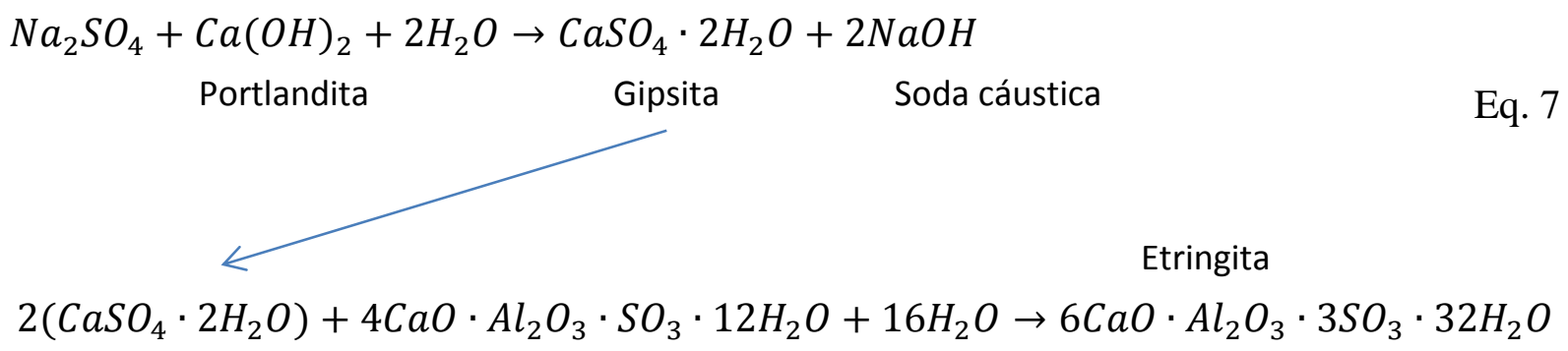

$2\left(\mathrm{CaSO}_{4} \cdot 2 \mathrm{H}_{2} \mathrm{O}\right)+4 \mathrm{CaO} \cdot \mathrm{Al}_{2} \mathrm{O}_{3} \cdot \mathrm{SO}_{3} \cdot 12 \mathrm{H}_{2} \mathrm{O}+16 \mathrm{H}_{2} \mathrm{O} \rightarrow 6 \mathrm{CaO} \cdot \mathrm{Al}_{2} \mathrm{O}_{3} \cdot 3 \mathrm{SO}_{3} \cdot 32 \mathrm{H}_{2} \mathrm{O}$

Eq. 8

Observa-se na Eq. 7 que na reação do sulfato de sódio com a portlandita há a formação de gipsita que é um produto expansivo, e de hidróxido de sódio (soda cáustica) que, de acordo com Mehta e Monteiro (2014), assegura a continuidade da alcalinidade do sistema, essencial para a estabilidade da fase $C-S-H$, pois se trata de uma base muito forte. Na Eq. 8, a reação entre a gipsita e monossulfoaluminato de cálcio hidratado (AFm) resulta na formação de etringita secundária.

Deve-se observar também neste caso que a reação entre sulfato de sódio e hidróxido de cálcio pode ocorrer separadamente da fase AFm e formar gipsita, como na Eq. 7, e então, esta pode reagir com o monossulfoaluminato de cálcio hidratado em meio aquoso e formar etringita.

Metais alcalinos, como por exemplo, sódio e potássio, possuem baixa energia de ionização e, consequentemente, têm tendência de ceder elétrons, nestes casos, apenas um. Portanto, é de se observar que, comumente, cátions de metais alcalinos oriundos das soluções de sulfato possuam tendência de reagir com o hidróxido de cálcio e o monossulfoaluminato de cálcio hidratado, buscando átomos ou moléculas que necessitam receber seu elétron de valência, para que ambos tenham comportamento ideal, ou seja, possuam sua camada de valência igual à de um gás nobre. Desta forma, a interação destes átomos geralmente ocorre 
com os hidróxidos $\left(\mathrm{OH}^{-}\right)$, formando produtos de $p H$ básico, como o próprio $\mathrm{Ca}(\mathrm{OH})_{2}$. Deixando que o ânion $\left(\mathrm{SO}_{4}^{2-}\right)$ seja o responsável direto pela formação de agentes agressivos, como por exemplo, gipsita $\left(\mathrm{CaSO}_{4} \cdot 2 \mathrm{H}_{2} \mathrm{O}\right)$ e etringita $\left(3 \mathrm{CaO} \cdot \mathrm{Al}_{2} \mathrm{O}_{3} \cdot 3 \mathrm{CaSO}_{4} \cdot 32 \mathrm{H}_{2} \mathrm{O}\right)$. Isto pode ser ilustrado com a Figura 3 cuja solução aquosa é composta por sulfato de sódio e é demonstrada a interação tanto dos cátions $\mathrm{Na}^{+}$como dos ânions $\mathrm{SO}_{4}^{2-}$ com os produtos da hidratação do cimento Portland.

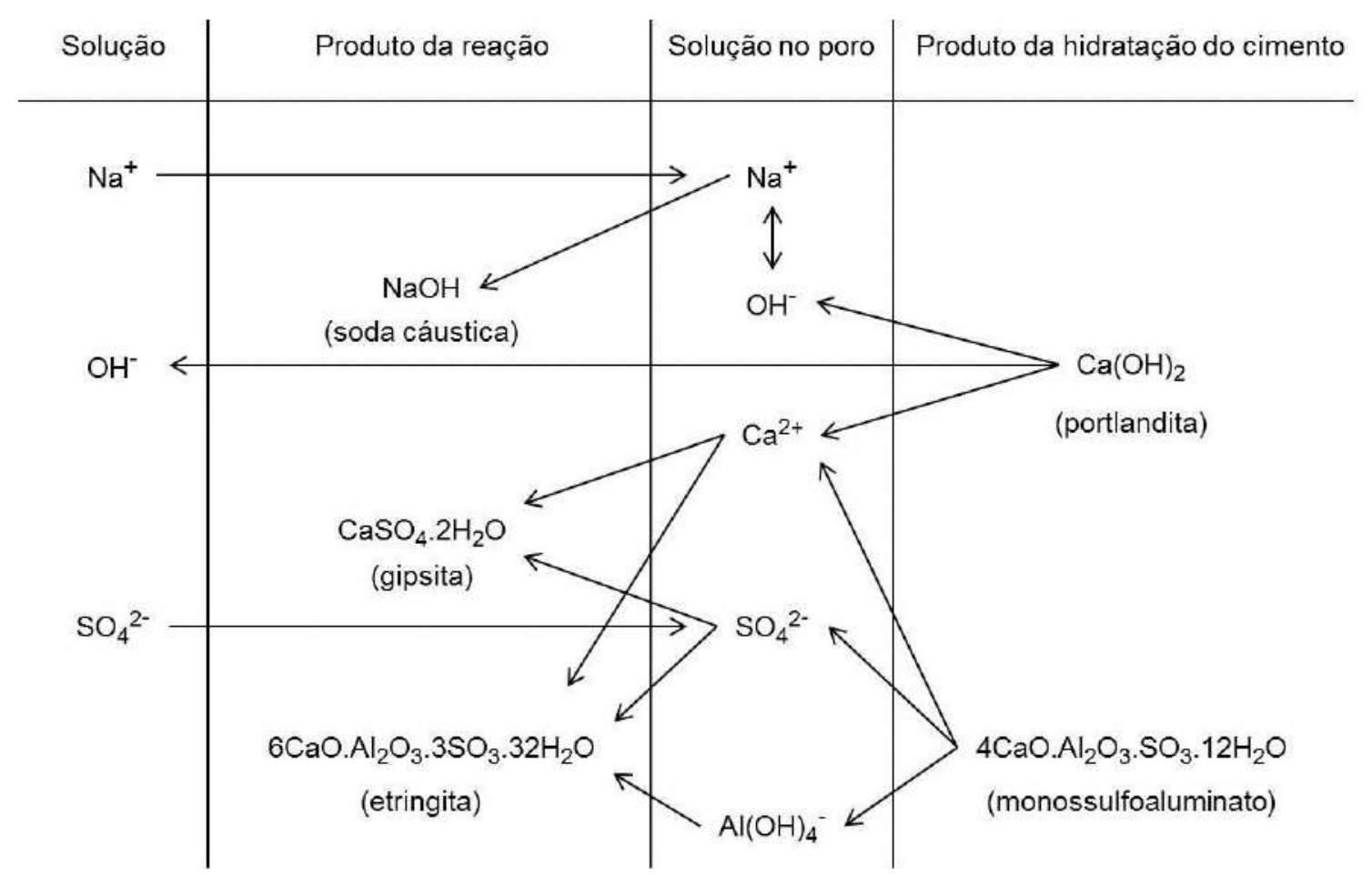

Figura 3: Reações entre solução de sulfato de sódio e produtos da hidratação do cimento Portland. Adaptado de Skalny, Marchand e Odler (2002).

Geralmente, no ataque por sulfato de sódio, pode-se dividi-lo em dois estágios, no primeiro, a variação dimensional do corpo de prova é relativamente branda e há melhora na resistência do mesmo, principalmente na dureza superficial. Isto porque, inicialmente, há o desenvolvimento dos produtos expansivos, que, somente preenchem a rede de poros do concreto, consequentemente, aumentam a área de contato na seção, e, para uma mesma tensão, necessitam de uma maior força aplicada, pois $\sigma=F / A$. No segundo estágio, a variação dimensional do corpo de prova é, evidentemente, mais severa do que no primeiro estágio e o efeito da perda de resistência passa a ser dominante, pois os produtos da reação tendem a ter uma expansão muito elevada e, consequentemente, passam a gerar tensões internas de tração no concreto e fissurações começam a ficar evidentes. Os efeitos descritos, quanto à variação dimensional para longas idades, são demonstrados por Santhanan et al. 
(2002) e podem ser observados com a Figura 4. Enquanto que os fenômenos de ganho e perda de resistência podem ser observados na Figura 5, baseada nos resultados obtidos por Ouyang et al. (2014).

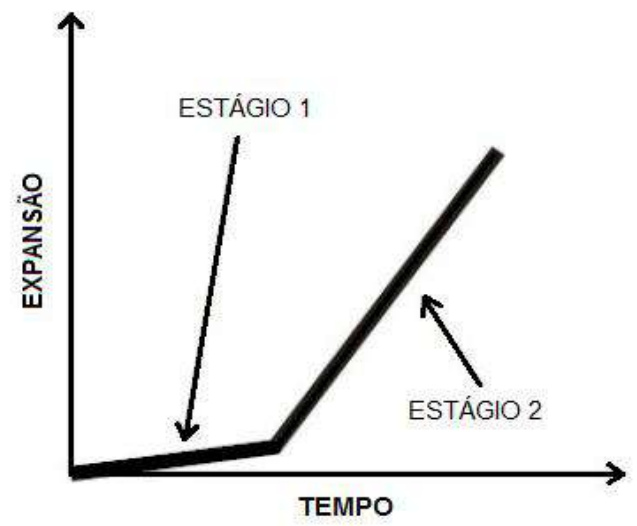

Figura 4: Modelo de variação dimensional de barras de argamassa expostas ao ataque por sulfato de sódio. Adaptado de Santhanan, Cohen e Olek (2002).

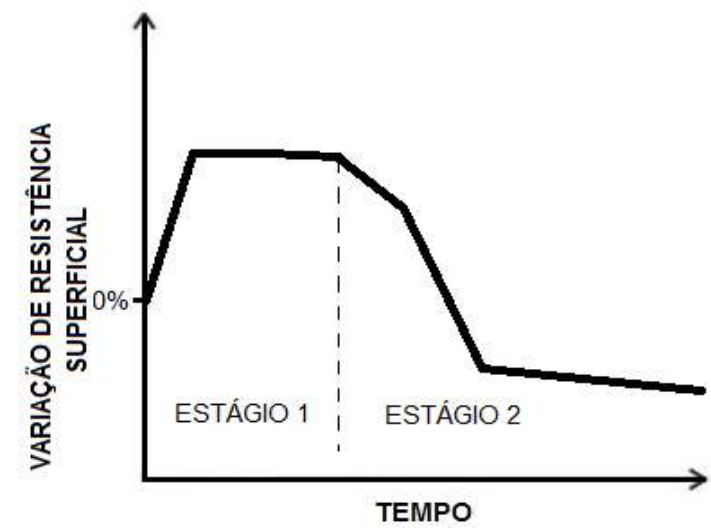

Figura 5: Esquema de variação da resistência superficial. Baseado nos resultados de Ouyang et al. (2014).

2.3.3 Reação química no ataque por sulfato de magnésio $\left(\mathrm{MgSO}_{4}\right)$.

O sulfato de magnésio anidro apresenta uma massa molar de 120,42 $\mathrm{g} / \mathrm{mol}$ composta em 20,19\% de $\mathrm{Mg}^{2+}$ e 79,81\% de $\mathrm{SO}_{4}^{2-}$, solubilidade de $26,9 \mathrm{~g} / 100 \mathrm{~mL}$ de água a uma temperatura de $0^{\circ} \mathrm{C}$, portanto é cerca de 5,5 vezes mais solúvel do que o sulfato de sódio e, aproximadamente, 100 vezes mais solúvel do que o sulfato de cálcio. Deste modo, o $\mathrm{MgSO}_{4}$ é o mais agressivo, no aspecto quantidade de íons $\mathrm{SO}_{4}^{2-}$ máxima em $100 \mathrm{~mL}$ de água, dentre os sulfatos mais comumente encontrados na natureza, isto pode ser visto na Tabela 1. 
Tabela 1: Comparação de solubilidade entre sulfato anidro, cálcio, sódio e magnésio.

\begin{tabular}{|c|c|c|c|c|c|c|}
\hline \multirow{2}{*}{ Molécula } & \multirow{2}{*}{$\begin{array}{l}\text { Massa molar } \\
(\mathrm{g} / \mathrm{mol})\end{array}$} & \multirow{2}{*}{$\begin{array}{c}\text { Cátion } \\
(\%)\end{array}$} & \multirow{2}{*}{$\begin{array}{l}\text { Ânion } \\
(\%)\end{array}$} & \multirow{2}{*}{$\begin{array}{l}\text { Solubilidade à } 0 \stackrel{\circ}{ } \mathrm{C} \\
\left(\mathrm{g} / 100 \mathrm{~mL} \text { de } \mathrm{H}_{2} \mathrm{O}\right)\end{array}$} & \multicolumn{2}{|c|}{$\begin{array}{c}\text { Teor máximo em } \\
100 \mathrm{~mL} \text { de } \mathrm{H}_{2} \mathrm{O} \text { a } 0{ }^{\circ} \mathrm{C}(\mathrm{g})\end{array}$} \\
\hline & & & & & Cátion & Ânion $\left(\mathrm{SO}_{4}^{2-}\right)$ \\
\hline $\mathrm{CaSO}_{4}$ & 136,14 & $29,44 \%$ & $70,56 \%$ & 0,19 & 0,06 & 0,13 \\
\hline $\mathrm{Na}_{2} \mathrm{SO}_{4}$ & 142,04 & $32,37 \%$ & $67,63 \%$ & 4,76 & 1,54 & 3,22 \\
\hline $\mathrm{MgSO}_{4}$ & 120,42 & $20,19 \%$ & $79,81 \%$ & 26,9 & 5,43 & 21,47 \\
\hline
\end{tabular}

Conforme Skalny et al. (2002), o primeiro passo da interação entre a pasta de cimento hidratada e a solução de sulfato de magnésio é a reação do sulfato com o hidróxido de cálcio da pasta, produzindo brucita (que é a forma mineral do hidróxido de magnésio $\mathrm{Mg}(\mathrm{OH})_{2}$ ) e gipsita $\left(\mathrm{CaSO}_{4} \cdot 2 \mathrm{H}_{2} \mathrm{O}\right)$. Esta reação é apresentada na Eq. 9:

$$
\underset{\text { Brucita }}{\mathrm{MgSO}_{4}+\mathrm{Ca}(\mathrm{OH})_{2}+\underset{\mathrm{H}_{2} \mathrm{O}}{\operatorname{Mg}(\mathrm{OH})_{2}}+\mathrm{CaSO}_{4} \cdot 2 \mathrm{H}_{2} \mathrm{O}}
$$

O principal efeito danoso da reação com o sulfato de magnésio é a decomposição dos cristais $C-S-H$ para $M-S-H$, conforme Eq. 10. Além disso, como efeito paralelo, ocorre a formação de gipsita.

$$
\begin{gathered}
3 \mathrm{Mg}^{2+}+3 \mathrm{SO}_{4}^{2-}+3 \mathrm{CaO} \cdot 2 \mathrm{SiO}_{2} \cdot 2 \mathrm{H}_{2} \mathrm{O}+2 \mathrm{H}_{2} \mathrm{O} \\
\rightarrow 3 \mathrm{MgO} \cdot 2 \mathrm{SiO}_{2} \cdot 2 \mathrm{H}_{2} \mathrm{O}+3 \mathrm{CaSO}_{4} \cdot 2 \mathrm{H}_{2} \mathrm{O} \\
\text { M-S-H }
\end{gathered}
$$

Mehta e Monteiro (2014) afirmam também que o ataque por sulfato de magnésio é o mais severo no concreto, justamente pela redução de estabilidade do $C-S-H$ no sistema devido à interação com os íons $M^{2+}$, e ainda, somando a este fato, há a interação dos íons $\mathrm{SO}_{4}^{2-}$ podendo formar gipsita e, em uma quantidade menor, etringita. Outra possível reação do sulfato de magnésio com estruturas de $C-S-H$ é a formação de brucita, gipsita e sílica gel conforme demonstrado na Eq. 11.

$$
\begin{aligned}
& 3 \mathrm{Mg}^{2+}+3 \mathrm{SO}_{4}^{2-}+3 \mathrm{CaO} \cdot 2 \mathrm{SiO}_{2} \cdot 2 \mathrm{H}_{2} \mathrm{O}+5 \mathrm{H}_{2} \mathrm{O} \\
& \rightarrow 3 \mathrm{CaSO}_{4} \cdot 2 \mathrm{H}_{2} \mathrm{O}+3 \mathrm{Mg}(\mathrm{OH})_{2}+2 \mathrm{SiO}_{2} \cdot 2 \mathrm{H}_{2} \mathrm{O} \\
& \text { Gipsita Brucita Sílica gel }
\end{aligned}
$$


Na Figura 6, cuja solução aquosa é composta por sulfato de magnésio, é demonstrada a interação tanto dos cátions $\mathrm{Mg}^{2+}$ como dos ânions $\mathrm{SO}_{4}^{2-}$ com os produtos da hidratação do cimento Portland, com base na publicação de Skalny et al. (2002).

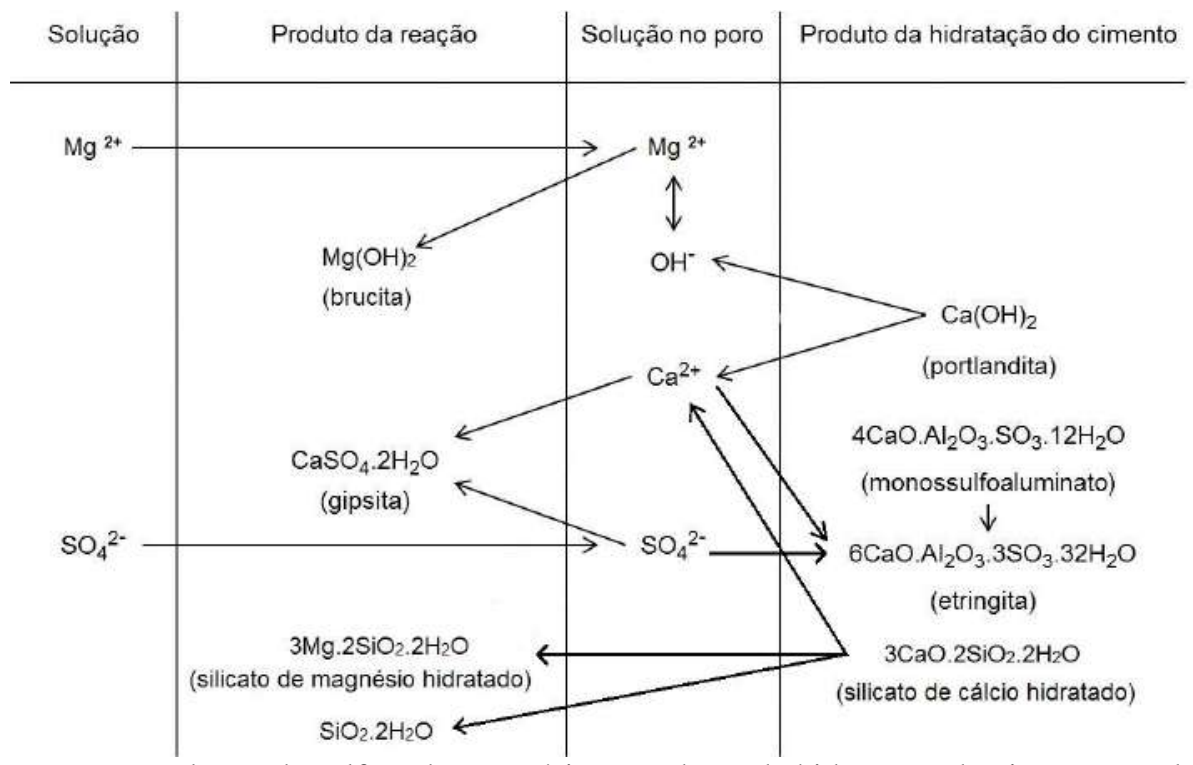

Figura 6: Reações entre solução de sulfato de magnésio e produtos da hidratação do cimento Portland. Adaptado de Skalny, Marchand e Odler (2002).

Diferente do ataque por sulfato de sódio, a variação dimensional de barras de argamassa expostas à solução de sulfato de magnésio, geralmente, têm uma expansão mais distribuída ao longo do tempo. Ou seja, para um mesmo período de tempo, barras expostas ao $\mathrm{MgSO}_{4}$ possuem uma expansão resultante menor do que as imersas em solução de $\mathrm{Na}_{2} \mathrm{SO}_{4}$. Isto pode ser observado, por exemplo, em publicações de Santhanam et al. (2002), demonstrada pela Figura 7, assim como nas de Diab et al. (2012) e Lee et al. (2005).

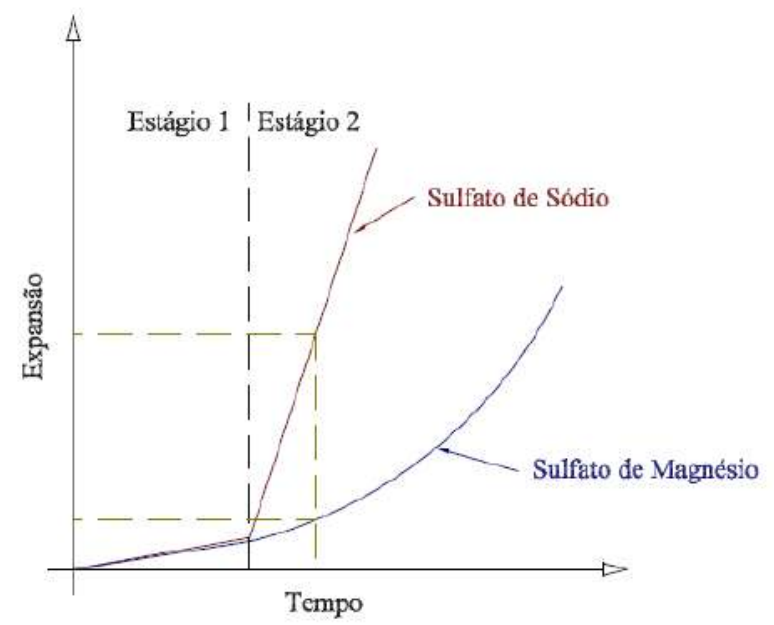

Figura 7: Modelo de variação dimensional de barras de argamassa expostas ao ataque por sulfato de magnésio e sulfato de sódio. Adaptado de Santhanan, Cohen e Olek (2002). 
Quando se diz respeito à perda de resistência à compressão, no ataque por sulfato de sódio isto se dá, basicamente, pelo acréscimo da fissuração causada por materiais expansivos formados com a reação, todavia, inicialmente há um ganho de resistência devido ao preenchimento dos poros. Porém, no ataque por sulfato de magnésio esta perda é muito mais elevada e inicia-se em um período de tempo mais curto, entretanto, isto não se deve ao efeito da expansão, mas sim, pela descalcificação da estrutura de $C-S-H$, como demonstrado anteriormente, e começa ocorrer pouco tempo após o início da interação da argamassa com íons sulfato e íons magnésio (HEKAL et al., 2002; LEE et al., 2005; DIAB et al., 2012).

\subsubsection{Variáveis que influenciam no ataque externo por sulfatos}

As consequências da interação dos íons sulfato com a matriz cimentícia das estruturas de concreto foram apresentadas anteriormente, cujas etapas deste processo podem ser dividas em: difusão dos agentes agressivos; reações químicas entre íons da solução agressiva e produtos da hidratação do cimento Portland; e, por fim, deterioração da matriz cimentante. Desta forma, algumas variáveis, tanto internas como externas ao concreto, influenciam diretamente na propagação da interação entre os íons da solução agressiva e o concreto.

\section{a) Composição do Cimento}

Segundo a ABNT NBR 5.737:1992, para um cimento Portland ser considerado resistente a sulfatos, o mesmo deve atender a algumas limitações, como por exemplo:

- Teor de $C_{3} A$ do clínquer deve ser igual ou inferior a $8 \%$ e cujo teor de adições carbonáticas seja igual ou inferior a $5 \%$ da massa do aglomerante total;

- Teor de escória de alto-forno entre $60 \%$ e $70 \%$ (para cimentos Portland de alto-forno);

- Teor de materiais pozolânicos entre 25\% e 40\% (para cimentos Portland pozolânicos);

A referida norma estabelece como forma de obtenção do teor de $C_{3} A$ no clínquer a equação de Bogue (Eq. 12).

$$
\left(C_{3} A\right)=2,650 \cdot\left(\mathrm{Al}_{2} \mathrm{O}_{3}\right)-1,692 \cdot\left(\mathrm{Fe}_{2} \mathrm{O}_{3}\right)
$$


Onde:

$\left(\mathrm{Al}_{2} \mathrm{O}_{3}\right)$ e $\left(\mathrm{Fe}_{2} \mathrm{O}_{3}\right)$ são teores das referidas fases contidas somente no clínquer.

A partir do momento em que a concentração de $\mathrm{SO}_{4}{ }^{2-}$ é elevada, em termos de ataque por sulfatos, teores de $C_{3} A$ inferiores a $9 \%$ comumente apresentam bom desempenho quanto à resistência aos sulfatos, antagônico a teores superiores a 12\%. Enquanto que na faixa entre estes valores mencionados, o comportamento do cimento é variável (TIKALSKY et al., 2002).

Tosun-Felekoglu (2012), por exemplo, apresenta resultados de amostras com diferentes teores de $C_{3} A(4,6 \%$ e $11,2 \%)$ e adição de filer calcário $(0 \%, 5 \%, 10 \%, 20 \%$ e $40 \%$ em substituição parcial do cimento), expostos tanto ao sulfato de magnésio quanto ao de sódio, em duas diferentes temperaturas $\left(5\right.$ e $\left.20^{\circ} \mathrm{C}\right)$. A autora conclui que a deterioração das amostras foi muito mais significativa em concretos contendo teores de $C_{3} A$ na faixa de $11,2 \%$ em ambas as soluções, e, isto se tornou ainda mais crítico em condições nas quais há maiores teores de substituições do cimento Portland por fíler calcário. Isto porque, segundo a autora, com o aumento do teor da adição fora aumentada a permeabilidade das amostras, principalmente em baixas idades, e, somando a este fato houve um aumento na formação de taumasita que fora agravada em baixas temperaturas. Um resultado semelhante fora obtido por Hossack e Thomas (2014) usando cimentos com teores moderados de $C_{3} A(8-9 \%)$ e elevados (11-12\%) e adição de fíler calcário.

Tikalsky et al. (2002) afirmam que, conforme a relação $C_{3} S / C_{2} S$ do clínquer aumenta maior será a formação de portlandita na hidratação, o que, pode deixar o concreto mais suscetível ao ataque por sulfatos. Nesta mesma linha, Lothenbach et al. (2011) e Bellmann e Stark (2007) alegam que há uma resistência maior ao ataque por sulfatos em cimentos com baixa relação $\mathrm{Ca} / \mathrm{Si}$, o que, também ocasiona uma menor formação de $\mathrm{Ca}(\mathrm{OH})_{2}$ na hidratação. Todavia, segundo Taylor (1997), cimentos contendo adições pozolânicas, o que, de modo geral, reduz a quantidade livre de hidróxido de cálcio, podem tornar o concreto mais suscetível ao ataque por sulfatos de magnésio, pois, conforme discutido no item 2.3.3 do presente trabalho, este tipo de sulfato pode reagir com o $C-S-H$, o qual apresenta menor degradação quando da presença de $\mathrm{Ca}(\mathrm{OH})_{2}$, devido ao controle do $\mathrm{pH}$.

Segundo Skalny et al. (2002), o $C_{4} A F$ pode produzir etringita, entretanto em uma taxa consideravelmente menor do que o $C_{3} A$, podendo, deste modo, um cimento com baixa relação $C_{3} A / C_{4} A F$ tornar-se menos expansivo. Esta afirmação pode ser observada na Figura 8. 


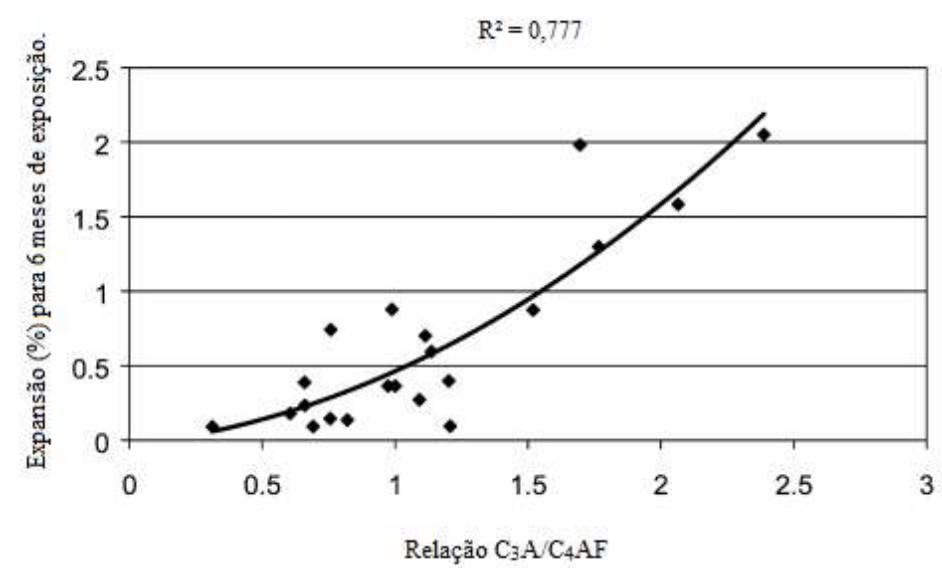

Figura 8: Influência da relação $\mathrm{C}_{3} \mathrm{~A} / \mathrm{C}_{4} \mathrm{AF}$ na expansão por ataque por sulfatos. Adaptado de Tikalsky et al. (2002)

Portanto, o cimento Portland deve apresentar baixo teor de $\mathrm{C}_{3} \mathrm{~A}$ na sua composição e, se possível, menor reserva alcalina na matriz hidratada, embora possa haver situações onde o menor teor de portlandita propicia maior degradação do C-S-H, o que ocorre na presença de íons magnésio.

b) Movimentação de fluidos no concreto

Como elemento fundamental na elaboração do concreto, a água exerce um papel atuante também na sua deterioração. Quando no estado fresco, o concreto reage com a água formando a estrutura resistente do material. Entretanto, no estado endurecido, a água pode servir como meio de transporte para substâncias agressivas provenientes do meio cujo material está inserido, possibilitando assim, a degradação do mesmo.

Neville (1997) distingue os conceitos de porosidade e permeabilidade, sendo porosidade a medida da proporção do volume total do concreto ocupada pelos poros, apresentada geralmente em porcentagem. Se a porosidade for grande e se os poros estiverem interligados, estes contribuem para o deslocamento de fluidos através do concreto, de modo que a permeabilidade também passa a ser alta.

Mehta e Monteiro (2014) subdividem a água na pasta endurecida, sendo sua classificação baseada no grau de dificuldade ou de facilidade com a qual pode ser removida:

- Água capilar, presente nos vazios maiores do que $50 \AA$ A. Pode ser descrita como o volume de água que está livre da influência de forças de atração exercidas pela superfície sólida. 
- Água adsorvida, está próxima à superfície do sólido, isto é, sob a influência de forças de atração e é a principal responsável pela retração da pasta.

- Água interlamelar, é associada à estrutura do C-S-H por pontes de hidrogênio e é perdida somente por secagem forte.

- Água quimicamente combinada, é parte integrante da estrutura de vários produtos hidratados do cimento, é conhecida por água de cristalização, é removida apenas com temperaturas muito elevadas.

Uma vez que a resistência e a permeabilidade são relacionadas uma a outra através da porosidade capilar, a forma mais eficaz de solucionar os problemas de durabilidade é buscar uma redução na possibilidade de permeação de fluidos no concreto, o que provoca melhores resultados do que os obtidos com modificações na composição química do cimento. $\mathrm{O}$ concreto pode apresentar um bom desempenho, mesmo em ambientes agressivos, desde que garanta uma baixa permeabilidade, através de uma dosagem e adensamento adequados, uso de adições e relação água/cimento reduzida (MEHTA e MONTEIRO, 2014).

A Figura 9 mostra um diagrama esquemático dos principais fatores influentes no processo de movimentação de fluidos no concreto.

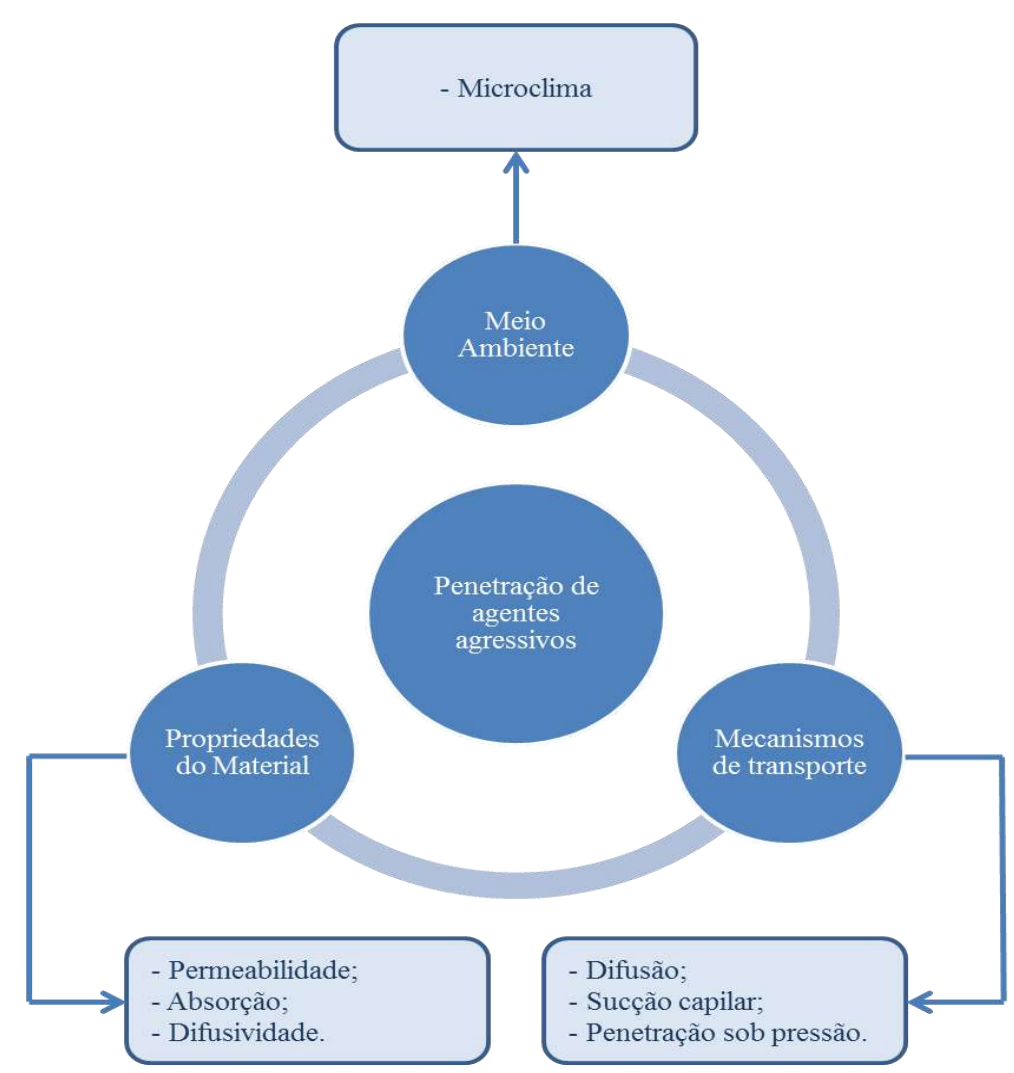

Figura 9: Diagrama dos principais fatores que influenciam no processo de transporte de fluidos no concreto. 
Os mecanismos de deterioração do concreto dependem, além de outros fatores, da concentração da solução agressiva cujo concreto está exposto, seja por presença de cloretos, ácidos, bases e sulfatos. Deste modo, a ABNT NBR 12.655:2015 determina requisitos e condições mínimas para assegurar a durabilidade das estruturas de concreto. A Tabela 2 mostra alguns destes requisitos quando há a possibilidade de interação com soluções contendo íons sulfato.

Tabela 2: Requisitos para concreto exposto a soluções contendo sulfatos.

\begin{tabular}{|c|c|c|c|c|}
\hline $\begin{array}{l}\text { Condições de } \\
\text { exposição em } \\
\text { função da } \\
\text { agressividade }\end{array}$ & $\begin{array}{l}\text { Sulfato solúvel } \\
\text { em água }\left(\mathrm{SO}_{4}\right) \\
\text { presente no solo } \\
(\% \text { em massa })\end{array}$ & $\begin{array}{l}\text { Sulfato solúvel } \\
\left(\mathrm{SO}_{4}\right) \text { presente } \\
\text { na água }(\mathrm{ppm})\end{array}$ & $\begin{array}{c}\text { Máxima relação } \\
\text { água/cimento, em } \\
\text { massa, para concreto } \\
\text { com agregado normal }^{\mathrm{a}} \text { aga }\end{array}$ & $\begin{array}{l}\text { Mínimo } f_{\text {ck }} \text { (para } \\
\text { concreto com } \\
\text { agregado normal } \\
\text { ou leve) }(\mathrm{MPa})\end{array}$ \\
\hline Fraca & & & & \\
\hline Moderada $^{c}$ & 0,10 a 0,20 & 150 a 1500 & 0,50 & 35 \\
\hline Severa $^{\mathrm{d}}$ & Acima de 0,20 & Acima de 1500 & 0,45 & 40 \\
\hline \multicolumn{5}{|c|}{$\begin{array}{l}\text { Baixa relação água/cimento ou elevada resistência podem ser necessárias para a obtenção de } \\
\text { baixa permeabilidade do concreto ou proteção contra a corrosão da armadura ou proteção a } \\
\text { processos de congelamento e degelo; }\end{array}$} \\
\hline \multicolumn{5}{|c|}{$\begin{array}{l}\text { b. Conforme classe de agressividade ambiental e qualidade do concreto (Tabela } 2 \text { da referida } \\
\text { norma); }\end{array}$} \\
\hline \multicolumn{5}{|c|}{$\begin{array}{l}\text { c. A água do mar é considerada para efeito do ataque de sulfatos como condição de agressividade } \\
\text { moderada, embora o seu conteúdo de } \mathrm{SO}_{4} \text { seja acima de } 1500 \mathrm{ppm} \text {, devido ao fato de que a } \\
\text { etringita é solubilizada na presença de cloretos; }\end{array}$} \\
\hline \multicolumn{5}{|c|}{$\begin{array}{l}\text { Para condições severas de agressividade, devem ser obrigatoriamente usados cimentos } \\
\text { resistentes a sulfatos. }\end{array}$} \\
\hline
\end{tabular}

Fonte: ABNT NBR 12.655 (2015, adaptado).

No documento ACI 318M-02 há a informação que a concentração do íon sulfato em água é um importante fator que governa a extensão dos danos no concreto. Neste documento também consta que as concentrações podem ser classificadas como, branda, moderada, severa e muito severa, nas faixas de $0-150$ ppm, $150-1.500$ ppm, $1.500-10.000$ ppm e acima de 10.000 ppm, respectivamente.

Akoz et al. (1995) estudaram o efeito das concentrações de sulfato de sódio sobre argamassas de cimento Portland contendo, ou não, sílica ativa. Os autores afirmam que em concentrações abaixo de 18.000 ppm (18 g/L), o sulfato de sódio não causa nenhum efeito significante nas propriedades das argamassas estudadas para 300 dias de exposição.

De acordo com Santhanam et al. (2002.b), em um primeiro estágio, as expansões, independente da concentração da solução, portam-se de forma análoga. Todavia, em um 
segundo estágio, a intensidade do ataque torna-se muito mais expressiva conforme mais concentrada é a solução. A Figura 10 apresenta um modelo, baseado nos resultados apresentados por Santhanam et al. (2002.b), sobre as tendências de expansão de argamassas de cimento Portland, imersas em solução de sulfato de sódio e de magnésio para diferentes concentrações.

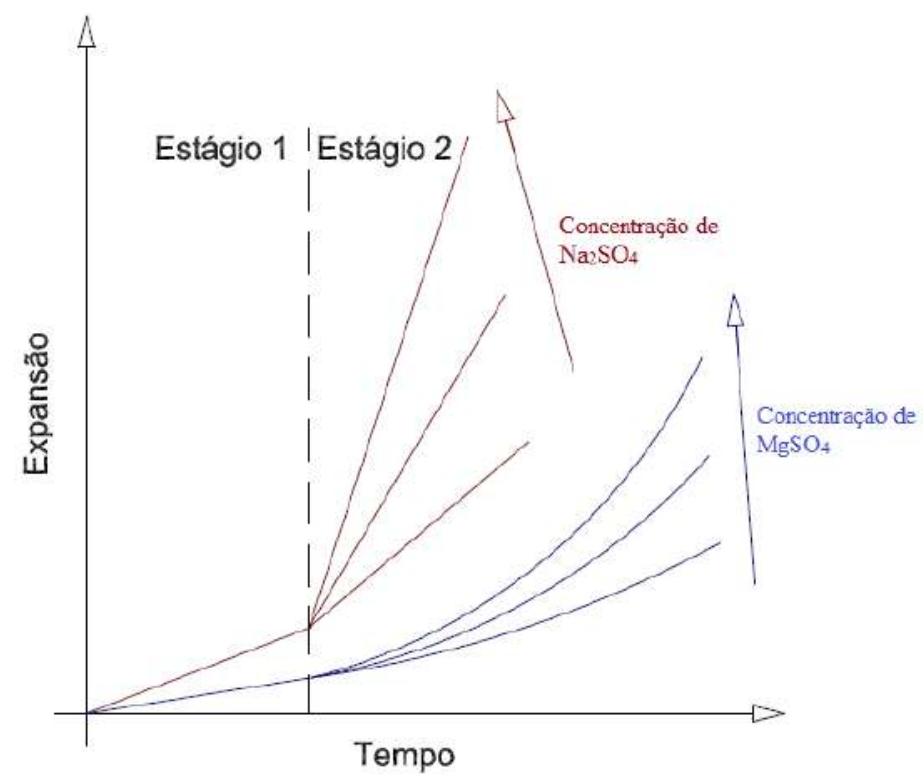

Figura 10: Modelo de tendência de expansão de argamassas de cimento Portland, imersas em soluções de sulfato de sódio e sulfato de magnésio em diferentes concentrações. Adaptado de Santhanan, Cohen e Olek (2002).

O efeito de concentrações variadas torna-se crítica especialmente em estruturas de campo onde a mesma peça de concreto pode ser atacada em diferentes regiões com diferentes concentrações de sulfatos devido ao desenvolvimento de frentes de secagem e de molhagem, o que, em outras palavras, pode formar um gradiente de concentração e, consequentemente, de expansibilidade.

d)

Temperatura

Em condições de campo, uma estrutura pode ser submetida a uma grande variação de temperatura ao longo de sua vida útil. Todavia, ensaios laboratoriais de análise dos efeitos de íons sulfato, comumente conduzem tais testes com exposição a temperaturas constantes.

Muitos pesquisadores têm investigado a correlação entre a diminuição da temperatura e a taxa de deterioração, associada, frequentemente, a formação de taumasita como consequência do ataque externo e interno de sulfatos (HARTSHORN et al. 2002; BROWN et al. 2003; SIBBICK et al. 2003; RAMEZANIANPOUR E HOOTON, 2013; HOSSACK E THOMAS, 2015). No entanto, tem sido observada a formação de taumasita também em casos 
de temperaturas mais elevadas $\left(20^{\circ} \mathrm{C}\right)$, conforme Sahu et al. (2002), Crammond (2003) e Irassar (2008). Somando ainda, conforme Santhanam et al. (2002), que além da formação de taumasita devido à influência da temperatura, a formação de etringita e gipsita também são afetadas por esta variação, o que, em outras palavras, pode acelerar ou retardar o processo de formação das mesmas.

É de consenso na literatura que, com o aumento da temperatura, há uma aceleração nas reações oriundas do ataque por sulfatos e, decorrente aceleração da expansão. Isto pode ser explicado, de maneira simplista e geral, pela cinética das reações químicas, ou seja, com o aumento da temperatura, há um aumento na energia cinética das partículas, que como consequência, acarreta em um acréscimo do número de partículas com energia maior ou igual à energia de ativação (Figura 11), favorecendo o aumento do número de colisões efetivas das mesmas e, por fim, acelerando a reação.

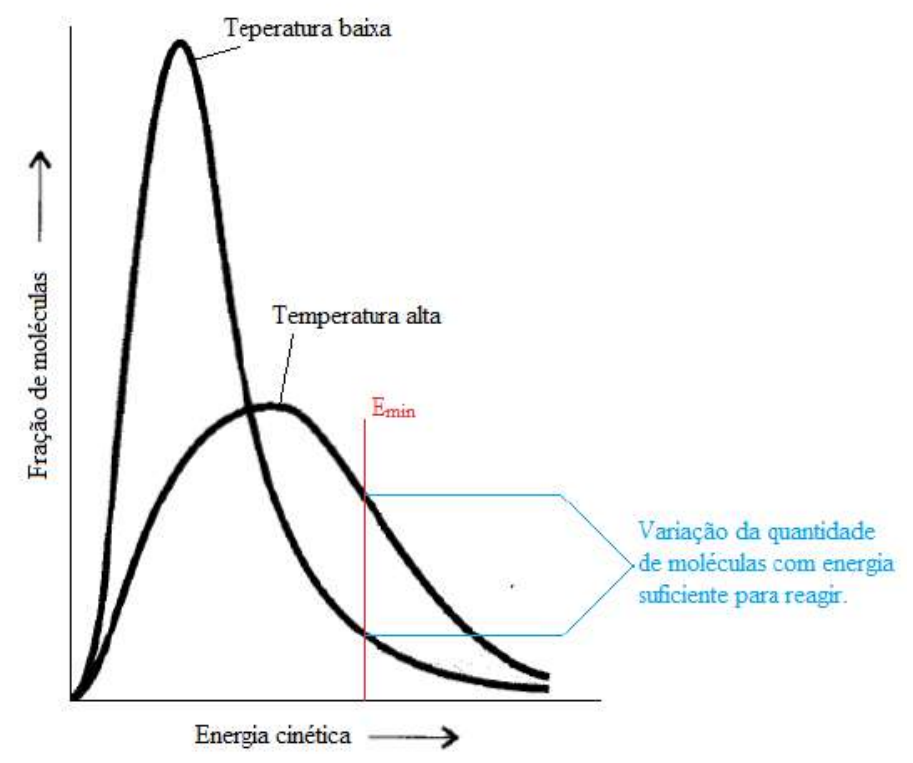

Figura 11: Representação da variação da quantidade de moléculas com energia para reação em função da temperatura. Adaptado de Atkins e Jones (2011).

A Figura 12 apresenta uma observação baseada nos resultados de Santhanam et al. (2002.b) da expansão de argamassas de cimento Portland imersas em solução de sulfato de sódio expostas em diferentes temperaturas. 


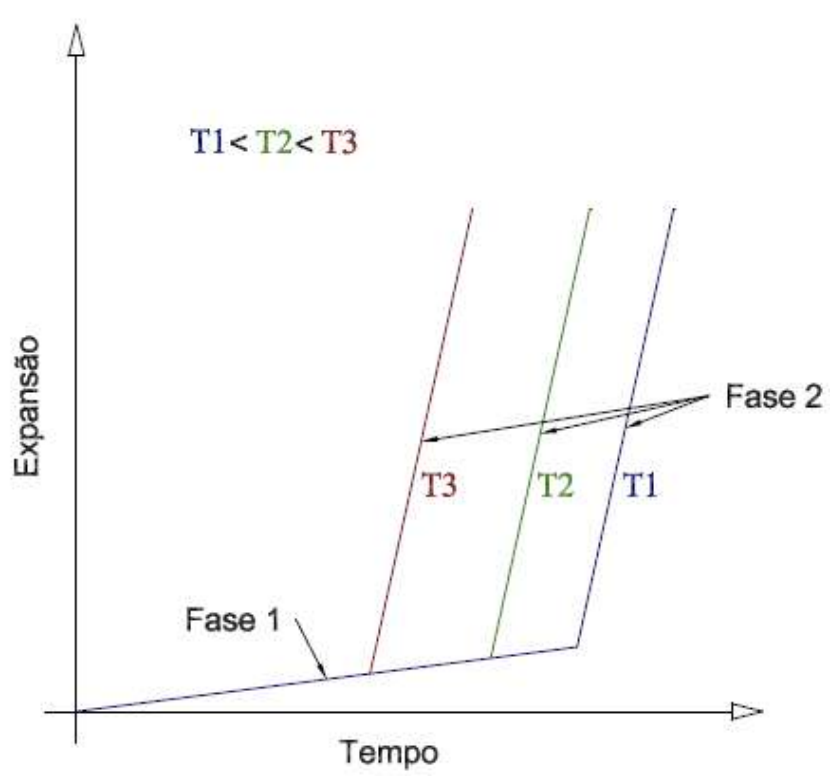

Figura 12: Tendência da expansão de barras de argamassa de cimento Portland expostas a diferentes temperaturas. Adaptado de Santhanam et al. (2002.b)

Os autores comentam que o aumento na temperatura, no entanto, não altera a taxa de expansão das amostras. Por exemplo, na Fase 2, não houve variação no coeficiente angular (inclinação) das retas, sendo estas, paralelas. O que houve, foi uma diminuição do tempo para uma mesma expansão final em temperaturas mais elevadas, assim como, uma diminuição do período inicial de expansão lenta (Fase 1).

Isto corrobora a explanação anteriormente citada sobre a cinética química, onde há uma aceleração das reações químicas conforme há a aplicação de energia no sistema, sendo esta, em forma de temperatura. Ao mesmo tempo, não há alteração relevante no processo de reação.

Assim sendo, o aumento da temperatura em ensaios laboratoriais é aplicado de forma a acelerar o tempo de indução do ataque, tendo em vista que a degradação por ataque por sulfatos é relativamente lenta. Contudo, deve-se respeitar uma temperatura limite de $60^{\circ} \mathrm{C}$, pois acima desta, a etringita não é estável e, há também, além da etringita secundária, o surgimento da etringita tardia, oriunda do próprio concreto (BROWN E BOTHE, 1993; METHA E MONTEIRO, 2014).

\subsubsection{Avaliação do ataque por sulfatos}

Metodologias e técnicas confiáveis de experimentos laboratoriais se fazem necessários quando o escopo é a predição da durabilidade das estruturas. Desse modo, é importante 
escolher o meio de avaliação do ataque por sulfatos nestes ensaios. A avaliação ocorre, normalmente, em função da perda de resistência mecânica (resistência à compressão) e ou por meio da análise da variação dimensional de corpos-de-prova com dimensões padronizadas.

\subsubsection{Perda de Resistência}

Um dos fatores que influenciam diretamente na resistência do concreto, segundo Neville (2004), é a presença de vazios. Isto posto, conjectura-se, que a formação de fissuras, dissolução de produtos da hidratação do cimento Portland, formação de novos produtos, porém com menor resistência, todos derivados do ataque por sulfatos, ocasionam uma redução na resistência à compressão.

Como afirmação da citação supracitada, Brown (1981) mostra que houve uma grande perda de resistência à compressão das amostras expostas em diferentes soluções de sulfato com concentrações de 0,35 $\mathrm{M}_{\text {de }} \mathrm{Na}_{2} \mathrm{SO}_{4}$ e 0,35 $\mathrm{M}$ de $\mathrm{MgSO}_{4}$, a partir de um tempo de exposição de aproximadamente duas semanas. O autor afirma também que esta perda de resistência acentuada é ocasionada por aumento da porosidade das amostras, decorrente da lixiviação do hidróxido de cálcio em regiões próximas da superfície e a subsequente formação da gipsita e da etringita secundária.

Todavia, tal afirmação não se faz totalmente sólida na da literatura pertinente. Um exemplo disso é a publicação de Kayyali (1989), onde o autor relata a exposição de cubos com dimensões de $50 \mathrm{~mm}$, compostos por pastas de cimento misturadas na relação água/cimento de 0,23, em soluções de $\mathrm{Na}_{2} \mathrm{SO}_{4}$, nas concentrações de 3300 ppm e 16500 ppm de $\mathrm{SO}_{3}$ e, $\mathrm{MgSO}_{4}$ também nas mesmas concentrações, para que então fosse avaliada a resistência à compressão e a porosidade ao longo do processo de degradação. Assim, o autor afirma que, como nos resultados de Brown (1981), houve perda de resistência das amostras ensaiadas expostas em soluções de sulfatos após um determinado período de tempo, contudo, o aumento da porosidade, seja por lixiviação, seja por fissuração, não foi a justificativa para tal queda na resistência. Isto porque, o autor analisou que ao longo do processo de degradação a porosidade, na realidade, diminuiu substancialmente até determinado ponto devido ao preenchimento dos vazios ocasionados pelos produtos expansivos.

Outros autores, como Lee et al. (2005), Sahmaran et al. (2007), Lee et al. (2008), Zhou et al. (2015) concordam nos resultados obtidos que inicialmente há, na realidade, um ganho de resistência do concreto quando exposto às soluções de sulfato, devido, essencialmente, pela colmatação dos poros do concreto por produtos da reação dos agentes 
agressivos com alguns produtos da hidratação do cimento. E que, na comparação entre sulfato de sódio e de magnésio, quando as amostras são expostas ao $\mathrm{MgSO}_{4}$, a perda de resistência é muito mais pronunciada, devido, em primeira instância, à interação do $M g^{2+} \operatorname{com~o~} C-S-$ $H$.

Ouyang et al. (2014) obtiveram resultados e conclusões semelhantes aos demais autores supracitados, contudo, o ganho inicial de resistência chega a 600\% em até 10 semanas de exposição. Porém, vale ressaltar que a pesquisa dos autores é direcionada a avaliação da resistência superficial do concreto pelo método da esclerometria.

Por fim, fica evidente na literatura, que há, inicialmente, ganho de resistência do concreto devido à exposição a soluções de sulfato e diminuição da porosidade, independentemente da solução analisada, seja $\mathrm{MgSO}_{4}$ ou $\mathrm{Na}_{2} \mathrm{SO}_{4}$. Posteriormente, há queda da resistência à compressão, que é muito mais acentuada em soluções expostas ao sulfato de magnésio, porém, o aumento da porosidade não é proporcional à queda de resistência para este tipo de solução. Em geral, pode-se afirmar que o sulfato de sódio não reduz a resistência à compressão diretamente, mas produz significativa expansão e fissuração que leva a perda de resistência, enquanto que o sulfato de magnésio reduz significativa e diretamente a resistência das amostras devido à degradação do $C-S-H$, sem, necessariamente, produzir expressiva expansão.

\subsubsection{Variação dimensional}

a) NBR 13.583:2014

A ABNT NBR 13.583:2014 estabelece um método para a determinação da variação dimensional de barras de argamassa de cimento Portland expostas à solução de sulfato de sódio.

Para este ensaio, deve-se elaborar argamassas com traço para materiais secos na proporção de 1:3,2 (em massa) de cimento/agregado miúdo, sendo este último, necessariamente, areia normal brasileira, conforme ABNT NBR 7214:2015, dividida em 1/4 para cada fração granulométrica. A relação água/cimento deve ser igual a 0,60. Assim, com a elaboração da argamassa são moldados corpos de prova (CP's) prismáticos com dimensões de $25 \times 25 \times 285 \mathrm{~mm}$, os quais devem ser mantidos em câmara úmida com temperatura de $23{ }^{\circ} \mathrm{C}$ por um período de 40 a 48 horas para posterior desmoldagem. Após esta primeira etapa, os corpos de prova devem ser mantidos em cura submersa em água saturada com cal por 12 dias. Ao 
fim deste período deve ser realizada a determinação do comprimento inicial dos CP's, com auxílio de um pórtico padrão dotado de extensômetro.

Assim sendo, após os primeiros 14 dias de idade das amostras e realizadas as leituras de comprimento inicial, as barras são imersas e mantidas em solução de sulfato de sódio na concentração de $100 \mathrm{~g} / \mathrm{L}$ de solução, ou seja, 100.000 ppm [equivale a uma concentração de $\mathrm{SO}_{4}{ }^{2-}$ de 67,63 g por litro (67.630 ppm)], durante 42 dias a temperatura de $40{ }^{\circ} \mathrm{C}$. Deste modo, leituras do comprimento das barras para acompanhamento da influência dos íons de sulfato devem ser realizadas no $14^{\circ}, 28^{\circ}$ e $42^{\circ}$ dia de exposição. A determinação da expansão resultante é o valor da subtração dos resultados da expansão das barras imersas em solução de sulfato de sódio por aqueles obtidos a partir da imersão em solução de água saturada com cal.

O trabalho publicado por Marciano (1993) que deu origem a ABNT NBR 13.583, primeiramente publicada em 1996, com atualização em 2014, mostra que a variação dimensional é o melhor parâmetro para avaliar a influência dos íons de sulfato. A autora conclui também que ensaios de resistência à tração na flexão de argamassas, assim como a de tração obtida a partir da compressão diametral não são bons parâmetros para acompanhamento da degradação. Por fim, Marciano estabelece que argamassas compostas por cimentos resistentes aos sulfatos devem apresentar expansão resultante inferior a $0,03 \%$ ao $42^{\circ}$ de exposição.

Vale ressaltar que a norma supracitada proporciona um método de avaliação da resistência de cimentos frente ao ataque por sulfato de sódio, porém, não oferece um parâmetro para comparação, nem mesmo, aborda soluções compostas pelos demais tipos de sulfatos, como o de magnésio, cálcio, potássio, amônio, entre outros. Esta pode ser considerada uma crítica à norma atual, pois estabelece um ensaio, mas não fornece um critério de avaliação de modo que a aplicação da NBR 13.583 muitas vezes fica comprometida. Outra questão a ser enfatizada é que esta norma é restrita ao sulfato de sódio, não sendo apropriado usar o resultado desta norma para tomar decisões quanto à especificação de cimentos para compor concretos que serão expostos a outros tipos de sulfatos. Desse modo, identifica-se uma lacuna na normalização nacional no campo do ataque por sulfatos em concreto.

b) ASTM C 452

Neste método, o agente agressivo, na forma de gesso, é adicionado durante o processo de amassamento da argamassa, uma vez que o teor de $\mathrm{SO}_{3}$ na composição de aglomerantes 
seja de $7 \%$. Deste modo, o processo de agressão dispensa a influência da difusão, tendo em vista que o sulfato é incorporado à pasta.

Para a avaliação da expansão são moldados corpos de prova prismáticos $(25 \times 25 \times 285 \mathrm{~mm})$ de argamassa, com traço composto de $400 \mathrm{~g}$ da mistura de cimento + gesso, $1100 \mathrm{~g}$ de areia e $194 \mathrm{~mL}$ de água (1:2,75, material ligante:areia, e, 0,485 relação a/ligante), os quais são curados em câmara úmida na temperatura de $23{ }^{\circ} \mathrm{C}$ de $22-23 \mathrm{~h}$, e, então, desmoldados.

Após a cura inicial os corpos de prova são imersos em água por um período de 30 minutos, e, em seguida, faz-se a leitura do comprimento inicial com um extensômetro. Por conseguinte, as barras estudadas são novamente submersas em água por um período de 14 dias, nesta data é realizada então a leitura final dos corpos de prova. A variação no comprimento é o parâmetro que define a resistência ou não frente a íons de sulfatos. As recomendações são que cimentos com moderada resistência a sulfatos devem, necessariamente, ter uma expansão limite de $0,06 \%$, enquanto que cimentos resistentes aos sulfatos devem apresentar expansão limite de 0,04\%.

Todavia, algumas publicações, como por exemplo, a de Brown (1981), sugerem que o método se faz útil por sua rapidez na obtenção dos resultados e, nas definições de cimentos potencialmente resistentes aos sulfatos. Porém, não condiz diretamente com a realidade, pois as barras ficam continuamente expostas à ação dos sulfatos desde o início da sua hidratação, ou seja, o gesso é incorporado na mistura e expõe a argamassa antes mesmo da hidratação ocorrer.

Hodhod e Salama (2014), por sua vez, também comentam que a maior vantagem do teste é o curto período de tempo para avaliação, e citam ainda, que o método se mostra errôneo quando usado para testes de argamassas compostas por cimento e adições minerais ativas. Pois, segundo os autores, o primeiro problema é que o cimento misturado, seja puro ou com adições minerais reativas, não desenvolvem maturidade suficiente durante o período de exposição de 14 dias. O segundo problema, é que o método não condiz com a realidade, assim como comentado por Brown (1981).

c) ASTM C 1012

O método ASTM C 1012 (2004) refere-se à estimativa do potencial do ataque por sulfatos em barras de argamassa de cimento Portland. Para isto, mensuram-se as variações de comprimento de tais barras expostas à solução composta por sulfatos. Um diferencial do 
presente método, frente aos demais métodos citados, é a possibilidade da aplicação em barras de argamassa de cimento Portland comuns e com adições minerais.

Assim sendo, para a referida norma, as barras devem ser moldadas de acordo com a ASTM C 109/C 109M (2008), com traço de 1:2,75 (em massa), relação a/c de 0,485 (ou de 0,460 para argamassas com ar incorporado). Assim, são moldados 9 corpos de prova cúbicos com dimensões de 50x50x50 mm e 6 barras prismáticas de dimensões 25x25x285 mm. Imediatamente após a moldagem, os moldes devem ser protegidos e então colocados em cura submersa a $38{ }^{\circ} \mathrm{C}$ por um período de 24 horas. Passado este tempo, é realizado a desmoldagem e duas das amostras cúbicas devem ser ensaiadas à compressão de acordo com a ASTM C 109, supracitada. Caso a resistência obtida for igual o superior a $20 \pm 1 \mathrm{MPa}$ as demais amostras prismáticas devem ter seu comprimento inicial mensurado com um extensômetro e serem imersas na solução agressiva. Todavia, caso a resistência citada não seja alcançada, os corpos de prova devem ser submersos em solução de água saturada com cal em uma temperatura de $23{ }^{\circ} \mathrm{C}$ até que a resistência de $20 \pm 1 M P a$ seja alcançada, ou superada.

A solução agressiva supracitada deve conter $5 \%$ de sulfato de sódio, ou seja, 0,352 moles/L de $\mathrm{Na}_{2} \mathrm{SO}_{4}(50 \mathrm{~g} / \mathrm{L})$, equivalente a uma concentração de 50.000 ppm, e ter temperatura constante próxima a $23{ }^{\circ} \mathrm{C}$. A proporção de volumes entre solução e amostras deve ser de, pelo menos, 4 para 1, e as leituras para determinação da expansão devem ser realizadas após 1, 2, 3, 4, 8, 13 e 15 semanas de imersão, caso a variação dimensional seja muito baixa, pode-se realizar leituras aos 4, 6, 9, 12, 15, 18 e 24 meses. Entretanto, na idade de seis meses, são considerados como amostras de resistência moderada ao sulfato aquelas que apresentam expansão inferior a $0,1 \%$, já as resistentes ao sulfato devem apresentar expansão inferior a $0,05 \%$.

Apesar de a referida norma ser uma das mais utilizadas atualmente no campo de pesquisa de ataque por sulfatos em compostos cimentícios, pesquisadores como Brown (1981); Tumidajski e Turc (1995); Neville (1997); Santhanan et al. (2001); Bonakdar e Mobasher (2010); entre outros, têm expressado algumas precauções de que este método pode, em determinadas circunstâncias, não representar bem a realidade. Assim sendo, a Tabela 3 apresenta algumas publicações que expressaram críticas quanto a algumas variabilidades não abrangidas pela norma. 
Tabela 3: Críticas à norma ASTM C 1012 segundo algumas publicações.

Publicação

Biczók (1972)

Brown (1981)

Tumidajski e Turc (1995)

Neville (1997)

Santhanan et al. (2001)

Bonakdar e Mobasher (2010)

\section{Crítica}

Devido ao longo tempo de exposição o mecanismo de reação pode mudar conforme há mudança de concentração na solução.

A composição do cimento afeta a taxa de consumo dos íons sulfato e introduz outra variável no método; o pH durante o ensaio é, em média, de 3 a 5 vezes diferente das condições de campo; Tempo de ensaio é excessivo, o que causa muita variabilidade na concentração dos íons de sulfato.

O método é muito sensível às geometrias dos corpos de prova, o que, em outras palavras, pode não representar a realidade.

Longa duração do ensaio; Ensaio é realizado com argamassa, assim, não abrange pontos críticos, como a zona de transição entre o agregado graúdo e a argamassa.

O método não leva em consideração a formação de taumasita ocasionada em reação dos sulfatos em baixas temperaturas.

Longa duração do ensaio; elevação do pH da solução ocasionada pela liberação de íons hidroxila.

Assim sendo, deve-se ter em vista a representatividade da pesquisa e ater-se às variáveis que mais a influenciam, de modo que, em termos estatísticos, a variabilidade da pesquisa seja reduzida ao máximo, facilitando a interpretação dos resultados.

\subsubsection{Análise da microestrutura}

Tem-se tornado, nos últimos anos, muito comum o uso de técnicas que possam analisar a microestrutura do concreto sob o ataque por sulfatos e, o fundamento para tal informação pode ser visto na abrangente bibliografia que aborda a análise referente ao ataque por sulfatos, como por exemplo, Lee et al. (2005); Rozière et al. (2009); Bonakdar e Mobasher (2010); Aye e Oguchi (2011); Lothenbach et al. (2011); Felekoglu (2012); Ogawa et al. (2012); Komljenovic et al. (2013); Skaropoulou et al. (2013); Ouyang et al. (2014); Hossack e Thomas (2015). Dentre as técnicas utilizadas, destaca-se a Difração de Raios-X (DRX), pois será abordada no presente trabalho.

a) Difração de Raios-X

Segundo Eisberg e Resnick (1994) e Russel (1994), esta técnica parte do princípio que qualquer radiação eletromagnética pode ser desviada por uma grade de difração, isto é, uma série de objetos (átomos, partículas, etc.). Assim, a utilização dos raios-X se faz satisfatório 
devido ao seu comprimento de onda relativamente curto e conhecido, suficiente para que haja alterações de direção ocasionada pela composição dos cristais. Haja vista, que a partir destas alterações na direção das ondas é possível mensurar o ângulo de difração e então calcular os espaçamentos interatômicos do cristal e, assim, pode-se determinar a estrutura cristalina (RUSSELL, 1994; EISBERG E RESNICK, 1994).

Um exemplo de uso desta técnica para identificação de produtos da interação dos íons sulfato com os da hidratação do cimento Portland, pode ser apreciado nos resultados apresentados por Lee et al. (2005), nos quais é possível verificar a formação de taumasita e gipsita na região superficial das argamassas de cimento Portland, conforme mostrado na Figura 13.

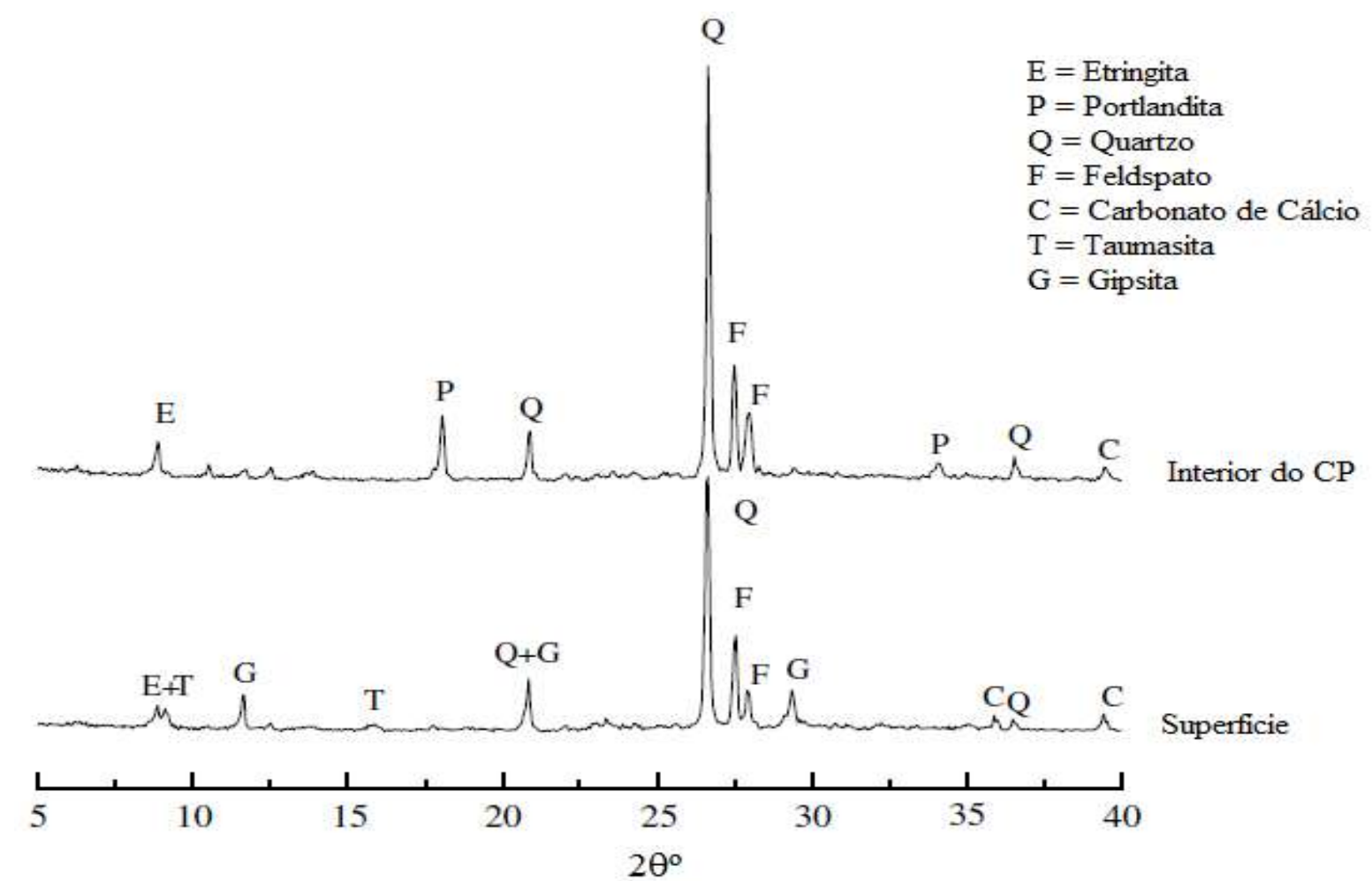

Figura 13: Difratograma de amostras de concreto deterioradas pelo ataque por sulfato de sódio após 510 dias de exposição. Fonte: Adaptado de Lee et al. (2005).

Como visto, os desvios das ondas de raios-X produzem picos característicos para cada mineral, assim, segundo Mehta e Monteiro (2014), se uma amostra contém mais de um mineral, como o concreto, a intensidade dos picos característicos individuais do mineral é proporcional a sua quantidade, a exemplo dos picos de quartzo da Figura 13. Porém, esta técnica não é aplicada no âmbito de quantificar a presença de determinado mineral, e sim, identificar sua presença. 
b) Termogravimetria

Segundo Hoppe Filho (2008), a termogravimetria determina a perda de massa de uma amostra hidratada em função da temperatura. $\mathrm{O}$ ensaio consiste em aquecer uma amostra a uma taxa constante, medindo a variação da massa da referida amostra ao longo do tempo. Haja vista, que cada composto hidratado possui uma determinada faixa de temperatura de decomposição é possível analisar o perfil da curva resultante $\Delta m=f(T)$, tanto qualitativa como quantitativamente.

\subsection{EFEITOS DAS ADIÇÕES MINERAIS}

No âmbito das adições minerais, todo e qualquer material sólido utilizado em conjunto com água, agregado graúdo e miúdo e cimento, podem ser considerados como tal, sendo este, adicionado, comumente, tanto antes ou durante a mistura (MALHOTRA E MEHTA, 1996).

De acordo com Mehta e Monteiro (2014) as adições são materiais finamente moídos, incorporados ao concreto em quantidades que variam em até $70 \%$ em relação à massa de cimento Portland. São geralmente utilizadas na produção de concretos que proporcionem aprimoramento das resistências mecânicas e de durabilidade. Dentre os benefícios obtidos pelo emprego das adições no concreto, os autores citam: melhora na resistência à fissuração térmica devido ao calor de hidratação mais baixo; melhoramento do comportamento mecânico; impermeabilidade por refinamento dos poros; fortalecimento da zona de transição; e, como resultado da redução da alcalinidade, uma maior durabilidade aos ataques químicos, tais como, águas sulfatadas e expansão álcali-agregado.

As adições minerais podem ser classificadas como cimentantes, inertes e pozolânicas. Para um melhor entendimento de cada uma destas, a seguir, serão discutidas as suas definições, propriedades e, posteriormente, a influência de suas adições frente ao ataque por sulfatos. Cabe comentar, que as adições cimentantes, não menos importantes, serão discutidas em menor escala, por estas não fazerem parte do plano experimental do presente trabalho.

a) Adições Cimentante

Os produtos cimentantes, possuem auto-hidratação lenta e a quantidade de produtos formados é insuficiente para obter uma capacidade mecânica para fins estruturais, porém, quando na presença de hidróxido de cálcio e gipsita torna-se acelerada (DAL MOLIN, 2011). 
Segundo Neville (1997), melhora a trabalhabilidade e torna a mistura mais coesiva, pois possuem uma melhor dispersão das partículas e possuem superfície mais lisa, consequentemente consomem menos água durante a mistura.

Exemplo, escória granulada de alto-forno, cinza volante de caráter básico;

b) Adições Inertes

De acordo com Neville (1997), é um material finamente moído, com aproximadamente a mesma finura do cimento Portland que, devido às suas propriedades físicas, tem um efeito benéfico sobre as propriedades do concreto. Este material não apresenta atividades químicas suficientes para ser considerado reativo, e sua ação está no efeito físico de preenchimento dos vazios da pasta e na colaboração da hidratação dos grãos de cimento. Segundo o autor, os fíleres são inertes, mas não é desvantajoso se eles apresentarem algumas propriedades hidráulicas ou se entrarem em reações não prejudiciais com os produtos de reações na pasta de cimento.

Exemplos, fíler calcário e fíler quartzoso.

a) Adições pozolânicas

Segundo a NBR 12.653:2015 é um material silicoso ou sílico-aluminoso que, por si só, possuem pouca ou nenhuma atividade aglomerante, mas que, quando finamente divididos, em presença de água, reage quimicamente com o hidróxido de cálcio originando compostos com propriedades aglomerantes e modificando a microestrutura da pasta.

O material pozolânico pode ser de origem natural (dispensa tratamento, além da moagem, para aprimorar reatividade) ou artificial. Cabe comentar, neste último caso, que no beneficiamento do material, tanto a temperatura de queima como o resfriamento, possuem grande influência na característica reativa do material (CORDEIRO, 2006). Isto porque, um sólido pode ser tido como cristalino ou amorfo e, o que o define de tal maneira é seu arranjo atômico regular ou irregular.

Assim sendo, quando um material no estado líquido é resfriado lentamente, de tal modo que a energia cinética de suas moléculas é reduzida vagarosamente, estas podem então arranjar-se de forma regular, produzindo um número máximo de ligações e levando a um mínimo de energia potencial. Já quando o resfriamento ocorre de forma abrupta, o mesmo não ocorre e a estrutura arranja-se irregularmente, tendo assim propriedades reativas muitas vezes 
superiores a de um sólido cristalino, até mesmo, um ponto de fusão muito inferior (RUSSELL, 1994; TIPLER E MOSCA, 2006).

A NBR 12.653:2012 classifica os materiais pozolânicos segundo três classes;

- Classe $N$ : pozolanas naturais e artificiais que obedeçam aos requisitos aplicáveis na norma, como certos materiais vulcânicos de caráter petrográfico ácido, "cherts" silicosos, terras diatomáceas e argilas calcinadas;

- Classe C: cinza volante produzida pela queima de carvão mineral em usinas termoelétricas que obedece aos requisitos aplicáveis na norma;

- Classe E: qualquer pozolana cujos requisitos diferem das classes anteriores.

A NBR 12.653 ainda estabelece que os materiais pozolânicos devam estar em conformidade com as exigências químicas e físicas estabelecidas nas Tabela 4 e Tabela 5:

Tabela 4: Exigências químicas.

\begin{tabular}{lccc}
\hline \multirow{2}{*}{ Propriedades } & \multicolumn{3}{c}{ Classe de material pozolânico. } \\
\cline { 2 - 4 } & $\mathbf{N}$ & $\mathbf{C}$ & $\mathbf{E}$ \\
\hline $\mathrm{SiO}_{2}+\mathrm{Al}_{2} \mathrm{O}_{3}+\mathrm{Fe}_{2} \mathrm{O}_{3}, \%$ mín. & 70 & 70 & 50 \\
$\mathrm{SO}_{3}, \%$ máx. & 4,0 & 5,0 & 5,0 \\
Teor de umidade, \% máx. & 3,0 & 3,0 & 3,0 \\
$\begin{array}{l}\text { Perda ao fogo, \% máx. } \\
\text { Álcalis disponíveis em } \mathrm{Na}_{2} \mathrm{O}, \\
\text { \% máx. }\end{array}$ & 10,0 & 6,0 & 6,0 \\
NBR 12.653 (ASSOSSIAÇÃO BRASILEIRA DE NORMAS TÉCNICAS, 2015).
\end{tabular}

Tabela 5: Exigências físicas.

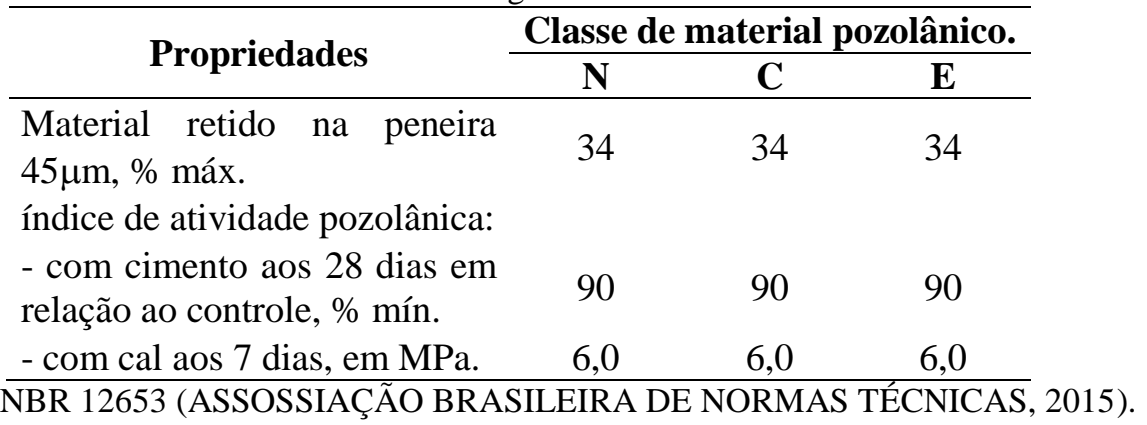

Exemplos de adições pozolânicas: sílica de casca de arroz, cinza volante, sílica ativa, metacaulim.

2.4.1 Influência das adições minerais no ataque por sulfatos

Os produtos de hidratação do cimento Portland mais suscetíveis ao ataque externo por sulfatos são o hidróxido de cálcio e os compostos hidratados que contêm alumina. Deste 
modo, é conveniente utilizar materiais ligantes que reduzam as quantidades finais de, ao menos, um destes compostos, transformando-os em produtos de hidratação mais resistentes. Por conseguinte, diferentes materiais são adicionados à matriz cimentante para aumentar a resistência aos sulfatos, como por exemplo, escória de alto forno (ATAHAN E DIKME, 2011; KOMLJENOVIC et al., 2013), cinza volante (CHINDAPRASIRT et al., 2007), sílica ativa (LEE, et al. 2005; HASSAN et al., 2012), metacaulim (LEE, et al. 2005; AL-AKHRAS, 2006; HASSAN et al., 2012; SAN NICOLAS et al. 2014), fíler calcário (GHRICI et al. 2007; LEE et al. 2008), entre outros.

A utilização de adições minerais na composição do material ligante, em substituição parcial ao cimento, provoca alterações microestruturais que interferem na porosidade da matriz hidratada e, principalmente, na distribuição do tamanho dos poros e na interconectividade dos mesmos, o que influencia positiva ou negativamente o ingresso de água contendo íons sulfato para o interior da estrutura. As adições minerais, independentemente do tipo (inertes, cimentantes ou pozolânicas), exercem efeito físico sobre a cinética de hidratação do cimento, pelos efeitos de diluição e de nucleação heterogênea (LAWRENCE et al., 2003; RAHHAL et al., 2012; ZENG et al., 2012), enquanto as adições ativas (cimentantes e pozolânicas), além do efeito físico, exercem efeito químico, com formação de $\mathrm{C}-\mathrm{S}-\mathrm{H}_{\mathrm{SECUNDÁRIO}}$. As diferentes microestruturas hidratadas formadas quando da presença de adições minerais comportam-se distintamente frente à ação de agentes deletérios.

Todavia, atualmente, o principal parâmetro que é utilizado para indiretamente controlar a durabilidade de estruturas de concreto é, tão somente, a resistência à compressão. O que, segundo Hoppe Filho et al. (2013), é inadequado, pois concretos de referência e com adições minerais com a mesma resistência à compressão, apresentaram coeficiente de difusão significativamente distintos quando submetidos à penetração de cloretos e, tal resultado, é decorrente das alterações da microestrutura da pasta.

Pelo ponto de vista da impermeabilidade e durabilidade, os efeitos da reação pozolânica são, provavelmente, mais significativos em argamassas do que em pasta endurecida de cimento, pois a permeabilidade da argamassa é maior devido às microfissuras da zona de transição. Tal região, deste modo, é mais porosa do que a pasta e contém um maior acúmulo de cristais de hidróxido de cálcio, tornando-a uma zona frágil, e quando sujeita a tensões, facilmente ocorrerão microfissuras. Portanto, a incorporação de adições minerais assume um papel importante, uma vez que são capazes de alterar e melhorar as características da zona de transição (MEHTA e MONTEIRO, 2014). 
A importância técnica dos concretos com adições pozolânicas deriva principalmente de três aspectos: Primeiramente, a reação é lenta, portanto, a liberação de calor devido às reações de hidratação também é lenta. Segundo, as reações causadas por estes materiais consomem hidróxido de cálcio, ao invés de produzi-los, contribuindo para a resistência da pasta frente às soluções agressivas de sulfato, por exemplo. Terceiro, a reação entre a interação do $\mathrm{SiO}_{2}$, do $\mathrm{Ca}(\mathrm{OH})_{2}$ e da água presente nos poros do concreto levam a formação de $C-S-H$.

Estudos como os de Bonen (1992) e Lee, et al. (2005) indicam que o uso de sílica ativa (SA) em substituição parcial do cimento Portland é benéfico na minoração do ataque por sulfatos. Para Bonen (1992), que estudou esta adição frente o ataque por sulfato de magnésio concluiu que a SA reduz a taxa de penetração de íons sulfato, assim como, produz gipsita e etringita em menores quantidades no interior das amostras de argamassa em virtude da sua elevada pozolanicidade. Porém, segundo o autor, as amostras contendo SA, quando comparadas à referência, apresentaram uma descalcificação do $C-S-H$ muito mais intensa, o que pode indicar uma perda percentual de resistência mecânica, também mais intensa.

Lee, et al. (2005) avaliaram a influência da substituição parcial do cimento Portland por sílica ativa nos seguintes teores, $5 \%$ ( $a / c$ de 0,45$), 10 \%(a / c$ de, $0,35,0,45$ e 0,55$)$ e $15 \%$ $(a / c$ de 0,45$)$ para exposição ao sulfato de magnésio e também para o sulfato de sódio. Para a solução de sulfato de sódio as amostras contendo diferentes composições com SA apresentaram significativa resistência. Fora observado que em $510^{\circ}$ dia de exposição às amostras apresentaram pequenas fissuras e perda de massa negligenciável, enquanto que amostras sem adição de SA apresentaram mais de $10 \%$ de perda de massa, severa fissuração mapeada, significativa expansão e uma perda de resistência à compressão cerca de $200 \%$ maior das que continham sílica ativa.

Para a exposição ao sulfato de magnésio, Lee et al. (2005) comentam que as composições de sílica ativa apresentaram considerável desintegração superficial com perda de seção das barras de argamassa devido à intensa descalcificação do $C-S-H$. Os autores acrescentam ainda que conforme maior for o teor de substituição do cimento por sílica ativa, maior será a perda de resistência à compressão destas. Os resultados obtidos mostram que tais perdas podem chegar a 50\% quando comparadas às séries sem a adição de sílica ativa.

Chatveera e Lertwattanaruk (2009) avaliaram a resistência aos sulfatos de barras de argamassa contendo a adição de sílica de casca de arroz (SCA). Foram estudadas composições com teores de SCA que variaram em 10\%, 30\% e 50\% e relação água/cimento em 0,55 e 0,65. Os autores concluíram que a durabilidade das argamassas expostas à solução 
de $\mathrm{Na}_{2} \mathrm{SO}_{4}$, com uso de SCA, obtiveram efeitos positivos na redução da expansão e perda de resistência à compressão das argamassas. As argamassas com substituição de $10 \%$ de SCA produziram expansões inferiores a 0,05\% com 6 meses de exposição. Enquanto que teores de $30-50 \%$ de substituição do cimento obtiveram expansões ainda menores, de 0,04\%. Em todos os casos, a adição de SCA colaborou para que as composições fossem classificadas como de elevada durabilidade frente o sulfato de sódio, segundo a ASTM C 1157.

Para exposição à solução de $\mathrm{MgSO}_{4}$, o uso da SCA também obteve um efeito positivo quanto à expansão, no entanto, a adição de SCA foi prejudicial às argamassas quanto à perda de resistência à compressão, obtendo resultados de variação superiores conforme maior o teor de substituição.

Trabalhos como os de Lee, et al. (2005), Al-Akhras (2006) e Chindaprasirt et al. (2007) estudaram a substituição parcial do cimento Portland por adições minerais pozolânica sílico-aluminosas (cinza volante e metacaulim). Segundo os autores, a adição destes materiais trazem benefícios quanto ao ataque por sulfatos, entretanto, conforme apresentado por Lee, et al. (2005), conforme maior o teor destas adições na composição, menores são os benefícios. Isto porque, tais adições, elevam os teores de aluminatos no sistema, favorecendo a formação de etringita.

O uso das adições minerais quimicamente inertes na composição de produtos cimentícios, são amplamente abordados na literatura (LAWRENCE, et al., 2003; HOPPE FILHO, 2008; NEVILLE E BROOKS, 2013; MEHTA E MONTEIRO, 2014), assim como as demais adições. É sabido, que tais materiais, podem influenciar nas características físicas, mecânicas e químicas do concreto, mesmo tratando-se de um material inerte. Podem ser observados três efeitos físicos de adições minerais quando usadas em materiais cimentícios (LAWRENCE, et al., 200). Duas destas, diluição do cimento e melhora no empacotamento das partículas, são consequências diretas da substituição ou adição destas partículas, enquanto que o terceiro efeito cabe ao melhoramento da nucleação do grão de cimento. No que tange à hidratação do cimento Portland, tais adições podem modificar a cinética deste fenômeno, especialmente quando considerado em baixas idades. Isto porque as partículas inertes e finamente moídas propiciam uma melhora na nucleação heterogênea (CYR, et al., 2003; LAWRENCE, et al., 2003; HOPPE FILHO, 2008).

O processo físico da nucleação conduz a uma ativação química da hidratação do cimento, ou seja, o material da adição catalisa o processo de nucleação através da redução da barreira de energia (CYR, et al., 2003; LAWRENCE, et al., 2003). Cabe comentar ainda que partículas de fíleres maiores que as do cimento pouco influenciaram na hidratação, neste caso, 
a precipitação dos hidratos ocorreram, exclusivamente, na superfície dos grãos de clínquer. Esta aceleração na hidratação do cimento Portland pode acarretar em uma maior resistência à degradação ocasionada pelos íons sulfato, em menores idades. Contudo, para maiores idades, composições contendo a adição de fíleres são mais vulneráveis ao ataque por sulfato, em relação às adições pozolânicas, por não consumirem parte da portlandita gerada na hidratação do cimento. Logo, possibilitando a formação de produtos expansíveis como a gipsita (IRASSAR et al., 2000; LEE et al., 2008; SKAROPOULOU et al., 2009).

Para Matschei et al. (2007), o fíler calcário, adicionado como material ligante, também pode apresentar alguma atividade reativa com o cimento Portland. Isto porque, uma pequena parcela deste material pode ser consumida na reação para a formação de monocarboaluminato de cálcio hidratado. Kakali et al. (2000) estudaram pastas de $\mathrm{C}_{3} \mathrm{~A}$ com teores de carbonato de cálcio que variaram de $0 \%$ a $35 \%$ e concluíram que a transformação da AFt em AFm foi retardada com a presença do carbonato de cálcio devido à formação de monocarboaluminato de cálcio hidratado.

Tendo vista que a adição de fíler calcário possa contribuir com a diminuição no teor de AFm, o sistema (cimento + fíler calcário) pode contribuir na minoração do grau do ataque dos íons sulfato, haja vista que, segundo Mehta e Monteiro (2014), quanto maior o teor de monossulfoaluminato de cálcio hidratado mais vulnerável o concreto estará frente ao ataque por sulfatos. Porém, Irassar et al. (2000), Lee et al., (2008) e Skaropoulou et al. (2009) mostram diferentes tendências quanto à adição de fíler calcário. Para os autores, a presença desta adição mineral também pode apresentar alguma atividade reativa, porém, pode ser prejudicial quando exposto aos íons sulfato, principalmente, para exposição às baixas temperaturas (inferiores a $15^{\circ} \mathrm{C}$ ). Isto em virtude da liberação de carbonatos passíveis de reação com os sulfatos e potencialização na formação de taumasita. 


\section{PROGRAMA EXPERIMENTAL}

Para o cumprimento do objetivo do presente trabalho, fora realizada uma pesquisa de caráter experimental, com foco na produção de resultados que possam gerar conhecimentos para uso e aplicação prática no âmbito da solução de problemas técnicos específicos ao tema estudado.

Portanto, com intuito de avaliar a influência de adições minerais na mitigação do ataque por sulfatos na matriz cimentícia, a presente pesquisa tem como tema central identificar os fatores que determinam ou que contribuem para a ocorrência dos fenômenos químicos e físicos relacionados à degradação. Sendo assim, a abordagem do problema implicará na manipulação de duas variáveis independentes, a solução agressiva de sulfato e a utilização de adição mineral na composição do material cimentícios, a ser variada em procedimentos técnicos experimentais de forma a obter os resultados inerentes a presente pesquisa.

Por fim, foi realizado tratamento estatístico para auxílio na identificação de tendências comportamentais para cada tipo de solução agressiva e adição mineral.

\subsection{VARIÁVEIS DO ESTUDO}

A partir do objetivo proposto, a elaboração do programa experimental abrange, além da variação da solução de sulfato, a variação da composição do material cimentício para moldagem de corpos de prova de argamassa e de pastas de cimento. Contudo, a composição do traço seguiu os critérios da NBR 13.583/2014, as quais foram submetidas ao ataque por sulfato de sódio, conforme recomendações da referida norma, e também ao ataque por sulfato de magnésio, que não é contemplado na norma, porém degrada consideravelmente a matriz cimentícia.

Desta maneira, os fatores controláveis e fixos são: relação água/finos (cimento + adição mineral) de 0,60 ; temperatura de exposição $\left(40{ }^{\circ} \mathrm{C}\right)$; tempo de exposição (140 dias).

Por outro lado, as variáveis independentes desta pesquisa são:

- Soluções agressivas de exposição: sulfato de sódio e sulfato de magnésio;

- Cimento Portland: CP V - ARI e CP V - ARI RS;

- Adições minerais utilizadas: fíler calcário; fíler quartzoso; resíduo de cerâmica vermelha; sílica de casca de arroz; cinza volante; metacaulim e sílica ativa; 
- Grau de moagem do resíduo de cerâmica vermelha: 0,5; 1,0; e 1,5 horas em moinho de bolas - equipamento para o ensaio de abrasão Los Angeles.

Enquanto que as variáveis de resposta que serão discutidas no presente trabalho estão listadas a seguir:

- Variação dimensional de barras de argamassa com dimensões de 25 x 25 x 285 mm, conforme NBR 13.583/2014;

- Variação volumétrica de barras de argamassa com dimensões de 40 x 40 x 160 mm;

- Resistência à tração na flexão;

- Resistência à compressão;

- Variação de massa;

- Difração de raios-X (realizada em amostras de pasta de cimento Portland);

- Velocidade de propagação de ondas ultrassônicas.

\subsection{CARACTERIZAÇÃO DOS MATERIAIS}

\subsubsection{Ensaios em cimento e adições minerais}

Para análise físico-química dos materiais utilizados no presente trabalho foram empregadas as seguintes técnicas:

a) Perda ao Fogo

De acordo com os critérios da ABNT NBR NM 18:2012, o ensaio da determinação de perda ao fogo consiste na calcinação de $1,0 \pm 0,001 \mathrm{~g}$ de amostra disposta em cadinho de porcelana e levada em forno mufla à temperatura entre 900 e $1000^{\circ} \mathrm{C}$ por um período de, no mínimo, 50 min, até obter massa constante. Após a calcinação da amostra, a mesma deve ser resfriada em dessecador até obter temperatura próxima a do ambiente. Por fim, a perda ao fogo deve ser calculada conforme Eq. 13, resultado este que se faz importante para a quantificação dos compósitos voláteis à temperatura, como a água, dióxido de carbono e carbono residual.

$$
P F=\frac{m_{1}-m_{2}}{m} \times 100
$$


Onde:

$m_{1} \quad=$ massa do cadinho mais massa inicial do material ensaiado $(\mathrm{g})$;

$m_{2} \quad$ = massa do cadinho mais massa final do material ensaiado $(\mathrm{g})$;

$m \quad$ = massa inicial do material ensaiado $(\mathrm{g})$.

b) Massa específica

A determinação da massa específica foi realizada para os materiais cimentantes e adições minerais.

O ensaio foi realizado seguindo os critérios preconizados pela NBR NM 23:2001 utilizando o frasco de Le Chatelier, com capacidade volumétrica de $250 \mathrm{~cm}^{3}$. Tendo em vista que a referida norma especifica que o líquido a ser utilizado não reaja quimicamente com os materiais estudados e que, deva ter densidade igual ou superior a $0,731 \mathrm{~g} / \mathrm{cm}^{3}$, optou-se então, pela utilização de água destilada para as adições minerais e de querosene para os cimentos CP V - ARI e CP V - ARI RS.

\section{c) Determinação da área superficial específica pelo método Blaine}

A área específica Blaine foi determinada fazendo uso do permeâmetro de Blaine com o qual é medido o tempo para que uma quantidade de ar passe pela camada de material compactada, de dimensões e porosidade especificadas, conforme NBR NM 16.372:2015. Este método somente permite uma determinação limitada das propriedades dos materiais em uso e o método de permeabilidade ao ar pode não fornecer resultados significativos para materiais contendo partículas ultrafinas, não sendo a técnica mais adequada para o estudo de adições minerais de elevada finura, logo este método somente foi utilizado para comparação da área superficial dos cimentos utilizados. O método é mais comparativo que absoluto e, portanto, requer uma amostra de superfície específica conhecida para calibração do aparelho.

\section{d) Determinação da área superficial específica pelo método BET}

O método BET (Stephen Brunauer, Paul Hugh Emmett e Edward Teller) baseia-se na adsorção física de moléculas de um gás inerte sobre uma superfície externa e interna dos poros abertos e interligados das partículas do sólido ensaiado. O equipamento de análise determina o volume de gás fixado na superfície da amostra e, a partir dos resultados, 
estabelece a área superficial específica considerando, por extrapolação, a adsorção de monocamada de gás inerte sobre as partículas do material analisado (ROCHA E PERES, 2009). Para tanto, a amostra a ser ensaiada deve passar por um processo de desgaseificação sob alta temperatura e vácuo, para a completa remoção de água e outros contaminantes adsorvidos na amostra.

A análise é realizada adicionando, em etapas, quantidades conhecidas de nitrogênio ao recipiente da amostra, de forma que diferentes pressões de vapor sejam alcançadas. Durante o procedimento, um sensor monitora as variações de pressão. Quando a pressão de saturação é alcançada a absorção de gás é interrompida. A amostra é removida da atmosfera de nitrogênio e aquecida para que ocorra a dessorção e quantificação das moléculas de nitrogênio adsorvidas no material.

e) Determinação da atividade pozolânica pelo método Chapelle modificado

O método Chapelle modificado, conforme NBR 15.895:2010 permite a quantificação da pozolanicidade de um determinado material, a partir de sua reação com o óxido de cálcio em condições controladas. Para tanto, adiciona-se, em um frasco Erlenmeyer de $500 \mathrm{~mL}$, a adição mineral estudada mais o óxido de cálcio na proporção 1:2, ou seja, 1,000 g de adição para 2,000 g de $\mathrm{CaO}$ e $250 \mathrm{~mL}$ de água isenta de dióxido de carbono. Por fim, mantem-se o frasco em banho-maria por $16 h$ à temperatura de $90 \pm 5{ }^{\circ} C$ com agitação constante.

A pozolanicidade do material é admitida quando o consumo de óxido de cálcio for superior a $330 \mathrm{mg} \mathrm{CaO/g}$ de adição, segundo Raverdy et al. (1980) apud Hoppe Filho (2008). A quantificação do consumo da cal, após ensaio, é por meio de titulação em solução de $\operatorname{HCl}(0,1 \mathrm{~N})$ e fenolftaleína $(1 \mathrm{~g} / L)$.

Tendo em vista que uma adição pozolânica poderá consumir, quando adicionada à pasta de cimento, a portlandita $\left[\mathrm{Ca}(\mathrm{OH})_{2}\right]$, se faz necessária à conversão relativa de consumo de $\mathrm{CaO}$ para $\mathrm{Ca}(\mathrm{OH})_{2}$. Para isto, basta multiplicar o valor obtido no ensaio por 1,3213 (valor este que é referente à relação molecular $\left.\mathrm{Ca}(\mathrm{OH}])_{2} / \mathrm{CaO}\right)$. Logo, pode-se considerar também, que o consumo mínimo de hidróxido de cálcio é de $436 \mathrm{mg} \mathrm{Ca}(\mathrm{OH})_{2} / \mathrm{g}$ de adição.

Ter conhecimento do consumo de portlandita a partir da adição mineral acrescentada a mistura se torna de grande valia, pois o teor remanescente deste composto tem probabilidade elevada de reação com os íons sulfato, podendo contribuir na formação de gipsita, brucita e de etringita secundária. 
Para tanto, o consumo máximo de portlandita que determinada adição acarretará, levando em consideração o teor utilizado em substituição parcial do cimento Portland pode ser obtido conforme Eq. 14.

$$
\mathrm{Ca}(\mathrm{OH})_{2 \text { consumo }}=\mathrm{Ca}(\mathrm{OH})_{2 \text { Chapelle }} \times \text { Teor da adição }
$$

Onde:

$\mathrm{Ca}(\mathrm{OH})_{2 \text { consumo }}=$ consumo máximo de portlandita a partir da adição utilizada (\%)

$\mathrm{Ca}(\mathrm{OH})_{2}$ Chapelle = valor obtido com os ensaios de Chapelle $\left(\mathrm{g} \mathrm{Ca}(\mathrm{OH})_{2} / g\right.$ de adição $)$

Teor da adição $\quad=$ teor de adição a ser utilizado $(\%)$

\section{f) Análise química por Fluorescência de raios-X}

O espectrômetro (instrumento óptico capaz de medir luzes em determinadas faixas do espectro eletromagnético) induz transições eletrônicas nos orbitais dos átomos da amostra testada, por meio da utilização de radiação eletromagnética. A julgar que os átomos possuem características individuais, tais transições eletrônicas resultam na emissão de radiação X com energia características de cada elemento podendo, a partir disso, mensurar sua abundância.

Neste estudo foram confeccionadas pastilhas dos materiais a serem avaliados para acoplamento no equipamento (Figura 14). O espectrômetro de fluorescência de raios-X utilizado foi o EDX - 720 da marca Shimadzu, conforme Figura 15.

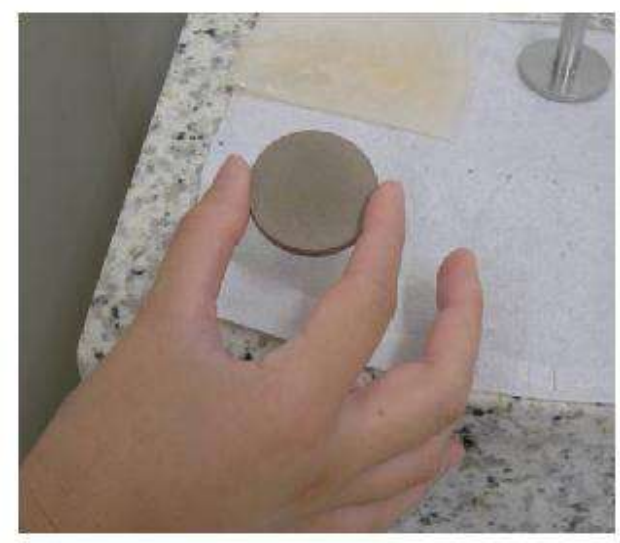

Figura 14: Preparo da amostra para ensaio de Fluorescência de Raios-X

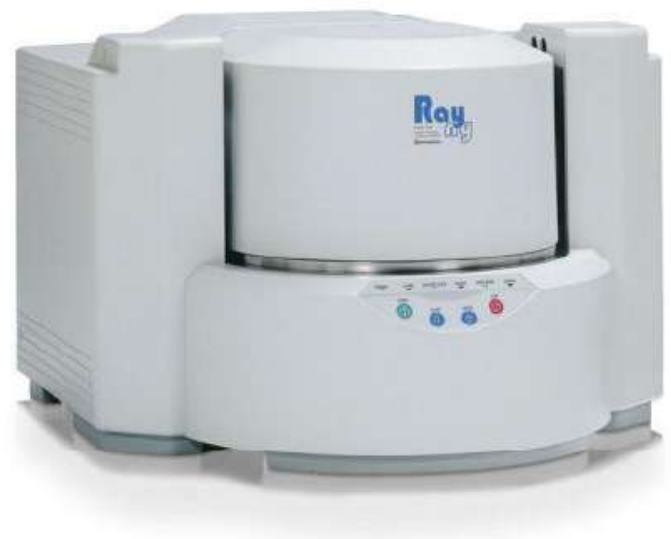

Figura 15: Espectrômetro de fluorescência de raios-X (Shimadzu). 


\section{g) Difração de raios-X}

Após preparo e acondicionamento das amostras, as mesmas passaram por processo de prensagem manual do pó no porta amostra de XRD para coleta dos difratogramas. Em seguida, foram expostas aos raios-X no equipamento RIGAKU Ultima IV X-ray diffractometer. A análise foi realizada de $5^{\circ}$ a $75^{\circ} 2 \theta$, com passo angular de $0,02^{\circ} 2 \theta$ e tempo por passo de 1 segundo. A análise utilizou tubo com ânodo de cobre, $40 \mathrm{kV} / 30 \mathrm{~mA}$ e fenda divergente de $1^{\circ}$.

\section{h) Distribuição granulométrica a laser}

A granulometria a laser parte do princípio do espalhamento de luz laser a partir da interação do feixe de luz com partículas em um meio fluido (água para as adições minerais e álcool etílico para a amostra de cimento). Neste método, um conjunto de lentes, detectores fotoelétricos e um microprocessador irão captar a intensidade da energia espalhada e transformá-la em distribuição volumétrica das partículas.

Logo, o ensaio consiste em analisar a amostra num equipamento composto por um sistema de dispersão e um sistema focal. A amostra é dispersa no fluido conforme supracitado e, a seguir, duas fontes de laser, posicionadas em $0^{\circ}$ e $45^{\circ}$, produzem um padrão de difração que varia conforme o tamanho das partículas. Foi utilizado o equipamento modelo CILAS 1064 com faixa de medição de 0,04-500 $\mu \mathrm{m}$.

Adicionada a amostra ao equipamento, este permanece por $60 \mathrm{~s}$ emitindo ondas ultrassônicas para desaglomeração das partículas adicionadas. Esta mistura é então, enviada até um recipiente por onde os feixes de laser irão atravessar e colidir com as partículas. Os resultados são coletados automaticamente por meio do software e a curva de distribuição granulométrica da amostra é representada.

\subsubsection{Materiais utilizados}

A seguir são apresentadas as características físico-químicas dos materiais empregados na presente pesquisa, obtidos a partir dos métodos supracitados. Comenta-se que a distribuição granulométrica dos materiais utilizados são apresentadas na Figura 94 presente no Apêndice 1 do presente trabalho. 


\subsubsection{Cimento Portland}

a) $C P V-A R I$ e $C P V-A R I R S$

A escolha destes aglomerantes fora devido suas composições serem de, basicamente, clínquer, gipsita e fíler calcário, sendo os cimentos comerciais com maior quantidade de clínquer do mercado brasileiro. Assim, não há influência de qualquer adição mineral no sistema de referência a ser avaliado, a não ser do teor de material carbonático permitido por norma. Menciona-se ainda que este tipo de cimento (CP V - ARI) é muito empregado na indústria de pré-moldados de concreto no Brasil devido, particularmente, a sua capacidade de alto ganho de resistência inicial. A utilização do cimento Portland do tipo CP V - ARI RS foi também por este ser vendido comercialmente como resistente aos sulfatos, deste modo, serve como auxiliar para a tomada de decisão na classificação da resistência aos íons sulfato das composições de argamassa contendo adições minerais.

A Tabela 6 apresenta as composições químicas dos cimentos CP V - ARI e CP V ARI RS. Cabe comentar que tal tabela é uma mescla dos resultados obtidos a partir da fluorescência de raios-X e de informações fornecidas pelo fabricante (conforme indicado na própria tabela). Já a Tabela 7 apresenta as características físicas dos cimentos.

Cabe comentar que a discussão dos resultados obtidos a partir dos compostos de Bogue, baseado nos resultados obtidos com a análise química apresentada, podem ser vistos no capítulo 4.2 do presente trabalho.

Tabela 6: Composição química dos cimentos CP V - ARI e CP V - ARI RS

\begin{tabular}{|c|c|c|c|c|c|c|c|c|c|c|}
\hline \multirow[b]{2}{*}{ Aglomerante } & \multicolumn{10}{|c|}{ Análise Química (\%) } \\
\hline & $\mathrm{CaO}$ & $\mathrm{SiO}_{2}$ & $\mathrm{Al}_{2} \mathrm{O}_{3}$ & $\mathrm{Fe}_{2} \mathrm{O}_{3}$ & $\mathrm{MgO}$ & $\mathrm{SO}_{3}$ & $\mathrm{~K}_{2} \mathrm{O}$ & $\begin{array}{c}\mathrm{CaO} \\
\text { livre* }\end{array}$ & $\begin{array}{c}\text { Res. } \\
\text { Insolúvel* }\end{array}$ & $\begin{array}{l}\text { Perda } \\
\text { Fogo }\end{array}$ \\
\hline CP V - ARI & 59,36 & 16,27 & 5,06 & 2,77 & 4,63 & 5,30 & 1,06 & 1,46 & 0,67 & 3,43 \\
\hline CP V - ARI RS & 55,40 & 20,10 & 4,80 & 3,50 & 5,60 & 2,80 & 1,00 & - & 0,90 & 5,97 \\
\hline
\end{tabular}

Tabela 7: Características físicas do cimento CP V - ARI

\begin{tabular}{cccc}
\hline \multirow{2}{*}{ Aglomerante } & \multicolumn{3}{c}{ Características Físicas } \\
& Blaine $\left(\mathrm{m}^{2} / \mathrm{g}\right)$ & BET $\left(\mathrm{m}^{2} / \mathrm{g}\right)$ & Massa específica $\left(\mathrm{g} / \mathrm{cm}^{3}\right)$ \\
\hline CP V - ARI & 0,451 & 1,070 & 3,13 \\
CP V - ARI RS & 0,503 & - & 3,21 \\
\hline
\end{tabular}


Quando comparadas as análises químicas de ambos os cimentos utilizados vê-se, para o RS, que o teor de óxido de cálcio é inferior em 3,96\%, o teor de $\mathrm{SiO}_{2}$ aumentou em 3,83\%, o teor de alumina é $0,26 \%$ inferior, e, por fim, mas não menos importante, o teor de $\mathrm{Fe}_{2} \mathrm{O}_{3}$ é 0,73\% superior. Tais resultados impactam diretamente quanto à capacidade de formação de produtos da hidratação do cimento passíveis de reação com os íons sulfato. Isto porque a diminuição da relação $\mathrm{Ca} / \mathrm{Si}$ de 3,65 para 2,76 resulta, segundo Bellmann e Stark (2007) e Lothenbach et al. (2011), em um consequente teor de $C_{3} S$ menor, assim como, uma menor formação de $\mathrm{Ca}(\mathrm{OH})_{2}$, após hidratação.

Neste mesmo sentido, segundo Skalny et al. (2002) e Tikalsky et al. (2002), uma diminuição no teor de alumina e um aumento no de $\mathrm{Fe}_{2} \mathrm{O}_{3}$ também influenciam positivamente na hidratação, isto porque, segundo os autores haverá uma menor formação de monossulfoaluminato de cálcio hidratado, que está diretamente relacionado à formação etringita secundária.

Entretanto, segundo Taylor (1997), cimentos com baixa quantidade livre de hidróxido de cálcio, pode tornar o concreto mais suscetível ao ataque por sulfatos de magnésio, pois, este tipo de sulfato pode reagir com o $C-S-H$.

Por fim, por análise gráfica a partir da distribuição granulométrica mostrada na Figura 94 (Apêndice 1), observa-se que o CP V - ARI apresenta distribuição média das partículas cerca de $1 \mu \mathrm{m}$ inferior ao cimento RS $(5 \mu \mathrm{m}$ para o CP V - ARI e $6 \mu \mathrm{m}$ para o CP V - ARI $\mathrm{RS})$.

\subsubsection{Adições minerais inertes}

As propriedades químicas obtidas a partir da fluorescência de raios-X referentes a estas adições minerais são apresentadas na Tabela 8.

Tabela 8: Composição química das adições minerais inertes.

\begin{tabular}{cccccccccc}
\hline & \multicolumn{10}{c}{ Composição química (\%) } \\
\cline { 2 - 9 } Adição Mineral & $\mathrm{CaO}$ & $\mathrm{SiO}_{2}$ & $\mathrm{Al}_{2} \mathrm{O}_{3}$ & $\mathrm{Fe}_{2} \mathrm{O}_{3}$ & $\mathrm{MgO}$ & $\mathrm{SO}_{3}$ & $\mathrm{~K}_{2} \mathrm{O}$ & $\begin{array}{c}\text { Demais } \\
\text { Oxidos }\end{array}$ & $\begin{array}{c}\text { Perda } \\
\text { Fogo }\end{array}$ \\
\hline Fíler Calcário & 42,77 & 1,62 & 0,95 & 0,24 & 8,25 & 0,66 & 0,17 & $0,14^{\mathrm{I}}$ & 45,2 \\
Fíler Quartzoso & - & 94,45 & 2,76 & - & - & 1,18 & 0,29 & $0,05^{\mathrm{II}}$ & 1,3 \\
\hline${ }^{\mathrm{I}} \mathrm{SrO}_{\mathrm{In}} \mathrm{MnO}^{\mathrm{II}} \mathrm{TiO}_{2}, \mathrm{Ho}_{2} \mathrm{O}_{3}, \mathrm{Ge} \mathrm{O}_{2}, \mathrm{CuO}, \mathrm{ZnO}$ e $\mathrm{NiO}$ \\
\hline
\end{tabular}


Observa-se com a análise química que o fíler calcário utilizado possui um elevado teor de óxido de magnésio de 8,25\%, contudo, segundo Bowles (1956), o mineral enquadra-se como uma rocha calcítica por possuir teor de $\mathrm{MgO}$ inferior a $10 \%$. Por outro lado, a composição química do fíler quartzoso, como esperado, apresentou um elevado teor de dióxido de silício, próximo de 95\%. Convergindo na mesma direção, a Figura 16 mostra a DRX de ambos os fíleres, indicando que no fíler calcário foram identificadas como fases mineralógicas predominantes a calcita, dolomita e quartzo, e no fíler quartzoso, apenas quartzo. Outra informação importante que pode ser retirada dos difratogramas é que, em ambos os casos, os materiais não apresentaram halo amorfo, portanto, não dispõem de fração vítrea passível de reatividade química com os compostos do cimento.

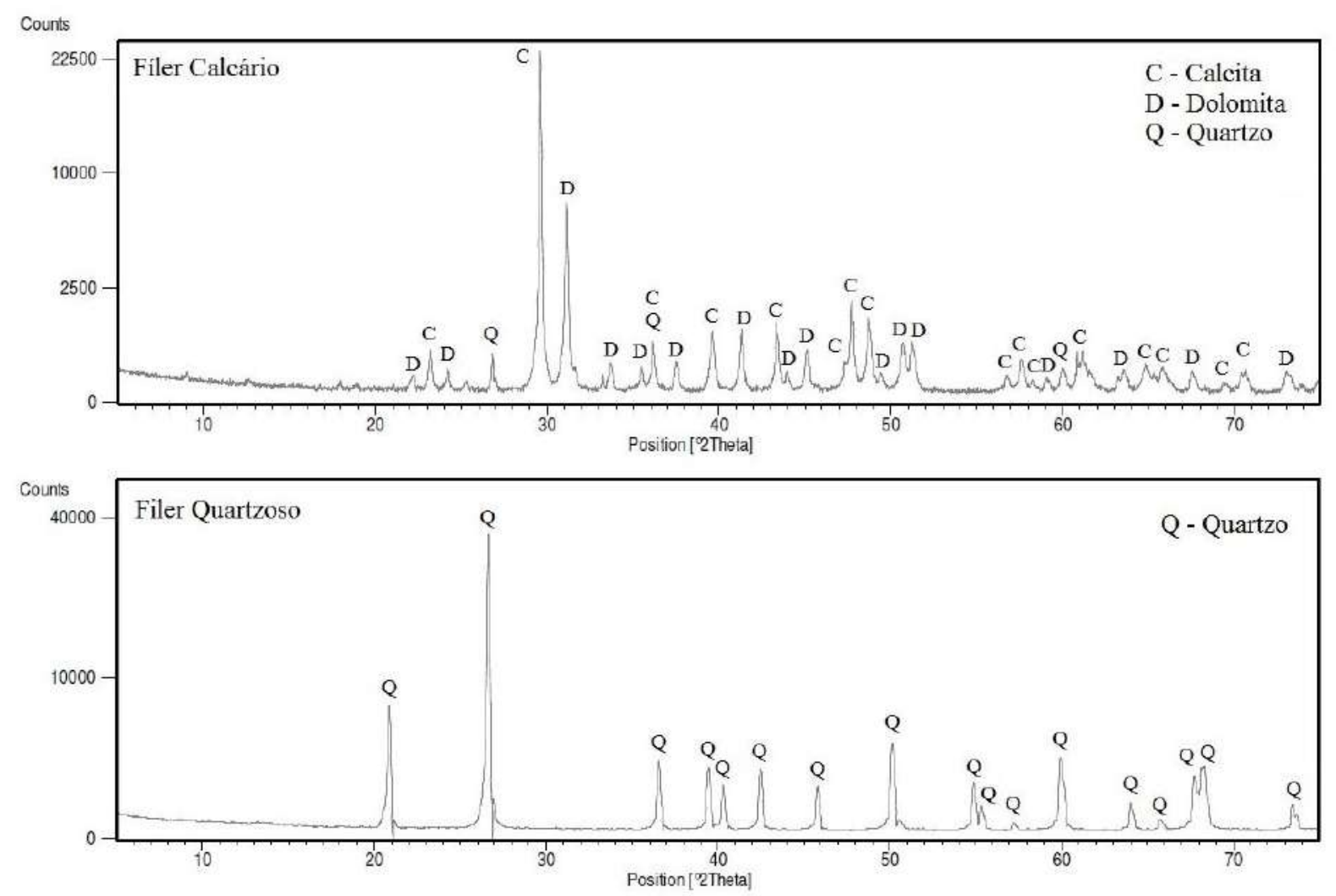

Figura 16: Difratogramas dos fíleres calcário e quartzoso.

Já as características físicas dos materiais inertes estudados podem ser observadas na Tabela 9. Logo se vê que ambas as adições apresentam maior área específica e menor massa específica do que o cimento CP V - ARI. Por outro lado, os fíleres calcário e quartzoso apresentaram distribuições granulométricas médias em torno de $11 \mu \mathrm{m}$ (Figura 94 no Apêndice 1), ou seja, cerca de $6 \mu \mathrm{m}$ superiores ao cimento CP V - ARI. 
Tabela 9: Características físicas das Adições Minerais Inertes

\section{Adição Mineral}

\section{Características físicas}

$\operatorname{BET}\left(\mathrm{m}^{2} / \mathrm{g}\right) \quad$ Massa específica $\left(\mathrm{g} / \mathrm{cm}^{3}\right)$

\begin{tabular}{ccc}
\hline Fíler Calcário & 1,413 & 2,70 \\
Fíler Quartzoso & 1,227 & 2,60 \\
\hline
\end{tabular}

\subsubsection{Adições minerais pozolânicas}

As adições minerais pozolânicas utilizadas na presente pesquisa foram: resíduo de cerâmica vermelha (RCV), metacaulim, cinza volante, sílica ativa, sílica de casca de arroz. Sendo, o RCV, oriundo de blocos cerâmicos de 6 e 8 furos provenientes de olarias da região de Prudentópolis, PR. Inicialmente o material foi triturado em britador de até obtenção de $100 \%$ de material passante pela peneira de abertura 4,8 mm (peneira $\mathrm{n}^{\circ} .4$ ). A partir disso o material passante foi moído em moinho de bolas (abrasão Los Angeles) durante os tempos determinados: 0,$5 ; 1,0$ e 1,5 horas. Desta forma, são três as amostras de cerâmica moída, ou seja:

- Resíduo cerâmico moído por $0,5 \mathrm{~h}$;

- Resíduo cerâmico moído por 1h;

- Resíduo cerâmico moído por 1,5h.

As composições químicas das adições minerais pozolânicas estão apresentadas na Tabela 10.

Tabela 10: Composição química das Adições Minerais Pozolânicas

\begin{tabular}{|c|c|c|c|c|c|c|c|c|c|}
\hline \multirow[b]{2}{*}{ Adição Mineral } & \multicolumn{9}{|c|}{ Composição química (\%) } \\
\hline & $\mathrm{CaO}$ & $\mathrm{SiO}_{2}$ & $\mathrm{Al}_{2} \mathrm{O}_{3}$ & $\mathrm{Fe}_{2} \mathrm{O}_{3}$ & $\mathrm{MgO}$ & $\mathrm{SO}_{3}$ & $\mathrm{~K}_{2} \mathrm{O}$ & $\begin{array}{l}\text { Demais } \\
\text { Óxidos }\end{array}$ & Perda Fogo \\
\hline Cerâmica Vermelha & 0,18 & 53,13 & 34,10 & 5,05 & - & 1,18 & 1,23 & $1,18^{\mathrm{I}}$ & 3,95 \\
\hline Metacaulim & 0,07 & 39,72 & 49,66 & 1,68 & - & 1,41 & - & $1,24^{\mathrm{II}}$ & 6,23 \\
\hline Cinza Volante & 1,60 & 57,80 & 26,30 & 6,20 & 0,80 & 0,30 & 3,00 & $1,78^{\mathrm{III}}$ & 1,99 \\
\hline Sílica Ativa & 0,19 & 92,35 & 2,21 & 0,05 & - & 1,52 & 0,94 & $0,04^{\mathrm{IV}}$ & 2,70 \\
\hline Sílica Casca Arroz & 0,43 & 88,47 & 2,72 & 0,05 & - & 1,55 & 1,46 & $0,49^{\mathrm{V}}$ & 4,84 \\
\hline $\begin{array}{l}{ }^{\mathrm{I}} \mathrm{TiO}_{2}, \mathrm{ZrO}_{2}, \mathrm{Cr}_{2} \mathrm{O}_{3} \\
{ }^{\mathrm{II}} \mathrm{TiO}_{2}, \mathrm{ZrO}_{2}, \mathrm{Cr}_{2} \mathrm{O}_{3} \\
{ }^{\mathrm{III}} \mathrm{TiO}_{2}, \mathrm{Rb}_{2} \mathrm{O}, \mathrm{MnO} \\
\mathrm{IV} \mathrm{CuO}_{\mathrm{ZnO}, \mathrm{MnO}} \\
{ }^{\mathrm{v}} \mathrm{CuO}, \mathrm{ZnO}, \mathrm{MnO},\end{array}$ & $\begin{array}{l}\mathrm{V}_{2} \mathrm{O}_{5} \\
\mathrm{Ga}_{2} \mathrm{O} \\
\mathrm{ZnO} \\
\mathrm{Rb}_{2} \mathrm{O} \\
{ }_{2} \mathrm{O}_{5}, \mathrm{~T}\end{array}$ & $\begin{array}{l}{ }_{2} \mathrm{O}_{3}, R \\
\mathrm{Y}_{2} \mathrm{O}_{3} \\
\mathrm{CuO}, \mathrm{P}_{2} \\
n_{2} \mathrm{O}_{3} \mathrm{e}\end{array}$ & $\begin{array}{l}\mathrm{O}, \mathrm{Gec} \\
b_{2} \mathrm{O}, \mathrm{G} \\
{ }_{5}, \mathrm{Tm}_{2} \\
b_{2} \mathrm{O}\end{array}$ & $\begin{array}{l}\mathrm{MnO} \\
2, \mathrm{MnC} \\
\text { e } \mathrm{SrO}\end{array}$ & $\begin{array}{l}2 O \text { e } S \\
Z n O \text { e }\end{array}$ & $\begin{array}{l}\mathrm{O} \\
\mathrm{SrO}\end{array}$ & & & \\
\hline
\end{tabular}


Materiais oriundos da calcinação de argilas, como o resíduo da cerâmica vermelha e o metacaulim (argilas cauliníticas), apresentam como características consideráveis teores de aluminatos e óxidos férricos, comuns às suas origens. Contudo, observa-se que o metacaulim apresenta resultados conflitantes com os requisitos mínimos e máximos preconizados pela ABNT NBR 15.894-1:2010, tais como: teor de $\mathrm{SiO}_{2}$, entre 44 e 65\%; teor de $\mathrm{Al}_{2} \mathrm{O}_{3}$ com limites entre 32 e $46 \%$, teor máximo de $\mathrm{SO}_{3}$ de $1 \%$; e, perda ao fogo de, no máximo, $4 \%$. Por conseguinte, tal material não cumpre os requisitos exigidos pela referida norma.

No que diz respeito à cinza volante $(\mathrm{CV})$, a queima adequada do carvão mineral (matéria-prima desta adição mineral) é determinante para a qualidade da adição, logo, teores de carbono presentes na composição química são indicativos da queima incompleta do carvão (AZEVEDO, 2002). Porém, a Tabela 10 não apresenta de forma explícita o quantitativo de carbono presente, para tanto, pode-se ter uma estimativa deste a partir do resultado de perda ao fogo. Todavia, evidencia-se que tal resultado inclui perda de carbono residual e água adsorvida.

Segundo Neville (1997), caldeiras modernas possuem alta eficiência de queima de carvão mineral e produzem cinzas volantes com baixos teores de carbono, comumente inferiores a 3\%. Acrescenta-se ainda que o dióxido de silício e de aluminato situam o material em faixas que classificam este material como de origem betuminosa.

Na Figura 17 pode ser visualizado que o resíduo de cerâmica vermelha (RCV) apresentou um difratograma das fases químicas predominantes compostas pelo quartzo $\left(\mathrm{SiO}_{2}\right)$, ilita $\left(\mathrm{K}, \mathrm{H}_{3} \mathrm{O}\right)(\mathrm{Al}, \mathrm{Mg}, \mathrm{Fe})_{2}(\mathrm{Si}, \mathrm{Al})_{4} \mathrm{O}_{10}\left[(\mathrm{OH})_{2}, \mathrm{H}_{2} \mathrm{O}\right]$ e hematita $\left(\mathrm{Fe}_{2} \mathrm{O}_{3}\right)$, além do halo amorfo característico de fração vítrea. No caso da amostra de metacaulim, evidenciam-se picos referentes ao quartzo, à caulinita, $\mathrm{Al}_{2} \mathrm{Si}_{2} \mathrm{O}_{5}(\mathrm{OH})_{4}$, e à muscovita $\mathrm{KAl}_{2}\left(\mathrm{AlSi}_{3} \mathrm{O}_{10}\right)(\mathrm{OH})_{2}$, e uma região de estrutura vítrea, composta por sílica e alumina. Por fim, a cinza volante apresenta predominância de compostos como o quartzo, hematita e mulita $\left(3 \mathrm{Al}_{2} \mathrm{O}_{3} \cdot 2 \mathrm{SiO}_{2}\right)$, além do halo amorfo da fração vítrea. 

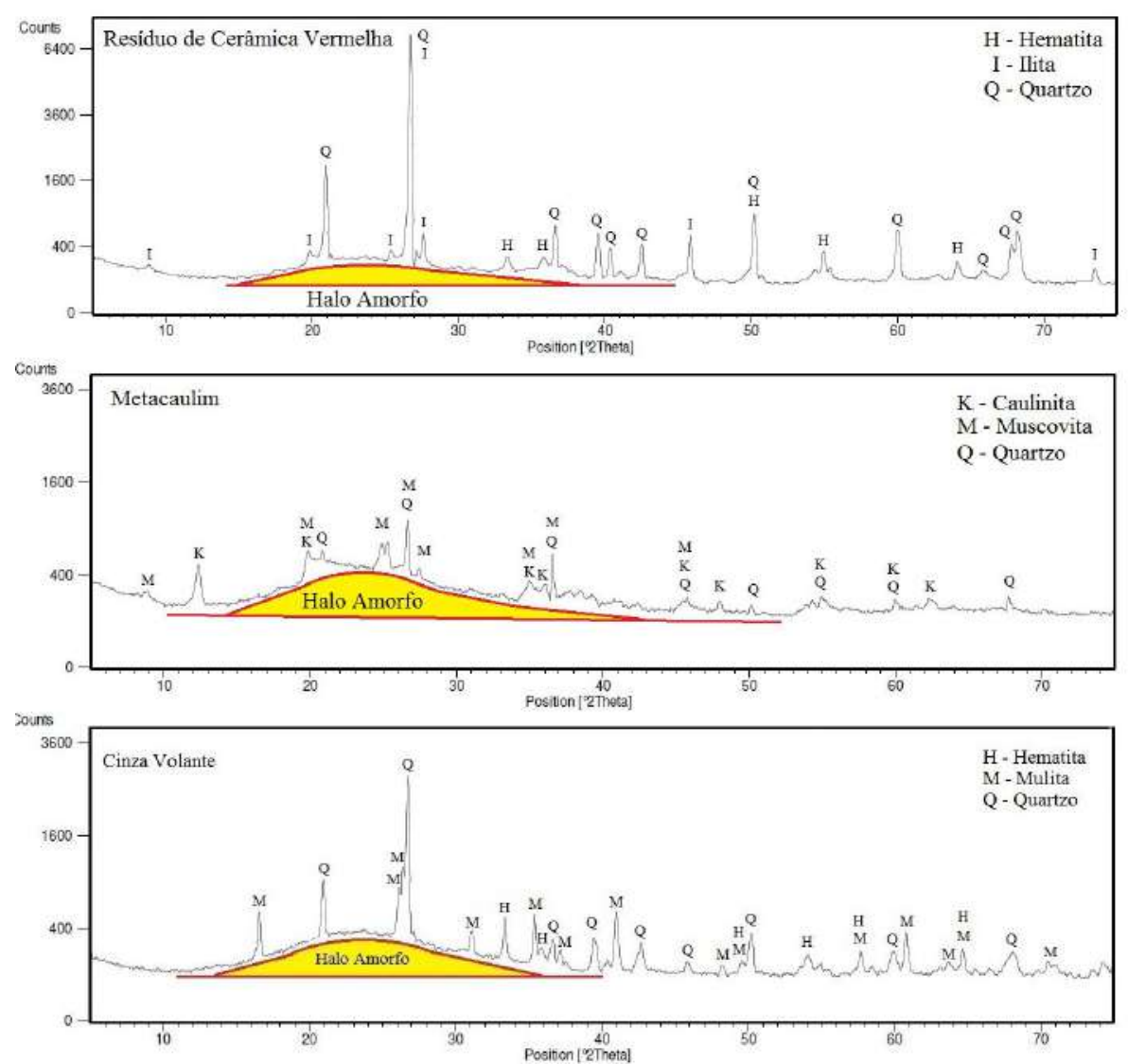

Figura 17: Difratogramas das adições minerais resíduo de cerâmica vermelha, metacaulim e cinza volante.

A sílica de casca de arroz (SCA) apresentou um elevado teor de dióxido de silício, característico da sílica, e pequenos teores de $\mathrm{CaO}$ e $\mathrm{K}_{2} \mathrm{O}$, provenientes possivelmente, do tratamento realizado no solo para plantação do arroz que acabam por compor o material. A perda ao fogo obtida indica que o material apresenta teores de carbono em sua composição e que podem ser de resquícios da queima em leito fluidizado para a produção de energia elétrica. Outro fator determinante para esta afirmação é a alteração de coloração da amostra no processo de ensaio de perda ao fogo (Figura 18) característico da contaminação e perda de carbono após a queima.

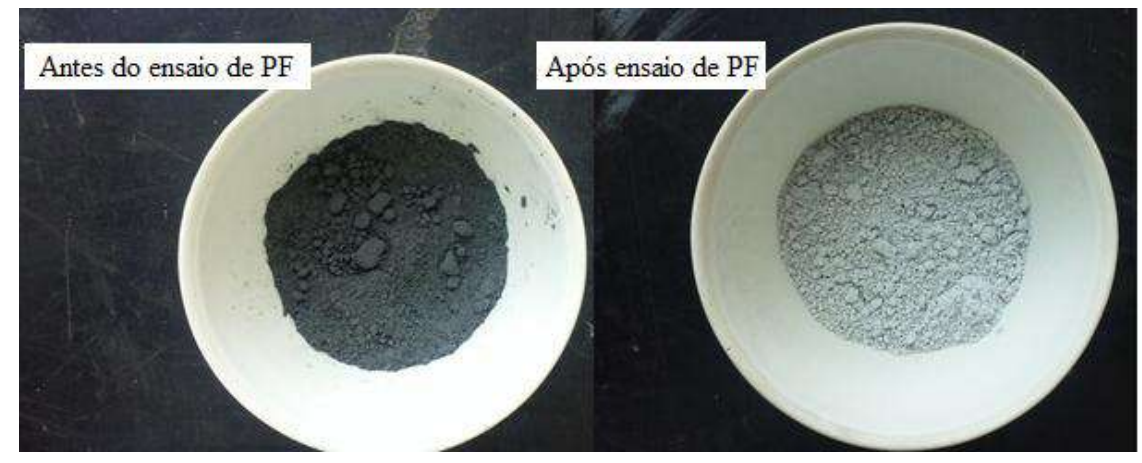

Figura 18: Mudança na coloração da amostra de SCA antes e após ensaio de Perda ao Fogo 
Pela análise do difratograma de raios-X, apresentado na Figura 19, a sílica ativa apresentou um halo amorfo, característica de sua alta reatividade química, com praticamente ausência de cristalinidade. Observa-se também que a sílica de casca de arroz apresentou uma parcela mineral no seu estado amorfo, com picos de difração resultantes da cristalinidade de sua fase predominante, a cristobalita.

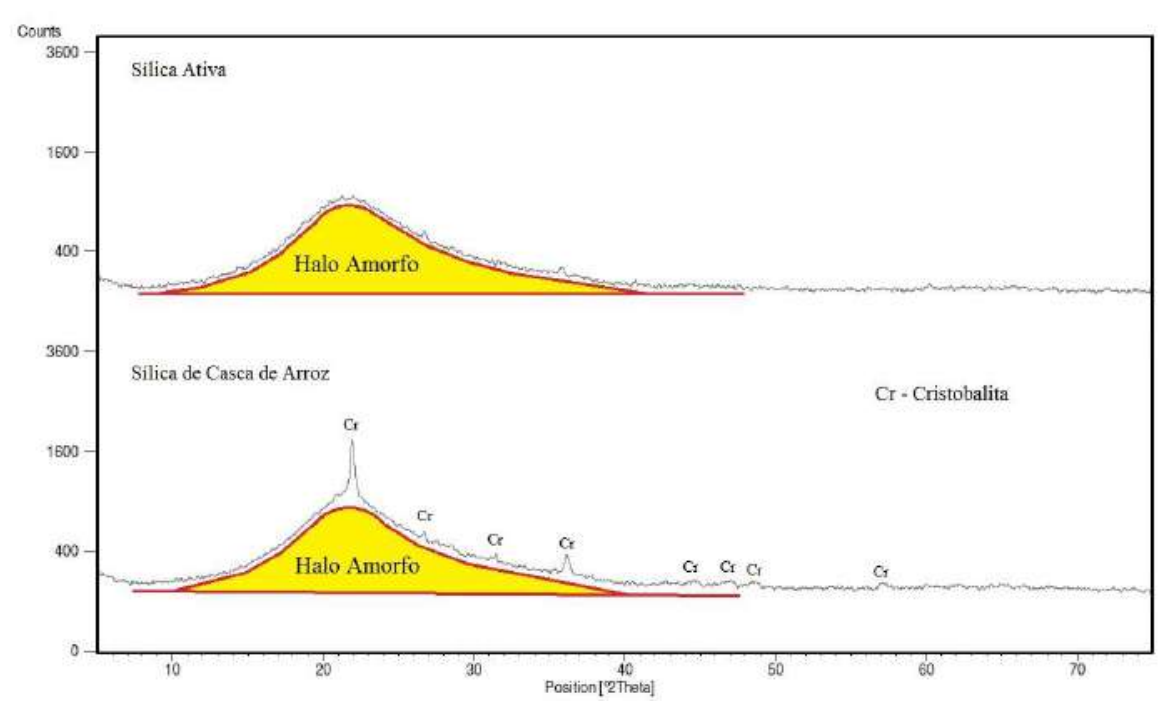

Figura 19: Difratogramas das adições minerais sílica ativa e sílica de casca de arroz.

Já as características físicas das adições minerais pozolânicas podem ser vistas na Tabela 11.

Tabela 11: Características físicas do Resíduo de Cerâmica Vermelha

\begin{tabular}{ccc}
\hline \multirow{2}{*}{ Adição Mineral } & \multicolumn{2}{c}{ Características físicas } \\
& $\begin{array}{c}\text { BET } \\
\left(\mathrm{m}^{2} / \mathrm{g}\right)\end{array}$ & $\begin{array}{c}\text { Massa esp. } \\
\left(\mathrm{g} / \mathrm{cm}^{3}\right)\end{array}$ \\
\hline Cerâmica vermelha 0,5h & 12,974 & \\
Cerâmica vermelha 1,0h & 13,078 & 2,63 \\
Cerâmica vermelha 1,5h & 13,112 & \\
Metacaulim & 23,258 & 2,50 \\
Cinza volante & 1,096 & 1,95 \\
Sílica ativa & 20,238 & 2,18 \\
Sílica casca arroz & 14,692 & 2,12 \\
\hline
\end{tabular}

De modo geral, observa-se que as adições pozolânicas apresentam elevada área específica, sendo que esta característica atua diretamente na pozolanicidade dos materiais e também na demanda de água de amassamento para um mesmo abatimento. Na maior parte, os 
resultados do ensaio B.E.T. deram acima de $12,974 \mathrm{~m}^{2} / \mathrm{g}$, a exceção da cinza volante que apresentou um valor de $1,096 \mathrm{~m}^{2} / \mathrm{g}$, resultado este inferior aos obtidos para os fíleres calcário e quartzoso.

Nota-se que os tempos de moagem do resíduo de cerâmica vermelha aumentaram a área específica B.E.T. do material, pois teve um acréscimo nos resultados conforme maior fora o tempo de permanência no moinho de bolas e não apresentando uma tendência de estabilização da finura da adição mineral. Isso leva a concluir que o material ainda possui capacidade de aumento da área específica, mesmo que em pequena escala, para tempos maiores de moagem do que os que foram realizados. A Figura 20 apresenta a correlação (com $\mathrm{R}^{2}$ de 0,92$)$ entre o tempo de moagem do RCV no moinho de bolas e os resultados de área específica B.E.T.

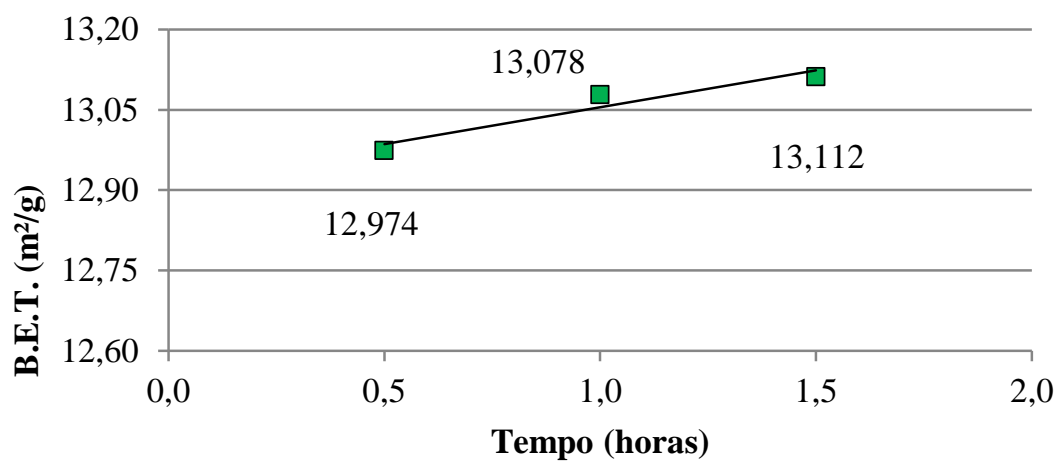

$\square$ Resíduo de Cerâmica Vermelha $\quad \mathrm{y}=0,138 \mathrm{x}+12,917$
$\mathrm{R}^{2}=0,921$

Figura 20: Correlação entre o tempo de moagem do RCV no moinho de bolas e os resultados de B.E.T.

Por outro lado, pela análise gráfica correspondente da distribuição granulométrica (Figura 94 no Apêndice 1), pode-se atribuir que os resíduos de cerâmica vermelha tiveram processos de moagem diferenciados com distribuição bimodal do tamanho médio de partículas a partir de $1 \mathrm{~h}$ de ensaio e que, mesmo assim, o processo de cominuição não foi suficiente para se obter uma distribuição média de partículas (em torno de 90, 60 e de $13 \mu \mathrm{m}$ ) próximas da obtida para o cimento, em torno de $6 \mu \mathrm{m}$, o qual foi o menor entre todas as amostras medidas.

O metacaulim apresentou características físicas que cumprem as exigências mínimas preconizadas pela ABNT NBR 15.894-1:2010, ou seja, B.E.T. superior a 15,000 m²/g. Já a composição da sílica ativa (SA) mostra que este material se enquadra nas exigências mínimas preconizadas pela ABNT NBR 13.956:2012 apresentando teor de $\mathrm{SiO}_{2}$, superior a 85\%, perda 
ao fogo menor que $6 \%$ e área específica B.E.T. compreendida entre 15,000 e $30,000 \mathrm{~m}^{2} / \mathrm{g}$. Comenta-se ainda adições de metacaulim, cinza volante, sílica ativa e sílica de casca de arroz obtiveram distribuições granulométricas médias de $10 \mu \mathrm{m}, 13 \mu \mathrm{m}, 10 \mu \mathrm{m}$ e $8 \mu \mathrm{m}$, respectivamente, todas superiores aos cimentos Portland utilizados.

\subsubsection{Agregado miúdo}

O agregado miúdo utilizado para composição do traço das argamassas foi a areia normal brasileira, conforme NBR 7.214:2015, com distribuição granulométrica dentro das especificações da referida norma (Figura 21). O uso deste agregado se deve às exigências da NBR 13.583/2014, que orienta a utilização deste material, para que o mesmo pouco influencie nos resultados, haja vista que este agregado é livre de contaminações. Tendo em vista que o objetivo do estudo é analisar a influência das adições minerais no ataque por sulfatos, a escolha deste material se fez necessária.

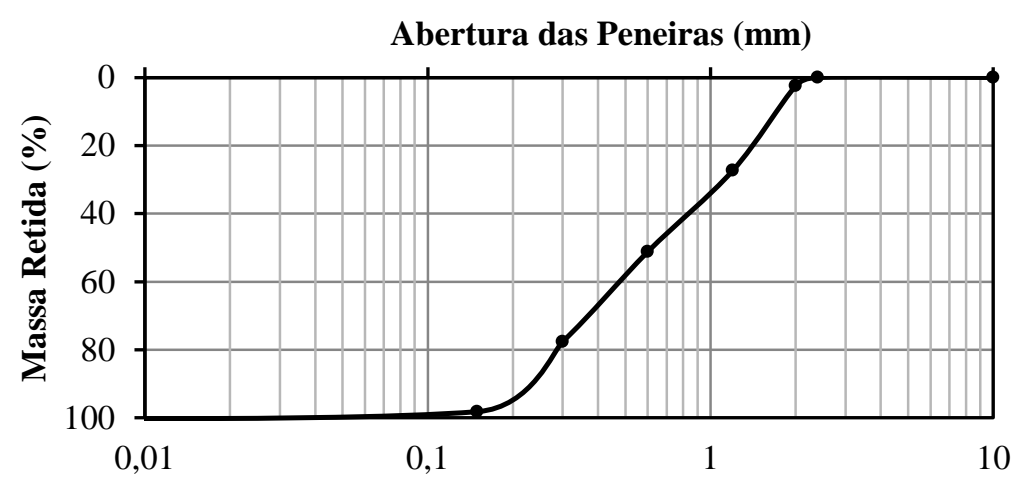

Figura 21: Distribuição granulométrica da Areia normal brasileira.

\subsection{ANÁLISE QUÍMICA TEÓRICA DAS COMPOSIÇÕES ESTUDADAS}

A análise química teórica foi realizada a partir dos resultados que constituem a composição química dos cimentos, e calculada com base na formulação de Bogue, publicada em 1947, por esta ser comumente utilizada e difundida na indústria cimenteira. Todavia, conforme Taylor (1997) se faz necessário fixar algumas considerações, como por exemplo:

- Assume-se que a composição das 4 fases predominantes do clínquer são $C_{3} S, C_{2} S, C_{3} A$ e $C_{4} A F$

- Assume-se que todo o $\mathrm{Fe}_{2} \mathrm{O}_{3}$ ocorre como $\mathrm{C}_{4} A F$; 
- Assume-se que todo o remanescente de $\mathrm{Al}_{2} \mathrm{O}_{3}$ ocorre como $\mathrm{C}_{3} \mathrm{~A}$;

Porém, antes dos cálculos dos compostos de Bogue, se faz necessário uma correção do teor de $\mathrm{CaO}$, ou seja, do valor total obtido pela composição química do cimento, deve-se descontar os teores de óxido de cálcio combinados como gipsita (Eq. 15) e carbonato de cálcio (Eq. 16), assim como, o da cal livre.

$$
\mathrm{CaO}_{\text {como gipsita }}=0,70042 \cdot \mathrm{SO}_{3}
$$

$$
\mathrm{CaO}_{\text {como carbonato de cálcio }}=0,56029 . \mathrm{CaCO}_{3}
$$

Eq. 16

Quando o teor de fíler calcário não for conhecido o mesmo pode ser calculado por estequiometria a partir do resultado de perda ao fogo $(\mathrm{PF})$, desde que o teor de sulfeto $\left(\mathrm{SO}_{3}\right)$ seja previamente conhecido. Desta forma, assumiu-se como hipótese que todo o material liberado nos ensaios de PF é constituído apenas de $\mathrm{CO}_{2}$ e $\mathrm{H}_{2} \mathrm{O}$ oriundo do $\mathrm{CaCO}_{3}$ e $\mathrm{CaSO}_{4} \cdot 2 \mathrm{H}_{2} \mathrm{O}$, sucessivamente. Logo, a presença de etringita, silicato de cálcio hidratado e portlandita a partir da reação do cimento Portland com a umidade relativa do ar foi desconsiderada. Assim, fez-se uso da Eq. 17 para alcance do teor de FC na composição do clínquer. Cabe comentar que a obtenção da equação supracitada foi a partir da combinação de cálculos estequiométricos, conforme demonstrado a seguir.

$$
P F=\mathrm{CO}_{2 \%}+\mathrm{H}_{2} \mathrm{O}_{\%} \quad \therefore \quad \mathrm{CO}_{2 \%}=\mathrm{PF}-\mathrm{H}_{2} \mathrm{O}_{\%}
$$

Sendo:

$$
\mathrm{CaSO}_{4} \cdot 2 \mathrm{H}_{2} \mathrm{O}_{\%}=\mathrm{SO}_{3 \%} \cdot \frac{\mathrm{CaSO}_{4} \cdot 2 \mathrm{H}_{2} \mathrm{O}_{\mathrm{g} / \mathrm{mol}}}{\mathrm{SO}_{3} \mathrm{~g} / \mathrm{mol}} \quad \therefore \quad \mathrm{CaSO}_{4} \cdot 2 \mathrm{H}_{2} \mathrm{O}_{\%}=\mathrm{SO}_{3 \%} \cdot 2,151
$$

Desta forma, $\mathrm{H}_{2} \mathrm{O}_{\%}$ fica como:

$$
\mathrm{H}_{2} \mathrm{O}_{\%}=\mathrm{CaSO}_{4} \cdot 2 \mathrm{H}_{2} \mathrm{O}_{\%} \cdot \frac{2 \mathrm{H}_{2} \mathrm{O}_{\mathrm{g} / \mathrm{mol}}}{\mathrm{CaSO}_{4} \cdot 2 \mathrm{H}_{2} \mathrm{O}_{\mathrm{g} / \mathrm{mol}}} \quad \therefore \quad \mathrm{H}_{2} \mathrm{O}_{\%}=\mathrm{SO}_{3 \%} \cdot 2,151 \cdot 0,2093
$$


Enquanto que o teor de $\mathrm{CaCO}_{3}$ fica:

$$
\mathrm{CaCO}_{3 \%}=\mathrm{CO}_{2 \%} \cdot \frac{\mathrm{CaCO}_{3} \mathrm{~g} / \mathrm{mol}}{\mathrm{CO}_{2} \mathrm{~g} / \mathrm{mol}}
$$

Logo,

$$
\mathrm{CaCO}_{3 \%}=\left(\mathrm{PF}-\mathrm{H}_{2} \mathrm{O}_{\%}\right) \cdot 2,27422
$$

Desta forma, obteve-se:

$$
\mathrm{CaCO}_{3} \text { teórico }=2,27422 \cdot \mathrm{PF}-1,02347 . \mathrm{SO}_{3}
$$

Deste modo, após correção do quantitativo de $\mathrm{CaO}$, utiliza-se as equações Eq. 18 Eq. 21 para obtenção dos compostos de Bogue:

$$
\begin{gathered}
\mathrm{C}_{3} \mathrm{~S}=4,0710 . \mathrm{CaO}-7,6024 . \mathrm{SiO}_{2}-6,7187 . \mathrm{Al}_{2} \mathrm{O}_{3}-1,4297 . \mathrm{Fe}_{2} \mathrm{O}_{3} \\
\mathrm{C}_{2} \mathrm{~S}=-3,0710 . \mathrm{CaO}+8,6024 . \mathrm{SiO}_{2}+5,0683 . \mathrm{Al}_{2} \mathrm{O}_{3}+1,0785 . \mathrm{Fe}_{2} \mathrm{O}_{3} \\
\mathrm{C}_{3} \mathrm{~A}=2,6504 . \mathrm{Al}_{2} \mathrm{O}_{3}-1,6920 . \mathrm{Fe}_{2} \mathrm{O}_{3} \\
\mathrm{C}_{4} \mathrm{AF}=3,0432 . \mathrm{Fe}_{2} \mathrm{O}_{3}
\end{gathered}
$$

Embora este método teórico auxilie, em muito, deve-se sempre levar em conta que o mesmo considera uma perfeita combinação dos óxidos, e que a constituição do clínquer é feita, somente, pela forma pura dos compostos $C_{3} S, C_{2} S, C_{3} A$ e $C_{4} A F$.

Já os cálculos, após hidratação do cimento, para obtenção dos teores de $C-S-H, C H$, Etringita e Monossulfoaluminato de cálcio hidratado, foram calculados por estequiometria. 
Enfim, cabe comentar, que todos os dados de entrada, seja, $\mathrm{CaO}, \mathrm{SiO}_{2}, \mathrm{Al}_{2} \mathrm{O}_{3}$, $\mathrm{Fe}_{2} \mathrm{O}_{3}, \mathrm{SO}_{3}, \mathrm{PF}$ e $\mathrm{CaCO}_{3}$ são em porcentagem. Logo, os dados de saída são apresentados também em percentual.

\subsection{AVALIAÇÃO DO ATAQUE POR SULFATOS EM ARGAMASSAS}

A seguir serão apresentados os procedimentos e práticas utilizadas para avaliação do ataque por sulfatos em argamassas, tais como, preparo de amostras para ensaios em argamassa; preparo das soluções de exposição; exposição das amostras de argamassa; ensaios de variação dimensional linear; variação volumétrica; variação de massa; resistência à compressão e à tração na flexão; variação de velocidade ultrassônica; e, módulo de elasticidade dinâmico.

3.4.1 Preparo de amostras para ensaios em argamassa

O grau do ataque por sulfatos em argamassas foi analisado, de modo geral, por dois principais grupos, sendo eles:

- Grupo 1: composto por 132 corpos de prova com dimensões de $25 \mathrm{~mm}$ x $25 \mathrm{~mm}$ x 285 mm (destinados às avaliações de expansão linear), divididos em 11 composições e 3 soluções de exposição final;

- Grupo 2: composto por 252 corpos de prova com dimensões de $40 \mathrm{~mm}$ x $40 \mathrm{~mm}$ x 160 mm (destinados às avaliações de variação volumétrica, variação de massa, resistências à compressão e à tração na flexão, velocidade de propagação de ondas ultrassônicas e variação de módulo de elasticidade dinâmico), divididos em 7 composições e 3 soluções de exposição final.

Ambos os grupos de corpos de prova foram expostos em três soluções distintas, $x \mathrm{H}_{2} \mathrm{O}+\mathrm{Na}_{2} \mathrm{SO}_{4}, x \mathrm{H}_{2} \mathrm{O}+\mathrm{MgSO}_{4}$ e $x \mathrm{H}_{2} \mathrm{O}+\mathrm{Ca}(\mathrm{OH})_{2}$, desta forma, ensaios para avaliação do ataque por sulfatos puderam ser distribuídos conforme a dimensão dos CP's, como apresentado na Figura 22. 


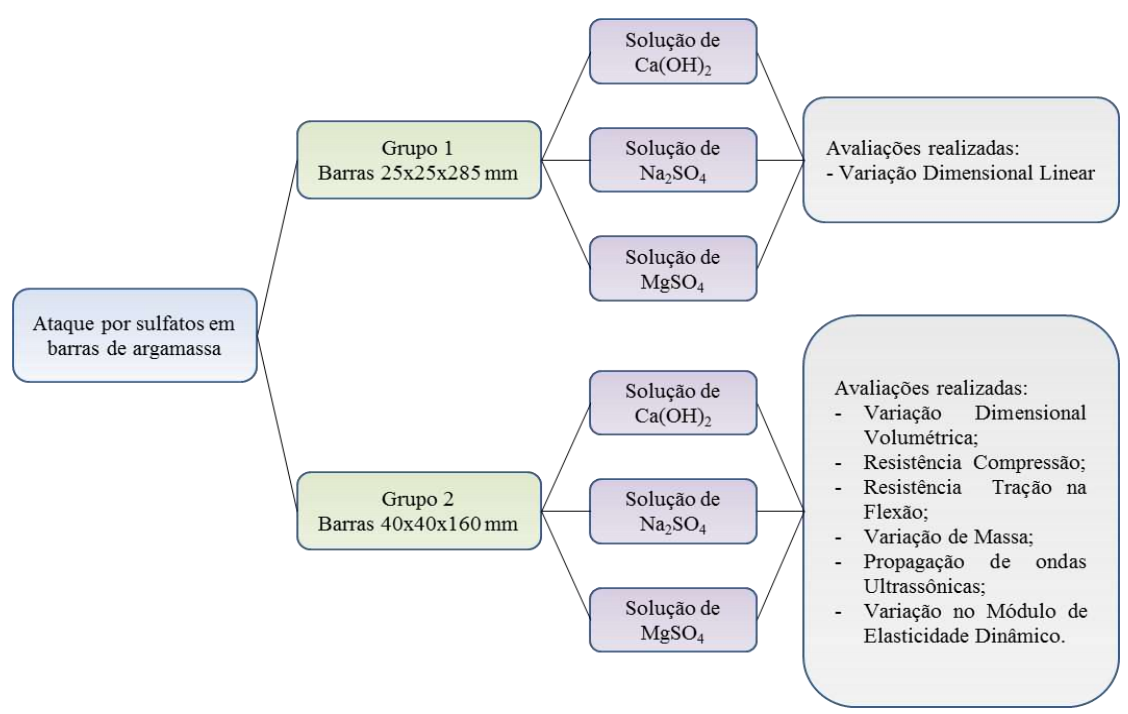

Figura 22: Esquema geral para representação das atividades realizadas em argamassa.

A composição do traço das argamassas teve fundamento a NBR 13.583:2014, ou seja, produzidas na proporção em massa de 1,0:3,2 (material ligante:agregado miúdo - areia normal brasileira composto por quatro frações granulométricas em iguais proporções entre si); com relação água/material ligante de 0,60. Nas séries que se fez uso das adições minerais, para composição do material ligante, fez-se substituição parcial do cimento Portland $(10 \% \mathrm{em}$ massa) pelo material questão (fíler calcário, fíler quartzoso, RCV, etc.). A Tabela 12 e Tabela 13 mostram os quantitativos dos materiais utilizados para composição dos corpos de prova em seus determinados grupos.

Tabela 12: Composição das argamassas para moldagem dos corpos de prova de $25 \mathrm{~mm}$ x $25 \mathrm{~mm}$ x $285 \mathrm{~mm}$

\begin{tabular}{|c|c|c|c|c|c|c|c|c|}
\hline \multirow{2}{*}{ Grupo } & \multicolumn{2}{|c|}{ Composição da série } & \multirow{2}{*}{$\begin{array}{c}\text { Nomenclatura } \\
\text { utilizada }\end{array}$} & \multicolumn{5}{|c|}{$\begin{array}{c}\text { Composição das argamassas para cada } \\
4 \text { CP's }\end{array}$} \\
\hline & Compo & içãa da série & & $\begin{array}{c}\text { Cimento } \\
(\mathrm{g})\end{array}$ & $\begin{array}{c}\text { Adição } \\
\text { (g) }\end{array}$ & $\begin{array}{c}\text { Água }^{I} \\
\text { (g) }\end{array}$ & $\begin{array}{c}\text { Areia } \\
(\mathrm{g})\end{array}$ & $\underset{\text { II }}{\mathbf{a} / \mathbf{a g}}$ \\
\hline \multirow{11}{*}{1} & \multirow{2}{*}{ Referência } & CP V - ARI & CP VARI & 500 & - & \multirow{11}{*}{300} & \multirow{11}{*}{1.600} & \multirow{11}{*}{0,60} \\
\hline & & CP V - ARI RS & CP V RS & 500 & - & & & \\
\hline & \multirow{2}{*}{$\begin{array}{l}\text { Material } \\
\text { Inerte }\end{array}$} & Fíler Calcário & $\mathrm{FC}$ & \multirow{9}{*}{450} & \multirow{9}{*}{50} & & & \\
\hline & & Fíler Quartzoso & FQ & & & & & \\
\hline & \multirow{7}{*}{$\begin{array}{l}\text { Material } \\
\text { Reativo }\end{array}$} & Cinza Volante & $\mathrm{CV}$ & & & & & \\
\hline & & Metacaulim & MT & & & & & \\
\hline & & Sílica Ativa & SA & & & & & \\
\hline & & $\begin{array}{l}\text { Sílica de Casca } \\
\text { de Arroz }\end{array}$ & SCA & & & & & \\
\hline & & $\begin{array}{l}\text { Res. Cerâmico } \\
0,5 \mathrm{~h}\end{array}$ & RCV 0,5 & & & & & \\
\hline & & $\begin{array}{l}\text { Res. Cerâmico } \\
1,0 \mathrm{~h}\end{array}$ & RCV 1,0 & & & & & \\
\hline & & $\begin{array}{l}\text { Res. Cerâmico } \\
1,5 \mathrm{~h}\end{array}$ & RCV 1,5 & & & & & \\
\hline
\end{tabular}


Tabela 13: Composição das argamassas para moldagem dos corpos de prova de $40 \mathrm{~mm}$ x $40 \mathrm{~mm}$ x $160 \mathrm{~mm}$.

\begin{tabular}{|c|c|c|c|c|c|c|c|c|}
\hline \multirow{2}{*}{ Grupo } & \multirow{2}{*}{\multicolumn{2}{|c|}{ Composição da série }} & \multirow{2}{*}{$\begin{array}{c}\text { Nomenclatura } \\
\text { utilizada }\end{array}$} & \multicolumn{5}{|c|}{$\begin{array}{c}\text { Composição das argamassas para cada } \\
4 \text { CP's }\end{array}$} \\
\hline & & & & $\underset{(g)}{\text { Cimento }}$ & $\begin{array}{l}\text { Adição } \\
\text { (g) }\end{array}$ & $\begin{array}{l}\text { Água }^{I} \\
(\mathrm{~g})\end{array}$ & $\begin{array}{c}\text { Areia } \\
(\mathrm{g})\end{array}$ & $\underset{\text { II }}{\text { a/ag }}$ \\
\hline \multirow{7}{*}{2} & Doforâni & CP V - ARI & CP VARI & 615 & - & \multirow{7}{*}{369} & \multirow{7}{*}{1.968} & \multirow{7}{*}{0,60} \\
\hline & Kererencia & CP V - ARI RS & CP V RS & 615 & - & & & \\
\hline & M. Inerte & Fíler Quartzoso & FQ & \multirow{5}{*}{553,50} & \multirow{5}{*}{61,50} & & & \\
\hline & \multirow{4}{*}{$\begin{array}{l}\text { Material } \\
\text { Reativo }\end{array}$} & Cinza Volante & $\mathrm{CV}$ & & & & & \\
\hline & & Metacaulim & MT & & & & & \\
\hline & & Sílica Ativa & SA & & & & & \\
\hline & & $\begin{array}{l}\text { Sílica de Casca } \\
\text { de Arroz }\end{array}$ & SCA & & & & & \\
\hline
\end{tabular}

Observa-se nas que para a elaboração de corpos de prova do Grupo 2 não foram utilizadas as adições de resíduo de cerâmica vermelha e de fíler calcário. Isto ocorreu devido à falta de material para as moldagens, tais como areia normal brasileira e as adições minerais citadas.

Como procedimento de mistura utilizou-se as recomendações da ABNT NBR 7.215:2009. Assim sendo, foi colocado, inicialmente, água de amassamento na cuba de mistura na quantidade pré-determinada e, adicionado, na sequência, todo o material ligante, então foi realizada a mistura destes componentes por $30 \mathrm{~s}$ na velocidade baixa do misturador. Ao término deste tempo e sem a paralização do funcionamento da argamassadeira, foi adicionada a areia normal (nas quatro frações de igual proporção previamente misturadas em um saco plástico) gradualmente durante um tempo de $30 \mathrm{~s}$. Logo após alterou-se a velocidade de mistura para alta, na qual permaneceu por mais $30 \mathrm{~s}$. Então o aparelho foi desligado para raspagem da argamassa aderida nas paredes e pá do equipamento por um período de $15 \mathrm{~s}$, posteriormente, a mistura permaneceu em repouso por 1 min e $15 \mathrm{~s}$, estando a cuba coberta com um pano úmido. Por fim, o misturador foi novamente ligado em velocidade alta por um tempo de $1 \mathrm{~min}$.

Ao término deste procedimento as argamassas foram transferidas aos moldes, estes, previamente untados com desmoldante, foram preenchidos em duas camadas, na qual, cada uma delas foi devidamente adensada, então foram rasadas (conforme NBR 13.583:2014) e levadas à cura inicial em câmara úmida (temperatura de $23 \pm 2{ }^{\circ} \mathrm{C}$ e U.R. de $100 \%$ ) por $48 \mathrm{~h}$. 
A cura dos corpos de prova foi realizada em três etapas, a primeira, já comentada anteriormente, a segunda trata-se de imersão em solução de água saturada com cal por 12 dias em temperatura ambiente, a terceira, por fim, trata-se da imersão nas soluções agressivas e de referência por um período que se estendeu por 140 dias, à temperatura de $40 \pm 2{ }^{\circ} \mathrm{C}$.

\subsubsection{Preparo das soluções de exposição}

Conforme citado anteriormente, após os dois procedimentos de cura inicial, os corpos de prova foram imersos nas soluções finais, agressivas ou de referência, onde permaneceram por 140 dias. A NBR 13.583:2014 recomenda que a concentração de sulfato de sódio anidro seja de $100 \mathrm{~g}$ de $\mathrm{Na}_{2} \mathrm{SO}_{4} / \mathrm{L}$ de solução, logo, devido à massa molar do sódio, enxofre e oxigênio define-se que a concentração de $\mathrm{SO}_{4}{ }^{2-}$ é de $67.630 \mathrm{ppm}(67,63 \mathrm{~g} / \mathrm{L})$. A partir da fixação deste resultado, por estequiometria, elaborou-se a solução de sulfato de magnésio. A Tabela 14 apresenta a composição das soluções utilizadas.

Tabela 14: Composição das soluções de cura final

\begin{tabular}{|c|c|c|c|c|c|}
\hline \multirow[b]{2}{*}{ Solução } & \multicolumn{5}{|c|}{ Composições para 1 litro de soluçãa } \\
\hline & $\begin{array}{c}\text { Água } \\
\text { destilada (g) }\end{array}$ & $\begin{array}{l}\text { Reagente } \\
\text { (g) }\end{array}$ & $\begin{array}{l}\text { Teor do metal } \\
\text { associado (g) }\end{array}$ & $\begin{array}{l}\text { Teor de } \\
\mathrm{SO}_{4}^{2-}(\mathrm{g})\end{array}$ & pH médio ${ }^{\text {II }}$ \\
\hline $\mathrm{Ca}(\mathrm{OH})_{2}+x \mathrm{H}_{2} \mathrm{O}$ & 990 & $10^{\mathrm{III}}$ & 5,41 & - & 12,9 \\
\hline $\mathrm{Na}_{2} \mathrm{SO}_{4}+x \mathrm{H}_{2} \mathrm{O}$ & 900 & 100 & 32,37 & 67,63 & 7,8 \\
\hline $\mathrm{MgSO}_{4}+x \mathrm{H}_{2} \mathrm{O}$ & 915,26 & 84,74 & 17,11 & 67,63 & 7,6 \\
\hline $\begin{array}{l}{ }^{(1)} \mathrm{O} \text { pH mensurado da } \\
{ }^{(11)} \text { Mensurados } 24 \mathrm{~h} \text { al } \\
{ }^{(111)} \text { Foi adotado tal va } \\
\text { Os cálculos para obte }\end{array}$ & $\begin{array}{l}\text { gua destilada ante } \\
\text { s elaboração das } \mathrm{s} \\
\text { r tendo em vista q } \\
\text { ão dos resultados }\end{array}$ & $\begin{array}{l}\text { da elaboração } \\
\text { uções, pouco } \\
\text { a solubilidad } \\
\text { dem ser visto }\end{array}$ & $\begin{array}{l}\text { as soluções foi de } \\
\text { tes da imersão das } \\
\text { em água do } \mathrm{Ca}(\mathrm{OH} \\
\text { no Apêndice. }\end{array}$ & $\begin{array}{l}\text { em média; } \\
\text { nostras; } \\
\text { é de } 1,85 \mathrm{~g} / \mathrm{L}\end{array}$ & \\
\hline
\end{tabular}

A relação volume de solução/volume de amostras foi fixada em 4,0/1,0, dentro do estabelecido pela NBR 13.583:2014. O preparo, por litro, das soluções seguiram o seguinte processo: inicialmente eram adicionados $800 \mathrm{~g}$ de água destilada em um Becker de vidro, posteriormente acrescentava-se o reagente de pureza analítica (p.a.) (quantidade conforme Tabela 14), em seguida, adicionava-se o restante de água destilada até obter um total de $1 \mathrm{~L}$. Ao término deste processo realizava-se homogeneização manual, com auxílio de um bastão de vidro. Por fim, as soluções ficavam em repouso por $24 \mathrm{~h}$ em temperatura igual as dos corpos de prova, ou seja, $23 \pm 2{ }^{\circ} \mathrm{C}$, até imersão dos mesmos. Só então eram levadas à estufa, solução e amostras, à temperatura de $40^{\circ} \mathrm{C}$. 


\subsubsection{Exposição das amostras de argamassa}

A Figura 23 mostra um exemplo de estocagem de 4 amostras do Grupo 1 após leitura inicial e imersas em solução agressiva. Ressalta-se o cuidado que se teve em deixar todas as faces dos prismas expostas à solução, com espaçamento de, no mínimo, 15 mm entre barras, laterais e fundo.

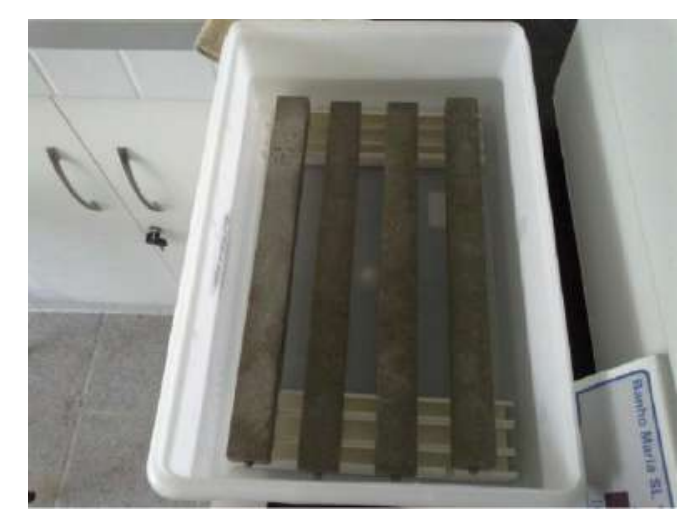

Figura 23: Corpos de prova imersos em solução de sulfato de sódio.

Para a realização das leituras, independentemente do ensaio, os recipientes foram retirados da estufa e levados a um ambiente controlado, com temperatura de $23 \pm 2{ }^{\circ} \mathrm{C}$ e com umidade relativa do ar de $50 \%$ (dentro do preconizado pela referida norma). Assim as amostras foram retiradas das soluções agressivas e deixadas em bancada para estabilização de suas temperaturas, por 10 minutos. Só então foram efetuados os testes e leituras dentro de um prazo de, no máximo, 5 minutos. Também, se teve atenção no manuseio dos corpos de prova, principalmente nas datas de maior exposição, para que os mesmos não fossem avariados devido à manipulação, tendo em vista o elevado grau de deterioração destes.

Por fim, ressalta-se que as barras expostas à solução de sulfato de magnésio passavam por um processo de limpeza superficial nas datas de efetuação das leituras. Isto porque, tais amostras, tinham um excessivo acúmulo de um gel gelatinoso formado na superfície, conforme pode ser visto na Figura 24. O acúmulo deste gel pode influenciar diretamente nos resultados devido ao excessivo volume, assim como, pode impedir a difusão dos íons de $\mathrm{SO}_{4}{ }^{2-}$. Para tanto, a limpeza, fora realizada com raspagem superficial com espátula de silicone para evitar avarias nas amostras. Este processo foi efetuado durante o tempo de estabilização da temperatura. 


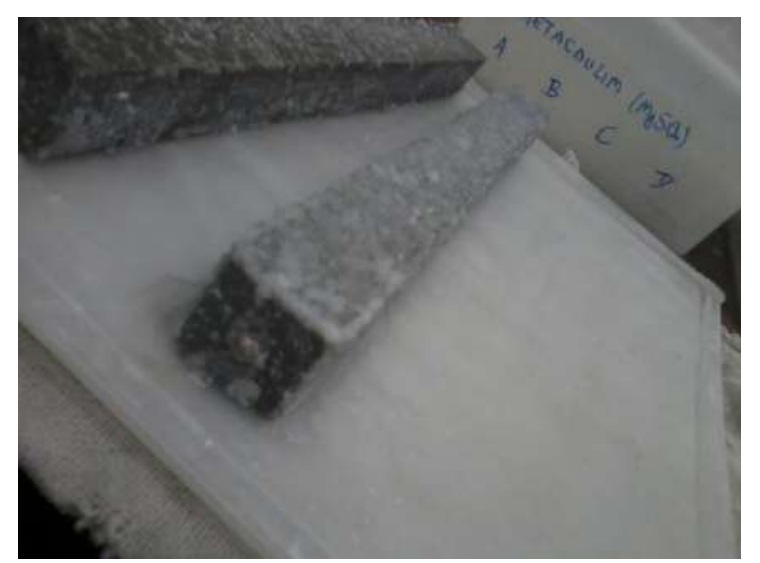

Figura 24: Detalhe da superfície de uma barra com acúmulo de gel durante a exposição à solução de sulfato de magnésio.

\subsubsection{Variação dimensional linear}

A avaliação da variação dimensional linear seguiu as recomendações da NBR 13.583:2014, porém, com tempo de exposição prolongado. Sendo assim, terminados os períodos de cura inicial (48 h) e cura intermediária (12 dias), as barras tiveram seus comprimentos mensurados com auxílio de pórtico metálico equipado com relógio comparador de resolução de $0,001 \mathrm{~mm}$ para que então, fossem expostas às soluções finais. A Figura 25 mostra a leitura de uma das barras ensaiadas com auxílio do equipamento mencionado.

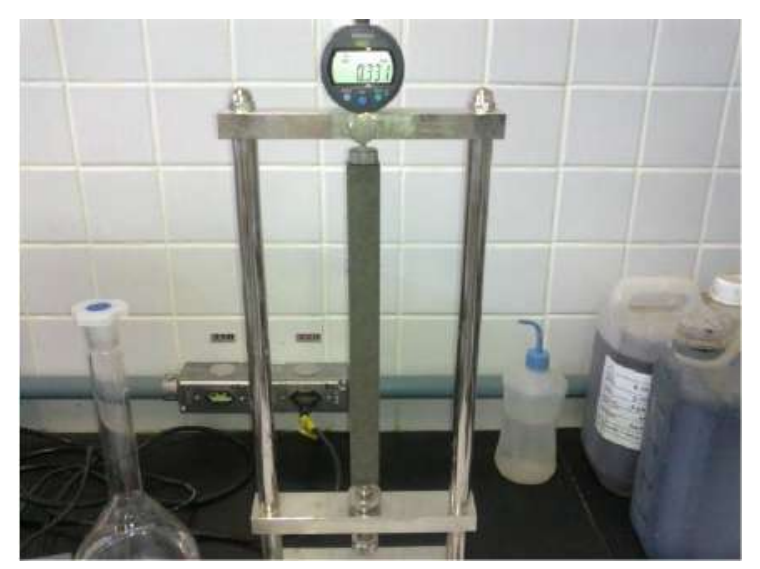

Figura 25: Leitura inicial sendo realizada com auxílio de um pórtico metálico dotado de relógio comparador.

Com a exposição das amostras nas soluções, as leituras para acompanhamento da variação dimensional linear foram realizadas após 2, 4, 6, 8, 10, 15 e 20 semanas de exposição. Para tanto as amostras foram posicionadas no pórtico metálico, sempre com a mesma face voltada para cima, e a leitura que fora anotada, refere-se a menor identificada pelo aparelho após giro de $360^{\circ}$ da barra. 
A variação dimensional de uma série amostral devido ao ataque da solução de sulfato de sódio ou magnésio é calculada em relação à variação dimensional da mesma série que fora exposta à solução de água saturada de hidróxido de cálcio.

A expansão ou retração individual das barras é dada pela diferença entre o valor medido no tempo de exposição correspondente e a leitura inicial, dividido pelo seu comprimento inicial e multiplicado por 100. Vale destacar que valores negativos implicam em retração e positivos em expansão. Além disso, os resultados obtidos foram arredondados ao milésimo mais próximo e o resultado de uma série foi obtido a partir da média entre as 4 barras referentes à mesma.

Deste modo, a variação dimensional linear das barras de argamassa é calculada conforme a Eq. 22:

$$
A e=E s-E a
$$

Eq. 22

Onde:

- Ae é a variação dimensional linear resultante (\%).

- Es é a variação dimensional linear média das barras curadas em solução agressiva de sulfato de sódio ou de magnésio (\%);

- Ea é a variação dimensional linear média das barras curadas em água saturada com cal $(\%)$

Foram observados e registrados nas datas de medição, toda e qualquer anomalia apresentada pelas amostras, como por exemplo:

- Fissuração;

- Tamanho e intensidade das fissuras;

- Desagregação parcial, total ou empenamento das barras;

- Evaporação da água das soluções, com necessidade de complementação.

Para variação dimensional linear média de até $0,020 \%$, não foi realizado nenhum tratamento estatístico. Para expansões superiores a este valor foi calculado o desvio relativo máximo-DRM (Eq. 23), este que deve ser inferior a 15\%, caso isto não ocorra, desconsiderase o valor mais discrepante, em relação à média, e então se calcula uma nova média e nova DRM. 


$$
D R M=\frac{(\text { expansão média }- \text { expansão individual mais distante da média })}{\text { expansão média }} \times 100
$$

Eq. 23

\subsubsection{Variação volumétrica}

Com o intuito de obter resultados de variações dimensionais que englobassem de forma mais ampla os corpos de prova realizou-se a avaliação da variação volumétrica nas amostras. Na prática, esta é uma informação de grande valia quando se trata de ataque por sulfatos, por exemplo, em barragem de concreto. Tendo em vista que uma análise tridimensional avalia a expansão de forma mais abrangente.

Assim, as leituras foram realizadas nas barras do Grupo 2 (40x40x160 mm), com parâmetros de exposição iguais às descritas no item 3.4.4 da presente pesquisa.

Para tanto, as medições foram realizadas com auxílio de paquímetro digital de resolução de 0,01 mm. Para cada corpo de prova foram feitas oito leituras, compostas de: três em cada uma das duas direções transversais; e, duas na longitudinal. A Figura 26 mostra os pontos nos quais o paquímetro fora posicionado para efetivação das leituras. Por fim, o valor adotado para cada direção foi a média aritmética dentre as leituras efetuadas para tal direção e, a obtenção do volume partiu da multiplicação das médias, conforme Eq. 24.

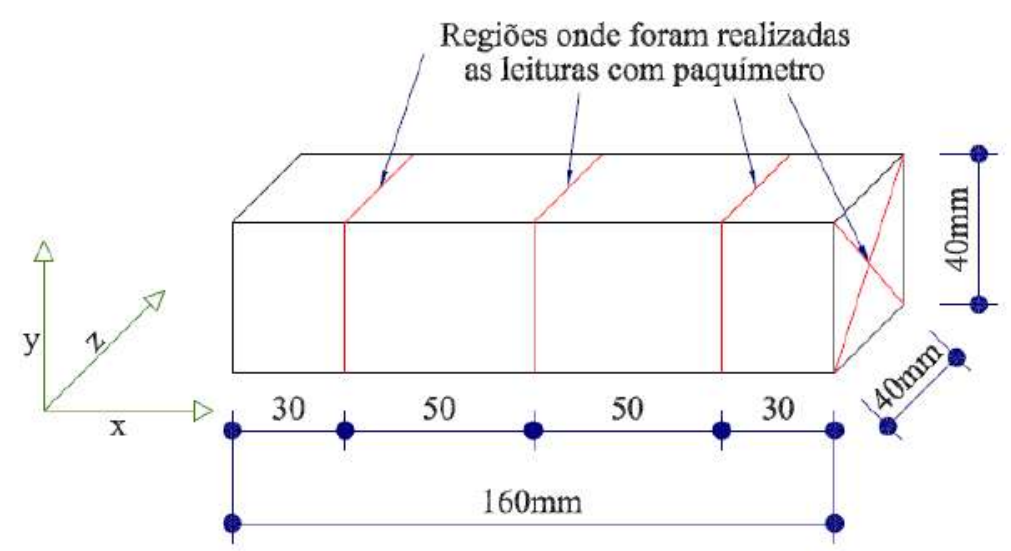

Figura 26: Esquema dos pontos nos quais se efetuaram as leituras.

$$
\text { Volume }=L \bar{x} \cdot L \bar{y} \cdot L \bar{z}
$$

Onde:

$L \bar{x}=$ média das leituras realizadas na direção $\mathrm{x} ;$

$L \bar{y}=$ média das leituras realizadas na direção $\mathrm{y}$; 
$L \bar{y} \quad=$ média das leituras realizadas na direção $\mathrm{z}$.

A variação volumétrica de cada barra é a diferença entre os valores dos volumes obtidos na idade correspondente e a leitura inicial, dividido pelo seu volume inicial e multiplicado por 100. Cabe comentar que para as leituras, as amostras encontravam-se em estado saturado com superfície seca (SSS).

Por fim, a determinação da expansão ou retração de uma série amostral foi obtida pela diferença entre os valores obtidos nas amostras expostas em solução agressiva descontando-se os resultados obtidos com a exposição em solução com água saturada com hidróxido de cálcio.

\subsubsection{Variação de massa}

A análise da variação de massa foi realizada por dois motivos, obtenção do módulo de elasticidade dinâmico, conforme será explicado no item 3.4.9 e, como suporte na explanação quanto às possíveis formações de novos produtos nos vazios capilares da argamassa ou na desagregação de sólidos devido à degradação dos produtos da hidratação do cimento Portland.

As leituras foram realizadas em balança com resolução de 0,001 g nos mesmos procedimentos que os ensaios de variação volumétrica.

A representação dos resultados foi feita pela média aritmética de cada série amostral para cada tempo de exposição pré-determinado, sempre em comparação à mesma série exposta à solução de referência. O tratamento estatístico dos resultados foi o mesmo utilizado nos ensaios de variação volumétrica e dimensional, ou seja, foi adotado um desvio relativo máximo em relação à média de $15 \%$.

\subsubsection{Resistência à compressão e à tração na flexão}

A resistência à compressão de concretos, pastas, ou argamassas, por exemplo, é, tradicionalmente, o parâmetro de comparação entre composições comumente utilizadas no meio técnico e científico.

Assim sendo, com intuito de avaliar a variação da resistência mecânica das barras de argamassa devido à influência das soluções agressivas, os ensaios de resistência à compressão e tração na flexão ocorreram em tempos de exposição das barras às soluções finais de $0 ; 2 ; 6$; 
10; e, 20 semanas. Seguiram-se as recomendações da NBR 13.279:2005 e os ensaios foram realizados em uma prensa com capacidade de carga de $100 \mathrm{kN}$ da marca EMIC.

Para o ensaio de resistência à tração na flexão a velocidade de aplicação de carga foi de $50 \pm 10 \mathrm{~N} / \mathrm{s}$ até a ruptura, assim, a resistência foi calculada a partir da Eq. 25.

$$
\mathrm{R}_{\mathrm{f}}=\frac{1,5 \cdot \mathrm{F}_{\mathrm{f}} \cdot \mathrm{L}}{40^{3}}
$$

Onde:

$$
\begin{array}{ll}
R_{f} & =\text { resistência à tração na flexão }(\mathrm{MPa}) ; \\
F_{f} & =\text { carga aplicada verticalmente no centro do prisma }(\mathrm{N}) ; \\
L & =\text { distância entre suportes }(\mathrm{mm}) .
\end{array}
$$

A Figura 27 mostra o posicionamento e ruptura de tração na flexão de uma das barras na prensa de ensaio.

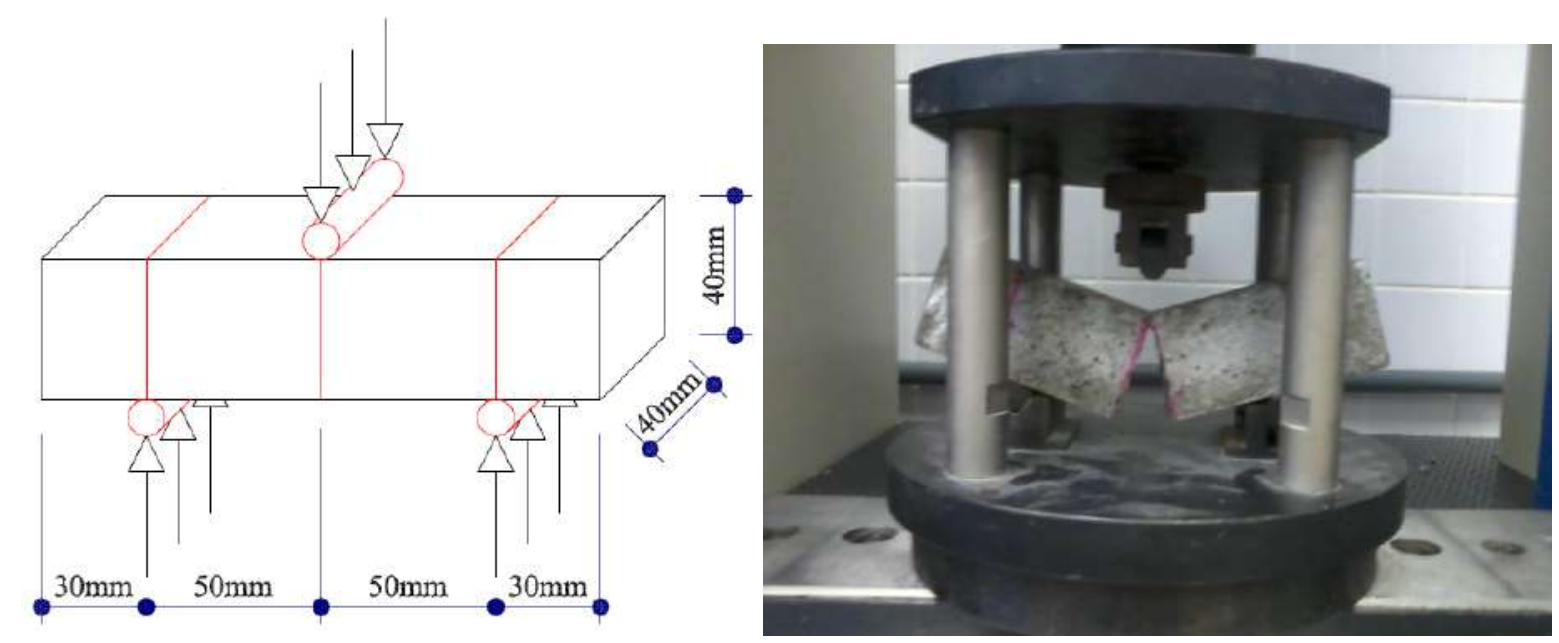

Figura 27: Detalhe do posicionamento e ruptura de tração na flexão do corpo de prova na prensa.

No ensaio de resistência à compressão foram utilizados 6 corpos de prova oriundos do rompimento de 3 amostras no ensaio de tração. A velocidade de aplicação de carga foi constante de $505 \pm 5 \mathrm{~N} / \mathrm{s}$ até a ruptura, assim, a resistência foi calculada a partir da Eq. 26.

$$
\mathrm{R}_{\mathrm{c}}=\frac{\mathrm{F}_{\mathrm{c}}}{1600}
$$


Onde:

$$
\begin{array}{ll}
R_{c} & =\text { resistência à compressão }(\mathrm{MPa}) ; \\
F_{c} & =\text { carga máxima aplicada }(\mathrm{N}) ;
\end{array}
$$

A Figura 28 mostra um exemplo de posicionamento e ruptura de um corpo de prova no ensaio de resistência à compressão.

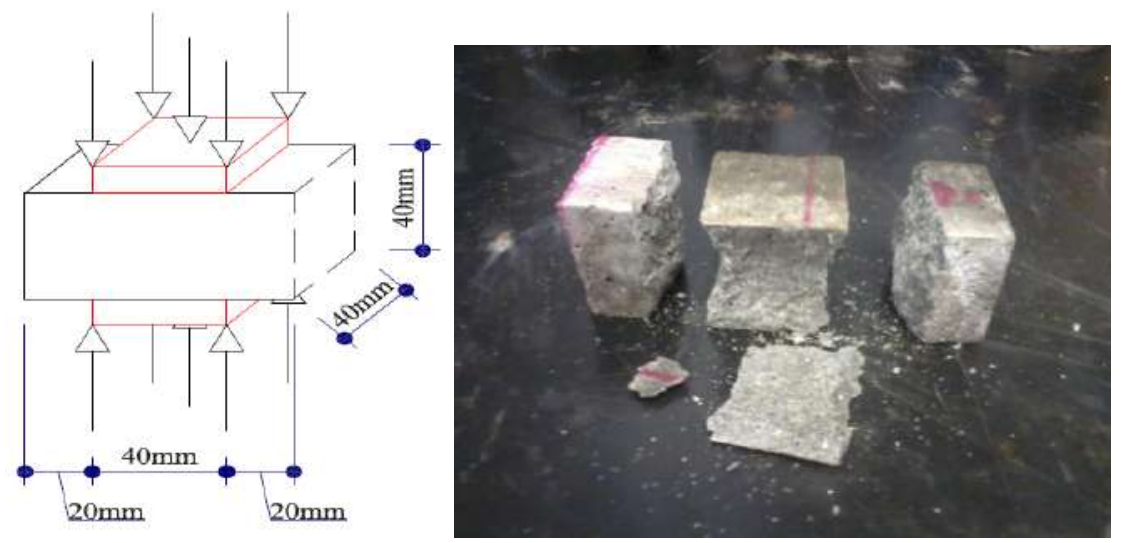

Figura 28: Detalhe de posicionamento e ruptura de compressão do corpo de prova.

Por fim, vale comentar que os corpos de prova foram rompidos em ambiente sem controle de temperatura nem umidade, todavia, buscou-se que estes estivessem na condição de saturados com superfície seca.

\subsubsection{Variação da velocidade ultrassônica}

A velocidade ultrassônica de um sólido, baseado no princípio da propagação de ondas, depende das propriedades elásticas do meio e está relacionada com o módulo de elasticidade dinâmico deste (TIPLER E MOSCA, 2006), conforme mostrado no item 3.4.9. Assim como na análise da variação de massa, a avaliação da velocidade ultrassônica foi realizada com dois objetivos, ou seja, como parâmetro para cálculo do módulo de elasticidade dinâmico e como fator que pudesse servir como argumento para explanações relacionadas à degradação do material.

As leituras foram realizadas com auxílio do equipamento Ultrasonic Pulse Velocity Pundit Lab do fabricante Proceq (Figura 29), constituído de dois transdutores que trabalham em conjunto na medição propriamente dita (um emissor e o outro receptor de ondas). Tendo em vista que os dados de entrada são a distância entre os transdutores, o aparelho lê a variação 
temporal entre a emissão e recepção do sinal e calcula a velocidade da onda automaticamente, o que facilita a obtenção dos dados.

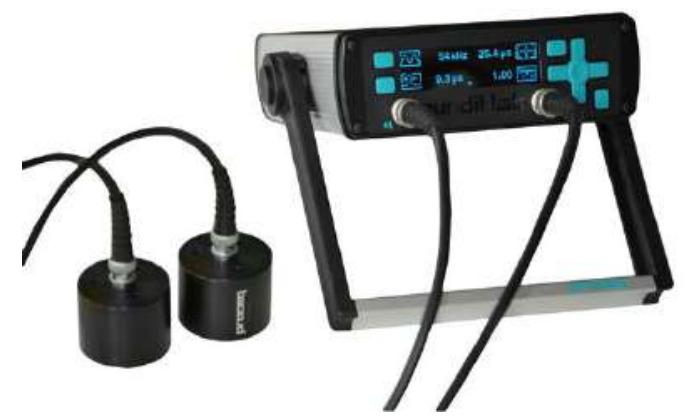

Figura 29: Equipamento Ultrasonic Pulse Velocity - Pundit Lab Fonte: www.proceq.com

Tal equipamento foi configurado com frequência de transmissão/recepção de $250 \mathrm{kHz}$, largura do pulso de 2,0 $\mu \mathrm{s}$ e diâmetro dos transdutores de aproximadamente 28 $\mathrm{mm}$.

Existem três maneiras de realizar a medição, as quais são definidas pela posição relativa entre os transdutores, sendo: transmissão direta (em faces opostas paralelas), semidireta (em faces ortogonais) e indireta (na mesma face). Todavia a forma de realização do teste neste trabalho compreendeu a transmissão direta entre os transdutores, isso faz com que as ondas sejam recebidas com maior intensidade, dando assim, maior confiabilidade aos resultados. Para tanto, os transdutores foram posicionado nas extremidades das barras de $40 \mathrm{x}$ 40 x 160 mm, conforme mostra a Figura 30, levando em conta que, para cada leitura, o gel de acoplamento era passado nos transdutores, este que é necessário para efetiva leitura do equipamento.

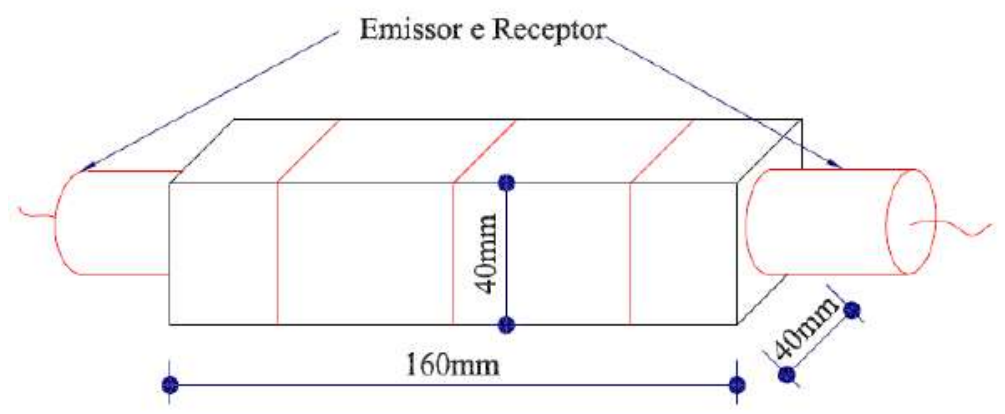

Figura 30: Esquema do posicionamento dos transdutores para emissão e recepção da onda ultrassônica.

Para que sua alta precisão seja efetiva, a aplicação do método exigiu alguns cuidados, como a limpeza da superfície (retirando qualquer material na superfície que possa mascarar 
ou impedir a penetração do feixe sônico). Para cada barra foram realizadas 4 leituras, das quais se calculou a média, que era utilizada como resultado final para a barra individualmente. Vale comentar que, em todos os casos, as quatro leituras tiveram um desvio relativo máximo em relação à média inferior a $0,5 \%$.

As avaliações das velocidades ultrassônicas ocorreram nos seguintes tempos de exposição: $0 ; 2 ; 4 ; 6 ; 8 ; 10 ; 15$; e, 20 semanas, com as amostras na condição de saturados com superfície seca.

A aferição da velocidade ultrassônica torna-se importante, pois as variações ocorridas ao longo das leituras realizadas indicam mudanças físicas ocorridas no material. Por exemplo, um corpo de prova cuja velocidade de propagação das ondas aumenta ao longo de aferições temporais, sugere que a amostra obteve ganho de densidade, ou seja, aumento da relação massa/volume. Por outro lado, velocidades de propagação mais lentas indicam uma diminuição da relação massa/volume, sugerindo um ganho substancial de volume, não acompanhado por um ganho de massa, além, claro, do surgimento de fissuras na amostra, as quais recorrem também a uma diminuição da velocidade de propagação de ondas ultrassônicas. Nada obstante, esta velocidade possui influência direta no módulo de elasticidade dinâmico do material, como será apresentado a seguir.

\subsubsection{Módulo de elasticidade}

Conforme citado, o módulo de elasticidade dinâmico está intrinsecamente relacionado com a velocidade de propagação das ondas ultrassônicas. Assim, a partir dos resultados obtidos com as leituras de velocidade de propagação do som, buscou-se definir o módulo de elasticidade dinâmico das barras de argamassa, conforme Eq. 27, de acordo com a norma BS1881 Part 203:1986.

$$
E_{d}=V^{2} \cdot \rho \cdot\left(\frac{(1+v) \cdot(1-2 v)}{(1-v)}\right)
$$

Sendo:

$$
\begin{array}{ll}
E_{d} & =\text { Módulo de elasticidade dinâmico, }(\mathrm{MPa}) ; \\
v & =\text { Coeficiente de Poisson (adotado como } 0,2) \\
V & =\text { Velocidade de propagação do som na argamassa, }(\mathrm{km} / \mathrm{s}) ; \\
\rho & =\text { Densidade do material, }\left(\mathrm{kg} / \mathrm{m}^{3}\right) .
\end{array}
$$


O coeficiente de Poisson é a razão entre a deformação transversal e longitudinal quando um corpo é submetido a uma carga de compressão axial. E, segundo a literatura, como, por exemplo, Carneiro (1999), em argamassas, tal coeficiente varia entre 0,10 e 0,20 de acordo com a capacidade de deformação do sólido, ou seja, quanto maior for o valor, menor será o modulo de elasticidade do sólido. No presente trabalho, fora adotado, como valor único, $v=0,20$, haja vista que tal valor é o mais comumente utilizado (ROZIÈRE et al., 2009; DIÓGENES et al., 2011; ISAIA et al., 2011; e BRUNETAUD et al., 2012).

\subsection{AVALIAÇÃO DO ATAQUE POR SULFATOS EM PASTAS DE CIMENTO}

Nesta parte da pesquisa, optou-se pela realização de ensaios de ataque por sulfatos em pastas de cimento Portland, pelo fato de que a interpretação dos resultados das análises por difração de raios-X seriam facilitadas por não haver a influência do quartzo do agregado miúdo utilizado, o que acaba por dificultar a análise dos resultados devido aos salientes picos de $\mathrm{SiO}_{2}$.

A Tabela 15 mostra a composição das pastas de cimento Portland utilizadas na presente pesquisa. Vale ressaltar que o estudo é composto por 9 séries, ou seja, duas referências (CP V - ARI e CPV - ARI RS) e sete séries, compostas cada uma delas, com uma adição mineral (sílica ativa, metacaulim, sílica de casca de arroz, cinza volante, fíler calcário, fíler quartzoso, resíduo de cerâmica vermelha). Cabe comentar, que se optou pela utilização de apenas uma das frações de resíduo de cerâmica vermelha para os ensaios em pasta, isto porque as propriedades químicas das adições são as mesmas, logo, a capacidade de formação de materiais degradantes são próximas, assim optou-se pelo uso da fração de RCV com 1,0 h de moagem.

Tabela 15: Composição das Pastas de cimento Portland

\begin{tabular}{ccccccc}
\hline \multirow{2}{*}{ Séries } & \multicolumn{6}{c}{ Composição das pastas de Cimento Portland } \\
\cline { 2 - 7 } & $\begin{array}{c}C P V- \\
A R I(g)\end{array}$ & $\begin{array}{c}C P V- \\
R S(g)\end{array}$ & $\begin{array}{c}\text { Adição } \\
\text { Mineral }(g)\end{array}$ & $\begin{array}{c}\text { Água } \\
(g)\end{array}$ & $\begin{array}{c}\text { Relação } \\
a / c\end{array}$ & $\begin{array}{c}\text { Relação } \\
\text { a/ag }\end{array}$ \\
\hline $\begin{array}{c}\text { Referência } \\
\text { CPV - ARI }\end{array}$ & 500 & - & - & 300 & 0,60 & 0,60 \\
$\begin{array}{c}\text { Referência } \\
\text { CPV - RS }\end{array}$ & - & 500 & - & 300 & 0,60 & 0,60 \\
$\begin{array}{c}\text { Séries com } \\
\text { adição mineral }\end{array}$ & 450 & - & 50 & 300 & 0,67 & 0,60 \\
\hline
\end{tabular}


3.5.1 Preparo de amostras para ensaios em pasta

O procedimento de mistura das pastas de cimento Portland seguiram os critérios estabelecidos pela ABNT NBR 13.276:2005, ou seja, inicialmente fora colocada água destilada na cuba de mistura, na quantidade pré-determinada, então foram adicionados os materiais sólidos dentro de um prazo de 30 s. Em seguida, o misturador mecânico foi acionado por $30 \mathrm{~s}$ na velocidade baixa. Com o término desta etapa, o misturador foi desligado e o material misturado ficou em repouso por um período de $90 \mathrm{~s}$. Por fim, a mistura final, em velocidade rápida, foi efetuada por mais $60 \mathrm{~s}$.

A técnica de difração de raios-X necessita de cuidados especiais no preparo e acondicionamento das amostras. Assim, logo após a mistura, as pastas foram lançadas em sacos plásticos $( \pm 25 \mathrm{~mL})$ e acondicionadas em recipientes poliméricos de $50 \mathrm{~mL}$, com tampa (Figura 31), objetivando minimizar a evaporação da água na cura e a interação com o meio. Para cada série, foi possível moldar 3 amostras, visando à realização de ensaios nos tempos de exposição às soluções finais de $0,6,10$ e 20 semanas.
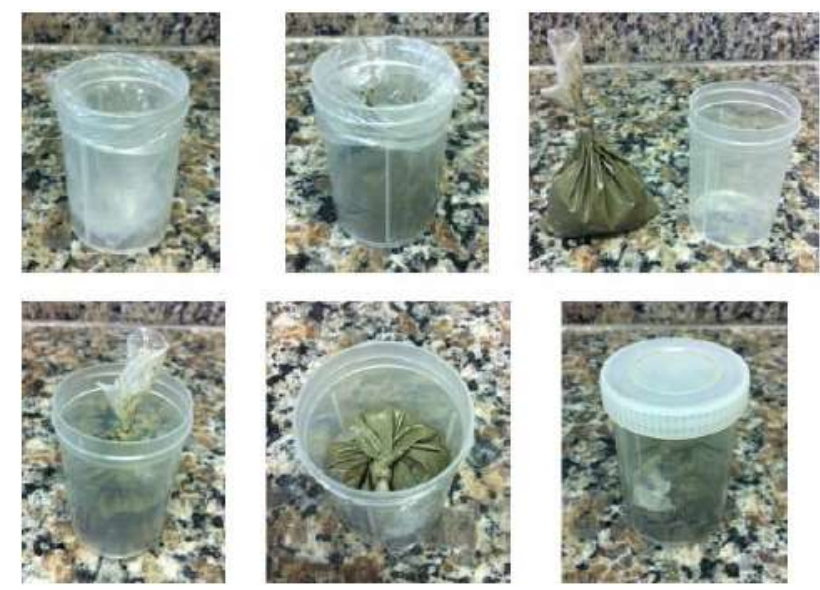

Figura 31: Etapa de acondicionamento das pastas para ensaios de DRX.

Os recipientes foram mantidos em ambiente controlado com temperatura de $23 \pm 2{ }^{\circ} \mathrm{C}$ por um período de 48 horas. Após, as amostras das diferentes pastas foram retiradas dos sacos plásticos e encaminhadas para o segundo período de cura, ou seja, imersão em solução de água destilada saturada com hidróxido de cálcio em temperatura controlada, também de $23 \pm 2{ }^{\circ} \mathrm{C}$, por um período de 12 dias.

Ao término deste tempo foi retirado um fragmento, com dimensão aproximada de 5,0 mm e então tiveram suas reações de hidratação interrompidas devido a um procedimento 
de extração da água livre e posterior secagem, restando nas amostras somente a água quimicamente combinada e parte da água adsorvida na estrutura dos compostos hidratados formados. Tal extração fora realizada com imersão das amostras de pasta em álcool etílico 99\% que, pela diferença de densidade deste, em relação à água, acaba por substituir a solução presente nos poros, assim sendo, as amostras foram mantidas imersas por um período de 24 horas. Posteriormente, foram retiradas da solução e levadas para secagem em estufa a $40 \pm 2{ }^{\circ} \mathrm{C}$ por um período de 24 horas.

Finalmente, após a secagem, as amostras foram finamente moídas em almofariz cerâmico com pistilo, acondicionadas em Eppendorf $(2 \mathrm{~mL})$ e estocadas em dessecador contendo sílica gel até a realização dos ensaios de DRX.

3.5.2 Exposição às soluções de sulfato de sódio e sulfato de magnésio

Os critérios de exposição, como, tempo, temperatura e composição da solução agressiva foram os mesmos utilizados nos ensaios em barras prismáticas de argamassa. A explanação detalhada de tais critérios podem ser vistas nos itens 3.4.1 e 3.4.2. 


\section{RESULTADOS E DISCUSSÕES}

A seguir serão apresentados e discutidos os resultados dos ensaios realizados, inicialmente a atividade pozolânica das adições minerais, posteriormente a análise química teórica das composições baseados nos resultados de análise química e a partir da determinação dos compostos de Bogue, conforme rotina apresentada no item 3.3 e, por fim, a influência das adições minerais frente ao ataque por sulfato de sódio e sulfato de magnésio.

\subsection{ATIVIDADE POZOLÂNICA DAS ADIÇÕES MINERAIS}

O estudo foi realizado com o objetivo de se ter conhecimento do consumo de portlandita a partir da adição mineral acrescentada à mistura. A Tabela 16 apresenta os resultados de atividade pozolânica das adições minerais utilizadas na presente pesquisa, determinados por meio do ensaio Chapelle modificado.

Tabela 16: Atividade Pozolânica pelo método Chapelle modificado

\begin{tabular}{cc}
\hline Adições minerais & $\begin{array}{c}\text { Atividade Pozolânica } \\
\left(\boldsymbol{m g} \boldsymbol{C a}(\boldsymbol{O H})_{2} / \text { g amostra }\right)\end{array}$ \\
\hline Fíler calcário & Não se aplica \\
Fíler quartzoso & 140 \\
Resíduo cerâmico $0,5 \mathrm{~h}$ & 454 \\
Resíduo cerâmico 1,0 h & 516 \\
Resíduo cerâmico 1,5 h & 537 \\
Metacaulim & 1.193 \\
Cinza volante & 408 \\
Sílica ativa & 1.542 \\
Sílica de casca de arroz & 1.336 \\
\hline Consumo mínimo de $\mathrm{Ca}(\mathrm{OH})_{2}$ para pozolanas é de $436 \mathrm{mg} / \mathrm{g}$. \\
\hline
\end{tabular}

O fíler calcário, em função da sua composição química, apresenta incompatibilidade com o princípio do ensaio, portanto, o método não foi aplicado a este material. O fíler quartzoso interagiu quimicamente com a cal, porém o teor fixado foi inferior ao mínimo recomendado para a classificação como adição pozolânica e, por isso, foi considerado inerte.

O metacaulim, sílica ativa e sílica de casca de arroz fixaram a cal em teores bastante elevados, acima de $1.100 \mathrm{mg} \mathrm{Ca}(\mathrm{OH})_{2} / \mathrm{g}$ amostra, fazendo com que possam ser classificadas como pozolanas de alta reatividade. Enquanto que as frações de resíduo de cerâmica vermelha após a moagem por $0,5 \mathrm{~h}$, foi capaz de fixar $454 \mathrm{mg} \mathrm{Ca}(\mathrm{OH})_{2} / \mathrm{g}$, ou seja, próximo ao valor 
mínimo recomendado. Para os tempos de moagem superiores (1,0 h e 1,5 h), o incremento na capacidade de fixar cal foi, respectivamente, $516 \mathrm{mg} \mathrm{Ca}(\mathrm{OH})_{2} / \mathrm{g}$ e $537 \mathrm{mg} \mathrm{Ca}(\mathrm{OH})_{2} / \mathrm{g}$, valores muito próximos ao da moagem por 0,5 h. Assim sendo, atribuiu-se a esta adição mineral uma baixa reatividade.

A cinza volante foi capaz de fixar $408 \mathrm{mg} \mathrm{Ca}(\mathrm{OH})_{2} / \mathrm{g}$, ou seja, próximo, porém abaixo do valor mínimo recomendado. Em estudos realizados por Gava e Prudêncio Jr (2007), os autores obtiveram um consumo $369 \mathrm{mg} \mathrm{Ca}(\mathrm{OH})_{2} / \mathrm{g}$ de cinza volante, valor, também inferior ao mínimo recomendado para a sua classificação como pozolana. Além disso, Kanning (2013) obteve como valor médio o consumo de $437 \mathrm{mg} \mathrm{Ca}(\mathrm{OH})_{2} / \mathrm{g}$ de cinza volante, o que lhe conferiu pozolanicidade, porém com baixa reatividade. Portanto, uma melhor moagem ou aumento da superfície específica do material (sendo que a cinza volante estudada apresentou B.E.T. de 1,096 $\mathrm{m}^{2} / \mathrm{g}$ ), tal como, uma melhoria na queima, possam fazer com que este passe a ter uma reatividade mais elevada e ser classificado como pozolânico.

Como já consagrado na química (RUSSELL, 1994), na cinética das reações a área específica é uma das características de um material que possui influência direta na velocidade de reações. Neste sentido, Cordeiro et al. (2011), Fitos et al. (2015) e Ilic et al. (2016) concluem em seus estudos que a pozolanicidade das adições minerais aumentam conforme maior for o amorfismo das partículas a suas superfícies de contato com os reagentes.

O resíduo de cerâmica vermelha mostrou, conforme a caracterização do material discutida no item 3.2.2.3, que ainda possuíra capacidade de aumento de sua área específica para maiores tempos de moagem. Logo, o mesmo ainda é capaz de ser beneficiado quanto a sua pozolanicidade. Entretanto, tal beneficiamento apresenta indícios insatisfatórios quanto aos custos energéticos, afinal, os tempos de moagem foram aumentados em 3 vezes (de $0,5 \mathrm{~h}$ para $1,5 \mathrm{~h}$ ), contudo, a capacidade do material em fixar a cal aumentou apenas $18 \%$, logo, fora da mesma proporção.

Por fim, acrescenta-se que não coube ao presente trabalho fazer um beneficiamento da cinza volante para a obtenção de melhores resultados. Portanto a cinza volante utilizada neste estudo não é, de fato, uma adição pozolânica. Deve ser classificada com material de baixa reatividade.

Com os resultados de consumo de hidróxido de cálcio, obtidos com os ensaios, fez-se uso da Eq. 14 para obtenção do teor de portlandita máximo que determinada adição pode consumir quando da utilização em teor de $10 \%$ em substituição parcial do cimento Portland. 
Tabela 17: Consumo de portlandita para cada adição estudada

\begin{tabular}{cc}
\hline Adições minerais & $\begin{array}{c}\text { Consumo percentual } \\
\text { de } \boldsymbol{C a}(\boldsymbol{O H})_{2}{ }^{*}\end{array}$ \\
\hline Fíler calcário & - \\
Fíler quartzoso & 1,40 \\
Resíduo cerâmico $0,5 \mathrm{~h}$ & 4,54 \\
Resíduo cerâmico $1,0 \mathrm{~h}$ & 5,16 \\
Resíduo cerâmico $1,5 \mathrm{~h}$ & 5,37 \\
Metacaulim & 11,93 \\
Cinza volante & 4,08 \\
Sílica ativa & 15,42 \\
Sílica de casca de arroz & 13,36 \\
\hline${\text { *o consumo de } \mathrm{Ca}(\mathrm{OH})_{2}}^{\text {é para }} 10 \%$ de adição \\
mineral em substituição parcial do cimento Portland. \\
\hline
\end{tabular}

Logo, observa-se que as adições com alta reatividade, como o metacaulim, sílica ativa e sílica de casca de arroz, tem potencial para consumir mais portlandita que as demais e, isto pode ter influência direta nos resultados obtidos devido ao ataque por sulfatos. Isto ocorre porque a quanto maior a disponibilidade de $\mathrm{Ca}(\mathrm{OH})_{2}$ da composição na matriz maior será o grau de ataque por sulfatos, devido, essencialmente, a formação de gipsita, sendo, este produto, base para conversão das estruturas de monossulfoaluminato de cálcio hidratados em etringita secundária (Eq. 7 e Eq. 8). Tal consumo de portlandita a partir das adições também influirá em um aumento da resistência devido a formação de estruturas $C$ - $S$ - $H_{\text {secundárias }}$, característicos das adições pozolânicas.

Por fim, deve-se evidenciar que tais valores obtidos de consumo percentual de hidróxido de cálcio são referentes a $100 \%$ da hidratação do cimento Portland. Fato este, que não será obtido dentro dos prazos dos ensaios realizados, haja vista que, de acordo com a bibliografia, como por exemplo, Neville (1997) e Mehta e Monteiro (2014), em média, o cimento necessita de aproximadamente de 150 a 200 anos para sua total hidratação. Todavia, o foco do presente trabalho, para utilização de tais resultados, é buscar explanações plausíveis quanto à degradação das argamassas, tendo como um dos parâmetros o consumo de portlandita. A julgar que a diferença de consumo de $\mathrm{CH}$ pode ter alta significância nos resultados de degradação.

\subsection{ANÁLISE QUÍMICA TEÓRICA DOS CIMENTOS}

A partir das hipóteses adotadas e dos resultados da análise química do cimento, a Tabela 18 apresenta os resultados teóricos dos cálculos de Bogue para os cimentos CP V - 
ARI e CP V - ARI RS. Levando em consideração que para o primeiro deles há duas composições: com $100 \%$ e $90 \%$ de cimento Portland, isto porque, neste último há a substituição do material cimentício por $10 \%$ de umas das adições minerais programadas para uso no estudo.

\begin{tabular}{cccc} 
Tabela 18: Teores dos compostos de Bogue para os cimentos CP V - ARI e CP V - \\
\cline { 2 - 4 } COMPOSTOS DE BOGUE DOS CIMENTOS UTILIZADOS \\
\hline Composto & CPV ARI & CPV ARI & CPV ARI RS \\
& $(\%)$ & $(\%)$ & $(\%)$ \\
\hline$C_{3} S$ & 59,47 & 53,53 & 3,06 \\
$C_{2} S$ & 1,79 & 1,61 & 55,33 \\
$C_{3} A$ & 8,72 & 7,85 & 6,80 \\
$C_{4} A F$ & 8,43 & 7,59 & 10,65 \\
Gipsita & 11,4 & 10,26 & 6,02 \\
Mat. Carbonático & 2,38 & 2,14 & 10,71 \\
$\mathrm{MgO}$ & 4,63 & 4,17 & 5,60 \\
$\mathrm{~K}_{2} \mathrm{O}$ & 1,06 & 0,95 & 1,00 \\
$\mathrm{CaO}$ livre & 1,46 & 1,31 & - \\
Res. Insolúvel & 0,67 & 0,6 & 0,90 \\
\hline TOTAL & $\mathbf{1 0 0 \%}$ & $\mathbf{9 0 \%}$ & $\mathbf{1 0 0 \%}$ \\
\hline
\end{tabular}

As altas resistências iniciais dos cimentos do tipo ARI são conseguidas, segundo Taylor (1990) e Hewlett (2003), pelo aumento significativo no teor de alita $\left(C_{3} S\right)$, por esta possuir uma elevada taxa de reação nas primeiras idades. Segundo Neville (1997), para este tipo de cimento, é comum que na composição do clínquer se tenha um teor de $C_{3} S$ superior a $55 \%$, podendo, em alguns casos, serem maiores que $70 \%$. Tendo em vista que o cimento CP V - ARI estudado apresenta um valor calculado de alita de 59,47 \%, o mesmo enquadra-se nas características dos cimentos do tipo ARI, segundo Neville (1997). Porém, isto não ocorre para o cimento do tipo ARI RS, já que tal cimento apresentou um teor de alita de 3,056\%, ou seja, muito inferior à faixa supracitada. Ao mesmo tempo, observa-se que tal cimento apresentara um teor de adição carbonática de $10,71 \%$, calculado a partir da perda ao fogo.

De acordo com a NBR 5.733:1991 os cimentos analisados esquadram-se fora dos requisitos mínimos e máximos exigidos pela referida norma. Ou seja, para estar de acordo, o somatório do clínquer $\left(C_{3} S+C_{2} S+C_{3} A+C_{4} A F\right)$ mais o sulfato de cálcio deve estar compreendido em uma faixa entre 95 e $100 \%$, porém quando quantificado o teor de $\mathrm{CaSO}_{4}$, conforme Eq. 28 (representando o cálculo para o CP V - ARI), observa-se que este somatório é igual a 87,43\% (CP V - ARI) e de 80,60 \% (CP V - ARI RS). 


$$
\mathrm{CaSO}_{4} \%=11,40 \cdot\left(\frac{136,14}{172,17}\right)=9,01 \%
$$

Eq. 28

Onde:

$11,40=$ teor de gipsita calculado $(\%)$;

136,14 = massa molar do sulfato de cálcio anidro $(\mathrm{g} / \mathrm{mol})$;

$172,17=$ massa molar da gipsita $(\mathrm{g} / \mathrm{mol})$.

Outra exigência de norma não cumprida pelo cimento CP V - ARI estudado foi quanto às determinações químicas referentes ao teor de tri óxido de enxofre, neste caso, o limite estabelecido para um quantitativo de $C_{3} A$ maior do que $8 \%$ deve ser de no máximo $4,5 \%$. Porém, na análise química apresentada no item 3.2.2.1 viu-se que o valor obtido por fluorescência de raios-X foi de 5,3\%. Resultado este, que sustenta o significativo teor de gipsita observado (Tabela 18). Em paralelo, devido ao fato dos valores obtidos para $C_{3} A$ e gipsita serem elevados, pressupõe-se que tal aglomerante demandará de maior quantidade de água para sua completa hidratação. Isto porque, consequentemente, haverá uma maior formação de etringita e monossulfoaluminato de cálcio hidratado, sendo que o aumento no teor deste último torna os concretos e argamassas de cimento Portland mais vulneráveis ao ataque por sulfatos, segundo Mehta e Monteiro (2014).

Para tanto, foi realizado uma análise química teórica da hidratação dos cimentos estudados por estequiometria a partir dos resultados dos compostos de Bogue, sendo, os valores encontrados, apresentados na Tabela 19.

Tabela 19a: Teores de minerais formados a partir da hidratação (teórica) dos cimentos

\begin{tabular}{cccc}
\hline \multicolumn{4}{c}{ COMPOSIÇÃO DOS CIMENTOS ESTUDADOS APÓS HIDRATAÇÃO } \\
\hline Produto da hidratação & $\begin{array}{c}\text { CP V - ARI } \\
(\mathbf{1 0 0 \% )}\end{array}$ & $\begin{array}{c}\text { CP V - ARI } \\
\mathbf{( 9 0 \% )}\end{array}$ & $\begin{array}{c}\text { CP V - ARI RS } \\
(\mathbf{1 0 0 \%})\end{array}$ \\
\hline$C-S-H$ & 46,38 & 41,742 & 57,30 \\
$C H$ & 29,34 & 26,402 & 13,39 \\
$C_{6} A \bar{S}_{3} H_{32}$ & 14,68 & 13,176 & 0,00 \\
$C_{4} A \bar{S} H_{12}$ & 19,36 & 17,484 & 21,77 \\
Hidrotalcita $^{A}$ & 1,16 & 1,041 & 1,40 \\
Hidrogranada $^{B}$ & 3,49 & 3,095 & 6,95 \\
Portlandita $^{*}$ & 2,91 & 2,629 & 0,00 \\
Brucita $^{*}$ & 6,03 & 5,427 & 7,29 \\
Fíler Calcário & 2,38 & 2,139 & 10,71 \\
Resíduo Insolúvel & 0,67 & 0,603 & 0,90 \\
\hline
\end{tabular}


Tabela 19a: Teores de minerais formados a partir da hidratação (teórica) dos cimentos

\begin{tabular}{cccc}
\hline $\mathrm{Fe}_{2} \mathrm{O}_{3}$ remanescente & 2,25 & 2,028 & 2,46 \\
$\mathrm{~K}_{2} \mathrm{O}$ & 1,06 & 0,954 & 1,00 \\
TOTAL & $\mathbf{1 2 9 , 7 0}$ & $\mathbf{1 1 6 , 7 1 8}$ & $\mathbf{1 2 3 , 1 6}$ \\
$\mathrm{H}_{2} \mathrm{O}$ para completa reação & 31,49 & 28,34 & 23,79 \\
$\quad$ Teor total de portlandita & & & \\
(teórico) & 32,25 & 29,03 & \\
${ }^{\mathrm{A}} \mathrm{Mg}_{6} \cdot \mathrm{Al}_{2} \cdot \mathrm{CO}_{3} \cdot(\mathrm{OH})_{16} \cdot 4 \cdot \mathrm{H}_{2} \mathrm{O}$ & & \\
${ }^{\mathrm{B}} \mathrm{Ca}_{3} \cdot \mathrm{Al}_{1,2} \cdot \mathrm{Fe}_{0,8} \cdot \mathrm{SiO}$ & \\
& $* \mathrm{Heferente} \mathrm{à} \mathrm{sobra} \mathrm{de} \mathrm{CaO}$, hidratado $^{*}$ & & \\
**Sobra de $\mathrm{MgO}$, hidratado & & \\
\hline
\end{tabular}

Com a obtenção dos resultados, quatro são os pontos que devem ser discutidos, comentados a seguir:

- Teor de portlandita: o valor obtido para reserva alcalina foi de $32,25 \%$ para $100 \%$ de cimento CP V - ARI e de $29,03 \%$ para $90 \%$ de cimento. Logo, em paralelo com os resultados apresentados na Tabela 17, referente ao consumo de $\mathrm{Ca}(\mathrm{OH})_{2}$, observa-se que em nenhum momento, seja qual for a adição mineral utilizada, e a idade do corpo de prova, haverá consumo total de $\mathrm{CH}$. Entretanto, nota-se que as adições de alta reatividade podem, em média, consumir até, aproximadamente, $50 \%$ do $\mathrm{CH}$, do exposto na hipótese de $100 \%$ de hidratação do cimento (Tabela 20). Este que pode ser um indicativo da diferença do grau de degradação das barras, em comparação entre as séries. Nada obstante, o CP V - ARI RS apresentou um teor de reserva alcalina de $13,39 \%$, cerca de $58,48 \%$ menor do que o outro cimento utilizado.

Tabela 20: Teor remanescente de portlandita após reação de hidratação do cimento Portland e consumo por atividade pozolânica.

\begin{tabular}{cc}
\hline SÉRIE & Teor remanescente de $\mathbf{C a}(\mathbf{O H})_{2}{ }^{*}$ \\
\hline CP V - ARI & $32,25(100 \%)$ - referência \\
CP V - ARI RS & 13,39 \\
CP V - ARI & $29,03(90 \%)-$ substituição parcial \\
Fíler Calcário & 29,03 \\
Fíler Quartzoso & 27,63 \\
Resíduo Cerâmico 0,5 h & 23,87 \\
Resíduo Cerâmico 1,0 h & 23,66 \\
Resíduo Cerâmico 1,5 h & 24,95 \\
Metacaulim & 17,10 \\
Cinza Volante & 24,49 \\
Sílica Ativa & 13,61 \\
Sílica de Casca de Arroz & 15,67 \\
\hline *Teor remanescente, hipotetizando 100\% de hidratação do cimento e \\
consumo de portlandita por atividade pozolânica idêntica à \\
quantificada no ensaio Chapelle. \\
\hline
\end{tabular}


- Brucita: os elevados teores de brucita para os cimentos estudados podem influenciar, dependendo do $\mathrm{pH}$ de exposição, em decomposição das estruturas $C-S$ - $H$ e formação de estruturas $M-S-H$ e que possui baixa resistência (TAYLOR, 1997). Processo este, semelhante ao exemplificado nos mecanismos de ataque por sulfato de magnésio, já comentados no presente trabalho.

- Etringita $\left(C_{6} A \bar{S}_{3} H_{32}\right)$ e Monossulfoaluminato de cálcio hidratado $\left(C_{4} A \bar{S} H_{12}\right)$ : com os cálculos, observa-se um elevado teor de etringita remanescente para o CP V - ARI, ou seja, não convertida em monossulfoaluminato, isto é decorrente do elevado teor de $\mathrm{SO}_{3}$ do cimento estudado. Todavia, os teores de monossulfoaluminato de cálcio hidratado encontrados, também elevados, são um potencial indicativo para futura degradação das composições estudadas, haja vista, que este material pode ser reconvertido em etringita secundária a partir de interações com os íons sulfato.

Desta maneira, hipotetizando uma total reconversão do monossulfoaluminato de cálcio hidratado em etringita secundária, para estipular um potencial de formação de $C_{6} A \bar{S}_{3} H_{32}$ a partir do ataque por sulfatos, tem-se um valor de $13,01 \%$ para o CP V ARI e de 14,631\% para o CP V - ARI RS, obtidos por cálculos estequiométricos. Estes, que são dois bons indicativos de degradação das amostras estudadas. Porém, verifica-se que ambos os cimentos apresentaram teores de $C_{4} A \bar{S} H_{12}$ próximos, o que indica uma formação de etringita secundária, a partir do ataque por sulfatos, também próxima, remetendo a crer que haverá um grau de ataque semelhante entre os cimentos estudados. Contudo, evidencia-se que a maior disponibilidade de $\mathrm{CH}$ para o cimento CP V - ARI torna este aglomerante mais vulnerável à formação de gipsita, ou seja, podendo indicar um maior grau do ataque por sulfatos.

Ao mesmo tempo, a partir da verificação do teor de etringita remanescente para o cimento CP V - ARI pode-se levantar a hipótese de que em uma composição com adição de material reativo com teores acentuados de óxidos de cálcio e alumínio, como por exemplo, o metacaulim, pode haver contribuição para que o teor de etringita remanescente seja minorado. Isto porque, com a disponibilidade de mais $\mathrm{Al}_{2} \mathrm{O}_{3}$ e $\mathrm{CaO}$ no sistema há a possibilidade de formação de mais AFm a partir do teor de $C_{6} A \bar{S}_{3} H_{32}$ (conforme será visto com os resultados de DRX no item 4.4), podendo, esta composição estar vulnerável a formação de um teor mais elevado de etringita secundária. 
Por fim, cabe comentar, novamente, que tais cálculos dos percentuais de produtos formados, são exemplos hipotéticos para $100 \%$ da hidratação do cimento Portland, assim, não representam a realidade em sua totalidade, porém, são resultados úteis e que podem servir como base para explanações sobre o ataque por sulfatos.

\subsection{ANÁLISE UNIDIMENSIONAL}

A seguir serão apresentados e discutidos os resultados obtidos para variação dimensional linear devido à exposição a soluções de sulfato de sódio e de magnésio. Os ensaios que seguiram, em primeira instância, a NBR 13.583:2014 e então tiveram um prolongamento do período de exposição. A metodologia de discussão seguirá da seguinte maneira, serão abordadas inicialmente as variações causadas para tempo de exposição de 42 dias (6 semanas), tendo como foco da discussão o período limite de exposição da qual a NBR 13.583:2014 preconiza, independentemente da referida norma não abordar a imersão em sulfato de magnésio. Posteriormente, serão comentadas, de modo geral, as variações ocorridas nas amostras para 20 semanas de exposição (140 dias) e, por fim, serão discutidos os comportamentos das séries de forma individual, porém subdivididas em 4 grupos (referência, adições minerais inertes, adições minerais de baixa reatividade e adições minerais de elevada reatividade). Assim, a Figura 32 apresenta a expansão resultante das séries expostas por 42 dias (6 semanas) ao sulfato de sódio, conforme a referida norma, e ao sulfato de magnésio. Ressalta-se que as análises comparativas entre médias são apresentadas em forma de tabelas no Apêndice 1 do presente trabalho.

Cabe comentar que a NBR 13.583:2014 não especifica um valor ao qual se pode considerar uma composição resistente, ou não, ao sulfato de sódio, pois se trata apenas de uma análise comparativa. Todavia, segundo Marciano (1993), composições com expansão resultante igual ou inferior a $0,03 \%$ ao $42^{\circ}$ dia de exposição (6 semanas) podem ser consideradas resistentes ao sulfato de sódio. Logo, observa-se que, as únicas séries que apresentariam resistência seriam as compostas por CP V - ARI RS, FQ, SA e SCA. 
Solução de $\mathrm{Na}_{2} \mathrm{SO}_{4}$

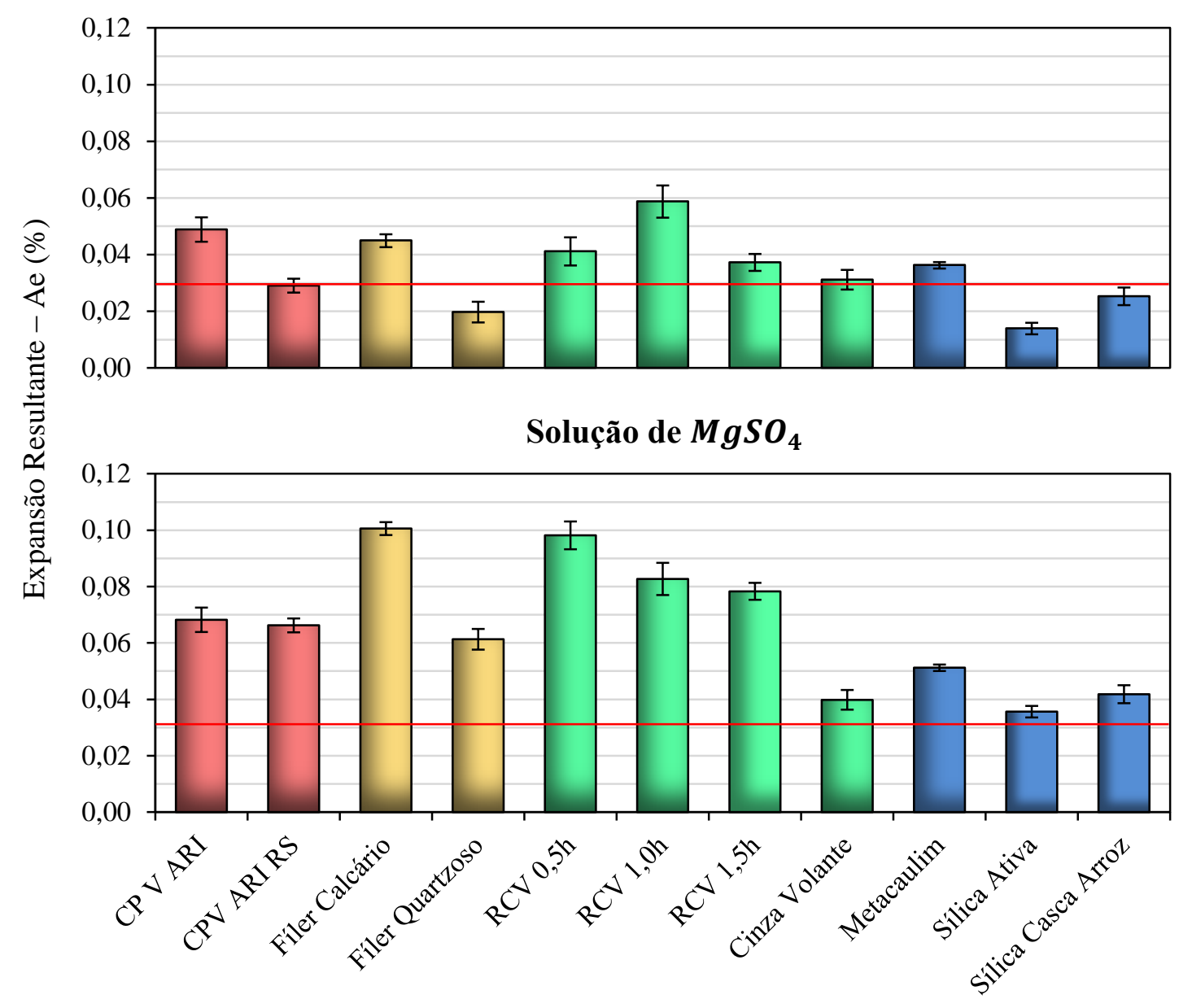

- Limite, segundo Marciano (1993) para solução de $\mathrm{Na}_{2} \mathrm{SO}_{4}$

Figura 32: Expansão resultante das séries expostas ao sulfato de sódio (segundo NBR 13.583:2014) e ao sulfato de magnésio por um período de 42 dias.

Em contrapartida, as séries de mesma composição não obtiveram o mesmo desempenho quanto à exposição ao sulfato de magnésio, assim como os demais grupos de amostra. De modo geral, as séries resultaram em uma expansão 1,88 vezes, em média, superiores às imersas em solução de $\mathrm{Na}_{2} \mathrm{SO}_{4}$. Tal fenômeno pode ser explicado pelo fato de que o $\mathrm{MgSO}_{4}$ possui solubilidade 5 vezes maior que o $\mathrm{Na}_{2} \mathrm{SO}_{4}$ e, em paralelo, o $\mathrm{SO}_{4}^{2-}$ possui uma influência maior na massa molar do sulfato de magnésio. Portanto, disponibilizando uma quantidade maior de íons sulfato, cerca de 6,67 vezes, para interação com as barras de argamassa.

A análise comparativa entre os resultados médios, teste de Tukey, podem ser vistos nas Tabela 25 e Tabela 26 presentes no Apêndice 1 do presente trabalho. Assim, deve-se comentar que na referida análise, as séries FQ, RCV 0,5 h, RCV 1,5 h, CV, MT e SCA podem ser consideradas estatisticamente equivalentes à série composta apenas por CP V - ARI RS, para exposição ao sulfato de sódio, este que pode ser um indicativo de que o período de 
ensaio é insatisfatório. Outra comparação interessante de se analisar, para a mesma solução de exposição, é a influência do tempo de moagem da RCV, pelo método de Tukey: a RCV 0,5 h e RCV 1,5 h mostraram-se equivalentes, enquanto que a RCV 1,0 h mostrou-se mais expansiva, e tal comportamento anômalo pode ser associado, simplesmente, ao baixo período de exposição e a variabilidades intrínsecas ao ensaio. Entretanto, analisando-as de modo geral, avalia-se que para 6 semanas de exposição, o tempo de moagem da RCV não possuiu influência nos resultados, tanto para solução de $\mathrm{MgSO}_{4}$ como de $\mathrm{Na}_{2} \mathrm{SO}_{4}$.

Genericamente, aos 42 dias de exposição ao sulfato de sódio, a substituição parcial do cimento Portland por adições minerais foi satisfatória, pois, com exceção da série RCV 1,0 h, porém considerada estatisticamente equivalente à referência (teste de Tukey), todas as demais mitigaram o efeito expansivo ocasionado pelo $\mathrm{Na}_{2} \mathrm{SO}_{4}$, ainda que não tenham propiciado a redução compatível com o limite proposto de $0,03 \%$.

Apesar de que na presente pesquisa não se tenha feito uso de um dos cimentos mais comumente vendido no mercado brasileiro, o CP II F, pode-se fazer um paralelo quanto à adição de Fíler Calcário. De acordo com a NBR 11.578:1997, os teores limites de material carbonáticos são 6 - $10 \%$, em massa. Assim sendo, o uso de FC aproxima o CP V - ARI do CP II F, já que o teor de calcita passa a ser de 12,38 \% (10 \% da adição + 2,38 contido no cimento). Mesmo que fora dos limites recomendados pela norma supracitada, pode-se pressupor que o cimento mais vendido no mercado brasileiro, teria um comportamento que muito se assemelha ao $\mathrm{CP} \mathrm{V}$ - ARI frente à solução de $\mathrm{Na}_{2} \mathrm{SO}_{4}$. Porém, quando exposto à solução de $\mathrm{MgSO}_{4}$ o mesmo não ocorre, pois a série $\mathrm{FC}$ passou a ter uma expressiva piora de desempenho.

A série composta com a adição de cinza volante apresentou, para exposição ao $\mathrm{Na}_{2} \mathrm{SO}_{4}$, uma equivalência estatística com a referência CP V - ARI RS e um valor muito próximo do estabelecido por Marciano (1993), ou seja, 0,031\% com desvio padrão de 0,003\%. Para exposição ao sulfato de magnésio, esta série apresentou melhorias significativas quando comparadas a ambas as séries de referência. Logo, estes resultados indicam que a adição de CV se faz satisfatória para exposição às duas soluções de sulfato.

As séries que apresentaram os melhores resultados para as duas soluções de sulfato foram as compostas por adições pozolânicas silicosas (SA e SCA) levando a crer, pelo menos para curtos períodos de exposição, que ambas as adições são as melhores opções para exposição tanto ao $\mathrm{Na}_{2} \mathrm{SO}_{4}$ como o de $\mathrm{MgSO}_{4}$. A Figura 33 apresenta os resultados da expansão linear das séries expostas à solução de sulfato de sódio e de sulfato de magnésio por um período de 20 semanas (140 dias). 
Solução de $\mathrm{Na}_{2} \mathrm{SO}_{4}$

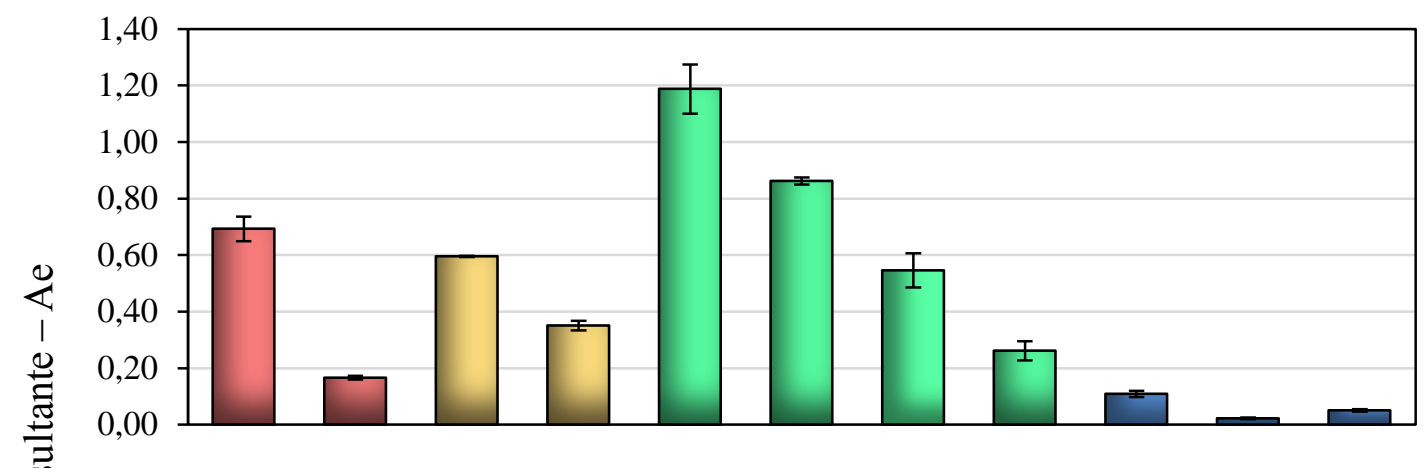

Solução de $\mathrm{MaSO}_{4}$

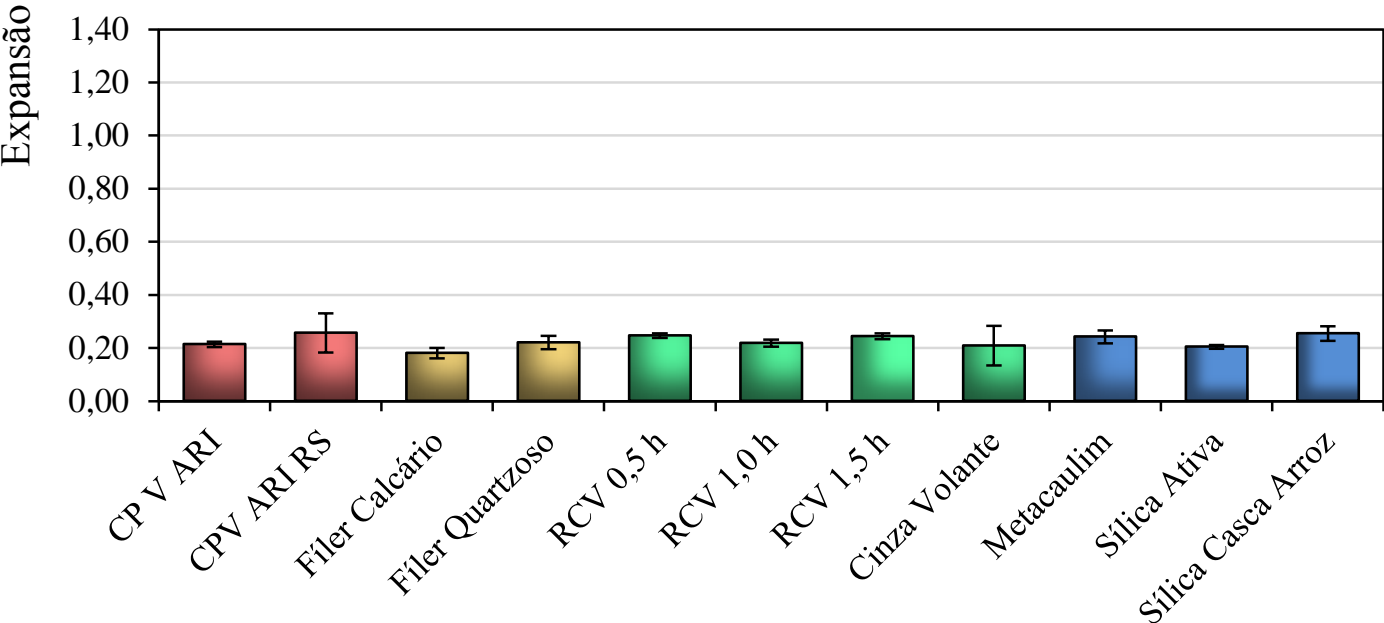

Figura 33: Expansão resultante das séries expostas ao sulfato de sódio e ao sulfato de magnésio por um período de 140 dias.

Mesmo se tratando de um ensaio acelerado (NBR 13.583:2014), 42 dias de exposição não é um período satisfatório para análise. Isto porque, composições ou cimentos compostos por adições pozolânicas podem não representar um resultado compatível com a realidade de longos períodos de exposição, exemplos disso, são as alterações vistas entre as séries metacaulim, cinza volante, CP V - ARI RS e fíler quartzoso quando comparado os resultados a 6 semanas e 20 semanas. Por exemplo, para 42 dias de exposição, a série FQ apresentou melhor desempenho enquanto a MT, pior, quando expostas ao sulfato de sódio e comparadas entre si. Contudo, para 140 dias de exposição o mesmo não ocorrera, o que se vê é que o desempenho da série MT fora mais satisfatória do que a FQ, contrariando os resultados obtidos em períodos curtos de exposição.

O grau do ataque por sulfato está diretamente relacionado com a quantidade de produtos formados a partir da interação entre os íons $\mathrm{SO}_{4}^{2-}$ e os produtos da hidratação do cimento Portland, essencialmente, porlandita e monossulfoalumito de cálcio hidratado, formando, gipsita e etringita, sucessivamente. Além disso, a interconectividade dos poros 
também é um fator de forte influência no grau do ataque (HOOTON, 1993; TIAN E COHEN, 2000; SKALNY et al. 2002; COLLEPARDI, 2003; AL-AKHRAS, 2006; MEHTA E MONTEIRO, 2014). Neste sentido, a Figura 34 apresenta a correlação entre os teores remanescentes de portlandita (considerando a atividade pozolânica), obtidos teoricamente para cada uma das composições (mostrado no item 4.2 e Tabela 20), e a expansão resultante causada pelo ataque por sulfato de sódio para um período de exposição de 20 semanas.

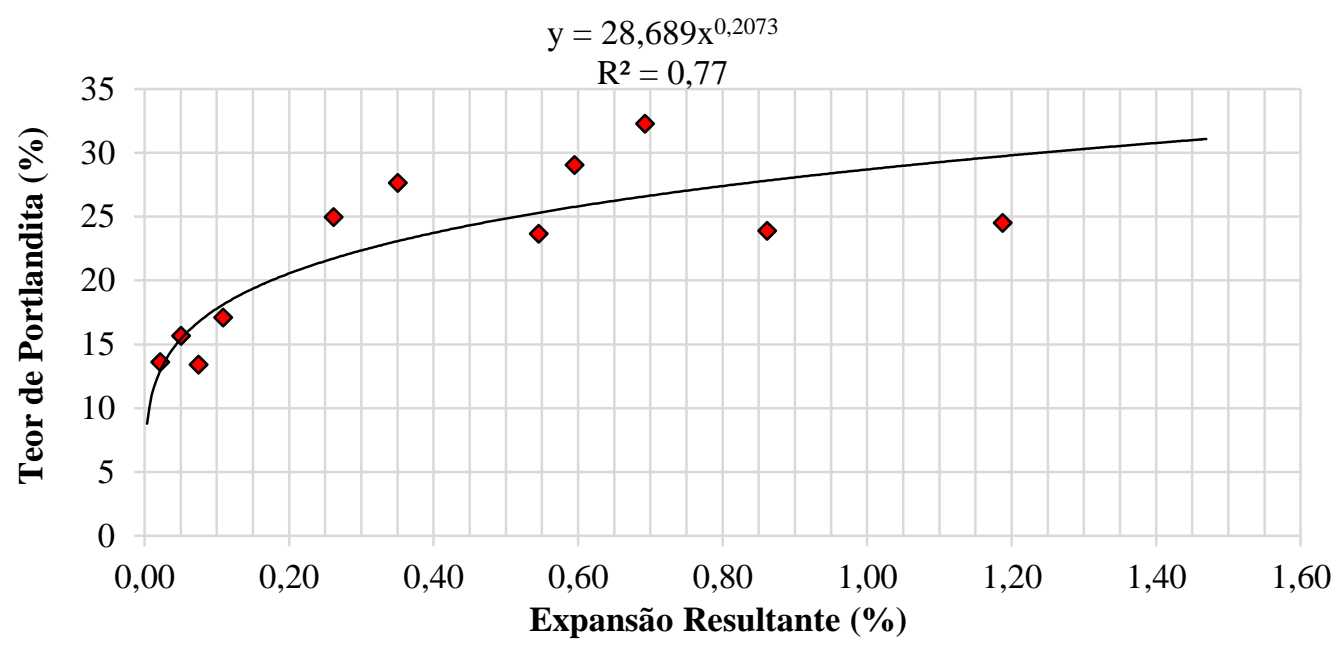

Figura 34: Correlação entre o teor de portlandita e a expansão resultante devido ao ataque por sulfato de sódio, para período de exposição de 20 semanas.

Portanto, mesmo que se tratando de uma análise teórica e para $100 \%$ de hidratação do cimento, a obtenção do teor de portlandita das composições torna-se uma importante informação quanto à predição de comportamento frente ao ataque por sulfato de sódio, corroborando as afirmações de autores como Hooton (1993), Tian e Cohen (2000), Skalny et al. (2002), Collepardi (2003), Al-Akhras (2006) e Mehta e Monteiro (2014). Ou seja, como pode ser visto na Figura 34, conforme menor for a disponibilidade de portlandita após a reação entre aglomerantes (cimento + adições) menor foi a expansão resultante para 20 semanas de exposição.

Em contrapartida, o mesmo não ocorre para expansão resultante devido à exposição ao $\mathrm{MgSO}_{4}$, sendo que, de modo geral, a variação dimensional foi expressivamente inferior à apresentada para o $\mathrm{Na}_{2} \mathrm{SO}_{4}$. Entretanto, Santhanam et al. (2002) afirmam que em um primeiro estágio, cujos produtos da interação com os íons de sulfato preenchem os poros da argamassa e iniciam a expansão, o comportamento, seja em solução de sulfato de sódio ou de magnésio, muito se assemelha. Todavia, em um segundo estágio, quando a expansão começa 
a modificar a microestrutura, para uma mesma idade, os resultados de expansão devido ao ataque por sulfato de sódio são muito mais expressivos.

De acordo com Bonen (1992), Santhanam et al. (2002), Skalny et al. (2002), Santhanam et al. (2003), Lee et al. (2005), Diab et al. (2012), Mehta e Monteiro (2014) e Makhloufi et al. (2016), o primeiro produto da interação entre o sulfato de magnésio e produtos da hidratação do cimento Portland é a brucita (hidróxido de magnésio), na qual o íon de magnésio, por afinidade eletrônica, substitui os íons cálcio da portlandita. Segundo os autores, tal material, apresenta-se na forma de gel preenchendo os vazios do concreto podendo precipitar na superfície do mesmo juntamente com a gipsita e composições de sulfato de magnésio hidratado (conforme visto no item 4.4). Neste mesmo norte, durante o processo de exposição das barras, foi observada uma excessiva formação de gel gelatinoso na superfície das amostras, especialmente, nas séries que possuíam elevado teor de $\mathrm{CH}$. A Figura 35 mostra uma barra da série FQ que apresentou uma excessiva formação deste gel superficial em suas seis superfícies expostas ao $\mathrm{MgSO}_{4}$.

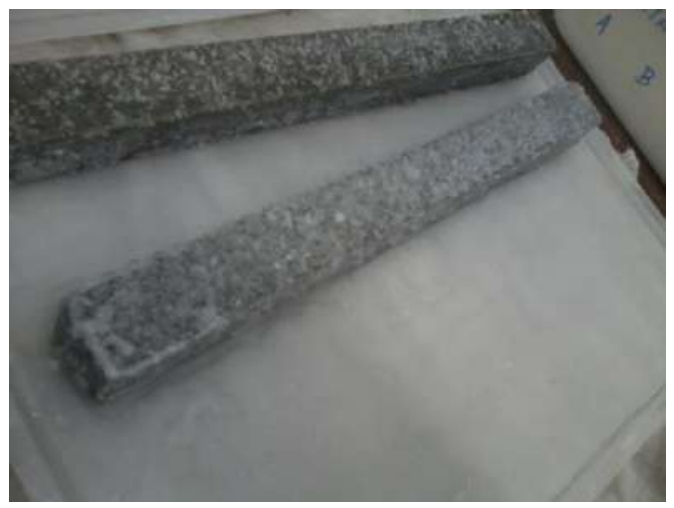

Figura 35: Barra de argamassa da série FQ com excessiva formação gelatinosa na superfície devido à interação com o sulfato de magnésio.

Portanto, tal indicação visual da interação entre o material cimentício e a solução agressiva poderia indicar uma expansibilidade maior das barras, porém, o mesmo não ocorreu. Tal formação de gel possui influência em retardar o processo de expansão, pois dificulta a difusão dos íons sulfato nas amostras, e isto pode ser visto com os resultados da Figura 36, onde foram comparados os resultados obtidos com duas séries compostas por cimento CP V ARI e sem qualquer adição mineral, sendo, a única diferença entre ambas, a limpeza ou não do gel acumulado na superfície. Esses resultados evidenciam que a presença do gel formado reduz a velocidade do mecanismo de degradação por ataque de $\mathrm{MgSO}_{4}$. 


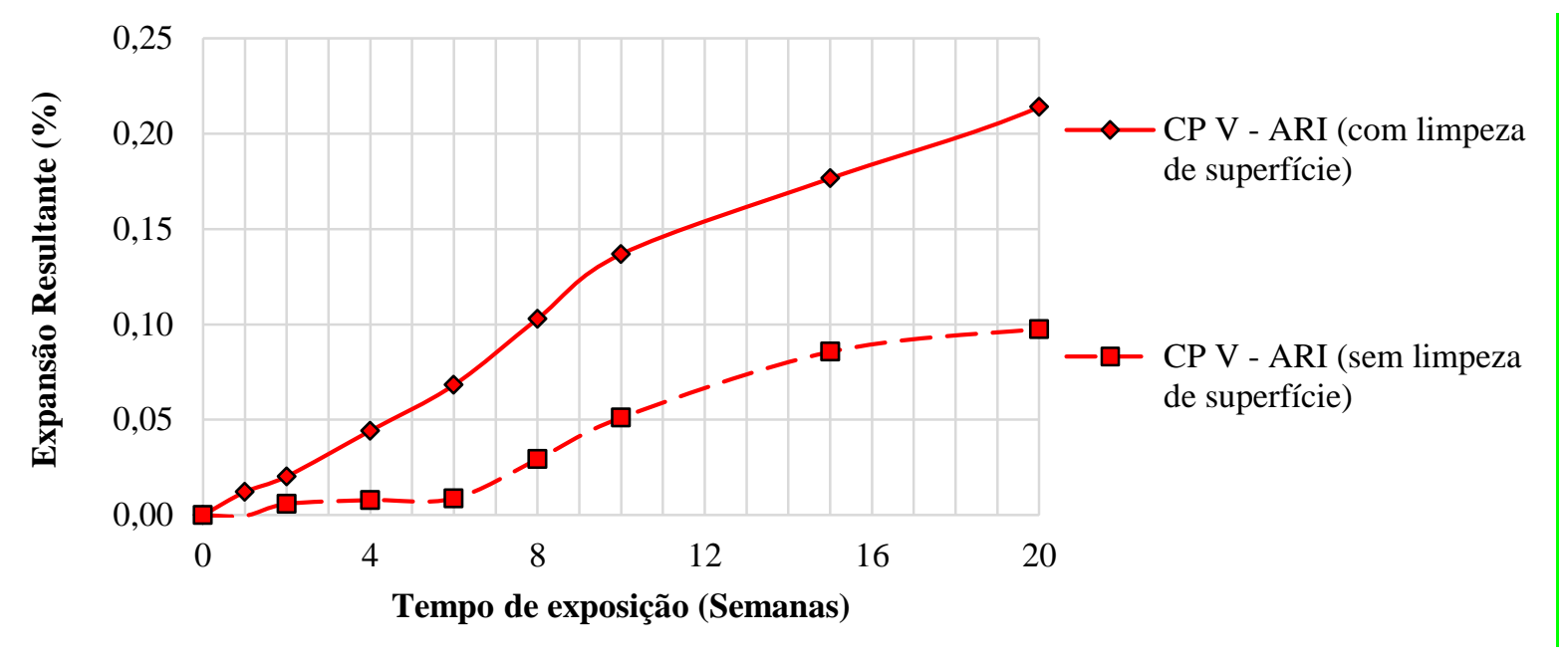

Figura 36: Comparação entre expansão resultante de duas séries de mesma composição e com diferentes formas de exposição, com e sem limpeza superficial quando expostas ao sulfato de magnésio.

Em compensação, a interação da solução de $\mathrm{MgSO}_{4}$ com as séries com teores menores de portlandita, como por exemplo, CP V - ARI RS, MT, SA e SCA ocorreram de forma distinta. Inicialmente estas séries também apresentaram formação de gel na superfície, porém com quantidade visivelmente menor, mas, com o decorrer da exposição, a formação do gel foi quase que interrompida. O que passou a ser observado então foi uma dissolução das camadas superficiais das amostras na solução. Tal ocorrência pode ser vista com a Figura 37.

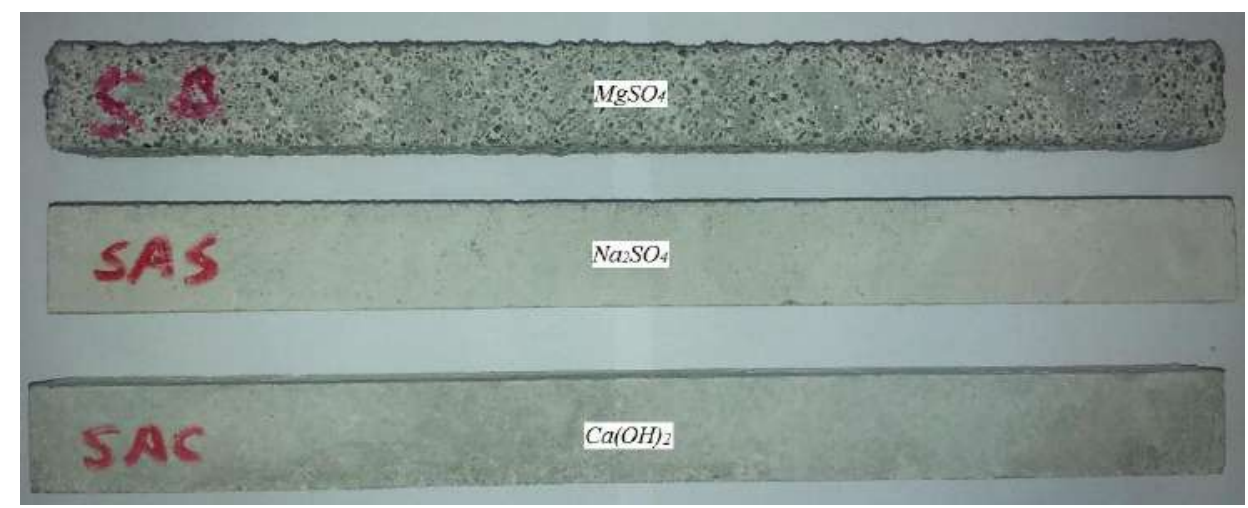

Figura 37: Comparação entre barras de argamassa da série SA expostas nas três diferentes soluções, por um período de 20 semanas.

Segundo autores como Santhanam et al. (2002), Skalny et al. (2002), Santhanam et al. (2003) e Makhloufi et al. (2016), momentos após a imersão na solução, a mesma tende a ter um aumento no $p H$ para uma faixa de 9 - 10 devido à interação com o $C H$ dos poros das amostras, e, juntamente com este fenômeno, há a formação de brucita, gipsita e etringita na superfície das barras. Com a excessiva formação de brucita e gipsita, o $p H$ da solução aquosa presente nos poros da argamassa começa a baixar, pois tais materiais possuem solubilidade 
muito inferior a da portlandita, logo, libera menos $O H^{-}$para a solução. Desta forma, há a desestabilização do $C-S-H$, o qual começa a liberar íons cálcio para elevação do $p H$. Todavia, este processo, além da descalcificação do silicato de cálcio hidratado, permite a formação de $M-S-H$ que não possui capacidade cimentante (a influência deste fenômeno na resistência à compressão será analisada no item 4.6). Nada obstante, após esta conversão os íons cálcio não conseguem promover a elevação do $\mathrm{pH}$ da solução, isto porque o $\mathrm{Ca}^{2+}$ acaba por interagir com íons sulfato e precipitam devido à baixa solubilidade do sulfato de cálcio. De modo a analisar tais afirmações, para a presente pesquisa, foram realizadas aferições de pH ao longo das datas de leituras de expansão, e a Figura 38 apresenta os resultados obtidos de forma comparativa entre as três soluções estudadas.

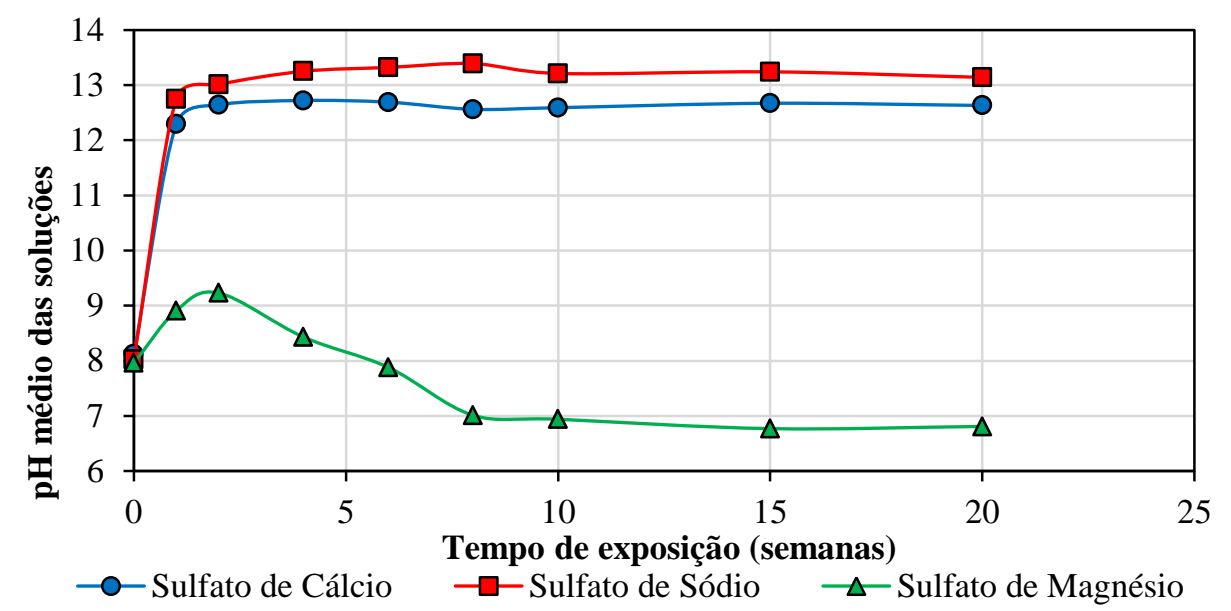

Figura 38: Análise comparativa do $\mathrm{pH}$ das soluções de $\mathrm{Ca}(\mathrm{OH})_{2}, \mathrm{Na}_{2} \mathrm{SO}_{4}$ e $\mathrm{MgSO}_{4}$ ao longo de 20 semanas.

Tais resultados apresentados na Figura 38 indicam que as soluções de sulfato de magnésio tornaram-se levemente ácidas, enquanto as demais soluções permaneceram com características de basicidade forte. Em virtude disso, observa-se que para o $\mathrm{MgSO}_{4}$, além da interação das argamassas com os íons de sulfato, há também um ataque ácido nas amostras, o que contribui na justificativa, juntamente com a forma de $M-S-H$, do desgaste superficial apresentado em algumas das séries. Nada obstante, fazendo um paralelo com obras reais passíveis de interação com o $\mathrm{MgSO}_{4}$, como fundações, alerta-se que além da degradação ocasionada pelo sulfato de magnésio, como descrita no presente trabalho, há a potencialização da ocorrência de corrosão das armaduras. Afinal, segundo Cascudo (1997), armaduras de aço CA 50 são despassivadas e ficam vulneráveis à corrosão para exposição a $p H$ inferiores a 9,6.

Segundo Adenot e Buil (1992), Lovera et al. (1997), Faucon et al. (1998) e Calvo et al. (2010), a descalcificação dos cristais de $C-S-H$ começa a ocorrer quando o ph das soluções nos poros tende a ser menores do que 10,5. E de acordo com os resultados obtidos, 
em todo o período de estudo, o $\mathrm{pH}$ da solução de $\mathrm{MgSO}_{4}$ manteve-se abaixo deste valor, sendo que após 8 semanas a solução passou a ter um caráter ácido, o que favorece ainda mais a dissolução superficial das barras.

A Figura 39 mostra o produto da desagregação da pasta de cimento devido à formação de gel de $M-S-H$, conforme afirmado pelos autores supracitados.

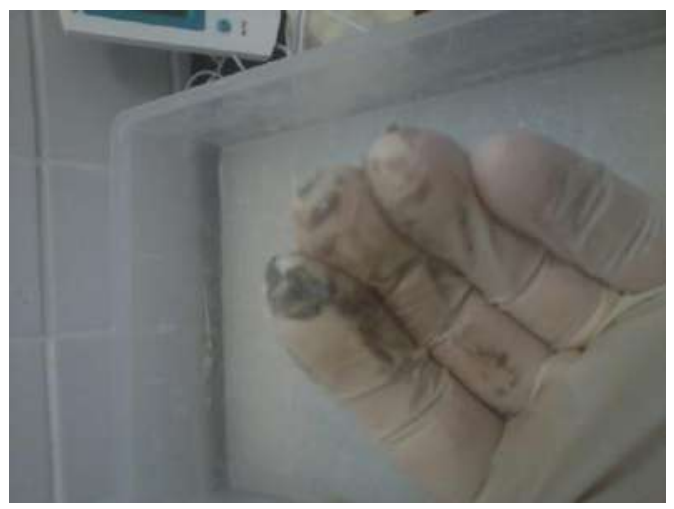

Figura 39: Desagregação da pasta de cimento Portland devido ao ataque por sulfato de magnésio.

A explicação para este fenômeno da diferença tão significativa de pH está relacionada, diretamente, com a solubilidade dos reagentes em água, conforme pode ser visto com as reações mostradas na Eq. 29. Assim como, na reação do sulfato de magnésio com o $C-S-$ $H$ decorrendo em formação de $M-S-H$ e sulfato de cálcio (Eq. 30), de solubilidade menor que o $\mathrm{MgSO}_{4}$, conforme visto no item 2.3.3 podendo haver precipitação deste material.

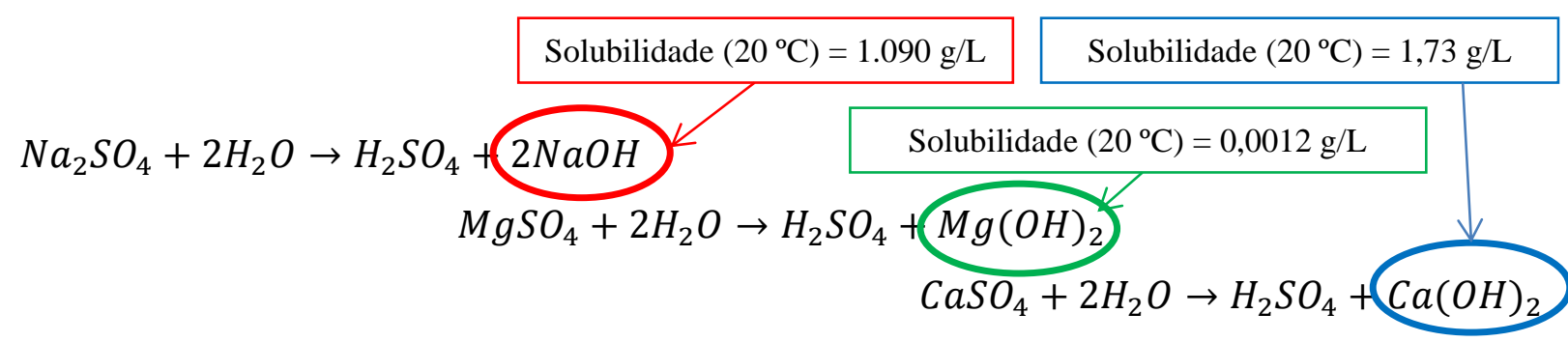

Eq. 29

$$
3 \mathrm{Mg}^{2+}+3 \mathrm{SO}_{4}^{2-}+3 \mathrm{CaO} \cdot 2 \mathrm{SiO}_{2} \cdot 2 \mathrm{H}_{2} \mathrm{O}+\mathrm{aq} . \rightarrow 3 \mathrm{MgO} \cdot 2 \mathrm{SiO}_{2} \cdot 2 \mathrm{H}_{2} \mathrm{O}+3 \mathrm{CaSO}_{4}+\mathrm{aq} .
$$

Eq. 30

A grande formação de gel na superfície das amostras também está vinculada com a solubilidade do $\mathrm{Mg}(\mathrm{OH})_{2}$, este por possuir um valor significativamente inferior aos demais reagentes tende a ter uma precipitação muito mais acentuada. 
Assim, com a elevada solubilidade do sulfato de magnésio, há o consumo de mais $\mathrm{Ca}(\mathrm{OH})_{2}$, precipitando mais brucita, e, resultando em formação de sulfato de cálcio (Eq. 31). Este último pode contribuir na formação de mais gipsita e etringita para o sistema, ou simplesmente, precipitar devido sua baixa solubilidade em relação ao sulfato de magnésio, como ocorreu em outros trabalhos (GANJIAN E POUYA, 2005; BARY et al., 2014; MAKHLOUFI et al., 2016). Por outro lado, o hidróxido de cálcio e o sulfato de sódio, por possuírem uma solubilidade maior, quando comparado com o hidróxido de magnésio, liberam mais $\mathrm{OH}^{-}$para o sistema, contribuindo para o $\mathrm{pH}$ de caráter básico.

$$
\begin{aligned}
\mathrm{MgSO}_{4}+2 \mathrm{H}_{2} \mathrm{O} \rightarrow \mathrm{H}_{2} \mathrm{SO}_{4}+\mathrm{Mg}(\mathrm{OH})_{2} \\
\mathrm{H}_{2} \mathrm{SO}_{4}+\mathrm{Mg}(\mathrm{OH})_{2}+\mathrm{Ca}(\mathrm{OH})_{2} \rightarrow \mathrm{CaSO}_{4}+\mathrm{Mg}(\mathrm{OH})_{2}+2 \mathrm{H}_{2} \mathrm{O}
\end{aligned}
$$

Eq. 31

A seguir, com a Figura 40 podem ser vistas as evoluções das expansões resultantes das séries estudadas para ambas as soluções de exposição ao longo de 20 semanas.

Solução de $\mathrm{Na}_{2} \mathrm{SO}_{4}$

Solução de $\mathrm{MgSO}_{4}$

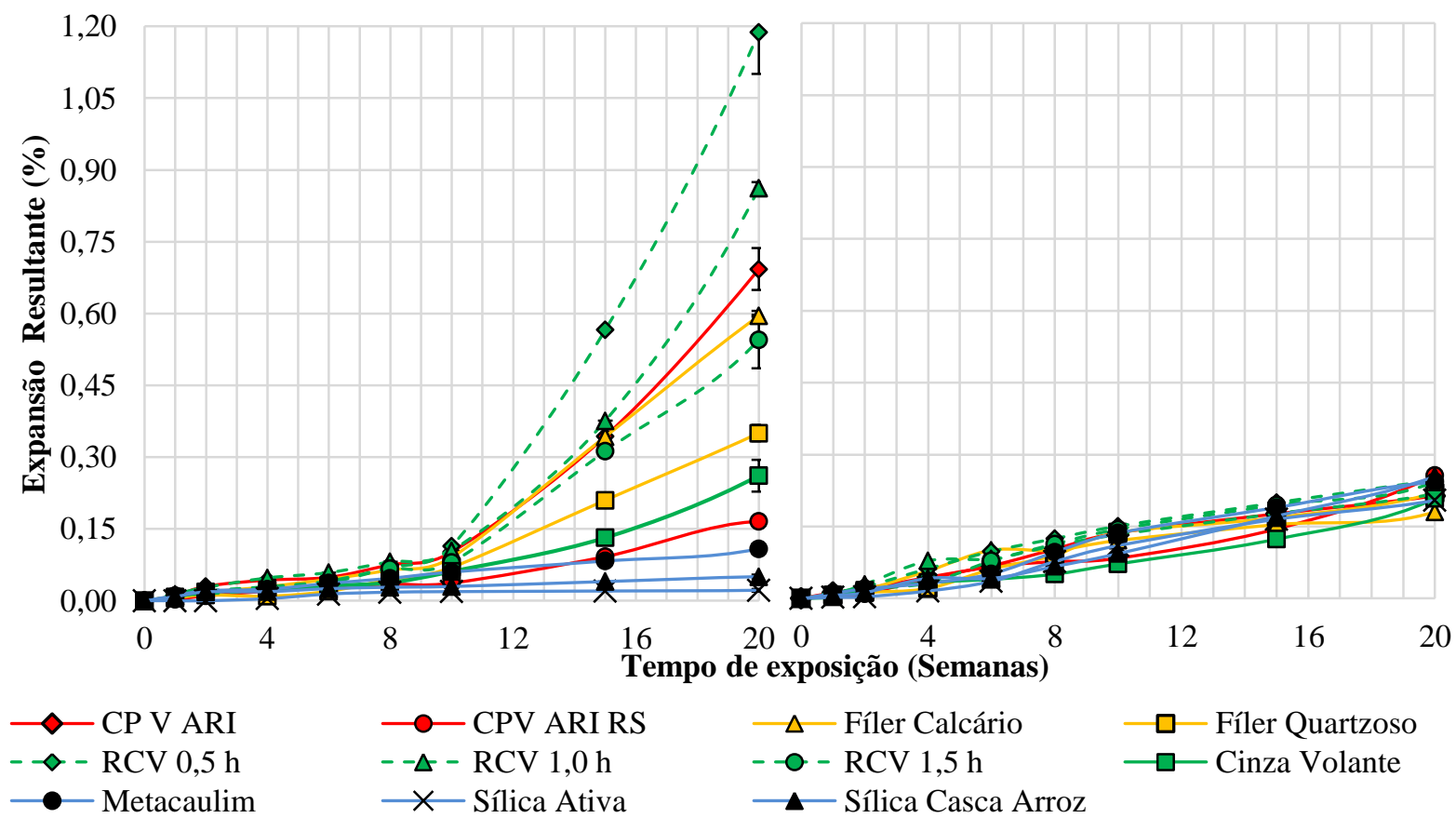

Figura 40: Expansão resultante das séries expostas por um período de 20 semanas nas soluções de sulfato de sódio e sulfato de magnésio.

Na sequência, serão discutidos, em formato de grupos, os resultados das séries estudadas. Cabe comentar que os testes de comparação mútua das médias, são mostrados nas Tabela 27 e Tabela 28 no Apêndice 1 do presente trabalho. 
- Séries referências (CPV-ARI e RS): na comparação entre ambas as séries, observase que a CP V - ARI apresentou expansão 4,18 vezes superior à RS para exposição ao $\mathrm{Na}_{2} \mathrm{SO}_{4}$ por 20 semanas. A explicação para este comportamento tange as constatações do trabalho de Tikalsky et al. (2002), que afirmam que a diminuição da relação $C_{3} A / C_{4} A F$ retarda o processo de expansão, tendo em vista que a produção de etringita a partir do $C_{4} A F$ ocorre em períodos de tempo muito superiores ao do $C_{3} A$. Desse modo, os resultados obtidos norteiam tais afirmações, pois esta relação passa de 1,04 (CP V - ARI) para 0,64 (CP V - ARI RS), e, de fato, a expansão foi inferior de um cimento para o outro. Contudo, a variação da solução agressiva não caminha tão intimamente com as alterações desta relação, pois este comportamento não se repetiu para o caso de exposição ao sulfato de magnésio.

Sobre este tema, também se deve considerar os teores de $\mathrm{CH}$ calculados para a hidratação dos cimentos estudados. Neste caso, o que se vê é que o teor de portlandita para o CP V - ARI foi de 32,25\%, enquanto que para o RS foi de 13,39\%. Esta grande diferença influi diretamente no ataque por sulfato de sódio, principalmente porque torna o CP V - ARI mais vulnerável à formação de gipsita.

- Séries com adições Inertes ( $F C$ e $F Q$ ): As séries compostas com a adição de fíler, seja calcário, seja quartzoso, de modo geral, mitigaram o efeito do ataque por sulfato de sódio, em menor ou maior escala. Frente à solução de $\mathrm{MgSO}_{4}$, em ambos os casos, os resultados obtidos indicaram equivalência estatística, segundo o teste de Tukey, com ambas às referências. Enquanto que para a solução de sulfato de sódio, o impacto das adições foi mais significativo, de modo que o FQ apresentou um bom desempenho frente à solução agressiva, semelhante à série composta por cinza volante. Por outro lado, a série FC, mesmo tendo apresentado um valor inferior à referência, possui equivalência estatística com o CP V - ARI. Porém, tais semelhanças são analisadas de forma positiva, haja vista que a adição não prejudicou o desempenho em nenhuma das soluções, assim, acentua a importância econômica, social e ambiental de se usar tais adições, pois contribuem nestes sentidos;

- Séries com adições de pozolanas de baixa reatividade (RCV e CV): Os resultados obtidos com a cinza volante se equivaleram aos das séries ARI RS e FQ, nas duas soluções agressivas. Paralelamente, na caracterização física, o material apresentou finura muito semelhante de ambos os materiais, e também, do cimento utilizado para composição da série. Juntamente a esta característica, a $\mathrm{CV}$ apresentou pouca 
reatividade com $\mathrm{Ca}(\mathrm{OH})_{2}$. Equivalentemente, pesquisas como as de Chindaprasirt et al. (2007), Sumer (2012) e Kandasamy e Shehata (2014) também apresentaram resultados próximos aos obtidos, mesmo que com pequenas variações experimentais.

Frente ao ataque por sulfato de magnésio, as composições de RCV mostraram-se semelhantes, portanto, neste caso, o tempo de moagem não influenciou nos resultados. De maneira antônima, frente à solução de $\mathrm{Na}_{2} \mathrm{SO}_{4}$, a significância da finura da RCV foi expressiva, conforme maior a área B.E.T., melhor foi o resultado obtido quanto à expansão resultante, levando a crer, que um beneficiamento ainda maior das partículas do material, produzirão resultados mais satisfatórios. Contudo, tempos de moagem de $0,5 \mathrm{~h}$ e $1,0 \mathrm{~h}$, resultaram em um efeito de majoração da degradação destoando dos resultados de análise química e física efetuados. Isto porque, ambas as séries apresentaram reação com $\mathrm{Ca}(\mathrm{OH})_{2}$ maiores que a $\mathrm{CV}$ e B.E.T. muito próxima a da SCA. Desta maneira, uma explicação plausível para este acontecimento é que, a adição de RCV, acarreta em um aumento da absorção capilar e do índice de vazios no sistema. Isso se deve ao fato de a morfologia da partícula argilosa ser mais porosa e propiciar uma expansão derivada de sua própria absorção capilar, levando a uma somatória de resultantes que acarretam em um desempenho insatisfatório. Tais afirmações têm como embasamento os resultados obtidos por Vieira (2005). A Figura 41 mostra uma comparação da expansão e da degradação ocasionada pelo ataque por sulfato de sódio e da solução de hidróxido de cálcio para a série RCV 1,0h.

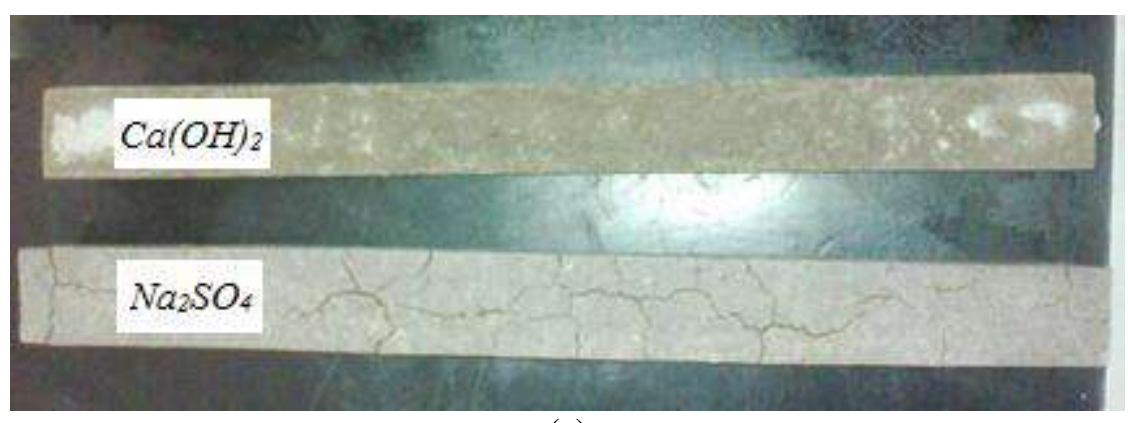

(a)

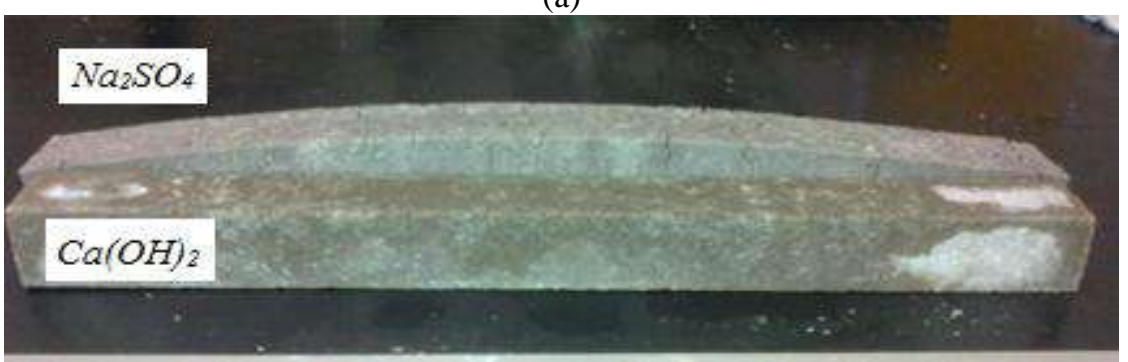

(b)

Figura 41: Comparação da expansão ocasionada pelo ataque por sulfato de sódio e da solução de hidróxido de cálcio para a série RCV 1,0 h. (a) fissuração mapeada apresentada e (b) empenamento. 
Em contrapartida, para 20 semanas de exposição, a série RCV 1,5 h mostrou uma capacidade mitigadora frente ao ataque por $\mathrm{Na}_{2} \mathrm{SO}_{4}$, isto porque, conforme supracitado, a série apresentou maior finura e maior reatividade quando comparada as outras duas séries de RCV. Entretanto, de modo a suprimir dúvidas quanto à capacidade mitigadora da RCV 1,5 h para maiores tempos de exposição, a Figura 42 apresenta resultados de expansão ao sulfato de sódio para as séries de RCV e de referência para um período de exposição de 210 dias.

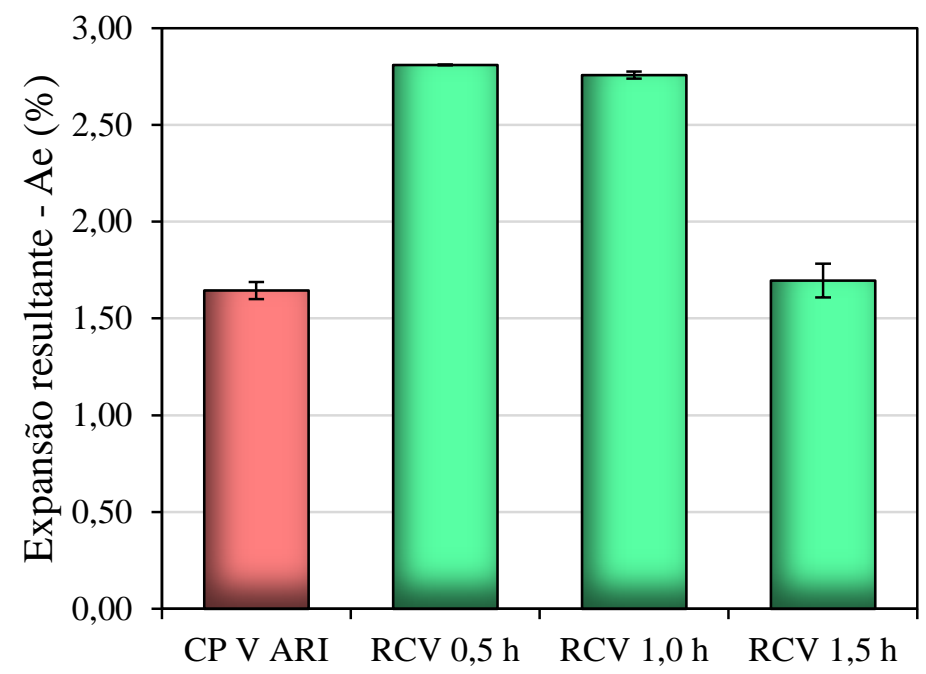

Figura 42: Expansão resultante das séries CP V - ARI e RCV expostas ao sulfato de sódio por um período de 210 dias (30 semanas).

Observa-se que a tendência da RCV é apresentar expansibilidade igual ou superior à referência. Fato interessante de se observar é que para 30 semanas de exposição às séries de RCV 0,5 h e RCV 1,0 h apresentaram resultados semelhantes, levando a acreditar que a barra com material de menor B.E.T. (RCV 0,5 h) chegou a um limite de expansão, permitindo a aproximação da série RCV 1,0 h. Neste mesmo norte, foi observado, aos 210 dias que ambas as amostras apresentavam-se friáveis, o que dificultou as leituras, logo, acredita-se que ambas estavam, de fato, em um limite de expansão. Com esta tendência, pressupõe-se que a RCV 1,5 h superará a referência e também se tornará prejudicial frente aos sulfatos, para maiores idades.

- Séries com adições de pozolanas de elevada reatividade (MT, SA e SCA): As pozolanas de alta reatividade apresentaram, de modo geral, resistência à expansão linear devido ao ataque por sulfatos, sendo consideradas semelhantes estatisticamente. Para tanto, avalia-se que características morfológicas como a finura das partículas, 
além, claro, de sua estrutura amorfa, contribuíram para o bom desempenho, favorecendo o empacotamento de partículas e o consumo de mais portlandita, o que favorece a formação de novos cristais de $C-S$ - $H$, além de deixar disponível menos $\mathrm{Ca}(\mathrm{OH})_{2}$ para interações com os íons de sulfato. Todavia, deve-se comentar, que dentre as três séries, somente a MT apresentou pequenas fissuras quando expostas ao $\mathrm{Na}_{2} \mathrm{SO}_{4}$ (Figura 43), as demais, permaneceram íntegras por toda a extensão do ensaio.

Figura 43: Fissuração apresentada pela série MT frente ao ataque por sulfato de sódio por um período de exposição de 20 semanas.

Por outro lado, as três séries, mesmo apresentando baixa expansão, quando expostas ao sulfato de magnésio exibiram um significativo desgaste superficial, conforme Figura 44. Isto ocorre, concordantemente devido à baixa no $p H$ da solução e descalcificação dos cristais de $C-S$ - $H$ já explanados anteriormente.

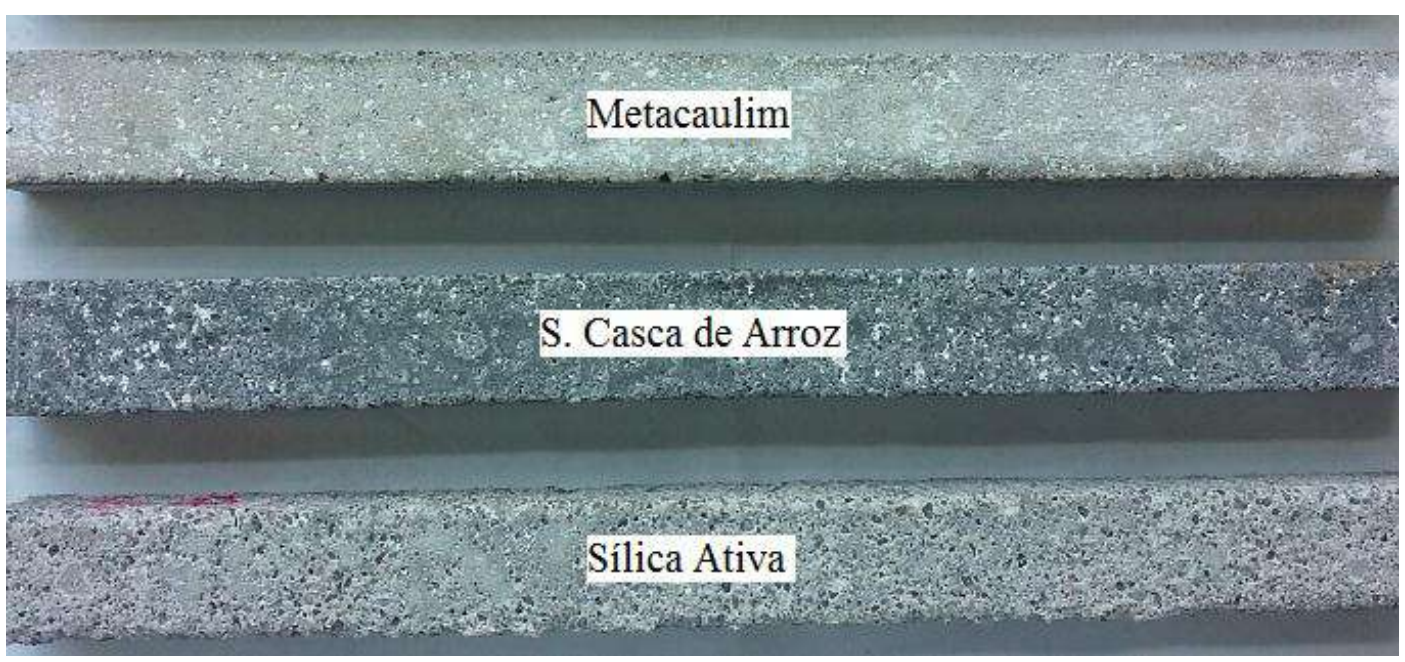

Figura 44: Comparação entre os desgastes superficiais das séries MT, SCA e SA. 


\subsection{ANÁLISE QUÍMICO-MINERALÓGICA DAS COMPOSIÇÕES ESTUDADAS}

Através da análise qualitativa da difração de raios-X foram identificados os minerais e compostos cristalinos presentes nas amostras. Os difratogramas obtidos para tempos de exposição de 0 e 140 dias podem ser vistos no Apêndice I, item 6.6, apresentados ao final do presente trabalho. Juntamente, neste mesmo item, é apresentada a Tabela 51 com o detalhamento (nome do mineral, abreviação e código da ficha de identificação) dos minerais observados nos difratogramas. Desta forma, a discussão de tais resultados será apresentada a seguir.

Segundo autores como Bonen (1992), Skalny et al. (2002), Santhanam et al. (2003), Lee et al. (2005), Diab et al. (2012) e Makhloufi et al. (2016), amostras compostas por cimento Portland e expostas à solução de sulfato de magnésio, tendem a formar, em primeira instância e nas superfícies das amostras, gipsita e brucita. De fato, notou-se ao longo dos testes realizados, a formação de um gel gelatinoso superficial nas amostras, essencialmente, em séries com elevado teor de hidróxido de cálcio.

Desta forma, o material superficial retirado fora levado para análise por difração de raios-X para que então se pudessem tirar conclusões a respeito do gel acumulado na superfície das amostras, contudo, antes da análise o gel gelatinoso passou por um processo de secagem em estufa a $40{ }^{\circ} \mathrm{C}$ por 24 horas, semelhante ao utilizado para amostras de argamassa. Assim, a Figura 45 mostra o difratograma de amostras do gel acumulado na superfície dos corpos de prova expostos à solução de sulfato de magnésio para 42 dias de exposição.

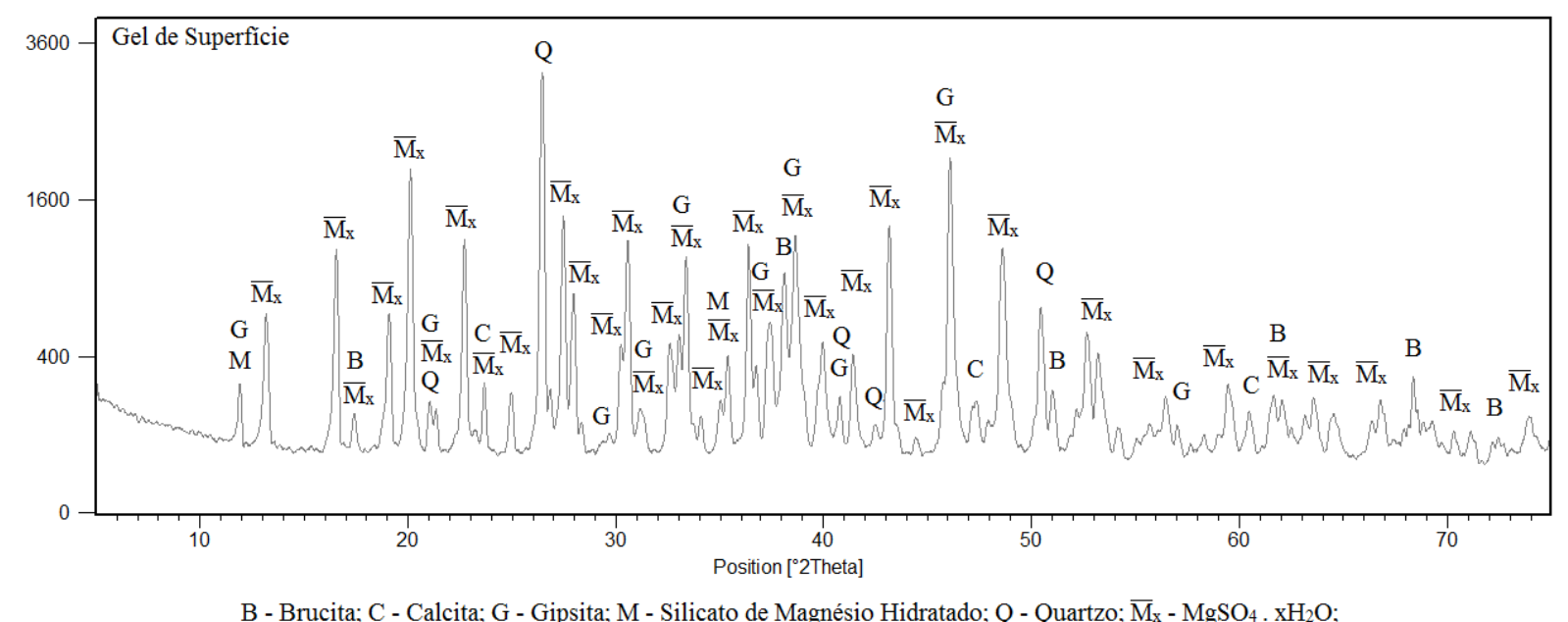

Figura 45: Difratograma de amostra do gel acumulado na superfície dos corpos de prova da série de referência CP V - ARI expostos à solução de sulfato de magnésio, para 42 dias de exposição. 
Portanto, se vê que além da formação de gipsita (G) e brucita (B), conforme indicado na literatura (SKALNY et al., 2002; SANTHANAM et al., 2003; LEE et al., 2005; MEHTA E MONTEIRO, 2014) houve também a identificação de quartzo, calcita e minerais oriundos da hidratação do sulfato de magnésio $\left(\mathrm{MgSO}_{4} \cdot x \mathrm{H}_{2} \mathrm{O}\right)$. De acordo com Bonen (1992), a partir da superfície da amostra, o que se vê é, em um primeiro plano, que há a formação de uma camada decorrente da reação dos íons de sulfato com a portlandita, formando gipsita, posteriormente há a formação de uma segunda camada superior de brucita, devido à interação dos íons magnésio com a portlandita, por fim, há a formação de mais duas camadas decorrentes da incorporação e hidratação do sulfato de magnésio (Figura 46).

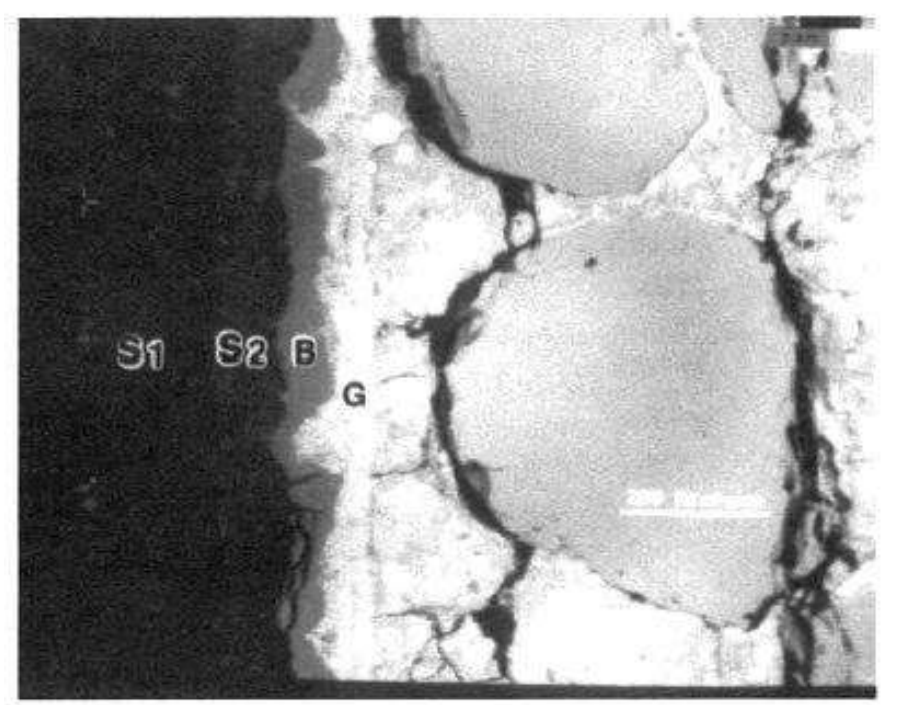

Figura 46: Micrografia eletrônica da deposição de camadas formadas a partir da reação de amostras de cimento Portland com solução de sulfato de magnésio (S1 e S2 - $\mathrm{MgSO}_{4} \cdot \mathrm{H}_{2} \mathrm{O}$; B - Brucita; e, G - Gipsita). Fonte: Bonen (1992).

Segundo Bonen (1992), com base no nível de tons de cinza, a camada mais externa (S1) aparenta conter uma maior quantidade de água em sua composição do que a camada mais interna S2. De acordo com o autor, as proporções molares do $M g$ e o $S$ nestas camadas são maiores do que 1 e aumentam, progressivamente, no sentido da camada de brucita. Isto sugere um aumento na concentração de magnésio e de, segundo o autor, uma crescente quantidade de brucita incorporada no interior das camadas de sulfato de magnésio, em virtude disso, a quantidade total de brucita que fora depositada na superfície da amostra é consideravelmente maior do que a camada de brucita indicada. Tais afirmações corroboram as observações feitas nas amostras, como por exemplo, de que composições que possuem um teor mais elevado de portlandita apresentaram uma maior formação de gel na superfície, haja vista que assim há a 
possibilidade de uma maior formação de gipsita, brucita e decorrente incorporação de camadas de sulfato de magnésio hidratado.

De maneira geral, as amostras estudadas apresentaram comportamentos semelhantes no que diz respeito à comparação entre soluções de exposição para uma mesma série. Ou seja, pode ser visto, por exemplo, que a contagem de etringita, de pico de $100 \%$ de intensidade em $9,14^{\circ} 2 \theta$, aumenta para exposição em soluções de sulfato, quando comparadas à exposição à solução de hidróxido de cálcio (Figura 47). Nada obstante, observou-se que para exposição às soluções agressivas também houve um aumento no consumo de portlandita (diminuição do pico referente ao mineral, $34,19^{\circ} 2 \theta$ ), influenciando, deste modo, em maior formação de produtos expansivos, como etringita, gipsita e brucita.

Neste mesmo norte, outro comportamento apresentado pelas séries foi a diminuição do

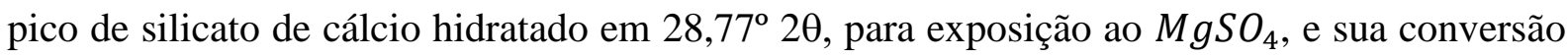
para silicato de magnésio hidratado, visto em 33,73 20, indicando a inversão catiônica dos cristais de $C-S-H$ entre o cálcio e o magnésio, conforme explorado e discutido no capítulo 2.3.3 e equações Eq. 10 e Eq. 11. De modo a servir de representação às afirmações supracitada, a Figura 47 mostra os picos dos minerais de calcita, etringita, gipsita, $C-S-H$, $M-S-H$ obtidos com os difratogramas da série FQ. Salienta-se, que o mesmo pode ser observado para as demais séries nos difratogramas apresentados no Apêndice I do presente trabalho.

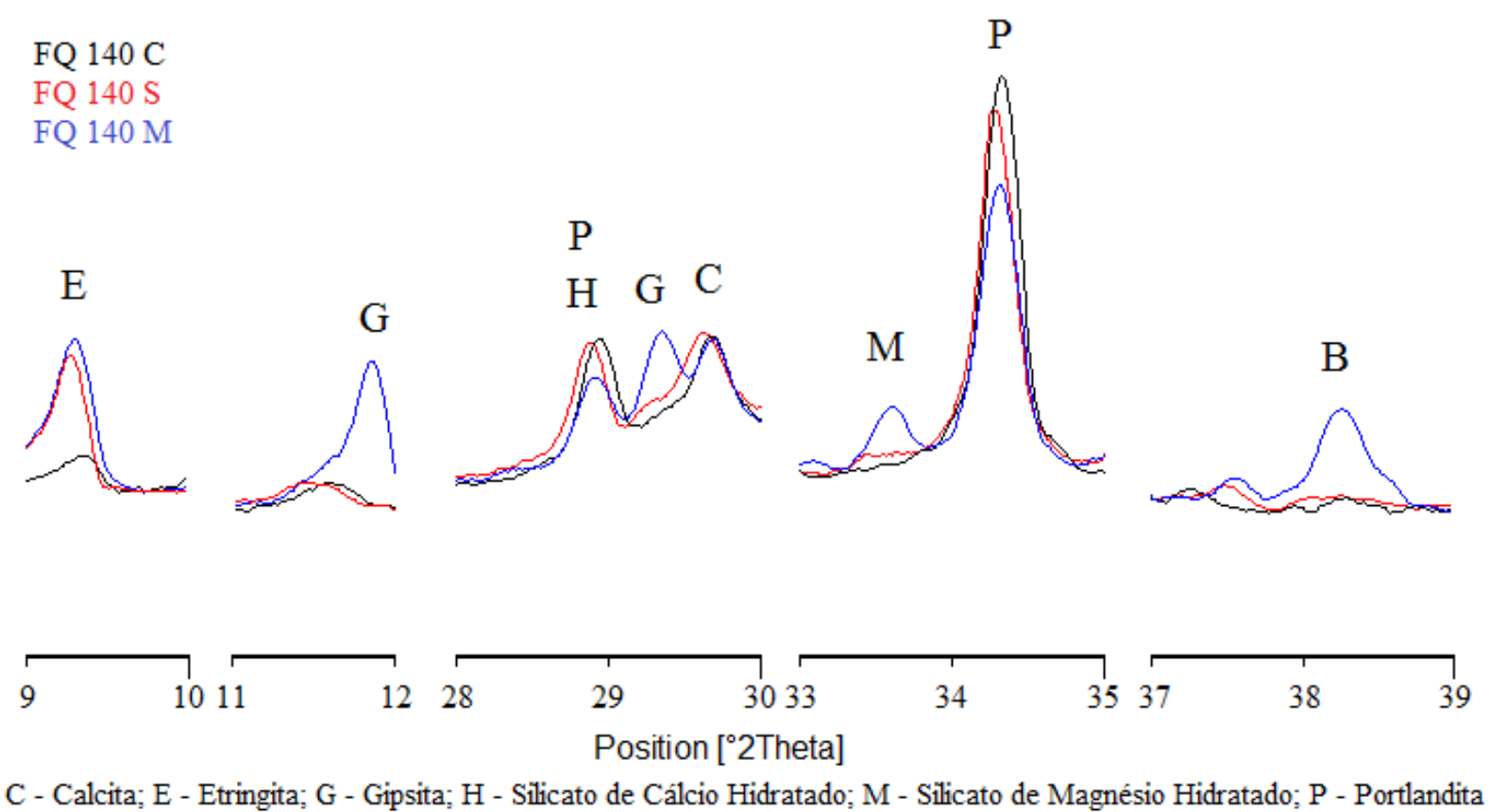

Figura 47: Representação dos picos de brucita, calcita, etringita, gipsita, C-S-H, M-S-H e portlandita para série FQ em exposição de 140 dias às soluções de $\mathrm{C}-\mathrm{Ca}(\mathrm{OH})_{2} ; \mathrm{S}-\mathrm{Na}_{2} \mathrm{SO}_{4} ; \mathrm{e}, \mathrm{M}-\mathrm{MgSO}_{4}$. 
Na sequência, serão discutidos, de forma comparativa e em formato de grupos, os resultados das séries estudadas. Os grupos serão divididos em: séries referências, CP V - ARI e CP V - ARI RS; séries com adição de material inerte (fíler calcário e fíler quartzoso); séries com adições de pozolanas de baixa reatividade (resíduo de cerâmica vermelha e cinza volante); e, por fim, séries com adições de super pozolanas (metacaulim, sílica ativa e sílica de casca de arroz).

- Séries referências (CP V-ARI e RS): na comparação entre difratogramas das séries de referência (Figura 48) observa-se que pastas compostas por cimento CP V - ARI apresentaram uma maior intensidade no pico de $10,20^{\circ} 2 \theta$, no qual se refere a minerais de AFm, para amostras em condições de cura de solução de hidróxido de cálcio. Por outro lado, se vê para esta mesma condição de cura, a presença de picos devido à formação de etringita, logo, indicando que não houve conversão total da AFt para AFm, corroborando as afirmações descritas na análise química teórica dos cimentos estudados (item 4.2). Ao mesmo tempo, pode-se observar um comportamento semelhante em pastas de cimento CP V - ARI RS.

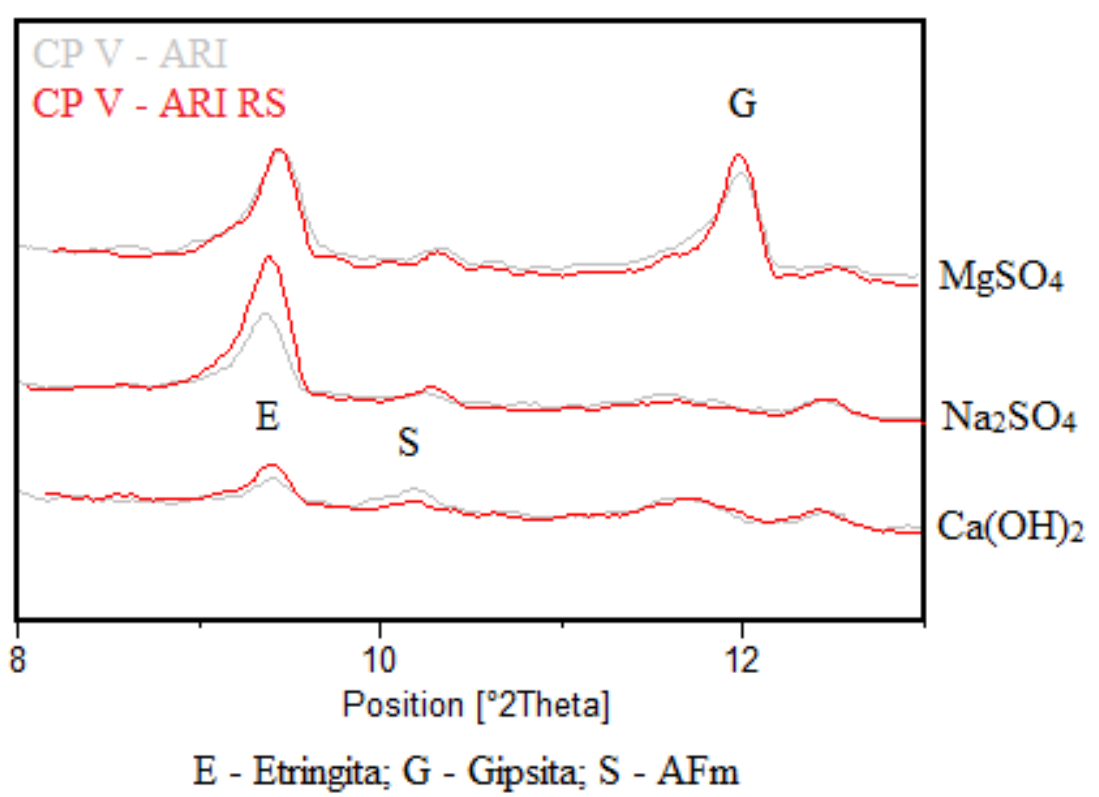

Figura 48: Difratograma das séries de referência (CP V - ARI e CP V - ARI RS) para exposição por 140 dias nas três soluções de cura final, nas posições de $2 \theta$ variando de $8^{\circ}$ a $13^{\circ}$.

Para exposição às soluções agressivas (sulfato de sódio e de magnésio) observa-se com a Figura 48, que as amostras compostas por cimento resistente aos sulfatos apresentaram uma contagem nos picos de etringita superiores às observadas para o 
cimento $\mathrm{CP} V$ - ARI. Indicando que a série $\mathrm{CP}$ V - ARI RS foi mais vulnerável à formação de agentes degradantes.

$\mathrm{Na}$ interação das amostras com o sulfato de magnésio observa-se a contagem de gipsita na posição próxima a $12,00^{\circ} 2 \theta$ pouco maior para a série CP V - ARI RS. A formação deste mineral, segundo Lee et al. (2005), está associada, entre outros fatores, a desestabilização da etringita secundária devido à baixa do $p H$ das soluções nos poros das amostras. Quando analisadas as contagens dos picos de etringita, observa-se que para exposição ao $\mathrm{MgSO}_{4}$ a produção deste mineral foi inferior à exposição ao $\mathrm{Na}_{2} \mathrm{SO}_{4}$, indicando que houve desestabilização deste mineral e decorrente maior produção de gipsita. Cabe comentar que no item 4.3 da presente pesquisa são apresentadas as aferições de $p H$ realizadas nas soluções de exposição, nas quais indicam que de fato as soluções de sulfato de magnésio apresentaram $p H$ próximo a 7 , o que auxilia as afirmações comentadas.

A seguir, a Figura 49 mostra os difratogramas das séries de referência (CP V - ARI e CP V - ARI RS) para exposição por 140 dias nas três soluções de cura final, nas posições de $2 \theta$ variando de $30^{\circ}$ a $35^{\circ}$.

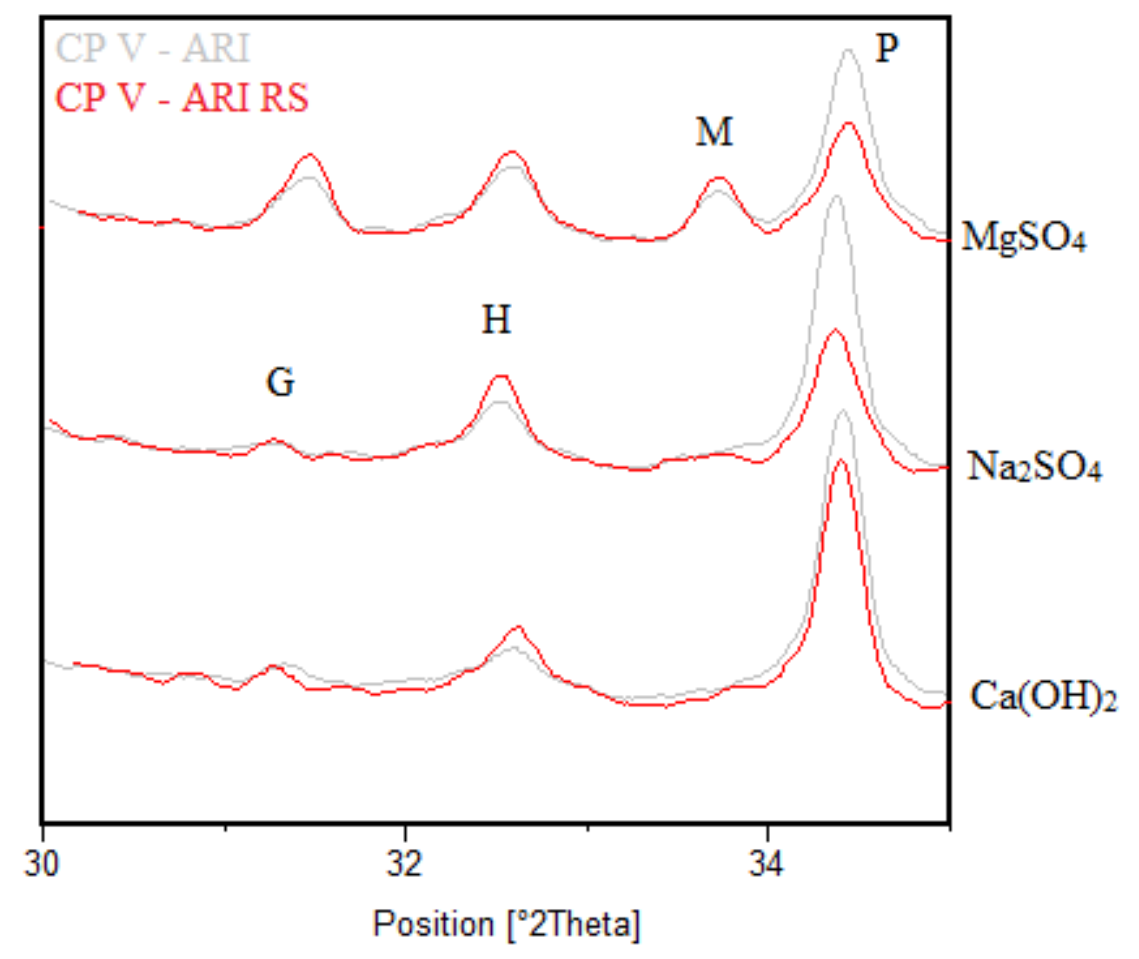

G - Gipsita; H - (C-S-H); M - (M-S-H); P - Portlandita

Figura 49: Difratograma das séries de referência (CP V - ARI e CP V - ARI RS) para exposição por 140 dias nas três soluções de cura final, nas posições de $2 \theta$ variando de $30^{\circ}$ a $35^{\circ}$. 
Logo, pode-se observar com o pico de $100 \%$ de intensidade da portlandita $\left(34,19^{\circ} 2 \theta\right)$, que a séries CP V - ARI RS, assim como previsto na análise química teórica, teve uma produção inferior deste mineral quando comparada ao cimento CP V - ARI, para cura em solução de hidróxido de cálcio, e isto se deve, entre outros fatores, à baixa proporção $C_{3} S / C_{2} S$ apresentada pelo cimento do tipo RS. Deste modo, indicando que esta baixa na produção de portlandita pode deixar esta série menos vulnerável ao ataque por sulfatos, porém, como visto na Figura 48, esta série obteve produção de agentes degradantes superiores a do CP V - ARI. Logo, levando a crer que, na realidade, a série $\mathrm{CP}$ V - ARI RS é menos resistente ao ataque por sulfatos.

Comenta-se também, que minerais de $C-S-H$ e $M-S-H$ são de difícil observação com a difratometria de raios-X em virtude de suas estruturas cristalinas inconstantes, o que dificulta a contagem do material pela difração.

- Série com adições Inertes (FC e $F Q)$ : as séries contento fíleres tiveram comportamentos que muito se assemelham com a referência CP V - ARI. Observa-se na Figura 50, para cura em solução de hidróxido de cálcio, que as três séries apresentaram picos referentes à formação de AFm e com teores remanescentes de AFt, convergindo para os valores obtidos na análise química teórica. Contudo, se vê para exposição à solução de sulfato de sódio que as séries obtiveram um comportamento muito próximo, produzindo quantidades de etringita bem próximas.

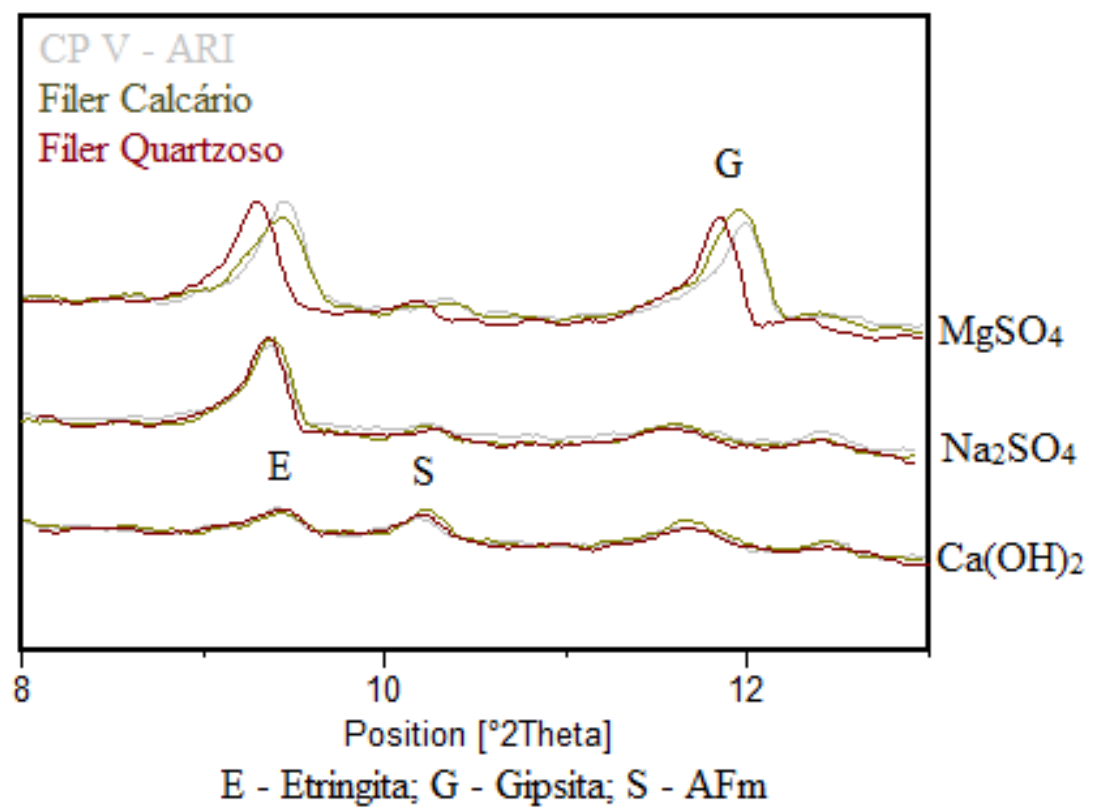

Figura 50: Difratograma das séries de adições inertes (Fíler calcário e Fíler Quartzoso) para exposição por 140 dias nas três soluções de cura final, nas posições de $2 \theta$ variando de $8^{\circ}$ a $13^{\circ}$ e em comparação à série de referência CP V - ARI. 
Entretanto, observa-se que há uma ligeira diminuição do pico de etringita para exposição à solução de sulfato de magnésio em comparação à solução de sulfato de sódio. Isto se dá devido à instabilidade da AFt para $p H$ menores que 9 (SKALNY et al., 2002; SANTHANAM et al., 2003), a partir da qual há reconversão da etringita para gipsita, o que justifica a grande diferença dos picos em $12,00^{\circ} 2 \theta$ entre as soluções de sulfato de sódio e magnésio para todas as séries estudadas. Outro ponto que corrobora esta explicação é o maior consumo da reserva alcalina da composição, ou seja, da portlandita (Figura 51) para exposição ao sulfato de magnésio, pois com o consumo deste mineral há uma decorrente diminuição no $p H$ da solução, conforme supracitado. Tais ocorrências convergem às encontradas na literatura como Skalny et al. (2002), Santhanam et al. (2003), Lee et al. (2005), Diab et al. (2012) e Mehta e Monteiro (2014).

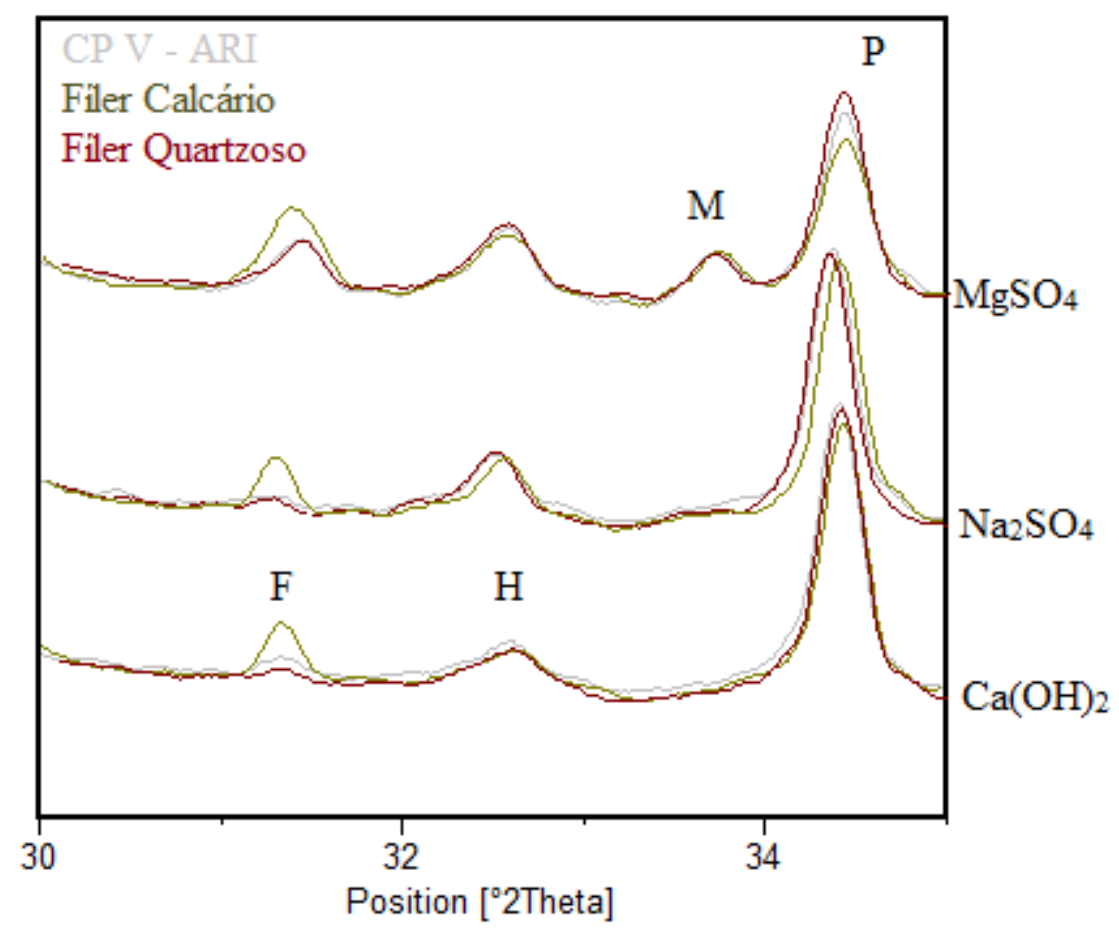

G - Gipsita; H - (C-S-H); M - (M-S-H); P - Portlandita

F - Monocarboaluminato de cálcio hidratado

Figura 51: Difratograma das séries de adições inertes (Fíler calcário e Fíler Quartzoso) para exposição por 140 dias nas três soluções de cura final, nas posições de $2 \theta$ variando de $30^{\circ}$ a $35^{\circ}$ e em comparação à série de referência $\mathrm{CP} \mathrm{V}$ - ARI. 
Com a Figura 51, observa-se que a série FC apresentou uma contagem mais elevada no pico de $31,33^{\circ} 2 \theta$, este pico pode ser associado à presença de outros dois minerais (além da gipsita comentada anteriormente), à calcita e ao monocarboaluminato de cálcio hidratado, o que explicaria esta divergência com as demais séries. Neste mesmo norte, se viu com a Figura 50 que a contagem de etringita para cura em solução hidróxido de cálcio foi menor do que a referência, o que abre a possibilidade de consumo de uma pequena parcela dos aluminatos para formação de monocarboaluminato de cálcio hidratado (KAKALI et al., 2000; MATSCHEI et al., 2007). Outro fator que reforça a produção deste mineral é o consumo de portlandita maior apresentado pela série FC, neste caso, a contagem do pico em 34,44 $2 \theta$ foi inferior ao $\mathrm{CP} \mathrm{V} \mathrm{-} \mathrm{ARI.} \mathrm{Segundo} \mathrm{Hoppe} \mathrm{Filho} \mathrm{(2008)} \mathrm{o} \mathrm{CaCO}_{3}$ reage com o aluminato de cálcio para formar os compostos de carboaluminato de cálcio hidratado de forma análoga à da formação de AFt e AFm.

A série FQ apresentou contagens superiores para os picos referentes à portlandita em comparação as outras duas séries para exposição às soluções agressivas, indicando, neste caso, uma possível aceleração na hidratação das partículas anidras do cimento Portland, haja vista, que as séries com adição de fíleres deveriam apresentar contagens inferiores de portlandita quando comparadas à referência (em caso de 100\% de hidratação para todas as séries). Em virtude da substituição parcial de $10 \%$ cimento utilizado.

- Série com adições de pozolanas de baixa reatividade ( $R C V$ e $C V$ ): conforme visto no item 3.2.2.3 do presente trabalho, ambas as séries, RCV e CV, apresentaram teores de $\mathrm{Al}_{2} \mathrm{O}_{3}$ de $34,10 \%$ e $26,30 \%$ em suas respectivas análises químicas. Deste modo, algumas características singulares destas adições podem ser observadas com a Figura 52, como por exemplo, para exposição à solução de hidróxido de cálcio, observa-se que ambas as séries produziram, consideravelmente, uma maior quantidade de AFm e, ao mesmo tempo, consumiram uma maior quantidade de $\mathrm{AFt}$, quando comparadas à referência. Conforme visto na análise química teórica dos cimentos estudados, o CP V - ARI apresentou, ao final dos cálculos estequiométricos, um teor de 14,68\% de etringita remanescente após hidratação, isto decorre da ausência de cálcio e alumínio para decomposição da etringita primária em monossulfoaluminato de cálcio hidratado. Logo, como ambas as adições possuem reatividade, mesmo que baixa, estas podem ter contribuído com aluminatos para a conversão, quase que total, da etringita. 


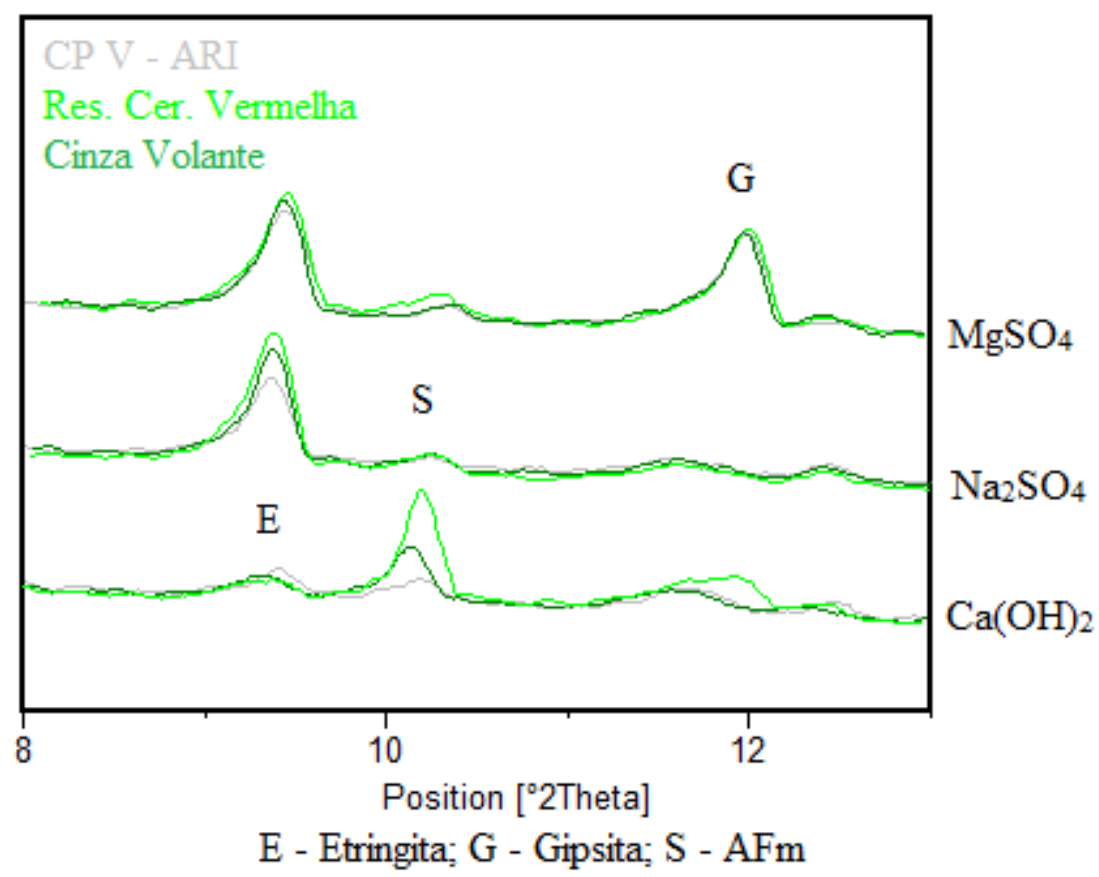

Figura 52: Difratograma das séries de adições de baixa reatividade (resíduo de cerâmica vermelha e cinza volante) para exposição por 140 dias nas três soluções de cura final, nas posições de $2 \theta$ variando de $8^{\circ}$ a $13^{\circ}$ e em comparação à série de referência $\mathrm{CP} V-\mathrm{ARI}$.

Por outro lado, a conversão de uma maior quantidade de AFt em AFm deixa as composições mais vulneráveis a uma formação, em maior quantidade, de etringita secundária. Fato este que pode ser visto nos picos de $100 \%$ de intensidade da etringita em $9,14^{\circ} 2 \theta$ que as séries RCV e CV produziram, devido ao ataque por sulfato de sódio, uma quantidade maior de etringita. Nada obstante, a contribuição de aluminatos reativos em solução com presença de portlandita e íons sulfato podem colaborar, conjuntamente, em uma produção mais acentuada de etringita (LEE et al., 2005). Em virtude disso o uso de adições sílico-aluminosas pode ser prejudicial às argamassas devido à potencialização da formação de etringita secundária.

Conforme avaliado no item 4.1, referente à atividade pozolânica das adições minerais utilizadas, o resíduo de cerâmica vermelha, com 1,0 h de moagem, apresentou reatividade com o hidróxido de cálcio 26,47\% superior à cinza volante. Nada obstante, pode ser visto com a Figura 53 que o consumo de portlandita das adições também foram diferenciados entre si, em ordem de suas pozolanicidades. 


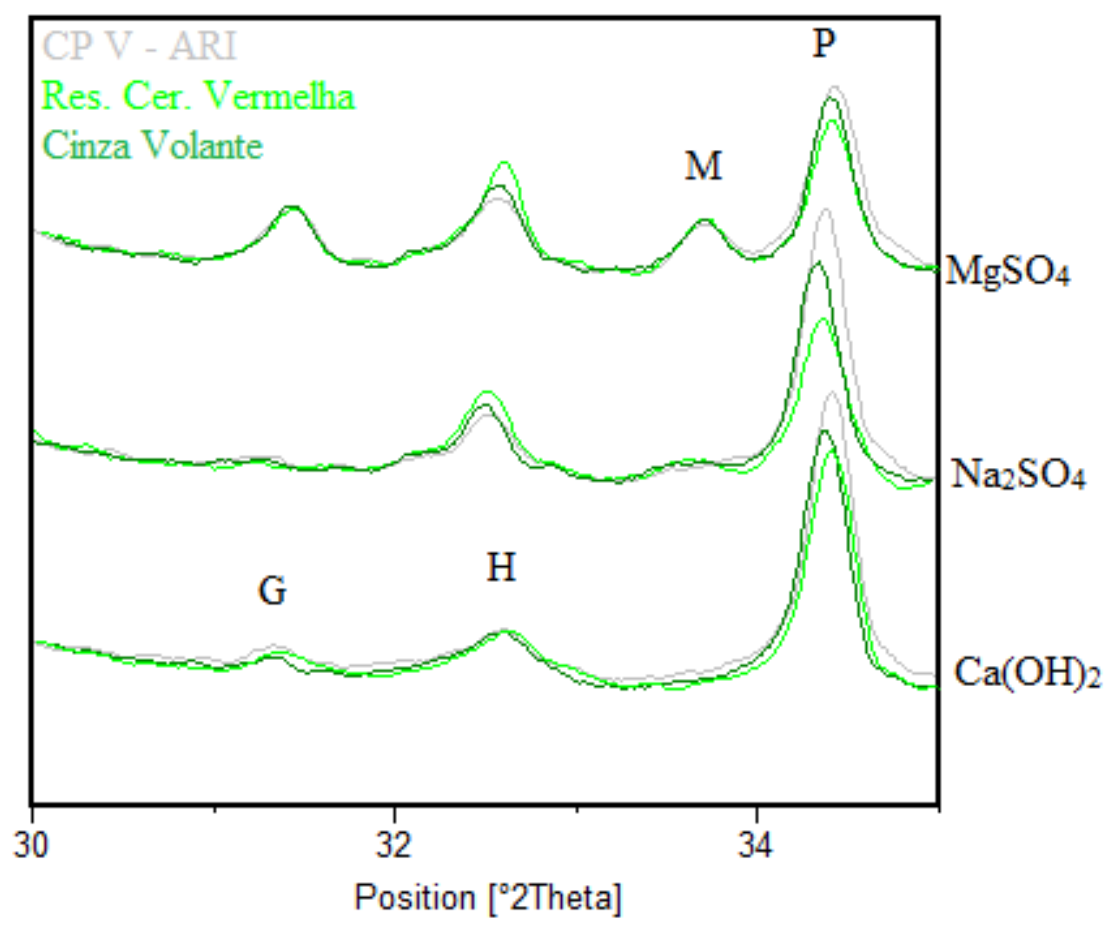

G - Gipsita; H - (C-S-H); M - (M-S-H); P - Portlandita

Figura 53: Difratograma das séries de adições de baixa reatividade (resíduo de cerâmica vermelha e cinza volante) para exposição por 140 dias nas três soluções de cura final, nas posições de $2 \theta$ variando de $30^{\circ}$ a $35^{\circ}$ e em comparação à série de referência CP V - ARI.

Na exposição às soluções agressivas, as séries apresentaram um consumo ainda mais acentuado da portlandita, por exemplo, para a solução de sulfato de sódio, a RCV consumiu maior quantidade para a mesma série frente à exposição ao $\mathrm{Ca}(\mathrm{OH})_{2}$, enquanto que a CV e a referência consumiram, respectivamente. Este consumo mais acentuado das adições está associado diretamente à interação dos íons sulfato na produção de etringita, em que ambas as séries produziram valores maiores do que a referência, conforme comentado anteriormente.

- Séries com adições de pozolanas de elevada reatividade (MT, SA e SCA): as séries tidas como de alta reatividade tiveram comportamentos distintos entre si em virtude de suas composições químicas. A SA e a SCA tangem às características químicas muito próximas, afinal, ambas são adições silicosas e com teores de aluminatos na faixa de $2 \%$. Por outro lado, o metacaulim é constituído de um teor mais elevado de aluminatos com consequente redução do teor de sílica e esta característica mostrou-se de grande influência nos resultados de difratometria de raios-X. Assim como visto nas adições de baixa reatividade, a contribuição de material aluminoso no sistema colaborou na formação de maior quantidade de AFm, etringita primária e secundária e monocarboaluminato de cálcio hidratado, como pode ser visto na Figura 54. 


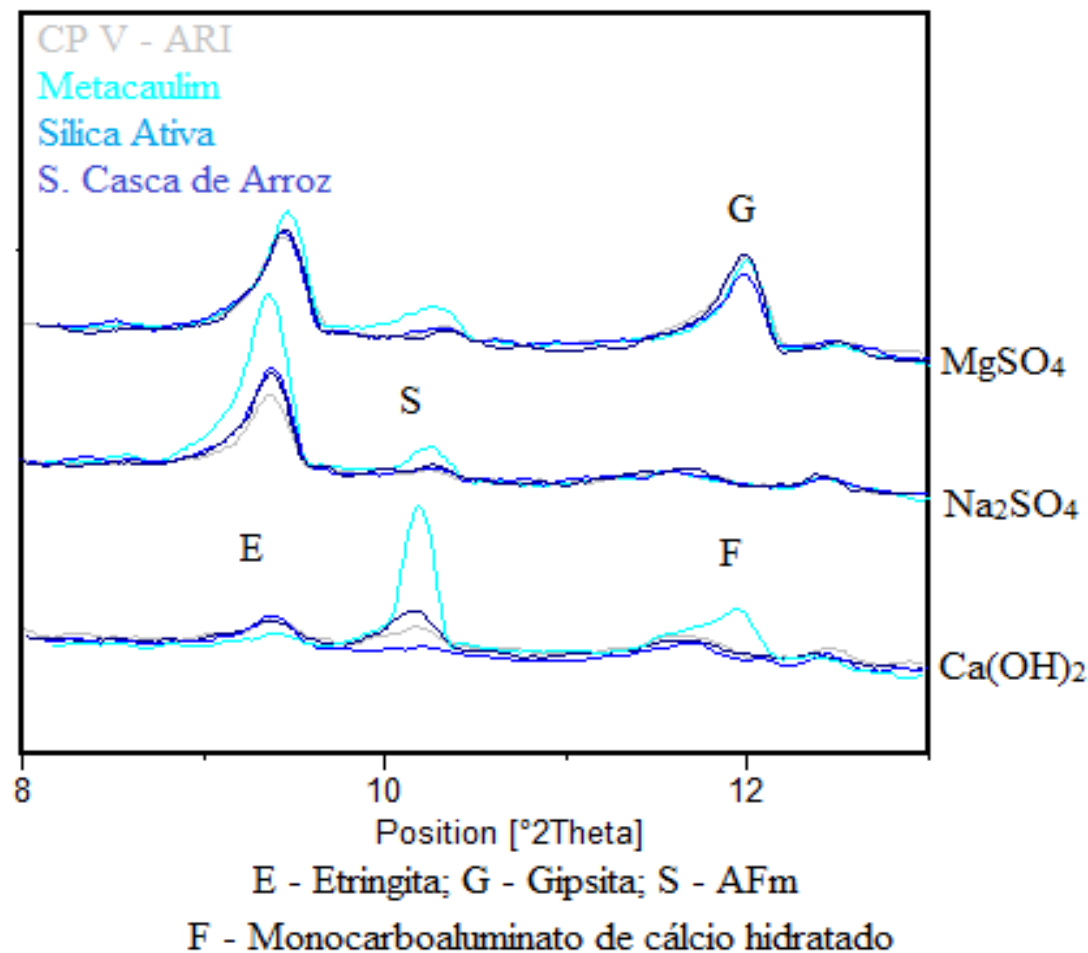

Figura 54: Difratograma das séries de adições de alta reatividade (metacaulim, sílica ativa e sílica de casca de arroz) para exposição por 140 dias nas três soluções de cura final, nas posições de $2 \theta$ variando de $8^{\circ}$ a $13^{\circ}$ e em comparação à série de referência $\mathrm{CP} V-\mathrm{ARI}$.

As séries de SA e SCA, para solução de exposição de hidróxido de cálcio, apresentaram contagem no pico referente à formação de etringita muito próximas, idênticos à referência, indicando a presença da etringita primária remanescente, o que pode indicar um grau de ataque menos intenso.

Por outro lado, a contagem dos picos em \pm 9,30 $2 \theta$, segundo Fryda et al. (1996), podemos ser explicados pela formação do mineral de Chabasita em sua composição calcítica $\left(\mathrm{Ca}\left[\mathrm{Si}_{4} \cdot \mathrm{Al}_{2}\right] \mathrm{O}_{12} \cdot 6 \mathrm{H}_{2} \mathrm{O}\right)$. Segundo os autores, a formação deste mineral se dá pelo elevado teor de sílica reativa no sistema e em conjunto a temperaturas mais elevadas, a partir de $40{ }^{\circ} \mathrm{C}$. A chabasita possui pico de intensidade de $100 \%$ para 9,50 $2 \theta^{1}$, logo, compatível com o observado nas amostras. Outra possível explicação é, segundo Taylor (1997), a presença de tobermorita $\left[\mathrm{Ca}_{5} \cdot \mathrm{Si}_{6} \cdot \mathrm{O}_{16} \cdot(\mathrm{OH})_{2}\right]$, este que é um tipo de estrutura de $C-S-H$, porém com relação $C a / S i$ menor que $1,0, \log$, assim como na chabasita, ocorre devido à presença de um teor mais elevado de sílica reativa. Nada obstante, a tobermorita possui em 9,40 20, pico com intensidade de $15 \%$.

\footnotetext{
${ }^{1}$ Ficha de identificação com numeração 02-0062
} 
Cabe comentar, que este mineral possui pico com $100 \%$ de intensidade para $29,61^{\circ}$ $2 \theta^{2}$, o qual fora identificado nas leituras dos difratogramas.

$\mathrm{Na}$ exposição à solução de sulfato de magnésio, a série SA apresentou contagem semelhante à referência quanto à formação de etringita, e, ao mesmo tempo, um menor grau na formação de gipsita, indicando que o consumo da reserva alcalina na reação pozolânica pode ter colaborado para a menor formação deste mineral. Este consumo pode ser observado em $34,40^{\circ} 2 \theta$ de acordo com a Figura 55. Nada obstante, observase que para a exposição à solução de $\mathrm{Ca}(\mathrm{OH})_{2}$ as séries com adições minerais apresentaram um consumo mais elevado de portlandita, logo, indicando a ocorrência da atividade pozolânica das adições.

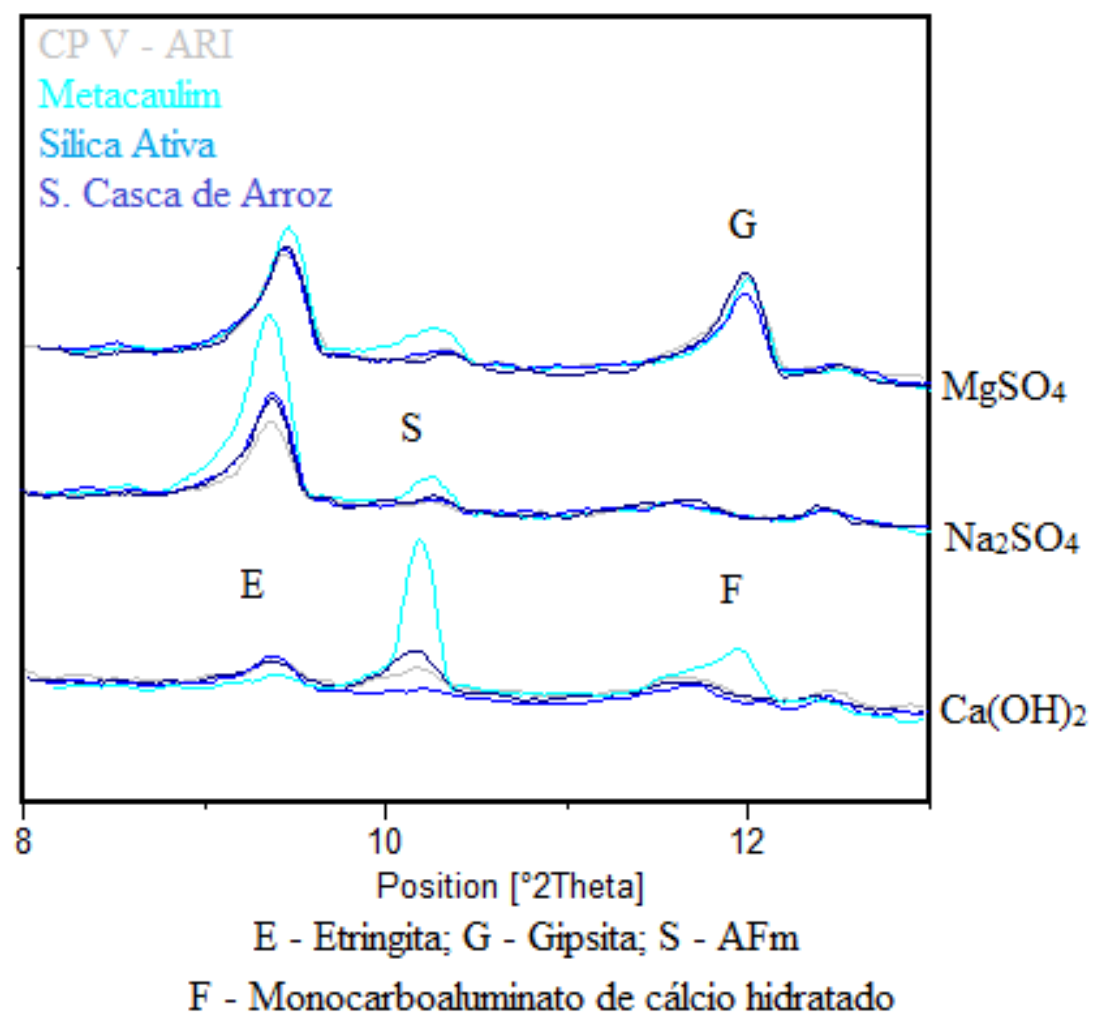

Figura 55: Difratograma das séries de adições de alta reatividade (metacaulim, sílica ativa e sílica de casca de arroz) para exposição por 140 dias nas três soluções de cura final, nas posições de $2 \theta$ variando de $30^{\circ}$ a $35^{\circ}$ e em comparação à série de referência $\mathrm{CP}$ V - ARI.

Para composição com adição de metacaulim e em exposição à solução de sulfato de sódio, o que se vê é uma contagem muito inferior do pico referente à portlandita em comparação as demais séries. Isto pode ser justificado pela maior formação de etringita como apresentada na Figura 54, haja vista que a o hidróxido de cálcio

\footnotetext{
${ }^{2}$ Ficha de identificação de numeração 29-0329
} 
presente nos poros contribui na formação de gipsita e decorrente etringita. Neste mesmo norte, observa-se no pico de 32,50² $2 \theta$ que a séries MT apresentou contagem muito superior às demais, entretanto, neste caso, isto não indica somete uma produção maior de $C-S-H$, pois este pico sobrepõe-se, juntamente, à formação de etringita, concernindo com as afirmações de intensa formação de etringita para a série MT.

Um ponto importante a ser discutido em maiores detalhes, após os resultados da difratometria de raios-X, é a influência das adições sílico-aluminosas na formação de AFm e etringita secundária. Isto porque, o incremento das adições de resíduo de cerâmica vermelha, cinza volante e metacaulim, contribuíram para a conversão de AFt em AFm para exposição em solução de hidróxido de cálcio, em virtude disso, na reconversão do monossulfoaluminato de cálcio hidratado em etringita secundária, devido à exposição às soluções agressivas de sulfato, houve uma formação mais acentuada de etringita. De modo a exemplificar a relação entre o teor de aluminatos no sistema cimento mais adição, elaborou-se a Figura 56 que mostra a correlação entre a contagem dos picos de $100 \%$ de intensidade de etringita $(9,142 \theta)$ devido à exposição à solução de $\mathrm{Na}_{2} \mathrm{SO}_{4}$ e monossulfoaluminato de cálcio hidratado $(9,93$ 20) devido exposição à solução de $\mathrm{Ca}(\mathrm{OH})_{2}$ com o teor de aluminato do sistema composto por $90 \%$ de cimento Portland e $10 \%$ de adições minerais sílico-aluminosas (resíduo de cerâmica vermelha, cinza volante e metacaulim).

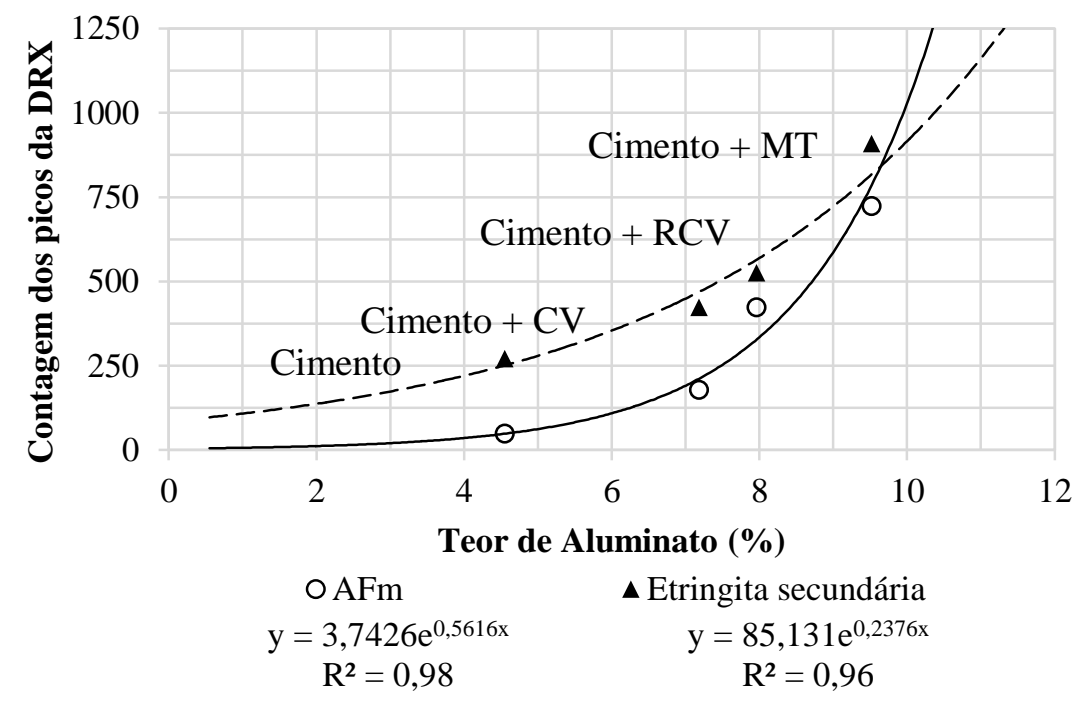

Figura 56: Correlação entre a contagem dos picos de $100 \%$ de intensidade de etringita $(9,142 \theta)$ devido a exposição à solução de $\mathrm{Na}_{2} \mathrm{SO}_{4}$ e monossulfoaluminato de cálcio hidratado $(9,932 \theta)$ devido exposição à solução de $\mathrm{Ca}(\mathrm{OH})_{2}$ com o teor de aluminato do sistema composto por $90 \%$ de cimento Portland e $10 \%$ de adições minerais sílico-aluminosas (resíduo de cerâmica vermelha, cinza volante e metacaulim). 
Isto mostra que a influência da composição química das adições impacta diretamente na formação de etringita quando em reação com íons sulfato. Observa-se com a Figura 56 que na faixa entre 1,0 e 9,0\% do teor de aluminato que a contagem de minerais de etringita secundária para exposição ao sulfato de sódio ficou acentuadamente maior do que a de AFm (para exposição à solução de $\mathrm{Ca}(\mathrm{OH})_{2}$ ), tal relação chega a uma razão de 3,06. O que pode indicar uma reconversão total da AFm para exposição ao sulfato de sódio. Porém, para teores maiores de $\mathrm{Al}_{2} \mathrm{O}_{3}$, acima de $9 \%$, observa-se uma tendência de diminuição desta relação, até então, que a mesma obtenha valores menores do que 1,0. Isto pode ser explicado pela ausência de íons sulfato na reação, indicando que a série MT, com relação etringita/AFm de 1,25 , teria potencial para formação de mais produtos expansíveis.

Em virtude disso o uso de adições sílico-aluminosas pode ser prejudicial às argamassas devido à potencialização da formação de etringita secundária.

\subsection{ANÁLISE POLIDIMENSIONAL}

A seguir são apresentados e discutidos os resultados obtidos a partir dos ensaios realizados de variação volumétrica, variação de massa e variação na propagação de ondas ultrassônicas, realizados nas séries CP V - ARI, CP V - ARI RS, FQ, CV, MT, SA e SCA em amostras com dimensões de $40 \times 40 \times 160 \mathrm{~mm}$. A metodologia de discussão seguirá como a apresentada no item referente à variação dimensional linear, anteriormente discutido. Sendo assim, serão abordadas inicialmente as variações causadas para tempo de exposição de 42 dias (6 semanas), tendo como foco da discussão o período limite de exposição da qual a NBR 13.583:2014 preconiza, independentemente da referida norma não abordar estes tipo de ensaios. Posteriormente, serão abordadas de modo geral, as variações ocorridas nas amostras para 20 semanas de exposição (140 dias) e, por fim, serão discutidos os comportamentos das séries de forma individual, porém subdivididas em 4 grupos (Referência, FQ, CV e adições pozolânicas de elevada reatividade).

Desta forma, a Figura 57 apresenta a variação volumétrica resultante das séries expostas à solução de sulfato de sódio e sulfato de magnésio por um período de 6 semanas (42 dias). A seguir é feita a discussão dos resultados obtidos. 

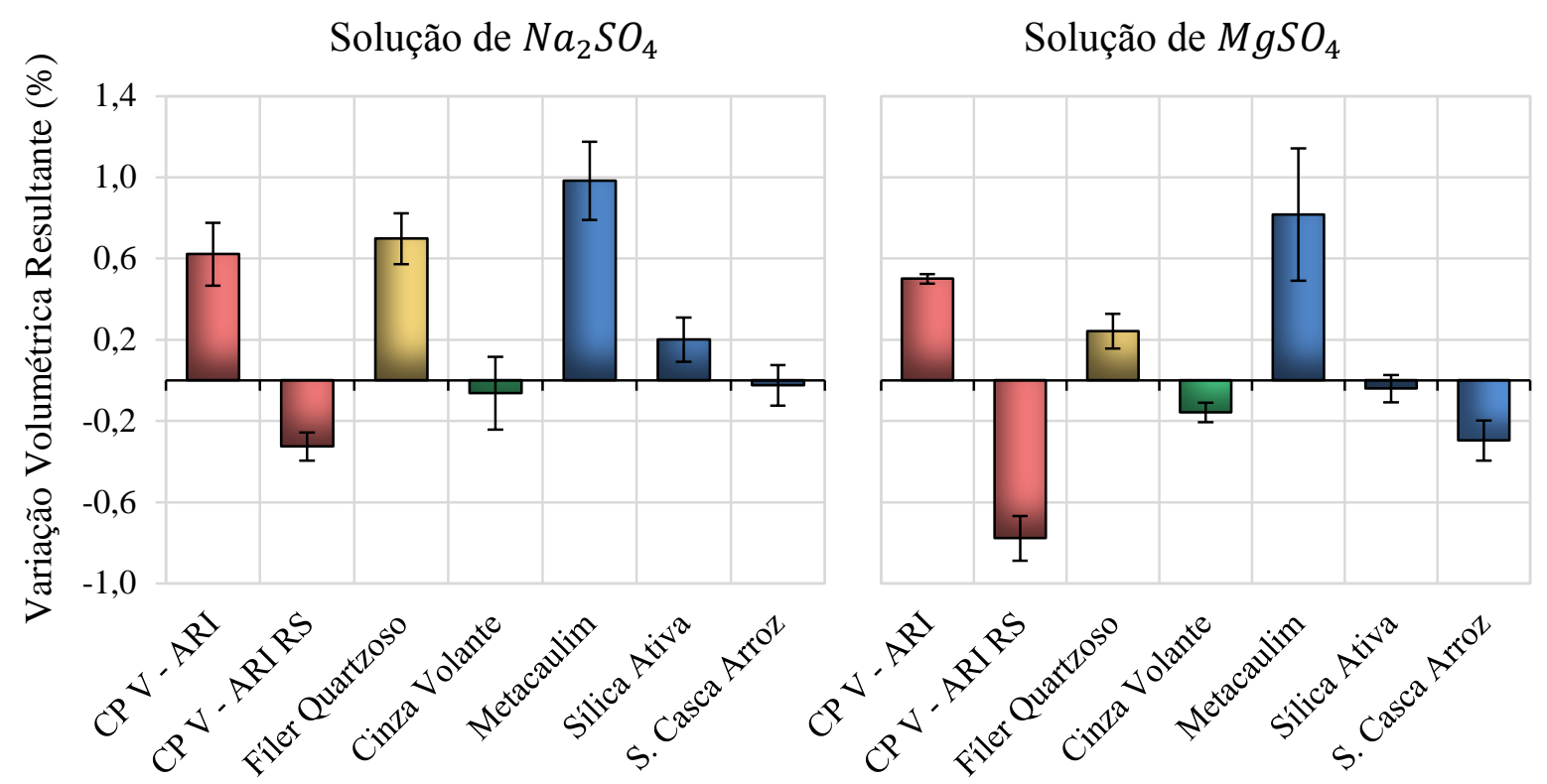

Figura 57: Variação volumétrica resultante das séries expostas à solução de sulfato de sódio e sulfato de magnésio por um período de 6 semanas (42 dias).

É visto na Figura 57 que as séries CP V - ARI RS, CV e SCA, apresentaram para exposição à solução de sulfato de sódio variações de volumétricas negativas. Para compreender este comportamento deve-se salientar que os resultados apresentados são comparativos às mesmas séries expostas à solução de hidróxido de cálcio, logo, estes valores indicam, em sua totalidade, um ganho volumétrico mais acentuado devido à imersão em solução de $\mathrm{Ca}(\mathrm{OH})_{2}$. Ou seja, a exposição a esta solução pode ter contribuído para a formação de produtos da hidratação do cimento Portland, o que pode ter gerado este ganho volumétrico maior. Enquanto que para a solução de sulfato de sódio, houve, de fato, um ganho volumétrico para as séries CP V - ARI RS, CV e SCA, porém, em menor escala.

Por outro lado, para solução de sulfato de magnésio, além do ganho de volume observado para exposição ao $\mathrm{Ca}(\mathrm{OH})_{2}$, houve também a perda de volume das amostras devido à degradação ocasionada pelo $\mathrm{MgSO}_{4}$. Isto justifica a perda de volume mais intensa verificada para as séries CP V - ARI RS, CV e SCA.

Concernindo à discussão tida no tópico de variação dimensional linear, 42 dias de exposição não são suficientes para avaliação concisa de composições expostas às soluções de sulfato, pois as amostras podem não representar um resultado compatível com a realidade de longos períodos de exposição, como é o caso de estruturas reais. Nestes casos, houve um comportamento semelhante entre a influência das soluções agressivas para 6 semanas ensaiadas e uma expressiva diferença ao final dos testes em 140 dias de exposição (indicando semelhança com a divisão de dois estágios para o ataque por sulfatos, segundo Santhanam et 
al. (2003)). De modo geral, ao final de 20 semanas as amostras expostas à solução de $\mathrm{Na}_{2} \mathrm{SO}_{4}$ apresentaram expansão e as expostas ao $\mathrm{MgSO}_{4}$, perda de volume devido à desagregação de material.

Nada obstante e, para avaliação desta atuação semelhante das soluções agressivas em baixos tempos de exposição, a Figura 58 mostra a análise comparativa dentre séries com mesma composição, porém expostas às soluções distintas (variação resultante devido exposição às soluções de $\mathrm{Na}_{2} \mathrm{SO}_{4}$ e $\mathrm{MgSO}_{4}$ em relação à solução de $\left.\mathrm{Ca}(\mathrm{OH})_{2}\right)$. E pode ser visto que das 7 comparações realizadas, 4 apresentaram similaridade de comportamento para intervalo de confiança de 95\%, o que pode levar a acreditar para proposições futuras, que a interação das distintas soluções tenderá a uma semelhança no horizonte do tempo de exposição, fato que não ocorreu.

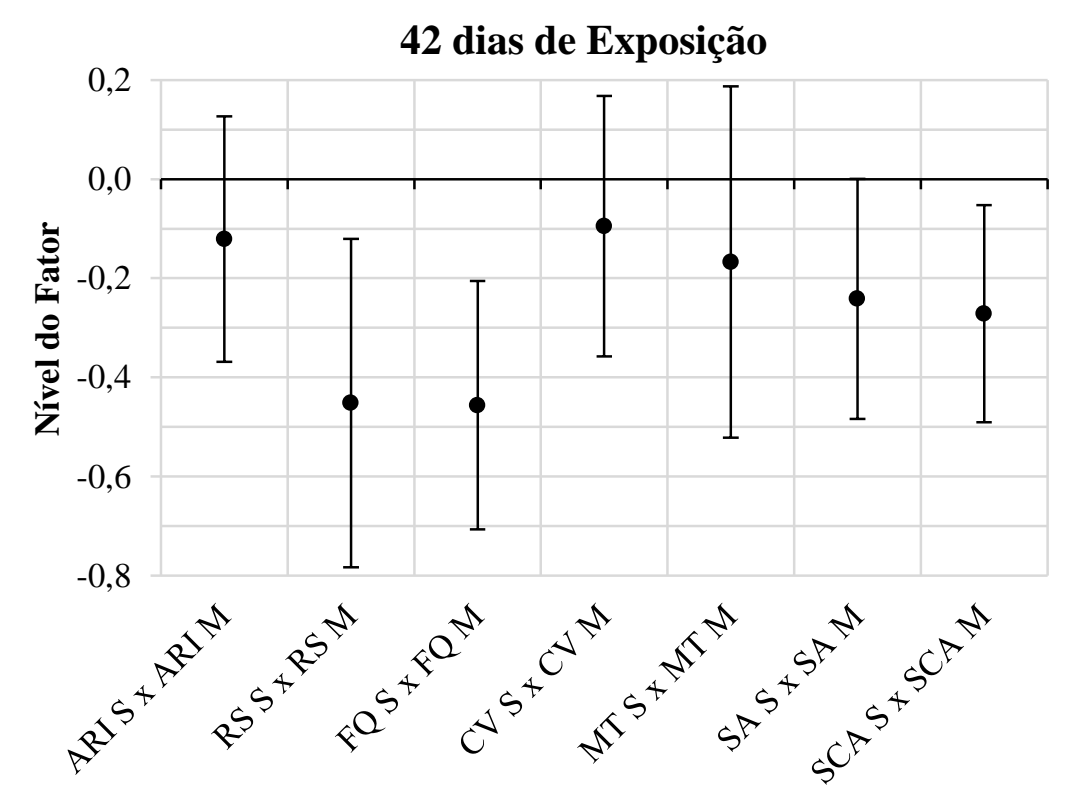

Figura 58: Análise comparativa entre médias de variação volumétrica (teste de Tukey, para nível de significância de 5\%) de mesmas séries para soluções agressivas distintas ( $\mathrm{S}$ - sulfato de sódio e $\mathrm{M}$ - sulfato de magnésio) para 6 semanas de exposição.

Com relação à solução de sulfato de sódio, as séries FQ e MT apresentaram incompatibilidades evidentes com os resultados de variação dimensional linear. Outrora estas mesmas séries mostraram comportamento mitigativo frente ao $\mathrm{Na}_{2} \mathrm{SO}_{4}$, entretanto nesta ocasião, pioraram o desempenho das argamassas. Todavia, as amostras de $\mathrm{FQ}$, de acordo com o teste de Tukey (Tabela 29, Apêndice 1), apresentaram igualdade com a referência, enquanto que o mesmo não ocorrera com a série MT (Tabela 30, Apêndice 1). Congruentemente ao comportamento frente ao $\mathrm{Na}_{2} \mathrm{SO}_{4}$, o metacaulim também potencializou a expansão quando exposto ao $\mathrm{MgSO}_{4}$ para período de exposição de 6 semanas. 
A Figura 59 e Figura 60 apresentam a variação resultante de massa e a variação da velocidade de ultrassom resultante das séries expostas à solução de sulfato de sódio e sulfato de magnésio por um período de 6 semanas (42 dias).

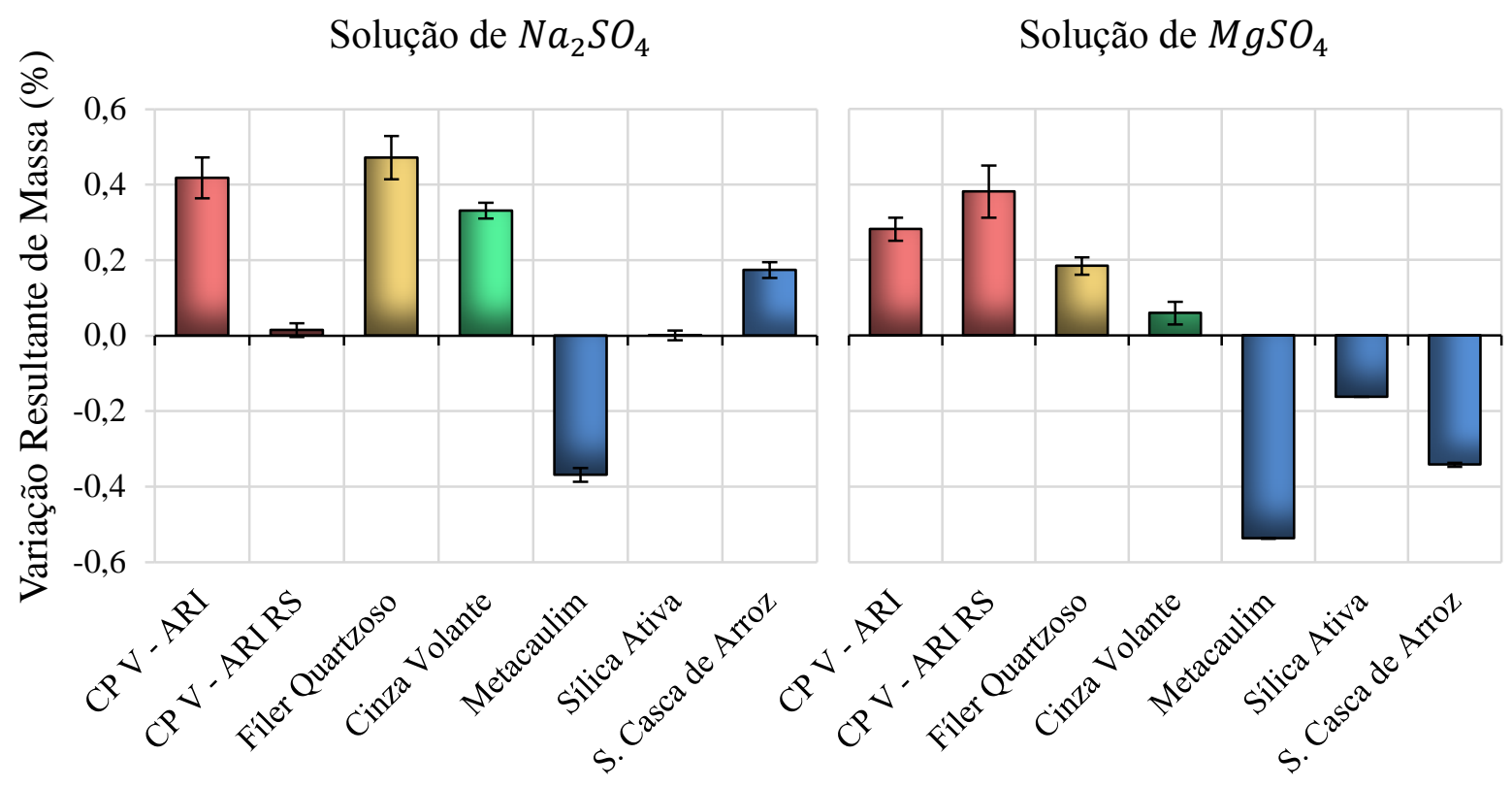

Figura 59: Variação resultante de massa das séries expostas à solução de sulfato de sódio e sulfato de magnésio por um período de 6 semanas (42 dias).

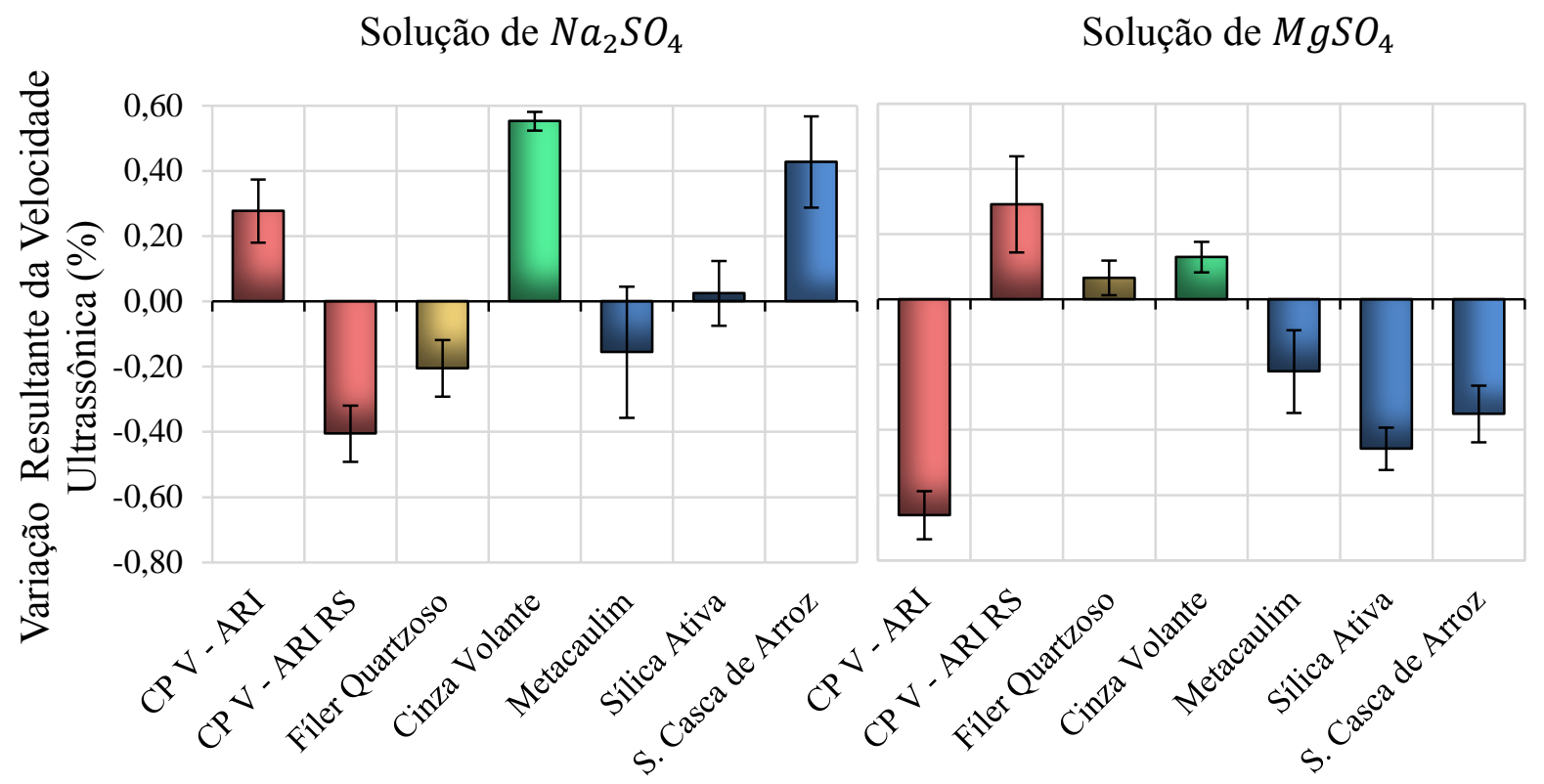

Figura 60: Variação resultante da velocidade ultrassônica das séries expostas à solução de sulfato de sódio e sulfato de magnésio por um período de 6 semanas (42 dias).

Contrariamente ao apresentado na variação volumétrica, para a variação resultante de massa, o comportamento das séries frente à solução de $\mathrm{MgSO}_{4}$ não fora análogo ao $\mathrm{Na}_{2} \mathrm{SO}_{4}$. 
Enquanto que para a variação na propagação de ondas ultrassônicas houve semelhança para as séries MT, SA e SCA, conforme pode ser visto com a Figura 61.

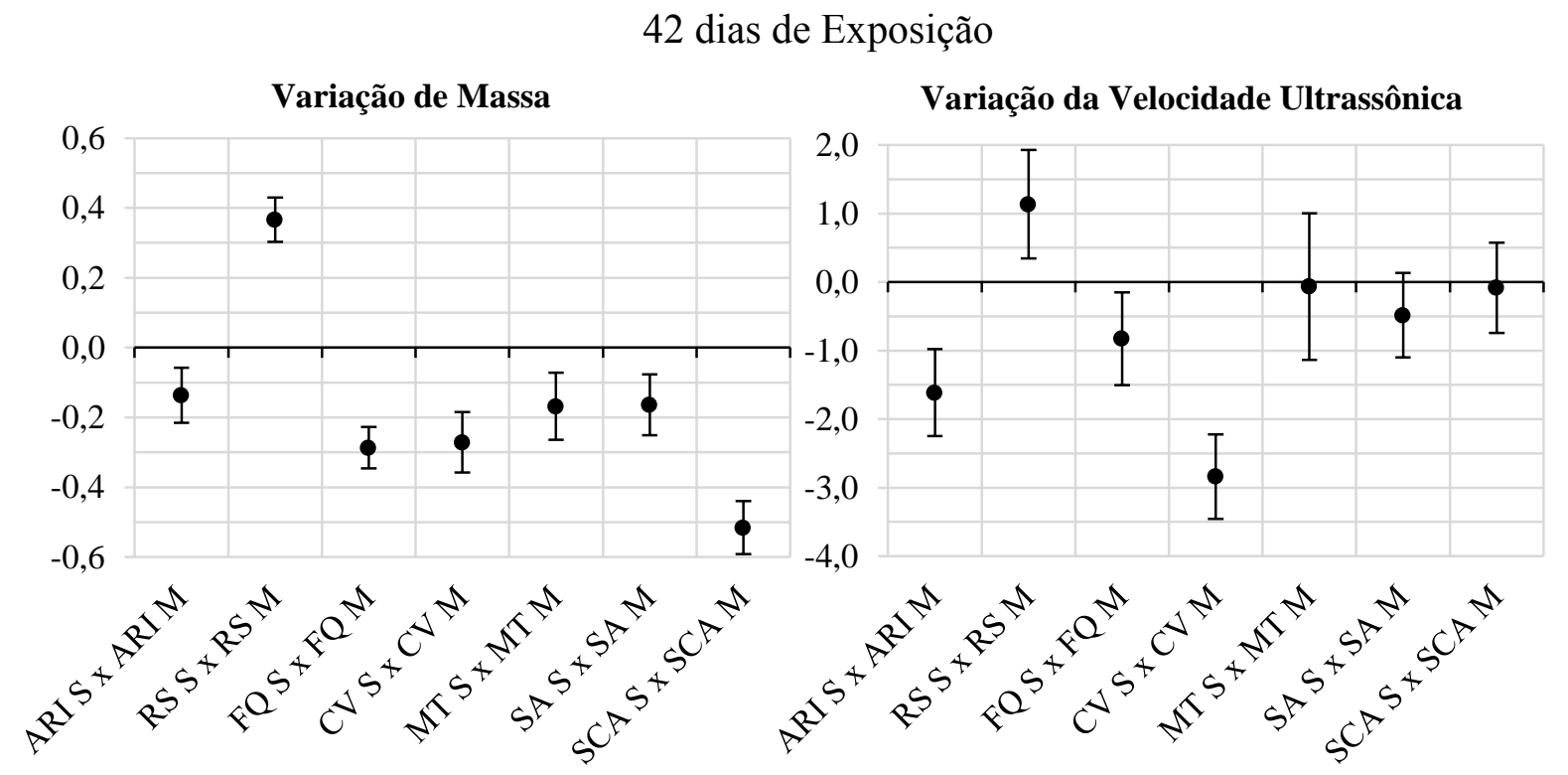

Figura 61: Análise comparativa entre médias de variação de massa e velocidade ultrassônica (teste de Tukey para nível de significância de 5\%) de mesmas séries para soluções agressivas distintas ( $\mathrm{S}$ - sulfato de sódio e M - sulfato de magnésio) para 6 semanas de exposição.

De maneira geral, observa-se que para exposição à solução de sulfato de magnésio as variações de massa apresentaram resultados menores, quando comparados ao $\mathrm{Na}_{2} \mathrm{SO}_{4}$ (exceto as séries CPV - ARI RS e FQ). Isto pode estar associação à massa molar das partículas formadas na reação. Por exemplo, para o sulfato de sódio as reações com o $C H$ tendem a ser para formação de gipsita (relação de massa molar $C \bar{S} H_{2} / C H=2,32$ ) e, posteriormente, etringita (relação de massas molares $C_{6} A \overline{S_{3}} H_{32} / C \bar{S} H_{2}=7,29$ e $C_{6} A \overline{S_{3}} H_{32} / C_{4} A \bar{S} H_{12}=2,02$ ). Enquanto, que para o $\mathrm{MgSO}_{4}$ as reações com a portlandita tendem a ser para formação de gipsita, em maior número, porém, a quantidade de etringita formada é substancialmente inferior, conforme visto do item 4.4. Logo, tendo-se como hipótese que a quantidade de etringita formada para uma mesma série em ambas as soluções agressivas foram diferenciadas, isto pode indicar o motivo da variação menor de massa do sistema.

A variação da velocidade de ondas longitudinais ultrassônicas seguiu uma conformidade esperada nos resultados, também apresentando, como a variação de massa obteve, de modo geral, uma diminuição nos resultados devido à exposição ao sulfato de magnésio. Isto pode ser explicado pelo fato das amostras terem apresentado uma congruência na variação volumétrica na comparação entre soluções e a tendência de diminuição da 
variação de massa para o $\mathrm{MgSO}_{4}$. Ou seja, com um volume igual e uma massa menor, menos denso fica o material, logo a propagação do som deve ser menor, como de fato ocorreu.

A Figura 40 apresenta os resultados da variação volumétrica, de forma comparativa, das séries expostas à solução de sulfato de sódio contra solução de sulfato de magnésio por período que se estendeu por 20 semanas (140 dias).

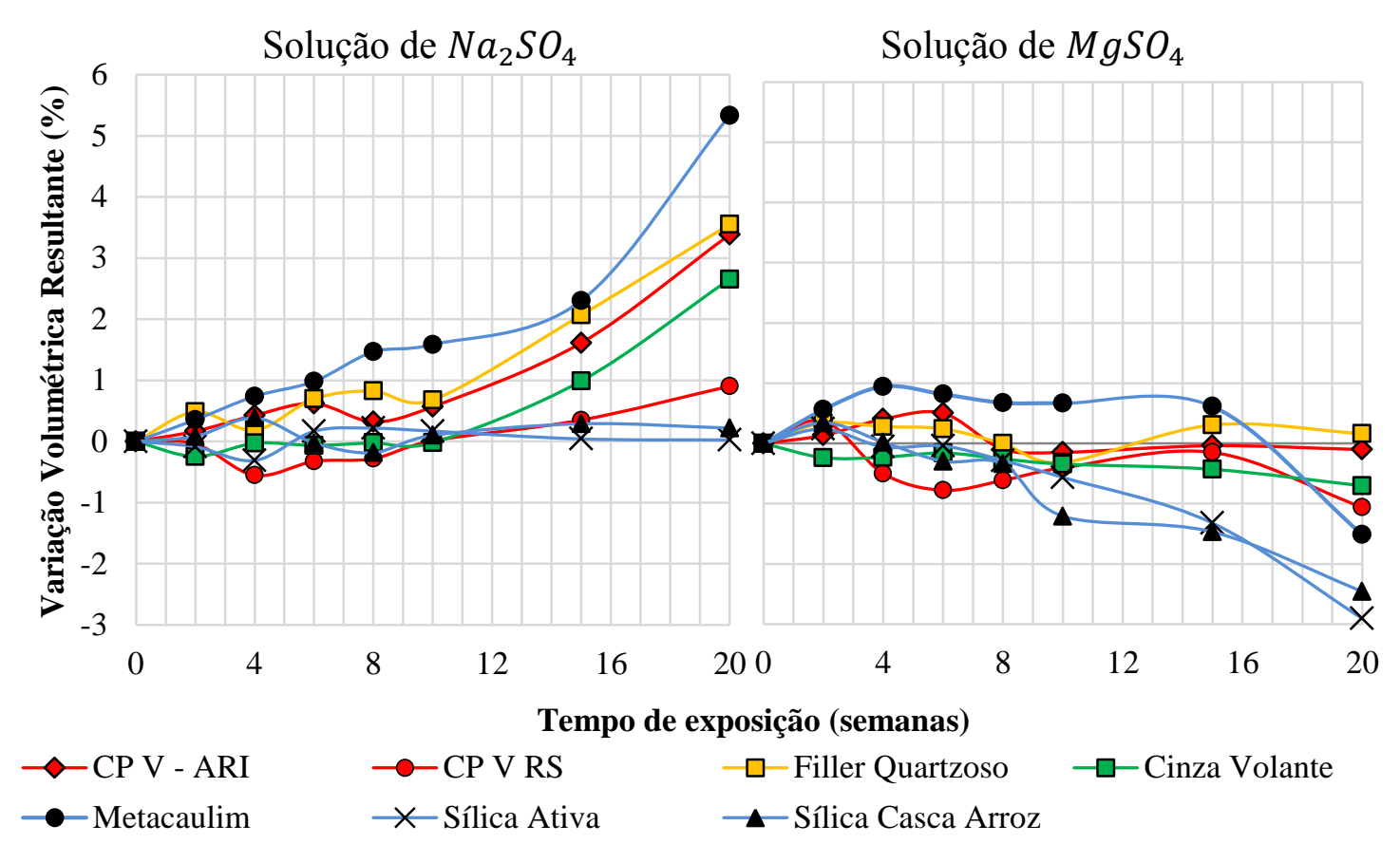

Figura 62: Variação volumétrica resultante das séries expostas por um período de 20 semanas nas soluções de sulfato de sódio e sulfato de magnésio.

Quando postas lado a lado, a variação volumétrica resultante e a variação dimensional linear percebe-se que a primeira apresenta uma escala de variação mais intensa em relação à segunda, e, isto se deve à multiplicação cúbica da expansão encontrada para cada uma das dimensões.

Todavia, na variação dimensional linear as séries expostas ao $\mathrm{MgSO}_{4}$ mostraram expansão, essencialmente, pela diferença de que, nas amostras de $25 \times 25 \times 285 \mathrm{~mm}$ as aferições são realizadas nos pinos acoplados à mesma, enquanto nas $40 \times 40 \times 160 \mathrm{~mm}$ as leituras são realizadas diretamente nas superfícies. Portanto, isto pode servir como prova de que não houve retração das barras, mas sim, perda de material das regiões superficiais.

Para séries expostas ao $\mathrm{Na}_{2} \mathrm{SO}_{4}$, contrariamente ao sulfato de magnésio, o que ocorreu foi um aumento na escala da expansão. Nada obstante, Ferraris et al. (1997) a fim de estudar a influência da geometria dos corpos de prova na expansão ocasionada pelo ataque por sulfatos, utilizaram, para uma mesma condição de exposição e de composição da amostra, amostras 
cilíndricas com diâmetros variáveis de $25 \mathrm{~mm}, 50 \mathrm{~mm}$ e $75 \mathrm{~mm}$. E concluíram que conforme maior for o diâmetro do corpo de prova, maior será o tempo necessário para uma mesma expansão, conforme Figura 63.

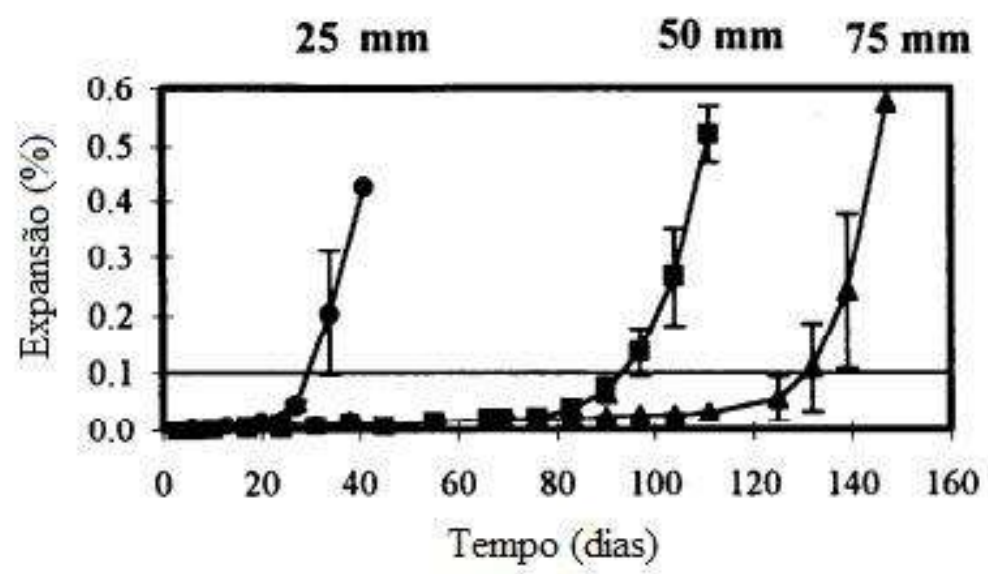

Figura 63: Influência da geometria dos corpos de prova na expansão resultante devido ao ataque por sulfatos Fonte: Ferrais et al. (1997).

Portando, com intuito de comparar a expansão dimensional linear e a expansão volumétrica, a Figura 64 mostra a correlação entre ambas. Na qual se observa o crescimento potencial do volume para uma pequena variação linear.

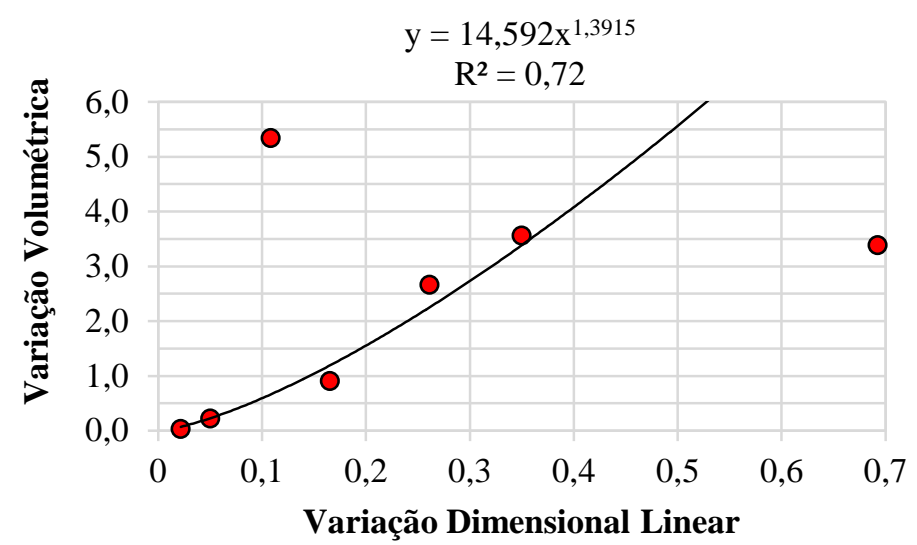

Figura 64: Correlação entre a expansão dimensional linear e a expansão volumétrica das amostras expostas ao sulfato de sódio por um período de 20 semanas

Outro comportamento relevante que pode ser observado na comparação entre as soluções, são os relacionados a duas adições pozolânicas de elevada reatividade, a SA e a SCA. Para a exposição ao $\mathrm{Na}_{2} \mathrm{SO}_{4}$, tais amostras apresentaram desempenhos de mitigação ótimos ao ataque por sulfatos em relação às referências, com variações de massa, volume e de propagação de ondas ultrassônicas muito próximas de 0\%. Em contrapartida, quando expostas ao sulfato de magnésio, ambas tiveram os piores resultados, pois obtiveram os maiores 
desgastes superficiais. A explicação para tal fenômeno está na descalcificação do $C-S-H$, na baixa do $p H$ e respectiva desagregação de materiais da superfície, que ocorreram de forma mais acentuada nas amostras com baixo teor de $\mathrm{CH}$, essencialmente, porque estas tiveram uma formação menor de gel na superfície.

Segundo Hooton (1993) e Al-Akhras (2006), a gipsita é cerca de 9,11 vezes mais volumosa do que a portlandita, enquanto que a etringita é cerca de 2,2 vezes mais volumosa que o monossulfoaluminato de cálcio hidratado, ao mesmo tempo em que a relação entre massas molares Gipsita/CH é de 2,32, já a relação Etringita/Monossulfoaluminato é de 2,02. Desta maneira, pressupõe-se que concomitantemente à expansão de uma amostra, a mesma apresente uma tendência de ganho de massa. Porém, o mesmo comportamento não é verificado para exposição à solução de $\mathrm{MgSO}_{4}$, devido a dois fatores, o primeiro, pela formação menor de etringita em relação ao $\mathrm{Na}_{2} \mathrm{SO}_{4}$ e, o segundo, pelo desgaste superficial ocorrido nas amostras cuja perda de material sólido contribui para a perda de massa.

Desta forma, a Figura 65 apresenta os resultados obtidos com a variação de massa para 20 semanas de exposição às soluções de sulfato de sódio e sulfato de magnésio. E em seguida, na Figura 66, são apresentadas os resultados de variação de velocidade de ultrassom resultante.

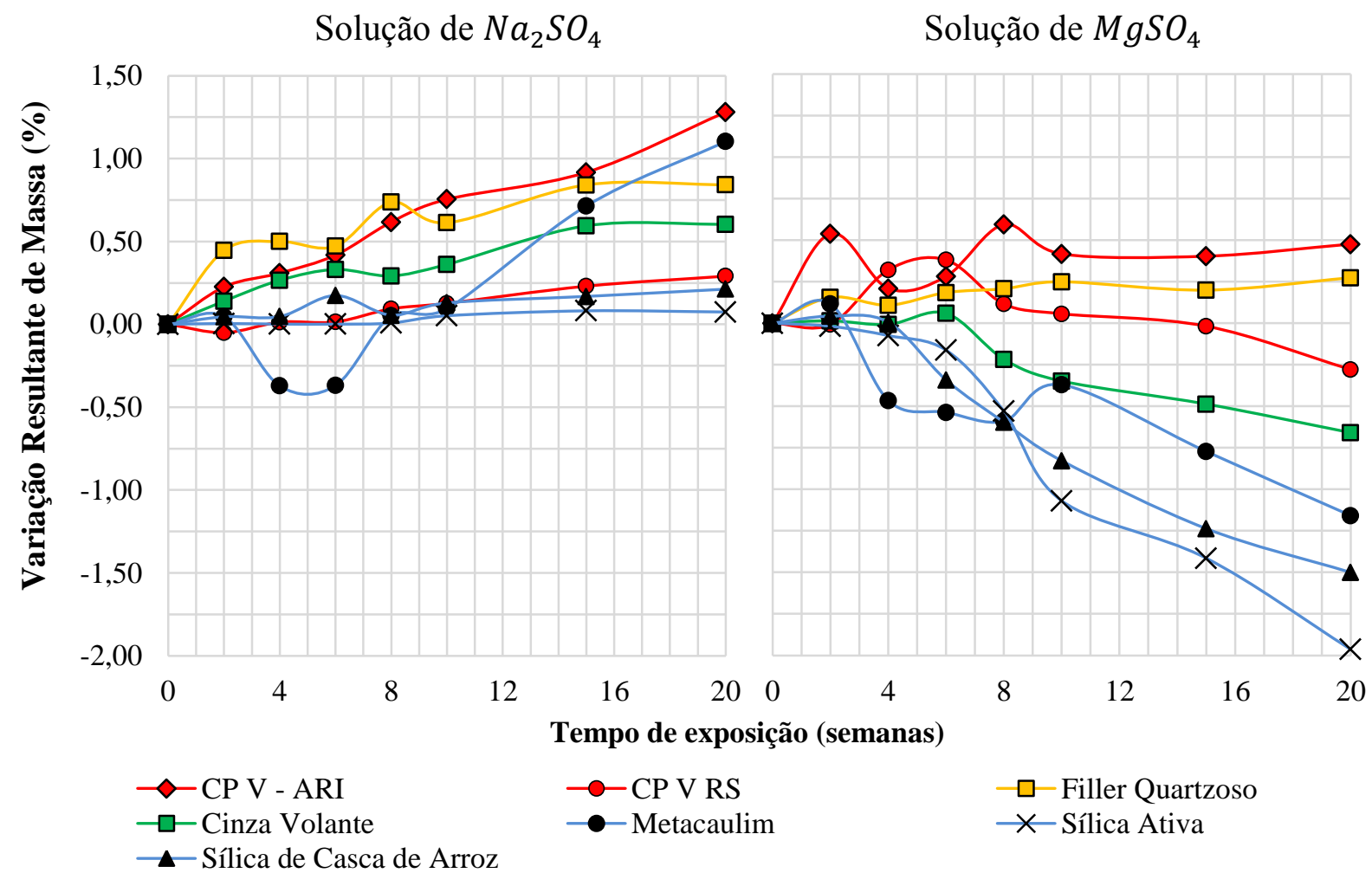

Figura 65: Variação Resultante de Massa das séries expostas por um período de 20 semanas nas soluções de sulfato de sódio e sulfato de magnésio. 


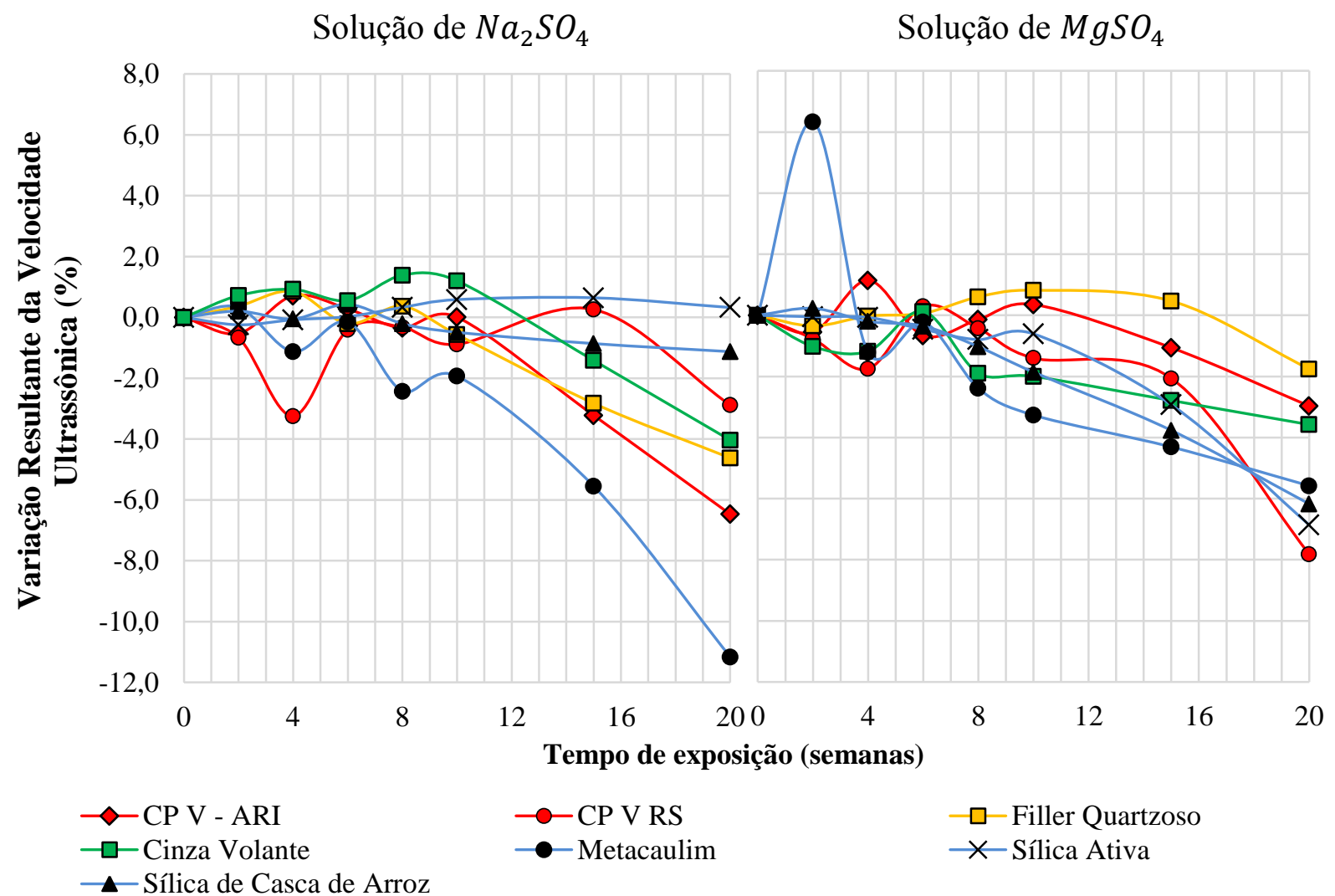

Figura 66: Variação Ultrassônica Resultante das séries expostas por um período de 20 semanas nas soluções de sulfato de sódio e sulfato de magnésio.

Logo, observa-se que para a solução de sulfato de sódio ambas as propriedades, volume e massa, tiveram acréscimo de valores, enquanto que para a variação de velocidade ultrassônica, houve perda. A explicação deste fenômeno está no ganho mais acentuado de volume do que de massa, sugerindo o surgimento de fissuras internas às amostras, o que diminui a relação massa/volume e, consequentemente a velocidade de propagação de ondas ultrassônicas.

No mesmo norte do apresentado para 42 dias de exposição, a tendência do comportamento da variação de massa, de modo geral, foi compatível com os encontrados nos estudos de Skaropoulou et al. (2009), Bary et al. (2014) e Sirisawat et al. (2014), dos quais indicam que para amostras imersas em solução de $\mathrm{Na}_{2} \mathrm{SO}_{4}$ também houve ganho de massa, enquanto que para o $\mathrm{MgSO}_{4}$ houve perda, a exceção das séries CP V - ARI e FQ. Por outro lado, para as variações na velocidade ultrassônica, em ambos os casos, as séries apresentaram redução de velocidade (exceto a série SA para exposição em sulfato de sódio). 
Acrescenta-se ainda, que para a exposição ao sulfato de sódio o processo de fissuração começou a ocorrer nas barras entre a sexta e a décima semana, ficando visíveis após os 70 dias de exposição. Justamente a partir deste ponto a perda de velocidade ultrassônica fica mais evidente e acentuada. Logo, tal medição, pode servir como parâmetro para identificação do processo de fissuração das barras.

Tal comportamento é semelhante ao encontrado nos trabalhos de Skaropoulou et al. (2009) e Skaropoulou et al. (2013), e segundos os autores, a avaliação da velocidade ultrassônica traz informações importantes quanto à degradação micro estrutural das amostras, essencialmente a partir do momento ao qual, inicia-se a degradação.

$\mathrm{Na}$ busca pela obtenção de respostas que esclareçam os comportamentos observados, a Figura 67 mostra a correlação dos resultados obtidos para 20 semanas de exposição ao sulfato de sódio para a variação resultante de massa, variação de velocidade de ultrassom resultante e variação resultante de volume com o teor de hidróxido de cálcio teórico calculado para as séries de referência e teor de hidróxido de cálcio remanescente para cada uma das séries com adição. No caso das que possuem adições minerais o valor considerado fora o produzido pela hidratação do cimento descontando o consumido por atividade pozolânica.

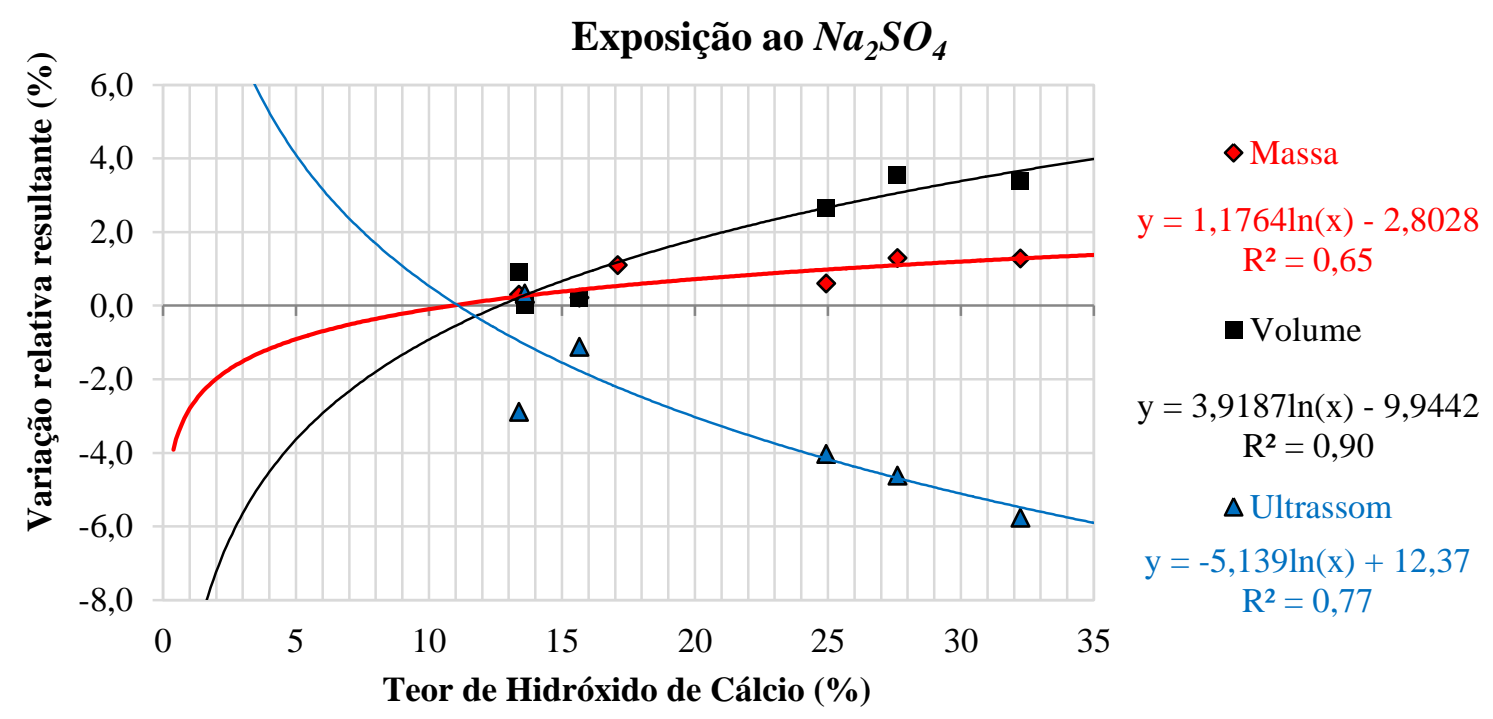

Figura 67: Correlação entre valores obtidos em 20 semanas de exposição para Variação Resultante de Massa, Variação de Volume e Variação da Velocidade Ultrassônica com o Teor de Hidróxido de Cálcio Teórico em exposição ao sulfato de sódio.

O grau do ataque por sulfato de sódio possui uma estreita relação com os teores de $\mathrm{CH}$ e $C_{3} A$ (BICZÓK, 1972; BROWN E BOTHE, 1993; FERRARIS et al., 1997; LEE et al., 2008; ATAHAN E DIKME, 2011; FELEKOGLU, 2012; NEVILLE E BROOKS, 2013; MEHTA E MONTEIRO, 2014). Neste sentido, observa-se com a Figura 67 que o teor de hidróxido de 
cálcio é, de fato, intimamente relacionado à degradação das argamassas, de modo que conforme maior o teor de $\mathrm{CH}$ remanescente, menor o desempenho de uma série frente ao $\mathrm{Na}_{2} \mathrm{SO}_{4}$.

Nesta mesma linha Tikalsky et al. (2002) afirmam que conforme maior é a relação $C_{3} S / C_{2} S$ do clínquer, mais suscetível estará o cimento quanto à exposição por sulfato de sódio, isto porque, conforme tal relação aumenta maior será a formação de portlandita na hidratação. Também neste sentido, Bellmann e Stark (2007) e Lothenbach et al. (2011) alegam que cimentos com baixa relação $\mathrm{Ca} / \mathrm{Si}$ são mais resistentes ao $\mathrm{Na}_{2} \mathrm{SO}_{4}$.

Entretanto, Taylor (1997) comenta que o consumo do hidróxido de cálcio por adições pozolânicas pode tornar o concreto mais vulnerável ao $\mathrm{MgSO}_{4}$ por sua reação com os cristais de $\mathrm{C}-\mathrm{S}-\mathrm{H}$ que são protegidos, em termos simplistas, pelo $\mathrm{Ca}(\mathrm{OH})_{2}$, essencialmente, por este estabilizar o $\mathrm{pH}$ do concreto em níveis de basicidade alta (em torno de 12). Nesta mesma perspectiva a Figura 68 mostra a mesma correlação apresentada na Figura 67, porém, neste caso, devido à exposição ao sulfato de magnésio.

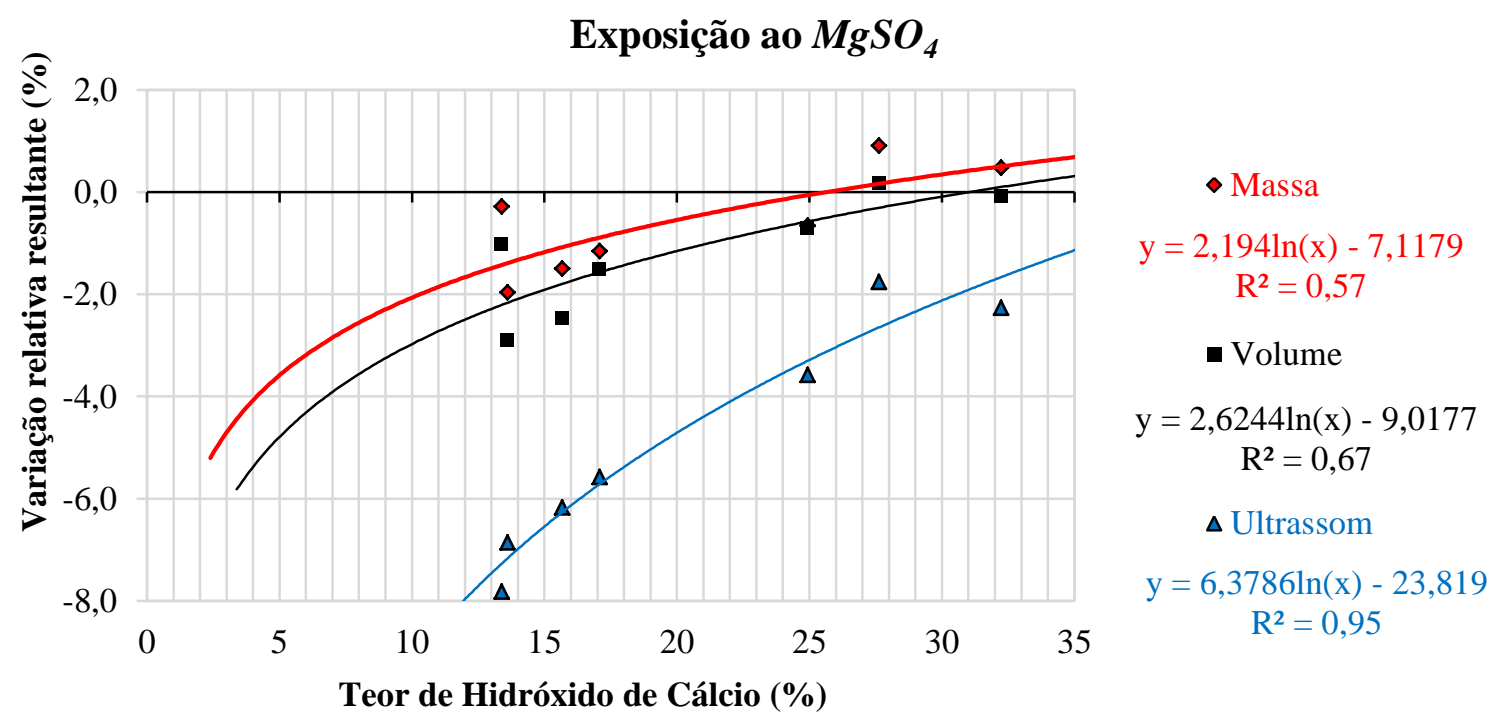

Figura 68: Correlação entre valores obtidos em 20 semanas de exposição para Variação Resultante de Massa, Variação de Volume e Variação da Velocidade Ultrassônica com o Teor de Hidróxido de Cálcio Teórico em exposição ao sulfato de magnésio.

Oposto à exposição ao $\mathrm{Na}_{2} \mathrm{SO}_{4}$ as barras imersas em solução de sulfato de magnésio, apresentaram maior degradação conforme menor o teor de portlandita disponível, e tal explicação está associada à afirmação dada por Taylor (1997), conforme supracitada. Sendo assim, com a queda do $p H$ presente nos poros superficiais das amostras maior foi a desagregação das barras de argamassa, logo, obtendo valores de variação relativa negativas para massa e volume. 
Porém, não são apenas estas as discussões que devam ser levantadas quanto à Figura 67 e Figura 68, mas também, as tendências congruentes entre si das variações apresentadas para ambas às soluções, e que, de modo geral, validam os resultados obtidos. Em razão de que, para solução de $\mathrm{Na}_{2} \mathrm{SO}_{4}$, os aumentos na variação de volume e de massa seguiram uma proporcionalidade na escala de $V_{\text {massa }}=-0,0339 \cdot V_{\text {volume }}{ }^{2}+0,3933 \cdot V_{\text {volume }}\left(\right.$ com $\mathrm{R}^{2}$ de 0,85), de modo que a alteração na massa foi menos acentuada. Este comportamento pode estar relacionado à morfologia da gipsita e do $C H$, no sentido de que a relação das massas molares $C \bar{S} H_{2} / C H=2,32$ e de volume das partículas $C \bar{S} H_{2} / C H=9,11$, logo, se uma nova relação for realizada, neste caso, entre volume e massa (Eq. 32), tem-se:

$$
\frac{\text { volume }}{\text { massa }}=\frac{9,11}{2,32}=3,93
$$

Assim, para servir de exemplo, tendo primeiramente como hipótese, apenas a influência da formação de gipsita no ataque por sulfato de sódio, o ganho de volume apresentaria, teoricamente, uma variação 3,93 vezes superior à variação de massa. Ao mesmo tempo, feitas as médias aritméticas das variações resultantes de volume e de massa tem-se 2,296 e 0,630, respectivamente, calcula-se a relação entre volume/massa real, neste caso, igual a 3,65, ou seja, muito próximo ao previsto teoricamente. Deste modo, indicando proporcionalidade entre a probabilidade de formação de gipsita, a partir do $\mathrm{CH}$, e as variações resultantes de volume e massa.

Em uma segunda análise, como hipótese, apenas a influência da formação de etringita no ataque por sulfato de sódio, o ganho de volume apresentaria, teoricamente, uma variação 1,51 vezes superior à variação de massa. A partir das análises de DRX realizadas, fez-se contagem das produções de etringita e gipsita a partir do ataque por sulfato de sódio, e, verificou-se que ambos os minerais tiveram produções muito próximas quando comparadas à exposição em hidróxido de cálcio. Contudo, tendo em vista que para a obtenção de uma molécula de etringita são necessárias 2 moléculas de gipsita (conforme Eq. 8 no item 2.3.2), assume-se que a produção de gipsita fora 3 vezes superior à verificada na DRX.

Desta forma, em uma análise da relação volume/massa englobando ambos os minerais degradantes, deu-se um peso a formação de gipsita 3 vezes maior do que para a etringita, conforme supracitado, assim obteve-se a seguinte relação volume/massa teórico, conforme Eq. 33: 


$$
\frac{\text { volume }}{\text { massa }}=\frac{3 \cdot 3,93+1 \cdot 1,51}{4}=3,33
$$

Assim observa-se uma relação entre volume/massa teórica muito próxima ao real de 3,65 indicando uma boa correlação entre as previsões teóricas e as ocorrências observadas na prática.

Outra análise referente aos resultados de sulfato de sódio é quanto às variações de velocidade ultrassônica. Observa-se que quando as variações de volume e massa tendem a zero, em função do teor de $\mathrm{CH}$, a variação resultante de velocidade ultrassônica também tende a ser nula, sendo tal resultado, indiscutivelmente, fidedigno. Isto porque se amostras de mesma composição e expostas às soluções de referência e de $\mathrm{Na}_{2} \mathrm{SO}_{4}$ não apresentarem variação relativa de massa e volume, assume-se que os corpos são equivalentes entre si, sendo assim, a variação da velocidade ultrassônica deve, de fato, também ser nula.

Por outro lado, vê-se que com teores maiores de portlandita que a variação na velocidade ultrassônica tem comportamento oposto à variação de volume, enquanto esta última aumenta a outra diminui. Contudo, isto era de se prever, haja vista que a variação de massa não cresce, em mesma proporção, que o volume, desta maneira, menos denso ficará o material. Ao mesmo tempo, pressupõem-se com o ganho acentuado de volume, que as microfissurações se iniciam, logo, com a soma destes dois fatores, menor será a propagação das ondas ultrassônica. Tais afirmações podem ser justificadas, por exemplo, pelo comportamento das três variações (massa, volume e velocidade ultrassônica) quando expostas ao sulfato de magnésio. Neste caso, como as variações de massa e volume tiveram aumentos proporcionais, a variação na velocidade de ondas ultrassônicas também seguiu uma proporcionalidade com ambas.

A seguir, com a Figura 69 podem ser vistas as variações resultantes de volume, massa e velocidade ultrassônica e seus respectivos desvios padrão das séries estudadas para ambas as soluções de agressivas, em um período de exposição de 20 semanas (140 dias). 
Solução de $\mathrm{Na}_{2} \mathrm{SO}_{4}$

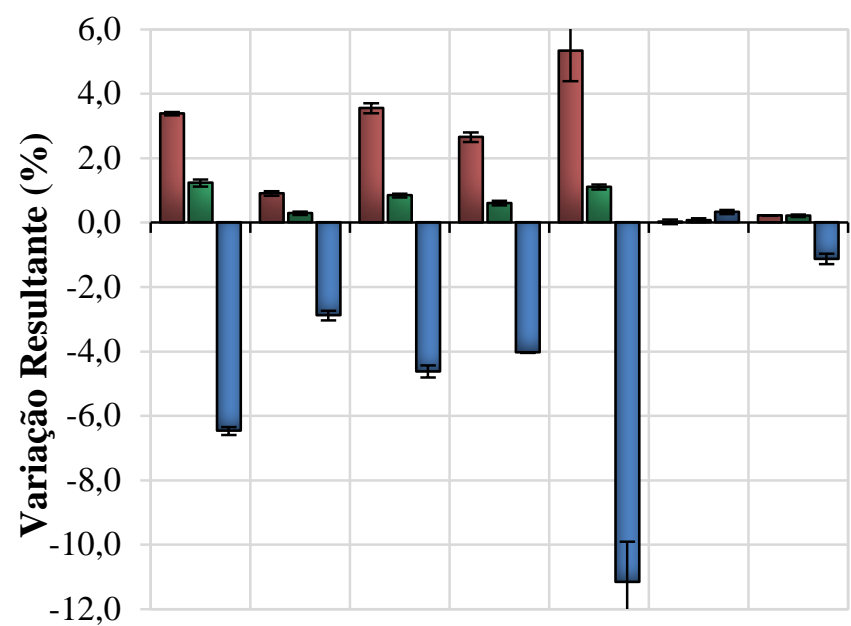

Solução de $\mathrm{MgSO}_{4}$

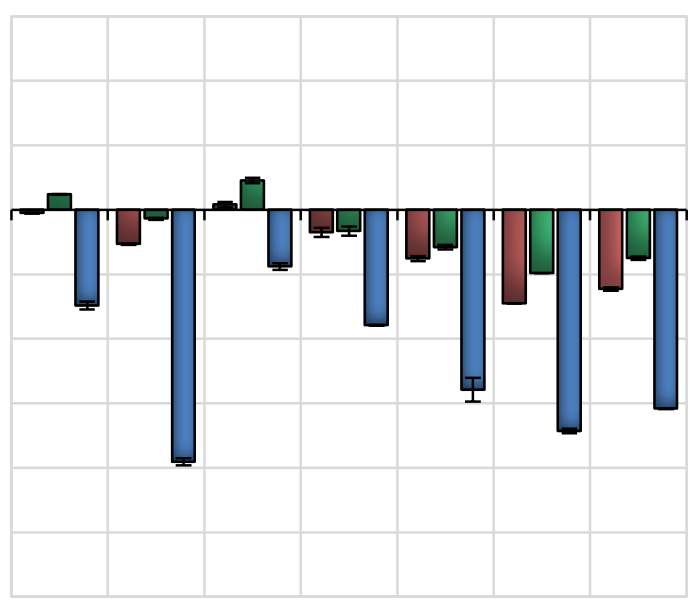

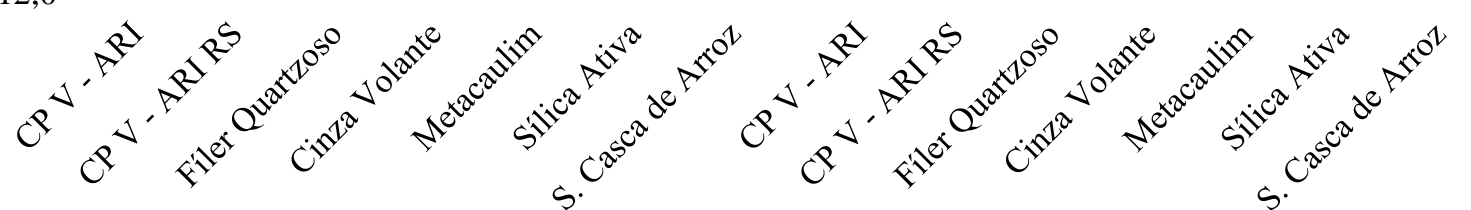

$\square$ Variação Resultante de Volume $\square$ Variação Resultante de Massa $\square$ Variação Resultante da V. Ultrassônica

Figura 69: Variações Resultantes de Volume, Massa e Velocidade Ultrassônica das séries expostas ao sulfato de sódio e ao sulfato de magnésio por um período de 140 dias.

$\mathrm{Na}$ sequência, serão discutidos, em formato de grupos, os resultados das séries estudadas. Cabe comentar que os testes de Tukey de comparação mútua das médias dos resultados apresentados, são mostrados nas Tabela 35Tabela 36 e Tabela 39Tabela 40 no Apêndice 1.

- Séries referências $(C P V-A R I$ e $R S)$ : Visualmente ambas as séries apresentaram pouca degradação devido à interação com as soluções agressivas. No caso da série resistente aos sulfatos (CP V - ARI RS) houve apenas desgastes superficiais ocasionados pela interação com o $\mathrm{MgSO}_{4}$. A série $\mathrm{CP} \mathrm{V}$ - ARI apresentou poucas fissuras, conforme Figura 70. Todavia, as séries obtiveram comportamentos ambíguos para diferentes soluções, a RS mostrou-se eficaz em mitigar o ataque por sulfato de sódio, sendo estatisticamente equivalente às séries SA e SCA, enquanto para solução de sulfato de magnésio apresentou elevado desgaste superficial, logo, obteve variações negativas de massa e volume, juntamente com uma maior perda na propagação de ondas ultrassônicas. 


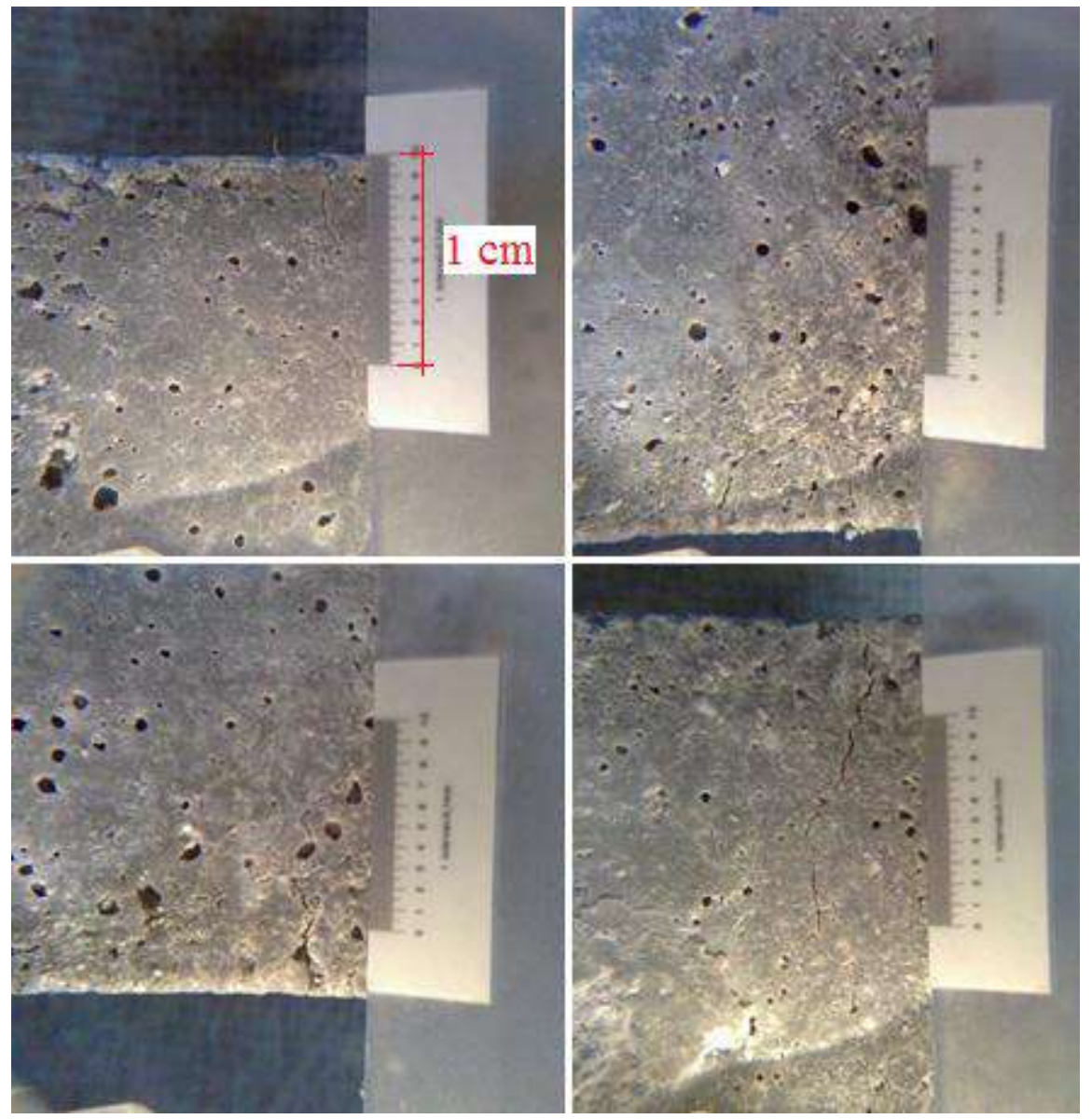

Figura 70: Fissuração causada pelo ataque por sulfato de sódio em barras de argamassa da série CP V - ARI exposta por um período de 20 semanas.

Por outro lado, a série CP V - ARI apresentou uma variação volumétrica de 3,383 \% e uma variação de massa de 1,232 \% e, conforme citado anteriormente, para um ganho de volume não acompanhado em mesmas proporções pelo ganho de massa, diminui-se a densidade, acarretando em uma variação negativa de velocidade ultrassônica, neste caso de $-6,470 \%$. O fato das amostras terem apresentado pequenas fissurações reforçam esta explicação. Soma-se ainda que a velocidade de propagação do som no ar é, expressivamente, inferior a de um sólido (aproximadamente 12,85 vezes inferior às argamassas), o que, em outras palavras, impacta nos resultados, haja vista que a fissuração proporciona um aumento nos vazios das barras.

- Série com adição Inerte $(F Q)$ : Contrariamente aos resultados obtidos com a expansão dimensional linear cuja série FQ apresentou mitigação significativa frente ao ataque por sulfato de sódio, para variação volumétrica o mesmo não ocorreu. Para a comparação de semelhança entre médias o FQ apresentou equivalência estatística com a série CP V - ARI para variações resultantes volumétricas e de massa. Isto pode estar associado ao fato de que estes testes são mais abrangentes do que a variação 
dimensional linear, ao mesmo tempo, também possuem maior vulnerabilidade às variáveis extrínsecas.

Da mesma forma como a série de referência, o FQ também apresentou pequenas fissuras que se iniciaram em 8 semanas de exposição, e que impactaram nos resultados obtidos para variação da velocidade ultrassônica, neste caso, menos intensa do que no CP V - ARI.

$\mathrm{Na}$ solução de $\mathrm{MgSO}_{4}$, o fíler quartzoso apresentou singularidade na variação resultante de volume, sendo a única com resultado positivo e, ao mesmo tempo, apresentou o maior ganho de massa e variação da velocidade ultrassônica mais branda.

- Série com adição de pozolana de baixa reatividade $(C V)$ : A CV que para expansão dimensional linear, inicialmente, havia apresentado comportamento satisfatório frente ao ataque por sulfatos, para a variação volumétrica apresentou semelhança estatística quando comparada à referência CP V - ARI. Isso indica mais uma vez que a expansibilidade média das amostras não segue uma linearidade para as três dimensões, essencialmente, em eixos de menores dimensões onde a expansão ocorre em maior intensidade quando analisada percentualmente em relação à dimensão do próprio eixo. E isto ocorre pelo fato de que a pressão de confinamento dos minerais degradante é menor para direções nas quais os comprimentos são menores, logo, permitindo uma expansibilidade maior. E tal comportamento fica mais evidente para períodos de exposição superiores a 8 semanas (56 dias) cuja expansão torna-se mais intensa.

Quando exposta ao sulfato de magnésio, a CV apresentou resultados muito próximos à série composta por cimento resistente aos sulfatos para variação de volume e de massa.

- Séries com adições de pozolanas de elevada reatividade (MT, SA e SCA): São três os pontos para discussão das séries compostas por adição de pozolanas de alta reatividade: comportamento da série MT; das séries SA e SCA frente à exposição ao sulfato de sódio; e, SA e SCA frente à exposição ao sulfato de magnésio.

Dentre os resultados obtidos, quando comparados à variação dimensional linear, a série MT foi a que apresentou os valores mais contraditórios. Linearmente o MT mostrou-se resistente ao $\mathrm{Na}_{2} \mathrm{SO}_{4}$, tendo como expansão resultante um valor 34,34\%, em média, inferior à série composta por cimento resistente aos sulfatos. Entretanto, nas variações de volume, quando comparada à mesma série, a MT apresentou expansão volumétrica $489,93 \%$, variação de massa $279,04 \%$ e variação de velocidade ultrassônica 286,79\%, maiores. 
Para a variação de volume, muito se deve à degradação que a série apresentou em suas arestas, mesmo fato ocorrido para expansão linear, porém, neste caso, pouco mais intenso e muito mais impactante nas aferições, haja vista que as leituras foram realizadas com uso de paquímetro digital. Assim se comparada com a utilização do pórtico metálico para leitura de variação linear, cujo apoio é no pino metálico encaixado no centro da seção do CP. A Figura 71 mostra a comparação entre a degradação das amostras de diferentes dimensões compostas pela série MT.

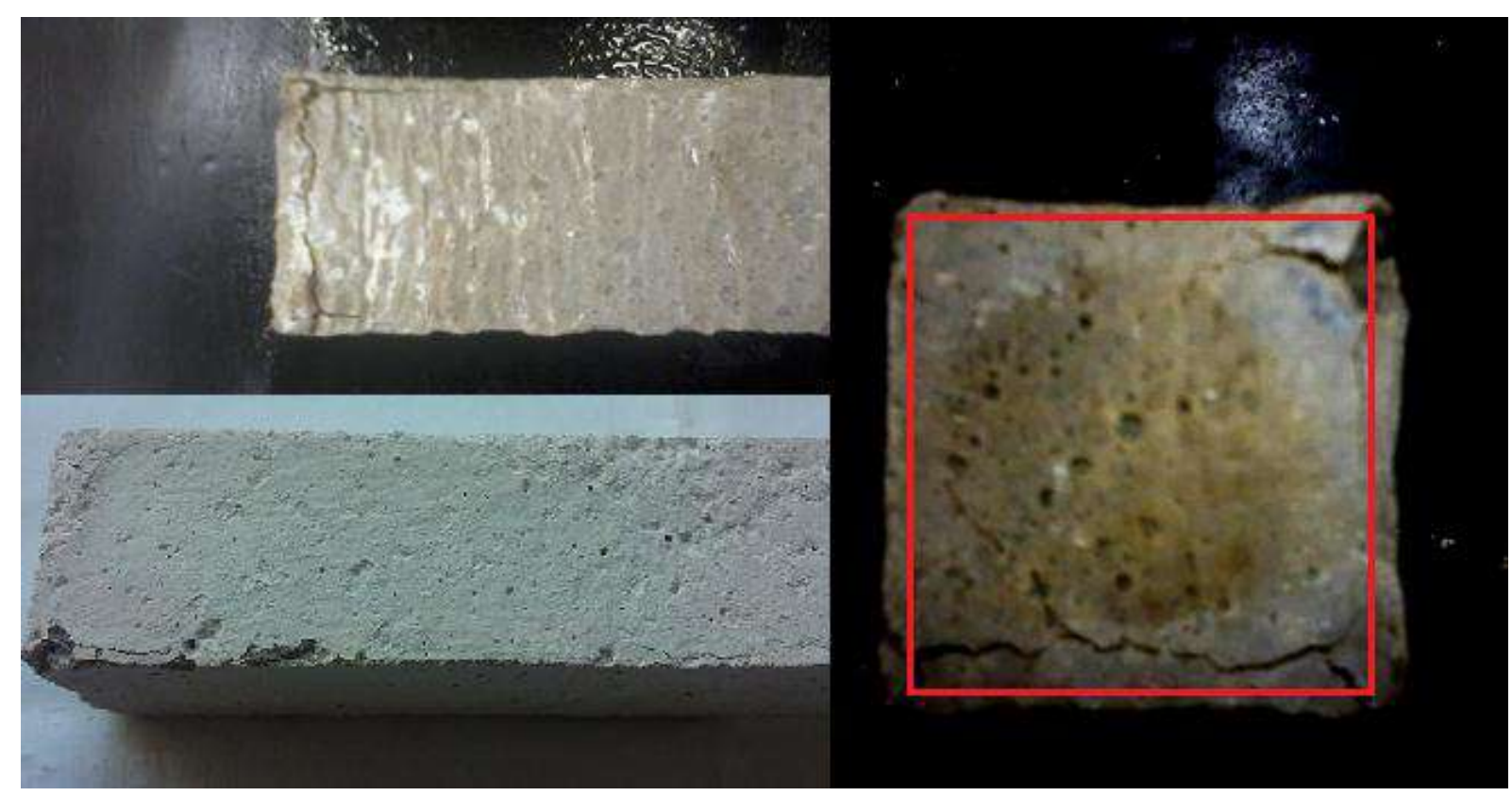

Figura 71: Comparação entre a degradação das amostras de diferentes dimensões (superior esquerda $40 \times 40 \times 160 \mathrm{~mm}$, inferior esquerda $25 \times 25 \times 285 \mathrm{~mm}$ e direita seção da amostra $40 \times 40 \times 160 \mathrm{~mm}$ ) da série MT exposta ao sulfato de sódio.

Para a variação de massa, a MT também ficou entre os piores resultados, nesse caso, somente a série de referência (CP V - ARI) obteve ganho de massa superior. Tais tendências degradantes da série podem estar associadas a sua composição química e sua reatividade elevada. Desse modo, o metaculim apresentou um teor de $\mathrm{Al}_{2} \mathrm{O}_{3}$ de $49,33 \%$, e ao mesmo tempo, uma elevada reatividade, desta maneira, pode ter contribuído para a formação de monossulfoaluminato, conforme verificado nos resultados de DRX e, posteriormente, etringita secundária, isto pela contribuição no aumento do teor de alumina na matriz. Contudo, ao levantar tal discussão, podem surgir questionamentos a respeito do elevado teor de alumina na CV e, do porquê a série não apresentou tamanha variação. Entretanto, a cinza volante apresentou teor de $\mathrm{Al}_{2} \mathrm{O}_{3}$ igual a $26,30 \%$ e reatividade baixa, $65,80 \%$ inferior ao metacaulim, podendo 
ter contribuído menos para a formação de etringita. Nesta mesma direção, a Figura 72 apresenta correlações significativas entre o teor de alumina nas adições pozolânicas e as variações resultantes de volume e massa para exposição ao sulfato de sódio por um período de 140 dias.

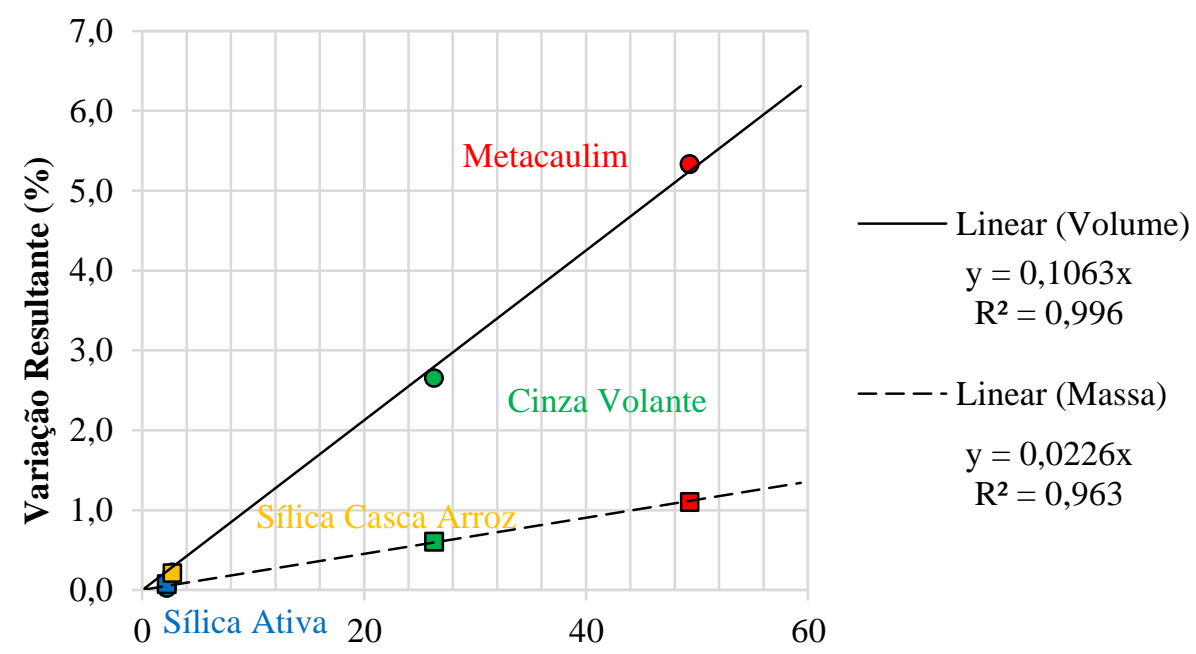

Teor de $\mathrm{Al}_{2} \mathrm{O}_{3}$ das Adições Minerais (\%)

Figura 72: Correlação entre o teor de $\mathrm{Al}_{2} \mathrm{O}_{3}$ das adições minerais pozolânicas e suas respectivas variações resultantes volumétricas para exposição ao sulfato de sódio por um período de 140 dias.

Associado a elevada fissuração que a série MT apresentou e as consequentes variações de volume e massa, houve, como esperado, uma perda singular na propagação de ondas ultrassônicas de $-11,159 \%$, a maior dentre as séries expostas ao sulfato de sódio, isto porque a propagação do som é função direta destas variáveis.

Quanto ao comportamento da MT frente ao sulfato de magnésio, a série, apresentou resultados semelhantes, porém inferiores, às séries SA e SCA. Posteriormente, a influência do $\mathrm{MgSO}_{4}$ nas adições de elevada reatividade serão mais bem discutidas, porém neste momento, evidenciam-se com a Figura 73 as distintas degradações que as soluções de $\mathrm{Na}_{2} \mathrm{SO}_{4}$ e $\mathrm{MgSO}_{4}$ causaram nas amostras da série MT. Na solução de sulfato de sódio prevaleceu à expansão volumétrica e fissuração, para a solução de sulfato de magnésio, ocorreu à desagregação superficial e consequente perda de volume. 


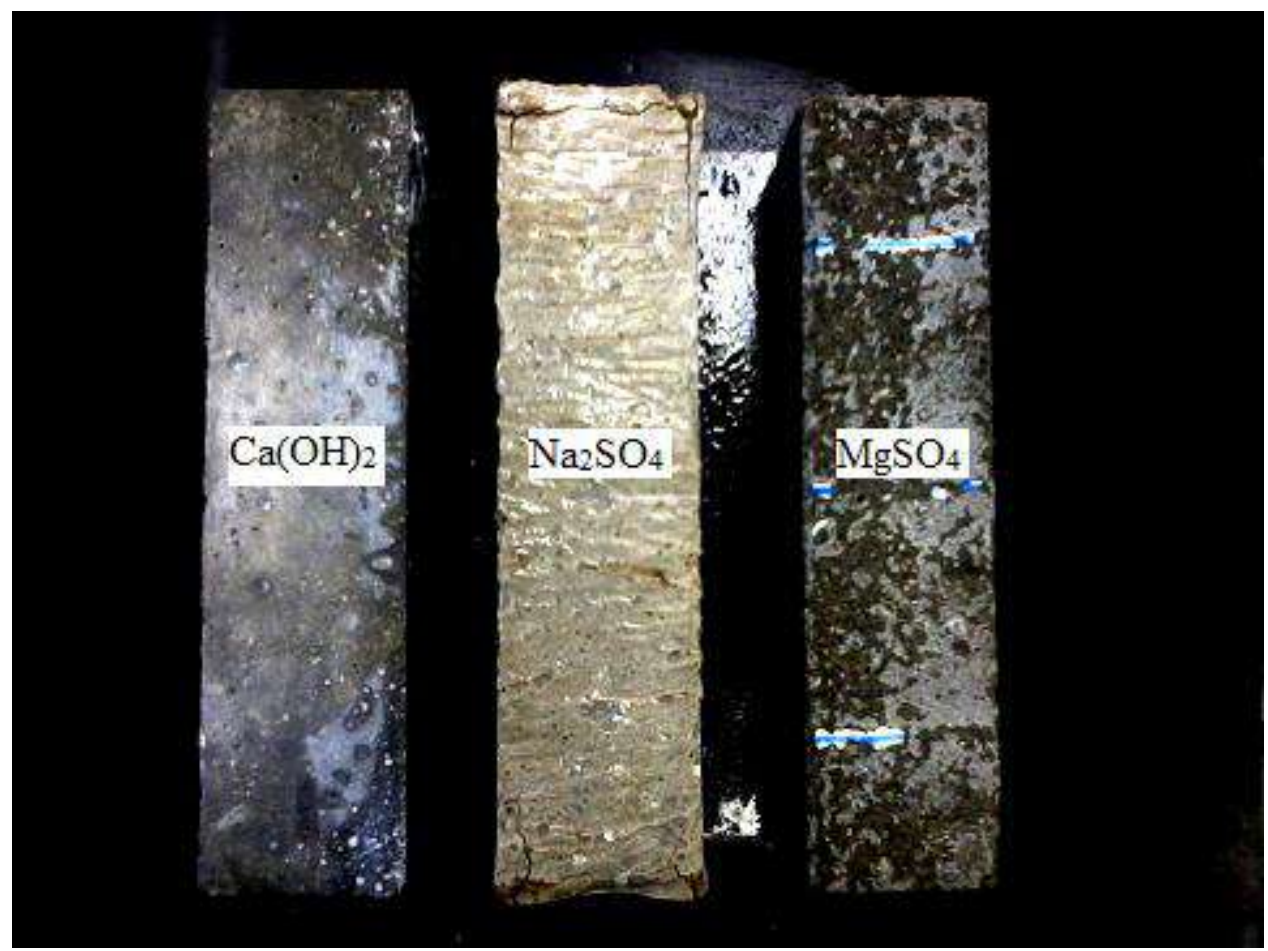

Figura 73: Comparação visual entre a influência das três soluções nas quais a série MT fora exposta $\left(\mathrm{Ca}[\mathrm{OH}]_{2}\right.$, referência; $\mathrm{Na}_{2} \mathrm{SO}_{4}$, sulfato de sódio; e $\mathrm{MgSO}_{4}$, sulfato de magnésio)

As demais séries de elevada reatividade (SA e SCA), frente ao ataque por sulfato de sódio, mostraram-se como as melhores opções no que tange a resistência à solução agressiva. Muito se deve a elevada finura de tais adições, colaborando para um melhor empacotamento de partículas. E, em paralelo, apresentaram as maiores reatividade no ensaio de Chapelle modificado, portanto, contribuem na formação de mais cristais de $C-S-H$ o que também colabora no embate ante íons sulfato.

Em contrapartida, quando expostas ao sulfato de magnésio apresentaram resultados piores do que a referência de CP V - ARI, ou seja, perderam mais volume, massa e velocidade de propagação de ondas ultrassônicas. Muito disso se deve a intensa degradação superficial que ambas apresentaram, de diagnóstico já explanado anteriormente. De modo a exemplificar melhor, a degradação ante as três soluções de imersão, a Figura 74 mostra a comparação entre a influência das três soluções nas quais a série SA fora exposta, evidenciando o intenso desgaste superficial ocasionado pela solução de sulfato de magnésio, comportamentos que se assemelham aos obtidos por Lee et al. (2005), Chatveera e Lertwattanaruk (2009) e Skaropoulou et al. (2009). 


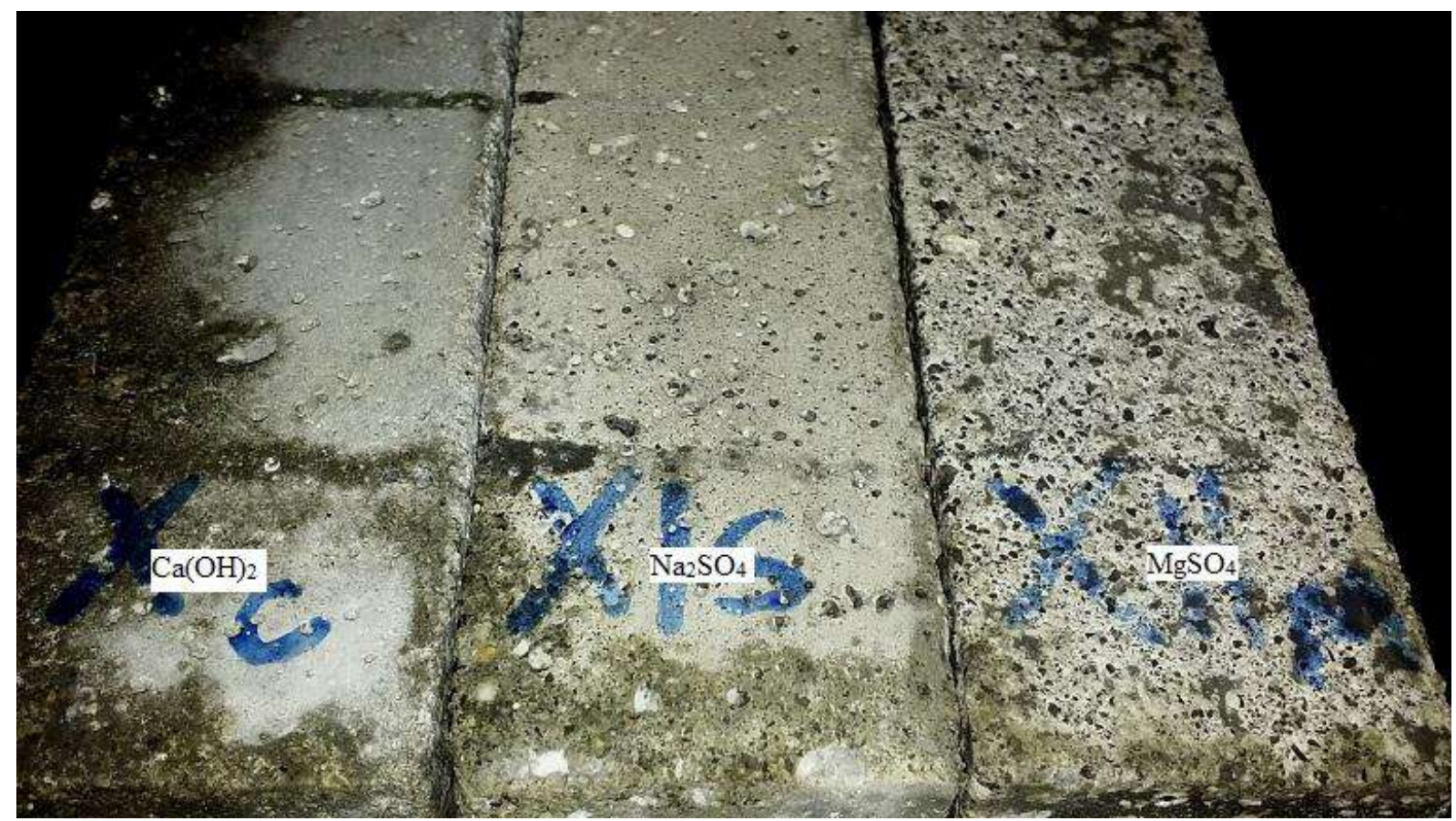

Figura 74: Comparação visual entre a influência das três soluções nas quais a série SA fora exposta $\left(\mathrm{Ca}[\mathrm{OH}]_{2}\right.$, referência; $\mathrm{Na}_{2} \mathrm{SO}_{4}$, sulfato de sódio; e $\mathrm{MgSO}_{4}$, sulfato de magnésio).

Por fim, comenta-se que a análise da degradação das séries expostas às soluções de sulfato pelos métodos das variações resultantes volumétricas, variações resultantes de massa e variações resultantes das velocidades ultrassônicas foram satisfatórias, pois apresentaram características singulares e que podem auxiliar na quantificação do grau de ataque por sulfatos. Essencialmente, no ataque por sulfato de sódio, houve uma correlação muito elevada entre os resultados obtidos nas barras de argamassa de $40 \times 40 \times 160 \mathrm{~mm}$ e as barras de $25 \times 25 \times 285 \mathrm{~mm}$, para 20 semanas de exposição, conforme Figura 75.

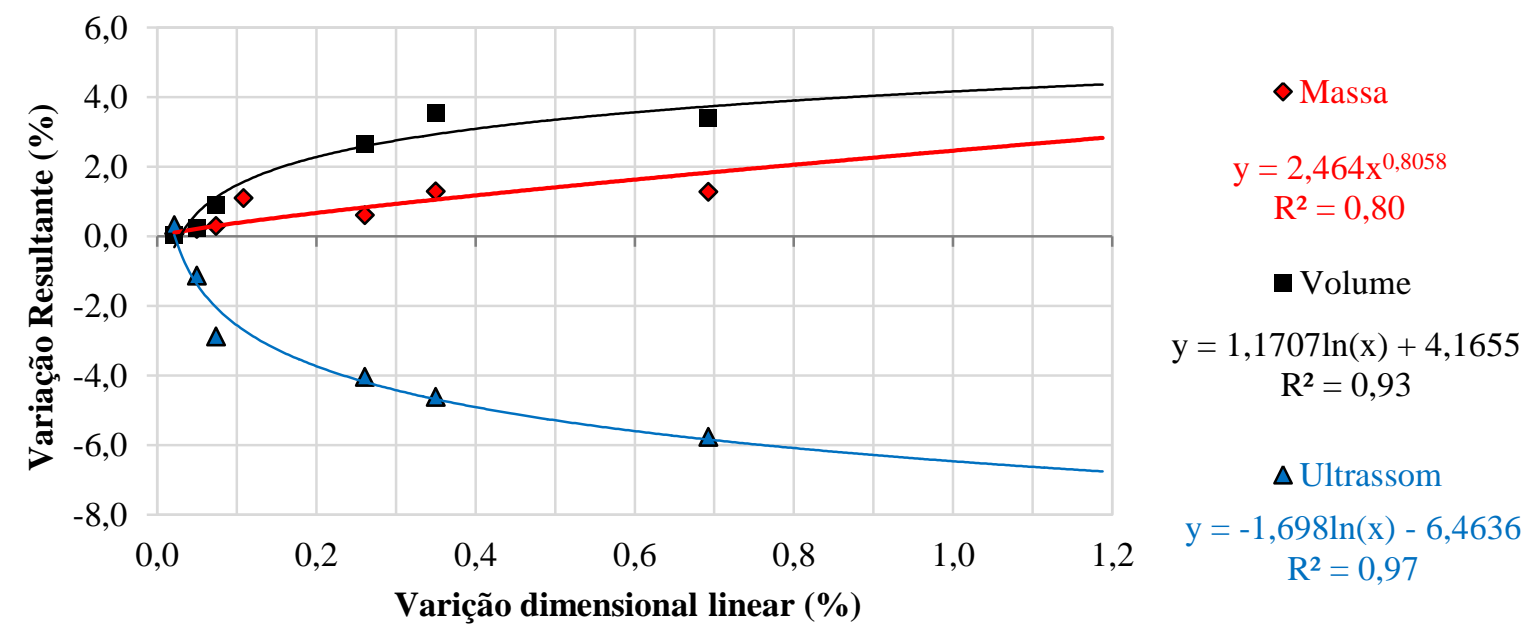

Figura 75: Correlação entre os resultados obtidos para amostras de dimensões $40 \times 40 \times 160 \mathrm{~mm}$ e $25 \times 25 \times 285 \mathrm{~mm}$ frente à exposição ao ataque por sulfato de sódio. 
Soma-se que a avaliação para maiores períodos de exposição também tornam os resultados mais confiáveis. Por exemplo, em sua maioria, as barras de argamassa tiveram, para todas as análises, uma intensificação da degradação a partir de 8 semanas de exposição, o que retifica comentários a respeito de que a NBR 13.583:2014 analisa pobremente a influência dos íons sulfato nas amostras estudadas.

O acompanhamento da degradação das barras de argamassa pela variação da velocidade ultrassônica mostrou resultados satisfatórios, essencialmente, para maiores idades. Em tempos de exposição de até 10 semanas, houve uma alta variabilidade nos resultados obtidos, todavia, de modo geral a tendência foi de queda da propagação da velocidade ultrassônica nas séries estudadas.

\subsection{ANÁLISE DO COMPORTAMENTO MECÂNICO}

A análise do comportamento mecânico das séries estudadas para as diferentes soluções de imersão serão apresentadas e divididas em três tópicos: Variação do módulo de elasticidade dinâmico (resultados obtidos a partir da obtenção da massa, volume e velocidade de propagação do som); Variação na resistência à tração na flexão; e, por fỉm, Variação na resistência à compressão.

\subsubsection{Variação no módulo de elasticidade dinâmico $\left(E_{c d}\right)$}

O módulo de elasticidade longitudinal dinâmico é relacionado diretamente com a propagação de ondas de ultrassom no corpo, contudo, segundo Isaia (2011), o $E_{c d}$ apresenta valor superior ao módulo de elasticidade estático. Segundo o autor, as características do concreto ou argamassa, afetam ambos os módulos de maneiras diferentes, não havendo uma relação única entre os mesmos. Independentemente desta diferença que ambas as propriedades possam apresentar, a obtenção do $E_{c d}$ torna-se importante por ser obtido através de ensaios não destrutivos e de fácil realização, que acrescenta informações qualitativas para avaliação e análise de elementos estruturais.

Desta maneira, com intuito de analisar a influência e avaliar o grau do ataque por sulfatos em corpos de prova de argamassa, inicialmente serão apresentados e discutidos os resultados de módulo de elasticidade dinâmico para exposição às soluções de imersão por um 
período de 6 semanas (42 dias), conforme Figura 76, visando uma análise quanto ao tempo de exposição preconizado pela NBR 13.583:2014.

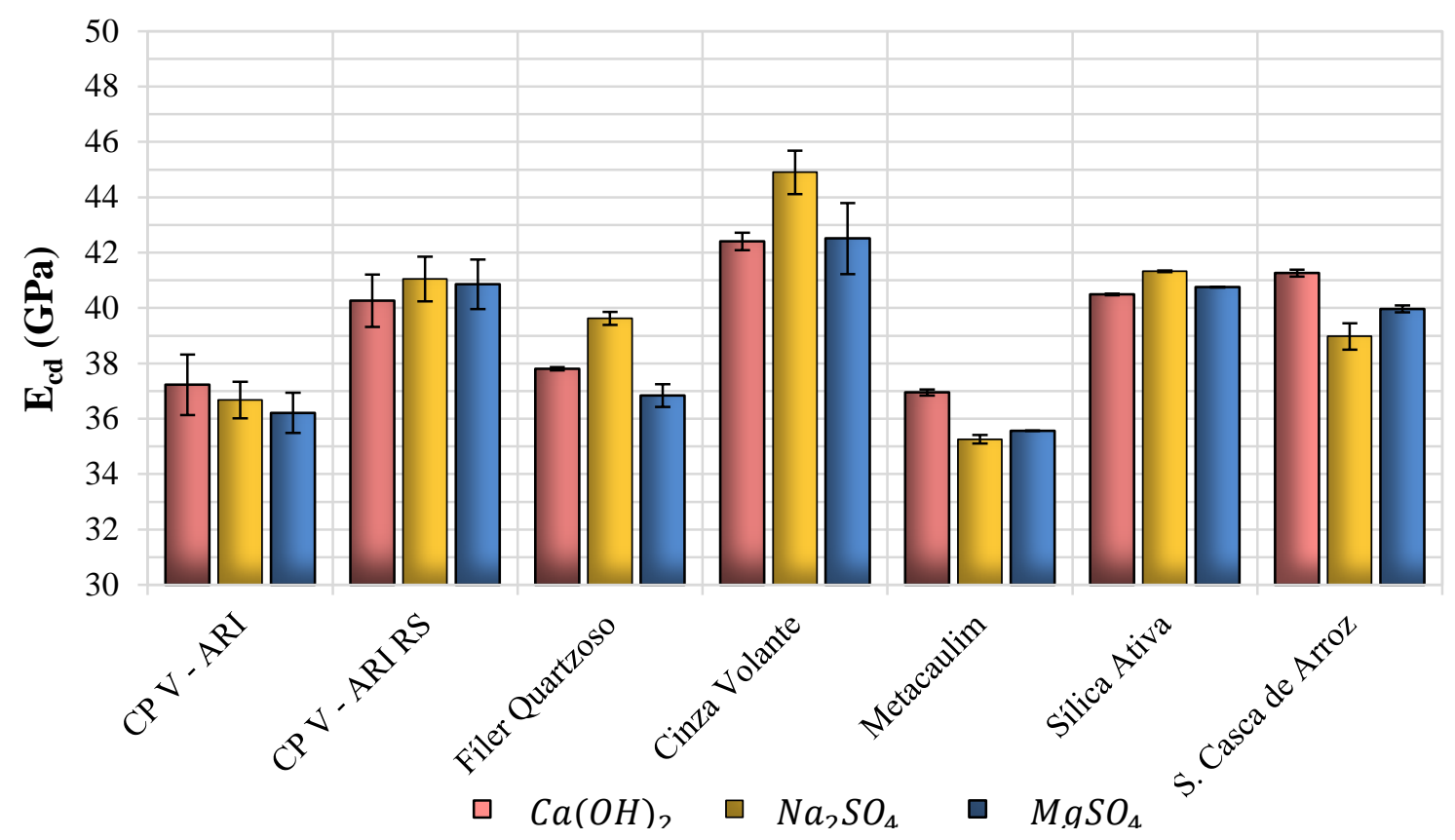

Figura 76: Módulo de Elasticidade Dinâmico para as séries estudadas e expostas por 6 semanas (42 dias) para cada uma das soluções de imersão: Esquerda, referência $\left(\mathrm{Ca}[\mathrm{OH}]_{2}\right)$; centro, sulfato de sódio $\left(\mathrm{Na}_{2} \mathrm{SO}_{4}\right)$; e, direita, sulfato de magnésio $\left(\mathrm{MgSO}_{4}\right)$.

De maneira geral, observa-se que para uma mesma série, as variações de soluções não tiveram grandes influências nos resultados, e isso se mostrou verdade com a análise comparativa entre médias pelo teste de Tukey ( 
Tabela 45, Apêndice 1) cujos resultados indicaram que apenas as seguintes combinações apresentaram comportamento não equivalente: FQ para soluções $\mathrm{Na}_{2} \mathrm{SO}_{4}$ e $\mathrm{MgSO}_{4}$; $\mathrm{SCA}$ para soluções $\mathrm{Ca}(\mathrm{OH})_{2}$ e $\mathrm{Na}_{2} \mathrm{SO}_{4}$; e, CV para soluções $\mathrm{Ca}(\mathrm{OH})_{2}$ e $\mathrm{Na}_{2} \mathrm{SO}_{4}$, e, $\mathrm{Na}_{2} \mathrm{SO}_{4}$ e $\mathrm{MgSO}_{4}$. Todas as demais 17 combinações mostraram equivalência estatística.

Portanto, 6 semanas não é um período de exposição suficiente para avaliação da influência das soluções de imersão no módulo de elasticidade dinâmico dos corpos de prova, o que indica, mais uma vez que, mesmo tratando-se de uma análise acelerada para o ataque por sulfatos, 42 dias, conforme preconizado pela NBR 13.583:2014, não são satisfatórios. Deste modo, a Figura 77 mostra a variação resultante do módulo de elasticidade dinâmico ao longo das 20 semanas de exposição para as soluções finais.

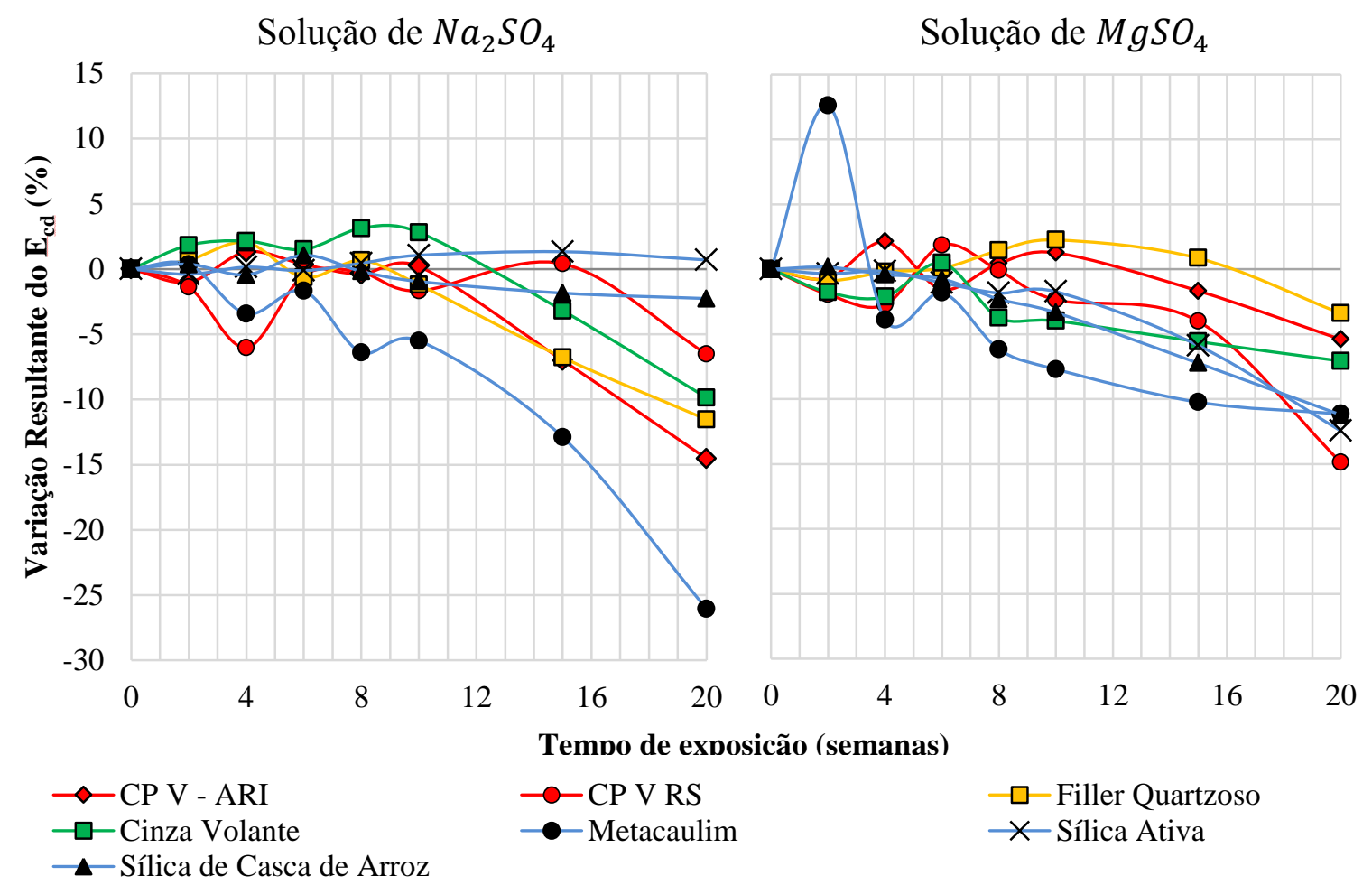

Figura 77: Variação Resultante no Módulo de Elasticidade Dinâmico das amostras expostas ao sulfato de sódio e ao sulfato de magnésio por um período de 20 semanas.

Houve uma tendência de diminuição do $E_{c d}$ nas séries estudadas, indicando que as amostras, ao longo do estudo, ficaram mais deformáveis para uma mesma solicitação de tensão, perdendo rigidez. Tais resultados são tangíveis aos analisados na bibliografia, como os de Rozière et al. (2009) e Brunetaud et al. (2012). Congruente com os demonstrados pelos autores, os resultados da presente pesquisa mostraram um ligeiro aumento na rigidez nas primeiras semanas de exposição. Tal ganho pode estar relacionado ao preenchimento dos vazios das argamassas por produtos da interação com os íons sulfato, o que favorece o ganho 
de massa e acelera a propagação do pulso ultrassônico, como de fato ocorreu, influenciando diretamente os resultados.

Entretanto, a aplicação do método para períodos curtos de exposição não apresentou boa sensibilidade para avaliação dos danos causados devido ao ataque por sulfatos. Todavia, a partir da oitava semana, as variações no módulo de elasticidade dinâmico foram significativas, essencialmente, devido ao início das fissurações, e, consequente deterioração das argamassas. Nesta linha de raciocínio, os resultados obtidos por Bassuoni e Nehdi (2009) indicam que em baixos períodos de exposição há uma maior variabilidade nos resultados obtidos para módulo de elasticidade dinâmico, contudo para tempos mais prolongados fica evidente a influência do ataque por sulfatos no $\mathrm{E}_{\mathrm{cd}}$, exatamente como foi constatado nesta pesquisa.

Comportamentos muito importantes que foram obtidos com tal análise são os das séries SA, SCA, e, principalmente, CPV - ARI RS, porque nos três casos, as séries mostraram-se como ótimas opções para mitigação do ataque por sulfato de sódio, porém, quando expostas ao sulfato de magnésio obtiveram os piores resultados, especialmente, a série composta por cimento do tipo resistente aos sulfatos.

Tamanha variação obtida para a série RS (-14,87\%), devido à exposição ao $\mathrm{MSSO}_{4}$, indica um sólido mais deformável. Se associado a grandes maciços, como por exemplo, uma barragem por gravidade ou blocos de fundações de edifícios, nos quais as solicitações de tensão são elevadas, as deformações diferenciais ${ }^{3}$ dos elementos podem ocasionar em fissurações subsequentes e sobrecarga. Em outras palavras, o cimento RS testado se configurou como uma má opção na composição de concretos expostos ao sulfato de magnésio.

Por se tratar de uma informação obtida através de equações em função de outras variáveis, $o E_{c d}$, por sua vez, acaba por ficar dependente, em maior ou menor escala, para cada uma destas. Desta forma, a Figura 78 mostra a relação entre as variáveis, variação resultante de massa, volume, velocidade ultrassônica e módulo de elasticidade dinâmico obtidos para 20 semanas de exposição ao sulfato de sódio e magnésio.

\footnotetext{
${ }^{3}$ pode ocorrer devido a presença de íons sulfato em diferentes concentrações em diferentes regiões do mesmo elemento, o que pode ocasionar em um gradiente de ataque, decorrendo em material mais deformável em alguns pontos e menos deformáveis em outros.
} 


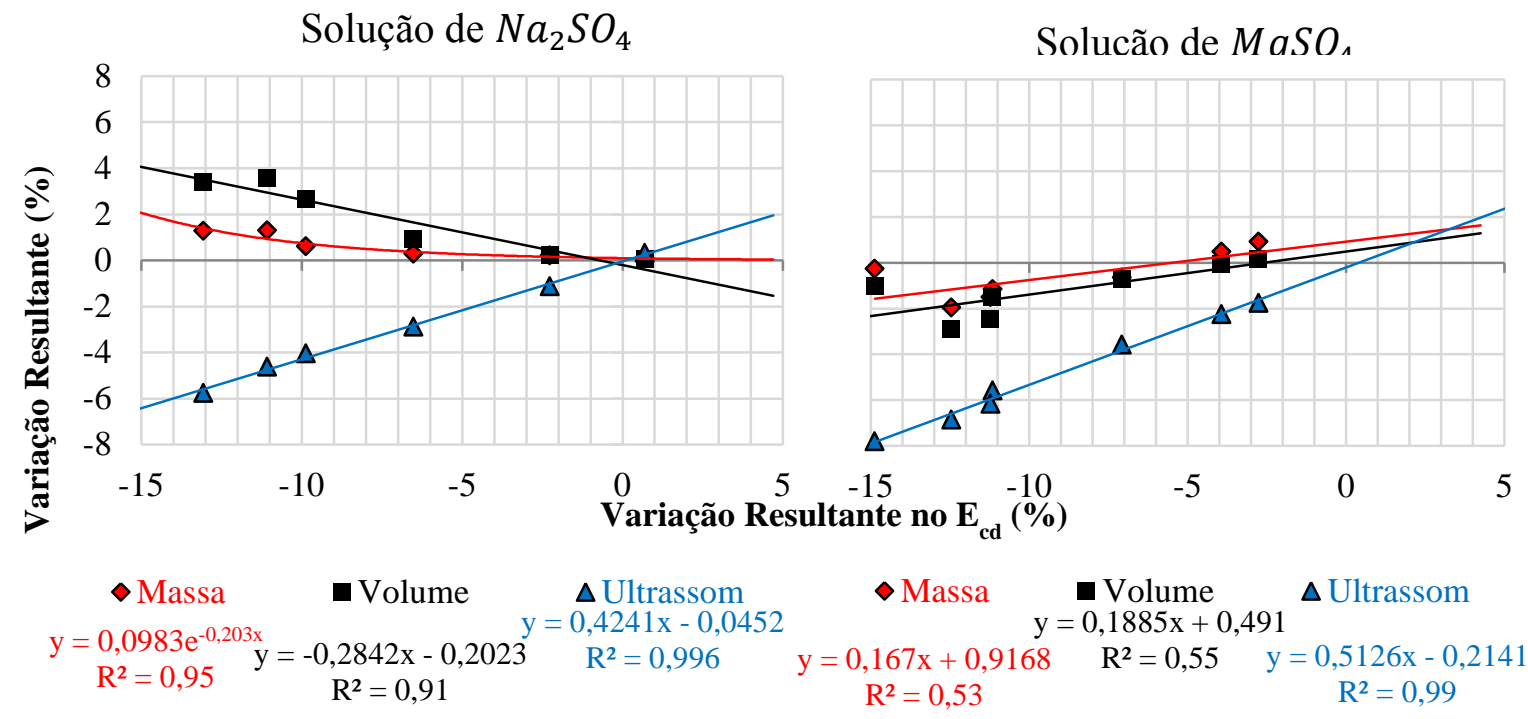

Figura 78: Relação entre as variações resultantes de volume, massa e de velocidade ultrassônica com a variação resultante do módulo de elasticidade dinâmico, para 20 semanas de exposição ao sulfato de sódio e sulfato de magnésio.

Deve observar, mais uma vez, a tendência inversa entre variação volumétrica e de massa para exposição ao ataque por sulfato de sódio e o sulfato de magnésio, assim como, que o módulo de elasticidade dinâmico, por ser função quadrática da velocidade, é muito mais sensível às variações de propagação de ondas ultrassônicas. Como já comentado, este último é função direta da variação volumétrica e de massa. Logo, os resultados destas três análises estão entrelaçados e possuem boa sensibilidade para exposição aos sulfatos por períodos maiores, gerando informações importantes quanto aos comportamentos das amostras, como por exemplo, o $\mathrm{E}_{\mathrm{cd}}$.

A seguir são apresentados com a Figura 79 os resultados de módulo de elasticidade dinâmico obtidos na $20^{\circ}$ semana de exposição devido à imersão nas três soluções finais. 


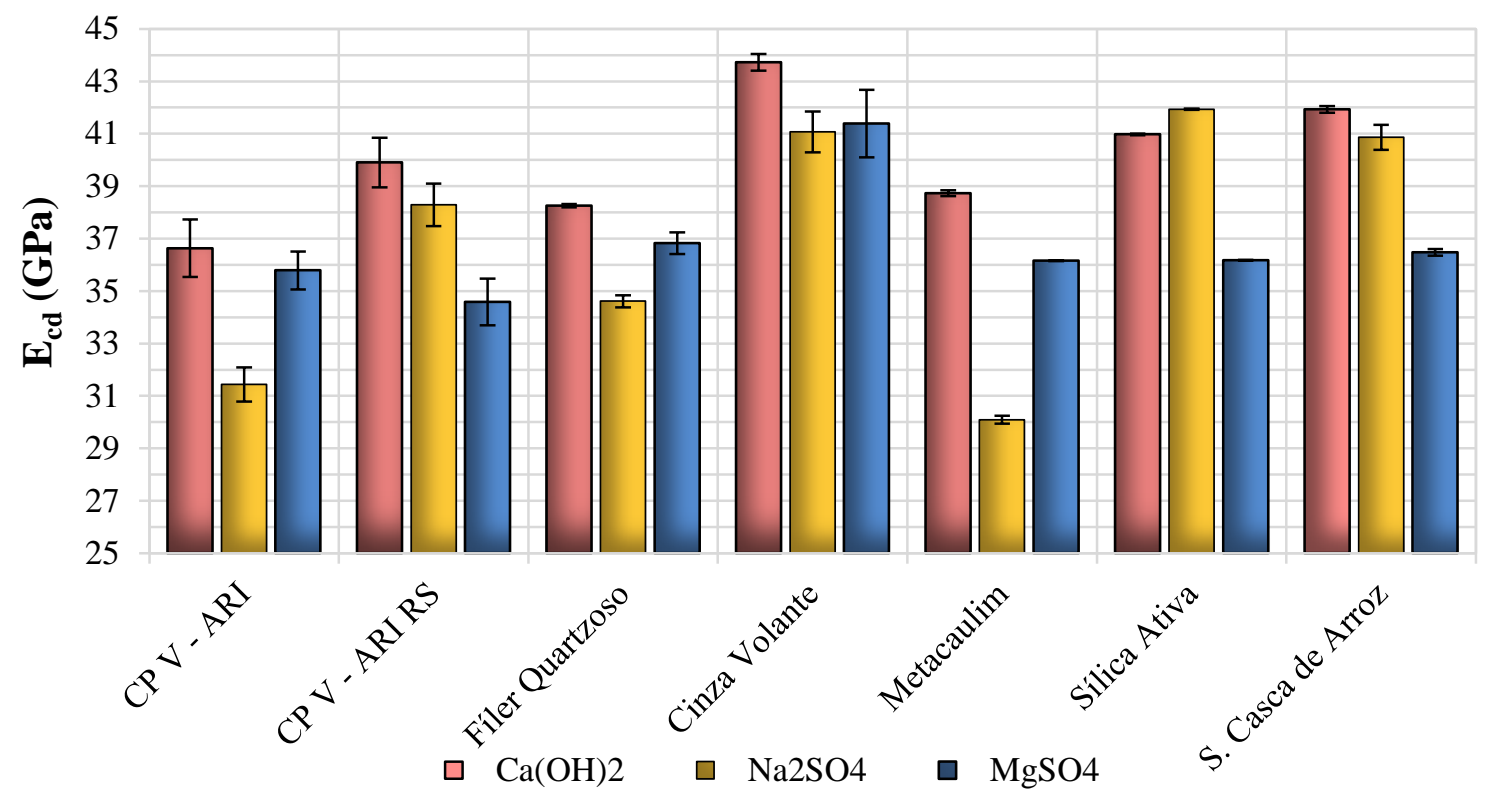

Figura 79: Módulo de Elasticidade Dinâmico para as séries estudadas e expostas por 20 semanas (140 dias) para cada uma das soluções de imersão: Esquerda, referência $\left(\mathrm{Ca}[\mathrm{OH}]_{2}\right)$; centro, sulfato de sódio $\left(\mathrm{Na}_{2} \mathrm{SO}_{4}\right)$; e, direita, sulfato de magnésio $\left(\mathrm{MgSO}_{4}\right)$.

Contrariamente a exposição de 6 semanas, para os 140 dias houve uma influência bastante significativa das soluções de sulfatos de sódio e de magnésio nas séries estudadas. Interessante evidenciar que, de modo geral, as séries CP V - ARI e FQ mostraram-se mais vulneráveis ao sulfato de sódio, enquanto as RS, SA e SCA tiveram desempenho pior frente ao sulfato de magnésio.

- Séries referências (CPV-ARI e RS): Ambas as séries, mais uma vez, apresentaram comportamentos opostos, a CP V - ARI mostrou-se mais propensa à degradação quanto ao $\mathrm{Na}_{2} \mathrm{SO}_{4}$ e estatisticamente equivalente quando comparados os resultados para imersão em $\mathrm{Ca}(\mathrm{OH})_{2}$ e $\mathrm{MgSO}_{4}$. Por outro lado, a CP V - ARI RS apresentou piores resultados quando exposta ao $\mathrm{MgSO}_{4}$ e um comportamento semelhante quando comparados $\mathrm{Ca}(\mathrm{OH})_{2}$ e $\mathrm{Na}_{2} \mathrm{SO}_{4}$.

Tais resultados obtidos trazem informações muito importantes, pois o cimento testado e vendido como RS não apresentou resistência contra o sulfato de magnésio, obteve resultados satisfatórios apenas para o $\mathrm{Na}_{2} \mathrm{SO}_{4}$. Portanto, antes da tomada de decisão quanto às definições dos materiais a serem utilizados em campo, é de suma importância ter conhecimento de qual o cátion associado ao ânion sulfato ao qual o concreto estará exposto.

- Série com adição Inerte $(F Q)$ : com a utilização de fíler quartzoso na composição das argamassas, os resultados foram muito semelhantes à referência $\mathrm{CP}$ V - ARI, e, com a 
utilização do teste de Tukey pôde-se concluir que ambas as séries são equivalentes, a exceção da exposição ao sulfato de sódio, na qual a FQ obteve resultados melhores. Logo, mesmo que a utilização de fíler quartzoso não tenha ocasionado grandes efeitos mitigativos frente ao ataque por sulfato de magnésio, seu uso seria interessante considerando as implicações econômicas e sustentáveis, afinal, a substituição parcial de $10 \%$ do cimento Portland por fíler na composição da matriz reduz o consumo de cimento, e, ao mesmo tempo, não piora o desempenho quanto ao ataque por sulfato de magnésio. Considerando o ataque por sulfato de sódio, o FQ se mostrou eficiente em reduzir os efeitos deletérios deste mecanismo de degradação.

- Série com adição de pozolana de baixa reatividade $(C V)$ : a $\mathrm{CV}$, dentre todas as séries, foi a que apresentou comportamento mais semelhante para ambas às soluções agressivas, sendo os resultados obtidos, segundo a comparação entre médias pelo método de Tukey, equivalentes entre si. Logo, pode-se dizer que não houve interferência significativa dos cátions associados aos íons sulfato no módulo de elasticidade dinâmico da $\mathrm{CV}$. Isto pode estar relacionado pelo fato da cinza volante ter apresentado propriedades químicas “intermediárias" entre as adições, ou seja, apresentou reatividade com o $\mathrm{CH}$, porém baixa. $\mathrm{O}$ que, de modo geral, foi benéfico quanto ao $\mathrm{Na}_{2} \mathrm{SO}_{4}$, quando comparado à referência, e ao mesmo tempo, pelo baixo consumo de portlandita, fez com que o ataque do $\mathrm{MgSO}_{4}$ também não se agravasse.

- Séries com adições de pozolanas de elevada reatividade (MT, SA e SCA): Mais uma vez, as adições de alta reatividade SA e SCA obtiveram resultados ambíguos, apresentando-se como excelentes opções no embate ao ataque por sulfato de sódio, todavia, frente ao $\mathrm{MgSO}_{4}$, o comportamento fora o oposto.

Já a MT, por sua vez, mostrou a maior degradação dentre as séries estudadas quando exposta ao $\mathrm{Na}_{2} \mathrm{SO}_{4}$, mesmo tratando-se de uma adição pozolânica de alta reatividade comumente associada a concretos de alta resistência e desempenho.

Portanto, fica claro com os resultados obtidos até então que se ter conhecimento do tipo de sulfato ao qual o material cimentício estará exposto é de suma importância, principalmente porque se viu uma singularidade na interação dos cátions associados ao $\mathrm{SO}_{4}^{2-}$ com as composições estudadas. Ou seja, séries com menor desempenho frente ao $\mathrm{Na}_{2} \mathrm{SO}_{4}$ obtiveram melhores resultados quando expostos ao $\mathrm{MgSO}_{4}$, e, quanto maior o desempenho frente o $\mathrm{Na}_{2} \mathrm{SO}_{4}$, piores foram os resultados para exposição ao $\mathrm{MgSO}_{4}$. 


\subsubsection{Variação na resistência à tração na flexão}

A seguir a Figura 80 mostra os resultados obtidos para resistência à tração na flexão das séries imersas nas três soluções finais para os períodos de exposição de 6 e 20 semanas.

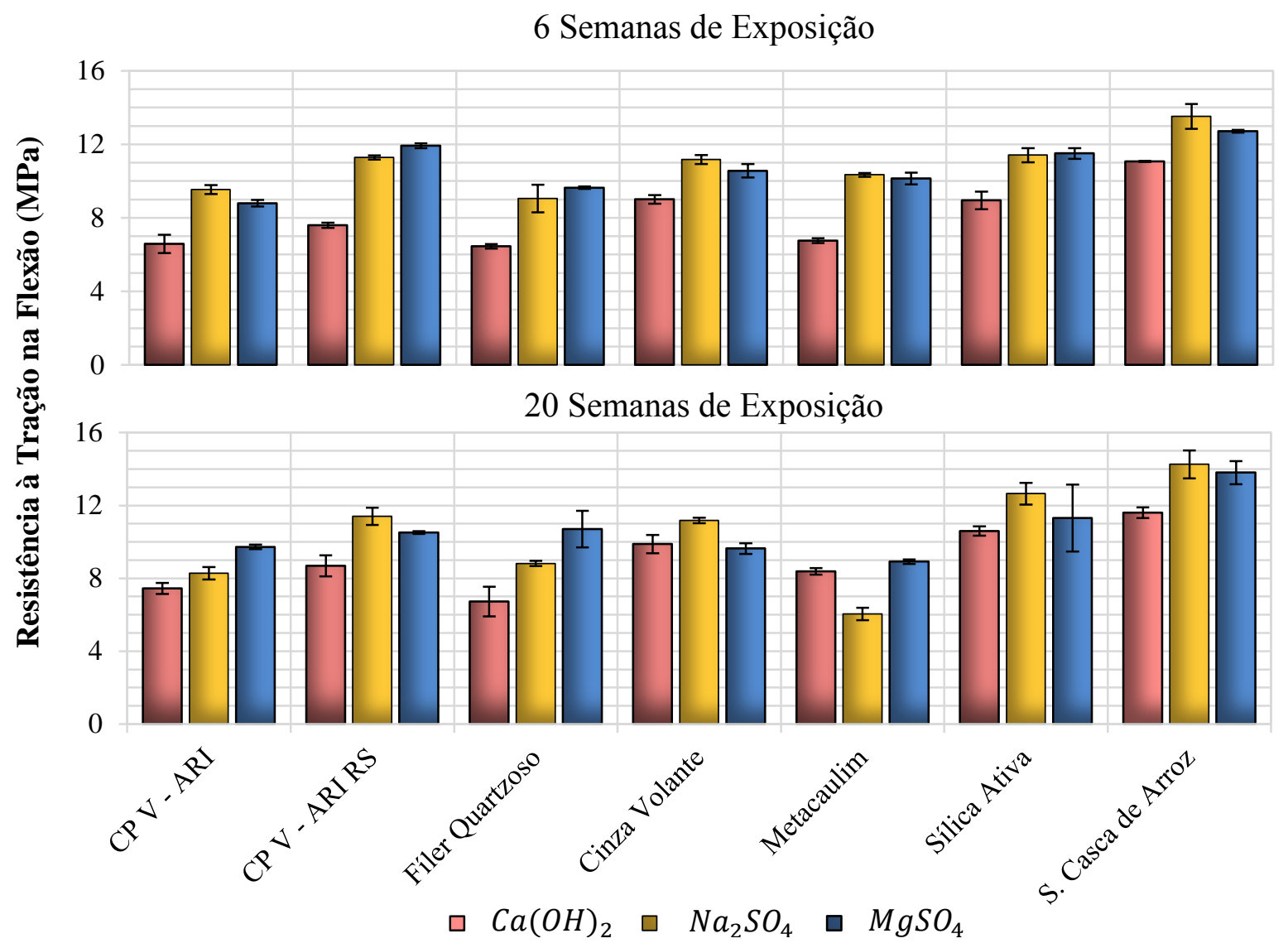

Figura 80: Resistencia à Tração na Flexão para exposição de 6 e 20 semanas às três soluções finais $\left(\mathrm{Ca}[\mathrm{OH}]_{2}\right.$, $\mathrm{Na}_{2} \mathrm{SO}_{4}$ e $\mathrm{MgSO}_{4}$ ).

De maneira geral, a influência das soluções agressivas favoreceu o aumento da resistência de tração na flexão das amostras estudadas, tendo como única exceção à interação da MT com o sulfato de sódio. Neste mesmo sentido, vê-se também que ambas as soluções agressivas mostraram comportamento semelhante nas amostras de acordo, por exemplo, com os resultados obtidos por Huang et al. (2015). Todavia, no presente trabalho, tais comportamentos podem, inclusive, ser considerados estatisticamente semelhantes, conforme pode ser visto com a Figura 81 que mostra o teste de Tukey para análise comparativa entre médias de mesmas séries para soluções distintas. Para as demais comparações, vê-se a Tabela 47 e Tabela 48, apresentada no Apêndice 1 do presente trabalho. 

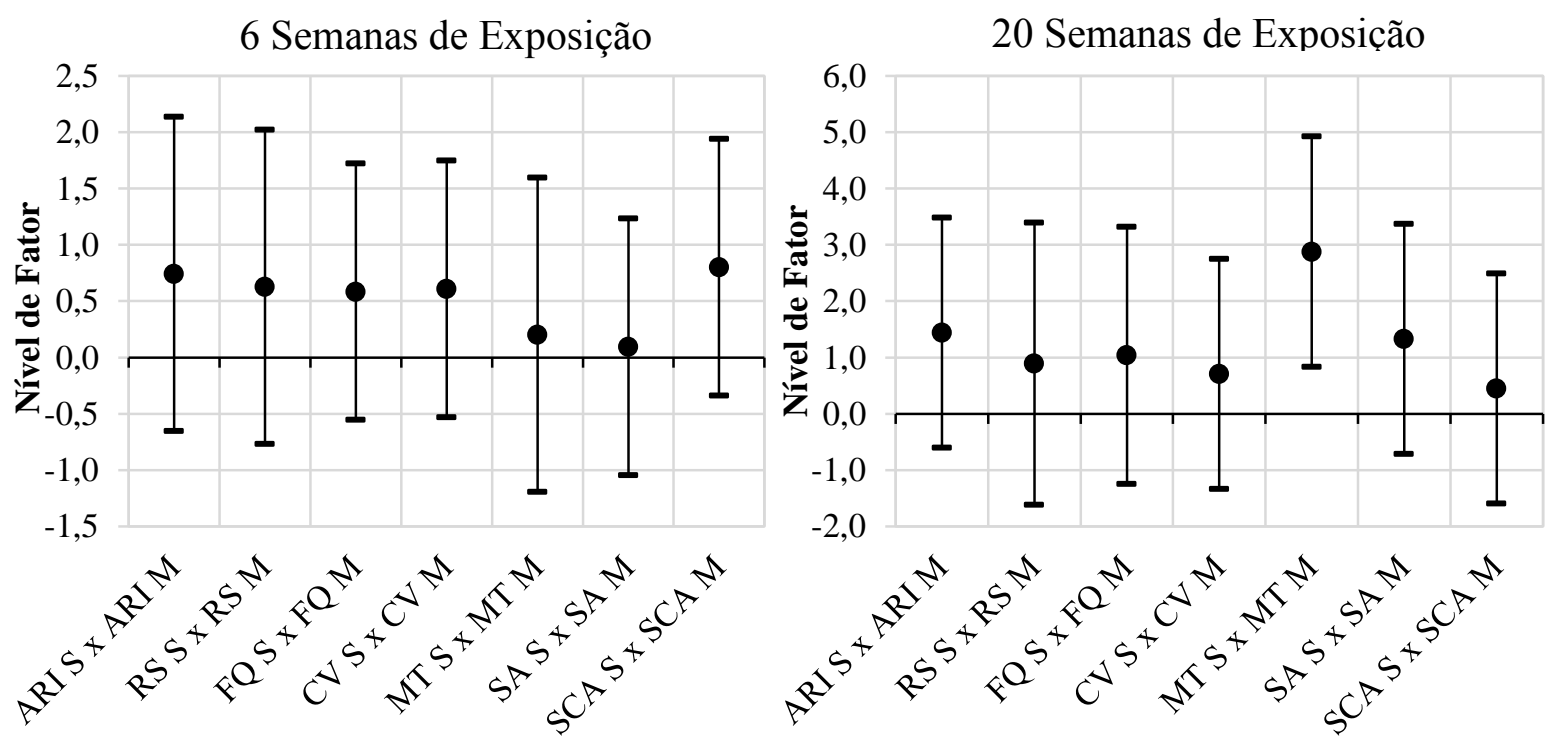

Figura 81: Análise comparativa entre médias (teste de Tukey para nível de significância de 5\%) de mesmas séries para soluções agressivas distintas ( $\mathrm{S}$ - sulfato de sódio e $\mathrm{M}$ - sulfato de magnésio) para 6 e 20 semanas de exposição.

De acordo com Isaia (2011), Neville e Brooks (2013) e Mehta e Monteiro (2014), adições minerais, de modo geral, causam redução na porosidade da matriz cimentícia e da zona de transição. Este fato leva a uma melhora tanto na resistência à compressão como na de tração, sendo para esta última em menor escala até que haja uma majoração da resistência intrínseca aos produtos da hidratação do cimento presentes na ZT. Ou seja, segundo Isaia (2011) enquanto houver teores elevados de $\mathrm{CH}$ nesta região, a resistência à tração permanecerá invariável. Assim, a adição de fíleres, ao mesmo tempo em que podem ocasionar um aumento significativo da resistência à compressão, na tração, a interferência pode ser mínima (ISAIA, 2011). Por outro lado, a utilização de adições pozolânicas, com a consequente redução no teor de cristais de portlandita na zona de transição, segundo os autores, ocasiona, também, um expressivo aumento na resistência à tração.

Desse modo, pôde ser observado com a Figura 80 que, de modo geral, a utilização de adições minerais tendeu a aumentar a resistência à tração na flexão, com exceção do fíler quartzoso, estando de acordo com as afirmações supracitadas.

Para Marciano (1993), a resistência à tração não é um bom parâmetro para acompanhamento da degradação ocasionada pelo ataque por sulfatos, seja para resistência à tração na flexão como na de compressão diametral, principalmente para ensaios de curto período de exposição. 
Todavia, Biczók (1972) e Irassar (1990) comentam que adotando o ensaio de resistência à tração na flexão observa-se que a variação da resistência aumenta com o tempo de exposição do ataque, até um ponto limite, a partir do qual se inicia um decréscimo da mesma. E, de acordo com Irassar (1990), pode-se extrair desta tendência parabólica, o tempo de início da microfissuração das amostras o que, segundo o autor, condiz com o ponto no qual há a mudança no sinal do coeficiente angular, logo, onde a derivada é igual à zero.

Desta forma, a Figura 82 apresenta os resultados de resistência à tração na flexão para as séries de amostras ao longo de 20 semanas de exposição às três soluções finais.

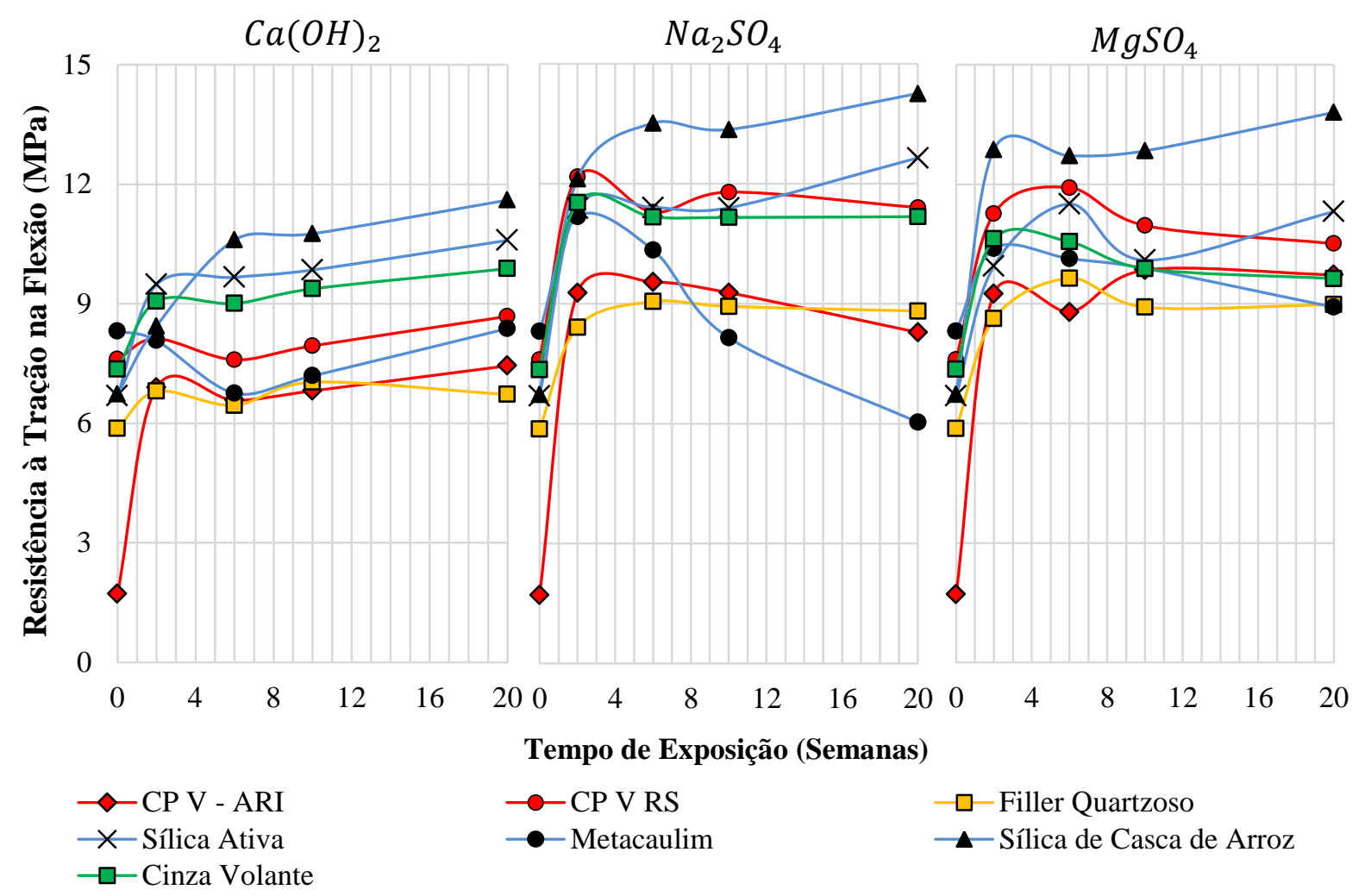

Figura 82: Resistência à Tração na Flexão para as séries de amostras ao longo de 20 semanas de exposição às três soluções finais $\left(\mathrm{Ca}[\mathrm{OH}]_{2}, \mathrm{Na}_{2} \mathrm{SO}_{4}\right.$ e $\left.\mathrm{MgSO}_{4}\right)$.

Seguindo o raciocínio de Irassar (1990), vê-se na Figura 82 que as amostras expostas à solução de hidróxido de cálcio, de maneira geral, obtiveram uma tendência de aumento da resistência em função do tempo, mesmo que apresentando algumas variações em 6 e 10 semanas. Desta maneira, pressupõe-se que as barras não manifestaram fissurações, como era de se esperar, haja vista que as argamassas permaneceram em condições ideais de cura. Em contrapartida, quando sujeitas às soluções agressivas, viu-se, de fato, conforme o autor supracitado, uma tendência de aumento da resistência ao longo do tempo até certo ponto ao qual se inicia a microfissuração, com exceção das séries SA e SCA que, apesar de certa 
variação ao longo do tempo, tenderam a ampliar suas resistências. Portanto, buscou-se obter a equação polinomial mais representativa para cada umas das séries e então obteve-se os pontos aos quais suas derivadas primeira igualam-se à zero, conforme Tabela 21.

Tabela 21: Tempo para Início da Fissuração das amostras expostas às soluções de $\mathrm{Na}_{2} \mathrm{SO}_{4}$ e $\mathrm{MgSO}_{4}$.

\begin{tabular}{ccccc}
\hline \multicolumn{2}{c}{ TEMPO DE INÍCIO DA MICROFISSURAÇÃO } \\
(Semanas)
\end{tabular}

De modo geral, o tempo de início da microfissuração, a partir do ensaio de resistência à tração na flexão, é menor em algumas semanas do que os tempos nos quais os resultados de variação volumétrica, de massa, velocidade ultrassônica e do módulo de elasticidade dinâmico também passam por maiores variações. Logo, pressupõe-se que este retardo de tempo possa estar associado à propagação da fissuração até um determinado ponto no qual a sensibilidade dos demais ensaios as detectam.

Contudo, a escala associada aos valores obtidos não condizem, de forma direta, ao grau do ataque por sulfato para cada uma das amostras, entretanto, a obtenção do tempo de fissuração mostrou-se valiosa para determinação do início da degradação pelas soluções agressivas.

Os resultados obtidos confirmam as afirmações contidas nos trabalhos de ISAIA, 2011; NEVILLE E BROOKS, 2013; e, MEHTA E MONTEIRO, 2014 a respeito do uso de adições minerais pozolânicas interferirem positivamente na resistência a tração das argamassas. Isto ocorre porque reduzem o teor de $\mathrm{CH}$ e aumentam a porção de cristais de $C-S-H$ presente nas regiões mais frágeis dos compostos.

Por fim, viu-se que houve nas leituras realizadas na semana 0 (idade das amostras igual a 14 dias) um acréscimo de resistência. Isto está relacionado a três efeitos físicos preponderantes. Segundo Lawrence et al. (2003), dois destes, diluição do cimento e melhora no empacotamento das partículas, são consequências diretas da substituição ou adição destas partículas, enquanto o terceiro efeito cabe ao melhoramento da nucleação heterogênea. No que tange à hidratação do cimento Portland, tais adições, podem modificar a cinética deste 
fenômeno, especialmente quando considerado em baixas idades. Isto porque as partículas finamente moídas propiciam uma melhora na nucleação heterogênea (LAWRENCE et al., 2003; CYR et al., 2005; e HOPPE FILHO, 2008).

\subsubsection{Variação de resistência à compressão}

Muitas das bibliografias estudadas, inclusive a ABNT NBR 13.583:2014 têm como foco na avaliação do ataque por sulfatos, apenas a expansão linear. Desta forma, para tornar a avaliação do grau do ataque mais abrangente, decidiu-se analisar a variação da resistência à compressão de corpos de prova em função do ataque por sulfato. Neste mesmo norte, Biczók (1972), Hekal et al. (2002), Santhanam et al. (2002), Skalny et al. (2002), Lee et al. (2005), Diab et al. (2012) e Ouyang et al. (2014) comentam que a resistência à compressão é um parâmetro essencial e de grande importância a ser considerado quanto ao grau do ataque por sulfatos.

Desta forma, serão abordadas as variações causadas para tempo de exposição de 42 dias (6 semanas), tendo em vista que este é o período limite de exposição da qual a NBR 13.583:2014 preconiza, independentemente da referida norma não abordar este tipo de ensaio. Posteriormente, serão abordadas as variações ocorridas nas amostras ao longo de 20 semanas de exposição (140 dias), e, por fim, serão discutidos os comportamentos das séries de forma individual.

Desse modo, na Figura 83 são apresentados os resultados obtidos de resistência à compressão para as séries estudadas e expostas por 6 semanas (42 dias) para cada uma das soluções de imersão: referência $\left(\mathrm{Ca}[\mathrm{OH}]_{2}\right)$; sulfato de sódio $\left(\mathrm{Na}_{2} \mathrm{SO}_{4}\right)$; e, sulfato de magnésio $\left(\mathrm{MgSO}_{4}\right)$. 


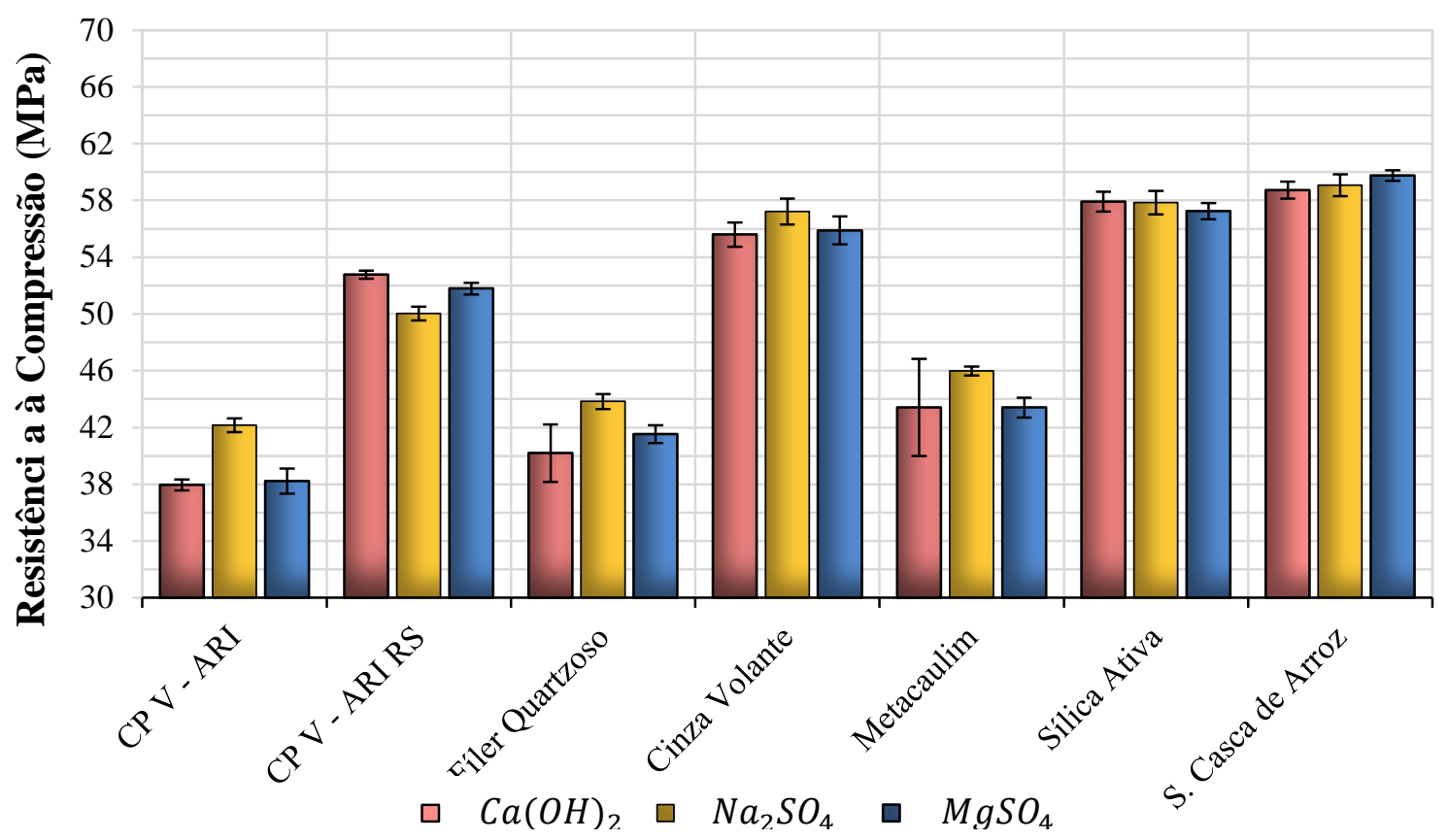

Figura 83: Resistência à Compressão para as séries estudadas e expostas por 6 semanas (42 dias) para cada uma das soluções de imersão: Esquerda, referência $\left(\mathrm{Ca}[\mathrm{OH}]_{2}\right)$; centro, sulfato de sódio $\left(\mathrm{Na}_{2} \mathrm{SO}_{4}\right)$; e, direita, sulfato de magnésio $\left(\mathrm{MgSO}_{4}\right)$.

Concernindo às discussões realizadas em tópicos anteriores, 42 dias de exposição não são suficientes para avaliação de composições expostas às soluções de sulfato. Mais uma vez, houve semelhança entre a influência das soluções finais para 6 semanas ensaiadas.

Neste mesmo norte, para a avaliação desta atuação semelhante das soluções em baixos tempos de exposição, a Figura 84 mostra o resultado do teste de Tukey realizado para comparação de equivalência dentre mesmas séries, porém expostas às soluções distintas. E, novamente, a similaridade de comportamento entre as amostras leva a acreditar que a solução de imersão não influi nos resultados para períodos curtos de exposição.

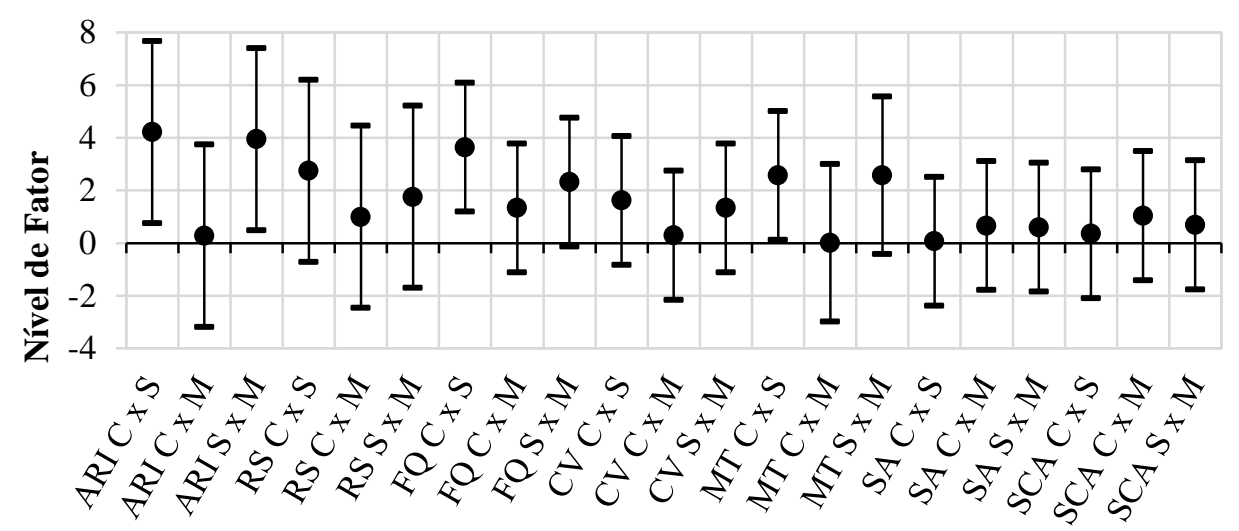

Figura 84: Análise comparativa entre médias de resistência à compressão (teste de Tukey para nível de significância de 5\%) de mesmas séries para soluções agressivas distintas (C - hidróxido de cálcio, $\mathrm{S}$ - sulfato de sódio e M - sulfato de magnésio) para 6 semanas de exposição. 
Apesar de os dados da Figura 83 não suportarem este fato, segundo Biczók (1972) e Ouyang et al. (2014), amostras expostas à solução de sulfato de sódio, em um momento inicial, têm sua resistência aumentada. Também neste sentido, Ouyang et al. (2014) analisando o ganho de dureza superficial do concreto expostos ao $\mathrm{Na}_{2} \mathrm{SO}_{4}$ obtiveram aumentos significativos de resistência nas primeiras idades, e uma perda abrupta para tempos de exposição maiores.

Analisando a evolução da variação de resistência à compressão ao longo de 20 semanas (Figura 85), as afirmações de Biczók (1972) e Ouyang et al. (2014) tornam-se mais evidentes.

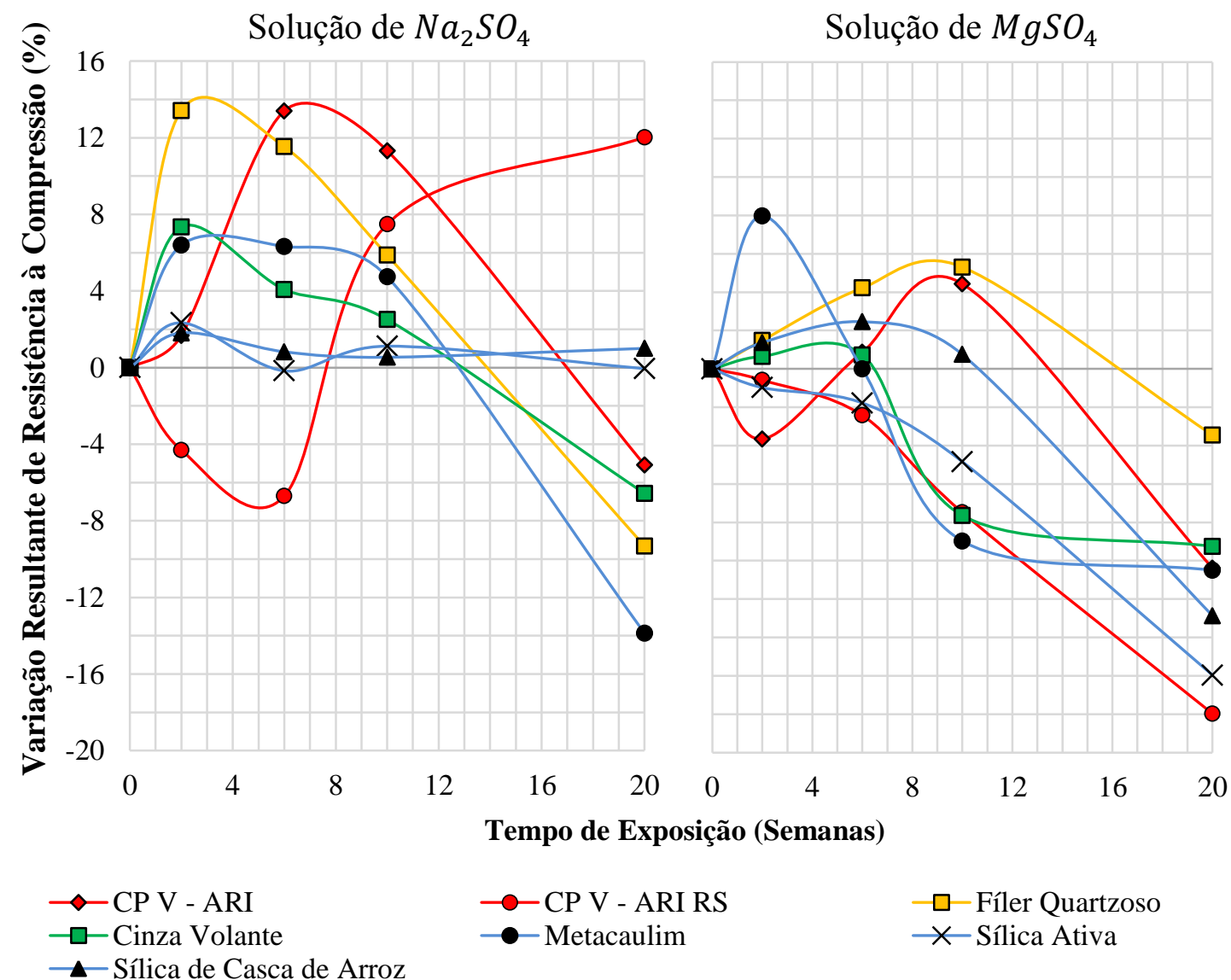

Figura 85: Variação Resultante de Resistência à Compressão das amostras expostas ao sulfato de sódio e ao sulfato de magnésio por um período de 20 semanas.

Segundo Biczók (1972) e Ouyang et al. (2014) este comportamento pode ser explicado pelo fato de que os poros das argamassas são preenchidos por cristais formados com reações de sulfatos, aumentando sua compacidade. Entretanto, estes cristais continuam a 
ganhar volume até o momento, no qual, passam a fissurar a matriz cimentante, sendo este o ponto cuja perda de resistência se inicia.

De maneira geral, observa-se ao longo das 20 semanas de exposição que o comportamento individual de cada série distingue-se entre ambas as soluções agressivas, indicando, mais uma vez, que os cátions associados aos íons sulfato também influenciam no grau do ataque. Por exemplo, vê-se que as séries SA e SCA apresentam em 20 semanas pouca variação de resistência frente ao $\mathrm{Na}_{2} \mathrm{SO}_{4}$ podendo ser consideradas com resistência elevada ao ataque por este tipo de sulfato. Contudo, as mesmas séries quando expostas ao $\mathrm{MgSO}_{4}$ mostram uma elevada redução de resistência à compressão, com perda de $12,87 \%$ para o SCA e 15,97\% para SA, que correspondem a perdas de 5,4 MPa e 5,9 MPa, respectivamente. Esta perda de resistência à compressão, segundo Skalny et al. (2002) e Lee et al. (2005) está associada à decomposição dos cristais de $C-S-H$, e, consequente, composição de estruturas $M$ $S-H$, que possuem pouca, ou nenhuma característica aglomerante e de resistência.

Desta forma, estes resultados condizem com a teoria e experimentos analisados na bibliografia, como as de Hekal et al. (2002), Santhanam et al. (2002), Diab et al. (2012), ou seja, a perda de resistência é muito mais significativa do que a expansão propriamente dita de amostras expostas ao ataque por sulfato de magnésio.

Logo, a avaliação unicamente da variação dimensional linear pode levar a conclusões errôneas de que, o ataque por sulfato de magnésio, não gera grandes deteriorações no concreto, argamassas ou pastas, quando comparado em um mesmo período de tempo para solução de $\mathrm{Na}_{2} \mathrm{SO}_{4}$. Todavia, tais resultados obtidos mostram uma realidade contrária, levando a crer que a análise do ataque por sulfatos pode ser insuficiente quando avaliado apenas pela variação dimensional linear. O que contrapõem, por exemplo, o preconizado pela NBR 13.583:2014.

No esforço para obtenção de respostas que justifiquem tais comportamentos observados, a Figura 86 mostra a correlação entre os resultados de variação de resistência à compressão (obtidos para 20 semanas de exposição ao sulfato de sódio e sulfato de magnésio) e o teor de hidróxido de cálcio remanescente teórico calculado. 


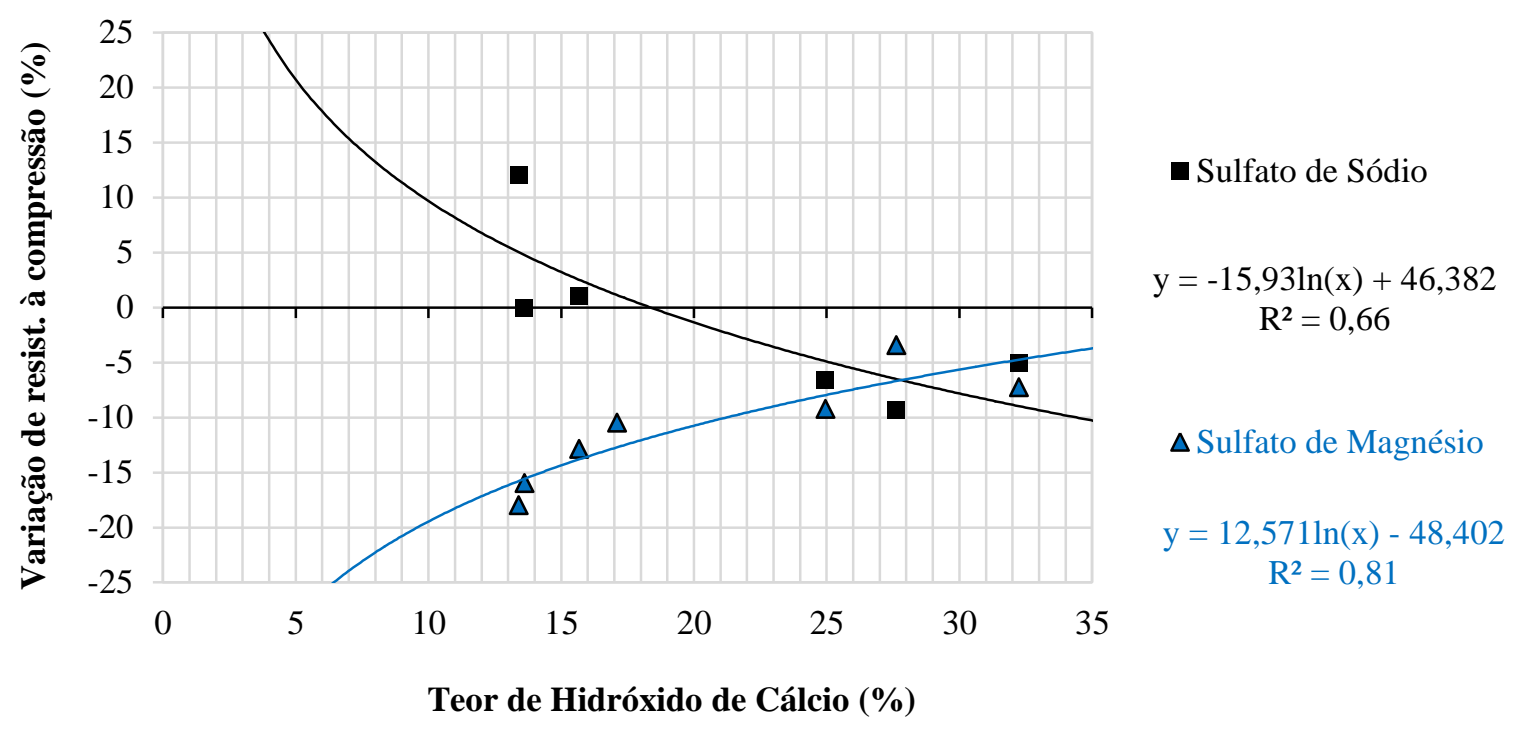

Figura 86: Correlação entre valores obtidos em 20 semanas de exposição para Variação da Resistência à Compressão com o Teor de Hidróxido de Cálcio Teórico em exposição ao sulfato de sódio e ao sulfato de magnésio.

Desta maneira, vê-se, mais uma vez, que a obtenção do teor residual de portlandita (considerando o consumo por atividade pozolânica a partir dos resultados do ensaio Chapelle) para uma composição é um bom parâmetro para tomada de decisão quanto à proteção ao ataque por sulfatos. Contudo, mais importante que a correlação obtida entre variação de resistência e teor de $\mathrm{CH}$ são os comportamentos singulares que as soluções agressivas apresentaram. Ou seja, observa-se que para exposição ao $\mathrm{Na}_{2} \mathrm{SO}_{4}$ quanto maior o teor de hidróxido de cálcio, maior o grau do ataque, tornando-os, desta forma, diretamente proporcionais. Todavia, de forma oposta, para exposição ao $\mathrm{MgSO}_{4}$, quanto menor o teor de $\mathrm{CH}$, maior o grau do ataque por sulfato de magnésio, caracterizando um comportamento inversamente proporcional.

E esta íntima relação entre o teor de $\mathrm{CH}$ e o grau do ataque por sulfatos condiz com a bibliografia, como por exemplo, Biczók (1972), Ferraris et al., (1997), Tikalsky et al. (2002), Bellmann e Stark (2007), Lee et al. (2008), Lothenbach et al. (2011), Felekoglu (2012); Neville e Brooks (2013) e Mehta e Monteiro (2014), que afirmam que a suscetibilidade de uma composição cimentícia está relacionada ao teor de portlandita que esta produzirá após a hidratação. Em contrapartida, Taylor (1997) e Santhanam et al. (2002) comentam que baixos teores de hidróxido cálcio após a hidratação deixam o concreto mais vulnerável ao $\mathrm{MgSO}_{4}$.

Nada obstante, um comportamento semelhante pode ser observado também com a análise da variação resultante do módulo de elasticidade dinâmico em função do teor de $\mathrm{CH}$ (Figura 87). 


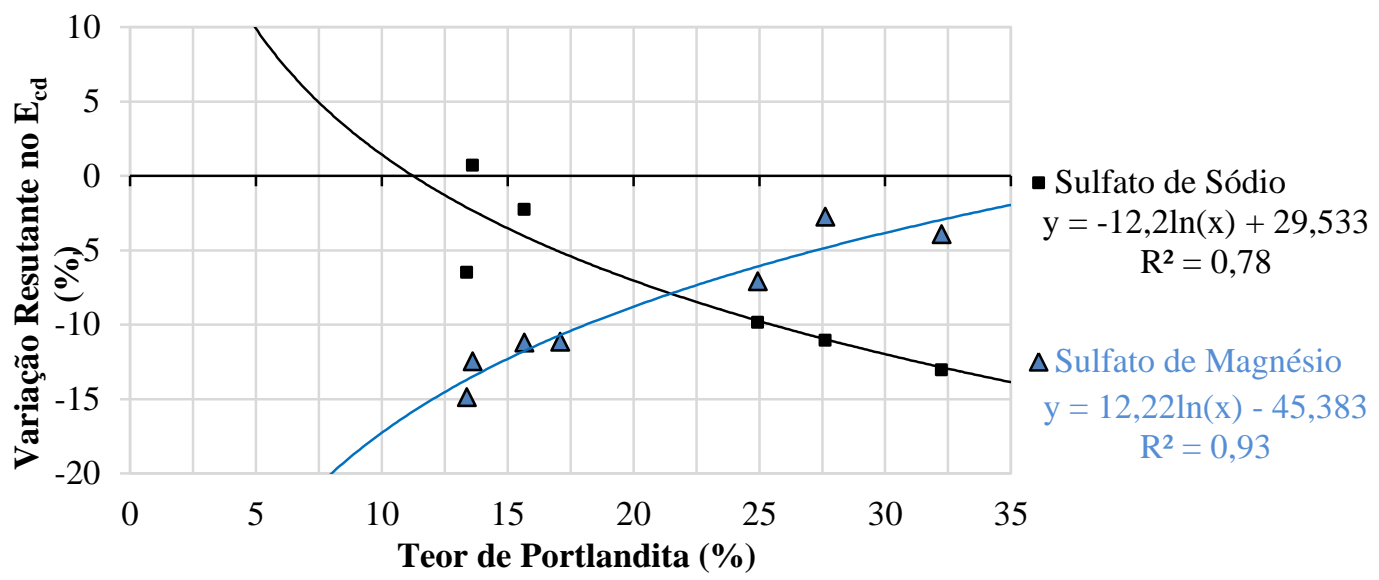

Figura 87: Correlação entre valores obtidos em 20 semanas de exposição para Variação Resultante no Módulo de Elasticidade Dinâmico com o Teor de Hidróxido de Cálcio Teórico em exposição ao sulfato de sódio e ao sulfato de magnésio.

Em outras palavras, esta semelhança comportamental das amostras reforça a validação da utilização dos ensaios de análise da variação de massa, volume, velocidade de propagação de ultrassom e $\mathrm{E}_{\mathrm{cd}}$.

A seguir a Figura 88 apresenta os resultados de resistência à compressão para as séries de amostras ao longo de 20 semanas de exposição às três soluções finais.

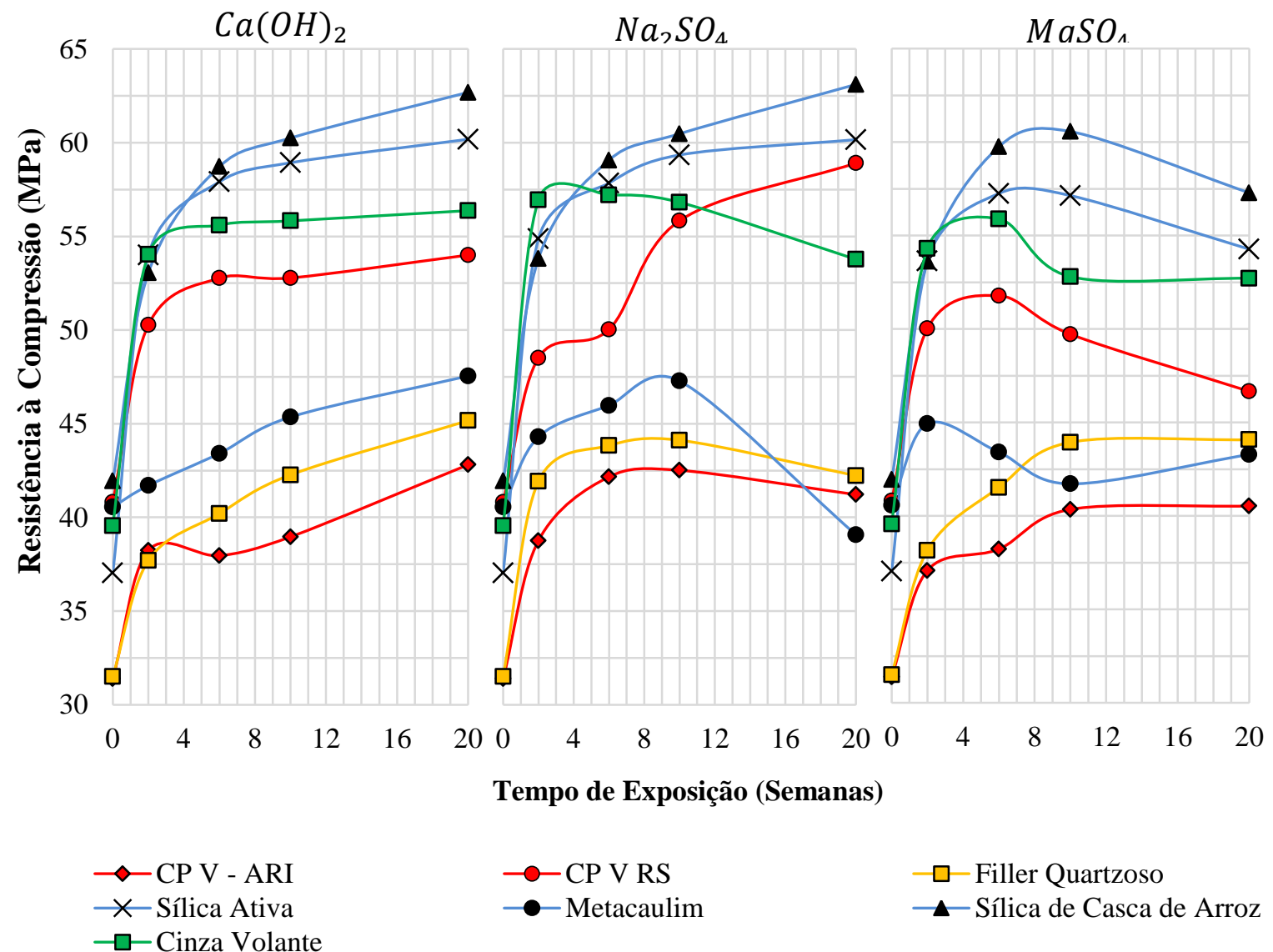

Figura 88: Resistência à Compressão para as séries de amostras ao longo de 20 semanas de exposição às três soluções finais $\left(\mathrm{Ca}[\mathrm{OH}]_{2}, \mathrm{Na}_{2} \mathrm{SO}_{4}\right.$ e $\left.\mathrm{MgSO}_{4}\right)$. 
No mesmo sentido do que foi mostrado para variação de resistência à tração na flexão, baseando-se nas afirmações de Irassar (1990) nas quais se pode extrair da evolução da resistência o ponto de iniciação da fissuração, o mesmo fora realizado para os resultados de resistência à compressão.

Assim sendo, vê-se que para exposição de amostras à solução de hidróxido de cálcio a tendência destas é de apresentarem coeficiente angular positivo ao longo das vinte semanas de imersão, ou seja, apresentando aumento na resistência à compressão. Logo, conclui-se que as barras não manifestaram fissurações. Neste mesmo sentido, as séries RS, SA e SCA para exposição ao sulfato de sódio, também apresentaram este comportamento, assim como, as ARI e FQ para o sulfato de magnésio.

Porém, as demais séries expostas em ambas às soluções agressivas mostraram características de início de fissuração. Em outras palavras, início da perda de resistência. Desta forma, a Tabela 22 apresenta os pontos nos quais a variação da resistência à compressão em função do tempo apresentam suas derivadas iguais à zero para ambas as soluções agressivas. E, se vê, de maneira geral, que tais valores são maiores do que os observados para resistência à tração na flexão, e, tal fenômeno pode ser explicado pelo fato de que a resistência à compressão é menos sensível à microfissuração das argamassas.

Tabela 22: Tempo para Início da Fissuração das amostras expostas às soluções de $\mathrm{Na}_{2} \mathrm{SO}_{4}$ e $\mathrm{MgSO}_{4}$.

\begin{tabular}{ccccc}
\hline \multicolumn{5}{c}{ TEMPO DE INÍCIO DA MICROFISSURAÇÃO } \\
\hline \multirow{2}{*}{ SÉRIE } & \multirow{2}{*}{ Solução } & $\frac{\boldsymbol{d} \boldsymbol{y}}{\boldsymbol{d} \boldsymbol{t}}=\mathbf{0}$ & Solução & $\frac{\boldsymbol{d} \boldsymbol{y}}{\boldsymbol{d} \boldsymbol{t}}=\mathbf{0}$ \\
\hline ARI & 7,15 & & 10,00 \\
RS & - & & 5,63 \\
FQ & Sulfato & 8,89 & Sulfato de & - \\
CV & de Sódio & 3,63 & Magnésio & 3,97 \\
MT & 8,86 & & 2,98 \\
SA & - & & 7,67 \\
SCA & - & & 7,40 \\
\hline - Não apresentaram $d y / d x=0$ para o intervalo de 0 \\
a 20 semanas de exposição. \\
\hline
\end{tabular}

Apesar de não indicar a intensidade do ataque por sulfatos, a obtenção dos tempos de início da fissuração tornam-se muito interessantes para se ter conhecimento do momento no qual as amostras passaram a obter variações comportamentais mais acentuadas devido à interação com os sulfatos. Ao mesmo tempo, observa-se que estes pontos coincidem com os 
padrões de variação analisados com os ensaios de variação de massa, volume, velocidade ultrassônica e módulo de elasticidade dinâmico, indicando boa relação entre os resultados.

A Figura 89 apresenta os resultados de resistência à compressão para as séries estudadas e expostas por 20 semanas (140 dias) para cada uma das soluções de imersão: referência $\left(\mathrm{Ca}[\mathrm{OH}]_{2}\right)$; sulfato de sódio $\left(\mathrm{Na}_{2} \mathrm{SO}_{4}\right)$; e, sulfato de magnésio $\left(\mathrm{MgSO}_{4}\right)$.

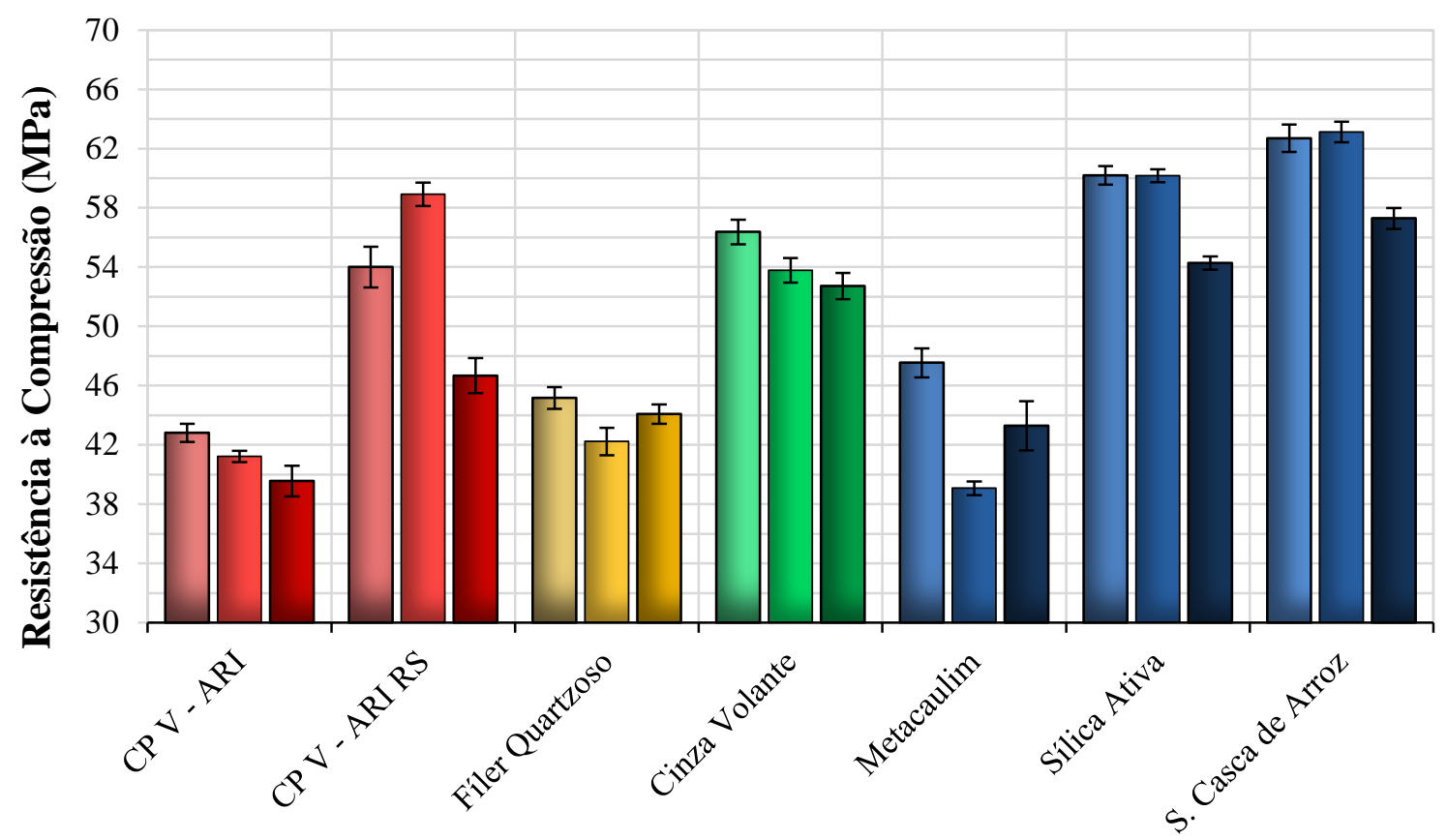

Figura 89: Resistência à Compressão para as séries estudadas e expostas por 20 semanas (140 dias) para cada uma das soluções de imersão: Esquerda, referência $\left(\mathrm{Ca}[\mathrm{OH}]_{2}\right)$; centro, sulfato de sódio $\left(\mathrm{Na}_{2} \mathrm{SO}_{4}\right)$; e, direita, sulfato de magnésio $\left(\mathrm{MgSO}_{4}\right)$.

A seguir, serão analisados e discutidos, em forma de grupos, os resultados observados na Figura 89. Comenta-se ainda que a análise comparativa entre médias (teste de Tukey) dos resultados podem ser visualizados na Tabela 49 e Tabela 50 presente no Apêndice 1 do presente trabalho.

- Séries referências (CPV-ARI e RS): vê-se que as composições químicas dos cimentos utilizados impactam diretamente nos resultados relacionados ao ataque por sulfatos. Exemplo disso, a relação $\mathrm{Ca} / \mathrm{Si}$ dos cimentos variou de 3,65 (CP V - ARI) para 2,76 (CP V - ARI RS), e, neste sentido, segundo Tikalsky et al. (2002), Bellmann e Stark (2007) e Lothenbach et al. (2011), a diminuição desta relação implica em redução no teor de portlandita após a hidratação, consequentemente, segundo os autores, isso torna a composição mais resistente ao sulfato de sódio. Opostamente, para o sulfato de magnésio, segundo Taylor (1997) e Santhanam et al. 
(2002), tal redução resulta em uma composição mais suscetível ao ataque. Desta forma, para ambos os casos, o que se viu foi, justamente, um comportamento das amostras conforme informações obtidas na literatura.

$\mathrm{Na}$ comparação direta entre os resultados obtidos para cada um dos cimentos utilizados, pode ser visto com a Figura 90, que a alteração dos aglomerantes hidráulicos possui significativa influência nos resultados de resistência à compressão e variação de resistência para soluções de sulfato de sódio e de magnésio.

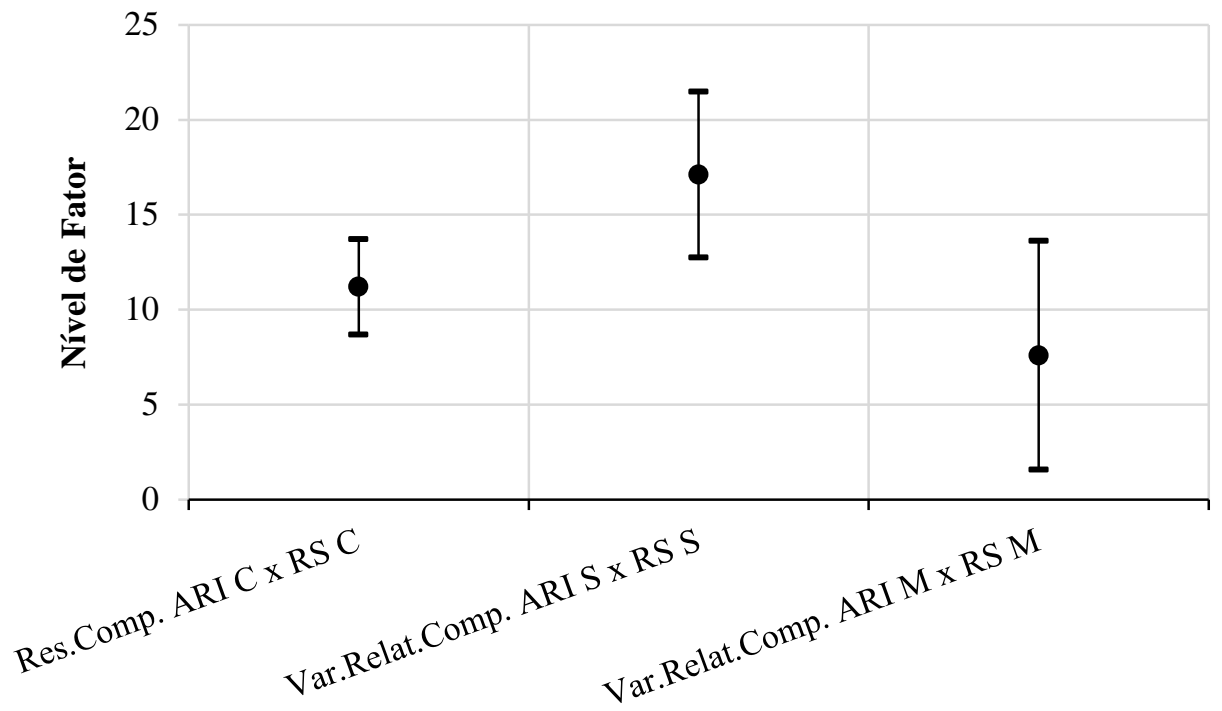

Figura 90: Análise comparativa entre médias de resistência à compressão (teste de Tukey para nível de significância de 5\%) entre as séries ARI e RS para soluções agressivas distintas (C - hidróxido de cálcio, $\mathrm{S}$ - sulfato de sódio e $\mathrm{M}$ - sulfato de magnésio) para 20 semanas de exposição.

Para a exposição da série CP V - ARI às soluções agressivas, de modo geral, houve redução nas resistências de compressão para 20 semanas de interação, podendo, inclusive, ser consideradas estatisticamente equivalentes. Logo, conclui-se que a interação, seja do $\mathrm{Na}_{2} \mathrm{SO}_{4}$ ou do $\mathrm{MgSO}_{4}$, obteve o mesmo comportamento para o CP V - ARI.

Por outro lado, o mesmo não ocorrera com o cimento do tipo RS, o que se vê para este caso, são comportamentos antônimos para ambas as soluções agressivas.

Para exposição ao sulfato de sódio, a série obteve um substancial ganho de resistência quando comparado à mesma série exposta à solução de $\mathrm{CH}$. Ao mesmo tempo, conforme discutido anteriormente, a RS obteve baixa expansão, logo, fazendo um paralelo entre estes resultados, o que se conclui é que, houve de fato, interação com os íons sulfato, porém, não de grau elevado. Ou seja, houve formação de gipsita nos 
poros das argamassas, porém não gerando esforços suficientes para maiores expansões e maiores degradações, assim, houve aumento de resistência. O que consolida tal afirmação é o ganho de massa de 0,29\% relacionado a esta série, assim como a análise de DRX realizada, que convergem que a RS obtivera formação de gipsita e também de etringita.

Deve-se ressaltar, que análises que forem realizadas para maiores períodos de exposição do que os testados podem indicar maiores degradações da referida série, afinal, houve formação de produtos degradantes preenchendo os poros da matriz, porém não suficientes para diminuir o desempenho da série para 20 semanas.

Contudo, contraditoriamente aos resultados da exposição ao $\mathrm{Na}_{2} \mathrm{SO}_{4}$, os obtidos a partir da interação com o $\mathrm{MgSO}_{4}$ apresentaram intensa degradação a este tipo de sulfato, no que diz respeito à variação de resistência à compressão. Resultados estes, que possuem informações importantes no que tange a degradação frente ao ataque por sulfatos, principalmente quando se faz um paralelo com estruturas reais, haja vista que estas sempre são projetadas a partir da resistência característica do concreto.

Ao mesmo tempo, tamanha degradação não foi observada para expansão dimensional linear, logo, conclui-se que parametrizar o ataque por sulfatos apenas pelo comportamento unidimensional pode ocasionar em erros na tomada de decisão para definição dos materiais a serem utilizados.

Conjuntamente, abordar apenas um tipo de sulfato, como recomenda a NBR 13.583:2014, não se faz satisfatório, pois, como visto na presente pesquisa, o cátion associado ao íon sulfato também implica em variações de comportamento das amostras.

- Série com adição Inerte $(F Q)$ : para exposição à solução de $\mathrm{CH}$, quando comparada à série CP V - ARI com a FQ, observa-se que esta última obteve um ganho de 2,355 MPa em média, que pode ser explicado pelo efeito fíler desta adição. Neste mesmo norte, havendo um melhoramento no empacotamento de partículas, pressupõe-se que ao mesmo tempo haverá maiores dificuldades para a difusão dos íons sulfato, acarretando, consequentemente, em uma intensidade de ataque inferior à referência para um mesmo período de tempo. Para expansão linear, de fato, isto ocorreu, porém, contrapondo-se as afirmações supracitadas, para avaliação da resistência à compressão, mesmo a $\mathrm{FQ}$ obtendo um ganho de resistência para exposição ao $\mathrm{CH}$, quando analisadas as semelhanças entre médias, o que se vê (Figura 91) é que estas podem ser consideradas iguais. O mesmo também ocorre quando analisada a variação 
devido ao ataque por sulfato de sódio, já para o $\mathrm{MgSO}_{4}$ o mesmo não acontece, contudo, neste caso, a série FQ apresentou desempenho melhor que a referência.

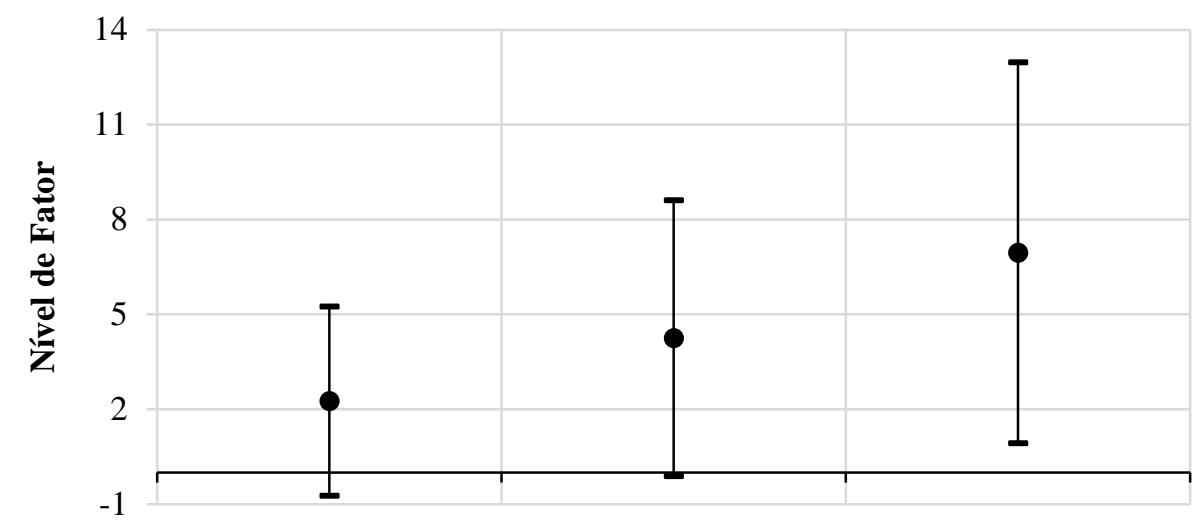

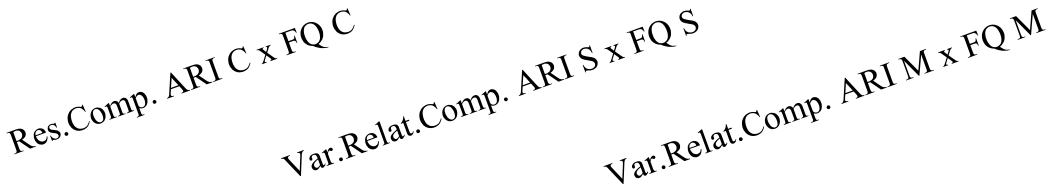

Figura 91: Análise comparativa entre médias de resistência à compressão (teste de Tukey) entre as séries ARI e FQ para soluções agressivas distintas $(\mathrm{C}$ - hidróxido de cálcio, $\mathrm{S}$ - sulfato de sódio e $\mathrm{M}$ sulfato de magnésio) para 20 semanas de exposição.

Logo, tanto para parâmetros de resistência como para o ataque por sulfato de sódio a opção pelo uso do fíler quartzoso caberia quanto às implicações econômicas e sustentáveis, afinal, o incremento de fíler na composição da matriz reduz o consumo de cimento, e, ao mesmo tempo, não piora o desempenho. Porém, para exposição ao sulfato de magnésio a utilização de fíler quartzoso se faz mais satisfatória.

- Série com adição de pozolana de baixa reatividade $(C V)$ : da mesma forma como ocorreu com a série CP V - ARI, para a CV na exposição às soluções agressivas houve redução das médias das resistências à compressão para 20 semanas, podendo estas ser consideradas estatisticamente equivalentes. Logo, conclui-se, da mesma forma, que a interação, seja do $\mathrm{Na}_{2} \mathrm{SO}_{4}$ ou do $\mathrm{MgSO}_{4}$, obteve o mesmo comportamento para a $\mathrm{CV}$.

Ainda comparando à referência, observa-se com a Figura 92, que a adição de cinza volante contribuiu, em muito, na resistência à compressão da composição. Isto está atrelado tanto ao efeito pozolânico da adição, como seu efeito fíler. Contudo, diante as interações com os íons sulfato as variações de resistência podem ser consideradas semelhantes ao CP V - ARI. 


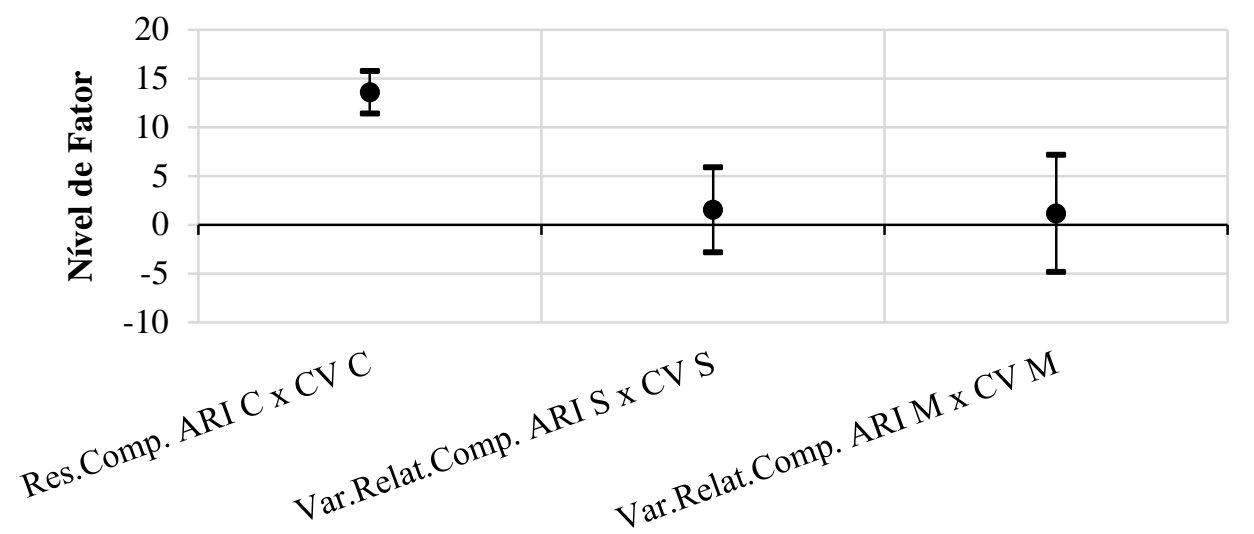

Figura 92: Análise comparativa entre médias de resistência à compressão (teste de Tukey para nível de significância de 5\%) entre as séries ARI e CV para soluções agressivas distintas (C - hidróxido de cálcio, $\mathrm{S}$ - sulfato de sódio e $\mathrm{M}$ - sulfato de magnésio) para 20 semanas de exposição.

Por fim, a opção pelo uso da cinza volante caberia quanto às implicações econômicas e sustentáveis, assim como o comentado para a série FQ.

- Séries com adições de pozolanas de elevada reatividade (MT, SA e SCA): a série composta por metacaulim foi, dentre todas as séries, a que apresentou o pior desempenho frente ao ataque por sulfato de sódio para análises tidas como poli dimensionais, o que contradiz os resultados obtidos com a avaliação da variação dimensional linear. Alguns aspectos como a variação volumétrica e de massa estão atrelados à intensa degradação que as amostras obtiveram em suas arestas, fato também observado na variação dimensional linear, como já discutido.

$\mathrm{Na}$ variação relativa de resistência à compressão, o valor, em percentual, obtido foi de 13,867\%, negativo, e, relativamente próximo ao obtido por Al-Akhras (2006), neste caso, o valor obtido foi de $-20 \%$. Tal comportamento pode estar atrelado ao teor de alumina presente no material, conjuntamente à alta reatividade, que pode ter favorecido a maior formação de etringita, conforme visualizado nos ensaios de DRX.

Quando exposto ao sulfato de magnésio, tanto a MT como as SA e SCA também apresentaram redução na resistência à compressão, entretanto, em valores estatisticamente semelhantes à referência, conforme pode ser visto com a Figura 93, na qual são apresentadas as análises comparativas entre médias de resistência à compressão (teste de Tukey) entre as séries ARI x MT, ARI x SA e ARI x SCA para soluções agressivas distintas. 


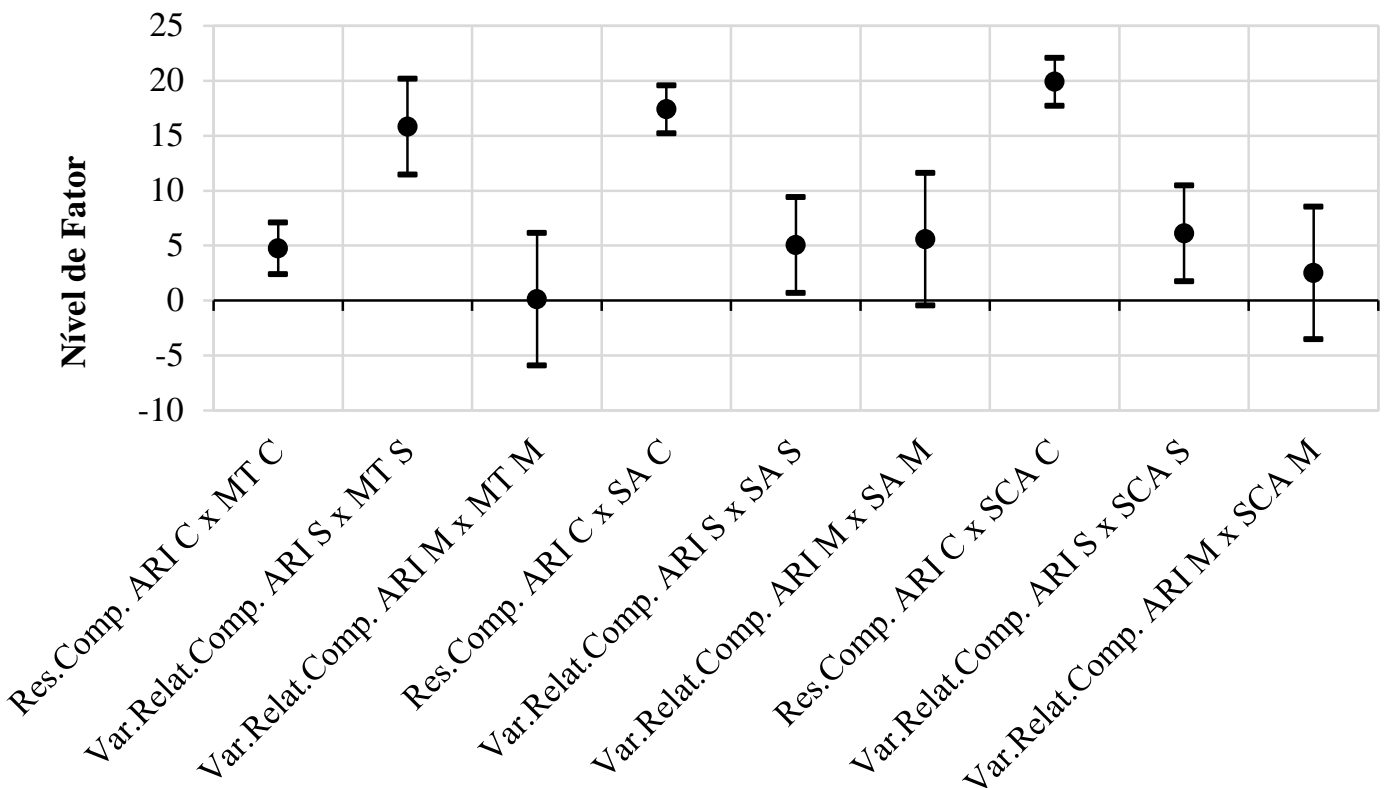

Figura 93: Análise comparativa entre médias de resistência à compressão (teste de Tukey para nível de significância de 5\%) entre as séries ARI x MT, ARI x SA e ARI x SCA para soluções agressivas distintas (C - hidróxido de cálcio, $\mathrm{S}$ - sulfato de sódio e $\mathrm{M}$ - sulfato de magnésio) para 20 semanas de exposição.

O que se vê é que as séries de alta reatividade impactaram, significativamente, nos resultados de resistência à compressão para exposição ao hidróxido de cálcio, o que era de se esperar. Contudo, a MT não acompanhou as outras duas, o que contradiz o comportamento desta pozolana segundo a bibliografia relacionada (ISAIA, 2011; NEVILLE E BROOKS, 2013; MEHTA E MONTEIRO, 2014).

Por fim, as séries compostas por sílica ativa e sílica de casca de arroz apresentaram resultados muito semelhantes entre si, mitigando o grau do ataque por sulfato de sódio não apresentando variação negativa de resistência, por outro lado, para o $\mathrm{MgSO}_{4}$ apresentaram perda, porém, semelhantes à referência, conforme pôde ser visto. 


\section{CONSIDERAÇÕES FINAIS}

O presente trabalho teve como objetivo analisar o comportamento e a influência da substituição parcial do cimento Portland por adições minerais inertes e pozolânicas em mitigar o grau do ataque por sulfato de sódio e sulfato de magnésio em argamassas e pastas de cimento Portland, por um período de exposição de 140 dias. A pesquisa foi fundamentada na análise e avaliação das características químicas do ataque por sulfatos, da variação dimensional e de propriedades físicas e mecânicas a partir da utilização de ensaios auxiliares, além dos preconizados por norma. A partir dos resultados obtidos com os ensaios descritos no programa experimental, seguem as conclusões das análises realizadas, sendo elas válidas às condições expostas ao longo deste trabalho.

\subsection{CONCLUSÕES}

\subsubsection{Quanto aos métodos utilizados para análise do ataque por sulfatos}

Mesmo se tratando de um ensaio acelerado, conforme a NBR 13.583:2014, 42 dias de exposição mostrou ser um período pouco satisfatório para a análise do ataque por sulfatos. Em virtude de que composições contendo adições pozolânicas não desenvolvem maturidade suficiente durante o período curto de exposição. Assim, a resistência ou não aos íons sulfatos está associada em maior grau às características físicas das adições, como finura e superfície específica, por exemplo. Enquanto que para períodos prolongados de exposição, as características químicas dos materiais prevalecem, logo, os resultados apresentam características mais próximas da realidade.

Desta maneira, sugere-se que na avaliação do ataque por sulfatos, que o período de exposição das amostras, segundo NBR 13.583:2014, seja prolongado, para que assim, cimento compostos possam apresentar resultados laboratoriais tangentes com os reais.

O acompanhamento do grau do ataque por sulfatos por métodos que vão além da verificação da variação dimensional linear se mostraram satisfatórios. Isto porque as aferições de variações volumétricas, de massa, propagação de ondas ultrassônicas, módulo de elasticidade dinâmico, resistência à tração na flexão e resistência à compressão tornam o acompanhamento do ataque poli dimensional, sendo então, mais abrangentes. 
A avaliação do ataque por sulfatos a partir da análise de variação volumétrica mostrou resultados de grande importância, pois apresentou comportamento antônimo aos resultados obtidos com a variação dimensional linear, no que diz respeito ao ataque por sulfato de magnésio. Isto porque, a tendência das amostras estudadas foi de perda de volume devido ao desgaste superficial, enquanto que na variação linear, obteve-se, pequena expansão.

Nada obstante, a análise da variação de massa também trouxe resultados satisfatórios, haja vista que o ganho de massa caminhou muito próximo à evolução da degradação das amostras, sugerindo que a formação de produtos decorrentes do ataque por sulfato de sódio acresce valor na mensuração da massa. Por outro lado, para o sulfato de magnésio, ocorrera perda de material decorrente da degradação das amostras, assim, houve também uma perda de massa.

Ao mesmo tempo, a validação do acompanhamento do ataque por sulfatos pelo método de leituras de pulsos ultrassônicos, e, consequente, obtenção do $E_{c d}$, tornou-se importante, essencialmente, por se tratar de um ensaio não destrutivo e de fácil realização, que acrescenta informações qualitativas para avaliação e análise de elementos estruturais. Podendo, desta forma, servir como parâmetro para balizamento do desempenho de obras reais atacados pelos sulfatos.

O acompanhamento das interações com os íons sulfato pela obtenção das resistências à tração na flexão e à compressão torna-se importante no que tange à identificação do tempo de início da microfissuração das argamassas. Além disso, a resistência à compressão é um parâmetro essencial e de grande importância a ser considerado quanto ao grau do ataque por sulfatos, haja vista, que estruturas reais são projetadas a partir da resistência característica do concreto. E, o que se viu nos resultados reforça este comentário, pois o comportamento individual de cada série distinguiu-se entre ambas as soluções agressivas, na qual as que apresentaram resistência ao sulfato de sódio foram as que tiveram pior desempenho frente ao sulfato de magnésio.

Neste mesmo sentido, conclui-se que para exposição ao sulfato de sódio há, preponderantemente, a expansão das amostras e suas devidas consequências. Expondo que composições com maiores teores aluminatos e formação de portlandita estão mais suscetíveis ao ataque.

Por outro lado, para o ataque por sulfato de magnésio há expansão em menor grau, porém, perda de resistência mecânica muito mais acentuada quando comparada ao $\mathrm{Na}_{2} \mathrm{SO}_{4}$. Apresentando que composições com menores teores de portlandita, independentemente do teor de aluminatos, estão passíveis de um grau de ataque mais severo. 
Isto indica que ambas as soluções de sulfato analisadas possuem características de ataque singulares entre si, porém, de importâncias equivalentes. Desta forma, destaca-se a relevância da inserção de mais soluções de sulfato na NBR 13.583:2014, para que esta possua uma abrangência maior.

\subsubsection{Quanto aos aglomerantes e adições}

Comprovou-se que as composições químicas das pastas (cimento + adição mineral) influenciam diretamente no grau do ataque por sulfatos, todavia, de forma antagônica para as soluções agressivas utilizadas.

Neste sentido, notou-se que a relação $C_{3} S / C_{2} S$ do clínquer possui influências opostas para ambas às soluções de sulfato. Quanto maior tal relação, mais vulnerável o cimento estará ao $\mathrm{Na}_{2} \mathrm{SO}_{4}$, enquanto que para o $\mathrm{MgSO}_{4}$, a relação torna-se mais prejudicial quanto menor for seu valor. Nada obstante, verificou-se que a diminuição da relação $C_{3} A / C_{4} A F$ amortizou o processo de expansão para exposição ao $\mathrm{Na}_{2} \mathrm{SO}_{4}$, haja vista que a produção de etringita a partir do $C_{4} A F$ ocorre em períodos de tempo muito superiores ao do $C_{3} A$. Porém, esta relação possui pouca influência quando analisado o ataque por sulfato de magnésio.

O cimento estudado, vendido no mercado brasileiro como resistente aos sulfatos mostrou-se, de fato, resistente ao ataque por sulfato de sódio. Todavia, o mesmo não ocorrera para exposição ao sulfato de magnésio, inclusive, dentre todas as composições testadas, fora a que apresentou a maior perda de resistência à compressão. Logo, indicando que este tipo de cimento não é uma boa opção em se tratando da exposição ao $\mathrm{MgSO}_{4}$.

As adições inertes, de modo geral, mitigaram os efeitos do ataque por sulfatos, em maior escala para o fíler quartzoso e menor para o calcário. Em momentos nos quais isto não ocorreu, ao menos, as séries apresentaram-se estatisticamente equivalentes à referência, logo, as adições não prejudicaram o desempenho das argamassas em nenhuma das soluções, assim, acentuam-se suas importâncias econômicas, sociais e ambientais na tomada de decisão de se usar tais adições.

A utilização de cinza volante, dentre as demais adições utilizadas, foi a que apresentou comportamentos mais próximos para ambas às soluções agressivas, indicando igualdade entre as interações com os dois tipos de sulfatos utilizados. Em sua maior parte, a adição mineral contribuiu na mitigação do ataque ocasionado, em momentos que isto não ocorrera, a mesma, ao menos, apresentou semelhança estatística à referência. Logo, concluiu-se que se trata de uma boa opção para a proteção frente aos sulfatos. 
As frações de RCV, frente ao ataque por sulfato de magnésio, mostraram-se estatisticamente semelhantes entre si e em relação à referência. Logo, o beneficiamento do material apresentou indícios insatisfatórios, pois houve aumento quanto aos custos energéticos aplicados, porém, não houve acompanhamento dos benefícios, indicando que uma maior moagem da RCV não acarreta em melhorias frente o $\mathrm{MgSO}_{4}$.

Contudo, frente ao $\mathrm{Na}_{2} \mathrm{SO}_{4}$, a significância da finura da $\mathrm{RCV}$ foi expressiva, conforme maior a área B.E.T., melhor foram os resultados. Todavia, em tempos de moagem de $0,5 \mathrm{~h}$ e 1,0 h, houve efeito de majoração da degradação, quando comparadas à referência CP V ARI. Das três frações da RCV, somente a com moagem de 1,5 h mostrou uma capacidade mitigadora frente ao $\mathrm{Na}_{2} \mathrm{SO}_{4}$, em virtude de suas propriedades físico-químicas superiores, como menor superfície especifica e maior pozolanicidade, quando comparada as outras duas séries de RCV.

A utilização de metacaulim levou a resultados contraditórios no presente trabalho, isto porque, em um primeiro momento, para variação dimensional linear, a série mostrou-se mitigadora do ataque por sulfato. Entretanto, com a realização dos ensaios tidos como poli dimensionais, os resultados foram opostos, indicando piora substancial de desempenho. Sugerindo que seu elevado grau de amorfismo, associado ao alto teor de alumina em sua composição, possam ter influenciado na formação de mais produtos expansivos, como por exemplo, etringita secundária.

As séries compostas por sílica ativa e sílica de casca de arroz mostraram-se como as mais eficientes e eficazes no embate ante o sulfato de sódio, obtendo resultados de variações dimensional próximos de zero. Em contrapartida, apresentaram intensa degradação quando expostas ao $\mathrm{MgSO}_{4}$, essencialmente, pelo alto consumo de portlandita o que deixou as argamassas mais suscetíveis à descalcificação do $C-S-H$ com a redução do $p H$, decorrente do ataque deste tipo de sulfato.

Por fim, ficou claro com os resultados obtidos, que se ter conhecimento do tipo de sulfato ao qual o material cimentício estará exposto é de suma importância, principalmente porque se viu uma singularidade na interação dos cátions associados ao $\mathrm{SO}_{4}^{2-} \operatorname{com}$ as composições estudadas. Ou seja, séries com menor desempenho frente ao $\mathrm{Na}_{2} \mathrm{SO}_{4}$ obtiveram melhores resultados quando expostos ao $\mathrm{MgSO}_{4}$, e, quanto maior o desempenho frente o $\mathrm{Na}_{2} \mathrm{SO}_{4}$, piores foram os resultados para exposição ao $\mathrm{MgSO}_{4}$. O que reforça, mais uma vez, que a abordagem para classificação do ataque por sulfatos deve sempre alcançar uma maior variabilidade de tipos de sulfatos. 


\subsection{ATUAÇÃO EM PUBLICAÇÕES}

Com o desenvolvimento do curso de mestrado, este discente participou da elaboração de diversas publicações, sendo algumas diretamente relacionadas ao tema e outras focadas em áreas correlatas.

\subsubsection{Artigos Publicados em Periódicos}

HOPPE FILHO, J.; SOUZA, D. J.; MEDEIROS, M. H. F; PEREIRA, E.; PORTELLA, K. F. Ataque de matrizes cimentícias por sulfato de sódio: adições minerais como agentes mitigadores. Revista Cerâmica, vol. 61, p.168-177, 2015.

\subsubsection{Artigos Aceitos para Publicação em Periódicos}

MEDEIROS, M. H. F; SOUZA, D. J.; PEREIRA, E.; HOPPE FILHO, J.; ADORNO, C. S.; QUARCIONI, V. A. Resíduo de cerâmica vermelha em compósito de cimento Portland: efeito no ataque por sulfatos e na reação álcali-sílica. Revista Matéria.

SOUZA, D. J.; REUS, G. C.; LACERDA FILHO, M.; CEZARIO, H. C.; FLOR, E. P.; SANTOS, E. S.; MARINHO, G.; CAMARA, L. A. Non-Destructive Testing In Bridge Structures Performance Evaluation: A Case Study. Journal of Civil Engineering and Architecture.

\subsubsection{Artigos em Processo de Avaliação para Publicação em Periódicos}

SOUZA, D. J.; YAMASHITA, L. Y.; DRANKA, F.; MEDEIROS, M. H. F.; MEDEIROSJUNIOR, R. A. Mortars containing addition of carbon nanotubes: shrinkage and sodium sulphate attack. Construction \& Building Materials.

MEDEIROS, M. H. F.; DRANKA, F.; SOUZA, D. J.; MEDEIROS-JUNIOR, R. A. Repair mortars with addition of carbon nanotubes: properties in freshly state and compressive strength. Materials and Structures.

SOUZA, D. J.; SAKAMORI, M. M.; MEDEIROS, M. H. F.; SCHEER, S. Avaliação da oportunidade de imobilização de um ativo: Um estudo de caso para uma microempresa do ramo de tecnologia de informação aplicada à construção civil. Revista Alconpat.

FERREIRA, I. R.; SOUZA, D. J.; MEDEIROS, M. H. F.; VALDÉS, A. C.; SANTOS FILHO, M. L. Proposta de aprimoramento do método dnit 010/2004-pro para avaliação de obras de arte especiais: estudo de caso em viaduto de 37 anos. Revista Alconpat.

MACIOSKI, G.; SOUZA, D. J.; BRANDAO, A. P. C.; MEDEIROS, M. H. F. Análise da corrosão de barras de aço em função da variação do pH do meio. Revista Alconpat. 
SOUZA, D. J.; AZAMBUJA, E.; MEDEIROS, M. H. F. Avaliação da eficiência de localizadores de armadura eletromagnéticos. Revista Techne.

\subsubsection{Artigos Publicação em Anais de Congresso}

SOUZA, D. J.; HOPPE FILHO, J.; MEDEIROS, M. H. F; PEREIRA, E. Potencial de mitigação do ataque por sulfatos provocado por adições minerais. In: Congresso Brasileiro de Patologia das Construções, 2014, Foz do Iguaçú. Congresso Brasileiro de Patologia das Construções - Anais. Porto Alegre: Alconpat, 2014. v. 1. p. 1419-1432.

SOUZA, D. J.; HOPPE FILHO, J.; MEDEIROS, M. H. F; PEREIRA, E. Mitigação do ataque por sulfatos empregando adições minerais: um estudo exploratório. In: Congresso Internacional Sobre Patologias e Recuperação de Estruturas, 2014, Santiago. Congresso Internacional Sobre Patologias e Recuperação de Estruturas. Santiago: Cinpar, 2014. v. 1.

SANTOS FILHO, M.; SOUZA, D. J.; FALAVIGNA, C.; ROSA, C. M.; ESTEVES, I. A. Análise das condições estruturais para recuperação de obras abandonadas: um estudo de caso (PRF). In: Congresso Brasileiro de Patologia das Construções, 2016, Belém. Anais Do Congresso Brasileiro De Patologia Das Construções CBPAT-2016, 2016. v. Único. p. 159170.

SOUZA, D. J.; MEDEIROS, M. H. F; ZORZAN, L. G.; OLIVEIRA, L. M. Estudo de caso de inspeção em uma estrutura de concreto armado através de esclerometria e ultrassom. In: Congresso Brasileiro de Patologia das Construções, 2016, Belém. Anais Do Congresso Brasileiro De Patologia Das Construções CBPAT-2016, 2016. v. Único. p. 1117-1128.

REUS, G. C.; SOUZA, D. J.; SILVESTRO, L.; MEDEIROS, M. H. F; GOMES, G. R. Influência da frente de carbonatação na resistência superficial do concreto obtida pelo método da esclerometria. In: Congresso Brasileiro de Patologia das Construções, 2016, Belém. Anais Do Congresso Brasileiro De Patologia Das Construções CBPAT-2016, 2016. v. Único. p. 1323-1330.

SOUZA, D. J.; CEZARIO, H. C.; FLOR, E. P.; SILVA, I. G. Manifestações patológicas mais frequentes em obras de arte especiais com duas vigas longitudinais. In: Congresso Brasileiro de Patologia das Construções, 2016, Belém. Anais Do Congresso Brasileiro De Patologia Das Construções CBPAT-2016, 2016. v. Único. p. 1677-1683.

SOUZA, D. J.; RAISDORFER, J.; MEDEIROS, M. H. F; CEZARIO, H. C.; REUS, G. C.; RODRIGUES, D. S.; NIKKEL, S.; TIBES, B. ; BECKER, A. C. C. Aplicação de soluções alcalinas para realcalinização de concretos carbonatados: uma alternativa para pontes de concreto armado. In: $1^{\text {o }}$ Encontro Nacional de Conservação Rodoviária, 2015, Foz do Iguaçu. $18^{\circ}$ Encontro Nacional de Conservação Rodoviária, 2015. v. 1. p. 1-15.

SOUZA, D. J.; REUS, G. C.; MEDEIROS, M. H. F; VERDERESI, T.; FERREIRA, I. R. Estudo de caso de previsão de vida útil de pontes e viadutos na região de Curitiba pelo método da resistividade elétrica e do potencial de corrosão. In: $\mathbf{1 8}^{\circ}$ Encontro Nacional de Conservação Rodoviária, 2015, Foz do Iguaçu. $18^{\circ}$ Encontro Nacional de Conservação Rodoviária, 2015. v. 1. p. 1-18 
SILVESTRO, L.; LEME, L. B. P.; KOSLOSKI, F.; SOUZA, D. J.; TORRE, E. M. L.; MEDEIROS, M. H. F. Obtenção da resistência à compressão do concreto de viadutos localizados na região de Curitiba por métodos de ensaios não destrutíveis: Esclerometria e Ultrassom. In: $\mathbf{1 8}^{\mathbf{0}}$ Encontro Nacional de Conservação Rodoviária, 2015, Foz do Iguaçu. $18^{\circ}$ Encontro Nacional de Conservação Rodoviária, 2015. v. 1. p. 1-16

FERREIRA, I. R.; SOUZA, D. J.; MEDEIROS, M. H. F. Vantagens obtidas pela realização de ensaios complementares em inspeções de avaliação de desempenho em obras de arte especiais: um estudo de caso. In: $5^{\circ}$ Congresso Brasileiro do Concreto, 2015, Bonito. Anais do $57^{\circ}$ Congresso Brasileiro do Concreto. São Paulo: IBRACON, 2015. v. Único. p. 115.

REUS, G. C.; SOUZA, D. J.; RAISDORFER, J.; MEDEIROS, M. H. F. Aplicação de soluções alcalinas para realcalinização de concretos carbonatados. In: $\mathbf{5 7}^{\circ}$ Congresso Brasileiro do Concreto, 2015, Bonito. Anais do $57^{\circ}$ Congresso Brasileiro do Concreto. São Paulo: IBRACON, 2015. v. Único. p. 1-12.

SOUZA, D. J.; AZAMBUJA, E.; MEDEIROS, M. H. F; LEVISKI, A. Avaliação da eficiência de localizadores de armadura eletromagnéticos: Inspeção preliminar em pilares de viadutos em Curitiba. In: Congresso Brasileiro de Patologias das Construções, 2014, Foz do Iguaçú. Congresso Brasileiro de Patologias das Construções - Anais. Porto Alegre: ALconpat, 2014. v. 1. p. 346-361.

\subsection{SUGESTÕES PARA TRABALHOS FUTUROS}

Com a realização deste estudo, algumas dúvidas e dificuldades geraram indicações de outros trabalhos de pesquisa que auxiliariam o avanço no conhecimento sobre o ataque por sulfatos em compósitos de cimento Portland.

Seguem algumas sugestões de trabalhos futuros:

Avaliação do ataque por sulfato de magnésio em elementos que representem o concreto armado, juntamente com uma análise do processo de corrosão das armaduras. Tendo em vista que em paralelo à interação do $\mathrm{MgSO}_{4}$ há uma brusca redução do $\mathrm{pH}$ da solução.

Avaliação da adição de fíler calcário frente o ataque por sulfatos em condições de exposição com temperaturas abaixo de $10{ }^{\circ} \mathrm{C}$, para uma análise da influência desta adição na formação de taumasita. 


\section{REFERÊNCIAS BIBLIOGRÁFICAS}

ADENOT, F.; BUIL, M. Modelling of the corrosion of the cement paste by deionized water. Cement and Concrete Research, vol. 22, p. 489 - 496, 1992.

Al-AKHRAS, N. M. Durability of metakaolin concrete to sulfate attack. Cement and Concrete Research, Vol. 36, p. 1727 - 1734, 2006.

AMERICAN CONCRETE INSTITUTE. ACI 318 Building Code Requirements for Structural Concrete and Commentary. 2011.

AKÖZ, F.; TURKER, F.; KORAL, S.; YUZER, N. Effects of sodium sulfate concentration on the sulfate resistance of mortars with and without silica fume. Cement and Concrete Research, Vol. 25, p. 1360 - 1368, 1995.

AMERICAN SOCIETY FOR TESTING AND MATERIALS. Designation C 109, Standard Test Method for Compressive Strength of Hydraulic Cement Mortars (Using 2-in. or [50-mm] Cube Specimens). Philadelphia, PA, 2013.

AMERICAN SOCIETY FOR TESTING AND MATERIALS. Designation C 452, Standard Test Method for Potential Expansion of Portland-Cement Mortars Exposed to Sulfate. Philadelphia, PA, 2010.

AMERICAN SOCIETY FOR TESTING AND MATERIALS. Designation C 1012, Standard Test Method for Length Change of Hydraulic Cement Mortar Exposed to Sulfate Solution. Philadelphia, PA, 2013.

ASSOCIAÇÃO BRASILEIRA DE NORMAS TÉCNICAS. NBR NM 23: Cimento portland e outros materiais em pó - Determinação da massa específica. Rio de Janeiro, 2001.

ASSOCIAÇÃO BRASILEIRA DE NORMAS TÉCNICAS. NBR 5737: Cimentos Portland resistentes a sulfatos. Rio de Janeiro, 1992.

ASSOCIAÇÃO BRASILEIRA DE NORMAS TÉCNICAS. NBR 5751: Materiais pozolânicos - Determinação de atividade pozolânica - índice de atividade pozolânica com cal - Método e ensaio. Rio de Janeiro, 2012. 
ASSOCIAÇÃO BRASILEIRA DE NORMAS TÉCNICAS. NBR 5752: Materiais pozolânicos - Determinação de atividade pozolânica com cimento Portland - índice de atividade pozolânica com cimento - Método e ensaio. Rio de Janeiro, 2012.

ASSOCIAÇÃO BRASILEIRA DE NORMAS TÉCNICAS. NBR 7214: Areia normal para ensaio de cimento - Especificação. Rio de Janeiro, 2012.

ASSOCIAÇÃO BRASILEIRA DE NORMAS TÉCNICAS. NBR 7215: Cimento Portland Determinação da resistência à compressão. Rio de Janeiro, 1997.

ASSOCIAÇÃO BRASILEIRA DE NORMAS TÉCNICAS. NBR 11578: Cimento Portland Especificação. Rio de Janeiro, 1991.

ASSOCIAÇÃO BRASILEIRA DE NORMAS TÉCNICAS. NBR 12653: Materiais Pozolânicos - Requisitos. Rio de Janeiro, 2015.

ASSOCIAÇÃO BRASILEIRA DE NORMAS TÉCNICAS. NBR 12655: Concreto de cimento Portland - Preparo, controle, recebimento e aceitação - Procedimento. Rio de Janeiro, 2015.

ASSOCIAÇÃO BRASILEIRA DE NORMAS TÉCNICAS. NBR 13276: Argamassa para assentamento e revestimento de paredes e tetos - Preparo da mistura e determinação do índice de consistência. Rio de Janeiro, 2005.

ASSOCIAÇÃO BRASILEIRA DE NORMAS TÉCNICAS. NBR 13279: Argamassa para assentamento e revestimento de paredes e tetos - Determinação da resistência à tração $n$ flexão e à compressão. Rio de Janeiro, 2005.

ASSOCIAÇÃO BRASILEIRA DE NORMAS TÉCNICAS. NBR 13583: Cimento Portland Determinação da variação dimensional de barras de argamassa de cimento Portland expostas à solução de sulfato de sódio. Rio de Janeiro, 2014.

ASSOCIAÇÃO BRASILEIRA DE NORMAS TÉCNICAS. NBR 15630: Argamassa para assentamento e revestimento de paredes e tetos - Determinação do módulo de elasticidade dinâmico através da propagação de onda ultra-sônica. Rio de Janeiro, 2008.

ASSOCIAÇÃO BRASILEIRA DE NORMAS TÉCNICAS. NBR 15894: Metacaulim para uso com cimento Portland em concreto, argamassa e pasta - Requisitos. Rio de Janeiro, 2010. 
ASSOCIAÇÃO BRASILEIRA DE NORMAS TÉCNICAS. NBR 15895: Materiais pozolânicos - Determinação do teor de hidróxido de cálcio fixado - Método Chapelle modificado. Rio de Janeiro, 2010.

ASSOCIAÇÃO BRASILEIRA DE NORMAS TÉCNICAS. NBR 15956: Sílica ativa para uso com cimento Portland em concreto, argamassa e pasta - Requisitos. Rio de Janeiro, 2012.

ASSOCIAÇÃO BRASILEIRA DE NORMAS TÉCNICAS. NBR 16372: Cimento Portland e outros materiais em pó - Determinação da finura pelo método de permeabilidade ao ar (método de Blaine). Rio de Janeiro, 2015.

ATAHAN, H. N.; DIKME, D. Use of mineral admixtures for enhanced resistance against sulfate attack. Construction and Building Materials, Vol. 25, p. 3450 - 3457, 2011.

ATKINS, P.; JONES, L. Princípios de Química. 5. ed. Porto Alegre: Bookman, 2011.

AYE, T.; OGUCHI, C. T. Resistance of plain and blended cement mortars exposed to severe sulfate attacks. Construction and Building Materials, Vol. 25, p. 2988 - 2996, 2011.

AZEVEDO, A. F. F. L. C. Betões de elevado desempenho com incorporação de cinzas volantes - Tese de Doutorado - Escola de Engenharia, Universidade do Minho, 2002

BARY, B.; LETERRIER, N.; DEVILLE, E.; BESCOP, P. L. Coupled chemo-transportmechanical modelling and numerical simulation of external sulfate attack in mortar. Cement and Concrete Composites, vol. 49, p. 70-83, 2014.

BASSUONI, M. T.; NEHDI, M. L. Durability of self-consolidating concrete to sulfate attack under combined cyclic environments and flexural loading. Cement and Concrete Research, Vol. 39, p. $206-226,2009$.

BAUER, L. A. F. Materiais de construção. 5. Ed. vol 1. Rio de Janeiro: LTC, 1994.

BAUER, L. A. F. Materiais de construção. 5. ed. vol 2. Rio de Janeiro: LTC, 1994.

BEHFARNIA, K.; FARSHADFAR, O. The effects of pozzolanic binders and polypropylene fibers on durability of SCC to magnesium sulfate attack. Construction and Building Materials, Vol. 38, p. $64-71,2013$. 
BELLMANN, F.; STARK, J. Prevention of thaumasite formation in concrete exposed to sulphate attack. Cement and Concrete Research, Vol. 37, p. 1215 - 1222, 2007.

BICZÓK, I. La corrosion del hormigon y su proteccion. Tradução de: ASENSI, E. J.D. 1. ed. Bilbao, Espanha: URMO, 1972.

BONAKDAR, A.; MOBASHER, B. Multi-parameter study of external sulfate attack in blended cement materials. Construction \& Building Materials, vol. 24, p. 61 - 70, 2010.

BONAVETTI, V. L.; RAHHAL, V. F.; IRASSAR, E. F. Studies on the carboaluminate formation in limestone filler-bended cements. Cement and Concrete Research, vol. 31, p. 853-859, 2001.

BONEN, D. A microstruntural study of the effect produced by magnesium sulfate on plain and silica fume-bearing Portland cement mortars. Cement and Concrete Research, vol. 23, p. $541-553,1993$.

BOWLES, O. Limestone and Dolomite. 1. ed. Michigan, Estados Unidos da América: U. S. Dept. of interior, Bureau of Mines, 1956.

BRITISH STANDARD ASSOCIATION. BS 1881 Part 203: Recommendations for measurement of velocity of ultrasonic pulses in concrete. 1986.

BROWN, P. W.; BOTHE J. J. V. The stability of ettringite. Advances in Cement Research. Vol. 18, p. $47-63,1993$.

BROWN, P. W. An evaluation of the sulfate resistance of cements in a controlled environment. Cement and Concrete Research, Vol. 11, p. 719 - 727, 1981.

BROWN, P. B. Thaumasite formation and other forms of sulfate attack. Cement and Concrete Research, Vol. 24, p. $301-$ 303, 2002.

BROWN, P. W.; HOOTON, R. D.; CLARK, B. A. The co-existence of thaumasite and ettringite in concrete exposed to magnesium sulfate at room temperature and influence of blast-furnace slag substitution on sulfate resistance. Cement \& Concrete Composites, Vol. 25, p. $939-945,2003$.

BRUNETAUD, X.; KHELIFA, M. R.; AL-MUKHTAR M. Size effect of concrete samples on the kinetics of external sulfate attack. Cement and Concrete Composites, Vol. 34, p. 370 $-376,2012$. 
CABRERA, J.; ROJAS, M. F. Mechanism of hydration of the metakaolin - lime - water system, Cement and Concrete Research, vol. 31, p. 177-182, 2001.

CALVO, J. L. G.; HIDAlGO, A.; ALONSO, C.; LUCO, L. F. Development of low-pH cementitious materials for HLRW repositories: Resistance against ground waters aggression. Cement and Concrete Research, vol. 40, p. 1290-1297, 2010.

CARNEIRO, A. M. P. Contribuição ao estudo da influência do agregado nas propriedades de argamassas compostas a partir de curvas granulométricas. 203 p. Tese (Doutorado em Engenharia da Construção Civil e Urbana) - Programa de Pós-Graduação em Engenharia Civil, Escola Politécnica, 1999.

CASCUDO, O. O controle da corrosão de armaduras em concreto: inspeção e técnicas eletroquímicas. 1. ed. Goiânia: UFG, 1997.

CHATVEERA, B.; LERTWATTANAURUK, P. Evaluation of sulfate resistance of cement mortars containing black rice husk ash. Journal of Environmental Management, Vol. 90, p. $1435-1441,2009$.

CHINDAPRASIRT, P.; KANCHANDA, P.; SATHONSAOWAPHAK, A.; CAO, H. T. Sulfate resistance of blended cements containing fly ash. Construction and Building Materials, Vol. 21, p. 1356 - 1361, 2007.

COHEN, M. D.; BENTUR, A. Durability of Portland Cement - silica fume pastes in magnesium sulfate and sodium sulfate solutions. ACI Materials Journal, Vol. 85, p. 148 157, 1998.

COLLEPARDI, M. A state-of-the-art review on delayed ettringite attack on concrete. Cement e Concrete Composites. v. 25, p. 401-407, 2003.

CORDEIRO, G. C. Utilização de cinzas ultrafinas do bagaço de cana-de-açucar e casca de arroz como aditivos minerais no concreto. Tese (Doutorado em Engenharia Civil) Universidade Federal do Rio de Janeiro. Rio de janeiro, 2006.

CORDEIRO, G. C.; TOLEDO FILHO, R. D.; TAVARES, L. M.; FAIRBAIRN, E. M. R.; HEMPEL, S. Influence of particle size and specific surface area on the pozzolanic activity of residual rice husk ash. Cement e Concrete Composites. v. 33, p. 529-534, 2011. 
CRAMMOND, N. J. The thaumasite form of sulfate attack in the UK. Cement and Concrete Composites, vol 25, p. $809-818,2003$.

CYR, M.; LAWRENCE, P.; RINGOT, E. Mineral admixtures in mortars Qualification of the physical effect inert materials on short-term hydration, Cement and Concrete Research, v. 35, 2005; p. 719-730.

DAFICO, D. A. Estudo da dosagem do concreto de alto desempenho utilizando pozolanas provenientes da casca do arroz. Tese (Doutorado em Engenharia) Universidade Federal de Santa Catarina, Florianópolis, 2001.

DAL MOLIN, D. C. C. Capítulo 8: Adições minerais. Concreto: Ciência e Tecnologia. Vol. 1, 1 Ed. São Paulo: IBRACON, 2011.

DIAB, A. M.; AWAD, A. E. M.; ELYAMANY, H. E.; ELMOATY, A. E. M. A. Guidelines in compressive strength assessment of concrete modified with sílica fume due to magnesium sulfate attack. Construction and Building Materials, Vol. 36, p. 311 - 318, 2012.

EISBERG, R.; RESNICK, R. Física Quântica. 9. Ed. São Paulo: Campus, 1994.

EL SOKKARY, T. M.; ASSAL, H. H.; KANDEEL, A. M. Effect of silica fume or granulated slag on sulphate attack of ordinary portland and alumina cement blend. Ceramics International, Vol. 30, p. 133 - 138, 2004.

FAUCON, P.; ADENOT, F.; JACQUINOT, J. F.; PETIT, J. C.; CABRILLAC, R.; JORDA, M. Long-term behaviour of cement pastes used for nuclear waste disposal: review of physicochemical mechanisms of water degradation, Cement and Concrete Research, vol. 28, p. 847-857, 1998.

FELEKOGLU, K. T. The effect of $\mathrm{C}_{3} \mathrm{~A}$ content on sulfate durability of Portland limestone cement mortars. Construction and Building Materials, Vol. 36, p. 437 - 447, 2012.

FERRARIS, C. F.; CLIFTON, J. R.; STUTZMAN, P. E.; GARBOCZI, E. J. Mechanisms of degradation of Portland cement-based systems by sulfate attack. Mechanisms of degradation of cement-based systems, London: E \& FN Spon, p. 185-192, 1997.

FITOS, M.; BADOGIANNIS, E. G.; TSIVILIS, S. G.; PERRAKI, M. Pozzolanic activity of thermally and mechanically treated kaolins of hydrothermal origin. Applied Clay Science, p. $182-192,2015$. 
FRYDA, H.; VETTER, G.; OLLITRAULT-FICHET, R.; CAPMAS, A. No Access Formation of chabazite in mixes of calcium aluminate cement and silica fume used for caesium immobilization. Advances in Cement Research. vol, 8, p. 29-39, 1996.

GANJIAN, E.; POUYA, H. S. Effect of magnesium and sulfate ions on durability of silica fume blended mixes exposed to the seawater tidal zone. Cement and Concrete Research, vol. 35, p. 1332-1343, 2005.

GAVA, G. P.; PRUDENCIO, L. R. Pozzolanic activity tests as a meansure of performance. Part 1. Magazine of Concrete Reseasch, vol. 59, p. 729 - 734, 2007.

GHRICI, M.; KENAI, S.; SAIS-MANSOUR, M. Mechanical properties and durability of mortar and concrete containing natural pozzolana and limestone blended cements. Cement and Concrete Composites, VoL. 29, p. 542-549, 2007.

GIL, A. C. Como Elaborar Projetos de Pesquisa. 4 ed. São Paulo: ATLAS S.A., 2002.

HARTSHORN, S. A.; SHARP, J. H.; SWAMY, R. N. The thaumasite form of sulfate attack in Portland-limestone cement mortars stored in magnesium sulfate solution. Cement $\&$ Concrete Composites, Vol. 24, p. $351-359,2002$.

HASSAN A. A. A.; LACHEMI, M.; HOSSAIN, K. M. A. Effect of metakaolin and silica fume on the durability of self-consolidating concrete. Cement \& Concrete Composites, Vol. 34, p. $801-807,2012$.

HEKAL, E. E.; KISHAR, E.; MOSTAFA, H. Magnesium sulfate attack on hardened blended cement pastes under different circumstances. Cement and Concrete Research, Vol. 32, p. $1421-1427,2002$.

HODHOD, O. A.; SALAMA, G. Simulation of expansion in cement based materials subjected to external sulfate attack, Ain Shams Engineering Journal, Vol. 5, p. 7 - 15, 2014.

HOOTON, R. D. Influence of silica fume replacement of cement on physical properties and resistance to sulfate attack, freezing and thawing, and alkali-silica reactivity. ACI Materials Journal, Vol. 90, p. 143 - 151, 1993.

HOOTON, R. D.; NOKKEN, M.; THOMAS, M. D. A. Portland-Limestone Cement: Stateof-the-art Report and Gap Analysis for CSA A 3000. SN3053. Toronto, Canadá, 2007. 
HOPPE FILHO, J. Sistemas Cimento, Cinza Volante e Cal Hidratada: Mecanismos de hidratação, microestrutura e carbonatação de concreto. 247 p. Tese (Doutorado em Engenharia de Construção Civil) - Escola Politécnica da Universidade de São Paulo, São Paulo, 2008.

HOPPE FILHO, J.; MEDEIROS, M. H. F.; PEREIRA, E.; HELENE, P.; ISAIA, G. C. Highvolume fly ash concrete with and without hydrated lime: chloride diffusion 127 coefficient from accelerated test. Journal of Materials in Civil Engineering, vol. 25, p. 411-418, 2013.

HOSSACK, A. M.; THOMAS, M. D. A. Evaluation of the effect of tricalcium aluminate content on the severity of sulfate attack in Portland cement and Portland limestone cement mortars. Cement \& Concrete Composites, Vol. 56, p. 115 - 120, 2015.

HUANG, Q.; WANG, C.; YANG, C.; ZHOU, L.; YIN, J. Accelerated sulfate attack on mortars using electrical pulse. Construction and Building Materials, vol. 95, p. 875$881,2015$.

ILIC, B.; RADONJANIN, V.; MALESEV, M.; ZDUJIC, M.; MITROVIC, A. Effects of mechanical and thermal activation on pozzolanic activity of kaolin containing mica, Applied Clay Science, Vol. 123, p. 173 - 181, 2016.

IRASSAR, E. F. Sulfate resistance of blended cement: Prediction and relation with flexural strength. Cement and Concrete Research, Vol. 20, p. 209 - 218, 1990.

IRASSAR, E. F.; GONZALEZ, M.; RAHHAL, V. Sulphate resistance of type V cements with limestone filler and natural pozzolana. Cement \& Concrete Composites, vol. 22, p. 361-368, 2000.

IRASSAR, E. F. Sulfate attack on cementious materials containing limestone filer - A review. Cement and Concrete Research, Vol. 39, p. 241 - 254, 2009.

ISAIA, G. C. Concreto: ciência e tecnologia. v. 1 e 2. São Paulo: IBRACON, 2011.

KANDASAMY, S.; SHEHATA, M. H. Durability of ternary blends containing high calcium fly ash and slag against sodium sulphate attack. Construction and Building Materials, vol. 53, p. $267-272,2014$.

KANNING, R. C. Utilização da cinza de folha de bananeira como adição em argamassas de cimento Portland. 192 p. Tese (Doutorado em Engenharia e Ciência dos Materiais) - 
Universidade Federal do Paraná, Curitiba, 2013.

KAYYALI, O. A. Porosity and compressive strength of cement paste in sulphate solution. Cement and Concrete Research. Vol. 19, p. 423 - 433, 1989.

KAKALI, G.; TSIVILIS, S.; AGGELI, E.; BATI, M. Hydration products of C3A, C3S and Portland cement in the presence of $\mathrm{CaCO}_{3}$. Cement and Concrete Research, vol 30, p. 1073-1077, 2000.

KOMLJENOVIC, M.; BASCAREVIC, Z.; MARJANOVIC, N.; NIKOLIC, V. External sulfate attack on alkali-activated slag. Construction and Building Materials. Vol. 49, p. 31 $-39,2013$.

LAWRENCE, P.; CYR, M.; RINGOT, E. Mineral admixture in mortars. Effect of inert materials on short-term hydration. Cement and Concrete Research, Vol. 33, p. 1939 - 1947, 2003.

HEWLETT, P. C. Lea's Chemistry of Cement and Concrete. 4 ed. ELSEVIER, 2003.

LEE, S. T.; MOON, H. Y.; SWAMY, R. N. Sulfate attack and role of silica fume in resisting strength loss, Cement and Concrete Composites, Vol. 27, p. 65 - 76, 2005.

LEE, S. T.; MOON, H. Y.; HOOTON, R. D.; KIM, J. P. Effect of solution concentrations and replacement levels of metakaolin on the resistance of mortars exposed to magnesium sulfate solutions, Cement and Concrete Research, Vol. 35, p. 1314 - 1323, 2005.

LEE, S. T.; HOOTON, R. D.; JUNG, H.; PARK, D.; CHOI, C. S. Effect of limestone filer on the deterioration of mortars and pastes exposed to sulfate solutions at ambient temperature. Cement and Concrete Research, Vol. 38, p. 68 - 76, 2008.

LOTHENBACH, B.; SCRIVENER, K.; HOOTON, R.D. Supplementary cementitious materials, Cement and Concrete Research, Vol. 41, p. 1244 - 1256, 2011.

LOVERA, P.; BESCOP, P. L.; ADENOT, F.; LI, G.; TANAKA, Y.; OWAKI, E. Physicochemical transformations of sulphated compounds during the leaching of highly sulphated cemented wastes. Cement and Concrete Research, Vol. 27, p. 1523 - 1532, 1997.

MAKHLOUFI, Z.; AGGOUN, S.; BENABED, B.; KADRI, E. H.; BEDERINA, M. Effect of magnesium sulfate on the durability of limestone mortars based on quaternary blended 
cements. Cement and Concrete Composites, Vol. 65, p. 186 - 199, 2016.

MALHOTRA, V. M.; MEHTA, P. K. Pozzolanic and Cementitious Meterials. Advances in Concrete Technology. Vol 1, CANEMET. Canadá, 1996.

MARCIANO, Z. A. N. Desenvolvimento de um método acelerado para avaliação da resistência de argamassas de cimento Portland expostas à solução de sulfato de sódio. 1993. 202 f. Dissertação (Mestrado em Engenharia) - Universidade de São Paulo, São Paulo, 1993.

MATSCHEI, T.; LOTHENBACH, B.; GLASSER, F. P. The role of calcium carbonate in cement hydration. Cement and Concrete Research, vol. 37, p. 551-558, 2007.

MEDEIROS JR, R. A.; LIMA, M. G.; MEDEIROS, M. H. F.; REAL, L. V. Investigação da resistência à compressão e da resistividade elétrica de concretos com diferentes tipos de cimento. Revista ALCONPAT, 2014. v. 4, n. 2, p. 116-132, 2014.

MEHTA, P. K.; PITT, N. A new process os rice husk utilization. In: International Conference on the Utilization of Rice By-Products, Valência, Espanha: IATA, p. 45-58, 1977.

MEHTA, P. K. Mechanics of sulfate attack on Portland cement concrete - another look. Cement and Concrete Research, Vol. 13, p. 401 - 406, 1983.

MEHTA, P. K. Mineral Admixtures. Concrete Admixtures Handbook-Proprieties, Science and Technology. Otawa, Canadá, p. 303-333, 1990.

MEHTA, P.K. Rice husk ash - A unique suplementary cementing material. In: Advances in concrete technology. CANMET. Ottawa, Canadá, p. 407-431, 1992.

MEHTA, P. K.; MONTEIRO, P. J. M. Concreto - Microestrutura, propriedades e materiais. 3 ed. São Paulo: IBRACON, 2014.

MONTEIRO, P. J. M. Caracterização da microestrutura do concreto: fases e interfaces; aspectos de durabilidade e de microfissuração. Tese (Livre Docência em Engenharia) Escola Politécnica da Universidade de São Paulo, São Paulo, 1993.

MONTEIRO, P. J. M.; KURTIS, K. E. Time to failure for concrete exposed to severe sulfate attack. Cement and Concrete Research, Vol. 33, p. 987 - 993, 2003. 
MUNHOZ, F. A. da C. Efeito de adições ativas na mitigação das reações álcali-sílica e álcali-silicato. 166 f. Dissertação (Mestrado em Engenharia) - Escola Politécnica da Universidade de São Paulo, São Paulo, 2007.

NEVILLE, A. Propriedades do concreto. Tradução de: GIAMMUSSO, S. E. 2. ed. São Paulo: PINI, 1997.

NEVILLE, A.; BROOKS, J. J. Tecnologia do concreto. 2 ed. Porto Alegre: Bookman, 2013.

NEVILLE, A. The confused world of sulfate attack on concrete. Cement and Concrete Research, Vol. 34, p. 1275 - 1296, 2004.

OGAWA, S.; NOZAKI, T.; YAMADA, K.; HIRAO, H.; HOOTON, R. D. Improvement on sulfate resistance of blended cement with high alumina slag. Cement and Concrete Research. Vol. 42, p. $244-251,2012$.

OUYANG, W.; CHEN, J.; JIANG, M. Evolution of surface hardness of concrete under sulfate attack. Construction and Building Materials, Vol. 53, p. 419 - 424, 2014.

PAIVA, M. das D. M. Otimização e análise mecânica de pastas geopoliméricas para uso em poços sujeitos à injeção cíclica de vapor. $172 \mathrm{f}$. Tese (Doutorado em Engenharia de Materiais) - Pós Graduação em Ciência e Engenharia de Materiais, Universidade Federal do Rio Grande do Norte, Natal, 2008.

PUBCHEM. Sodium Sulfate. Disponível em: <http://pubchem.ncbi.nlm.nih.gov〉. Acesso em: 08/04/2014.

RAHHAL, V.; BONAVETTI, V.; TRUSILEWICZ, L.; PEDRAJAS, C.; TALERO, R. Role of the filer on Portland cement hydration at early ages. Construction and Building Materials, Vol. 27, p. 82 - 90, 2012.

RAMEZANIANPOUR, A. M.; HOOTON, R. D. Thaumasite sulfate attack in Portland and Portland-limestone cement mortars exposed to sulfate solution. Construction and Building Materials, Vol. 40, p. $162-173,2013$.

ROBSON, C. Real world research: a resource for social scientists and practitionerresearchers. 2 ed. Malden: Blackwell Publishers, 2002. 
ROCHA, G. G. N. Caracterização microestrutural do metacaulim de alta reatividade. 84 f. Dissertação (Mestrado em Engenharia) - Curso de Pós-Graduação em Engenharia Metalúrgica e de Minas, Escola de Engenharia da Universidade Federal de Minas Gerais, Belo Horizonte, 2005.

ROCHA, L.; PERES, A. E. C. Aproveitamento econômico das lamas de ferro. Revista Escola de Minas, vol. 62, p.291 - 295, 2009.

ROZIÈRE, E.; LOUKILI, A.; HACHEM R. E.; GRONDIN, F. Durability of concrete exposed to leaching and external sulphate attacks. Cement and Concrete Research. Vol. 39, p. $1188-1198,2009$.

RUSSELL, J. B. Química Geral. 2 ed. vol 1. São Paulo: Makron Books, 1994.

RUSSELL, J. B. Química Geral. 2 ed. vol 2. São Paulo: Makron Books, 1994.

SAHU, S.; BADGER, S.; THAULOW, N. Evidence of thaumasite formation in Southern California concrete. Cement \& Concrete Composites, Vol. 24, p. 379 - 384, 2002.

SAN NICOLAS, R.; CYR, M.; ESCANDEILLAS, G. Performance-based approach to durability of concrete containing flash-calcined metakaolin as cement replacement. Construction and Building Materials, Vol. 55, p. 313-322, 2014.

SANTHANAM, M. Studies on sulfate attack: mechanisms, test methods, and modeling. 275f. PhD. Thesis - Purdue University, United States, 2001.

SANTHANAM, M.; COHEN, M. D.; OLEK, J. Mechanism of sulfate attack: A fresh look: Part 1: Summary of experimental results. Cement and Concrete Research, Vol. 32, p. 915 921, 2002.

SANTHANAM, M.; COHEN, M. D.; OLEK, J. Modeling the effects of solution temperature and concentration during sulfate attack on cement mortars. Cement and Concrete Research, Vol. 32, p. $585-592,2002 . b$.

SANTHANAM, M.; COHEN, M. D.; OLEK, J. Mechanism of sulfate attack: A fresh look: Part 2: Proposed mechanisms. Cement and Concrete Research, Vol. 33, p. 341 - 346, 2003.

SENHADJI, Y.; ESCADEILLAS, G.; MOULI, M. KHELAFI, H. BENOSMAN. Influence of 
natural pozzolan, silica fume and limestone fine on strength, Powder Technology, Vol. 254, p. $314-323,2014$.

SCHNEIDER, U.; CHEN, S. W. The chemomechanical effect and the mechanochemical effect on high-performance concrete subjected to stress corrosion. Cement and Concrete Research, Vol. 28, p. $509-522,1998$.

SIBBICK, T.; FENN, D.; CRAMMOND, N. The occurrence of thaumasite as a product of seawater attack. Cement \& Concrete Composites, Vol. 25, p. 1059 - 1066, 2003.

SILVEIRA, A. A. Contribuição ao estudo do efeito da incorporação de cinza de casca de arroz em concreto submetido à reação álcali-agregado. $223 \mathrm{f}$. Tese (Doutorado em Engenharia) - Programa de Pós-Graduação em Engenharia Civil, Universidade Federal do Rio Grande do Sul, Porto Alegre, 2007.

SIRISAWAT, T.; SAENGSOY, W.; BAINGAM, L.; KRAMMART, P.; TANGTERMSIRIKUL, S. Durability and testing of mortar with interground fly ash and limestone cements in sulfate solutions. Construction and Building Materials, Vol. 64, p.3946, 2014.

SKAROPOULOU, A.; TSIVILIS, S.; KAKALI, G.; SHARP, J. H.; SWAMY, R. N. Long term behavior of Portland limestone cement mortars exposed to magnesium sulfate attack. Cement \& Concrete Composites, Vol. 31, p. 628 - 636, 2009.

SKAROPOULOU, A.; SOTIRIADIS, K.; KAKALI, G.; TSIVILIS, S. Use of mineral admixtures to improve the resistance of limestone cement concrete against thaumasite form of sulfate attack. Cement \& Concrete Composites, Vol. 37, p. 267 - 275, 2013.

SKALNY, J.; MARCHAND, J.; ODLER, I. Sulfate Attack on Concrete. 1. ed. Londres: SPON PRESS, 2002.

SNIC - PRESS KIT 2008 - Sindicato Nacional da Indústria de Cimento. Disponível em:<http://www.snic.com.br>. Acesso em: 21/03/2014.

SOUZA, P. S. L.; DAL MOLIN, D. C. C. Estudo da viabilidade do uso de argilas calcinadas, como metacaulim de alta reatividade (MCAR). Engenharia Civil. Guimarães, Portugal, n. 15, p. 45-54, set, 2002.

SOUZA, V. C. M. de; RIPPER, T. Patologia, recuperação e reforço de estruturas de concreto. 1. ed. São Paulo: PINI, 1998. 
SUMER, M. Compressive strength and sulfate resistance properties of concretes containing Class F and Class C fly ashes. Construction and Building Materials, Vol. 34, p. 531 - 536, 2012

TAYLOR, H. F. W. Cement Chemistry. 2. ed. London: Thomas Telford, 1997.

TIKALSKY, P. J.; ROY, D.; SCHEETZ, B.; KRIZE, T. Redefining cement characteristics for sulfate-resistant Portland cement. Cement and Concrete Research. Vol.32, p.1239-1246, 2002.

TIPLER, P. A.; MOSCA, G. Física para Cientistas e Engenheiros. 5. ed. vol 3. Rio de Janeiro: LTC, 2006.

TOSUN-FELEKOGLU, K. The effect of C3A content on sulfate durability of Portland limestone cement mortars. Construction and Building Materials. Vol. 36, p.437-447, 2012.

TUMIDAJSKI, P. J.; TURC, I. A rapid test for sulfate ingress into concrete, Cement and Concrete Research, vol. 25, p. $924-928,1995$.

VANDERLEI, R. D. Análise experimental do concreto pós reativo: dosagem e propriedades mecânicas. $167 \mathrm{f}$. Tese (Doutorado em Engenharia) - Escola de Engenharia de São Carlos da Universidade de São Paulo, São Carlos, 2004.

VIEIRA, A. de A. P. Estudo do aproveitamento de resíduos de Cerâmica vermelha como substituição Pozolânica em argamassas e concretos. 127 f. Dissertação (mestrado) Universidade Federal da Paraíba, Paraíba, 2005.

WEE, T. H.; SURYAVANSHI, A. K.; WONG, S. F.; ANISUR, R. A. K. M. Sulfate resistence of concrete containing mineral admixtures. ACI Materials Journal. Vol. 97, p. $536-549,2000$.

ZAMPIERI, V. A. Mineralogia e mecanismo de ativação e reação das pozolanas de argilas calcinadas. $191 \mathrm{f}$. Dissertação (Mestrado em Geociências) - Instituto de Geociências da Universidade de São Paulo, São Paulo, 1989.

ZENG, Q.; Li, K.; FEN-CHONG, T.; DANGLA, P. Determination of cement hydration and pozzolanic extents for fly-ash cement pastes. Construction and Building Materials, Vol. 27, p. $560-569,2012$. 


\section{APÊNDICE 1}

\subsection{DISTRIBUIÇÃO GRANULOMÉTRICA DOS AGLOMERANTES}

A seguir a Figura 94 mostra a distribuição granulométrica dos aglomerantes utilizados no presente trabalho.

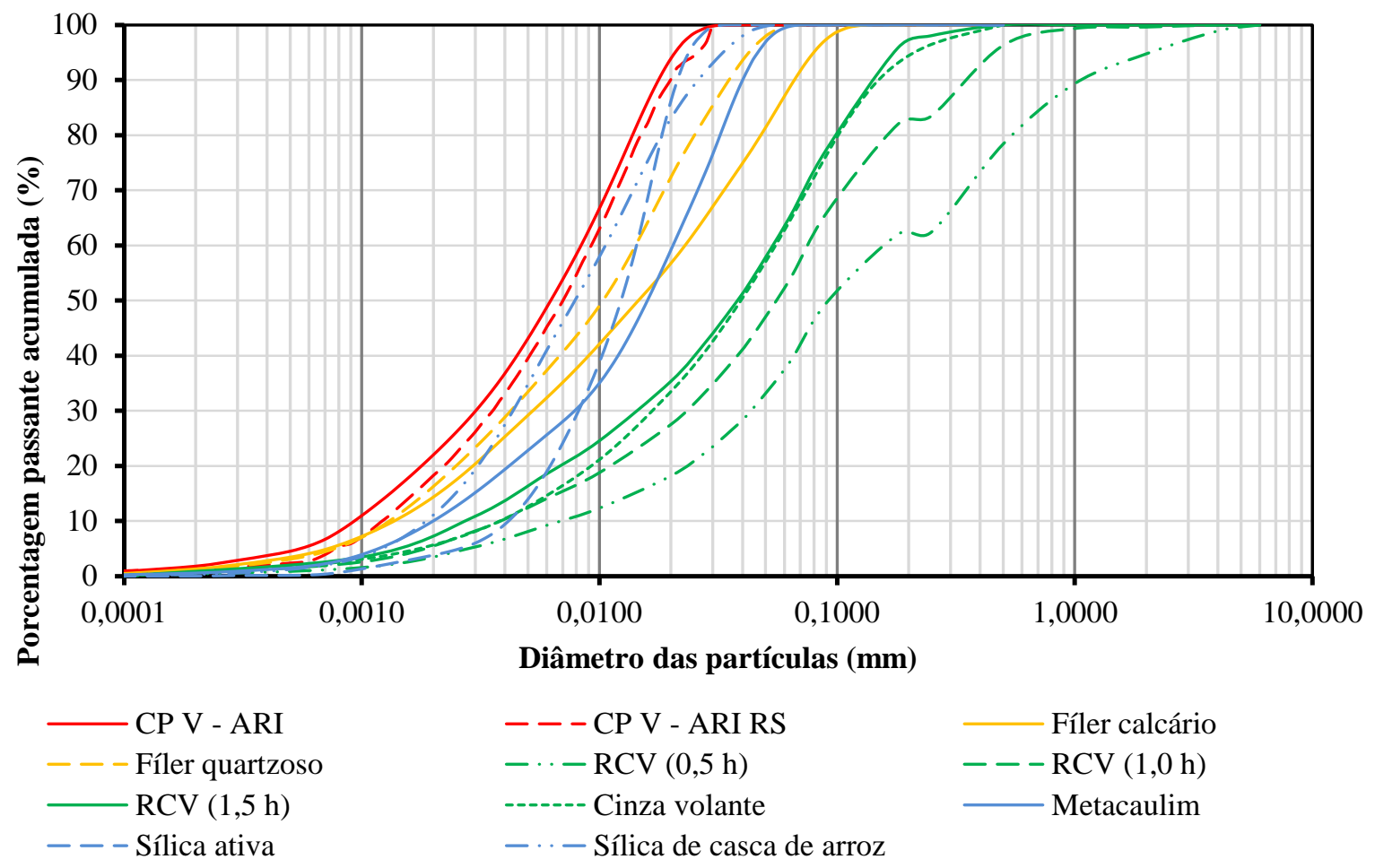

Figura 94: Distribuição granulométrica dos aglomerantes utilizados.

\subsection{COMPOSIÇÃO DAS SOLUÇÕES DE CURA FINAL}

$H=1,008 \mathrm{~g} / \mathrm{mol} ; O=15,999 \mathrm{~g} / \mathrm{mol} ; \mathrm{Na}=22,989 \mathrm{~g} / \mathrm{mol} ; \mathrm{Mg}=24,305 \mathrm{~g} / \mathrm{mol} ; S=$ $32,060 \mathrm{~g} / \mathrm{mol} ; \mathrm{Ca}=40,078 \mathrm{~g} / \mathrm{mol}$

- Cálculo do quantitativo do reagente anidro de sulfato de magnésio a partir do teor fixado por norma de sulfato de sódio, para $1000 \mathrm{~g}$ de solução:

$$
\begin{aligned}
& 1000 \mathrm{~g}_{\text {solução }}=900 \mathrm{~g} \mathrm{de} \mathrm{H}_{2} \mathrm{O}+100 \mathrm{~g} \mathrm{de} \mathrm{Na}_{2} \mathrm{SO}_{4} \\
& 2 \mathrm{Na}^{+}+\mathrm{SO}_{4}^{2-} \rightarrow \mathrm{Na}_{2} \mathrm{SO}_{4} \\
& 45,978 \mathrm{~g} / \mathrm{mol}+96,061 \mathrm{~g} / \mathrm{mol} \rightarrow 142,039 \mathrm{~g} / \mathrm{mol} \\
& \mathrm{SO}_{4}^{2-} \mathrm{g}=100 \mathrm{~g}_{\mathrm{Na}_{2} \mathrm{SO}_{4}} \cdot\left(96,061_{\mathrm{g} / \mathrm{mol}} / 142,039_{\mathrm{g} / \mathrm{mol}}\right)=67,63 \mathrm{~g} \\
& \mathrm{Mg}^{2+}+\mathrm{SO}_{4}^{2-} \rightarrow \mathrm{MgSO}_{4}
\end{aligned}
$$




$$
\begin{aligned}
& 24,305 \mathrm{~g} / \mathrm{mol}+96,061 \mathrm{~g} / \mathrm{mol} \rightarrow 120,366 \mathrm{~g} / \mathrm{mol} \\
& \mathrm{MgSO}_{4} \mathrm{~g}=67,63 \mathrm{~g} \cdot\left(120,366_{\mathrm{g} / \mathrm{mol}} / 96,061_{\mathrm{g} / \mathrm{mol}}\right)=84,741 \mathrm{~g}
\end{aligned}
$$

- Cálculo do teor do metal associado para 1000 g de solução, em gramas:

$$
\begin{aligned}
& \mathrm{Ca}^{2+}+(\mathrm{OH})_{2}^{2-} \rightarrow \mathrm{Ca}(\mathrm{OH})_{2} \\
& 40,078 \mathrm{~g} / \mathrm{mol}+34,014 \mathrm{~g} / \mathrm{mol} \rightarrow 74,092 \mathrm{~g} / \mathrm{mol} \\
& \mathrm{Ca}^{2+} \mathrm{g}=10 \mathrm{~g} \cdot\left(40,078_{\mathrm{g} / \mathrm{mol}} / 74,092_{\mathrm{g} / \mathrm{mol}}\right)=5,409 \mathrm{~g} \\
& 2 \mathrm{Na}^{+} \mathrm{g}=100 \mathrm{~g} \cdot\left(45,978_{\mathrm{g} / \mathrm{mol}} / 142,039_{\mathrm{g} / \mathrm{mol}}\right)=32,370 \mathrm{~g} \\
& \mathrm{Mg}^{2+} \mathrm{g}=84,741 \mathrm{~g} \cdot\left(24,305_{\mathrm{g} / \mathrm{mol}} / 120,366_{\mathrm{g} / \mathrm{mol}}\right)=17,110 \mathrm{~g}
\end{aligned}
$$

\subsection{CONSUMO DE PORTLANDITA PARA CADA ADIÇÃO ESTUDADA}

- Cálculo do consumo de portlandita para cada adição mineral a partir dos resultados obtidos com o ensaio de Chapelle modificado:

$\mathrm{Ca}(\mathrm{OH})_{2 \text { consumo }} \%=\mathrm{Ca}(\mathrm{OH})_{2 \text { Chapelle }(\mathrm{g} / \mathrm{g})} \times$ Teor da adição $\%$

- Resíduo de cerâmica vermelha, 0,5 h

$\mathrm{Ca}(\mathrm{OH})_{2 \text { consumo }} \%=0,454_{\mathrm{g} / \mathrm{g}} \times 10_{\%}=4,54 \%$

- Resíduo de cerâmica vermelha, 1,0 h

$\mathrm{Ca}(\mathrm{OH})_{2 \text { consumo }} \%=0,516_{\mathrm{g} / \mathrm{g}} \times 10_{\%}=5,16 \%$

- Resíduo de cerâmica vermelha, $1,5 \mathrm{~h}$

$\mathrm{Ca}(\mathrm{OH})_{2 \text { consumo }} \%=0,537_{\mathrm{g} / \mathrm{g}} \times 10_{\%}=5,37 \%$

- Cinza volante

$\mathrm{Ca}(\mathrm{OH})_{2 \text { consumo }} \%=0,408_{\mathrm{g} / \mathrm{g}} \times 10_{\%}=4,08 \%$

- Metacaulim

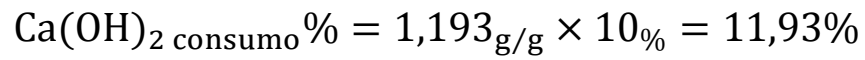

- Sílica ativa

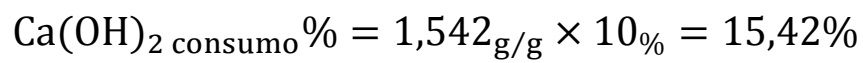

- Sílica de casca de arroz

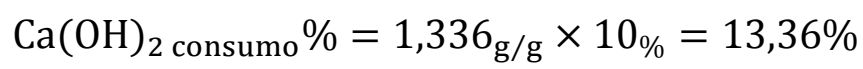




\subsection{CÁLCULO DOS TEORES DOS COMPOSTOS DE BOGUE}

- Cálculo dos compostos de Bogue para 100\% de cimento Portland CP V - ARI:

Tabela 23: Analise química do cimento CP V - ARI

\begin{tabular}{cccccccccc}
\hline \multicolumn{10}{c}{ Análise Química (\%) } \\
\hline $\mathrm{CaO}$ & $\mathrm{SiO}_{2}$ & $\mathrm{Al}_{2} \mathrm{O}_{3}$ & $\mathrm{Fe}_{2} \mathrm{O}_{3}$ & $\mathrm{MgO}$ & $\mathrm{SO}_{3}$ & $\mathrm{~K}_{2} \mathrm{O}$ & $\begin{array}{c}\mathrm{CaO} \\
\text { livre* }\end{array}$ & $\begin{array}{c}\text { Res. } \\
\text { Insolúvel* }\end{array}$ & $\begin{array}{c}\text { Perda } \\
\text { Fogo }\end{array}$ \\
59,36 & 16,27 & 5,06 & 2,77 & 4,63 & 5,30 & 1,06 & 1,46 & 0,67 & 3,43 \\
\hline
\end{tabular}

Correção do teor disponível de $\mathrm{CaO}$ :

$\mathrm{CaO}_{\text {como gipsita }}=0,70042 . \mathrm{SO}_{3}=3,712 \%$

$\mathrm{CaCO}_{3 \text { teórico }}=2,27422 \cdot \mathrm{PF}-1,02347 \cdot \mathrm{SO}_{3}=2,376 \%$

$\mathrm{CaO}_{\text {como carbonato de cálcio }}=0,56029 . \mathrm{CaCO}_{3}=1,331 \%$

$\mathrm{CaO}_{\text {corrigido }}=\mathrm{CaO}-\mathrm{CaO}_{\text {gipsita }}-\mathrm{CaO}_{\text {carbonato de cálcio }}-\mathrm{CaO}_{\text {gipsita }}=54,316 \%$

$\mathrm{C}_{3} \mathrm{~S}=$ 4,0710. $\mathrm{CaO}-7,6024 . \mathrm{SiO}_{2}-6,7187 . \mathrm{Al}_{2} \mathrm{O}_{3}-1,4297 . \mathrm{Fe}_{2} \mathrm{O}_{3}$

$C_{3} S=59,474 \%$

$\mathrm{C}_{2} \mathrm{~S}=-3,0710 \cdot \mathrm{CaO}+8,6024 . \mathrm{SiO}_{2}+5,0683 . \mathrm{Al}_{2} \mathrm{O}_{3}+1,0785 . \mathrm{Fe}_{2} \mathrm{O}_{3}$

$C_{2} S=1,788 \%$

$\mathrm{C}_{3} \mathrm{~A}=2,6504 . \mathrm{Al}_{2} \mathrm{O}_{3}-1,6920 . \mathrm{Fe}_{2} \mathrm{O}_{3}$

$C_{3} A=8,724 \%$

$\mathrm{C}_{4} \mathrm{AF}=3,0432 . \mathrm{Fe}_{2} \mathrm{O}_{3}$

$C_{4} A F=8,430 \%$

Teor de Gipsita:

$\mathrm{CaSO}_{4} \cdot 2 \mathrm{H}_{2} \mathrm{O}=\mathrm{CaO}_{\text {como gipsita } \%} \cdot\left(\frac{\mathrm{CaSO}_{4} \cdot 2 \mathrm{H}_{2} \mathrm{O}_{\mathrm{g} / \mathrm{mol}}}{\mathrm{CaO}}\right)=11,397 \%$

- Cálculo dos compostos de Bogue para 100\% de cimento Portland CP V - ARI RS:

Tabela 24: Analise química do cimento CP V - ARI

\begin{tabular}{ccccccccccc}
\hline \multicolumn{10}{c}{ Análise Química (\%) } \\
\hline $\mathrm{CaO}$ & $\mathrm{SiO}_{2}$ & $\mathrm{Al}_{2} \mathrm{O}_{3}$ & $\mathrm{Fe}_{2} \mathrm{O}_{3}$ & $\mathrm{MgO}$ & $\mathrm{SO}_{3}$ & $\mathrm{~K}_{2} \mathrm{O}$ & $\begin{array}{c}\mathrm{CaO} \\
\text { livre* }\end{array}$ & $\begin{array}{c}\text { Res. } \\
\text { Insolúvel* }\end{array}$ & $\begin{array}{c}\text { Perda } \\
\text { Fogo }\end{array}$ \\
55,40 & 20,10 & 4,80 & 3,50 & 5,60 & 2,80 & 1,00 & - & 0,90 & 5,97 \\
\hline
\end{tabular}


Correção do teor disponível de $\mathrm{CaO}$ :

$\mathrm{CaO}_{\text {como gipsita }}=0,70042 . \mathrm{SO}_{3}=1,961 \%$

$\mathrm{CaCO}_{3 \text { teórico }}=2,27422 \cdot \mathrm{PF}-1,02347 . \mathrm{SO}_{3}=10,711 \%$

$\mathrm{CaO}_{\text {como carbonato de cálcio }}=0,56029 . \mathrm{CaCO}_{3}=6,001 \%$

$\mathrm{CaO}_{\text {corrigido }}=\mathrm{CaO}-\mathrm{CaO}_{\text {gipsita }}-\mathrm{CaO}_{\text {carbonato de cálcio }}-\mathrm{CaO}_{\text {gipsita }}=47,437 \%$

$\mathrm{C}_{3} \mathrm{~S}=4,0710 . \mathrm{CaO}-7,6024 . \mathrm{SiO}_{2}-6,7187 . \mathrm{Al}_{2} \mathrm{O}_{3}-1,4297 . \mathrm{Fe}_{2} \mathrm{O}_{3}$

$C_{3} S=3,056 \%$

$\mathrm{C}_{2} \mathrm{~S}=-3,0710 \cdot \mathrm{CaO}+8,6024 . \mathrm{SiO}_{2}+5,0683 . \mathrm{Al}_{2} \mathrm{O}_{3}+1,0785 . \mathrm{Fe}_{2} \mathrm{O}_{3}$

$C_{2} S=55,331 \%$

$\mathrm{C}_{3} \mathrm{~A}=2,6504 . \mathrm{Al}_{2} \mathrm{O}_{3}-1,6920 . \mathrm{Fe}_{2} \mathrm{O}_{3}$

$C_{3} A=6,800 \%$

$\mathrm{C}_{4} \mathrm{AF}=3,0432 . \mathrm{Fe}_{2} \mathrm{O}_{3}$

$C_{4} A F=10,651 \%$

Teor de Gipsita:

$\mathrm{CaSO}_{4} \cdot 2 \mathrm{H}_{2} \mathrm{O}=\mathrm{CaO}_{\text {como gipsita } \%} \cdot\left(\frac{\mathrm{CaSO}_{4} \cdot 2 \mathrm{H}_{2} \mathrm{O}_{\mathrm{g} / \mathrm{mol}}}{\mathrm{CaO}}\right)=6,021 \%$

\subsection{CÁLCULOS ESTEQUIOMÉTRICOS PARA HIDRATAÇÃO DO CIMENTO PORTLAND CP V - ARI}

- Fases Silicatos.

Previsão do teor de portlandita a partir da alita e belita:

\begin{tabular}{|c|c|c|c|c|c|c|c|}
\hline \multirow{9}{*}{$\mathrm{C}_{3} \mathrm{~S}$} & 2. $\mathrm{C}_{3} \mathrm{~S}$ & & & & 2. $\left(3 \mathrm{CaO} . \mathrm{SiO}_{2}\right)(\mathrm{g} / \mathrm{mol})$ & $=$ & 456,630 \\
\hline & $6 . \mathrm{H}$ & & & & $6 . \mathrm{H}_{2} \mathrm{O}(\mathrm{g} / \mathrm{mol})$ & $=$ & 108,090 \\
\hline & $\mathrm{C}_{3} \mathrm{~S}_{2} \mathrm{H}_{3}$ & & & & 3. $\mathrm{CaO} \cdot 2 \cdot \mathrm{SiO}_{2} \cdot 3 \cdot \mathrm{H}_{2} \mathrm{O}(\mathrm{g} / \mathrm{mol})$ & $=$ & 342,444 \\
\hline & 3.CH & & & & 3. $\mathrm{CaO} .3 . \mathrm{H}_{2} \mathrm{O}(\mathrm{g} / \mathrm{mol})$ & $=$ & 222,276 \\
\hline & 2. $\mathrm{C}_{3} \mathrm{~S}$ & + & $6 . \mathrm{H}$ & $==$ & $\mathrm{C}_{3} \mathrm{~S}_{2} \mathrm{H}_{3}$ & + & 3.CH \\
\hline & 456,630 & + & 108,090 & $==$ & 342,444 & + & 222,276 \\
\hline & $80,86 \%$ & + & $19,14 \%$ & $==$ & $60,64 \%$ & + & $39,36 \%$ \\
\hline & \multicolumn{3}{|c|}{ Teor (Bogue) } & & \multicolumn{3}{|c|}{$\%$ de $\mathrm{CH}$ calculado $\left(\mathrm{C}_{3} \mathrm{~S}\right)$} \\
\hline & $\mathrm{C}_{3} \mathrm{~S}$ & $=$ & 59,474 & & $C H_{\%}=C_{3} S_{\%} \cdot\left(\frac{3 \cdot C H_{g / m o l}}{2 \cdot C_{3} S_{q / m o l}}\right)$ & $=$ & 28,951 \\
\hline
\end{tabular}




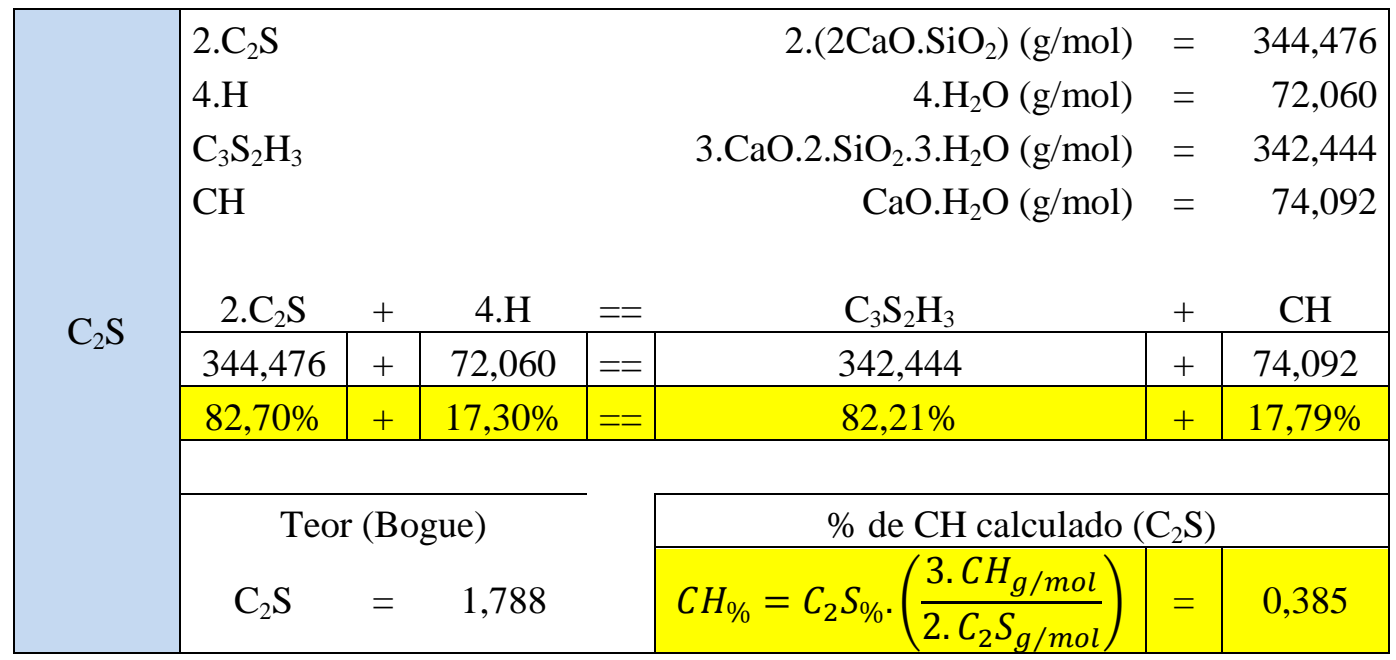

$C H_{\text {Teórico }}=28,951+0,385=29,335$

Previsão do teor de $C-S-H$ a partir da alita e belita:

$C-S-H_{\%}=C_{3} S_{\%} \cdot\left(\frac{C_{3} S_{2} H_{3} \mathrm{~g} / \mathrm{mol}}{2 . C_{3} S_{\mathrm{g} / \mathrm{mol}}}\right)=44,602 \%$

$C-S-H_{\%}=C_{2} S_{\%} \cdot\left(\frac{C_{3} S_{2} H_{3} \mathrm{~g} / \mathrm{mol}}{2 . C_{2} S_{\mathrm{g} / \mathrm{mol}}}\right)=1,778 \%$

$C-S-H_{\text {Teórico }}=44,602+1,778=46,380 \%$

- Fases Aluminatos.

Previsão do teor de portlandita a partir da alita e belita:

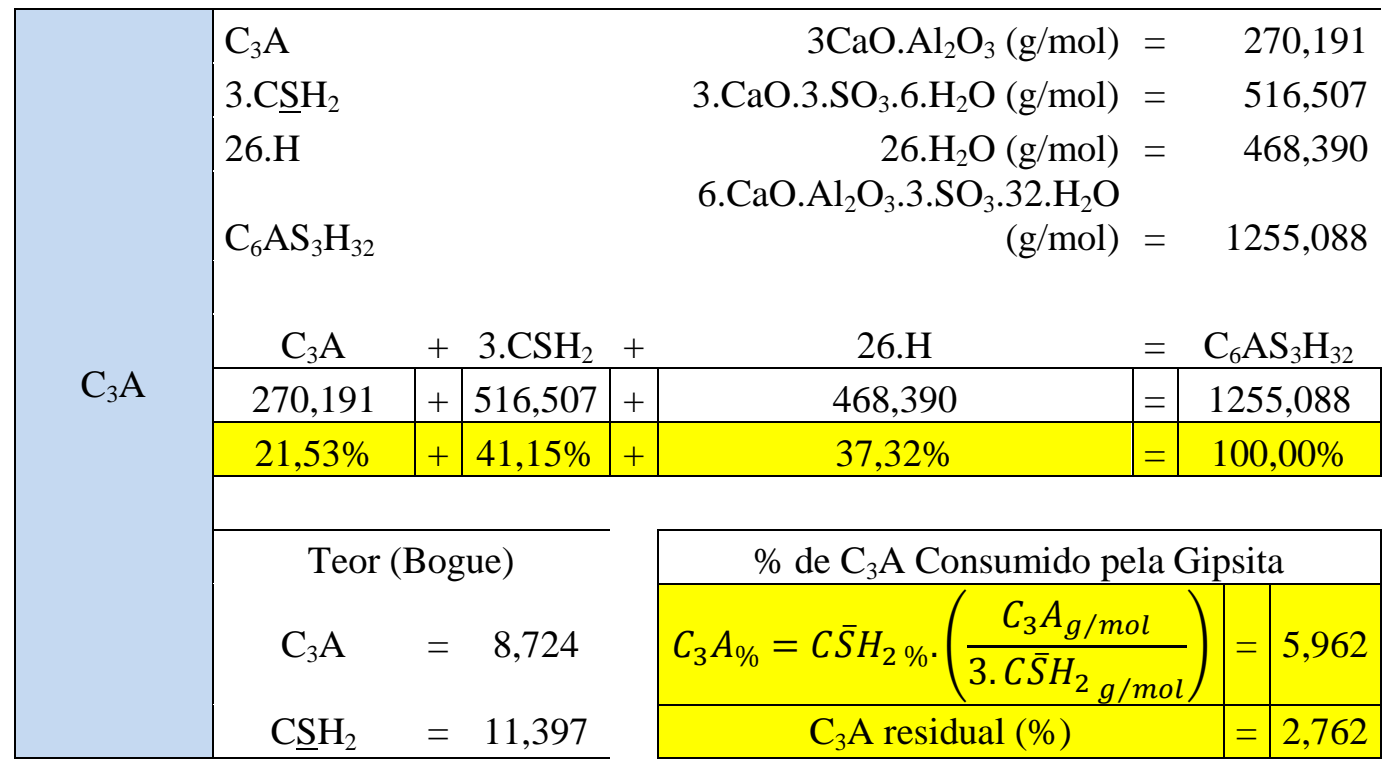

$\%$ de etringita teórico: 
$C_{6} A \bar{S}_{3} H_{32 \%}=C \bar{S} H_{2 \%} \cdot\left(\frac{C_{6} A \bar{S}_{3} H_{32} \mathrm{~g} / \mathrm{mol}}{3 . C \bar{S} H_{2} \mathrm{~g} / \mathrm{mol}}\right)=27,695 \%$

Teor de monossulfoaluminato de cálcio hidratado, conversão a partir da etringita:

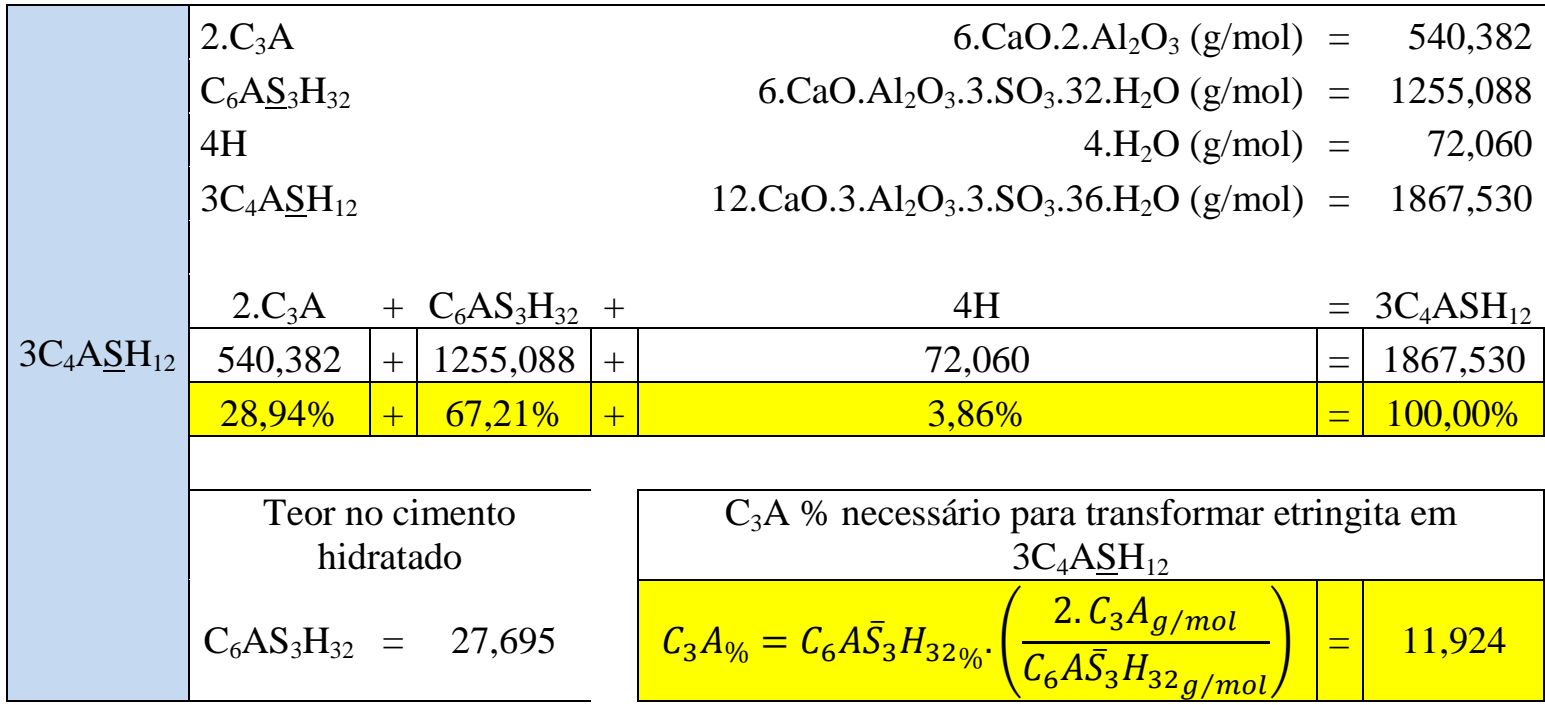

Portanto, teor insuficiente de $\mathrm{C}_{3} \mathrm{~A}$ para completa transformação de etringita em monossulfoaluminato de cálcio hidratado:

$C_{3} A_{\% \text { necessário }}=11,924-2,762=9,162 \%$

Assim, será adotado como hipótese que para conversão de etringita haverá consumo do $\mathrm{C}_{4} \mathrm{AF}$ :

\begin{tabular}{|c|c|c|c|}
\hline $\mathrm{C}_{4} \mathrm{AF}$ & & $\mathrm{C}_{3} \mathrm{~A}$ & \\
\hline Teor no cimento (BOGUE) & $=8,430$ & Teor de $\mathrm{C}_{3} \mathrm{~A}$ insuficiente & $=9,162$ \\
\hline 4. $\mathrm{CaO}(\mathrm{g} / \mathrm{mol})$ & $=224,308$ & 3. $\mathrm{CaO}(\mathrm{g} / \mathrm{mol})$ & $=168,231$ \\
\hline $\mathrm{Al}_{2} \mathrm{O}_{3}(\mathrm{~g} / \mathrm{mol})$ & $=101,960$ & $\mathrm{Al}_{2} \mathrm{O}_{3}(\mathrm{~g} / \mathrm{mol})$ & $=101,960$ \\
\hline $\mathrm{Fe}_{2} \mathrm{O}_{3}(\mathrm{~g} / \mathrm{mol})$ & $=159,687$ & & \\
\hline \multicolumn{4}{|c|}{ TEORES CORRESPONDENTES } \\
\hline $\mathrm{CaO}(\%)$ & $=3,891$ & $\mathrm{CaO}(\%)$ & 5,705 \\
\hline $\mathrm{Al}_{2} \mathrm{O}_{3}(\%)$ & 1,769 & $\mathrm{Al}_{2} \mathrm{O}_{3}(\%)$ & $=3,457$ \\
\hline
\end{tabular}

Portanto, vê-se que não haverá conversão total da etringita em monossulfoaluminato de cálcio hidratado, isto porque o teor necessário de $\mathrm{C}_{3} \mathrm{~A}$ para tanto é de 3,457, porém há apenas 1,769 disponível. Entretanto, a seguir é apresentado o teor total de monossulfoaluminato de cálcio hidratado: 


$$
\begin{aligned}
& \mathrm{Al}_{2} \mathrm{O}_{3} \text { \% equivalente }=\mathrm{Al}_{2} \mathrm{O}_{3} \mathrm{C}_{4} \mathrm{AF} \cdot\left(\frac{\mathrm{Al}_{2} \mathrm{O}_{3} \mathrm{~g} / \mathrm{mol}}{3 . \mathrm{CaO} \mathrm{g} / \mathrm{mol}}\right)=1,072 \% \\
& \mathrm{CaO}_{\% \text { equivalente }}=\mathrm{Al}_{2} \mathrm{O}_{3} \% \text { equivalente } \cdot\left(\frac{3 . \mathrm{CaO}_{\mathrm{g} / \mathrm{mol}}}{\mathrm{Al}_{2} \mathrm{O}_{3} \mathrm{~g} / \mathrm{mol}}\right)=1,769 \%
\end{aligned}
$$

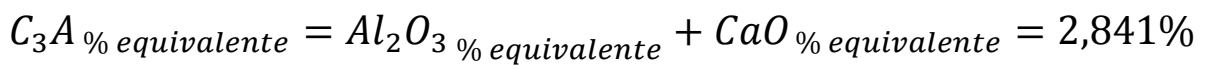

$$
\begin{aligned}
& C_{3} A_{\% \text { disponível }}=C_{3} A_{\% \text { residual }}+C_{3} A_{\% \text { equivalente }}=2,762+2,841=5,603 \%
\end{aligned}
$$

Sendo assim, total de etringita convertida em monossulfoaluminato de cálcio hidratado:

$$
C_{3} A_{\% \text { disponível }} \cdot\left(\frac{C_{6} A \bar{S}_{3} H_{32} \mathrm{~g} / \mathrm{mol} \mathrm{g} / \mathrm{mol}}{C_{3} A_{\mathrm{g} / \mathrm{mol}}}\right)=13,013 \%
$$

Logo, o teor remanescente de etringita será $=27,695-13,013=14,682$.

Previsão do teor de hidrotalcita formado:

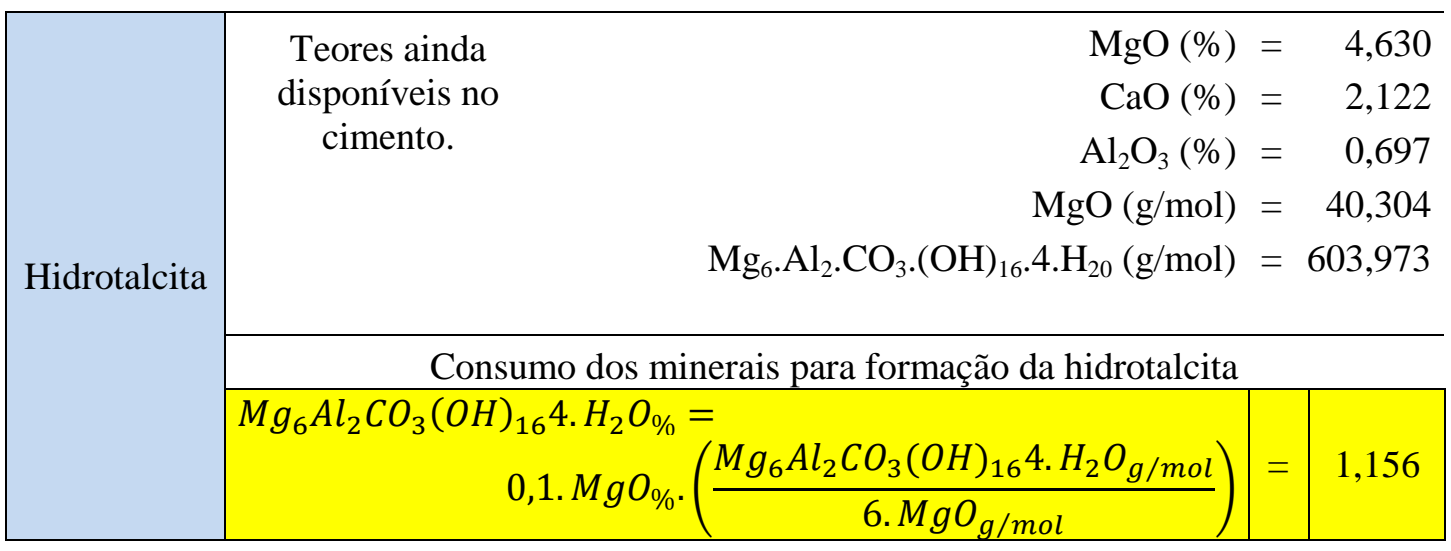

Previsão do teor de hidrogranada formado:

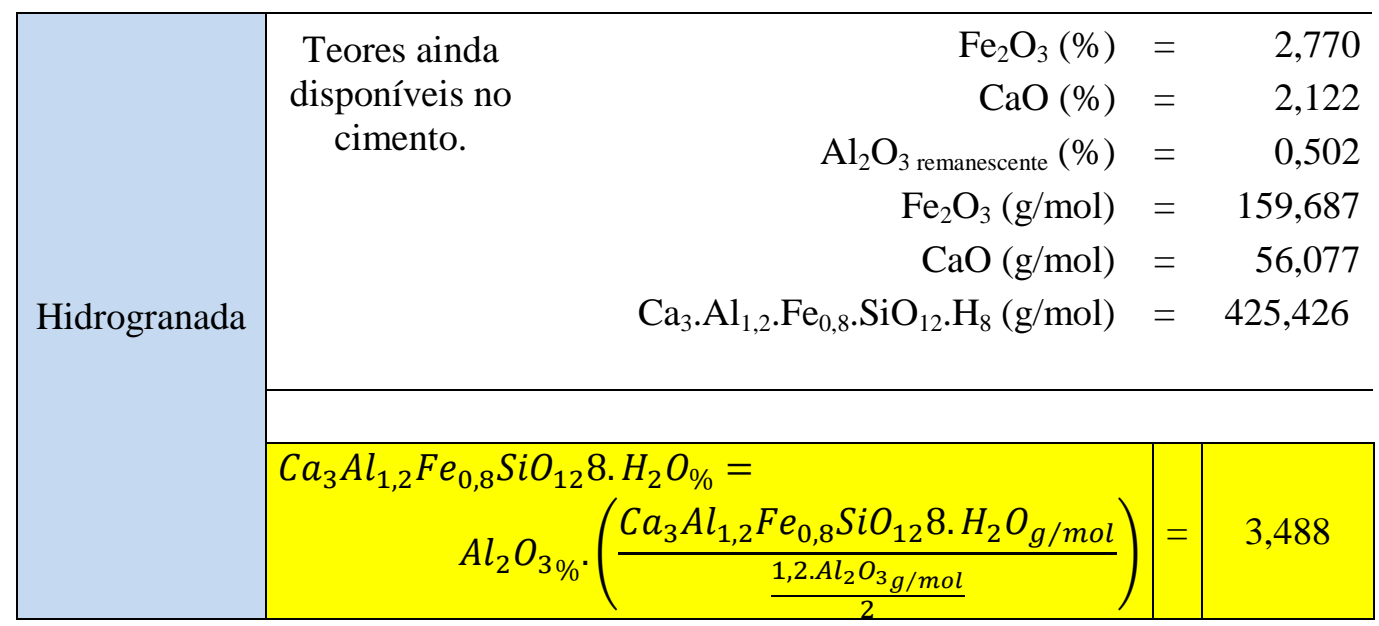




\subsection{ANÁLISE COMPARATIVA ENTRE MÉDIAS (TESTE DE TUKEY)}

As tabelas a seguir apresentam a análise comparativa entre médias (teste de Tukey para nível de significância de 5\%) para os resultados apresentados. Cabe comentar, que as tabelas são apresentadas aqui na mesma ordem conforme expostos os resultados no capítulo 4 do presente trabalho.

\subsubsection{Variação Dimensional Linear}

Tabela 25: Teste de Tukey para resultados de Variação Dimensional Linear das amostras expostas em solução de sulfato de Sódio por um período de 6 semanas, conforme NBR 13.583:2014

\begin{tabular}{|c|c|c|c|c|c|c|c|c|c|c|c|c|}
\hline \multicolumn{2}{|c|}{ SÉRIE } & $\mathbf{A}$ & B & $\mathbf{C}$ & D & $\mathbf{E}$ & $\mathbf{F}$ & $\mathbf{G}$ & $\mathbf{H}$ & I & $\mathbf{J}$ & $\mathbf{K}$ \\
\hline CPV ARI & $\mathbf{A}$ & $\mathbf{X}$ & 2 & 1 & 2 & 1 & 1 & 1 & 2 & 2 & 2 & 2 \\
\hline CPV RS & B & & $\mathbf{X}$ & 2 & 1 & 1 & 2 & 1 & 1 & 1 & 2 & 1 \\
\hline $\mathrm{FC}$ & $\mathrm{C}$ & & & $\mathbf{X}$ & 2 & 1 & 2 & 1 & 2 & 1 & 2 & 2 \\
\hline FQ & D & & & & $\mathbf{X}$ & 2 & 2 & 2 & 1 & 2 & 1 & 1 \\
\hline RCV $0,5 \mathrm{~h}$ & $\mathbf{E}$ & & & & & $\mathbf{X}$ & 2 & 1 & 1 & 1 & 2 & 2 \\
\hline RCV 1,0h & $\mathbf{F}$ & & & & & & $\mathbf{X}$ & 2 & 2 & 2 & 2 & 2 \\
\hline $\mathrm{RCV} 1,5 \mathrm{~h}$ & G & & & & & & & $\mathbf{X}$ & 1 & 1 & 2 & 1 \\
\hline $\mathrm{CV}$ & H & & & & & & & & $\mathbf{X}$ & 1 & 2 & 1 \\
\hline MT & I & & & & & & & & & $\mathbf{X}$ & 2 & 1 \\
\hline $\mathrm{SA}$ & $\mathbf{J}$ & & & & & & & & & & $\mathbf{X}$ & 1 \\
\hline SCA & K & & & & & & & & & & & $\mathbf{X}$ \\
\hline & & 1 & & O há & ff. si & ifica & & 2 & & if. & ific & \\
\hline
\end{tabular}

Tabela 26: Teste de Tukey para resultados de Variação Dimensional Linear das amostras expostas em solução de sulfato de Magnésio por um período de 6 semanas, adaptação da NBR 13.583:2014

\begin{tabular}{|c|c|c|c|c|c|c|c|c|c|c|c|c|}
\hline \multicolumn{2}{|c|}{ SÉRIE } & $\mathbf{A}$ & B & $\mathbf{C}$ & D & $\mathbf{E}$ & $\mathbf{F}$ & G & $\mathbf{H}$ & I & $\mathbf{J}$ & $\mathbf{K}$ \\
\hline CPV ARI & $\mathbf{A}$ & $\mathbf{X}$ & 1 & 2 & 1 & 1 & 1 & 1 & 2 & 1 & 2 & 1 \\
\hline CPV RS & B & & $\mathbf{X}$ & 2 & 1 & 1 & 1 & 1 & 1 & 1 & 1 & 1 \\
\hline $\mathrm{FC}$ & C & & & $\mathbf{X}$ & 2 & 1 & 1 & 1 & 2 & 2 & 2 & 2 \\
\hline FQ & D & & & & $\mathbf{X}$ & 2 & 1 & 1 & 1 & 1 & 1 & 1 \\
\hline RCV 0,5h & $\mathbf{E}$ & & & & & $\mathbf{X}$ & 1 & 1 & 2 & 2 & 2 & 2 \\
\hline $\mathrm{RCV} 1,0 \mathrm{~h}$ & $\mathbf{F}$ & & & & & & $\mathbf{X}$ & 1 & 2 & 1 & 2 & 2 \\
\hline $\mathrm{RCV} 1,5 \mathrm{~h}$ & G & & & & & & & $\mathbf{X}$ & 2 & 1 & 2 & 2 \\
\hline $\mathrm{CV}$ & H & & & & & & & & $\mathbf{X}$ & 1 & 1 & 1 \\
\hline MT & I & & & & & & & & & $\mathbf{X}$ & 1 & 1 \\
\hline SA & $\mathbf{J}$ & & & & & & & & & & $\mathbf{X}$ & 1 \\
\hline SCA & K & & & & & & & & & & & $\mathbf{X}$ \\
\hline & & 1 & & $\overline{\mathrm{O}}$ há & f. si & ficat & & 2 & & lif. $s$ & ific & \\
\hline
\end{tabular}


Tabela 27: Teste de Tukey para resultados de Variação Dimensional Linear das amostras expostas em solução de sulfato de Sódio por um período de 20 semanas

\begin{tabular}{|c|c|c|c|c|c|c|c|c|c|c|c|c|}
\hline \multicolumn{2}{|l|}{ SÉRIE } & $\mathbf{A}$ & B & C & D & $\mathbf{E}$ & $\mathbf{F}$ & $\mathbf{G}$ & $\mathbf{H}$ & I & $\mathbf{J}$ & $\mathbf{K}$ \\
\hline CPV ARI & $\mathbf{A}$ & $\mathbf{X}$ & 2 & 1 & 2 & 2 & 2 & 2 & 2 & 2 & 2 & 2 \\
\hline CPV RS & B & & $\mathbf{X}$ & 2 & 2 & 2 & 2 & 2 & 1 & 1 & 2 & 1 \\
\hline $\mathrm{FC}$ & C & & & $\mathbf{X}$ & 2 & 2 & 2 & 1 & 2 & 2 & 2 & 2 \\
\hline FQ & D & & & & $\mathbf{X}$ & 2 & 2 & 2 & 1 & 2 & 2 & 2 \\
\hline RCV 0,5h & $\mathbf{E}$ & & & & & $\mathbf{X}$ & 2 & 2 & 2 & 2 & 2 & 2 \\
\hline $\mathrm{RCV} 1,0 \mathrm{~h}$ & $\mathbf{F}$ & & & & & & $\mathbf{X}$ & 2 & 2 & 2 & 2 & 2 \\
\hline $\mathrm{RCV} 1,5 \mathrm{~h}$ & $\mathbf{G}$ & & & & & & & $\mathbf{X}$ & 2 & 2 & 2 & 2 \\
\hline $\mathrm{CV}$ & $\mathbf{H}$ & & & & & & & & $\mathbf{X}$ & 2 & 2 & 2 \\
\hline MT & I & & & & & & & & & $\mathbf{X}$ & 1 & 1 \\
\hline SA & $\mathbf{J}$ & & & & & & & & & & $\mathbf{X}$ & 1 \\
\hline SCA & $\mathbf{K}$ & & & & & & & & & & & $\mathbf{X}$ \\
\hline
\end{tabular}

Tabela 28: Teste de Tukey para resultados de Variação Dimensional Linear das amostras expostas em solução de sulfato de Magnésio por um período de 20 semanas

\begin{tabular}{|c|c|c|c|c|c|c|c|c|c|c|c|c|}
\hline \multicolumn{2}{|l|}{ SÉRIE } & $\mathbf{A}$ & B & C & D & $\mathbf{E}$ & $\mathbf{F}$ & G & H & I & $\mathbf{J}$ & K \\
\hline CPV ARI & $\mathbf{A}$ & $\mathbf{X}$ & 1 & 1 & 1 & 1 & 1 & 1 & 1 & 1 & 1 & 1 \\
\hline CPV RS & B & & $\bar{X}$ & 1 & 1 & 1 & 1 & 1 & 1 & 1 & 1 & 1 \\
\hline $\mathrm{FC}$ & $\mathrm{C}$ & & & $\mathbf{X}$ & 1 & 1 & 1 & 1 & 1 & 1 & 1 & 1 \\
\hline FQ & D & & & & $\mathbf{X}$ & 1 & 1 & 1 & 1 & 1 & 1 & 1 \\
\hline RCV $0,5 \mathrm{~h}$ & $\mathbf{E}$ & & & & & $\mathbf{X}$ & 1 & 1 & 1 & 1 & 1 & 1 \\
\hline $\mathrm{RCV} 1,0 \mathrm{~h}$ & $\mathbf{F}$ & & & & & & $\mathbf{X}$ & 1 & 1 & 1 & 1 & 1 \\
\hline RCV 1,5h & G & & & & & & & $\mathbf{X}$ & 1 & 1 & 1 & 1 \\
\hline $\mathrm{CV}$ & $\mathbf{H}$ & & & & & & & & $\mathbf{X}$ & 1 & 1 & 1 \\
\hline MT & I & & & & & & & & & $\mathbf{X}$ & 1 & 1 \\
\hline SA & $\mathbf{J}$ & & & & & & & & & & $\mathbf{X}$ & 1 \\
\hline SCA & K & & & & & & & & & & & $\mathbf{X}$ \\
\hline & & 1 & NÃC & dif & gnif & & & & & dif. $s$ & iific & \\
\hline
\end{tabular}

\subsubsection{Variação Resultante Volumétrica}

Tabela 29: Teste de Tukey para resultados de Variação Volumétrica das amostras expostas em solução de sulfato de Sódio por um período de 6 semanas

\begin{tabular}{|c|c|c|c|c|c|c|c|c|}
\hline \multicolumn{2}{|l|}{ SÉRIE } & $\mathbf{A}$ & B & C & D & $\mathbf{E}$ & $\mathbf{F}$ & G \\
\hline CPV ARI & $\mathbf{A}$ & $\mathbf{X}$ & 2 & 2 & 1 & 2 & 2 & 2 \\
\hline CPV ARI RS & B & & $\mathbf{X}$ & 2 & 2 & 2 & 1 & 1 \\
\hline Metacaulim & $\mathbf{C}$ & & & $\mathbf{X}$ & 1 & 2 & 2 & 2 \\
\hline Fíler Quartzoso & D & & & & $\mathbf{X}$ & 2 & 2 & 2 \\
\hline Sílica Ativa & $\mathbf{E}$ & & & & & $\mathbf{X}$ & 1 & 1 \\
\hline S. Casca Arroz & $\mathbf{F}$ & & & & & & $\mathbf{X}$ & 1 \\
\hline Cinza Volante & $\mathbf{G}$ & & & & & & & $\mathbf{X}$ \\
\hline & & 1 & & lá di & 1 & nifi & & \\
\hline & & 2 & & dife & $\mathrm{cas}$ & fica & & \\
\hline
\end{tabular}


Tabela 30: Teste de Tukey para resultados de Variação Volumétrica das amostras expostas em solução de sulfato de Magnésio por um período de 6 semanas

\begin{tabular}{|c|c|c|c|c|c|c|c|c|}
\hline \multicolumn{2}{|l|}{ SÉRIE } & $\mathbf{A}$ & B & $\mathrm{C}$ & D & $\mathbf{E}$ & $\mathbf{F}$ & G \\
\hline CPV ARI & $\mathbf{A}$ & $\mathbf{X}$ & 2 & 2 & 2 & 2 & 2 & 2 \\
\hline CPV ARI RS & B & & $\mathbf{X}$ & 2 & 2 & 2 & 2 & 2 \\
\hline Metacaulim & $\mathbf{C}$ & & & $\mathbf{X}$ & 2 & 2 & 2 & 2 \\
\hline Fíler Quartzoso & D & & & & $\mathbf{X}$ & 2 & 2 & 2 \\
\hline Súlica Ativa & $\mathbf{E}$ & & & & & $\mathbf{X}$ & 2 & 1 \\
\hline S. Casca Arroz & $\mathbf{F}$ & & & & & & $\mathbf{X}$ & 1 \\
\hline Cinza Volante & $\mathbf{G}$ & & & & & & & $\mathbf{X}$ \\
\hline & & 1 & & a d al & $n c ̧$ & nifi & & \\
\hline & & 2 & & dife & cas & fica & & \\
\hline
\end{tabular}

Tabela 31: Teste de Tukey para resultados de Variação Volumétrica das amostras expostas em solução de sulfato de Sódio por um período de 20 semanas

\begin{tabular}{|c|c|c|c|c|c|c|c|c|}
\hline \multicolumn{2}{|l|}{ SÉRIE } & \multirow{2}{*}{$\begin{array}{l}\mathbf{A} \\
\mathbf{X}\end{array}$} & \multirow{2}{*}{$\frac{\text { B }}{2}$} & \multirow{2}{*}{$\begin{array}{l}\text { C } \\
2\end{array}$} & \multirow{2}{*}{$\frac{\mathbf{D}}{1}$} & \multirow{2}{*}{$\frac{\mathbf{E}}{2}$} & \multirow{2}{*}{$\frac{\mathbf{F}}{2}$} & \multirow{2}{*}{$\frac{\mathbf{G}}{1}$} \\
\hline CPV ARI & $\mathbf{A}$ & & & & & & & \\
\hline CPV ARI RS & B & & $\mathbf{X}$ & 2 & 2 & 1 & 1 & 2 \\
\hline Metacaulim & $\mathbf{C}$ & & & $\mathbf{X}$ & 2 & 2 & 2 & 2 \\
\hline Fíler Quartzoso & D & & & & $\mathbf{X}$ & 2 & 2 & 1 \\
\hline Sílica Ativa & $\mathbf{E}$ & & & & & $\mathbf{X}$ & 1 & 2 \\
\hline S. Casca Arroz & $\mathbf{F}$ & & & & & & $\mathbf{X}$ & 2 \\
\hline Cinza Volante & $\mathbf{G}$ & & & & & & & $\mathbf{X}$ \\
\hline & & 1 & & á́ di & ença & nifi & & \\
\hline & & 2 & & dife & ça si & fica & & \\
\hline
\end{tabular}

Tabela 32: Teste de Tukey para resultados de Variação Volumétrica das amostras expostas em solução de sulfato de Magnésio por um período de 20 semanas

\begin{tabular}{|c|c|c|c|c|c|c|c|c|}
\hline \multicolumn{2}{|l|}{ SÉRIE } & \multirow{2}{*}{$\begin{array}{l}\mathbf{A} \\
\mathbf{X} \\
\end{array}$} & \multirow{2}{*}{$\begin{array}{c}\text { B } \\
2\end{array}$} & \multirow{2}{*}{$\begin{array}{l}\mathrm{C} \\
2\end{array}$} & \multirow{2}{*}{$\frac{\mathbf{D}}{2}$} & \multirow{2}{*}{$\begin{array}{c}\mathbf{E} \\
2\end{array}$} & \multirow{2}{*}{$\begin{array}{l}\mathbf{F} \\
2\end{array}$} & \multirow{2}{*}{$\frac{\mathbf{G}}{2}$} \\
\hline CPV ARI & $\mathbf{A}$ & & & & & & & \\
\hline CPV ARI RS & $\mathbf{B}$ & & $\mathbf{X}$ & 2 & 2 & 2 & 2 & 2 \\
\hline Metacaulim & $\mathbf{C}$ & & & $\mathbf{X}$ & 2 & 2 & 2 & 2 \\
\hline Fíler Quartzoso & $\mathbf{D}$ & & & & $\mathbf{X}$ & 2 & 2 & 2 \\
\hline Sílica Ativa & $\mathbf{E}$ & & & & & $\mathbf{X}$ & 2 & 2 \\
\hline S. Casca Arroz & $\mathbf{F}$ & & & & & & $\mathbf{X}$ & 2 \\
\hline Cinza Volante & $\mathbf{G}$ & & & & & & & $\mathbf{X}$ \\
\hline \multirow{2}{*}{ Cinta v viante } & & 1 & \multicolumn{5}{|c|}{ Não há diferença significativa } & \\
\hline & & 2 & \multicolumn{5}{|c|}{ Há diferença significativa } & \\
\hline
\end{tabular}




\subsubsection{Variação Resultante de Massa}

Tabela 33: Teste de Tukey para resultados de Variação Resultante de Massa das amostras expostas em solução de sulfato de Sódio por um período de 6 semanas

\begin{tabular}{|c|c|c|c|c|c|c|c|c|}
\hline \multicolumn{2}{|l|}{ SÉRIE } & $\mathbf{A}$ & B & $\mathrm{C}$ & D & $\mathbf{E}$ & $\mathbf{F}$ & G \\
\hline CPV ARI & $\mathbf{A}$ & $\mathbf{X}$ & 2 & 2 & 1 & 2 & 2 & 2 \\
\hline CPV ARI RS & $\mathbf{B}$ & & $\mathbf{X}$ & 2 & 2 & 1 & 2 & 2 \\
\hline Metacaulim & $\mathrm{C}$ & & & $\mathbf{X}$ & 2 & 2 & 2 & 2 \\
\hline Fíler Quartzoso & D & & & & $\mathbf{X}$ & 2 & 2 & 2 \\
\hline Sílica Ativa & $\mathbf{E}$ & & & & & $\mathbf{X}$ & 2 & 2 \\
\hline S. Casca Arroz & $\mathbf{F}$ & & & & & & $\mathbf{X}$ & 2 \\
\hline Cinza Volante & G & & & & & & & $\mathbf{X}$ \\
\hline & & 1 & & רá di & nça & nnifi & & \\
\hline & & 2 & & dife & 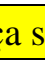 & fica & & \\
\hline
\end{tabular}

Tabela 34: Teste de Tukey para resultados de Variação Resultante de Massa das amostras expostas em solução de sulfato de Magnésio por um período de 6 semanas

\begin{tabular}{|c|c|c|c|c|c|c|c|c|}
\hline \multicolumn{2}{|l|}{ SÉRIE } & $\mathbf{A}$ & B & $\mathbf{C}$ & D & $\mathbf{E}$ & $\mathbf{F}$ & G \\
\hline CPV ARI & $\mathbf{A}$ & $\mathbf{X}$ & 2 & 2 & 2 & 2 & 2 & 2 \\
\hline CPV ARI RS & B & & $\mathbf{X}$ & 2 & 2 & 2 & 2 & 2 \\
\hline Metacaulim & $\mathbf{C}$ & & & $\mathbf{X}$ & 2 & 2 & 2 & 2 \\
\hline Fíler Quartzoso & D & & & & $\mathbf{X}$ & 2 & 2 & 2 \\
\hline Sílica Ativa & $\mathbf{E}$ & & & & & $\mathbf{X}$ & 2 & 2 \\
\hline S. Casca Arroz & $\mathbf{F}$ & & & & & & $\mathbf{X}$ & 2 \\
\hline Cinza Volante & $\mathbf{G}$ & & & & & & & $\mathbf{X}$ \\
\hline & & 1 & & á di & enç & nifi & & \\
\hline & & 2 & & dife & ça s & fica & & \\
\hline
\end{tabular}

Tabela 35: Teste de Tukey para resultados de Variação Resultante de Massa das amostras expostas em solução de sulfato de Sódio por um período de 20 semanas

\begin{tabular}{|c|c|c|c|c|c|c|c|c|}
\hline \multicolumn{2}{|l|}{ SÉRIE } & $\mathbf{A}$ & B & $\mathrm{C}$ & D & $\mathbf{E}$ & $\mathbf{F}$ & G \\
\hline CPV ARI & $\mathbf{A}$ & $\mathbf{X}$ & 2 & 1 & 1 & 2 & 2 & 2 \\
\hline CPV ARI RS & B & & $\mathbf{X}$ & 2 & 2 & 2 & 1 & 2 \\
\hline Metacaulim & $\mathrm{C}$ & & & $\mathbf{X}$ & 1 & 2 & 2 & 2 \\
\hline Fíler Quartzoso & D & & & & $\mathbf{X}$ & 2 & 2 & 2 \\
\hline Sílica Ativa & $\mathbf{E}$ & & & & & $\mathbf{X}$ & 1 & 2 \\
\hline S. Casca Arroz & $\mathbf{F}$ & & & & & & $\mathbf{X}$ & 2 \\
\hline Cinza Volante & $\mathbf{G}$ & & & & & & & $\mathbf{X}$ \\
\hline & & 1 & & á di & nça & nifi & & \\
\hline & & 2 & & $\overline{\text { dife }}$ & a si & fica & & \\
\hline
\end{tabular}


Tabela 36: Teste de Tukey para resultados de Variação Resultante de Massa das amostras expostas em solução de sulfato de Magnésio por um período de 20 semanas

\begin{tabular}{|c|c|c|c|c|c|c|c|c|}
\hline \multicolumn{2}{|l|}{ SÉRIE } & $\mathbf{A}$ & B & $\mathrm{C}$ & D & $\mathbf{E}$ & $\mathbf{F}$ & $\mathbf{G}$ \\
\hline CPV ARI & $\mathbf{A}$ & $\mathbf{X}$ & 2 & 2 & 2 & 2 & 2 & 2 \\
\hline CPV ARI RS & B & & $\mathbf{X}$ & 2 & 2 & 2 & 2 & 2 \\
\hline Metacaulim & $\mathbf{C}$ & & & $\mathbf{X}$ & 2 & 2 & 2 & 2 \\
\hline Fíler Quartzoso & D & & & & $\mathbf{X}$ & 2 & 2 & 2 \\
\hline Sílica Ativa & $\mathbf{E}$ & & & & & $\mathbf{X}$ & 2 & 2 \\
\hline S. Casca Arroz & $\mathbf{F}$ & & & & & & $\mathbf{X}$ & 2 \\
\hline Cinza Volante & $\mathbf{G}$ & & & & & & & $\mathbf{X}$ \\
\hline & & 1 & & lá di & $n c ̧$ & nifi & & \\
\hline & & 2 & & dife & cas & fica & & \\
\hline
\end{tabular}

\subsubsection{Variação Resultante de Velocidade Ultrassônica}

Tabela 37: Teste de Tukey para resultados de Variação Resultante de Velocidade Ultrassônica das amostras expostas em solução de sulfato de Sódio por um período de 6 semanas

\begin{tabular}{|c|c|c|c|c|c|c|c|c|}
\hline \multicolumn{2}{|l|}{ SÉRIE } & \multirow{2}{*}{$\begin{array}{l}\mathbf{A} \\
\mathbf{X}\end{array}$} & \multirow{2}{*}{$\begin{array}{c}\text { B } \\
2\end{array}$} & \multirow{2}{*}{$\begin{array}{l}\mathbf{C} \\
2\end{array}$} & \multirow{2}{*}{$\begin{array}{c}\mathbf{D} \\
1\end{array}$} & \multirow{2}{*}{$\begin{array}{c}\mathbf{E} \\
2\end{array}$} & \multirow{2}{*}{$\begin{array}{l}\mathbf{F} \\
2\end{array}$} & \multirow{2}{*}{$\begin{array}{c}\mathbf{G} \\
1\end{array}$} \\
\hline CPV ARI & $\mathbf{A}$ & & & & & & & \\
\hline CPV ARI RS & B & & $\mathbf{X}$ & 1 & 2 & 1 & 1 & 2 \\
\hline Metacaulim & $\mathrm{C}$ & & & $\mathbf{X}$ & 2 & 1 & 1 & 2 \\
\hline Fíler Quartzoso & $\mathbf{D}$ & & & & $\mathbf{X}$ & 2 & 2 & 2 \\
\hline Sílica Ativa & $\mathbf{E}$ & & & & & $\mathbf{X}$ & 1 & 2 \\
\hline S. Casca Arroz & $\mathbf{F}$ & & & & & & $\mathbf{X}$ & 2 \\
\hline Cinza Volante & $\mathbf{G}$ & & & & & & & $\mathbf{X}$ \\
\hline & & 1 & & aá di & 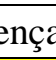 & nifi & & \\
\hline & & 2 & & dife & ça s & fica & & \\
\hline
\end{tabular}

Tabela 38: Teste de Tukey para resultados de Variação Resultante de Velocidade Ultrassônica das amostras expostas em solução de sulfato de Magnésio por um período de 6 semanas

\begin{tabular}{|c|c|c|c|c|c|c|c|c|}
\hline \multicolumn{2}{|l|}{ SÉRIE } & $\mathbf{A}$ & B & C & D & $\mathbf{E}$ & $\mathbf{F}$ & G \\
\hline CPV ARI & A & $\mathbf{X}$ & 2 & 1 & 2 & 1 & 1 & 2 \\
\hline CPV ARI RS & B & & $\mathbf{X}$ & 2 & 2 & 2 & 2 & 2 \\
\hline Metacaulim & $\mathbf{C}$ & & & $\mathbf{X}$ & 1 & 1 & 1 & 2 \\
\hline Fíler Quartzoso & D & & & & $\mathbf{X}$ & 1 & 1 & 2 \\
\hline Sílica Ativa & $\mathbf{E}$ & & & & & $\mathbf{X}$ & 1 & 2 \\
\hline S. Casca Arroz & $\mathbf{F}$ & & & & & & $\mathbf{X}$ & 2 \\
\hline Cinza Volante & $\mathbf{G}$ & & & & & & & $\mathbf{X}$ \\
\hline & & 1 & & lá di & ఆţ̧ & $\mathrm{nII}$ & & \\
\hline & & 2 & & dife & cas & fica & & \\
\hline
\end{tabular}


Tabela 39: Teste de Tukey para resultados de Variação Resultante de Velocidade Ultrassônica das amostras expostas em solução de sulfato de Sódio por um período de 20 semanas

\begin{tabular}{|c|c|c|c|c|c|c|c|c|}
\hline \multicolumn{2}{|l|}{ SÉRIE } & $\mathbf{A}$ & B & $\mathrm{C}$ & D & $\mathbf{E}$ & $\mathbf{F}$ & $\mathbf{G}$ \\
\hline CPV ARI & $\mathbf{A}$ & $\bar{X}$ & 2 & 2 & 2 & 2 & 2 & 2 \\
\hline CPV ARI RS & B & & $\mathbf{X}$ & 2 & 2 & 2 & 2 & 2 \\
\hline Metacaulim & $\mathrm{C}$ & & & $\mathbf{X}$ & 2 & 2 & 2 & 2 \\
\hline Fíler Quartzoso & D & & & & $\mathbf{X}$ & 2 & 2 & 1 \\
\hline Sílica Ativa & $\mathbf{E}$ & & & & & $\mathbf{X}$ & 2 & 2 \\
\hline S. Casca Arroz & $\mathbf{F}$ & & & & & & $\mathbf{X}$ & 2 \\
\hline Cinza Volante & $\mathbf{G}$ & & & & & & & $\mathbf{X}$ \\
\hline & & 1 & & lá di & nçc & nifi & & \\
\hline & & 2 & & dife & s & fica & & \\
\hline
\end{tabular}

Tabela 40: Teste de Tukey para resultados de Variação Resultante de Velocidade Ultrassônica das amostras expostas em solução de sulfato de Magnésio por um período de 20 semanas

\begin{tabular}{|c|c|c|c|c|c|c|c|c|}
\hline \multicolumn{2}{|l|}{ SÉRIE } & $\mathbf{A}$ & B & $\mathrm{C}$ & D & $\mathbf{E}$ & $\mathbf{F}$ & G \\
\hline CPV ARI & $\mathbf{A}$ & $\mathbf{X}$ & 2 & 2 & 2 & 2 & 2 & 2 \\
\hline CPV ARI RS & B & & $\mathbf{X}$ & 2 & 2 & 2 & 2 & 2 \\
\hline Metacaulim & $\mathbf{C}$ & & & $\mathbf{X}$ & 2 & 2 & 2 & 2 \\
\hline Fíler Quartzoso & $\mathbf{D}$ & & & & $\mathbf{X}$ & 2 & 2 & 2 \\
\hline Sílica Ativa & $\mathbf{E}$ & & & & & $\mathbf{X}$ & 2 & 2 \\
\hline S. Casca Arroz & $\mathbf{F}$ & & & & & & $\mathbf{X}$ & 2 \\
\hline Cinza Volante & $\mathbf{G}$ & & & & & & & $\mathbf{X}$ \\
\hline & & 1 & & á́ di & enç: & nifi & & \\
\hline & & 2 & & dife & ça s & fica & & \\
\hline
\end{tabular}

\subsubsection{Variação Resultante no Módulo de Elasticidade Dinâmico}

Tabela 41: Teste de Tukey para resultados de Variação Resultante no Módulo de Elasticidade Dinâmico das amostras expostas em solução de sulfato de Sódio por um período de 6 semanas

\begin{tabular}{|c|c|c|c|c|c|c|c|c|}
\hline \multicolumn{2}{|l|}{ SÉRIE } & $\mathbf{A}$ & B & C & D & $\mathbf{E}$ & $\mathbf{F}$ & G \\
\hline CPV ARI & $\mathbf{A}$ & $\mathbf{X}$ & 2 & 2 & 2 & 2 & 2 & 2 \\
\hline CPV ARI RS & $\mathbf{B}$ & & $\mathbf{X}$ & 2 & 1 & 1 & 2 & 2 \\
\hline Metacaulim & $\mathrm{C}$ & & & $\mathbf{X}$ & 2 & 2 & 1 & 2 \\
\hline Fíler Quartzoso & D & & & & $\mathbf{X}$ & 1 & 2 & 2 \\
\hline Sílica Ativa & $\mathbf{E}$ & & & & & $\mathbf{X}$ & 2 & 2 \\
\hline S. Casca Arroz & $\mathbf{F}$ & & & & & & $\mathbf{X}$ & 2 \\
\hline Cinza Volante & G & & & & & & & $\mathbf{X}$ \\
\hline & & 1 & & רá di & enç & nifi & & \\
\hline & & 2 & & dife & ça s & fica & & \\
\hline
\end{tabular}


Tabela 42: Teste de Tukey para resultados de Variação Resultante no Módulo de Elasticidade Dinâmico das amostras expostas em solução de sulfato de Magnésio por um período de 6 semanas

\begin{tabular}{|c|c|c|c|c|c|c|c|c|}
\hline \multicolumn{2}{|l|}{ SÉRIE } & $\mathbf{A}$ & B & $\mathbf{C}$ & D & $\mathbf{E}$ & $\mathbf{F}$ & G \\
\hline CPV ARI & $\mathbf{A}$ & $\mathbf{X}$ & 1 & 2 & 2 & 1 & 2 & 2 \\
\hline CPV ARI RS & B & & $\mathbf{X}$ & 2 & 2 & 1 & 2 & 2 \\
\hline Metacaulim & $\mathbf{C}$ & & & $\mathbf{X}$ & 2 & 2 & 1 & 2 \\
\hline Fíler Quartzoso & D & & & & $\mathbf{X}$ & 1 & 2 & 1 \\
\hline Sílica Ativa & $\mathbf{E}$ & & & & & $\mathbf{X}$ & 1 & 1 \\
\hline S. Casca Arroz & $\mathbf{F}$ & & & & & & $\mathbf{X}$ & 2 \\
\hline Cinza Volante & $\mathbf{G}$ & & & & & & & $\mathbf{X}$ \\
\hline & & 1 & & lá di & IÇC & nifi & & \\
\hline & & 2 & & dife & a s & fica & & \\
\hline
\end{tabular}

Tabela 43: Teste de Tukey para resultados de Variação Resultante no Módulo de Elasticidade Dinâmico das amostras expostas em solução de sulfato de Sódio por um período de 20 semanas

\begin{tabular}{|c|c|c|c|c|c|c|c|c|}
\hline \multicolumn{2}{|l|}{ SÉRIE } & $\mathbf{A}$ & B & $\mathrm{C}$ & D & $\mathbf{E}$ & $\mathbf{F}$ & G \\
\hline CPV ARI & $\mathbf{A}$ & $\mathbf{X}$ & 2 & 2 & 2 & 2 & 2 & 2 \\
\hline CPV ARI RS & B & & $\mathbf{X}$ & 2 & 2 & 2 & 1 & 1 \\
\hline Metacaulim & $\mathbf{C}$ & & & $\mathbf{X}$ & 2 & 2 & 2 & 2 \\
\hline Fíler Quartzoso & $\mathbf{D}$ & & & & $\mathbf{X}$ & 2 & 2 & 2 \\
\hline Sílica Ativa & $\mathbf{E}$ & & & & & $\mathbf{X}$ & 2 & 2 \\
\hline S. Casca Arroz & $\mathbf{F}$ & & & & & & $\mathbf{X}$ & 2 \\
\hline Cinza Volante & $\mathbf{G}$ & & & & & & & $\mathbf{X}$ \\
\hline & & 1 & & á di & $n$ ņc & nII1 & & \\
\hline & & 2 & & dife & ça s & fica & & \\
\hline
\end{tabular}

Tabela 44: Teste de Tukey para resultados de Variação Resultante no Módulo de Elasticidade Dinâmico das amostras expostas em solução de sulfato de Magnésio por um período de 20 semanas

\begin{tabular}{|c|c|c|c|c|c|c|c|c|}
\hline \multicolumn{2}{|l|}{ SÉRIE } & A & B & $\mathbf{C}$ & D & $\mathbf{E}$ & $\mathbf{F}$ & $\mathbf{G}$ \\
\hline CPV ARI & A & $\mathbf{X}$ & 2 & 1 & 2 & 2 & 2 & 2 \\
\hline CPV ARI RS & B & & $\mathbf{X}$ & 2 & 2 & 2 & 1 & 2 \\
\hline Metacaulim & $\mathbf{C}$ & & & $\mathbf{X}$ & 2 & 2 & 2 & 2 \\
\hline Fíler Quartzoso & D & & & & $\mathbf{X}$ & 2 & 2 & 2 \\
\hline Sílica Ativa & $\mathbf{E}$ & & & & & $\mathbf{X}$ & 1 & 2 \\
\hline S. Casca Arroz & $\mathbf{F}$ & & & & & & $\mathbf{X}$ & 2 \\
\hline Cinza Volante & G & & & & & & & $\mathbf{X}$ \\
\hline & & 1 & & lá di & enç: & gnifi & & \\
\hline & & 2 & & dife & ça s & ifica & & \\
\hline
\end{tabular}


Tabela 45: Teste de Tukey para resultados de Módulo de Elasticidade Dinâmico das amostras expostas às soluções de: C - Hidróxido de cálcio; S - Sulfato de Sódio; e M - Sulfato de Magnésio por um período de 6 semanas

\begin{tabular}{|c|c|c|c|c|c|c|c|c|c|c|c|c|c|c|c|c|c|c|c|c|c|c|}
\hline \multicolumn{2}{|c|}{ SÉRIE } & 1 & 2 & 3 & 4 & 5 & 6 & 7 & 8 & 9 & 10 & 11 & 12 & 13 & 14 & 15 & 16 & 17 & 18 & 19 & 20 & 21 \\
\hline C. ARI & 1 & $\mathbf{X}$ & 2 & 1 & 1 & 2 & 2 & 2 & 1 & 2 & 2 & 2 & 2 & 1 & 2 & 1 & 2 & 1 & 1 & 2 & 2 & 2 \\
\hline C. RS & 2 & & $\mathbf{X}$ & 2 & 2 & 1 & 1 & 2 & 2 & 1 & 2 & 1 & 1 & 1 & 2 & 2 & 1 & 2 & 2 & 1 & 1 & 2 \\
\hline C. MT & 3 & & & $\mathbf{X}$ & 1 & 2 & 2 & 2 & 1 & 2 & 1 & 2 & 2 & 2 & 2 & 1 & 2 & 1 & 1 & 2 & 2 & 2 \\
\hline C. FQ & 4 & & & & $\mathbf{X}$ & 2 & 2 & 2 & 1 & 2 & 2 & 1 & 2 & 1 & 2 & 1 & 2 & 2 & 1 & 2 & 2 & 2 \\
\hline C.SA & 5 & & & & & $\mathbf{X}$ & 2 & 2 & 2 & 1 & 2 & 1 & 1 & 1 & 2 & 2 & 1 & 2 & 2 & 1 & 1 & 2 \\
\hline C. SCA & 6 & & & & & & $\mathbf{X}$ & 2 & 2 & 1 & 2 & 1 & 1 & 2 & 2 & 2 & 1 & 2 & 2 & 1 & 1 & 1 \\
\hline C. $\mathrm{CV}$ & 7 & & & & & & & $\mathbf{X}$ & 2 & 1 & 2 & 2 & 1 & 2 & 2 & 2 & 1 & 2 & 2 & 1 & 2 & 1 \\
\hline S. ARI & 8 & & & & & & & & $\mathbf{X}$ & 2 & 1 & 2 & 2 & 2 & 2 & 1 & 2 & 1 & 1 & 2 & 2 & 2 \\
\hline S. RS & 9 & & & & & & & & & $\mathbf{X}$ & 2 & 1 & 1 & 2 & 2 & 2 & 1 & 2 & 2 & 1 & 1 & 1 \\
\hline S. MT & 10 & & & & & & & & & & $\mathbf{X}$ & 2 & 2 & 2 & 2 & 1 & 2 & 1 & 1 & 2 & 2 & 2 \\
\hline S. FQ & 11 & & & & & & & & & & & $\mathbf{X}$ & 1 & 1 & 2 & 2 & 1 & 2 & 2 & 1 & 1 & 2 \\
\hline S. SA & 12 & & & & & & & & & & & & $\mathbf{X}$ & 1 & 2 & 2 & 1 & 2 & 2 & 1 & 1 & 1 \\
\hline S. SCA & 13 & & & & & & & & & & & & & $\mathbf{X}$ & 2 & 2 & 2 & 2 & 1 & 1 & 1 & 2 \\
\hline S. CV & 14 & & & & & & & & & & & & & & $\mathbf{X}$ & 2 & 2 & 2 & 2 & 2 & 2 & 2 \\
\hline M. ARI & 15 & & & & & & & & & & & & & & & $\mathbf{X}$ & 2 & 1 & 1 & 2 & 2 & 2 \\
\hline M. RS & 16 & & & & & & & & & & & & & & & & $\mathbf{X}$ & 2 & 2 & 1 & 1 & 2 \\
\hline M. MT & 17 & & & & & & & & & & & & & & & & & $\mathbf{X}$ & 1 & 2 & 2 & 2 \\
\hline M. FQ & 18 & & & & & & & & & & & & & & & & & & $\mathbf{X}$ & 2 & 2 & 2 \\
\hline M. SA & 19 & & & & & & & & & & & & & & & & & & & $\mathbf{X}$ & 1 & 1 \\
\hline M. SCA & 20 & & & & & & & & & & & & & & & & & & & & $\mathbf{X}$ & 2 \\
\hline M. CV & 21 & & & & & & & & & & & & & & & & & & & & & $\mathbf{X}$ \\
\hline
\end{tabular}


Tabela 46: Teste de Tukey para resultados de Módulo de Elasticidade Dinâmico das amostras expostas às soluções de: C - Hidróxido de cálcio; S - Sulfato de Sódio; e M - Sulfato de Magnésio por um período de 20 semanas

\begin{tabular}{|c|c|c|c|c|c|c|c|c|c|c|c|c|c|c|c|c|c|c|c|}
\hline \multirow{2}{*}{\multicolumn{2}{|c|}{ SÉRIE }} & \multirow{3}{*}{\begin{tabular}{|c|}
1 \\
$\mathbf{X}$ \\
\end{tabular}} & \multirow{3}{*}{\begin{tabular}{|l|}
3 \\
2 \\
\end{tabular}} & \multirow{3}{*}{\begin{tabular}{|l|}
4 \\
2 \\
\end{tabular}} & \multirow{3}{*}{\begin{tabular}{|l|}
5 \\
2 \\
\end{tabular}} & \multirow{2}{*}{\begin{tabular}{|l|}
6 \\
2 \\
\end{tabular}} & \multirow{3}{*}{\begin{tabular}{|l|}
8 \\
2 \\
\end{tabular}} & \multirow{3}{*}{\begin{tabular}{|l|}
9 \\
2 \\
\end{tabular}} & \multirow{3}{*}{$\begin{array}{l}11 \\
\end{array}$} & \multirow{3}{*}{\begin{tabular}{|c|}
12 \\
2
\end{tabular}} & \multirow{3}{*}{$\begin{array}{c}13 \\
2 \\
\end{array}$} & \multirow{3}{*}{\begin{tabular}{|c|}
14 \\
2 \\
\end{tabular}} & \multirow{3}{*}{\begin{tabular}{c|}
15 \\
1 \\
\end{tabular}} & \multirow{3}{*}{\begin{tabular}{|c|}
16 \\
2 \\
\end{tabular}} & \multirow{3}{*}{\begin{tabular}{|c|}
17 \\
1 \\
\end{tabular}} & \multirow{3}{*}{\begin{tabular}{|c|}
18 \\
1 \\
\end{tabular}} & \multirow{3}{*}{\begin{tabular}{|c|}
19 \\
1 \\
\end{tabular}} & \multirow{3}{*}{$\begin{array}{c}20 \\
1\end{array}$} & \multirow{3}{*}{\begin{tabular}{|c|}
21 \\
2 \\
\end{tabular}} \\
\hline & & & & & & & & & & & & & & & & & & & \\
\hline C. ARI & 1 & & & & & \begin{tabular}{|l|}
7 \\
2 \\
\end{tabular} & & & & & & & & & & & & & \\
\hline C. RS & 2 & \begin{tabular}{|l|}
$\mathbf{X}$ \\
\end{tabular} & 1 & 2 & \begin{tabular}{l|l}
1 & 2 \\
\end{tabular} & 2 & \begin{tabular}{|l|l|}
2 \\
\end{tabular} & \begin{tabular}{l|l}
2 & 2
\end{tabular} & \begin{tabular}{|l|l|}
2 & 2 \\
\end{tabular} & 2 & 1 & 1 & 2 & 2 & 2 & 2 & 2 & 2 & 1 \\
\hline C. MT & 3 & & $\mathbf{X}$ & 1 & \begin{tabular}{l|l}
2 & 2 \\
\end{tabular} & 2 & 2 & 1 & 2 & 2 & 2 & 2 & 2 & 2 & 2 & 2 & 2 & 2 & 2 \\
\hline C. FQ & 4 & & & $\mathbf{X}$ & \begin{tabular}{l|l}
2 & 2 \\
\end{tabular} & 2 & 2 & 1 & 2 & 2 & 2 & 2 & 2 & 2 & 2 & 1 & 2 & 2 & 2 \\
\hline C. SA & 5 & & & & \begin{tabular}{l|l}
$X$ & 2 \\
\end{tabular} & 2 & 2 & 2 & 2 & 1 & 1 & 1 & 2 & 2 & 2 & 2 & 2 & 2 & 1 \\
\hline C. SCA & 6 & & & & \begin{tabular}{l|l} 
& $\mathbf{X}$ \\
\end{tabular} & \begin{tabular}{l|l}
$x$ & 2
\end{tabular} & 2 & 2 & 2 & 1 & 1 & 1 & 2 & 2 & 2 & 2 & 2 & 2 & 1 \\
\hline C. CV & 7 & & & & & $\mathbf{X}$ & 2 & 2 & 2 & 2 & 2 & 2 & 2 & 2 & 2 & 2 & 2 & 2 & 2 \\
\hline S. ARI & 8 & & & & & & $\mathbf{X}$ & 2 & 2 & 2 & 2 & 2 & 2 & 2 & 2 & 2 & 2 & 2 & 2 \\
\hline S. RS & 9 & & & & & & & $\mathbf{X}$ & 2 & 2 & 2 & 2 & 2 & 2 & 2 & 1 & 2 & 2 & 2 \\
\hline S. MT & 10 & & & & & & & $\mathbf{X}$ & 2 & 2 & 2 & 2 & 2 & 2 & 2 & 2 & 2 & 2 & 2 \\
\hline S. FQ & 11 & & & & & & & & $\mathbf{X}$ & 2 & 2 & 2 & 1 & 1 & 1 & 2 & 2 & 2 & 2 \\
\hline S.SA & 12 & & & & & & & & & $\mathbf{X}$ & 1 & 1 & 2 & 2 & 2 & 2 & 2 & 2 & 1 \\
\hline S. SCA & 13 & & & & & & & & & & $\mathbf{X}$ & 1 & 2 & 2 & 2 & 2 & 2 & 2 & 1 \\
\hline S. CV & 14 & & & & & & & & & & & $\mathbf{X}$ & 2 & 2 & 2 & 2 & 2 & 2 & 1 \\
\hline M. ARI & 15 & & & & & & & & & & & & $\mathbf{X}$ & 1 & 1 & 1 & 1 & 1 & 2 \\
\hline M. RS & 16 & & & & & & & & & & & & & $\mathbf{X}$ & 2 & 2 & 2 & 2 & 2 \\
\hline M. MT & 17 & & & & & & & & & & & & & & $\mathbf{X}$ & 1 & 1 & 1 & 2 \\
\hline M. FQ & 18 & & & & & & & & & & & & & & & $\mathbf{X}$ & 1 & 1 & 2 \\
\hline M. SA & 19 & & & & & & & & & & & & & & & & $\mathbf{X}$ & 1 & 2 \\
\hline M. SCA & 20 & & & & & & & & & & & & & & & & & $\mathbf{X}$ & 2 \\
\hline M. CV & 21 & & & & & & & & & & & & & & & & & & $\mathbf{X}$ \\
\hline
\end{tabular}

\begin{tabular}{|l|l|l|l|}
1 & NÃO há dif. significativa & 2 & Há dif. significativa \\
\hline
\end{tabular} 


\subsubsection{Variação na Resistência à Tração na Flexão}

Tabela 47: Teste de Tukey para resultados de Resistência à Tração na Flexão das amostras expostas às soluções de: C - Hidróxido de cálcio; S - Sulfato de Sódio; e M - Sulfato de Magnésio por um período de 6 semanas

\begin{tabular}{|c|c|c|c|c|c|c|c|c|c|c|c|c|c|c|c|c|c|c|c|c|c|c|}
\hline \multicolumn{2}{|c|}{ SÉRIE } & 1 & 2 & 3 & 4 & 5 & 6 & 7 & 8 & 9 & 10 & 11 & 12 & 13 & 14 & 15 & 16 & 17 & 18 & 19 & 20 & 21 \\
\hline C. ARI & 1 & $\mathbf{X}$ & 1 & 1 & 1 & 2 & 2 & 2 & 2 & 2 & 2 & 2 & 2 & 2 & 2 & 2 & 2 & 2 & 2 & 2 & 2 & 2 \\
\hline C. RS & 2 & & $\mathbf{X}$ & 1 & 1 & 1 & 2 & 1 & 2 & 2 & 2 & 2 & 2 & 2 & 2 & 1 & 2 & 2 & 2 & 2 & 2 & 2 \\
\hline C. MT & 3 & & & $\mathbf{X}$ & 1 & 2 & 2 & 2 & 2 & 2 & 2 & 2 & 2 & 2 & 2 & 2 & 2 & 2 & 2 & 2 & 2 & 2 \\
\hline C. FQ & 4 & & & & $\mathbf{X}$ & 2 & 2 & 2 & 2 & 2 & 2 & 2 & 2 & 2 & 2 & 2 & 2 & 2 & 2 & 2 & 2 & 2 \\
\hline C.SA & 5 & & & & & $\mathbf{X}$ & 2 & 2 & 1 & 2 & 1 & 1 & 2 & 2 & 2 & 1 & 2 & 1 & 1 & 2 & 2 & 2 \\
\hline C. SCA & 6 & & & & & & $X$ & 2 & 2 & 1 & 1 & 2 & 1 & 2 & 1 & 2 & 1 & 1 & 2 & 1 & 2 & 1 \\
\hline C. CV & 7 & & & & & & & $\mathrm{X}$ & 1 & 2 & 2 & 1 & 2 & 2 & 2 & 1 & 2 & 2 & 1 & 2 & 2 & 2 \\
\hline S. ARI & 8 & & & & & & & & $\mathbf{X}$ & 2 & 1 & 1 & 2 & 2 & 2 & 1 & 2 & 1 & 1 & 2 & 2 & 1 \\
\hline S. RS & 9 & & & & & & & & & $\mathbf{X}$ & 1 & 2 & 1 & 2 & 1 & 2 & 1 & 1 & 2 & 1 & 2 & 1 \\
\hline S. MT & 10 & & & & & & & & & & $\mathbf{X}$ & 2 & 1 & 2 & 1 & 2 & 2 & 1 & 1 & 1 & 2 & 1 \\
\hline S. FQ & 11 & & & & & & & & & & & $\mathbf{X}$ & 2 & 2 & 2 & 1 & 2 & 1 & 1 & 2 & 2 & 2 \\
\hline S. SA & 12 & & & & & & & & & & & & $\mathbf{X}$ & 2 & 1 & 2 & 1 & 1 & 2 & 1 & 2 & 1 \\
\hline S. SCA & 13 & & & & & & & & & & & & & $\mathbf{X}$ & 2 & 2 & 2 & 2 & 2 & 2 & 1 & 2 \\
\hline S. CV & 14 & & & & & & & & & & & & & & $\mathbf{X}$ & 2 & 1 & 1 & 2 & 1 & 2 & 1 \\
\hline M. ARI & 15 & & & & & & & & & & & & & & & $\mathbf{X}$ & 2 & 1 & 1 & 2 & 2 & 2 \\
\hline M. RS & 16 & & & & & & & & & & & & & & & & $\mathbf{X}$ & 2 & 2 & 1 & 1 & 2 \\
\hline M. MT & 17 & & & & & & & & & & & & & & & & & $\mathbf{X}$ & 1 & 2 & 2 & 1 \\
\hline M. FQ & 18 & & & & & & & & & & & & & & & & & & $\mathbf{X}$ & 2 & 2 & 1 \\
\hline M. SA & 19 & & & & & & & & & & & & & & & & & & & $\mathbf{X}$ & 2 & 1 \\
\hline M. SCA & 20 & & & & & & & & & & & & & & & & & & & & $\mathbf{X}$ & 2 \\
\hline M. CV & 21 & & & & & & & & & & & & & & & & & & & & & $\mathbf{X}$ \\
\hline
\end{tabular}

\begin{tabular}{l|l|l|l|}
1 & NÃO há dif. significativa & 2 & Há dif. significativa \\
\hline
\end{tabular}


Tabela 48: Teste de Tukey para resultados de Resistência à Tração na Flexão das amostras expostas às soluções de: C - Hidróxido de cálcio; S - Sulfato de Sódio; e M - Sulfato de Magnésio por um período de 20 semanas

\begin{tabular}{|c|c|c|c|c|c|c|c|c|c|c|c|c|c|c|c|c|c|c|c|c|c|c|}
\hline \multicolumn{2}{|c|}{ SÉRIE } & 1 & 2 & 3 & 4 & 5 & 6 & 7 & 8 & 9 & 10 & 11 & 12 & 13 & 14 & 15 & 16 & 17 & 18 & 19 & 20 & 21 \\
\hline C. ARI & 1 & $\mathbf{X}$ & 1 & 1 & 1 & 1 & 2 & 2 & 1 & 2 & 1 & 1 & 2 & 2 & 2 & 1 & 2 & 1 & 2 & 2 & 2 & 2 \\
\hline C. RS & 2 & & $\mathbf{X}$ & 1 & 1 & 1 & 2 & 1 & 1 & 2 & 2 & 1 & 2 & 2 & 2 & 1 & 1 & 1 & 1 & 2 & 2 & 1 \\
\hline C. MT & 3 & & & $\mathbf{X}$ & 1 & 1 & 2 & 1 & 1 & 2 & 2 & 1 & 2 & 2 & 2 & 1 & 1 & 1 & 2 & 2 & 2 & 2 \\
\hline C. FQ & 4 & & & & $\mathbf{X}$ & 2 & 2 & 2 & 1 & 2 & 1 & 2 & 2 & 2 & 2 & 2 & 2 & 1 & 2 & 2 & 2 & 2 \\
\hline C.SA & 5 & & & & & $\mathbf{X}$ & 2 & 2 & 1 & 1 & 2 & 1 & 2 & 2 & 2 & 1 & 1 & 1 & 1 & 1 & 2 & 1 \\
\hline C. SCA & 6 & & & & & & $\mathbf{X}$ & 2 & 2 & 1 & 2 & 1 & 1 & 2 & 1 & 1 & 1 & 2 & 1 & 1 & 2 & 1 \\
\hline C. CV & 7 & & & & & & & $\mathbf{X}$ & 1 & 1 & 2 & 1 & 2 & 2 & 1 & 1 & 1 & 1 & 1 & 1 & 2 & 1 \\
\hline S. ARI & 8 & & & & & & & & $\mathbf{X}$ & 2 & 2 & 1 & 2 & 2 & 2 & 1 & 1 & 1 & 2 & 2 & 2 & 2 \\
\hline S. RS & 9 & & & & & & & & & $\mathbf{X}$ & 2 & 1 & 1 & 2 & 1 & 1 & 1 & 2 & 1 & 1 & 2 & 1 \\
\hline S. MT & 10 & & & & & & & & & & $\mathbf{X}$ & 2 & 2 & 2 & 2 & 2 & 2 & 2 & 2 & 2 & 2 & 2 \\
\hline S. FQ & 11 & & & & & & & & & & & $\mathbf{X}$ & 2 & 2 & 1 & 1 & 1 & 1 & 1 & 1 & 2 & 1 \\
\hline S.SA & 12 & & & & & & & & & & & & $\mathbf{X}$ & 1 & 1 & 2 & 1 & 2 & 1 & 1 & 1 & 1 \\
\hline S. SCA & 13 & & & & & & & & & & & & & $\mathbf{X}$ & 2 & 2 & 2 & 2 & 2 & 2 & 1 & 2 \\
\hline S. CV & 14 & & & & & & & & & & & & & & $\mathbf{X}$ & 1 & 1 & 2 & 1 & 1 & 2 & 1 \\
\hline M. ARI & 15 & & & & & & & & & & & & & & & $\mathbf{X}$ & 1 & 1 & 1 & 1 & 2 & 1 \\
\hline M. RS & 16 & & & & & & & & & & & & & & & & $\mathbf{X}$ & 1 & 1 & 1 & 2 & 1 \\
\hline M. MT & 17 & & & & & & & & & & & & & & & & & $\mathbf{X}$ & 1 & 2 & 2 & 2 \\
\hline M. FQ & 18 & & & & & & & & & & & & & & & & & & $\mathbf{X}$ & 1 & 2 & 1 \\
\hline M.SA & 19 & & & & & & & & & & & & & & & & & & & $\mathbf{X}$ & 2 & 1 \\
\hline M. SCA & 20 & & & & & & & & & & & & & & & & & & & & $\mathbf{X}$ & 2 \\
\hline M. CV & 21 & & & & & & & & & & & & & & & & & & & & & $\mathbf{X}$ \\
\hline
\end{tabular}

\begin{tabular}{l|l|l|l|}
1 & NÃO há dif. significativa & 2 & Há dif. significativa \\
\hline
\end{tabular}


6.5.7 Variação na Resistência à Compressão

Tabela 49: Teste de Tukey para resultados de Resistência à Compressão das amostras expostas às soluções de: C - Hidróxido de cálcio; S - Sulfato de Sódio; e M - Sulfato de Magnésio por um período de 6 semanas

\begin{tabular}{|c|c|c|c|c|c|c|c|c|c|c|c|c|c|c|c|c|c|c|c|c|c|c|}
\hline \multicolumn{2}{|c|}{ SÉRIE } & 1 & 2 & 3 & 4 & 5 & 6 & 7 & 8 & 9 & 10 & 11 & 12 & 13 & 14 & 15 & 16 & 17 & 18 & 19 & 20 & 21 \\
\hline C. ARI & 1 & $\mathbf{X}$ & 2 & 2 & 1 & 2 & 2 & 2 & 2 & 2 & 2 & 2 & 2 & 2 & 2 & 1 & 2 & 2 & 2 & 2 & 2 & 2 \\
\hline C. RS & 2 & & $\mathbf{X}$ & 2 & 2 & 2 & 2 & 1 & 2 & 1 & 2 & 2 & 2 & 2 & 2 & 2 & 1 & 2 & 2 & 2 & 2 & 2 \\
\hline C. MT & 3 & & & $\mathbf{X}$ & 2 & 2 & 2 & 2 & 1 & 2 & 2 & 1 & 2 & 2 & 2 & 2 & 2 & 1 & 1 & 2 & 2 & 2 \\
\hline C. FQ & 4 & & & & $\mathbf{X}$ & 2 & 2 & 2 & 1 & 2 & 2 & 2 & 2 & 2 & 2 & 1 & 2 & 2 & 1 & 2 & 2 & 2 \\
\hline C.SA & 5 & & & & & $\mathbf{X}$ & 2 & 2 & 2 & 2 & 2 & 2 & 1 & 1 & 1 & 2 & 2 & 2 & 2 & 1 & 1 & 1 \\
\hline C. SCA & 6 & & & & & & $\mathbf{X}$ & 2 & 2 & 2 & 2 & 2 & 1 & 1 & 1 & 2 & 2 & 2 & 2 & 1 & 1 & 2 \\
\hline C. CV & 7 & & & & & & & $\mathbf{X}$ & 2 & 2 & 2 & 2 & 1 & 2 & 1 & 2 & 2 & 2 & 2 & 1 & 2 & 1 \\
\hline S. ARI & 8 & & & & & & & & $\mathbf{X}$ & 2 & 2 & 1 & 2 & 2 & 2 & 2 & 2 & 1 & 1 & 2 & 2 & 2 \\
\hline S. RS & 9 & & & & & & & & & $\mathbf{X}$ & 2 & 2 & 2 & 2 & 2 & 2 & 1 & 2 & 2 & 2 & 2 & 2 \\
\hline S. MT & 10 & & & & & & & & & & $\mathbf{X}$ & 1 & 2 & 2 & 2 & 2 & 2 & 1 & 2 & 2 & 2 & 2 \\
\hline S. FQ & 11 & & & & & & & & & & & $\mathbf{X}$ & 2 & 2 & 2 & 2 & 2 & 1 & 1 & 2 & 2 & 2 \\
\hline S. SA & 12 & & & & & & & & & & & & $\mathbf{X}$ & 1 & 1 & 2 & 2 & 2 & 2 & 1 & 1 & 1 \\
\hline S. SCA & 13 & & & & & & & & & & & & & $\mathbf{X}$ & 1 & 2 & 2 & 2 & 2 & 1 & 1 & 2 \\
\hline S. CV & 14 & & & & & & & & & & & & & & $\mathbf{X}$ & 2 & 2 & 2 & 2 & 1 & 2 & 1 \\
\hline M. ARI & 15 & & & & & & & & & & & & & & & $\mathbf{X}$ & 2 & 2 & 2 & 2 & 2 & 2 \\
\hline M. RS & 16 & & & & & & & & & & & & & & & & $\mathbf{X}$ & 2 & 2 & 2 & 2 & 2 \\
\hline M. MT & 17 & & & & & & & & & & & & & & & & & $\mathbf{X}$ & 1 & 2 & 2 & 2 \\
\hline M. FQ & 18 & & & & & & & & & & & & & & & & & & $\mathbf{X}$ & 2 & 2 & 2 \\
\hline M. SA & 19 & & & & & & & & & & & & & & & & & & & $\mathbf{X}$ & 2 & 1 \\
\hline M. SCA & 20 & & & & & & & & & & & & & & & & & & & & $\mathbf{X}$ & 2 \\
\hline M. CV & 21 & & & & & & & & & & & & & & & & & & & & & $\mathbf{X}$ \\
\hline
\end{tabular}

\begin{tabular}{l|l|c|l|}
1 & NÃO há dif. significativa & 2 & Há dif. significativa \\
\hline
\end{tabular} 
Tabela 50: Teste de Tukey para resultados de Resistência à Compressão das amostras expostas às soluções de: C - Hidróxido de cálcio; S - Sulfato de Sódio; e M - Sulfato de Magnésio por um período de 20 semanas

\begin{tabular}{|c|c|c|c|c|c|c|c|c|c|c|c|c|c|c|c|c|c|c|c|c|c|c|}
\hline \multicolumn{2}{|c|}{ SÉRIE } & 1 & 2 & 3 & 4 & 5 & 6 & 7 & 8 & 9 & 10 & 11 & 12 & \begin{tabular}{|l|l|}
13 \\
\end{tabular} & 14 & 15 & 16 & 17 & 18 & 19 & 20 & 21 \\
\hline C. ARI & 1 & $\mathbf{X}$ & 2 & 2 & 2 & 2 & 2 & 2 & 1 & 2 & 2 & 1 & 2 & 2 & 2 & 2 & 2 & 1 & 1 & 2 & 2 & 2 \\
\hline C. RS & 2 & & $\mathbf{X}$ & 2 & 2 & 2 & 2 & 2 & 2 & 2 & 2 & 2 & 2 & 2 & 1 & 2 & 2 & 2 & 2 & 1 & 2 & 1 \\
\hline C. MT & 3 & & & $\mathbf{X}$ & 2 & 2 & 2 & 2 & 2 & 2 & 2 & 2 & 2 & 2 & 2 & 2 & 1 & 2 & 2 & 2 & 2 & 2 \\
\hline C. FQ & 4 & & & & $\mathbf{X}$ & 2 & 2 & 2 & 2 & 2 & 2 & 2 & 2 & 2 & 2 & 2 & 1 & 1 & 1 & 2 & 2 & 2 \\
\hline C.SA & 5 & & & & & $\mathbf{X}$ & 2 & 2 & 2 & 1 & 2 & 2 & 1 & 2 & 2 & 2 & 2 & 2 & 2 & 2 & 2 & 2 \\
\hline C. SCA & 6 & & & & & & $\mathbf{X}$ & 2 & 2 & 2 & 2 & 2 & 2 & 1 & 2 & 2 & 2 & 2 & 2 & 2 & 2 & 2 \\
\hline C. CV & 7 & & & & & & & $X$ & 2 & 2 & 2 & 2 & 2 & 2 & 2 & 2 & 2 & 2 & 2 & 2 & 1 & 2 \\
\hline S. ARI & 8 & & & & & & & & $\mathbf{X}$ & 2 & 1 & 1 & 2 & 2 & 2 & 1 & 2 & 1 & 2 & 2 & 2 & 2 \\
\hline S. RS & 9 & & & & & & & & & $\mathbf{X}$ & 2 & 2 & 1 & 2 & 2 & 2 & 2 & 2 & 2 & 2 & 1 & 2 \\
\hline S. MT & 10 & & & & & & & & & & $\mathbf{X}$ & 2 & 2 & 2 & 2 & 1 & 2 & 2 & 2 & 2 & 2 & 2 \\
\hline S. FQ & 11 & & & & & & & & & & & $\mathbf{X}$ & 2 & 2 & 2 & 2 & 2 & 1 & 2 & 2 & 2 & 2 \\
\hline S. SA & 12 & & & & & & & & & & & & $\mathbf{X}$ & 2 & 2 & 2 & 2 & 2 & 2 & 2 & 2 & 2 \\
\hline S. SCA & 13 & & & & & & & & & & & & & $\mathbf{X}$ & 2 & 2 & 2 & 2 & 2 & 2 & 2 & 2 \\
\hline S. CV & 14 & & & & & & & & & & & & & & $\mathbf{X}$ & 2 & 2 & 2 & 2 & 1 & 2 & 1 \\
\hline M. ARI & 15 & & & & & & & & & & & & & & & $\mathbf{X}$ & 2 & 2 & 2 & 2 & 2 & 2 \\
\hline M. RS & 16 & & & & & & & & & & & & & & & & $\mathbf{X}$ & 2 & 2 & 2 & 2 & 2 \\
\hline M. MT & 17 & & & & & & & & & & & & & & & & & $\mathbf{X}$ & 1 & 2 & 2 & 2 \\
\hline M. FQ & 18 & & & & & & & & & & & & & & & & & & $\mathbf{X}$ & 2 & 2 & 2 \\
\hline M. SA & 19 & & & & & & & & & & & & & & & & & & & $\mathbf{X}$ & 2 & 1 \\
\hline M. SCA & 20 & & & & & & & & & & & & & & & & & & & & $\mathbf{X}$ & 2 \\
\hline M. CV & 21 & & & & & & & & & & & & & & & & & & & & & $\mathbf{X}$ \\
\hline
\end{tabular}

\begin{tabular}{l|l|l|l|}
1 & NÃO há dif. significativa & 2 & Há dif. significativa \\
\hline
\end{tabular}

\subsection{DIFRATOGRAMAS DAS COMPOSIÇÕES ANALISADAS}

Tabela 51: Detalhamento dos minerais observados nos difratogramas apresentados

\begin{tabular}{|c|c|c|c|c|c|}
\hline Mineral & Abreviação & Fichas & Mineral & Abreviação & Fichas \\
\hline Brucita & $\mathrm{B}$ & $02-1092$ & M-S-H & $\mathrm{M}$ & $21-0963$ \\
\hline Calcita & $\mathrm{C}$ & 03-0596 & Portandita & $\mathrm{P}$ & 02-0968 \\
\hline Etringita & E & $13-0350$ & Quartzo & Q & $46-1045$ \\
\hline M.C.A.Ca.H.* & $\mathrm{F}$ & $14-0083$ & Afm & $\mathrm{S}$ & $18-0275$ \\
\hline Gipsita & G & 03-0044 & Starkeyite & $\mathrm{Mx}$ & $24-0720$ \\
\hline C-S-H & $\mathrm{H}$ & $15-0642$ & Pentahidrita & $\mathrm{Mx}$ & $25-0532$ \\
\hline Ilita & I & $02-0056$ & Hexahidrita & $M x$ & 01-0354 \\
\hline Caulinita & K & $29-1488$ & Epsomita & $\mathrm{Mx}$ & 01-0399 \\
\hline
\end{tabular}

* Monocarboaluminato de cálcio hidratado 


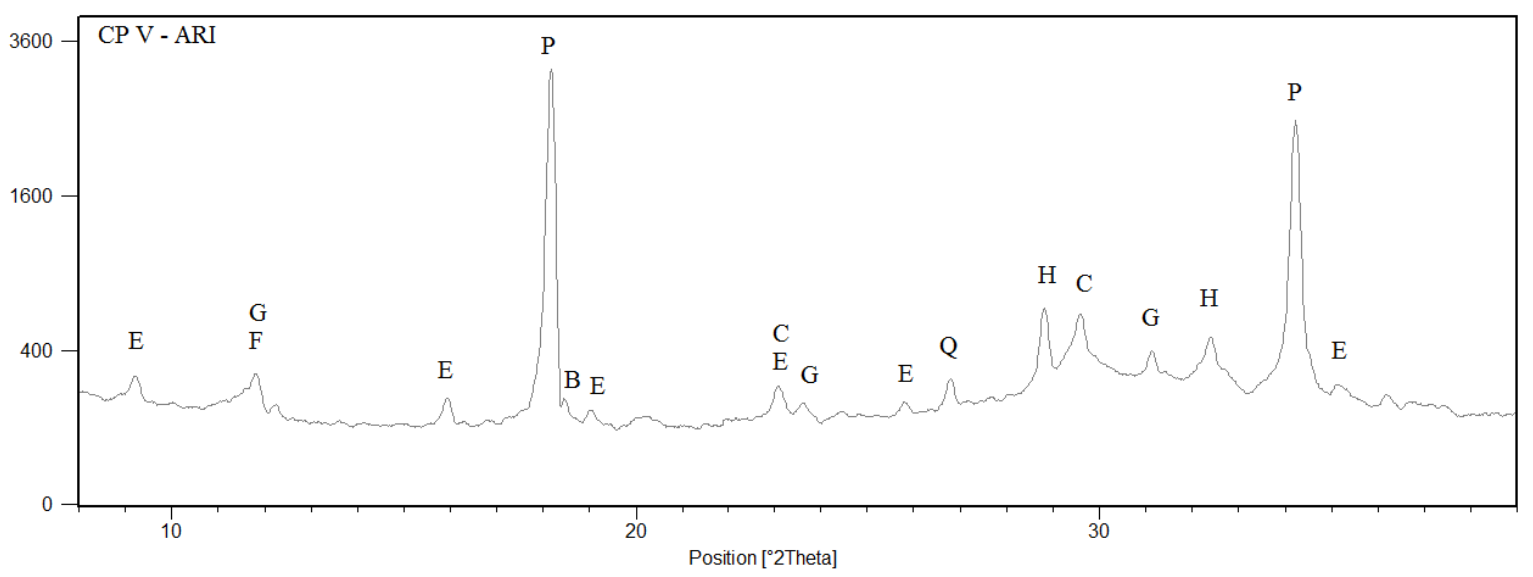

B - Brucita; C - Calcita; E - Etringita; F - Monocarboaluminato de Cálcio Hidratado; G - Gipsita; H - Silicato de Cálcio Hidratado; P - Portlandita; Q - Quartzo; S - Monossulfoaluminato de Cálcio Hidratado

Figura 95: Difratograma das amostras da série CP V - ARI para 14 dias de idade e 0 dias de exposição nas posições de $2 \theta$ variando de $8^{\circ}$ a $39^{\circ}$

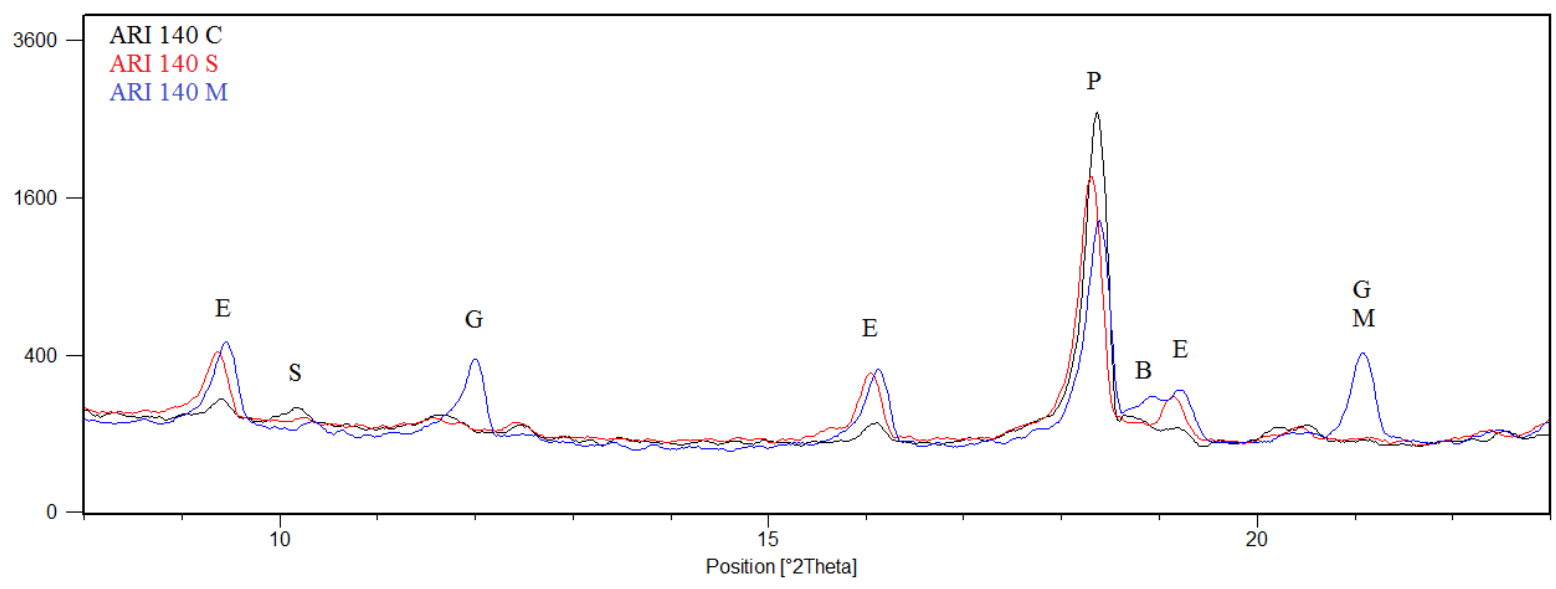

B - Brucita; E - Etringita; G - Gipsita; M - Silicato de Magnésio Hidratado; P - Portlandita; S - Monossulfoaluminato de Cálcio Hidratado

Figura 96: Difratograma das amostras da série CP V - ARI para 140 dias de exposição nas posições de $2 \theta$ variando de $8^{\circ}$ a $23^{\circ}$ (Soluções de exposição: $\mathrm{C}-\mathrm{Ca}(\mathrm{OH})_{2} ; \mathrm{S}-\mathrm{Na}_{2} \mathrm{SO}_{4} ; \mathrm{e}, \mathrm{M}-\mathrm{MgSO}_{4}$ )

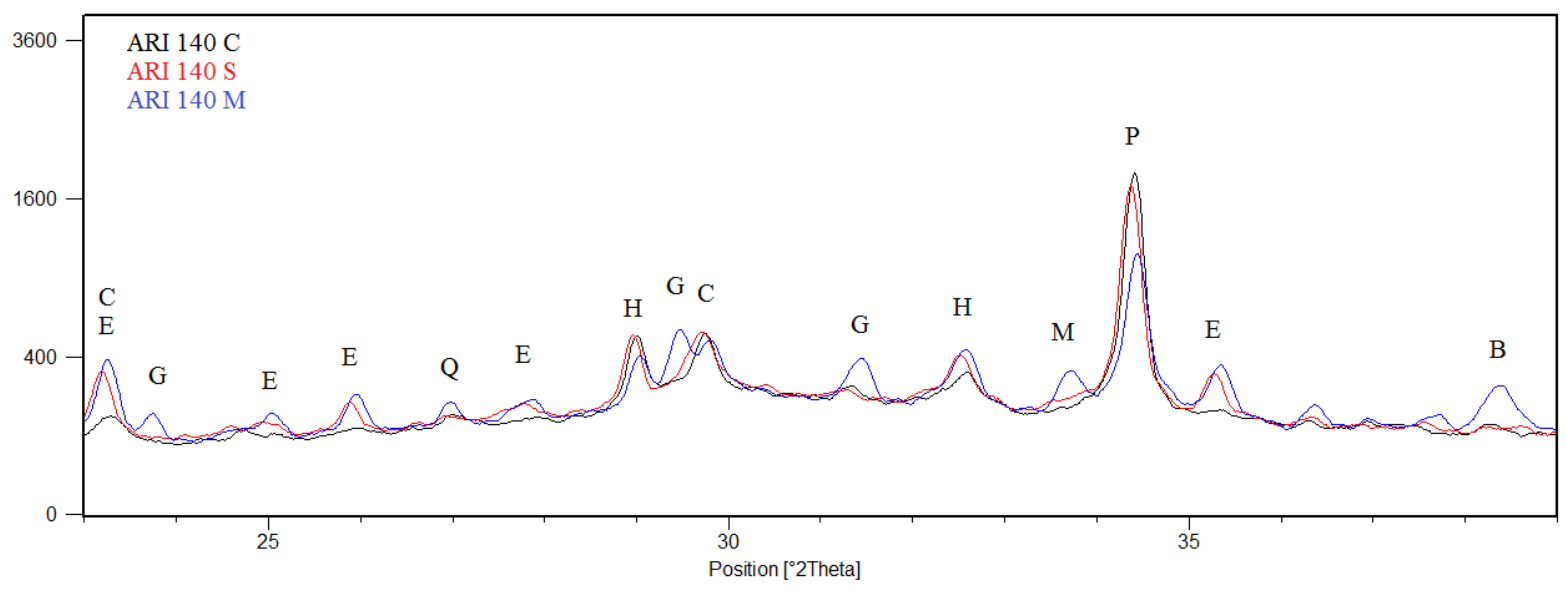

B - Brucita; C - Calcita; E - Etringita; G - Gipsita; H - Silicato de Cálcio Hidratado; M - Silicato de Magnésio Hidratado; P - Portlandita; Q - Quartzo

Figura 97: Difratograma das amostras da série CP V - ARI para 140 dias de exposição nas posições de $2 \theta$ variando de $23^{\circ}$ a $39^{\circ}$ (Soluções de exposição: $\mathrm{C}-\mathrm{Ca}(\mathrm{OH})_{2} ; \mathrm{S}-\mathrm{Na}_{2} \mathrm{SO}_{4} ; \mathrm{e}, \mathrm{M}-\mathrm{MgSO}_{4}$ ). 


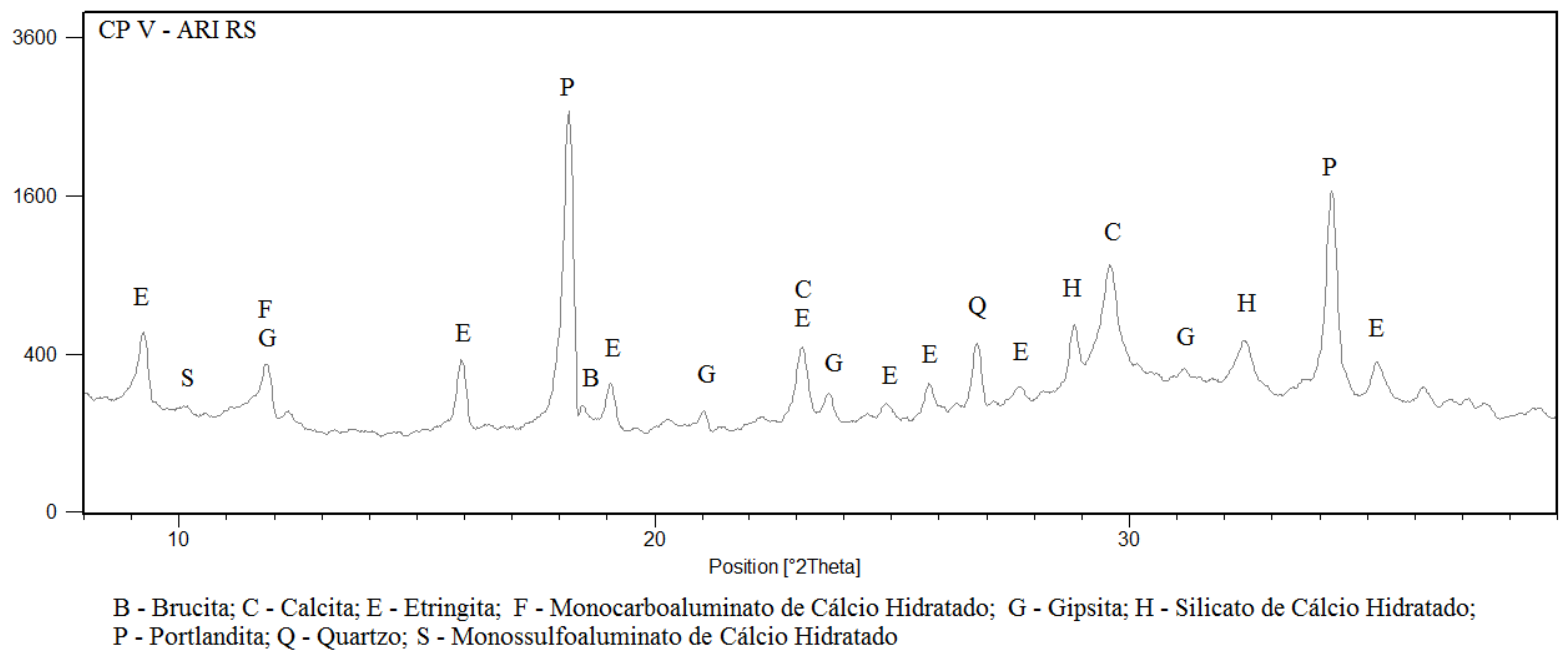

Figura 98: Difratograma das amostras da série CP V - ARI RS para 14 dias de idade e 0 dias de exposição nas posições de $2 \theta$ variando de $8^{\circ}$ a $39^{\circ}$

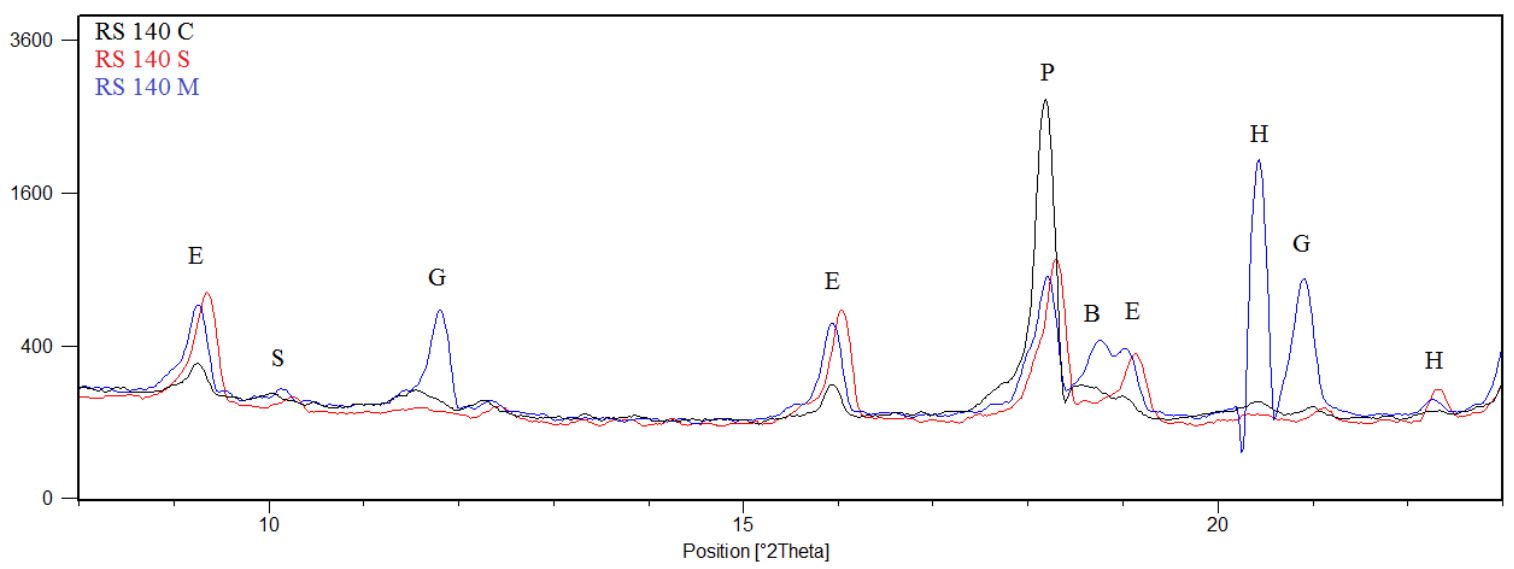

B - Brucita; E - Etringita; G - Gipsita; H - Silicato de Cálcio Hidratado; M - Silicato de Magnésio Hidratado; P - Portlandita; Q - Quartzo S - Monossulfoaluminato de Cálcio Hidratado

Figura 99: Difratograma das amostras da série CP V - ARI RS para 140 dias de exposição nas posições de $2 \theta$ variando de $8^{\circ}$ a $23^{\circ}$ (Soluções de exposição: $\mathrm{C}-\mathrm{Ca}(\mathrm{OH})_{2} ; \mathrm{S}-\mathrm{Na}_{2} \mathrm{SO}_{4} ; \mathrm{e}, \mathrm{M}-\mathrm{MgSO}_{4}$ ).

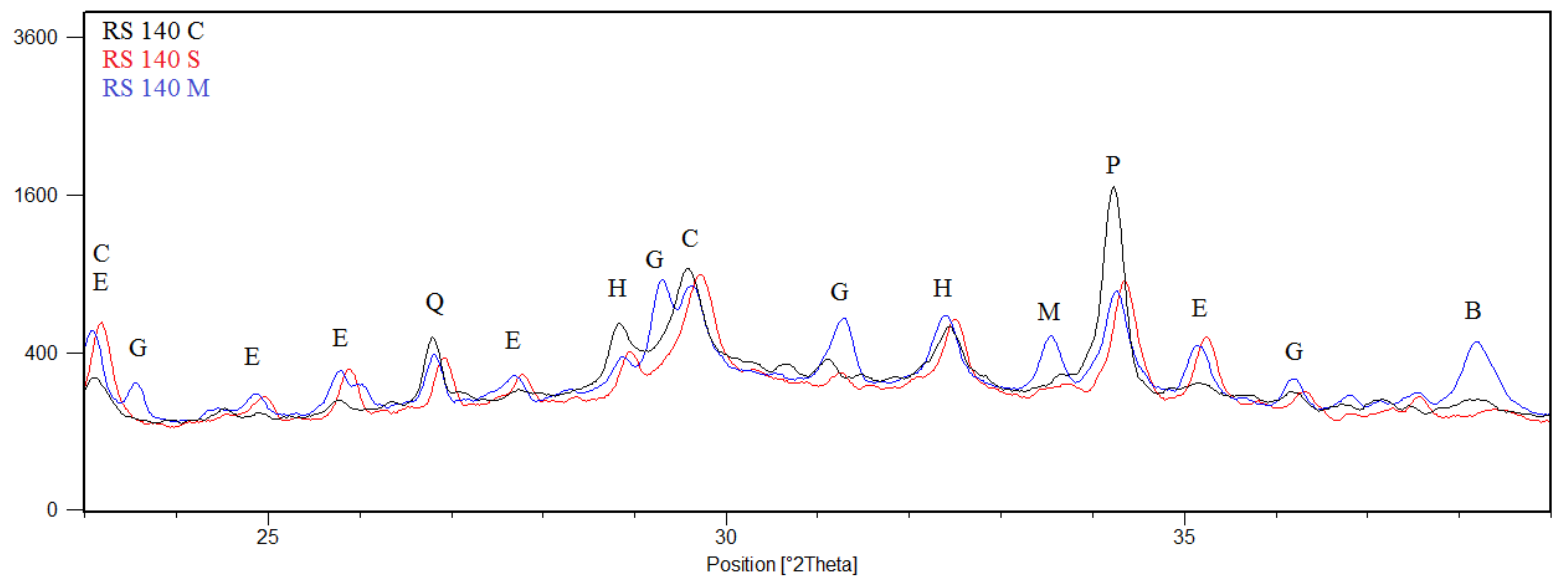

B - Brucita; C - Calcita; E - Etringita; G - Gipsita; H - Silicato de Cálcio Hidratado; M - Silicato de Magnésio Hidratado; P - Portlandita; Q - Quartzo

Figura 100: Difratograma das amostras da série CP V - ARI RS para 140 dias de exposição nas posições de $2 \theta$ variando de $23^{\circ}$ a $39^{\circ}$ (Soluções de exposição: $\mathrm{C}-\mathrm{Ca}(\mathrm{OH})_{2} ; \mathrm{S}-\mathrm{Na}_{2} \mathrm{SO}_{4} ; \mathrm{e}, \mathrm{M}-\mathrm{MgSO}_{4}$ ). 


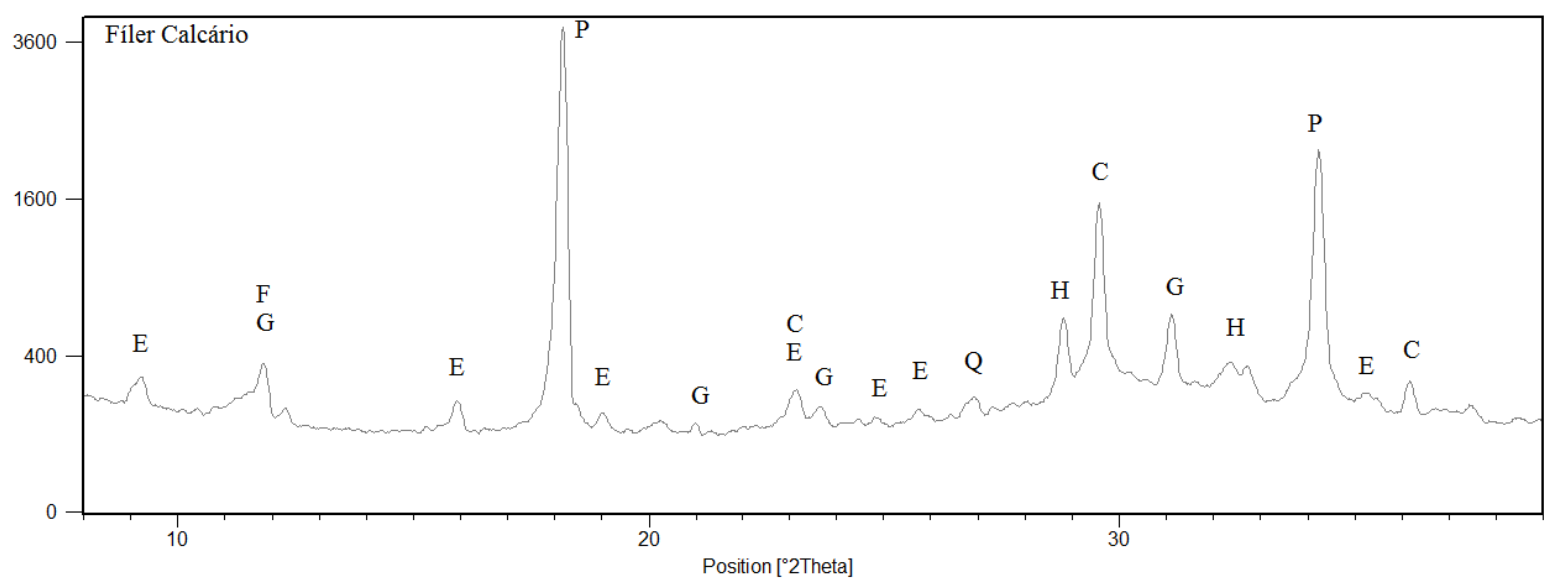

B - Brucita; C - Calcita; E - Etringita; F - Monocarboaluminato de Cálcio Hidratado; G - Gipsita; H - Silicato de Cálcio Hidratado; P - Portlandita; Q - Quartzo; S - Monossulfoaluminato de Cálcio Hidratado

Figura 101: Difratograma das amostras da série FC para 14 dias de idade e 0 dias de exposição nas posições de $2 \theta$ variando de $8^{\circ}$ a $39^{\circ}$

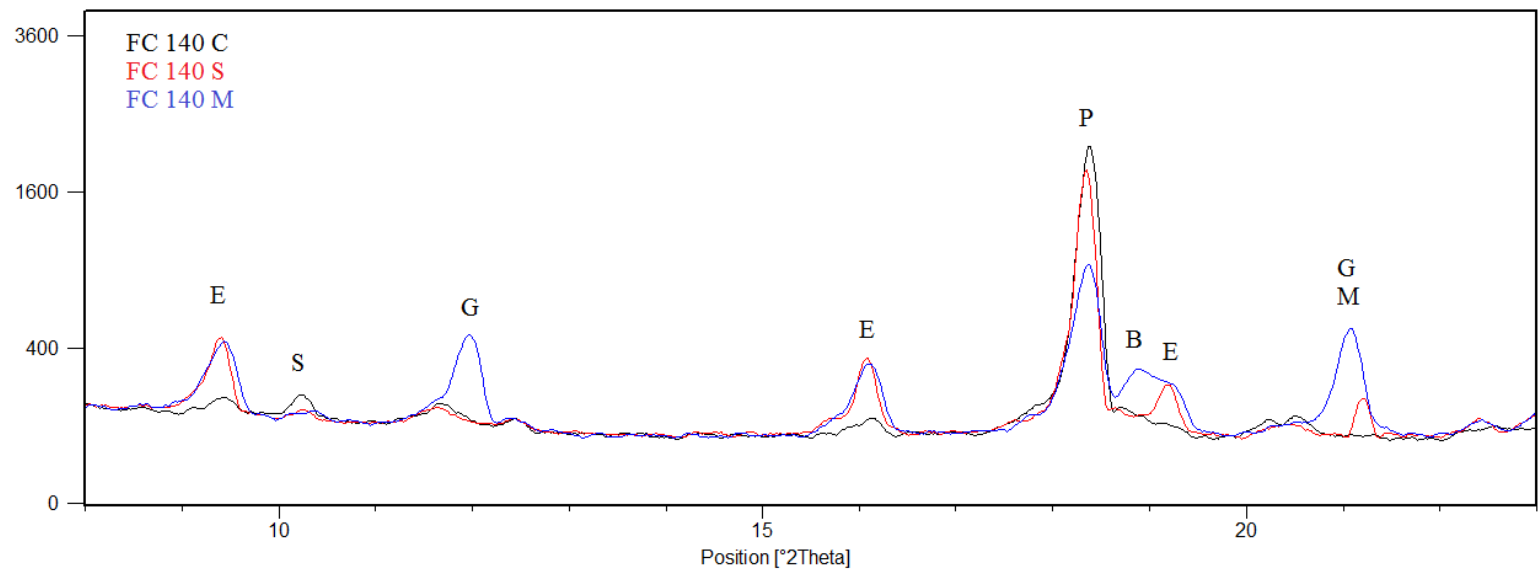

B - Brucita; E - Etringita; G - Gipsita; M - Silicato de Magnésio Hidratado; P - Portlandita; S - Monossulfoaluminato de Cálcio Hidratado

Figura 102: Difratograma das amostras da série FC para 140 dias de exposição nas posições de $2 \theta$ variando de $8^{\circ}$ a $23^{\circ}$ (Soluções de exposição: $\left.\mathrm{C}-\mathrm{Ca}(\mathrm{OH})_{2} ; \mathrm{S}-\mathrm{Na}_{2} \mathrm{SO}_{4} ; \mathrm{e}, \mathrm{M}-\mathrm{MgSO}_{4}\right)$.

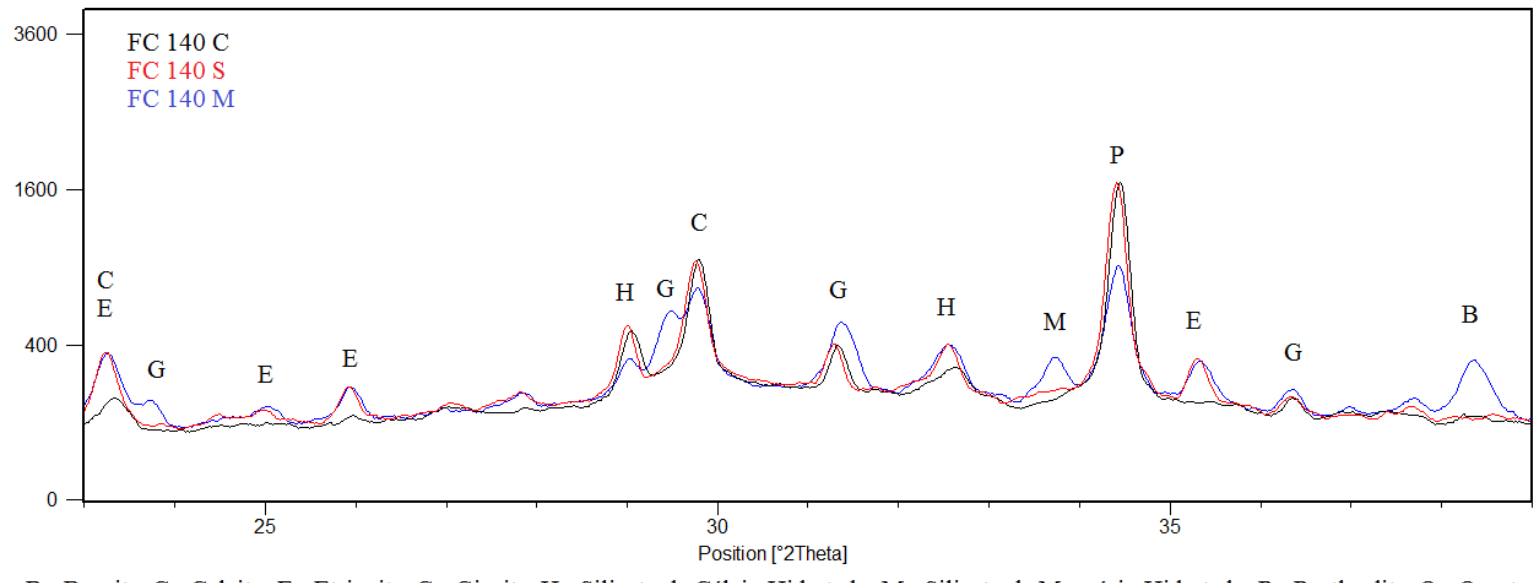

B - Brucita; C - Calcita; E - Etringita; G - Gipsita; H - Silicato de Cálcio Hidratado; M - Silicato de Magnésio Hidratado; P - Portlandita; Q - Quartzo

Figura 103: Difratograma das amostras da série FC para 140 dias de exposição nas posições de $2 \theta$ variando de $23^{\circ}$ a $39^{\circ}$ (Soluções de exposição: $\mathrm{C}-\mathrm{Ca}(\mathrm{OH})_{2} ; \mathrm{S}-\mathrm{Na}_{2} \mathrm{SO}_{4} ; \mathrm{e}, \mathrm{M}-\mathrm{MgSO}_{4}$ ). 


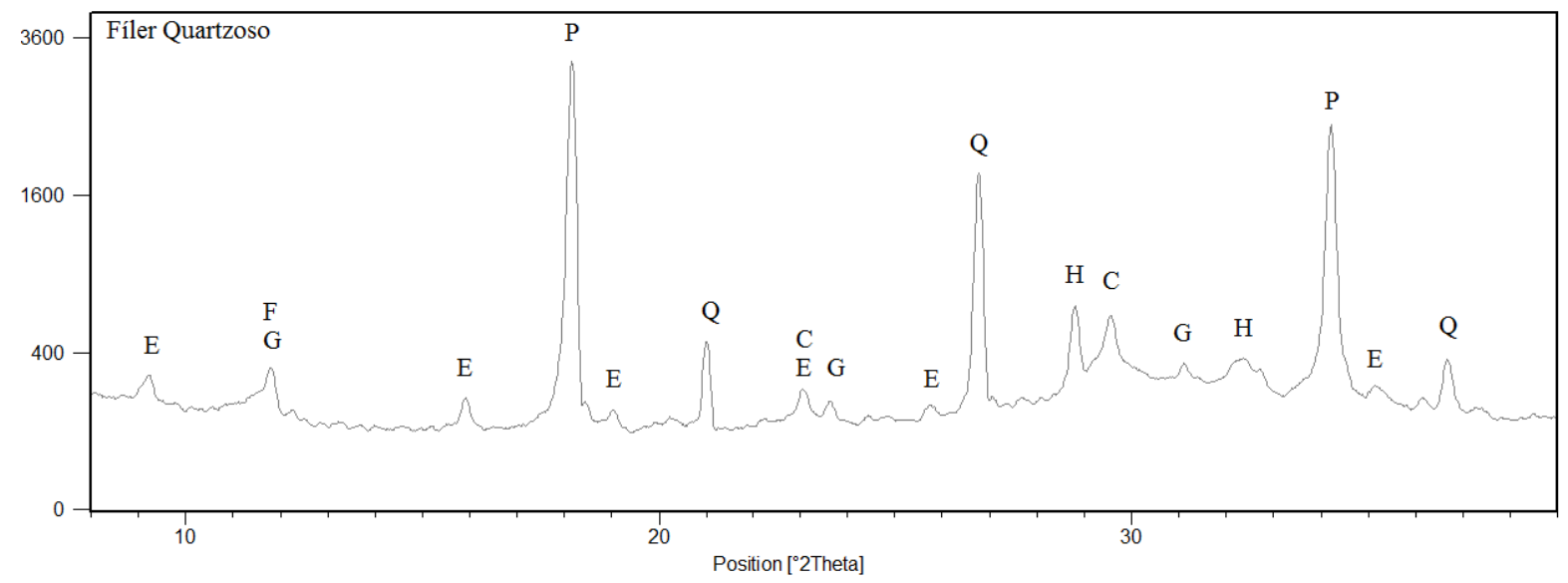

B - Brucita; C - Calcita; E - Etringita; F - Monocarboaluminato de Cálcio Hidratado; G - Gipsita; H - Silicato de Cálcio Hidratado; P - Portlandita; Q - Quartzo; S - Monossulfoaluminato de Cálcio Hidratado

Figura 104: Difratograma das amostras da série FQ para 14 dias de idade e 0 dias de exposição nas posições de $2 \theta$ variando de $8^{\circ}$ a $39^{\circ}$

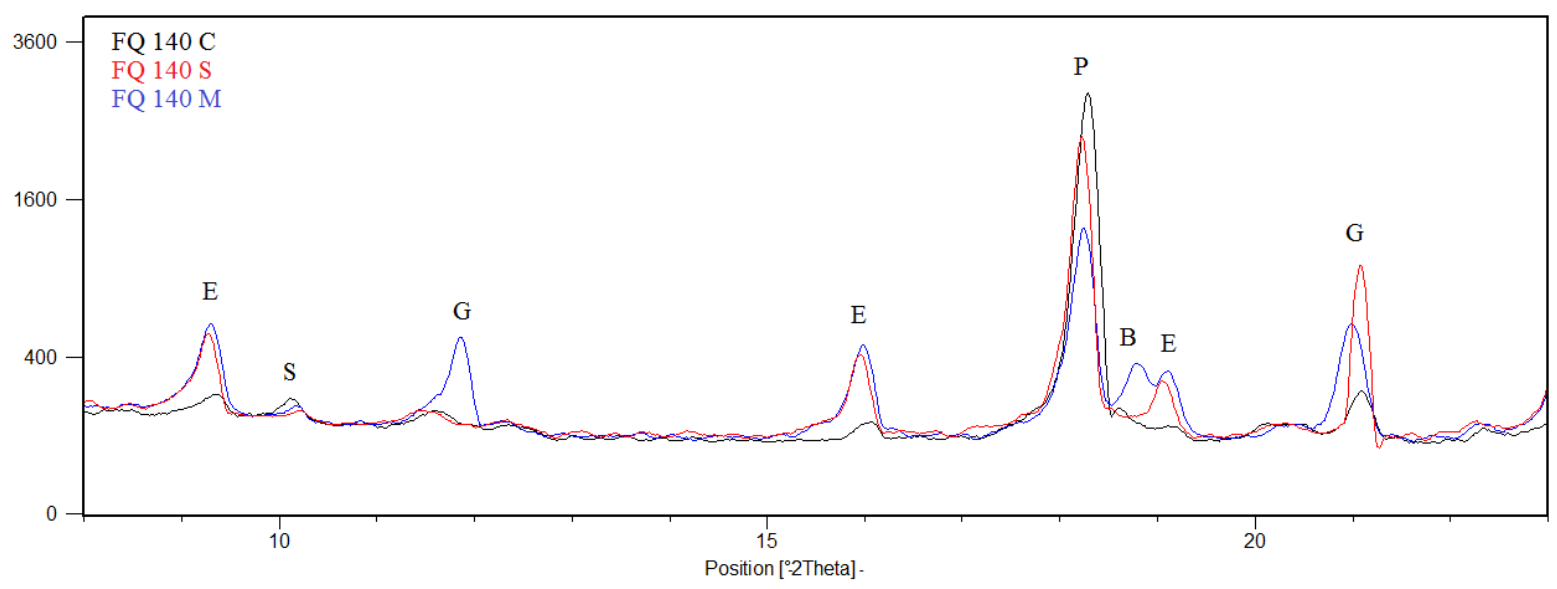

B - Brucita; E - Etringita; G - Gipsita; M - Silicato de Magnésio Hidratado; P - Portlandita; S - Monossulfoaluminato de Cálcio Hidratado

Figura 105: Difratograma das amostras da série FQ para 140 dias de exposição nas posições de $2 \theta$ variando de $8^{\circ}$ a $23^{\circ}$ (Soluções de exposição: $\mathrm{C}-\mathrm{Ca}(\mathrm{OH})_{2} ; \mathrm{S}-\mathrm{Na}_{2} \mathrm{SO}_{4} ; \mathrm{e}, \mathrm{M}-\mathrm{MgSO}_{4}$ ).

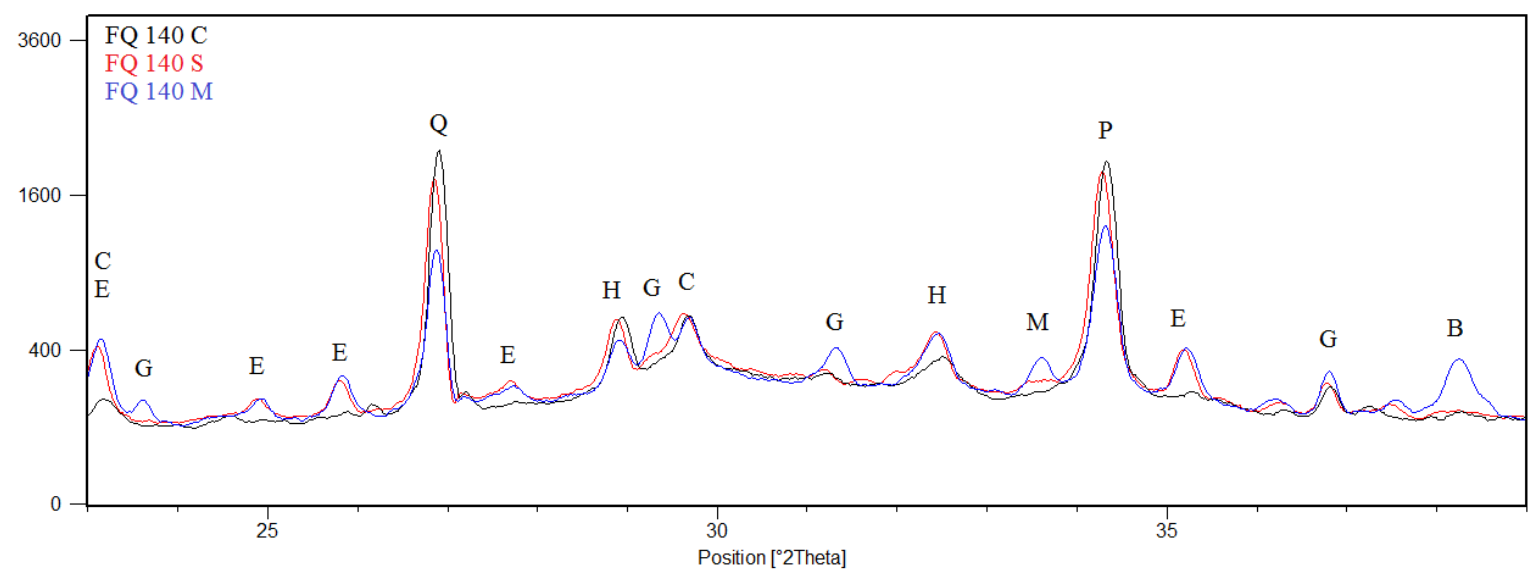

B - Brucita; C - Calcita; E - Etringita; G - Gipsita; H - Silicato de Cálcio Hidratado; M - Silicato de Magnésio Hidratado; P - Portlandita; Q - Quartzo

Figura 106: Difratograma das amostras da série FQ para 140 dias de exposição nas posições de $2 \theta$ variando de $23^{\circ}$ a $39^{\circ}$ (Soluções de exposição: $\mathrm{C}-\mathrm{Ca}(\mathrm{OH})_{2} ; \mathrm{S}-\mathrm{Na}_{2} \mathrm{SO}_{4} ; \mathrm{e}, \mathrm{M}-\mathrm{MgSO}_{4}$ ). 


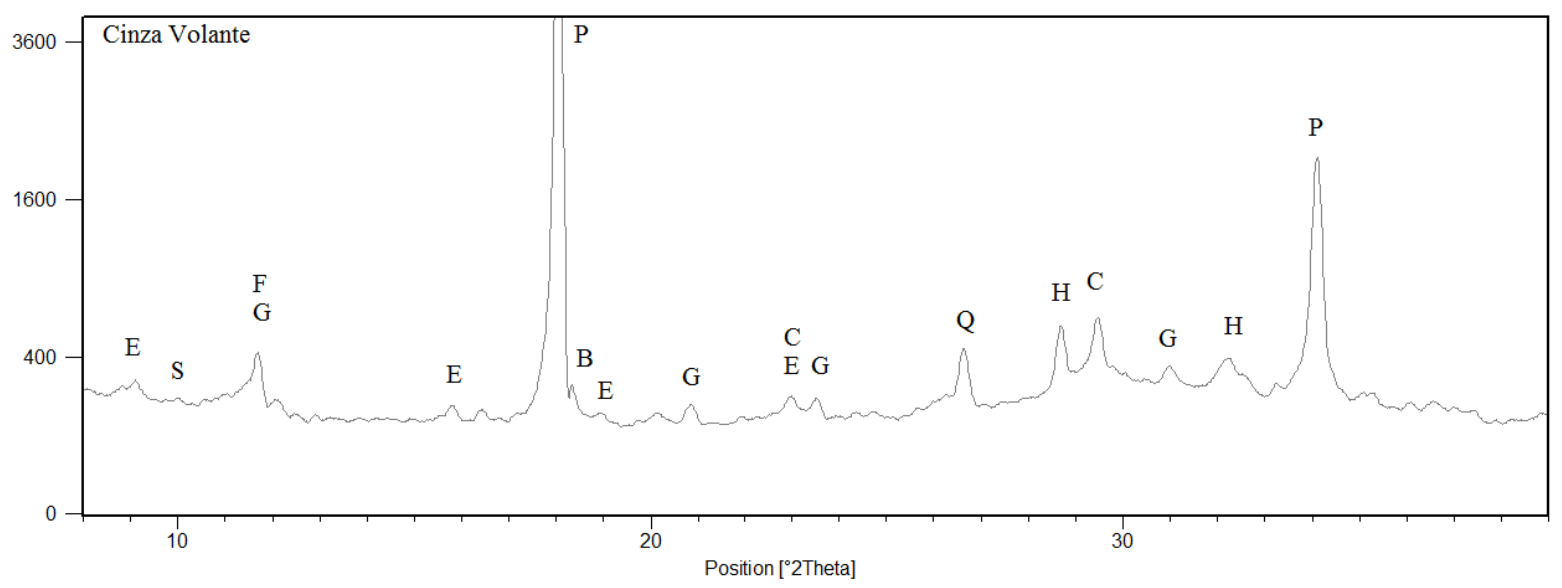

B - Brucita; C - Calcita; E - Etringita; F - Monocarboaluminato de Cálcio Hidratado; G - Gipsita; H - Silicato de Cálcio Hidratado; P - Portlandita; Q - Quartzo; S - Monossulfoaluminato de Cálcio Hidratado

Figura 107: Difratograma das amostras da série CV para 14 dias de idade e 0 dias de exposição nas posições de $2 \theta$ variando de $8^{\circ}$ a $39^{\circ}$

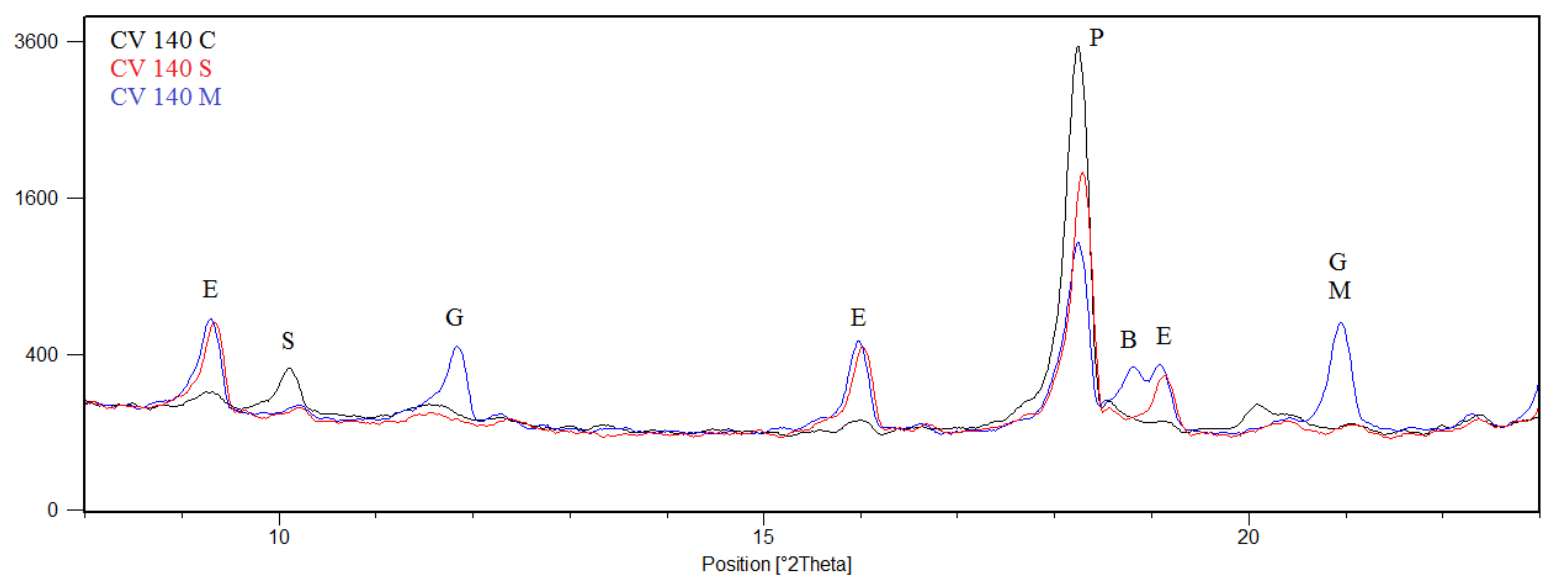

B - Brucita; E - Etringita; G - Gipsita; M - Silicato de Magnésio Hidratado; P - Portlandita; S - Monossulfoaluminato de Cálcio Hidratado

Figura 108: Difratograma das amostras da série $\mathrm{CV}$ para 140 dias de exposição nas posições de $2 \theta$ variando de $8^{\circ}$ a $23^{\circ}$ (Soluções de exposição: $\mathrm{C}-\mathrm{Ca}(\mathrm{OH})_{2} ; \mathrm{S}-\mathrm{Na}_{2} \mathrm{SO}_{4} ; \mathrm{e}, \mathrm{M}-\mathrm{MgSO}_{4}$ ).

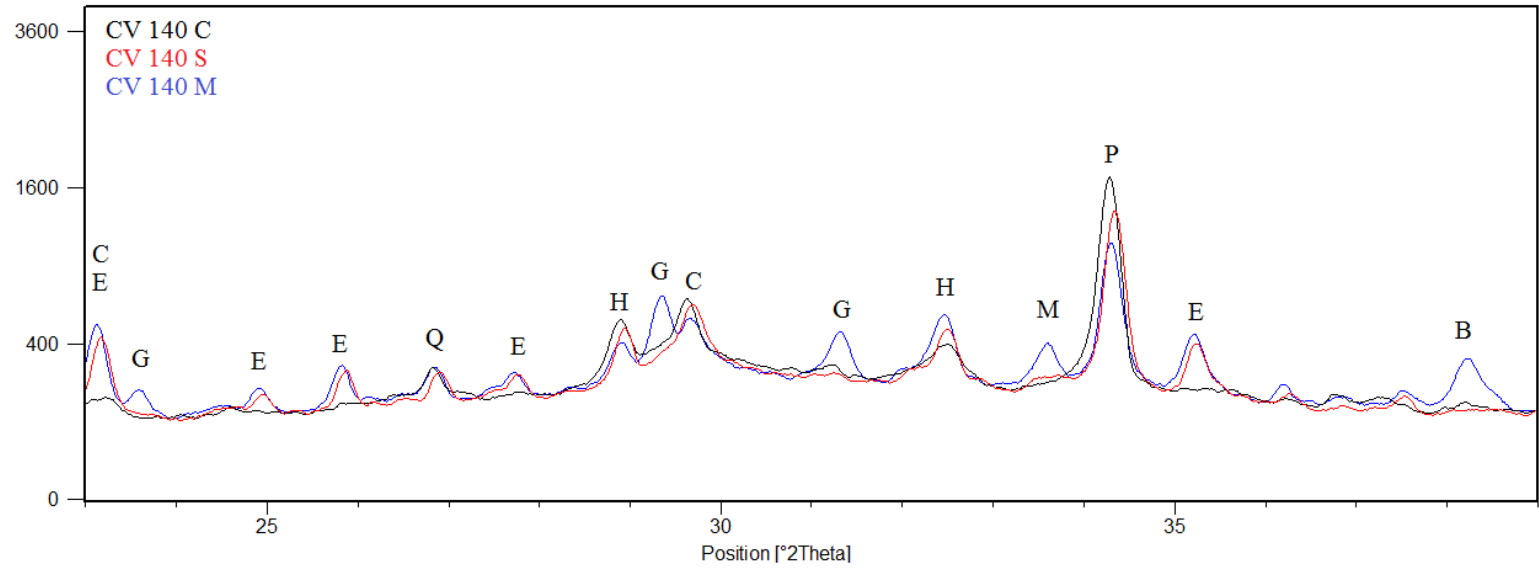

B - Brucita; C - Calcita; E - Etringita; G - Gipsita; H - Silicato de Cálcio Hidratado; M - Silicato de Magnésio Hidratado; P - Portlandita; Q - Quartzo

Figura 109: Difratograma das amostras da série CV para 140 dias de exposição nas posições de $2 \theta$ variando de $23^{\circ}$ a $39^{\circ}$ (Soluções de exposição: $\mathrm{C}-\mathrm{Ca}(\mathrm{OH})_{2} ; \mathrm{S}-\mathrm{Na}_{2} \mathrm{SO}_{4} ; \mathrm{e}, \mathrm{M}-\mathrm{MgSO}_{4}$ ). 


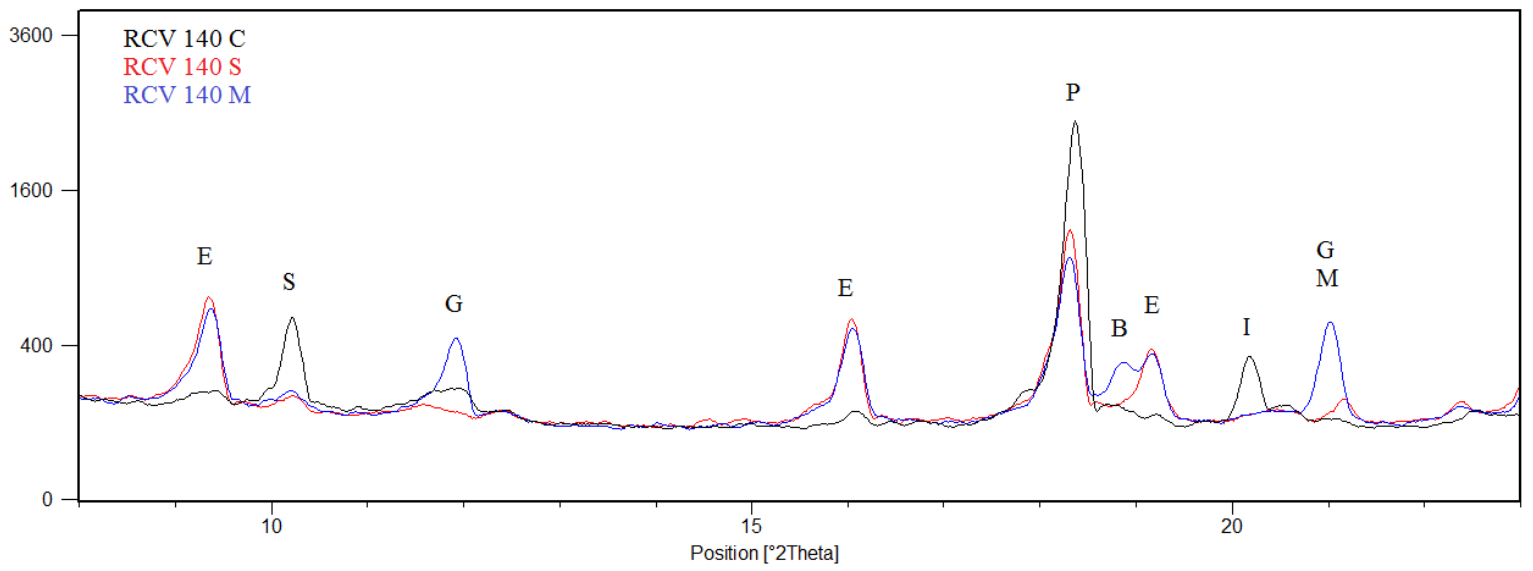

B - Brucita; E - Etringita; G - Gipsita; I - Ilita; M - Silicato de Magnésio Hidratado; P - Portlandita; S - Monossulfoaluminato de Cálcio Hidratado

Figura 110: Difratograma das amostras da série RCV para 140 dias de exposição nas posições de $2 \theta$ variando de $8^{\circ}$ a $23^{\circ}$ (Soluções de exposição: $\mathrm{C}-\mathrm{Ca}(\mathrm{OH})_{2} ; \mathrm{S}-\mathrm{Na}_{2} \mathrm{SO}_{4} ; \mathrm{e}, \mathrm{M}-\mathrm{MgSO}_{4}$ ).

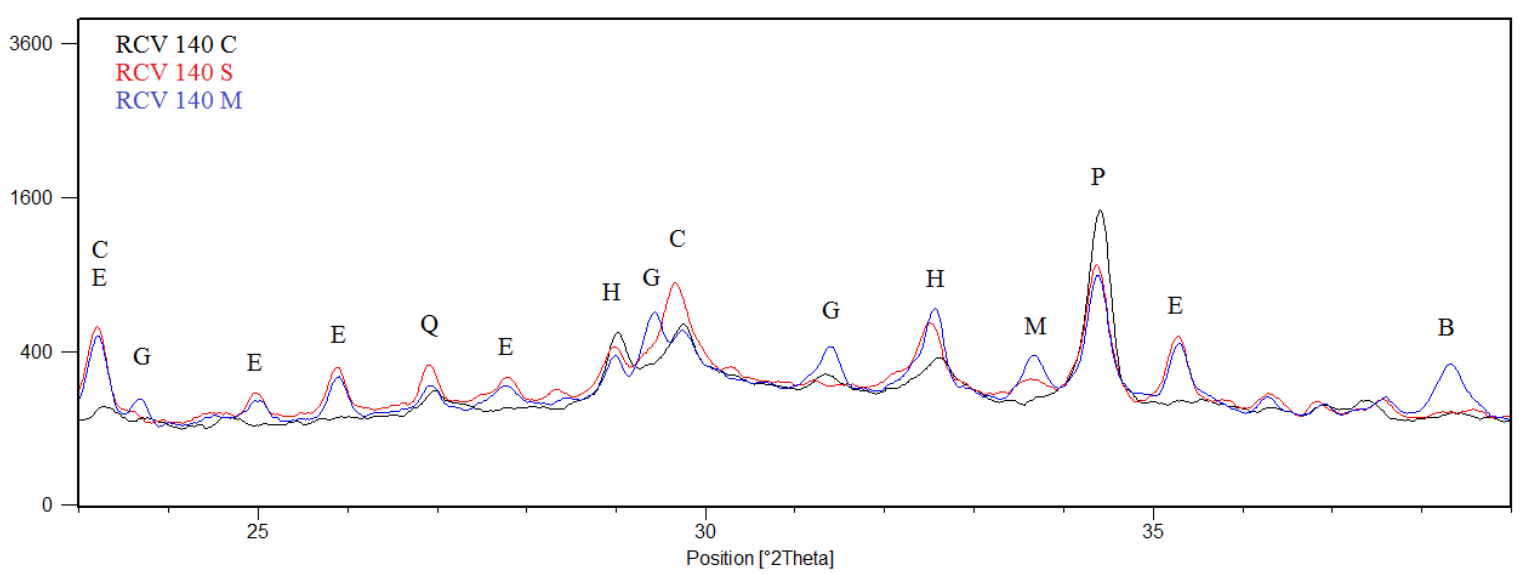

B - Brucita; C - Calcita; E - Etringita; G - Gipsita; H - Silicato de Cálcio Hidratado; M - Silicato de Magnésio Hidratado; P - Portlandita; Q - Quartzo

Figura 111: Difratograma das amostras da série RCV para 140 dias de exposição nas posições de $2 \theta$ variando de $23^{\circ}$ a $39^{\circ}$ (Soluções de exposição: $\mathrm{C}-\mathrm{Ca}(\mathrm{OH})_{2} ; \mathrm{S}-\mathrm{Na}_{2} \mathrm{SO}_{4} ; \mathrm{e}, \mathrm{M}-\mathrm{MgSO}_{4}$ ).

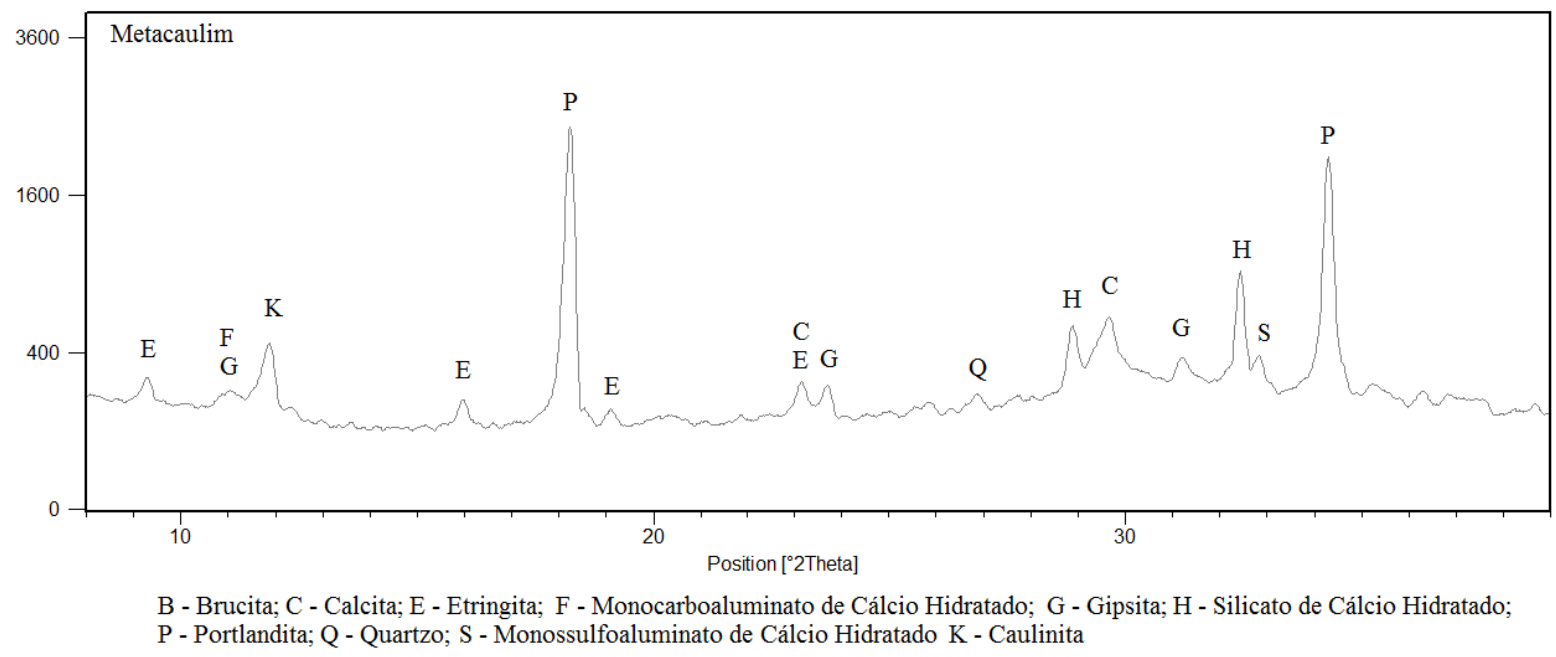

Figura 112: Difratograma das amostras da série MT para 14 dias de idade e 0 dias de exposição nas posições de $2 \theta$ variando de $8^{\circ}$ a $39^{\circ}$ 


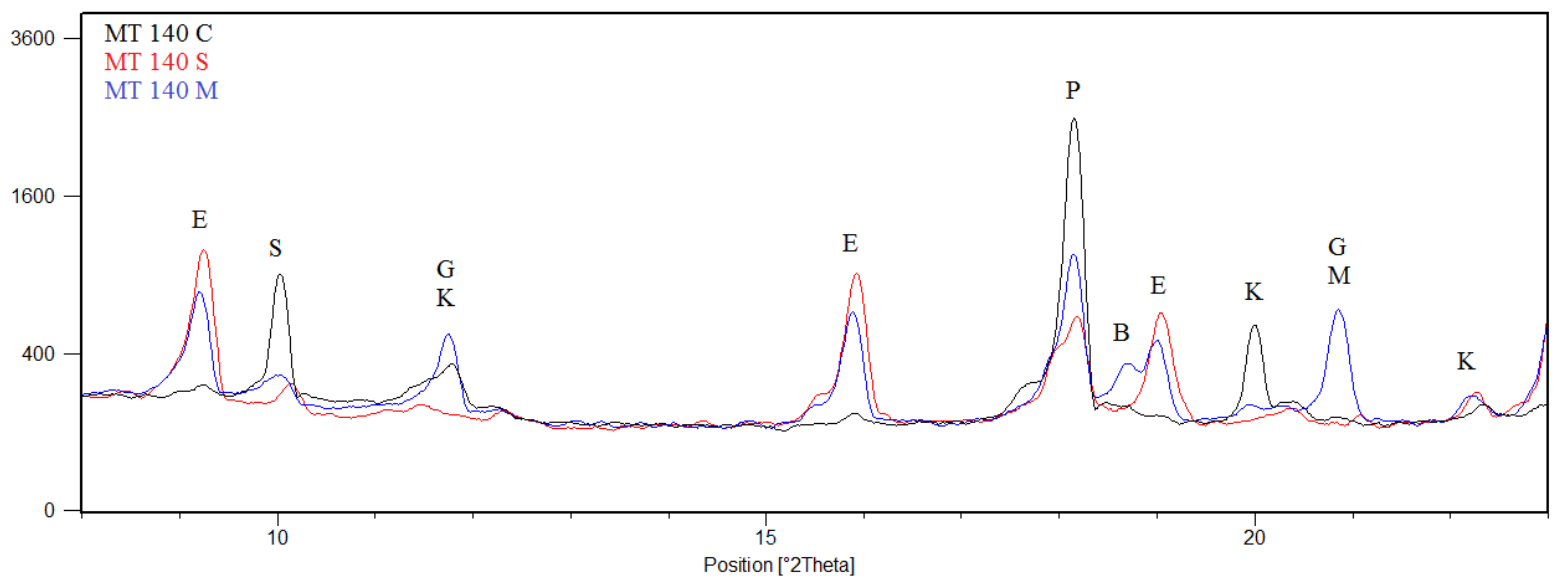

B - Brucita; E - Etringita; G - Gipsita; K - Caulinita; M - Silicato de Magnésio Hidratado; P - Portlandita; S - Monossulfo Aluminato de Cálcio Hidratado

Figura 113: Difratograma das amostras da série MT para 140 dias de exposição nas posições de $2 \theta$ variando de $8^{\circ}$ a $23^{\circ}$ (Soluções de exposição: $\mathrm{C}-\mathrm{Ca}(\mathrm{OH})_{2} ; \mathrm{S}-\mathrm{Na}_{2} \mathrm{SO}_{4} ; \mathrm{e}, \mathrm{M}-\mathrm{MgSO}_{4}$ ).

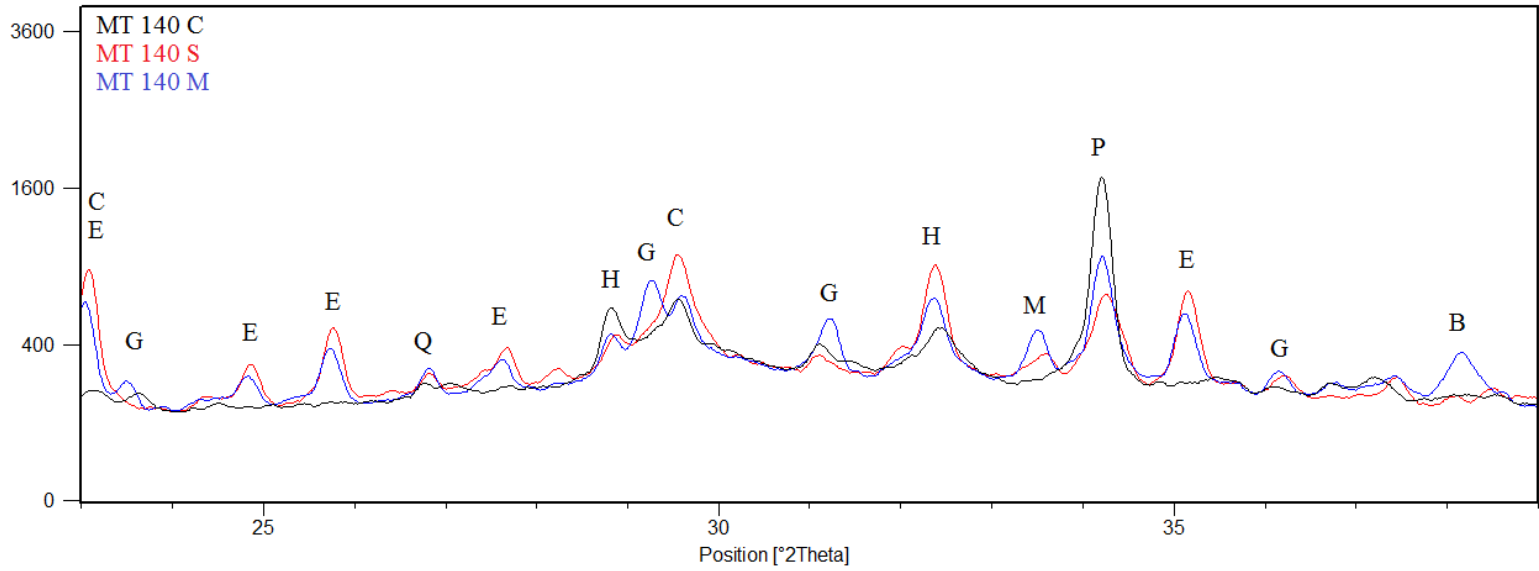

B - Brucita; C - Calcita; E - Etringita; G - Gipsita; H - Silicato de Cálcio Hidratado; M - Silicato de Magnésio Hidratado; P - Portlandita; Q - Quartzo

Figura 114: Difratograma das amostras da série MT para 140 dias de exposição nas posições de $2 \theta$ variando de $23^{\circ}$ a $39^{\circ}$ (Soluções de exposição: $\mathrm{C}-\mathrm{Ca}(\mathrm{OH})_{2} ; \mathrm{S}-\mathrm{Na}_{2} \mathrm{SO}_{4} ;$ e, $\mathrm{M}-\mathrm{MgSO}_{4}$ ).

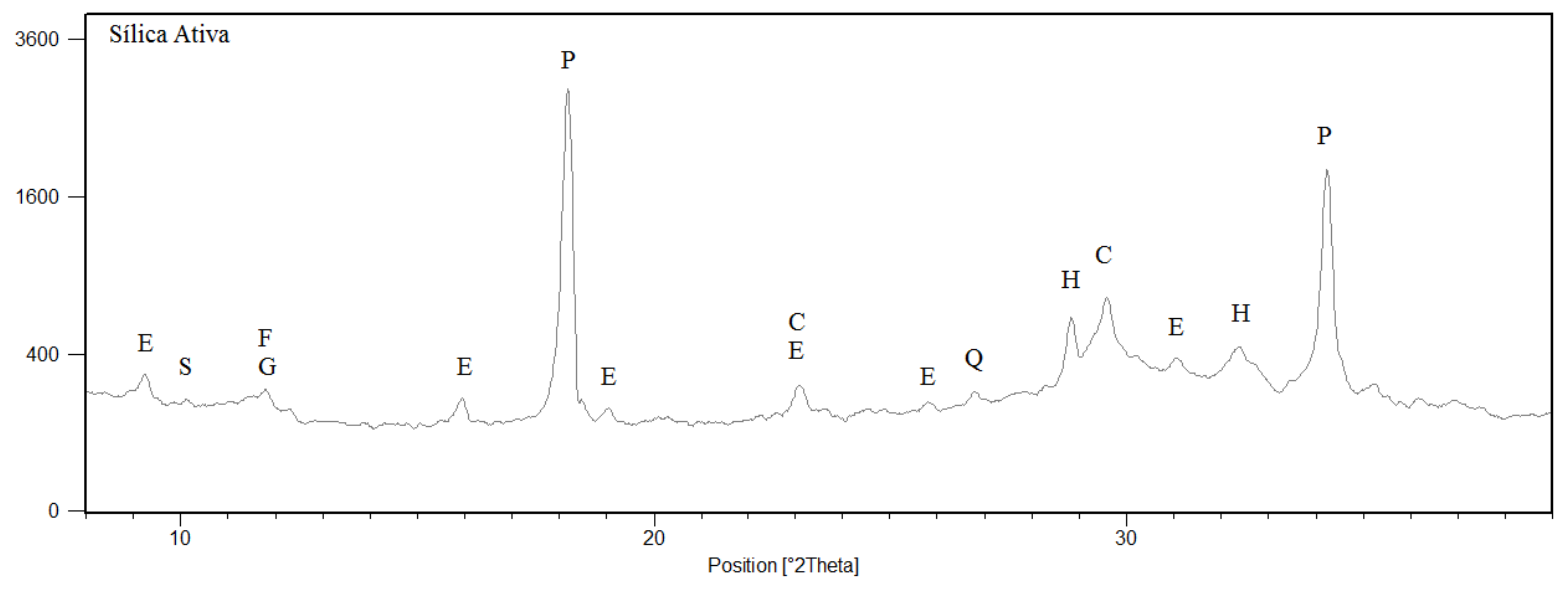

B - Brucita; C - Calcita; E - Etringita; F - Monocarboaluminato de Cálcio Hidratado; G - Gipsita; H - Silicato de Cálcio Hidratado; P - Portlandita; Q - Quartzo; S - Monossulfoaluminato de Cálcio Hidratado K - Caulinita

Figura 115: Difratograma das amostras da série SA para 14 dias de idade e 0 dias de exposição nas posições de $2 \theta$ variando de $8^{\circ}$ a $39^{\circ}$ 


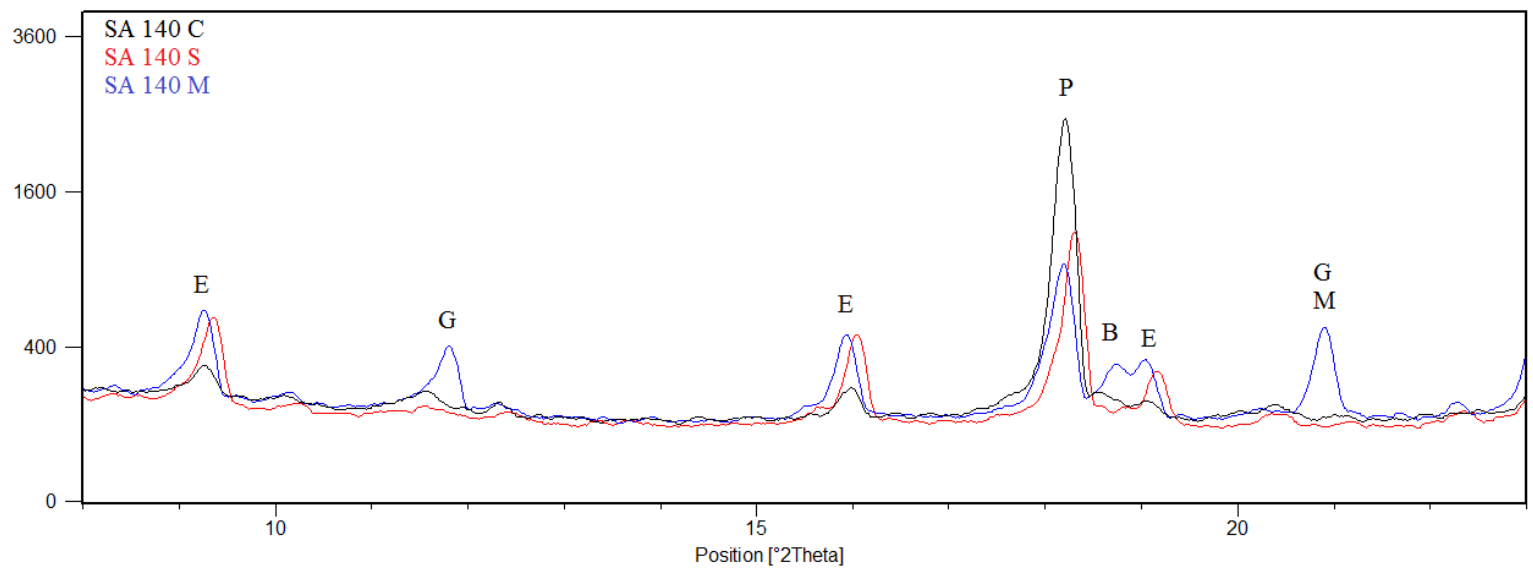

B - Brucita; E - Etringita; G - Gipsita; M - Silicato de Magnésio Hidratado; P - Portlandita; S - Monossulfoaluminato de Cálcio Hidratado

Figura 116: Difratograma das amostras da série SA para 140 dias de exposição nas posições de $2 \theta$ variando de $8^{\circ}$ a $23^{\circ}$ (Soluções de exposição: $\mathrm{C}-\mathrm{Ca}(\mathrm{OH})_{2} ; \mathrm{S}-\mathrm{Na}_{2} \mathrm{SO}_{4} ; \mathrm{e}, \mathrm{M}-\mathrm{MgSO}_{4}$ ).

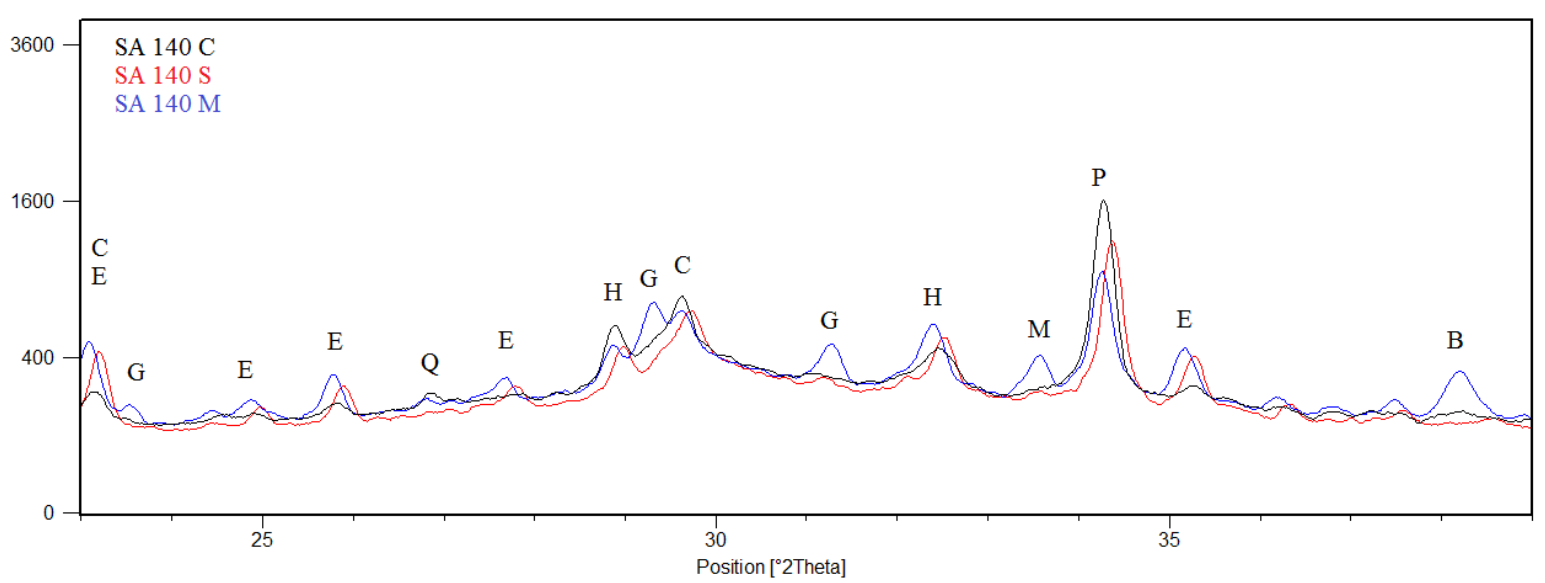

B - Brucita; C - Calcita; E - Etringita; G - Gipsita; H - Silicato de Cálcio Hidratado; M - Silicato de Magnésio Hidratado; P - Portlandita; Q - Quartzo

Figura 117: Difratograma das amostras da série SA para 140 dias de exposição nas posições de $2 \theta$ variando de $23^{\circ}$ a $39^{\circ}$ (Soluções de exposição: $\mathrm{C}-\mathrm{Ca}(\mathrm{OH})_{2} ; \mathrm{S}-\mathrm{Na}_{2} \mathrm{SO}_{4} ; \mathrm{e}, \mathrm{M}-\mathrm{MgSO}_{4}$ ).

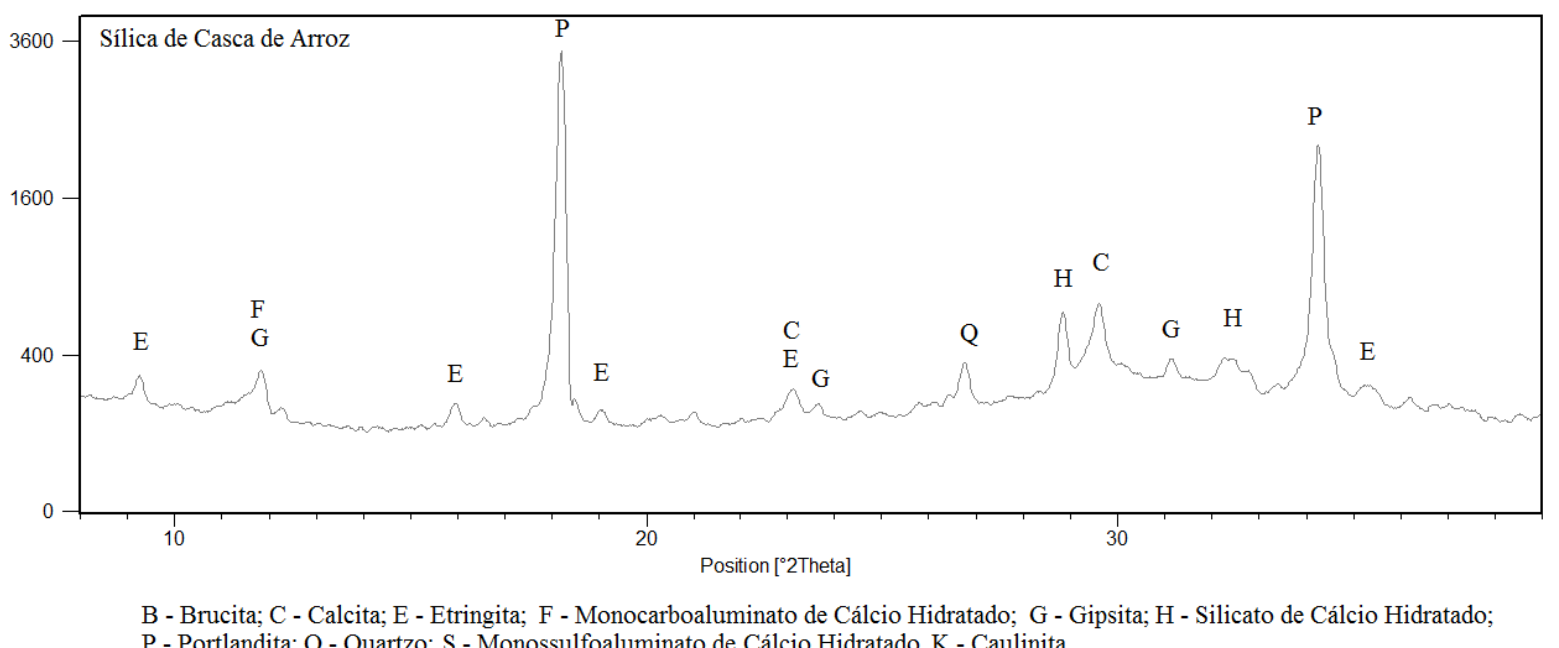

Figura 118: Difratograma das amostras da série SCA para 14 dias de idade e 0 dias de exposição nas posições de $2 \theta$ variando de $8^{\circ}$ a $39^{\circ}$ 


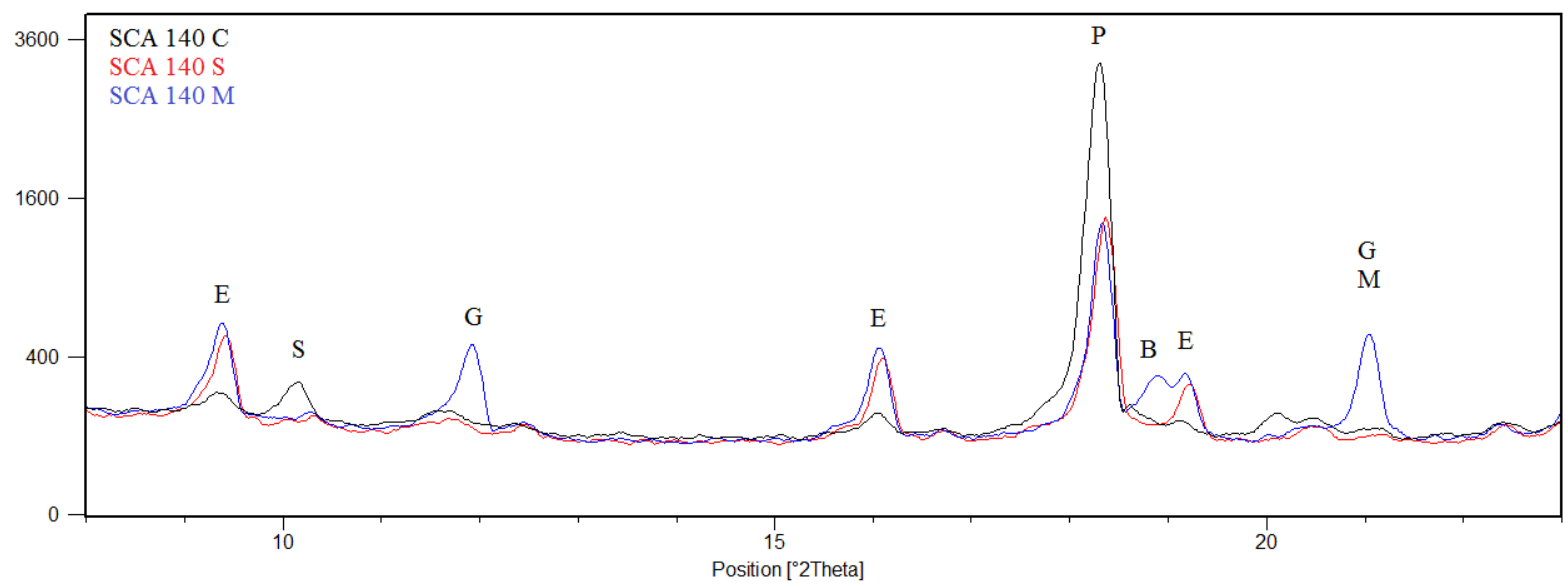

B - Brucita; E - Etringita; G - Gipsita; M - Silicato de Magnésio Hidratado; P - Portlandita; S - Monossulfoaluminato de Cálcio Hidratado

Figura 119: Difratograma das amostras da série SCA para 140 dias de exposição nas posições de $2 \theta$ variando de $8^{\circ}$ a $23^{\circ}$ (Soluções de exposição: $\mathrm{C}-\mathrm{Ca}(\mathrm{OH})_{2} ; \mathrm{S}-\mathrm{Na}_{2} \mathrm{SO}_{4} ; \mathrm{e}, \mathrm{M}-\mathrm{MgSO}_{4}$ ).

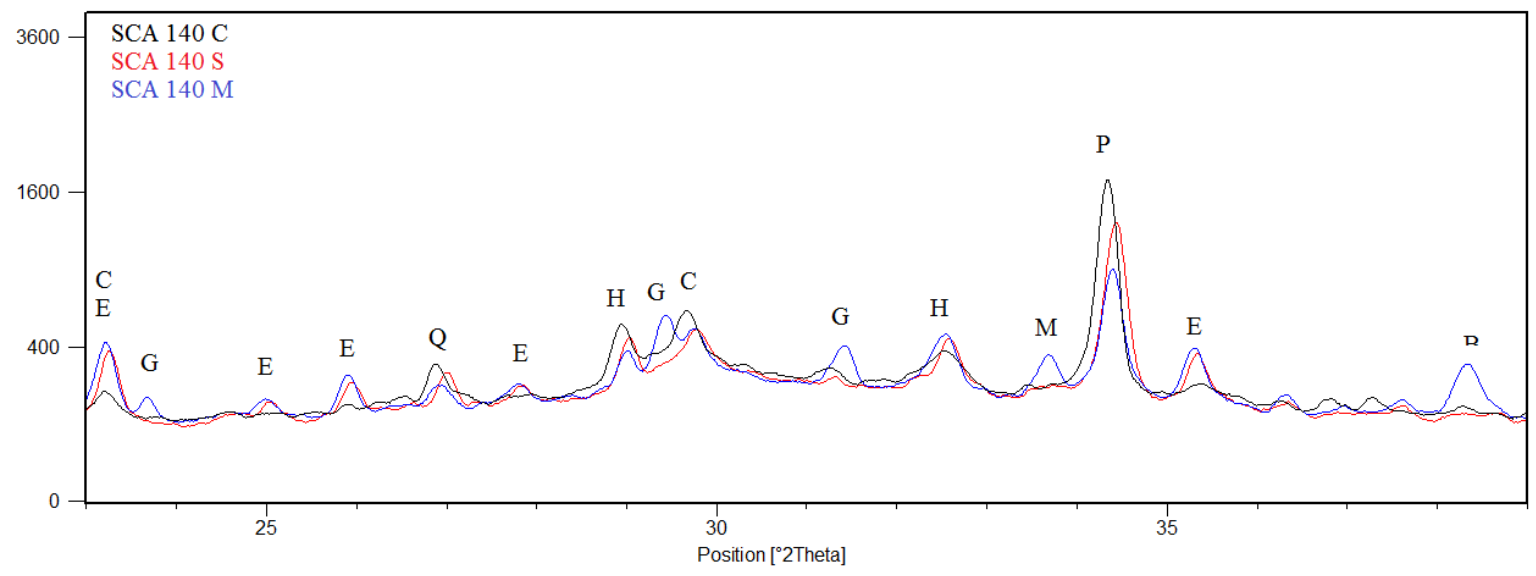

B - Brucita; C - Calcita; E - Etringita; G - Gipsita; H - Silicato de Cálcio Hidratado; M - Silicato de Magnésio Hidratado; P - Portlandita; Q - Quartzo

Figura 120: Difratograma das amostras da série SCA para 140 dias de exposição nas posições de $2 \theta$ variando de $23^{\circ}$ a $39^{\circ}$ (Soluções de exposição: $\mathrm{C}-\mathrm{Ca}(\mathrm{OH})_{2} ; \mathrm{S}-\mathrm{Na}_{2} \mathrm{SO}_{4} ; \mathrm{e}, \mathrm{M}-\mathrm{MgSO}_{4}$ ). 